

\section{LIBRARY OF CONGRESS.}

\section{UNITED STATES OF AMERICA.}

Chap.

Shelf.

PRESENTED BY 




The accompanying report was published under a joint resolution of Congress, which reads as follows:

S. R. 148.-Joint resolution providing for the printing of House Document No. 396, relating to the Beet-Sugar Industry in the United States.

Resolved by the Senate and House of Representatives of the United States of America in Congress assembled, That there be printed 60,000 copies of House Document No. 396, 55th Congress, being a Special Report on the Beet-Sugar Industry in the United States, 27,000 copies for the use of the House of Representatives, 13,000 copies for the use of the Senate, and 20,000 copies for the use of the Department of Agriculture. 



\section{SPECIAL REPORT}

ON THE

Duplicate.

\section{BEET-SUGAR INDUSTRY}

IN THE

UNTTED STATES.

WASHINGTON :

GOVERNMENT PRINTING OFFICE.

1898. 


\section{$S B 219$ \\ . A5 \\ 1898}

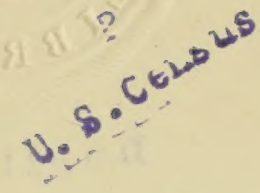

เัว 2742

\section{ES A G E.}

To the Congress :

I transmit herewith, for the information of the Congress, a communication from the Secretary of Agriculture, covering a detailed report showing the present condition of the beet-sugar industry in this country and the results of experiments made by the Department of Agriculture in the production of sugar from beets in the United States during the past year.

WILLIAM MCKINLEY.

Executive Mansion, 


\section{LETTER OF TRANAMITITAL.}

\section{U. S. DEPARTMENT OF AGRIGULTURE, OfFICE OF THE SÉCRETART, Weshington, D. C., Mareh 25, 1898.}

Mr. I'RINIDENT: In a communication which I addressed to the VicePresident on the 17th of last January, in obedience to a resolution of the United States Senate, on the subject of sugar importation, production, etc., I made the following statement:

Sugar will be grown in the United States by farmers. The Department of Agri('nlture has been experimenting in two-thirds of the States of the Uniom during the past year, and will experiment in all the States during the coming year, to ascertain where we can grow sugar-producing plants most profitably. A detailed report now being propared for Congress will show the results of the work.

I now have the honor to transmit, for your information and that of the Congress of the Cnited States, that portion of the detailed report above referred to covering the subject of beet sugar. For the convenience of its realer's, I have divided it into two distinct parts, one part consisting of the report of the Chemist of this Dejartment, Dr. H. W. Wiley, who for many years, and until the work was intermitted for a few years preceding my assumption of office, was in charge of the sugar-experiment work, which has formed the basis of most of the work undertaken by private enterprise in this important industry.

The second part consists of the report of the field agent, Mr. Charles F. Saylor, appointed May 10, 1897, who has personally visited during the past season every State and locality mentioned in his report, inspecting sugar-beet plantations and beet-sugar factories and interviewing the practical growers and maunfacturers.

During the past five year's the people of the United States have paid to foreign producers over hali a billion dollars for imported sugar. The total domestic product for 1897 was $335,6.76$ tons, the total refined product of beet sugar $1,760,607$ tons, making the total consumption for that year $2,096,263$ tons.

Of the total consumption of sugar' in the United states in 1897,45 per cent was beet sugar. As the production of beet sugar in the United Sitates in 1897 was barely $12 \frac{1}{2}$ per cent of the total domestic product, it follows that the percentage of beet sugar imported last year to the entire sugar imports must have been considerably over 45 . 
Inasmuch as the total amount of sugar now imported into the Inited States can be produced npon a million acres devoted to sugar cropss, it is manifestly of the first importance that the selection of localities for the production of sugar beets should be most carefully and judicionsly made, and to do this requires that the sections of the country best adapted to the growth of this valuable crop should be definitely determined. This determination I conceive to be a duty clearly devolving. upon this Department.

The fatets and figures as briefly presented to your attention eninently justify, in my opinion, the devotion of time, money, and talents on the part of this Department to the development of this important industry. They also explain the widespread popular interest in this subject, expressions of which reach us on every side and from all quarters of the country. The demand for a farmers' bulletin on the subject of the sugar beet, prepared last year by the Chemist of the Department, both from Members of Congress for distribution to their constituents and from correspondents of the Department, has been such as to sererely tax our limited appropriation for this class of publications. Nearly 150,000 copies of this bulletin have already been distributed, and the demand appears to be mabated. These facts, I believe, warrant the recommendation I have the honor to make in regard to this report, namely, that it be printed by the order of C'ongress in an edition sufficient to affird to this Department for its own distribution at least 20,000 copies, apart from the allotment which Congress may in its wistom make for the use of its own Members. Another and very important reason exists for the printing of this report by Congressthat under the present law, without the special authorization of Congress, only 1,000 copies could be printed by this Department.

I have the honor to remain, Mr. President, Very respectfully,

JAMES WILSON, Secretary.

The President, Executive Mansion. 


\section{CONTENTS.}

\section{REPORT OF CHEMIST.}

Letter of transmittal.......................................... 5

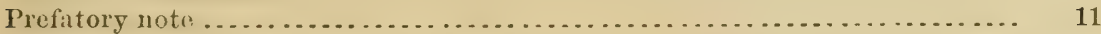

References in Aunual Report of the Department of Agriculture to matters

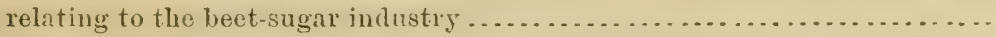

List of bulletins issuer by the division of chemistry, relating in whole or in

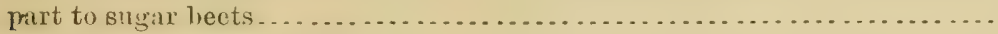

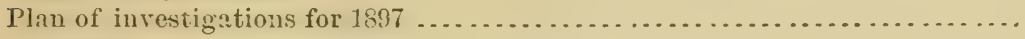

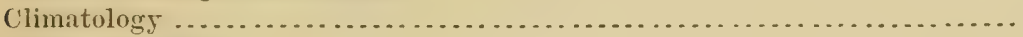

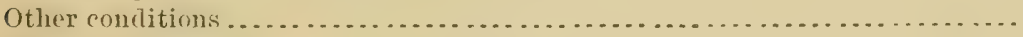

Map of themal helt. . . . . . . . . . . . . . . . . . . . . . . . . . . . .

C'hanges in the new maps. . . . . . . . . . . . . . . . . . . . . . . . .

'Triple isothemal lines . . . . . . . . . . . . . . . . . . . . . . . . . .

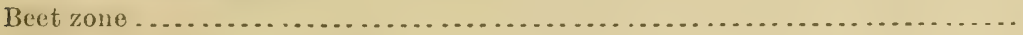

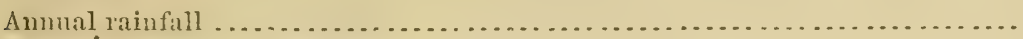

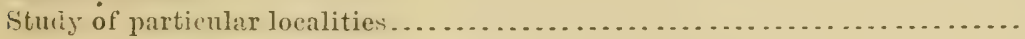

North Carolina and West Virginia ..........................

Eastern Shore of Maryland . . . . . . . . . . . . . . . . . . . . . . . . .

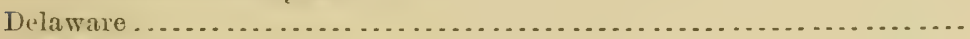

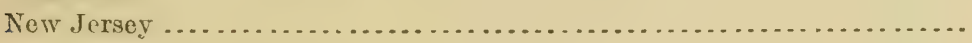

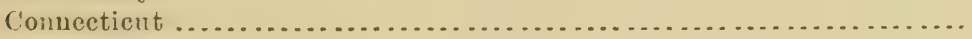

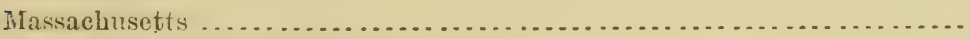

New Hampshiro and Temont . . . . . . . . . . . . . . . . . . . . . . . . .

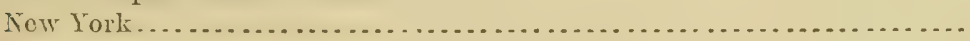

Penusylvania . . . . . . . . . . . . . . . . . . . . . . . . . . . . . . . .

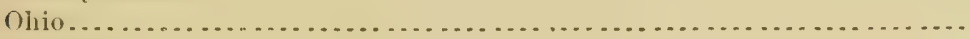

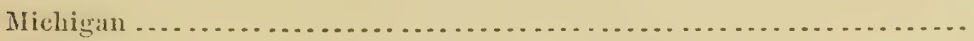

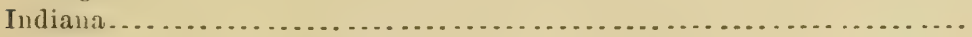

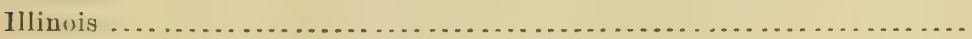

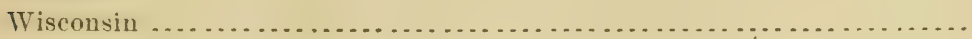

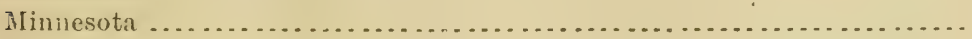

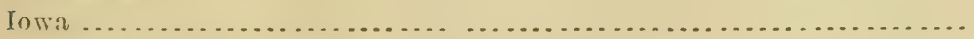

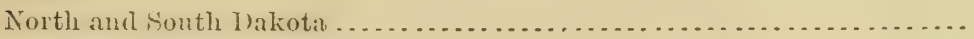

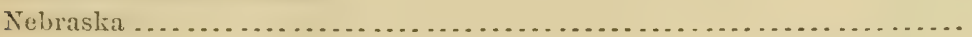

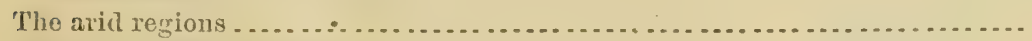

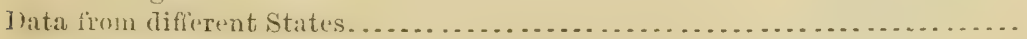

Data obtained in the laboratory of the Department of Agrienlture..........

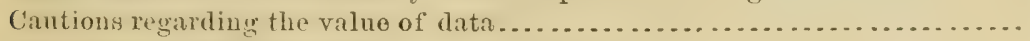

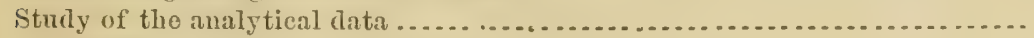

Arizona . . . . .......................................

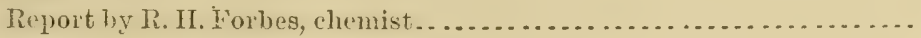

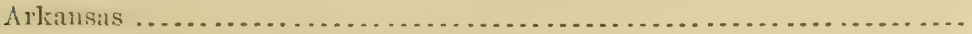

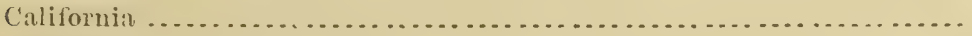

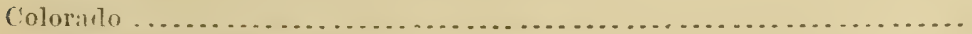

Roport by William J'. Headlen, chemist.................... 0 . 
Study of the analytical data-Continued. Page.

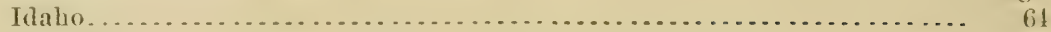

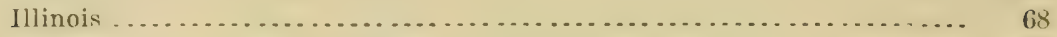

Indianil . . . . . . . . . . . . . . . . .

Roport by H. A. Huston and J. M. Barrett...................... 71

Iowit . . . . . . . . . . . . . . . . .

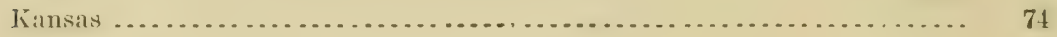

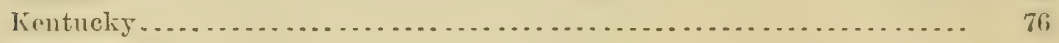

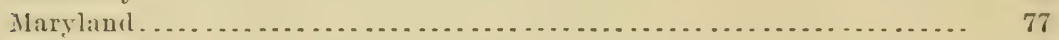

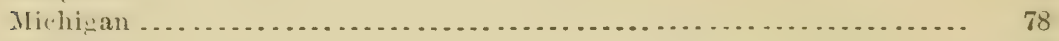

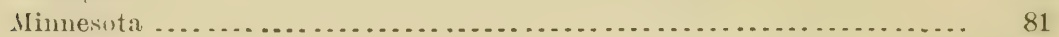

Report by Harry Snyder, chemist......................... 82

Missumri . . . . . . . . . . . . . . . . . . . . . . . . . . . . . . . . . . . 83

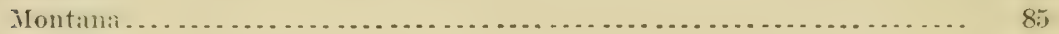

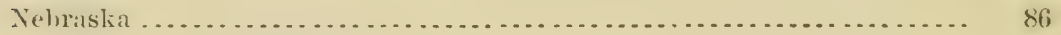

Report by H. H. Nicholson ................................ 86

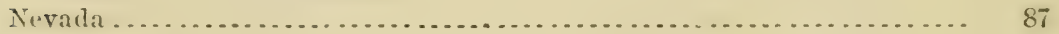

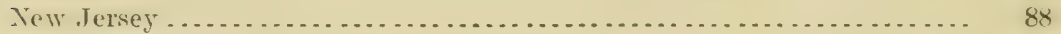

Experiments by James B. Vredenburgh ..................... 89

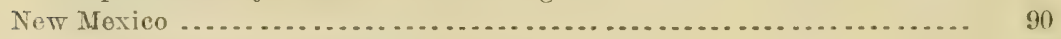

Report by C.'T. Jordan, special agent ...................... 90

New York ................................................. 93

Report by IV.S.Jordau, director of experiment station at Geneva... . 94

Report by I. P. Roberts, director of experiment station at Ithaca.... . 96

Elerations of region of New York suited to beet culture........... . 98

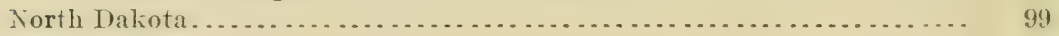

North Carolina. . . . . . . . . . . . . . . . . . . . . . . . . . . . . . . . . 99

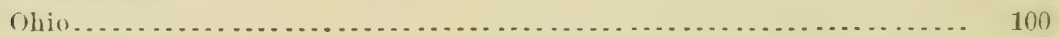

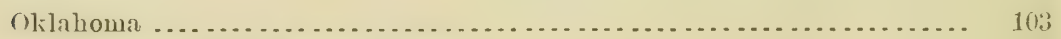

Report ly G. E. Horrow, director ........................ 103

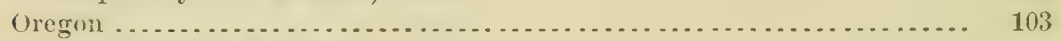

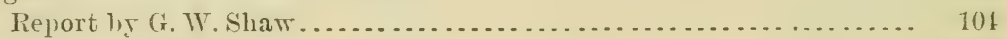

Pennsylvania ........................................... 10.

Rhode Island ............................................... 110

Sulth Cirolina............................................. 110

South Dakuta.......................................... 110

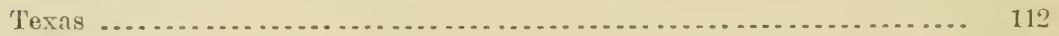

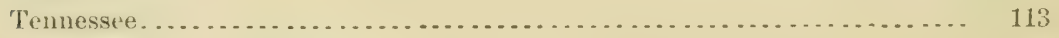

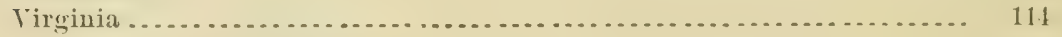

Report by William B. Alwood, vice-director . . . . . . . . . . . . . . . . 111

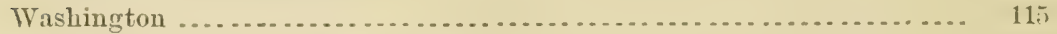

Report by Elton Fulmer, chemist ....................... 116

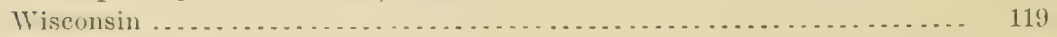

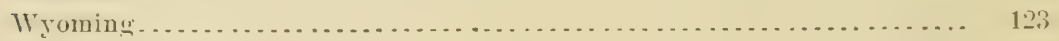

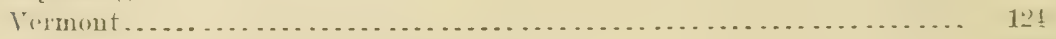

Report by Joseph L. Hills, director....................... 125

Influence of temperature on the quality of sugar beets . . . . . . . . . . . . . 12.

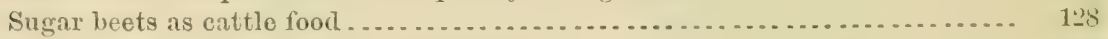

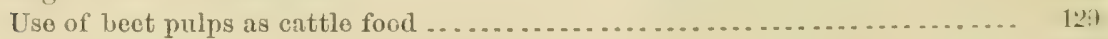

Diffusion pulps or exhausted cosettes......................... 130

Feeding experiments with beet pulp........................... 131

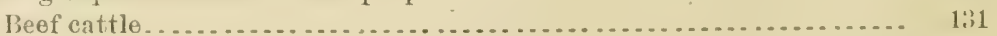

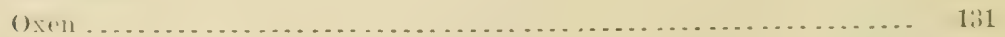

Mil.

-

Experiments male with ewes ........................... 1:3.)

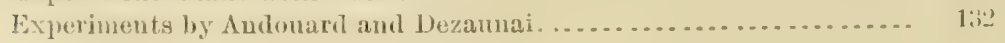


Summary of data collected in previous years ........................ 134

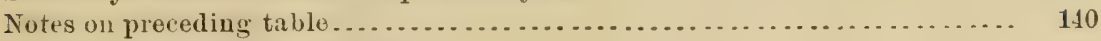

Investigation in seed production. . . . . . . . . . . . . . . . . . . . . . . . 141

Teunessee..................................................... 144

Report by Charles WV. Vauderford ........................ 145

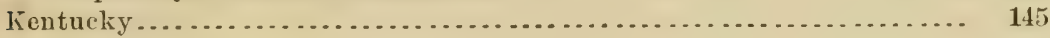

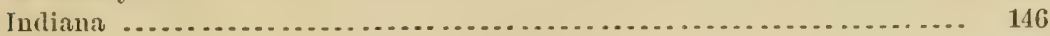

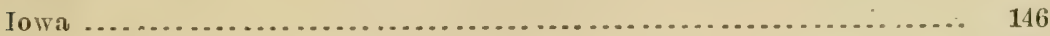

Report by C. F. Curtiss................................... 147

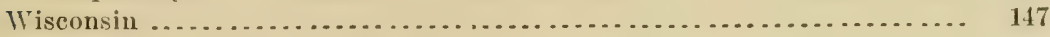

Analyses made in laboratory of Department of Agriculture.......... 150

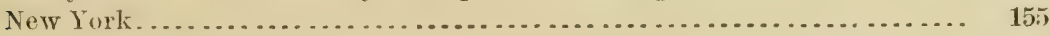

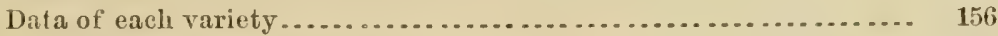

Vilmorin's la plus riche ............................... 156

Vilmorin's Improved Schuyler seed ...................... 156

Vilmorin's Improved . .................................. 156

Demesmay .......................................... 157

Vilmoriu's Improved Elite, grown by Dippe Bros.............. 157

High Grade Commercial Kleinwanzlebener.................. 157

Original Kleinwanzlebener (Holland) ...................... 157

Klein wanzlebener Elite ............................. 157

Classification of the beets of all varieties............................ 158

Preservation of mother beets ....................................... 158

Growth of seed from mothers above described ........................ 158

Necessity of seed development ................................. 158

\section{REPOR'T OF FIELD AGENT.}

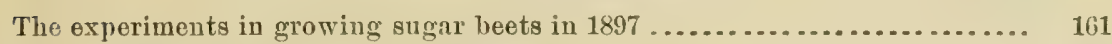

The extensive consumption of sugar........................... 161

Present status of the industry ............................. 16y

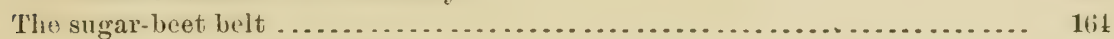

The work of the Department ..................................... 165

Modifying conditions.......................................... 166

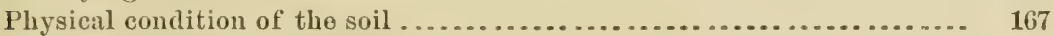

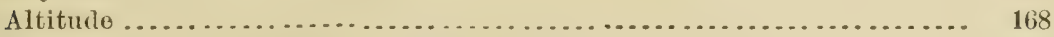

The importance of the industry to this country . . . . . . . . . . . . . . . . . . . 169

Rents aud values......................................... 169

High state of land culture .................................... 170

Employment of labor and demand for crude material ................ 170

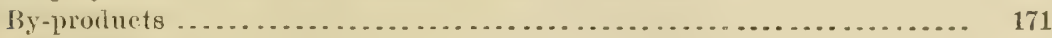

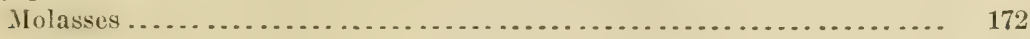

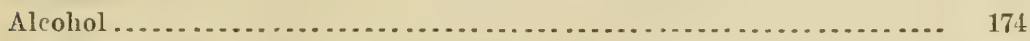

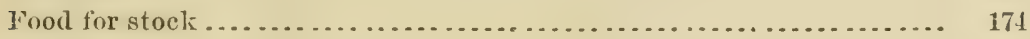

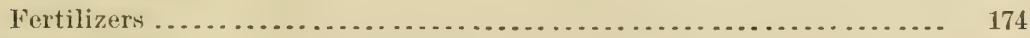

The United States as a competitor of Europe in the beet-sugar industry ..... 175

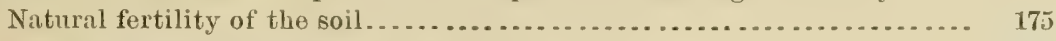

American ingenuity and enterprise .......................... 176

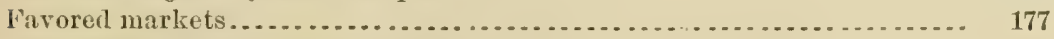

Comparatively sinall area needed........................... 177

General observations on experiments of last year ...................... 178

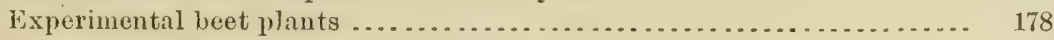

Preparation of the soil for experiments . . . . . . . . . . . . . . . . . . . . . 179

Planting of experimental beds............................... 180

Cultivation of experimontal plats ............................ 181 
General observations on experiments of last year-Continued.

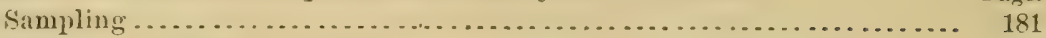

Yield, or "tounage," per acre .................................. 182

Smill beets ............................................ 182

The factor of intelligence in farming ........................... 183

Local prosperity attendiug tho beot-sugar industry ................... 181

The work of the experiment stations ............................ 181

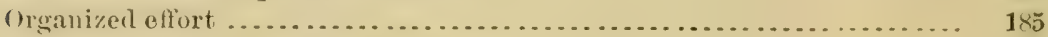

General suggestions, for raising sugar bets . . . . . . . . . . . . . . . . . . . 186

Soil and preparation of the seed bed $\ldots \ldots \ldots \ldots \ldots \ldots \ldots \ldots \ldots \ldots \ldots \ldots$

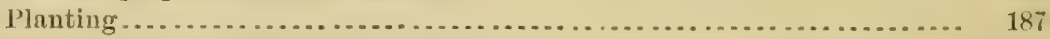

Planting aud cultivating implemonts......................... 188

Wirlth of rows ............................................. 189

'Ihiming and bunching . . . . . . . . . . . . . . . . . . . . . . . . . . . . . 190

The time for thinning . . . . . . . . . . . . . . . . . . . . . . . . . . . . . . . . . . 190

Criltivation ............................................... 191

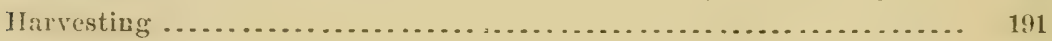

Silos............................................... 191

Harvesting implements . . . . . . . . . . . . . . . . . . . . . . . . . . . 192

Irrigation . . . . . . . . . . . . . . . . . . . . . . . . . . . . . . . . . 193

Subirrimation ........................................... 195

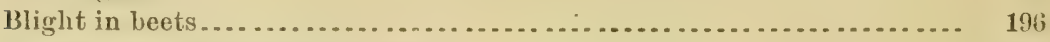

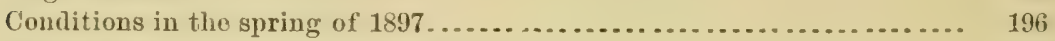

Value of crop ............................................... 197

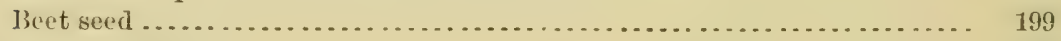

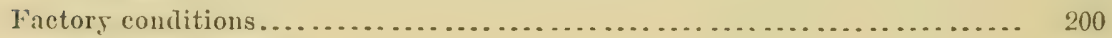

Quality of beets .......................................... 201

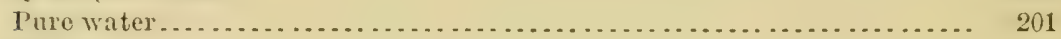

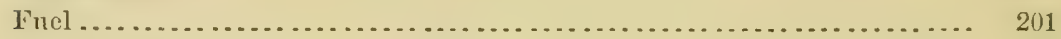

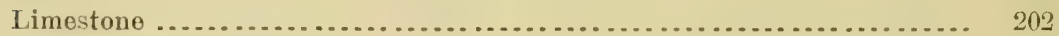

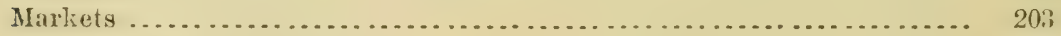

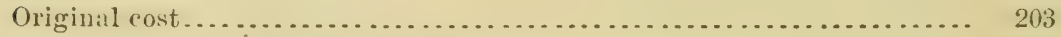

Permanent agricultural conditions ............................... 203

Limo and water for beet-sugar factory purposes...... . . . . . . . . . . . . . . 20

Salts in solution and their eftect in water used in sugar manufacture ..... 2205

Mr.lassigenie salts................................... 2116

Lime rocks and waters used in the manufacturo of beet sugar.......... 2/7

Auswers of factory ofticials to questions relative to fuctory work.......... 208

Observations growing out of answers to quostions submitted to factory

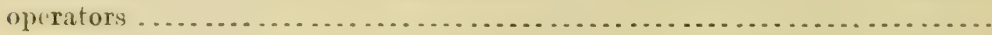

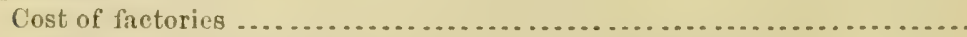

Estimate of a beet-sugar factory of 300 tons capacity por day .........

Estimate of cost, ruming oxpenses, and profits of a beet-sugar factory of capacity of 500 tons of beets per day . . . . . . . . . . . . . . . . . . . .

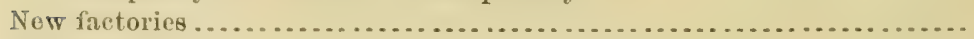

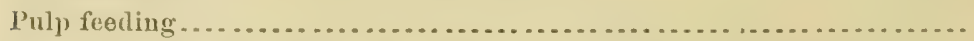

Crude materials required per ton of boets worked . . . . . . . . . . . . . .

Sugar consumption of leading European countries and tho United Statos....

Rate of increaso in consumption of sugar per eapita . . . . . . . . . . . . .

lhe bect-sugar industry in Gormany . . . . . . . . . . . . . . . . . . . . . . . .

Experience of suecessful growers of sugar beets . . . . . . . . . . . . . . . . . . .

Answers to questious . ... . . . . . . . . . . . . . . . . . . . . . . . . . . . . 


\section{ITLUSTRATIONS.}

Plate 1. Map showing isothermal lines of $68^{\circ}, 69^{\circ}, 70^{\circ}$, and $71^{\circ} \mathrm{F}$. for the months of June, July, and August, and mean temperatures for the same months at other points in the State of New York and parts

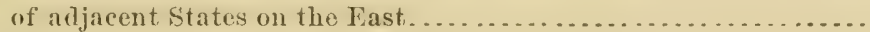

2. Map showing the probable aroas suited to beet culturo 



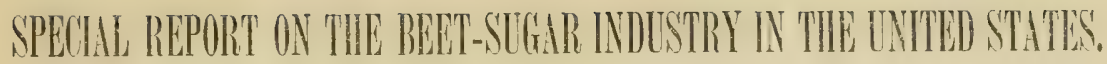

\section{REPORT OF 'THE CHEMIS'.}

H. W. WILEY,

\section{IETTER OF SUBMITTAL.}

U. S. Department of Agriculture, Division of Chemistry, Trashington, D. C., March 2, 1898 .

SIn: I subnit herewith for your consideration the manuscript containing the data of recent investigations on the growth of sugar beets and the manufacture of sugar therefrom.

Respectfully,

Hon. Jalies WILSON, Secretary of Agriculture.
H. W. WIIET, Chief of Division of Chemismy.

PREFATORY NOTE.

The investigations conducted by the Dejartment of Agriculture for many years in the study of sugar-ploducing plants and methods of manufacturing sugar in the United States were suspended by order of Secretary Morton in 189:\%. In resuming the study of this subject by orler of Serretary Wilson, it is important that citations to the rork alleady done be presented. The student of the subject will he able from these citations to have a general idea of the scope of the work which has been accomplished, and will be guided in further research by the data container in the brief resums which will be appencled. It is not possible in such a list of citations to refer to the work which has been done by the arrienltural experiment stations nor by private indi. vicluals. A collection of the titles of all accessible works in English relating to the subject of the sugar beet has been issued hy the library of this Department as the library builetin for June, 1897, entitlou Tederences to the Liturature on the Sugar Beet, Exclusive of Wrotis in Foreign Languages. 
In the résume of citations given below are first noted the publications which have been made in the annual reports of the Department of Agrieulture, and afterwards a list of the special bulletins relating to beet sugar will be found. Many important papers have been pub. lished in the anmual reports, which students of the beet-sugar industry might wish to consult. It is interesting to know that as early as 1867 Dr. Antisell, at that time the Chemist of the Department, pointer out the probability that an area or belt suited to the culture of the heet might be mapped ont. He gave also some of the probable data which would be used in determining the limits of this belt. The anmual report for 1868 contains a reference to the fact that Henry Clay visited Europe and made a study of the beet sugar industry on the Continent, and presented the results of his studies in a speech delivered in the Congress of the United States. Careful search of the records has not been able to discover this report in print.

It is to be regretter that many of the agricultural reports are entirely 'out of print, and the same is true of the greater part of the bulletins which have been issued on the subject of beet sugar. It will therefore not be possible for the Superintendent of Public Documents to supply the bulletins which are marked out of print to those who may lesire to secure them.

Following the résume of the work alceady done is given an account of the investigations conducted under the supervision of the Chemical Division of this Department during the year 1897.

REFERENCES IN ANNUAL REPORTS OF THE DEPARTMENT OF $A$ GRICLL-

TURE TO MATIERS RELATING TO THE SUGAR-BEET INDUSTRT.

1862. 536. Relative to the composition of beet juice.

1867. 32. Report of 'Thomas Antisell, Chemist, Department of $\Lambda$ griculture.

Dr. Antisell indicates the following as the probable "beet belt," based on temperature conditions:

"The northorn limit of the beet enlture is doubtful. On the plains of Russia it is grown where the isocheimal line is $10^{\circ}$. If this would hold good ou this continent, there is no portion of the United States too cold for its culture. This vast extent of country is naturally divided into two regions, viz: (1) The middle division of the temperate zone of the United States, lying between parallels 39 and 43 , comprising Massachusetts, Rhode Island, Counecticut, Now York, New Jersey, Pennsylvania, Ohio, Indiann, Illinois, Iowa, Nebraska, southeru Idaho, with an area of 453,000 square miles, is favorable to beet culture, tho mean annual temperature rarying between $47^{\circ}$ and $53^{\circ} \mathrm{F}$; (2) the district betweon parallels $36^{\circ}$ and $39^{\circ}$, embracing the border States, Dolaware, Maryland, Virginia, West Virginia, Kentucky, 'Tennessee, Missonri, with Kansas, Colorado, Utah, Nevada, and northern California, possessing an area of 675,000 square miles and a mean annual temperature of $58^{\circ}$ to $600^{\circ} \mathrm{F}$, is also favorable to the beet; so that a belt of eountry $7^{\circ}$ wide in latitude and with au extent of $1,129,000$ square miles is open to this industrial art." 
In experiments in beet culture on the Department grounds the maximum percentage of sugar in the juice is given for each variety:

\begin{tabular}{|c|c|c|}
\hline Variety. & $\begin{array}{l}\text { Number } \\
\text { of tests. }\end{array}$ & $\begin{array}{l}\text { Per cent } \\
\text { of sugar. }\end{array}$ \\
\hline Whito Silesian : & & \\
\hline $\begin{array}{l}\text { Red } \text { top } \ldots \ldots \ldots \\
\text { Green top }\end{array}$ & $\begin{array}{l}12 \\
10\end{array}$ & $\begin{array}{l}6.97 \\
7.20\end{array}$ \\
\hline W lite Magdeburg. & 12 & 7.74 \\
\hline 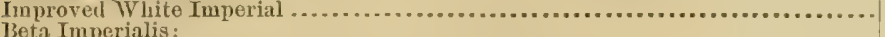 & 11 & 7.34 \\
\hline 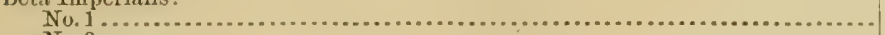 & 12 & 6. 70 \\
\hline 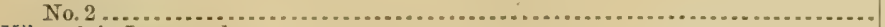 & 12 & 7. 40 \\
\hline $\begin{array}{l}\text { Vilmorin's Improved } \ldots . . . \ldots \ldots \ldots \\
\text { Castlenandry Yellow }\end{array}$ & 12 & 7.40 \\
\hline Castlenandry Yellor & & \\
\hline
\end{tabular}

1867. 48. Methods of sugar manufacture in Europe.

1868. 158. Report of Theodore Gennert to the Commissioner of Agriculture. A general article on the statistics and manufacture of beet sugar.

1868. 164. Notes on the manufacture of beet sugar in Europe.

In 1867 the Department sent nine varieties of seed to Chatsworth, Ill., for trial, with the following results:

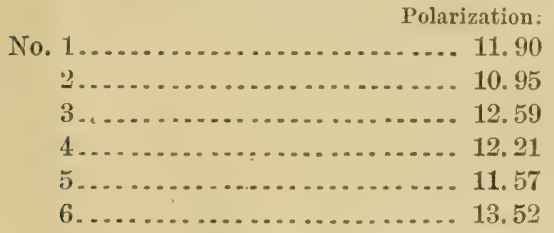

Polarization.

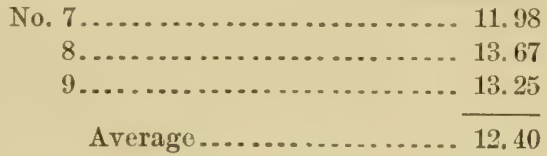

Mention is made in this article that while in Europe Henry Clay took much inverest in the beet-sugar industry and afterwards, in a speeeh in Congress, predicted great results from the introduction of the industry into the United States.

1869. 334. A review of the manufacture of sugar in Europe.

1869. 345. A letter included in the above review. It reviews the manufacture in Europe and mentions trials made in the United States. The first abtempt to produce beet sugar in this country, mentioned in this review, was by Jolm Vaughn and. James Ronaldson, Philadelphia. Seed was imported and boets wore grown, but no factory was built.

1870. 98. Report of the Chemist on Beet Sugar. He states that the returns of the growth of sugar beets in this country have not yet shown an approach to that amount of sugar which is yielded by the growth of France and northern Germany. Beets grown at Chatsworth, Ill., from seeds supplied by the Department of Agriculture contained from 9.31 to $11.24 \mathrm{per}$ cent of sugar.

1870. 215. Progress of the beet sugar industry in Europe. A brief statistical article.

1870. 210. Largely historical. Three establishments were in operation-Chatsworth, Ill., Alvarado, Cal., Sauk County, Wis. Capacity of the Chatswortl factory, 50 tons of beets per day.

1872. 154. Report of Ryland T. Brown, Chemist, United States Department of Agriculture. Following are some of the chief points mentioned:

The experiments of Havid L. Child, at Northampton, Mass., $1 \times 38$, ale probahy the earliest recorded in this country.

The factory of Bonesteel and Otto, at Foud du Lac, IVis., 1867, had a capacity of 10 tons of beets per day; capital, $\$ 12,000$. 
Analyses of beets grown on the experimontal firm of the University of Virginia, 1872, viz:

\begin{tabular}{|c|c|c|}
\hline Variety. & Weight. & $\begin{array}{l}\text { Sugar in } \\
\text { the juice. }\end{array}$ \\
\hline 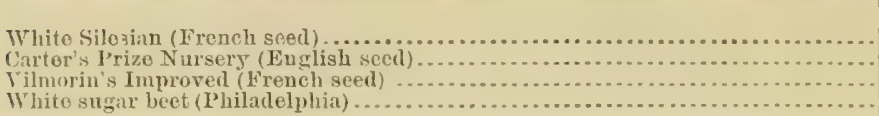 & $\begin{array}{l}\text { Ounces: } \\
21 \\
16 \\
30 \frac{1}{4} \\
33 \frac{1}{2}\end{array}$ & $\begin{array}{r}\text { Ter cent. } \\
11.75 \\
13.72 \\
12.51 \\
10.17\end{array}$ \\
\hline
\end{tabular}

1872. 151. April, 1872, the legislature of New Jersey passed an act, operative for ten years, exempting beet-sugar factories from taxation.

1873. 108. A brief report by the Statistician.

Whe two California factories produced an estimated total of 750 tons of sugar during 1873.

1873. 287. Relative to the capacity and product of the Alvarado factory. Capacity, 7,000 tons of beets per annum.

1875. 512. A résumé of a German report on the composition of sugar beets.

1876. 153. Statistics of the production of sugar in various conntries. Mention is made in this article of a factory at Soquel, Santa Cruz County, Cal. 'The State Agricultural Society of California reported in 1874 that the production of beet sngar in the State amomnted in 1870 to 500,000 pounds; in 1871 to 800,000 pounds; in 1872 to $1,125,000$ pounds, and in 1873 to $1,500,000$ pounds.

1876. 266. Statistics of the yield of beet sugar, by countries.

1877. 213. A hrief statement as to soils suitable for beets.

1877. 579. German statisties.

1878. 117. Analysis of a sample of beet-root sirup.

1879. 67. A report on the analysis of seven sugar beets received from varions parts of the country. The percentage of sugar in the juice rauger from 8.9 to 14.3 , tho latter samplo being from Oswego, N. Y.

1879. 184. General sugar statistics.

1880. 9. Report of the Commissioner of Agrienlture. A report of the condition of the Maine Beet Sugar Company and a statement of the experiments in Delaware were male. Capacity of the Maine factory, 150 tons per day. In 1877 the State legislature of Delaware appropriated $\$ 300$ as premiums to farmers for crops of sugar beets, and in $1878 \$ 1,500$ were appropriated for the same purpose. Imperfect experiments were made in 1878 by the Dela ware Beet Sugar Company. The total crop : imonnted to 350 tons of roots, yielding an average of 9 per cent of sllgar. A new factory was built by Colwell Brothers, of New York, costing $\$ 30,000$, with a capacity of 60 tons of roots per day of twenty-four hours. The company did not make running expenses, but the experiment was encouraging.

1880. 619. A lotter from E. H. Dyer urging a bounty law.

1881. 675. Statistics of sugar production. Statisties of domestic sugar are given in brief. Beet sugar was made successfully for three successive seasous in California in one factory. The Maine factory, which was in operation for three seasons, producing in one year $1,200,000$ pounds and in another $1,000,000$ pounds of sugar, was obliged to suspentl operations for want of beets, which the farmers thought they could not grow at the prices ofiered, namely, $\$ 5.5$ to $\$ 6$ per ton.

1881. 22. Report of $\mathrm{H}$. W. Wiley to the Commissioner of $\Lambda$ griculture on the Northern sugar industry in 1883. This is an abstract of data given in Bulletin No. 3 of the Division of Chemistry.

1884. 529. Yield of beet sugar in Russia.

1886. 341. Analyses of sugar beots grown in various parts of the country. Most of these samples contained very little sugar, with one exception. 'This sample contained 18.84 per cont, and was from Menominee, Mich. The highest percentago of sugar in the other samples was 11.71. Twenty-eight tests wero made. 
1889. 140. Cultivatiou of the sugar beet. Report of the Chemist.

1890. 167. Experiments with sugar beets. Abstract of a report published in full in Bulletin No. 27 of the Division of Chemistry.

1891. 150. Experiments with sugar beets. Abstract of a report published in full in Bulletin No. 30 of the Division of Chemistry.

1891. 156. Laws relating to taxation and bounties in various countries.

1892. 128. A résumé of experiments with sugar beets. Full details of this work are published in Bulletin No. 36 of the Division of Chemistry.

1892. 467. Statistics of beet-sugar production for the year 1892 :

Pounds.

Utah Beet Sugar Company ............................... 1,473, 500

Alameda Sugar Company................................ 2, 506,860

Western Beet Sugar Company............................... 11, 390, 921

Chino Valley Beet Sugar Company .......................... 7, . . . . . . .

Oxnard Beet Sugar Company ............................... 2, 110, 100

Norfolk Beet Sugar Company ............................. 1, 698,400

Total ........................................... . 27, 083, 322

In 1891 these factories produced a total of 12,001,838 pounds.

1893. 175. Experiments with sugar beets. This is an abstract of a report published in full in Bulletin No. 39 of the Division of Chemistry.

1893. 184. Growth of beets at different altiturles.

\section{LIST OF BULLETINS ISSUED BY 'IHE DIVISION OF CHEMISTRY} RELATING IN WHOLE OR IN PART 'IO SUGAR BEETS.

Bulletin No. 3, Division of Chemistry, Department of Agriculture. The Northern Sugar Industry; edited by 11. W. Wiley, 1884; pp. 118 (out of print). Pages 24 to 29 of this report relate to the beet sugar industry.

Builetin No.5, Division of ('hemistry, Department of Agriculture. The Sugar Influstry of the United States; edited by H. W. Wiley, 1885; pp. 224 (out of print).

Part second of this report, including pp. 73 to 136 , inclusive, 12 plates, relates to the beet-sugar industry.

Bulletin No. 27, Division of Chemistry, Department of Agriculture. The Sugar Industry: Culture of the Sugar Beet, and Manufacture of Beet Sugar; edited by H. W. Wiley, 1890 ; pp. 262 (out of print).

Bulletin No. 30, Division of Chemistry, Department of Agriculture. Experiments with Sugar Beets in 1890; edited by H. W. Wiley, 1891; pp. 93 (out of print).

Bulletin No. 33, Division of Chemistry, Department of Agriculture. Experimonts with Sugar Beets in 1891; edited by H. W. Wiles, 1892; pp. 158 (out of print).

Bulletin No. 36, Division of Chemistry, Department of Agriculture. Experiments with Sugar Beets in 1892; edited by H. W. Wiley, 1893; p1. 74 (out of print).

Bulletin No. 39, Division of Chemistry, Department of Agriculture. Lxperiments with Sugar Beets in 1893; by Harvey W. Wiley, with the collaboration of Walter Maxwell, 189.1; pl. 59 .

\section{MISCELIANEOUS BULLETINS AND REPORT.}

Special Report No. 28, United States Department of Agrienlture. Report on the Culture of the Sugar Beet and the Manufacture of Sugar 'Therefrom, in France and the United States; by Wm. MeMurtrie, 1880; pp. 294 (out of print).

Farmer's' Bulletin No. 3, United States Department of Agriculture. Culture of the Sugar Beet; by H. W. Wiley, 1891; pp. 24 (out of print).

Farmers' Bulletin No. 52, United States Department of Agriculture. The Sugar Beet: Culture, Seed Development, Manufacture, and Statistics; by H. W. Wiley, 1897; pp. 48. 


\section{PLAN OF THE INVESTIGA'TIONS FOR 1897.}

On the 11th day of Janmary, 1897, the following letter was addressed to the Secretary of Agriculture:

Sul: Numerons inquiries for sugar-beet seed have come to this division instead of to the seed division, and I am unable to give any definite answer to our correspondents in respect of the policy of the Department regarding the distribution of the seeds in question. I would be glad to know if it would be possible for the Department of Agriculture to provide a few thousand packages of high-grade beet seed which could bo distributed to inquiring farmers. There is a widespreat interest in this country in the sugar-beet industry, and it appears to me that a part of the money voted by Congress for the distribution of seeds could be very profitably used in supplying experimenters with the best quality of sugar-beet seed. Farmers can not be certain in buying beet seods from dealers that they are getting anything more than the ordinary quality of garden seeds. The guaranty of the Department, however, that they are securing high-grade sugar-beet seeds would be of great advantage.

I am now engaged in a revision of Farmers' Bulletin No.3, to be used in supplying the information which is so largely asked for respecting the culture of the singar beet and the manufacture of sugar erefrom. It wonld be of interest to make a statement in this bulletin in regard to tho possibility of securing the soeds from the Department. An early reply to this inquiry will be appreciated.

I am, respectfully,

H. W. Wiley, Chief of Division.

The lionorable tho Secretary of Agriculture.

In reply to this request, in the following letter the information was conveyed that no funds were available for the purchase of beet seeds:

United States Department of Agriculture, OFFICE OF THE Assistant SECRETARY, Washington, D. C., January 13, $189 \%$.

1)ExI SIn: The Secrotary has handed me your letter of the 11 th instant, calling his attention to the arlvisability of distributing some sugar-beet seed in connection with tho present Congressional seed distribution.

If this matter had heen mentioned in time it would have heen possible to purchase a supply of beet seed. As it is now, however, the whole appropriation for the purchase of seed is exhausted. There is not a dollar left with which sugar-beet seed could be purchased. If you will bring the matter up early next June it will be possible to include sugar-beet seed in the distribution of the following year.

Very truly, yours,

Dr. H. W. Wilex, Chiemist.

Cinas. W. Dabney, Jr., Assistant Secretary.

All further attempts to reestablish the investigations looking to the introduction of the sugar-beet industry in the United States, which had been suspended during four years, were therefore deferred to a wait the action of the new Administration.

Immediately after Secretary Wilson assumed the duties of his office, arrangements were made for a renewal of the investigations, but that late was entirely too late to purchase seeds directly from the growers in Europe; therefore arrangenents were male with the Oxuard Beet Sugar Company, which kindly oftered to donate the quantity of seed required for the purpose. As rapidly as possible the seeds were sent 
to different parties in the United States interested in the subject, special attention being given to distributing the seed in those localities where the theoretical conditions for the production of sugar were the best. Packages rere sent directly to the addresses of parties in different parts of the country, and large quautities of seed were distributed through the media of agrienltural experiment stations, boards of trade, business men's associatious, and others interested particularly in the culture. It is impossible, therefore, to determine the number of persons who were actively engaged in the work during the year.

In so far as possible the cooperation of the agricultural experiment stations was secured, it being deemed advisable to conduct the experiments in each State under the direct auspices of the State authorities. It was only when such cooperation could not be secured or where preference was shown for direct communication with the Department of A griculture, and in miscellaneons cases, that the experiments were conducted directly under the auspicns of the Department. Copies of Farmers' Bulletin No. 52, contair ‘ _rections for planting and cultivating the crop, were sent to every person directly interested in the experiments, as well as to many others.

The promiscuous method of investigation which has been practiced during this and preceding years is faulty and unsatisfactory. In former reports the objections to such investigations have been outlined. In Bulletin No. 27 of this division (on pages 6,7 , and $S$ ) is found a number of statements relating to the general condurt of experimental work, which are still pertinent. Inasmuch as this bulletin is out of print, it will be found of interest to repeat these statements here:

It must be understood that the object of this bulletin is not to give a complete treatise upou the culture of the sugar heet and the manufacture of sugar therefrom, lut simply to indicate, for the information of those interested, the general principles of this industry. One cspecial object which will be kept in view is to prevent those intending to eugage in this industry from going wrong in the luginning and squandering their money and timo in battling with problems which science has already met and overcome. It is further hoped that the careful study of the data presented will prevent any mistakes from being made which would eud in financial disaster and which are so apt to attend the varly history of every industry.

There will probably be found for many years to come in the United States more enthusiasm than knowlerge connected with the sugar beet, and the result of this will be, unless great care is taken, that many rentures will be made which may result in financial disaster, disaster which could have been avoided by a thorough comprehension of the fundamental priuciples of the inclustry.

In so far as the manufacture of sugar from the matured beet is concerned, we are able to start at the present time with the accumulated knowledgo and experience of three quarters of a century of investigation. So perfect have the processes of mauufacture become that nearly all of the sugar which is stored in the beet can be secured in merchantable form and by comparatively inexpensivo methods. By the term inexpensive, however, it must be understood thit the actual processes of manufacture are denoted and not the cost of the machinery. The various processes for the extraction of the sugar from the beet, the best methods of clarifying the juice aud of evaporating it and for separating the sugar from the molasses, are thoroughly H. Doc. 396 
well urlerstood and are no longer logitimate subjects for public experiment. 'The great prolulem in this couniry is the agricultural one. The selection of suitablesoil, the finding of the proper clinitic conditions, and instruction in the method of planting, cultivating, and harvesting tho beets, are all matters of vital importance. Writhout a carefinl study of these suhjects, and without the proper knowledge thoreof, it is a hopeless task to attempt to introdnco snecessfully tho beet-sugar industry into this country.

One of the great dangers to be avoided is the formation of hasty conclusions in regard to the proper localities for the production of the sugar beet. Often without any study whatever of the climatic conditions or of the character of the soil, eftorts aro male to build large and expensive factories, which as often have to bo al bandoned on account of hiving been wrongly located. The studies which have been made heretofore in rogard to climatic conditions have been of such a nature as to locate, in a general way, the areas in the United States suitable for the culture of the sugar beet.

It has been found in general that the coast valleys of California, and probably large areas in Oregon and Washington, certain parts of the Dakotas and Nebraska, lncalities in Minnesota, Iowa, Wisconsin, and Michigan, parts of northern Illinois, Intiana, Ohio, and New York present favorable conditions for sugar-bect culture; but in the regions thus broadly intimated there are certain restricted areas most suitable to the sugar beet, and it is only these restricted areas to which we must look for success. The fact that in one locality, for instauce in Nebraska, good sugar beets can be produced would be no warrant whatever for assuming that all parts of that State were equally suitable for this purpose, and this remark may be applied to every one of the States mentioned above.

Sugar beets have also been raised in other sections in the United States, notably in New England, Now Jersey, Delaware, and Kansas, and whilo thero may bo areas in the New England States where beets can bo sucessfully grown, it must bo adjuitted that the States last named stand in the second rank of beot-sugar producing localities. In Kansas, during the last year, as will be shown in tho body of this report, sugar beets were grown and a considerable quantity of sugar manufactured therefrom. This, however, does not show that Kausas will be able to compete with more favorable States in the production of beet sugar.

In general, it mąy bo said that the summers in Kansas aro too hot to expect the proluction of a sugar beet uniform in its nature and containing a high percentige of sugatr.

If the sugar-beet industry is to succeed in this country, the success must come from sharp competitiou with the same industry in older countries, where its conditions are better understood and where the localities suited to it havo been selected by long and often costly experience. It must also compete with the sugar-cane inchustry, both of this country and of tropical countries, and for this reason we cau only expect it to survive in those regions where soil and elimatic conditions, proximity to fuel, cheapness of labor, and other favorable environments are found.

It is to bo hoped that the mistakes which have so long threatened the sorghumsugar industry with destruction may be avoided with the sugar beet. Calu judgment and sober reason must not give way to enthusiasm and oxtraragant expectations. All conditions of success must bo carefully studied, all tho difticulties in the way of success must bo intimately investigated and smmounted, and ample capital, coupled with judicious perseverance, must be enlisted in its behalf.

For the proper orection and complotion of a beet-8ugar factory not less than twelve months should he allower, and even in this timo it can only he properly acomplished under experiencerl technical control. 


\section{In Bulletin No. 30 (ou page 7 ) the following observations are fouml:}

Only in a fow instances were the directions of the Department followed out to the letter. In most cases the planting and cultivation of the beet seed wero condructed according to such mothods as the agrienlturist might hit npon at the time. From the information gathored it was foum that the chief variation from the instruetions was in tho preparation of the soil. In very fer cases was a subsoil plow ubed and most of the beets which were sent to the Department were evidently grown in soil of insufficient depth. In some cases, where tho exact directions for cultivation were carriel out, tho charaeter of the beets received showed by contrast with the others the absolute necessity of employing the best methods of agriculture for their proanction.

\section{In Bulletin No. 33 (on page 9) the following statement is marle:}

One of the most striking features in regard to this mothod of conducting experimental work is found in the fact that it is almost impossil, le to secure compliance with directions. It is ovident, at once, that tho value of uxperimental work depends upou the care with which it is done aud the aecuracy with which flio directions preserjbed are followed. It is not to be wondered at that farmers, busy with their other occupations, failed to comply with the minuto directions necessary to secure the greatest advantage in experimental work.

Very few of the blanks were returned properly filled out. In many cases the data which were returned were palpably orroneous. In one instance a yield of 99 tons per acro was reported, and in a great many casos the reported yiold per acre was so great as to show inaccuracy on the part of the measurement of the land or the weighing of the beets. In making ont returns for such reported phenumenal y iehls the theoretical quantity of sugar per acro given was always questioned. TVeare accustomed to look with suspicion upon any yield of sugar beets which exceeds 25 tons per acre. While it is not impossible to securo a higher yield than this, and of beets of goorl saccharino quality, jet it is so rare as to throw doubt upou miscellaneons data showing an excess of that yield.

Another point, which makes the returns obtainerl less valuable, is found in the fuet of the length of time which necessarily elapsed between tho harvesting of the beets and their reception at the laboratory. Nearly all the samples received wero from distant States, requiring for packages of this kind from three to eight days iu tho mails. Althongh tho beets were in most eases well wrapped, accoriling to directions, our experiments have shown that they must have lost a considerable quantity of moisture by evaporation duriug their long transit. 'The data, therefore, showing the content of sugar in the juice would be uniformly too high for normal boets. It is estimated that not less than 10 per cent should be subtracted from the numlier for sugar to express the normal perecntage of sugar in the beets as originally harvested.

In Bulletin No. 35 (on page 2S) the ideas ontlined above are somewhat expanded in the following words:

Before proceeding to discuss the data in the preceding talbles, attention should be called to the fact that in previous reports of this kind some dissatisfaction has been expressed in some States on aceount of the poor showing of the samples therefrom. In former reports attontion has been particularly ealled to the probability that the dita obtained by this method of experimentation are not wholly reliablo and in all citses do not truiy represent the apabilities of any locality for beet-sugar production. It is true that a large number of data received from a given State will indicate, in a general way, whether or not that State is capable of producing a good sugar beet, but where the number of clata is limited, it may be that the agricultural conditions under which the samples were prodnced wero so poor, or the scason so exceptional, as to prevent a fair judgment of the capabilities of the soil and cliwate. On the 
othor hand, the culturo which tho samples recoived may have beon so careful and tho seasonal conditions so favorable as to produce a beet far above the average which conld be produced in tho whole State.

Arain, tho loss of moisture luring transportation, or the failme of the farmers to send their heets in as soon as harvested, may tend to reduce the amount of water present in the beet and to raise corresponoingly tho quantity of sugar therein. Inasmuch as the analyses aro mado on the expressed juice, this wonld tend to show always an increased amount of sugar over that present naturally in the beets.

All these disturbing influences must be taken iuto consideration in julging the data which have been recorded. This has been said in general explanation so as to forestall any eriticisms which may bo made of the valuo of the data obtained.

To illustrate more particularly what is meant, attention is called to tho instance, say, of Colorado and Montana. From the State of Colorado one lundred and twentythrce samples were received for analysis, and from the Stato of Mtontana only one sample. Any comparison, therefore, between the average results of the two States would bo simply absurd. While ono hundred and twenty-threo samples from Colorado, showing, as they do, fine possibilities of sugar-beet culture, indicato that the State of Coloraclo is capable of produeing beets of high auality, the single samplo from Montana, whether it provel exceptionally poor or exceptionally tine, eould have been no eriterion by which the capabilities of the state for beet sugar combl be juclged.

In connection with the tentative results which have been obtained by this kind of work shonld be considered the characteristies of the soil and climate of each locality, and by putting the two togother a fairly good illea can bo formed of the possibilities of beet-sugar production. Tho reader should carefully bear the above explanation in mind, both in looking over the data in the tables and in reading tho remarks thereon which follow.

In Isulletin No. 39 (on page s) in commenting on the results of the year's work, the following statements are made:

The general results of the rrork this jear aro somewhat disconaging as compared with previous years. Throughout a great part of the beet-growing region the summor was excessively dry, and largo numbers of total failures wero reported.

In former reports attention has been called to the fact that the present method of experiment is musatisfactory, aud the reasons therefor havo been fully set forth. The farmers are so busy with other work that, as a rule, they are not able to giro cirreful attention to the exporimental details. They do not linve the timo to suitably preparo the soil for beet culture, nor do they gise the growing beet proper attention. When tho timo for harresting comes they aro usnally engaged in other farm work, so that the beets are not harrested at the right time, nor are data obtained by means of which any accurate estimate of the yield per acro can bo determined. Tho analytical data, therefore, of such work are usually fragmentary and far from teaching any definite lesson in regard to the industry itself. In general, however, the data bear ont those of previous years in showing the areas in this conntry where tho best beets can be grown. It is in these regions that the developuent of the industry must to expected.

'There is probably not a State or Territory in the Union which is not capable of growing a fin article of sugar beets. Even in the fir Sonth beots of finir sugir content have been produced, and with good tonnage; but when the compotition of the world is to be met, with the price of sugar as low as it is now, only those parts of the country where the soil and elimate are especially firvorable can bo expectecl to

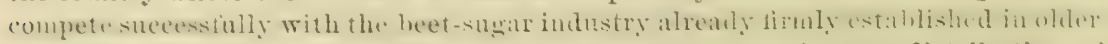
countries. The sole valuable lesson, therefore, of tho promiscuous distribution of beet seed is in the finct that, in a rule, those regions best suiterl to the growth of tho sugar beet will gratually bo outlined, and intending investors led to tho propror localities for the establishment of factories. 
The great success of the beet-sugar indnstry on the Pacific coast leads to the conclusion that if the northern part of the eastern and central portions of our country is to become the seat of a great sugar industry, overy possible advantage must be taken of soil and location, in order to compete successfully with the beot fields of California, Washington, and Oregon.

The experience of the past season, as will be scen from the data in the following pages, has served only to give additional point to the observations made in previous bulletins.

The sugar-beet industry in this country has now reacher a point where it is incumbent upon the National Government to secure a complete and accurate agricultural survey of the country in respect of growing beets. The competition in sugar making is now so keen that only those localities where natural conditions are best will, in the end, be found sustaining the industry. If we depend upon costly experiment to delimit these localities, hundreds of thousands of dollars will be wasted in the attempt. At a comparatively small expense, the Department of Agriculture will be able to have made careful and accurate surveys, based upon experimental data, to point out the regioms where the sugar industry is most likely to succeed. This, however, can not be done by the promiscuns kind of experimentation which the Department has bern compeller heretofore to pursue. Up to this time a sufficient scientific interest in the matter has not boen aroused among the people to secure the kind of a survey which is neressary. Now, however, the conditions have changed. The agricultural experiment stations in most of the States are thoronghly aroused in this matter. They are willing, with the cooperation of the Department, to undertalie an agricultural survey of their respective localities. In addition to this, intelligent men, either in their calparity of private citizens or as representatives of boarls of trade, or of business men's associations, are realy to supervise, in limited districts, series of experiments which will give satisfactory answers to the questions which must be answered before the sugar-beet industry is fully established. It will therefore be the object of the Department in subsequent work, espe. cially that of 1898 , to secure in each locality interesterl in the matter, a few carefully conducted experiments. To this end it is urgerl that the experiment stations in the varions states arrauge with $25,50,100$, or more representative farmers, who can be relied upon to do good work, to grow plats of beets in size of not less than half an acre.

\section{CLIMATOLOGY.}

It is evident that one of the first things to be considered, after the soil itself, in connection with the sugar-beet industry is tho climate. 'The sugar beet is a plant very susceptible to climatic conditions. At the beginning of its growth the beet plant is peculiarly helpless. It can not lift, in passing from the germ to the new plant, the linglitest clod. A rain which packs the surface of the soil immediately after germination will sometimes prevent the plant from reaching the liglit. 
After the plant is established it requires a considerable quantity of water for its proper growth; this water must be supplied either by the rainfall of the locality, by irrigation, or by the subsoil. IIigh temperatures extending over long periods of time are peculiarly injurious to the storing of sugar in the tuber. While high temperatures may not diminisl the tonnage yielded by a field, nor apparently produce any injuri. ous effects, in so far as the external appearance of the mature plant is roncerned, it will be found, as a rule, that plants grown under such eonditions of temperature are less rich in sugar than others grown in an milder climate. Since the production of sugar in the leaf of a plant is a joint function of the chlorophyll cells and sunlight, it is found that the high northern latitudes, where tiue summer days are exceptionally long and the nights correspondingly short, tend to produce, other conditions being the same, a beet rich in sugar. The climatic conditions of this country are so different from those of Europe as to render of little value the general conclusions which experience has drawn from the effect of climate, in the beet-sugar producing countries of Europe, on the susar content of the beet itself. Nevertheless, it is seen that in Europe the great centers of the heet-sugar industry are in regions far to the north, in fact, so far north as to make it impracticable ever to expect, in this country, to establish the centers of the inclustry on the same paraliels of latitude. When it is considered for a moment that the great eap:tals of Ėurope-St. Petersburg, London, and Berlin-are situated 1,4tit, sio, and 910 miles, respectively, north of Washington, and yet in pros. perous agrienltural communities the above statement floes not reate surprise. The vicissitudes of elimatic enditions in northern Europe are also less marked than they are in the United States. Throughont the beet-growing area of Enrope it is expected that the summers will be mild. They are not attended with many days of excessive heat. Springereses early and permanently; the antumn comes slowly and late. In France and Polgium a severe frost is not expected in May, nor is it anticipated that ice of a considerable thiekness will form in October. Ther summer days in these localities are considerably longer than even in the more northern portions of our conntry, and at least an hom longer thin in the centers of our greatest agrienltural prosperity. We find, there. forc, so sweat a deriation in their climatie conditions that we ean not anly with rigidity in this country the rules respeeting the climate derluced fiom the experience of Iuropean comntries. With those rules applieable in this country, it would be easily demonstrable that the great cinter ol the sugar-beet industry on this eontinent would be in C'mada, and not in the United States. We have, therefore, had to depent so far largely on theory in the appliention of the principles of elimatology in the enlture of the sugar beet in the Uniterl States. 'The? "xperimental data which have been at our disposal have been fragmentaly, amblas has already been noted, have notbeen seened in the systemat ic way desirable. 'l'he result is, even to day, that many of our theories 

$?$ 



\section{CORRECTIONS.}

For Plate I read Plate II.

For Plate II read Plate I. 

in regard to climate are not yet substantiated by facts. In the light of the data at hand, in the publication of previons reports it has been assumed that the beet-sugar zone of the United States would be found located over an area of which the southern limit would be marked by the mean isotherm of $71^{\circ} \mathrm{F}$. for the summer months of June, July, and August. While this temperature is considerably higher than the mean temperature of the European beet-sugar areas for the same period of time, it has always been evident that the beet area of the United States: wonld neeessarily be situated farther south than the like area of Europe. There are two reasons which make this location imperative. In the first place, the more northern latitudes not only have late springs, but even after the suring is once established the occurrence of a heavy frost is not musual. In the second place, these same latitules have short autumns, and the oceurrence of heavy frosts in late October or early Norember are not at all nuexpected. As a result of this, the season for the growth and harvest of the beet is too short if we should apply for the mean summer temperature the same rules as obtain in Europe. It is evident, however, that the assmmption of the mean isotherm of $71^{\circ}$ for June, July, and August as the southern limit of the beet-sugar area is based upon so many independent conditions as to render it only useful as a working basis.

\section{OTHER CONDITIONS.}

In connection with the temperature must be considered the rainfall, the contour and the nature of the soil, the possibility of irrigation, the abundance of subsoil moisture, the proximity of coal, limestone, and water, price of labor, facilities for distribution and transportation, and many other matters which are important in a discussion of the subject. It is further evident that the tracing of a single isothermal line and the arbitrary addition thereto of a certain width of land on either side do not give even the proper theoretical thermal basis for a careful study of elimatic conditions.

\section{MAP OF THERMAL BELT'}

For this reason, the present report is supplied with a new map (Plate I), which has been kindly prepared by the Weather Bureau at our request, in which the isothermal lines for June, July, and August have been traced with greater care and from data exteuding over a longer period of time. ${ }^{1}$

The result of these new studies has been to change from former maps, in some cases slightly aud in some cases considerably, the position of the mean isotherm of $70^{\circ}$ for the three summer months named. This change, as will be seen by consulting the new map, is most marked in

Data supplied, through the courtesy of Mr. Willis S. Moore, chief of the Weather Burean, by Mr. A. J. Ifenry. The map was drawn by the draftsmen of the Bureau, under Mr. Henry's direction. 
the case of the State of New York, where in former maps the mean isotherm of 60 was traced in a line rumning almost directly west from Albany to Buffialo.

\section{CHANGES IN TIIE NEW MAT.}

In the new map the influence of the Allegheny ilountains on tempera. ture has been more carefully studied, and as a renult there has been a considerable deflection of the isotherm of $70^{\circ}$ to the sonth and southwest. The general trend of this isotherm from Albany is in a sonthwesterly direction mutil the Allegheny Momutains are crossed, where it turns in a westerly direction until it reaches its former location practically in the neighborhood of Cleveland, Ohio. The position of this isotherm from this point westward is so nearly the same as that of the other map as to require no particular mention. The State of New York, however, especially that portion of it lying between Albany and Iuffinlo, has peculiar thermal conditions, and these are shown in a special map of that State (Pl. II). A considerable area of the State with a mean summer temperature of $70^{\circ}$ is found in the northwestern part in the neighborhood of Rochester, while between this area and the continuons isotherm of $70^{\circ}$, as traced upon the map, is a considerable space of territory where the mean summer temperature is consirlerably below 70 . This area, however, corresponds more nearly to the beet areas of northern Lurope than any other jortions of our country. The temperature and other climatic conditions in this area are more uniform by reason of the modifying effects of the Great Lakes on the winds whith blow from the west and northwest. The experimental data which have been collected show, therefore, that this area, although in many cases the mean summer temperature is below $70^{\circ}$, is peculiarly snited to the production of beets oi" a high sugar content. The comparatively mild springs and antumns also favor the planting and harvesting of the beet, so that the conditions of this area are as furorable to the production of beets of the proper grade as those areas lying immerliately contignons to the mean isotherm of $70^{\circ}$.

\section{TRIPLE ISOTHERMAL LINES.}

As a single isothermal line passing across the country affords a very narrow basis for study, it has been deemed advisable in the map here. with presented to take as the nuclens of the isothermic sugar zone not mereiy the isotherm of 70 , but that belt of territory, varying in width, which is bounded by the isotherms of $69^{\circ}$ upon the north and $71^{\circ}$ njon the south. The isotherm of $70^{\circ}$ is found between these two, usually oceupying the center of the helt, or nearly so, but sometimes alpuroaching more nearly the one or the other. If, now, we add to the outside of the belt of irregular wirth, thus outlined by the two isotherms mentioned, on the sonth a strip of comntry of varying width and on the north an area boumled by the limit of dangerous frosts, this area will 



practically include the whole of the United States which, from theo. retical conditions of temperature, is best suited to the growth of sugar beets of a high saccharine content.

\section{BEE'T \%ONE.}

The sharded portions of the map, herewith presented indicate in a general way this area. No attempt has been made to extend this lateral shading west of the Missouri River. The paucity of data for the western part of the country, in connection with the extreme vicissiturles of elimate, renders of litite value any extension of the thermal belt.

\section{ANNUAL RAINFALL.}

Connected with this study, the annual precipitation is of the ntmost importance. There has therefore been mirked npon the map, in the area covered by this belt, the mean precipitation, in inches, from so io 40 , from 40 to 30 , and $s 0$ on down to the least recorded quantities of rainfall in the far western arid regions.

The mean annual precipitation is, of course, of importance in cletermining the relations of the different regions to the water supply and the need of irrigation. It is also important to know the mean preeipitation for the months dining which the chief growth of the crop and the harvest take place, namely, for April, May, June, July, August, September, and october. The mean precipitation for each of these three months, as furnished by the Weather Bureau for the localities mentioned, is indicated in the following tables:

Montluly arerages of rainfall, April-October.

\begin{tabular}{|c|c|c|c|c|c|c|c|c|c|c|c|c|}
\hline Stations. & $\begin{array}{l}\text { I ati. } \\
\text { turle. }\end{array}$ & $\begin{array}{l}\text { Longi- } \\
\text { tulte. }\end{array}$ & $\begin{array}{c}\text { Elera- } \\
\text { tion. }\end{array}$ & $\begin{array}{l}\text { Num- } \\
\text { berout } \\
\text { years. }\end{array}$ & A]r. & Maș. & J1110. & July. & $A u g$. & Sicpt. & let. & 'lotal. \\
\hline \multicolumn{13}{|l|}{ MIASSACHUSETTS. } \\
\hline 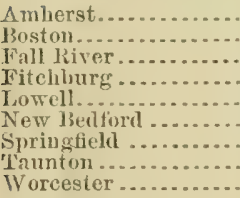 & $\begin{array}{ll}42 & 22 \\
42 & 21 \\
41 & 42 \\
42 & 36 \\
42 & 39 \\
41 & 39 \\
42 & 05 \\
41 & 54 \\
42 & 16\end{array}$ & $\begin{array}{ll}72 & 38 \\
71 & 04 \\
71 & 09 \\
71 & 50 \\
71 & 17 \\
70 & 56 \\
72 & 35 \\
71 & 05 \\
71 & 49\end{array}$ & $\begin{array}{r}235 \\
12 \\
259 \\
433 \\
104 \\
100 \\
70 \\
30 \\
473\end{array}$ & $\begin{array}{l}61 \\
79 \\
22 \\
32 \\
42 \\
83 \\
47 \\
22 \\
43\end{array}$ & $\begin{array}{l}3.1 \\
3.8 \\
3.9 \\
2.9 \\
3.6 \\
3.6 \\
3.2 \\
3.6 \\
3.7\end{array}$ & $\begin{array}{l}3.9 \\
3.7 \\
4.0 \\
3.8 \\
3.7 \\
3.8 \\
4.2 \\
3.3 \\
4.1\end{array}$ & \begin{tabular}{l|}
3.7 \\
3.2 \\
3.1 \\
3.3 \\
3.3 \\
3.0 \\
3.8 \\
2.5 \\
3.1
\end{tabular} & $\begin{array}{l}4.5 \\
3.6 \\
3.5 \\
3.7 \\
3.8 \\
3.1 \\
4.5 \\
3.5 \\
3.8\end{array}$ & $\begin{array}{l}4.4 \\
4.3 \\
4.4 \\
4.3 \\
4.4 \\
3.9 \\
4.5 \\
4.2 \\
4.5\end{array}$ & $\begin{array}{l}3.4 \\
3.4 \\
3.3 \\
3.2 \\
3.3 \\
3.3 \\
3.4 \\
2.8 \\
3.5\end{array}$ & $\begin{array}{l}3.9 \\
3.8 \\
4.5 \\
4.1 \\
3.8 \\
3.7 \\
4.2 \\
3.8 \\
4.4\end{array}$ & $\begin{array}{l}26.9 \\
25.8 \\
26.7 \\
25.3 \\
25.9 \\
24.4 \\
27.8 \\
23.7 \\
27.1\end{array}$ \\
\hline \multicolumn{13}{|l|}{ CONNECTICUT. } \\
\hline 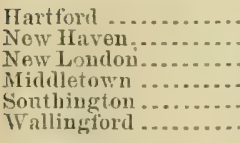 & $\begin{array}{ll}41 & 45 \\
41 & 18 \\
41 & 21 \\
41 & 33 \\
41 & 35 \\
41 & 27\end{array}$ & $\begin{array}{ll}72 & 40 \\
72 & 56 \\
72 & 05 \\
72 & 39 \\
72 & 51 \\
72 & 49\end{array}$ & $\begin{array}{r}38 \\
10 \\
8 \\
37 \\
152 \\
73\end{array}$ & \begin{tabular}{l|}
27 \\
45 \\
26 \\
$3: 3$ \\
26 \\
35
\end{tabular} & $\begin{array}{l}3.0 \\
3.3 \\
3.7 \\
3.4 \\
3.1 \\
3.6\end{array}$ & $\begin{array}{l}3.6 \\
3.9 \\
3.6 \\
3.8 \\
3.2 \\
4.2\end{array}$ & $\begin{array}{l}3.0 \\
3.1 \\
3.2 \\
3.5 \\
2.8 \\
3.6\end{array}$ & $\begin{array}{l}4.1 \\
4.5 \\
4.0 \\
4.3 \\
3.9 \\
4.2\end{array}$ & $\begin{array}{l}4.6 \\
4.6 \\
4.7 \\
4.8 \\
4.6 \\
5.0\end{array}$ & $\begin{array}{l}3.2 \\
3.8 \\
3.4 \\
3.6 \\
2.9 \\
3.6\end{array}$ & $\begin{array}{l}3.9 \\
3.8 \\
4.4 \\
4.1 \\
3.6 \\
4.2\end{array}$ & $\begin{array}{l}25.4 \\
27.0 \\
27.0 \\
27.5 \\
24.1 \\
28.4\end{array}$ \\
\hline \multicolumn{13}{|l|}{ NEW YOIRK. } \\
\hline 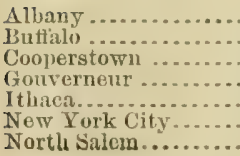 & $\begin{array}{ll}42 & 40 \\
42 & 53 \\
42 & 42 \\
44 & 25 \\
42 & 27 \\
40 & 43 \\
41 & 20\end{array}$ & $\begin{array}{ll}73 & 45 \\
78 & 53 \\
74 & 57 \\
75 & 35 \\
76 & 30 \\
73 \quad 58 \\
73 & 34\end{array}$ & $\begin{array}{r}32 \\
587 \\
1,300 \\
423 \\
375 \\
52 \\
361\end{array}$ & $\begin{array}{l}69 \\
27 \\
43 \\
21 \\
36 \\
61 \\
23\end{array}$ & $\begin{array}{l}2.8 \\
2.5 \\
2.6 \\
2.1 \\
2.2 \\
3.4 \\
3.4\end{array}$ & $\begin{array}{l}3.6 \\
3.4 \\
3.6 \\
2.7 \\
3.4 \\
4.0 \\
4.4\end{array}$ & $\begin{array}{l}4.1 \\
3.5 \\
4.1 \\
2.7 \\
3.7 \\
3.8 \\
3.5\end{array}$ & $\begin{array}{l}4.2 \\
3.2 \\
4.3 \\
2.8 \\
3.5 \\
4.0 \\
4.0\end{array}$ & $\begin{array}{l}4.0 \\
3.2 \\
4.1 \\
2.3 \\
3.0 \\
4.7 \\
4.1\end{array}$ & $\begin{array}{l}3.5 \\
3.3 \\
3.4 \\
3.1 \\
3.0 \\
3.4 \\
3.1\end{array}$ & $\begin{array}{l}3.5 \\
3.6 \\
3.3 \\
3.4 \\
2.9 \\
3.6 \\
4.1\end{array}$ & $\begin{array}{l}25.7 \\
22.7 \\
25.4 \\
19.1 \\
21.7 \\
26.9 \\
20.0\end{array}$ \\
\hline
\end{tabular}


Monthly averages of rainfall, April-October-Continued.

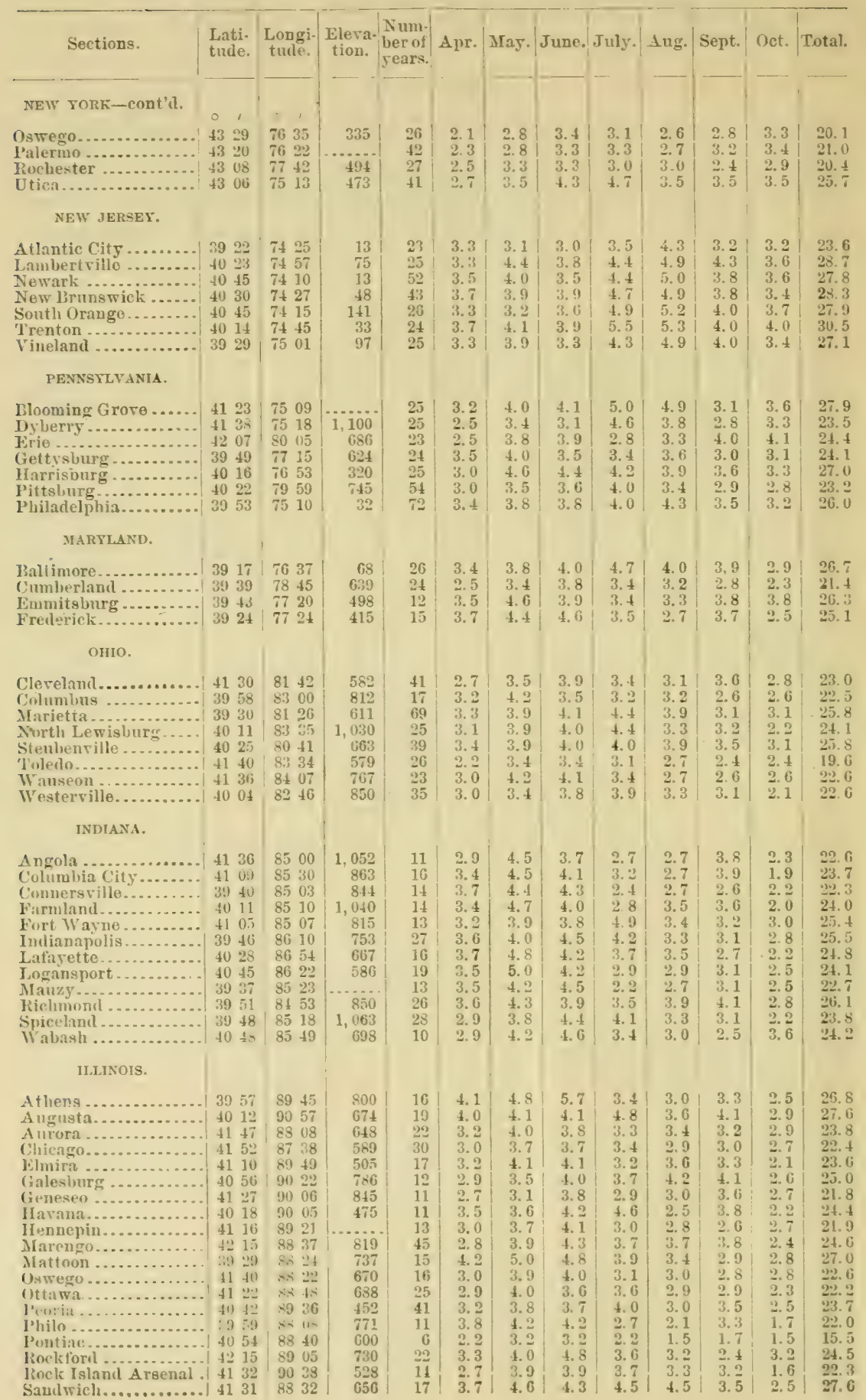


Monthly averagcs of rainfall, Aprit-October-Continued.

\begin{tabular}{|c|c|c|c|c|c|c|c|c|c|c|c|c|}
\hline Sections. & $\begin{array}{l}\text { Lati- } \\
\text { tude. }\end{array}$ & $\begin{array}{l}\text { Longi- } \\
\text { tude. }\end{array}$ & $\begin{array}{l}\text { Elora- } \\
\text { tion. }\end{array}$ & $\begin{array}{l}\text { Numi- } \\
\text { ber of } \\
\text { yoars. }\end{array}$ & Apr. & May. & June. & July. & Aug. & Sept. & Oet. & Total. \\
\hline ITIINOIS- & $0 \quad 1$ & 01 & & & & & & & & & & \\
\hline 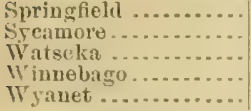 & $\begin{array}{ll}39 & 48 \\
42 & 0() \\
40 & 48 \\
42 & 17 \\
41 & 30\end{array}$ & $\begin{array}{ll}89 & 39 \\
88 & 42 \\
87 & 45 \\
89 & 13 \\
89 & 45\end{array}$ & $\begin{array}{l}644 \\
800 \\
640 \\
861 \\
750\end{array}$ & $\begin{array}{r}17 \\
15 \\
7 \\
18 \\
11\end{array}$ & $\begin{array}{l}3.7 \\
3.6 \\
3.7 \\
3.2 \\
3.8\end{array}$ & $\begin{array}{l}5.0 \\
4.3 \\
5.6 \\
4.0 \\
4.6\end{array}$ & $\begin{array}{l}4.1 \\
5.0 \\
3.7 \\
4.1 \\
4.5\end{array}$ & $\begin{array}{l}2.8 \\
3.6 \\
3.0 \\
3.5 \\
4.2\end{array}$ & $\begin{array}{l}2.4 \\
2.9 \\
2.4 \\
3.2 \\
4.7\end{array}$ & $\begin{array}{l}3.2 \\
3.0 \\
2.9 \\
3.6 \\
4.8\end{array}$ & $\begin{array}{l}2.7 \\
3.1 \\
2.6 \\
2.3 \\
2.4\end{array}$ & $\begin{array}{l}24.2 \\
25.5 \\
23.9 \\
23.9 \\
29.0\end{array}$ \\
\hline 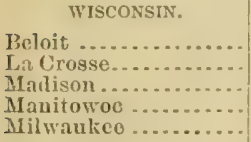 & 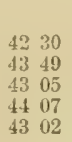 & $\begin{array}{ll}89 & 11 \\
91 & 15 \\
89 & 24 \\
87 & 46 \\
87 & 54\end{array}$ & $\begin{array}{l}711 \\
657 \\
857 \\
593 \\
591\end{array}$ & $\begin{array}{r}30 \\
24 \\
28 \\
33 \\
53\end{array}$ & $\begin{array}{l}2.9 \\
2.4 \\
2.6 \\
2.4 \\
2.8\end{array}$ & $\begin{array}{l}3.2 \\
3.3 \\
3.5 \\
2.6 \\
3.4\end{array}$ & $\begin{array}{l}4.0 \\
4.5 \\
1.5 \\
3.6 \\
3.8\end{array}$ & $\begin{array}{l}3.5 \\
4.0 \\
4.0 \\
3.5 \\
3.2\end{array}$ & $\begin{array}{l}3.6 \\
3.2 \\
3.1 \\
3.2 \\
2.7\end{array}$ & $\begin{array}{l}3.4 \\
4.2 \\
3.1 \\
3.0 \\
3.0\end{array}$ & $\begin{array}{l}2.5 \\
2.3 \\
2.6 \\
2.6 \\
2.2\end{array}$ & $\begin{array}{l}23.1 \\
23.9 \\
23.4 \\
20.9 \\
21.1\end{array}$ \\
\hline MCUIGAN. & & & & & & & & & & & & \\
\hline 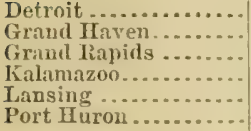 & $\begin{array}{ll}42 & 20 \\
43 & 05 \\
42 & 57 \\
42.20 \\
42 & 44 \\
43 & 00\end{array}$ & $\begin{array}{ll}83 & 03 \\
86 & 18 \\
85 & 40 \\
85 & 38 \\
84 & 32 \\
82 & 26\end{array}$ & $\begin{array}{l}580 \\
593 \\
601 \\
770 \\
836 \\
584\end{array}$ & $\begin{array}{l}46 \\
25 \\
14 \\
20 \\
33 \\
22\end{array}$ & $\begin{array}{l}2.6 \\
2.6 \\
2.8 \\
2.6 \\
2.4 \\
2.1\end{array}$ & $\begin{array}{l}3.1 \\
3.4 \\
3.6 \\
4.4 \\
3.4 \\
3.4\end{array}$ & $\begin{array}{l}3.8 \\
3.8 \\
4.2 \\
4.5 \\
4.0 \\
3.5\end{array}$ & $\begin{array}{l}3.6 \\
2.8 \\
2.4 \\
3.2 \\
3.1 \\
2.4\end{array}$ & $\begin{array}{l}2.6 \\
2.7 \\
2.4 \\
2.6 \\
2.7 \\
2.6\end{array}$ & $\begin{array}{l}3.0 \\
3.6 \\
3.4 \\
3.2 \\
2.9 \\
2.6\end{array}$ & $\begin{array}{l}2.6 \\
3.2 \\
2.5 \\
2.8 \\
2.5 \\
2.8\end{array}$ & $\begin{array}{l}21.3 \\
22.1 \\
21.3 \\
23.3 \\
21.0 \\
19.4\end{array}$ \\
\hline
\end{tabular}

\section{STUDY OF PARTICULAR LOCALITIES,}

Norti Carolina and West Virginia.

The elerater areas of the mountain regions of North Carolina and West Virginia afford conditions of temperature and precipitation which are favorable to the growth of sugar beets. The rongh and momntainous character of this portion of the country, however, presents mechanieal difficulties in cultivation of suficient magnitude to warrant the statement that the beet industry on a large scale is not likely to be established within it. A portion of the region specitied has a mean ammual rainfall of more than 50 inches, while the most of it is supplief with a rainfall of 46 inches. It is not probable, on aceount of the consideration mentioned above, that the beet-sngar industry, on a seale of any magnitude, will ever be established in the regions speeified.

EASTERN Sirore of MARYland.

The isotherm of $71^{\circ}$ enters Maryland at a point about the center of the Atlantic coast of the eastern shore, and runs north by northcast almost to l'onghkeepsie, N. Y. It is evident, therefore, that the temperature conditions of this region are similar to those on $\mathrm{or}^{\circ}$ sonth of the isotherm of $71^{\circ}$ in other parts of the enuntry, althongh here in this area the region lies to the west of this isotherm. Judged by this factor, and also by the mean ammal rainfall, which is 40 inches for this locality, the enltivation of the sugar beet might be successfully inangurated along the Atlantic coast of the eastern shore; in fact, practically over the whole of the southern portion of the eastern shore of Maryland. The eharacter of the soil in this locality is mostly sandy, and its natural fertility has been considerably diminished by long years 
of enltivation. There is no reason to donbt, howerer, the fact that with proper fertilization and cultivation the requisite degree of fertility for the production of sugar beets could be secured. The general tend. ency in this region is in the direction of a too ligh temperature and too few hours of sunshine. The above observatious apply also to Accomac County, Va.

\section{DELATHARE.}

The observations which have been made in regard to the eastern shore of II aryland also apply to the eastern region of Jelaware. (On account of the ravages of the "yellows" among the peach orchincis of southern Delaware, it might he worth while for the agrisultural experiment station to make a careful survey of the sontheastern portion of the state with reference to the possibility of producing sugar beets of the resuisite degree of saccharine strength. The surface of the soil is generally level; a good deal of it is of a sandy nature, and so far as its plysical properties are concerned, it may he regarded as favomalle to beet growth.

\section{NEW JERSEY.}

The mean isotherm of $71^{\circ}$ degrees passes northwarl almost parallel to the Atlantic coast of New Jersey, and at varying distaned therefrom. The part of New Tersey lying betreen this isotherm and the seacoast is mostly composed of sandy soils, reasomably level. There are no mechanical diftenties of any magnitude connedes with the eulture of the beet, and the problem of fertilization of the soil is one which is easily solved. The same observations in regatrd to possibilities of beet eulture may be made of this region of New Jervey an have been made in respect of Maryland and Delaware. This general obser. vation relating to the whole may be added:

We have in this area a mean summer temperature of 710. In $n$ place does it reach the isotherm of 70 . 'The whole region may there. fore be regarded as representing that of a maximum temperature ("ompatihle with beet cullure. It may be further said that the culture of the heet should only be pushed sonth and beyond the isotherm of 71 , where pervliar natural advantages, inderendent of thermal factors, are afforder. These natural advantages eonsist of exceptionally firtile soil, favorable contour of the surface, cheapness of fucl, falcilities firr transportation, ete. I lare portion of the region which has lreen mentioned is devoted to truck farming for the madeets of large citien, and it is doubthul if this remunerative form of agrienlture condel l: replaced suecessfinly with sugar-beet enlture in competition with more? northern localities, where rieher beets can be prolueed. Nevertheless, the possible produetion of fariry good berts in the resgion indieated must be admited fiom the point of view of temperature and presipitation alone. 
CONNECTICUT.

It will be observed that, both in respect of precipitation and temperature, the whole of Comnecticut may be rewarded as lying in the beet belt. From theoretical considerations, therefore, it conld be predieted that beets grown in Connecticut wonld show a satisfactory content of sugar and possess a high purity. So favorable are the theoretical conditions in that locality that it would be advisable for the agrieultural experiment stations of the state to make a systematio agricultural survey of the possibilities of growing beets. The valley of the Commecticut liver affords a fertile tield of experiment where the mechanical conditions of culture and the natural conditions of the soil are factors which favor success. There are large areas of the State, however, so broken in contour as to render the possibilities of beet culture unpromising, but wherever large bodies of fairly level land with good fertility can be found it is fair to presume that the culture of the sugar beet would be attended with success. Conditions which obtain in Connecticut are also found in the State of Rhode Island, althouglt a portion of that State lies north of the isotherm of 69 ? As will he seen firther along, however, in discussing the conditions of growth in New York, there are many localities in the Cnited States north of the isotherm of $69^{\circ}$ where beets fiourish; in fact, it may be said that the posisibilities of growing beets north of the isotherm of 69 , where real. sonably mild autumns can be expected, are nuch better than south of the isotherm of $71^{\circ}$.

\section{Massacinusertrs.}

The valley of the Connectient, in the State of Mastachusetts, foubtless affords as fine fucilities for beet culture as in the State of Connerticut. The greater part of the State lies north of the isstherm of 69. As in the case of Connecticut, there are doubtless many regions in this state north of the isotherm of $69^{\circ}$ where, owing to the rinild antumns, the sugar beet may be expected to grow satisfactorily for sugar-making purposes. A large part of the state is mutitted, by reason of its contour and the nature of the soil, for the culture of beets, but at least the Connecticut Valley and similar stretehes of soil might be nsed to good advantage for this purpose.

\section{New Hampsimte and Verriont.}

These States, lying north of the isotherm of 69 , will have to contend. in the growth of beets with the shorter growing season and less hean for the three months of June, July, and August for forcing the liects to maturity. Nevertheless, it is doubtles true that for a distance of 100 miles, or even more, north of the isutherm of $69^{\circ}$ beet culture could be practiced with success on account of the longer summer days. Samples of beets received from Vermont and analyzed in this laboratory show 
favorable contents of sugar, and high purities. Those grown also at the experiment station of Vermont, as will be seen farther on, afford enconraging data. The thing to be feared in these localities is not inability to grow a beet rieh in sugar, but the possibility of being able to harvest and secure it proprerly before the advent of winter. These areas do not enjoy the immunity fiom sudden changes of temperature, due to the lake breezes, which is characteristic of the great plain of the State of New York between Albany and Buflilo.

\section{NEW YORK.}

In this state we have a remarkable variety of ther" lal conditions. The mean isotherms of 690 and 702 lass in a sonthwesterly direction from Albany into the State of Pennsylvania, following, in general, the trend of the ranges of the Allegheny Nomntains. The influence of these high altitudes is seen in foreing these isotherms to the sonth. 'The southeastern portion of the State of New York lies, therefore, within the belt of isotherms peculiarly favorable to beet culture, with the exception of the valley of the Ifudson from a point a few miles above Poughkeepsie to the mouth of the river. 'This valley, including the city of New York, has a higher temperature than that deemed most suitable to beet culture. As this valley is, however, multed by reason of its contour to the eniture of beets, the above fact is of little importance. Passing to the west of Albany, the mean summer temperatures for the three months of June, July, and August are considerably below the standards which have been mentioned until the region immediately east of liochester is reached, where again we find a mean isotherm of $70^{\circ}$, and about Palmyra of almost 71 ? South. west of this the mean temperatures of the summer are again below 69 ? Nevertheless, a fairly satisfactory agricultural survey of this region has shown that it is capable of producing beets of high quality; and the eflects of the lake breazes upon the climate have donbtless much to do with this condition. For instance, in regions in this area where the mean summer temperature is below bgo the antumns are lar nome mild than in the similar regions in Mimesota, so that the months of October and November an both be relied upon with great certainty for securing the harvest of the heets. Is has heen before mentioned, we have in this region a nearer approateh to the eonditions of bect growing in northern Europe than in any other place in the Uniter States. This whole region, therefore, nust be considered and imblnderl in the areat of onr comntry where the theoretical conditions, and where the actual conditions, of temperature and preeipitation firsor the pro. duction of a beef of high saceharine content. If we should leave out of the calculation the sonthern deflection of the isotherms of ton and Fo? , due to the Appalachian system, and connect directly the area, in the neighborhood of Rochester, where these temperatures obtain, with Albany, neglecting the intermediate temperatures, we should have the isotherms oecupying practically the same position in this new mal that 
they were made to ocenpy in the former maps furnished by the Signal Ofince for this llepartment. In the absence of definite information on the subject, it is fair to presume that the former maps were made in this way, and this accounts for the discrepancy in the position of the isotherm of $70^{\circ}$ found in these maps and in the one now presented. Abundant experimental data go to show that the total area of the Siate of New York south of Saratoga is well suited to the growth of beets, wherever the physical conditions of contour are firorable and the soil suitable. The map of the beet area has therefore been extended so as to include this regiou in the beet belt.

Pennsyivania.

$A$ large portion of the State of Pennsylvania, from the thermal point of view alone, is well suited to the grow th of beets. The position oecupied by the belt of territory ineluded between the isotherms of 69 and 71 , however, in the State of Pennsylvauia indicates an area which, for physical reasons, is mostly unsuited to beet culture, as it covers principally the mountainous region of that State. The northwestern part of the State, especially the portion bordering on Lake Erie, has the same favorable conditions for beet culture as are found in the great valley of the State of New York; and the principal development of the industry in that State, for the physieal reasons mentioned above, wust be looked for in that section. South of the isotherm of $71^{\circ}$ there may be favorable regions in the sonthern and eastern purtions of the State, but the altitude has pusherl the isotherms too far south to look for the best results in the sonthwestern part of the State, on account of the shorter days due to the more sonthern latitude. Where conditions of contour and fertility of soil are favorable, the whole portion of P'ennsylvania north and west of the isotherm of $71^{\circ}$ may be regarded as favorable to beet culture. The precipitation immediately west of the Allegheny Momtains is not so great as on the east, lut there is an area in the extreme northwestern part of the State where the mean average precipitation is nearly the same as that east of the mountains, namely, between 40 and 50 inches.

\section{OIIIO.}

The northeastern and northern parts of Ohio are well sitnated for beet culture. In general, the contour of the land is fitvorable, being reasonably level, and the soil is fairly fertile. The conditions in these localities are fairly comparable with those in the State of New York, except that the mean temperature is higher, the mean isotherm of 70 ? running in a north westerly direction across the northern part of Ohio and entering the lake near Saudusky. It is probable also that to a considerable distance south of the isotherm of $71^{\circ}$, good beets can be grown, but where so large au area is found with more favoring climatic conditions, it is not well to push the industry too far south until more favorable localities are fully exploited. 


\section{Michigan.}

A large part of the sonthern peninsula of Michigan is directly in the heart of the beet belt. The contour of the soil is also fiuvorable, being reatioubly level, with an average fertility, and the data which have been secured in actual experiments in those regions are of the most encouraging kind. There seems to be no doubt of the fact that this locality is anong the best in the United Slates for beet culture, and the modifying influence of the lake on the autumnal relimate must not be lost sight of.

INIDANA.

The northern counties of Indiana, especially the northwestern, are situated in the beet area, and it is probable that the culture of the beet may be extended southward, as in the case of Ohio, as far as fort Wayne and Iafayette, although it is not arlvisable for intending investors to locate in the more southern areas until the more northern have been fully exploited. The agricultural survey of the northern part of the state, mulertaken by the experiment station at Lafayette, in conjunction with the work of this Department, will inclicate finally with more aceuracy than a mere theoretical maj the most favorable conditions of culture. Great interest has been manifested in Indiana in the extreme southwestern portion, near Fvansville, in the culturo of the beet, and, as will be seen in the following data, many samples have been secured from that portion of the State. In many respects this region is most lavorable to beet culture, particularly on account of the facilities for transportation, cheapness of fuel, and the fertility of the soil. The mean summer temperature, however, is so high as to canse grave doubts conceruing the future success of beet growth in that locality.

The soil in northern Indiana is much like that of Michigan-sandy, reasonably level, and fairly fertile-and there is reason to believe that an industry profitable both to the farmer and manufacturer may grow up in that part of the country.

ILLINOIS.

The northern part of Illinois is in the beet-sugar belt, and the conditions in respect of eontour of the surface and fertility of the soil, fircilities and cheapness of transportation, ete, are excellent for the sugar-beet industry. Tho elaracter of the soil in northern Illinois, lowever, is quite different from that of northern Intianis and the southem peninsula of Michigan. It is mostly a prairie soil, dark and moderlat with clay, so that the physical conditions of culture are probably not so favorable as in the other sections just named.

WISCONSIN.

Sonthern IVisconsin oceupies a most firvorable position for beet culture, and the data which have been obtained from that state by the agricultural experiment station at Malison, in conjunetion with the 
work of this Department, are favorable, and show great possibilities of success for the industry in that region. We begin to notice here the effects of the southwestern breezes in foreing northward the isotherms of $70^{\circ}$ and $69^{\circ}$, and these hot breezes ent off from the culture of the beet large areas where soil and other conditions are extremely fuvorable. The same remark should be applied to the belt of country immediately south of the isotherm of $71^{\circ}$ that has heretofore been made, namely, that there are doubtless many sections where the successful culture of the beet may be secured. This is dependent upon local conditions which must be determined by careful agrieultural surveys in the future.

\section{MinNesota.}

The deflection in a northwesterly direction of the isotherms of $70^{\circ}$ and $69^{\circ}$ includes in the sugar-beet area a large portion of the State of Minnesota, especially the southeastern portion. Here there is no question of the growth of the crop and the production of beets of high saccharine qualities. The great point to be feared in this locality is the early approach of winter, and this is true of all the cis-montine western regions. We find here a drop in the rainfall from an annul average of 30 to 40 inches to one of from 20 to 30 inches. We therefore meet here a greater possibility of suffering from a dry season than in the regions of the East. As a rule, however, the quantity of rainfall during the growing season is sufficient for the production of a good crop.

Iow A.

A remarkable deflection of the isotherms of $69^{\circ}$ and $70^{\circ}$ is noticed in passing from Minnesota to Iowa. Not only are these isotherms deflected toward the south, but they actually take a back ward course toward the east, so that their direction for a considerable distance is east of south. 'This brings the theoretical beet belt, so far as temperature is concerned, almost through the center of the State of Iowa. The well-known fertility of the soil of this State, with the generally level character of the surface, shows that the agricultural possibilities for the growth of sugar beets are great. In the greater part of the State the rainfall reaches 30 inches per annum, but in the northwesteru part the approach to the arid region is shown by a dropping off of the average rainfall, so that it is between 20 and 30 inches. Nevertheless, experience shows that, as a rule, a sufficient rainfall is provided in all parts of the State for the growth of ordiuary agricultural crops. The isotherms of $69^{\circ}$ and 70 , after passing partly across the State of Iowa, take a sudden turn toward the north and west and pass ont of the state again into Minnesota, where they reach a more northeru latiturle than Minneapolis. With the exception of the sonthwestern comuties of Iowa it is fair to presume that almost the whole of the area of the State, in so far as thermal conditious and rainall are concerned, is H. Doc. $396-3$ 
suited to the growth of beets. Of course, in this matter, it should be rememberer, that local conditions of soil, transportation, fuel supply, and other factors must be taken into cousideration. Iowa also oceupies a position where there is no tempering influence of the northwestern winds, so that it begins to feel the rigors of the winter at an earlier clate than is experienced on the same isotherms east of the Great Lakes.

\section{NorTh AND SOUTH DAKota.}

The conditions which prevail in North and South Dakota are somewhat unique. From the highest position attained in Minnesota, at the border line between that State and North and South Dakota, the isother'm of 690 turns again east and south and suflers a considerable deflection, due douhtless to the lower altitude of the Red River Valley. Passing, however, into Dakota the isotherms are rapidly pushed northward by reason of the hot sonthwest winds which are so often experiencer in the summer time in those localities. For these reasons the isotheru of $69^{\circ}$ reaches almost as far north as Bismarck, and the isotherm of 70 is ouly a few miles south of it. From this point the isotherms of $69^{\circ}$ and $70^{\circ}$ run almost due south from North Daliota entirely across the State of South Dakota and into Nebraska. The most favorable beet-sugar belt, in so far as the temperature alone is concerned, would be the area bounded by the isotherms of 71 and 69 degrees, oceupying a belt of considerable breadth rmuing north and south through South Dakiota into North I)akota, and southeast through Torth Dakota back into South Dakota. The depression due to the Missomi River causes an area of higher temperature to extend in a northresterly direction into South Diliota. This area, although perlaps not so favorable to beet growth as the other, is still situated in a fertile country, ani doubtloss has many advantages for growing beets not possessed by the higher lands to the east and rest of it. There is no question of the ability of both the regions within the area sperified to grow beets of fine saccharine strength. Abundant experimental data have bcen secured from both the States to substantiate this statement. Caution, howerer, must again be given in regard to the sudden alvent of the winters, especially in North Dakota, where sometimes in October, and usually in November, temperatures approaching zero or even below zero, degrees Fahrenheit, are observed. These sudden falls of temperature mould prove disistrous to the beet han vests, and hence tend to restrict to a certain degree the spread of the industry in that comitry. Again, attention shomld be aalled to the fint that the whole of the areas in the two Dakotas, where the thermal comblitions are best suiter to beet culture, has an average ammal rainfall of ouly from 15 to 20 inches. The danger of drought and the possible shortage or loss of the corop from that source are therefore incerased, and we begin to approach an area where artificial irrigation must be looked to in many seas(f) Probably, however, in the majority of seasons the mainfall in this vicinity would be sufficient to secure a good crop. 
Nebrasisa.

A study of the position of the isotherms shows that the best part of the State of Nebraska, both as respects soil and rainfall, has an average temperature of more than 710 during the summer months. The most favorable conditions of temperature are found almost in the center of the State over an area of somewhat irregular shape, and occupying a position where the extreme distance separating the isotherms of $71^{\circ}$ and $69^{\circ}$ is the greatest of any in the country. In Nebraska the two isotherms of $69^{\circ}$ and $70^{\circ}$ run almost parallel, but the isotherm of $71^{\circ}$ runs first in a southeasterly direction, then almost south, and finally almost due west, forming a stomach-shaped area occupying a portion of Dakota and the central portion of Nebraska. The agricultural and analytical data which have been obtained in Nebraska are very extensive, and it will be observed that both of the sugar factories which have been established in that State are south of the limit of $71^{\circ}$. It has been observed also, by those who have had access to the analytical data of these two factories, that the saccharine contents of the beets which have been delivered to them have not been equal to those of beets grown in more favorable localities in the United States. On the other hand, the insufficiency of the rainfall in the central and western portions of the State renders less certain the growth of sugar beets, and tends to crowd the sngar factories and the sugar industry into the wetter and more fertile portions, in spite of the fact that the temperature is higher.

\section{The ARID Regions.}

It will now be necessary to trace the theoretical sugar-beet belt, so far as thermal conditions are concerned, by States throngh the arid regions. There is so little of the area embraced in this belt which is subject to irrigation, that it is understood at once that the possible beetsugar industry of that region must be confined to the most favorable localities. It is interesting to see, however, how the elevation produced by the Rocky Mountain range deflects the isotherms which have been traced in a generally westerly direction up to this point so far to the south. Passing from Nebraska, the isotherm of $70^{\circ}$ runs in a southwesterly direction to a point southwest of Denver, whence it turns in a sontheasterly direction to New Mexico, thence almost due sonth to near the Mexican border. Being deflected to the west, it ascends on the other side of the Rocky Mountain range in a general northerly and westerly direction, passing in a northwesterly direction through Utah, thence turning west and south in Nevada, being deflected again to the sonth by the Sierra Nevarla range of mountains, which it crosses, passing from Nevada into California, whence it passes northward again along the western slope of the Sierra Nevada Mountaius until it comes near the coast line in the northern part of California. Thence the isotherm of $70^{\circ}$ is defleeted southward, almost parallel with the coast line, until it passes into lower Califoruia. It is seen that all the coast; 
valleys of California are included in the thermal belt most favorable to beet culture. The greater part of the area included in the thermal belt which has just been traced across the arid region is totally unsuited, on account of the mountainous and rough region of the surface, for agricultural uses. It is therefore evident that it is only in isolated places, where the surface of the land is smooth and irrigation can be practiced, that beet culture can be established. In connection with the thermal belt, the map shows that the mean average rainfall in many cases does not exceed 5 inches per annum.

In addition to the continuous belt this marked out, there are some areas of varying temperature which demand attention, as, for instance, the elliptical area bounded by the isotherm of 700 in Idaho, of which Boise City is the center, and another area bound " by the isotherm of $70^{\circ}$, within which an isotherm of $71^{\circ}$ is found, in the State of Washington. There is also one locality in Montana, on the Yellowstone River, where the average summer temperature is 710 .

In so far as thermal conditions are concerned, vast areas of the arid regions could be devoted to beet culture if the other conditions of culture were favorable. The differences of elevation of the plateaus cause numerous sudden changes of temperature, so that there are dloubtless many localities not marked on the map where the mean sunmer temperature is almost identieal with that which has been already mapped out. By reason of the meagerness of data, experimental and otherwise, relating to this whole region west of the Missouri River, the shading showing the jrobable extension of the beet area beyond the borders of the basic thermal belt has been omitted. The general discussion of this thermal belt, accompanied as it is by the chart of precipitation, is not necessary at this point. In general, in connection with this sturly, the remarks which are marle in Bulletin No. 27 , on page 169, and repented in Farmers' Bulletin No. 52, may be recalled with profit:

The mistake nust not bo made of supposing that all the region included within the boundaries of this zone is suitable for beet culture. IRivers, hills, and monntains occupy a largo portion of it, and much of the rest would be excluded for various reasons. In the western portion, perhaps all but a small part of it would be cxcluted by nonntains and dronght. Beginning at a point midway between the one hundredth aud one hundredth and first meridian, as indicated by the dotted line, beets conld be grown only in exceptional places withont irrigation. On the Pacific coast only that portion of the zone lying near the ocean will bo found suitable for beet culture.

On the other hand, there are many localities lying ontside the indicated belt, both north and south, where donhtless the sugar beet will bo found to thrive. The map, therefore, must be taken to inlicate only in as crencal way those localities at or near which wo should expect snceess to attend tho growth of sugar heots in the most favorable conditions other than temperature alone.

The present map (Plate 1 ) gives in greater detail than ever before the boundaries of this thermal belt, by reason of the fact that the 
observations of the ' Teather Burean have been more numerous, and have been compiled in a more systematic manner. It would be idle to assert that subsequent observations of the Weather Bureau may not change in a marked degree the boundaries of the belt which has been mapped. It is also quite true that the agricultural surveys which will be conducted by the several States will locate definitely, beyond the limits already outlined, the areas where successful beet culture will be practiced. I may venture the prediction, however, that these areas will be contiguous to the zone which is alrearly mapped out, and that the future beet-sugar industry of the United States, when it shall have reached a magnitude sufficient to supply to our people a large part of the sugar they consume, will be located almost entirely within the areas which have thus been traced.

\section{DATA FROM DIFFERENT STA'TES.}

Two methods of collecting the data from States have been pursned. In the first place, those receiving seeds directly from the Department of Agriculture were supplied with Farmers' Bulletin No. 52, giving instructions for preparing the soil, and planting and cultivating the beets. Each person was also supplied with a series of blanks for the purpose of obtaining cultural and climatic data, and for securing as great accuracy as possible in the reports which were made. The data blanks used are represented in the following forms:

United States Departuent of Agriculture, Washington, D. C., August 15, 1897.

Directions for Taking SaMples of Sugar Beets for analysis.

Prepared by H. W. WILEY, Chief of Division of Chemistry.

When the beets appear to be mature (September 15 to November 15 , according to latitude and time of planting) and before any second growth can take place, select an average row or rows, and gather every plant along a clistance which should vary as follows, according to the width between rows:

From rows 16 iuches apart, length 75 From rows 22 inches apart, length 54 f feet.

From rows 13 inches apart, length 66 feet.

From rows 20 inches apart, length 59 feet. feet.

From rows 24 inches apart, length 50 feet.

From rows 28 inches apart, length $422^{9} \sigma$ feet.

The beets growing in the row, of the length above mentioned, are counted. The tops are removed, leaving about an inch of the stems, the beets carefully washed free of all dirt and wiped with a towel. Where the row is not long enough to meet the conditions, take enough from the adjacent row or rows to make up the required length. Rows of average excellence must be selected; avoicl the best or poorest. Throw the beets promiscuously in a pile and divide the pile into two parts. This subdivision, of one-half each time, is continued until there are about ten beets in a pile. From these ten select two of medium size. Be careful not to select the largest or smallest. 
From all of the rest of the beets, save these two, the necks are removed with a sharp knife at the point indicated by the dotted line in the figure (fig. 1). The beets, including the two saved as a sample, are then weighed.

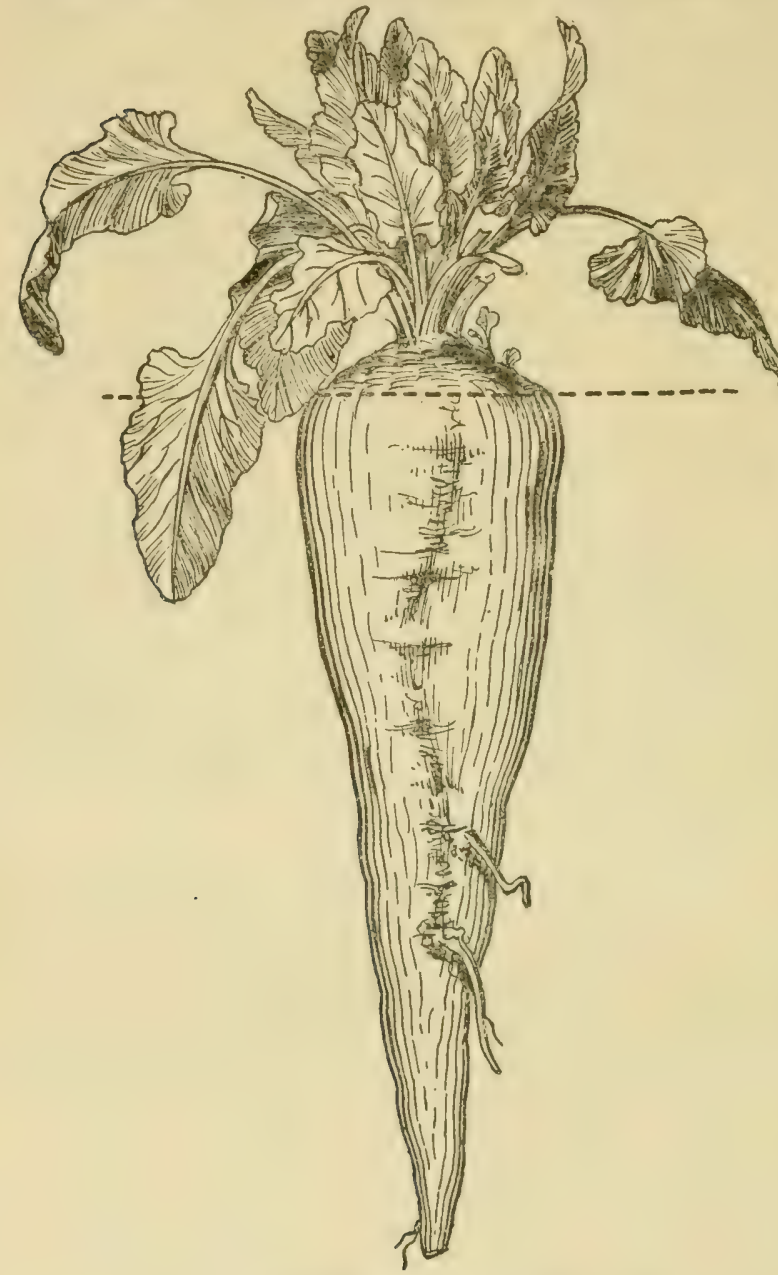

Fra. 1.- Tllustration for remoral of top of beet.

The number of beets Lirvested multiplied by 435.6 will give the total number per acre. The total weight of beets harvested multiplied by 435.6 will give the yield per acre.

Wrap the two sample beets carefully in soft paper, and write your name legibly thereon. The beets must be perfectly dry. Fill out the blank describing the beets, inclose it in the envelope, and sew it up in the bas with the beets. Attach the inclosed shipping taig to the bag and send the package by mail.

No beets will be analyzed which are not sampled as described above and properly identified.

Miscellaneous analyses of samples without accurate description are of no value.

Blanks are sent to each one for two sets of samples. From two to four weeks should elapse between the times of sending the two sets of samples.

If additional analy. ses be desired, other blanks will be sent on application, but not more than four analyses can be made for any one person, except in special cases.

A model, showing how blanks should be filled out, is inclosed.

[Model 13.]

U. S. DEPARTMENT OF AGIRICULTURE.

monel folr Describlng Sample of Sugaj Beets.

Prepared by H. W. WILEY, Chief of Division of Chemistry.

Variety: Kleinwanzlebener.

Date planterl: May 3, 1897.

Date thinned: June 3, 1897.

Dato harvested: November 5, 1897. 
Character of soil: Black prairie loam; in eultivation for 20 years, chiefly in corn; level, tile-drained; last crop, oats; no fertilizer was used; varuyard manure applied in 1895.

Character of cultivation (dates, implements, etc.): Plowed November, 1896, 8 inches deep, subsoiled 6 inches; harrowed with disk harrow May 1, 1897; rolled; seed planted with hand drill one-half inch deep; plants up May 16; stand excellent; hoed by haud May 22; plowed with horse hoe May 28 and June 8, 16, 24, July 3, 10, and 17.

Length of row harvested (feet): 66 .

Width between rows (inches): 18 .

Number of beets harvested: 88 .

Total weight of beets, less necks and tops (pounds): 88 .

Weather for each month: May, dry; June, copious rains; July, fine growing weather; August, hot and dry; September, dry until the 24th, when it heavy rain fell.

State: Iowa.

Post-office: Hanover, Buena Vista County.

Date: November 17, 1897.

Name: Robert Simpsou.

NoTE.-Beets will not be analyzed unless accompanied with description as above.

It is evident that in promiscuons experimentation of this kind, even when directions are closely followed, and when all the operations are conducted in accordance with the direetions in Farmers' Bulletin No. 5:, and the procedure described in the blanks for taking samples faithfully followed, the data are still of an unsatisfactory nature. For instance, when a plot of beets has been harvested and quartered until the two beets required for a sample have been selected in accordance with directions, we still have an uncertainty prevailing as to whether the two beets correctly represent the whole lot. In fact, it is well known that the variations in the character of beets grown side by side are very great, far more so than is the case with sugar canes. As an illustration of this, the following analyses, giving the weight and sugar content of every beet grown in a row at the experiment station of Kentucky, is sufficient evidence:

Analyses of all the beets in a row, Kentucky station.

\begin{tabular}{|c|c|c|c|c|c|c|c|c|}
\hline $\begin{array}{l}\text { Serial } \\
\text { No. }\end{array}$ & $\begin{array}{l}\text { Weight } \\
\text { after } \\
\text { topping. }\end{array}$ & $\begin{array}{l}\text { Sucrose } \\
\text { in beets. }\end{array}$ & $\begin{array}{l}\text { Serial } \\
\text { No. }\end{array}$ & $\begin{array}{l}\text { Weight } \\
\text { after } \\
\text { topping. }\end{array}$ & $\begin{array}{l}\text { Sucrose } \\
\text { in beets. }\end{array}$ & $\begin{array}{l}\text { Serial } \\
\text { No. }\end{array}$ & $\begin{array}{l}\text { Weight } \\
\text { after } \\
\text { topping. }\end{array}$ & $\begin{array}{l}\text { Sucrose } \\
\text { in beets. }\end{array}$ \\
\hline & Ounces. & Per cent. & & Ounces. & Per cent. & & Ounces. & Per cent. \\
\hline 1985 & $\begin{array}{l}27 \\
25\end{array}$ & $\begin{array}{l}7.7 \\
9.9\end{array}$ & $\begin{array}{l}2009 \\
2010\end{array}$ & $\begin{array}{l}8 \\
4\end{array}$ & $\begin{array}{l}8.2 \\
9.3\end{array}$ & $\begin{array}{l}2033 \\
2034\end{array}$ & 10 & $\begin{array}{l}8.1 \\
7.2\end{array}$ \\
\hline 1987 & 24 & 10.4 & 2011 & $\begin{array}{l}4 \\
1\end{array}$ & $\begin{array}{l}9.3 \\
9.9\end{array}$ & $\begin{array}{l}2034 \\
2035\end{array}$ & $12 \frac{1}{2}$ & 9.1 \\
\hline 1988 & 24 & 10.6 & 2012 & 1 & 10.5 & $2036^{\circ}$ & $11^{2}$ & 9.0 \\
\hline 1989 & 20 & 8.6 & 2013 & 2 & 9.6 & 2037 & ui & 9.8 \\
\hline 1990 & 20 & 7.9 & 2014 & $3 \frac{1}{2}$ & 10.9 & 2038 & 9 & 8.8 \\
\hline 1991 & 28 & 6.7 & 3015 & $3 \frac{1}{2}$ & 9.9 & 2039 & 9 & 7.4 \\
\hline 1992 & 31 & 9.0 & 2016 & $34^{2}$ & 8.2 & 2040 & 8 & 9.7 \\
\hline 1993 & 18 & 10.4 & 2017 & 27 & 7.0 & 2041 & 11 & 8.9 \\
\hline 1994 & 24 & 9.0 & 2018 & 20 & 9.3 & 2042 & 8 & 9.3 \\
\hline 1995 & 53 & 4.8 & 2019 & 8 & 11.9 & 2043 & 9 & 6.9 \\
\hline 1996 & 19 & 8.2 & 2020 & 16 & 6.2 & 2044 & 8 & 10.4 \\
\hline 1997 & 33 & 2.6 & 2021 & 22 & 8.0 & 2045 & 7 & 9.4 \\
\hline 1998 & 16 & 9.9 & 2022 & 15 & 6.8 & 2016 & 5 & 8.2 \\
\hline 1999 & 2 & 10.7 & 2023 & 20 & 9.8 & 2047 & 4 & 8.4 \\
\hline 2000 & 2 & 8.8 & 2021 & 26 & 9.0 & 2048 & 5 & 8.6 \\
\hline 2001 & 2 & 9.6 & 2025 & 16 & 9.4 & 20.19 & 4 & 8.7 \\
\hline 2002 & 13 & 8.9 & 2026 & 18 & 9.7 & 2050 & 4 & 10.5 \\
\hline 2003 & 8 & $y .6$ & 2027 & 18 & 6.6 & 2051 & 4 & 9.3 \\
\hline 2004 & 12 & 11.0 & 2028 & 15 & 8.6 & 2052 & 3 & 10.7 \\
\hline 2005 & 6 & 10.5 & 2029 & 11 & 9.3 & 2053 & 2 & 12.2 \\
\hline 2046 & 3 & 11.1 & 2030 & 17 & 4.9 & 2054 & $1 \frac{1}{2}$ & 10.6 \\
\hline 2007 & 5 & 10.6 & 2031 & 12 & 6.8 & 2055 & 1 & 9.9 \\
\hline 2008 & 13 & 10.2 & 2032 & 12 & 6.9 & 2056 & $1 \frac{1}{2}$ & 11.2 \\
\hline
\end{tabular}


The great variations which exist, both in size and quality of beets, are most strikingly shown by the above figures. The variation in size extends from 1 to $\tilde{3} 3$ ounces, and in sugar content from 2.6 to 12.2 per cent. When, however, it is considered that all overgrown and undergrown beets are rejected in taking the samples, and only those of medium size and perfect form selected, it is evident that the chances of the sample representing fairly the average of the whole lot are very much improved. Even granting this, however, it is unsatisfactory to depend upon the analysis of two or three samples alone for determining the character of the whole plot. It is evident, however, that on account of the nature of the method of investigation and the undesirability of burdening the mails with too many samples, it is impracticable to do better than has been done in this matter. The analyses of all of the samples which were sent to the Department of Agriculture from each of the States and Territories are given in the tables which are found farther along. For convenience of reference, the analyses are taibulated by counties in each case.

The second method of collecting data was through the cooperation of the agricultural experiment stations. To facilitate this, the Secretary of Agriculture appointed the directors of these stations special correspondents of the Department for distributing the seed and collecting the beets for analysis. The analyses were made by the chemists of the several stations, and they are given below, grouped under the various States. Where the cooperation of the agricultural experiment stations was secured, the reports are given by the director or officer in charge. Inasmuch as the details of these analyses are published by the various stations, including the mames and residences of the persons who grew the beets, in the present report only the averages of the analyses by counties or sections, together with such observations as have seemed desirable, are given. The reports of the directors and other officers in charge contain much interesting material, aud in some cases are given without abbreviation.

\section{DATA OBTAINED IN TIE LABORATORY OF THE DEPARTMENT OF AGRICULTURE.}

The analytical data obtained during the season of 1597 in the Department of Agriculture have been classified as follows:

The data obtained from each State or Territory collected by counties or sections and the general average for each county are as follows:

The analytical tables showing the data of the Department samples contain the names of the States and counties arranged alphabetically. The name of each county is followed by a symbol in the shape of a square to designate the position of the county in the State. The plain square shows that the county is situated in the central portion, while a straight line attached to the center of the top of the square shows the county is in the northern part of the State; attached in a diagonal 
direction to the upper right-hand corner, that it is in the northeastern portion of the State; attached to the center of the right side, shows it is in the eastern portion of the State; attached to the lower right-hand corner, that it is in the southeastern portion; attached to the center of the lower side of the square, that it is in the sonthern part; to the lower left-hand comer, in the sonthwestern; to the center of the lefthand side of the square, in the western part, and to the upper left-hand corner, in the northwestern.

The tables also state the number of samples received from each county, the average weight of the samples in ounces, the average per cent of sugar in the beet, the average purity coefficient of the juice, and the maxima and minima percentages of sugar in the juice and the coefficients of purity.

In many cases the quantity of juice was too small to compute the purity in the usual way, and in others the low perceutage of sugar rendered the ascertainment of the purity unnecessary. These two reasons account for the omission in many instances of the number express. ing the purity of the juice.

CAUTIONS REGARDING THE VALUE OF THE DATA.

It is highly important that the persons using the analytical data contained in the following tables be cautioned in regard to the value which shonld be attacher thereto. It is evident, in the first place, that samples which have been grown in such a promiscuons way as those received by the Department, in so many different characters of soil, under so many different climatic conditions, and with such variable culture, water supply, and fertilizing maierials, must lack that miformity of value which should characterize scientific data in general. Attention has alrealy been called, moreover, to the fact that the fer samples of beets which have been sent can not be regarded as exactly representing the whole mass of which they originally formed a part. The variations in individuals are so great under practically identical conditions as to render somewhat doubtful data which are based upon a few samples alone. For instance, in the comparison of different States in respect of sugar-producing qualities, it may be that one State is represented by perhaps less than 50 samples, while others may have 500 or 1,000 . In such cases the average of the 50 samples does not in any way present such convincing rlata as the average of 1,000 . The greater the number of samples examined, the more nearly will the disturbing influenees of individuals be eliminated. When it comes to a comparison of the counties in the several States, the same remarks are true. In many instances a county may be represented by a single sample. It may be that the sample is extremely good or extremely poor. In neither ease is it representative. It would be unjust, therefore, to compare a county with one sample with another from which 50, 100, or 200 samples have been received. Even in the averages representing 
the samples from a single county or locality care must be taken not to be misled. The samples may include, for instance, a very small beet with an excessive sugar content, or a very large one with a deficient sugar content. In case ouly two or three samples constitute the whole number, the influence of these abnormal samples is raised to a maximum. As an illustration of this, the analysis of samples fiom Clinton County, Ill., may be eited as a type of many others. Three samples were received from this county, the average weight of which was 13 ounces, and the average sugar content 15.7 per cent. One of these samples, however, weighed only 4 ounces, and had the abnormal sugar content of 21.2 per cent. It is evident, therefore, that the average percentage of sugar in the three samples is very much higher than it would have been had they all been normal in size.

Another point must not be forgotten, and that is, granting that the samples of any locality are representative, they represent only one season. That season may have been peculiarly favorable or unfavorable, and hence no section should be judged by the results of a single year's experiment. The reader who wishes to study critically the data which follow must take all these facts into consideration, and the judgment which he may form in regard to any particular section must be subject to the rectificatious indicated by the variable factors mentioned above. 

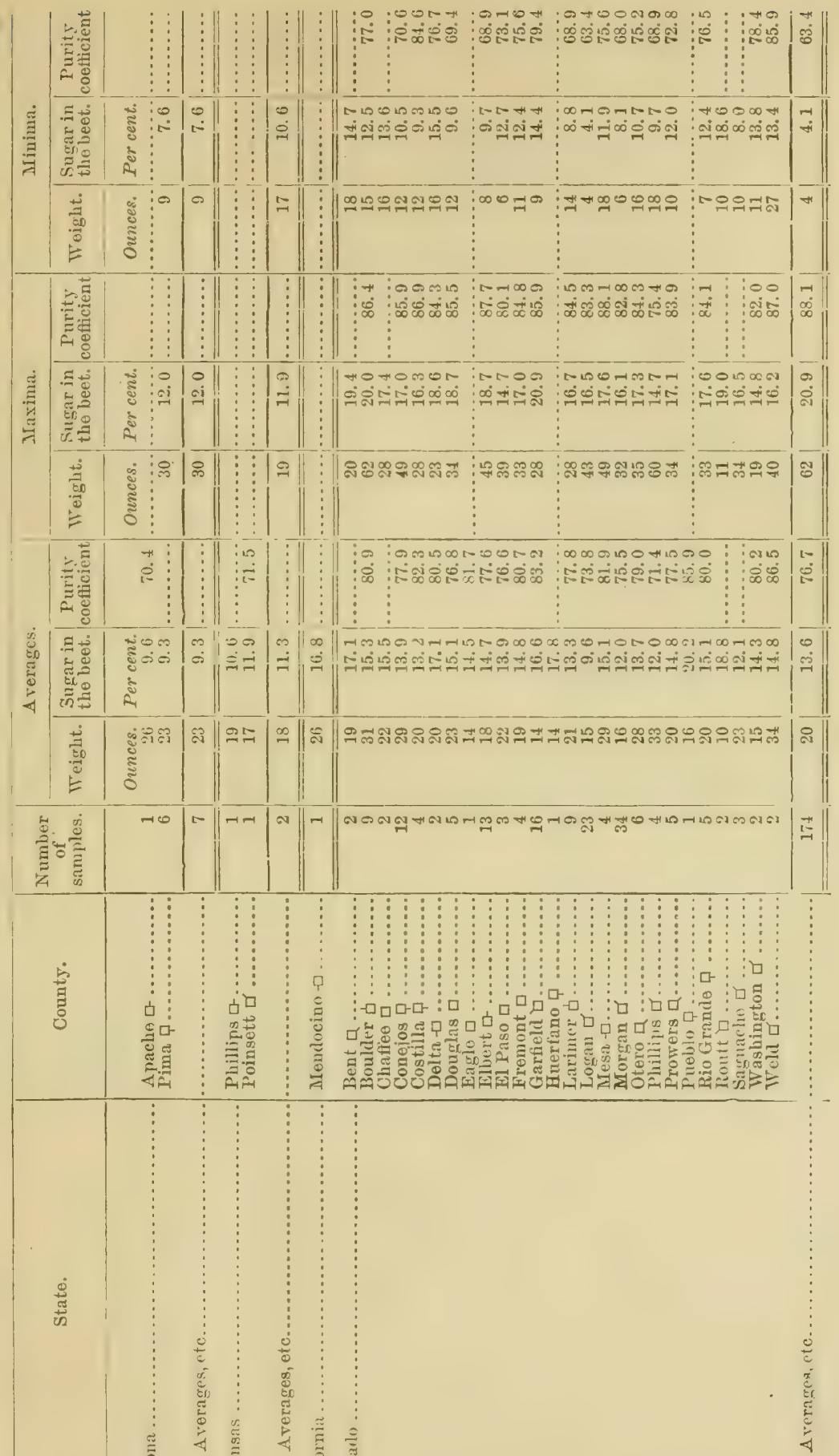


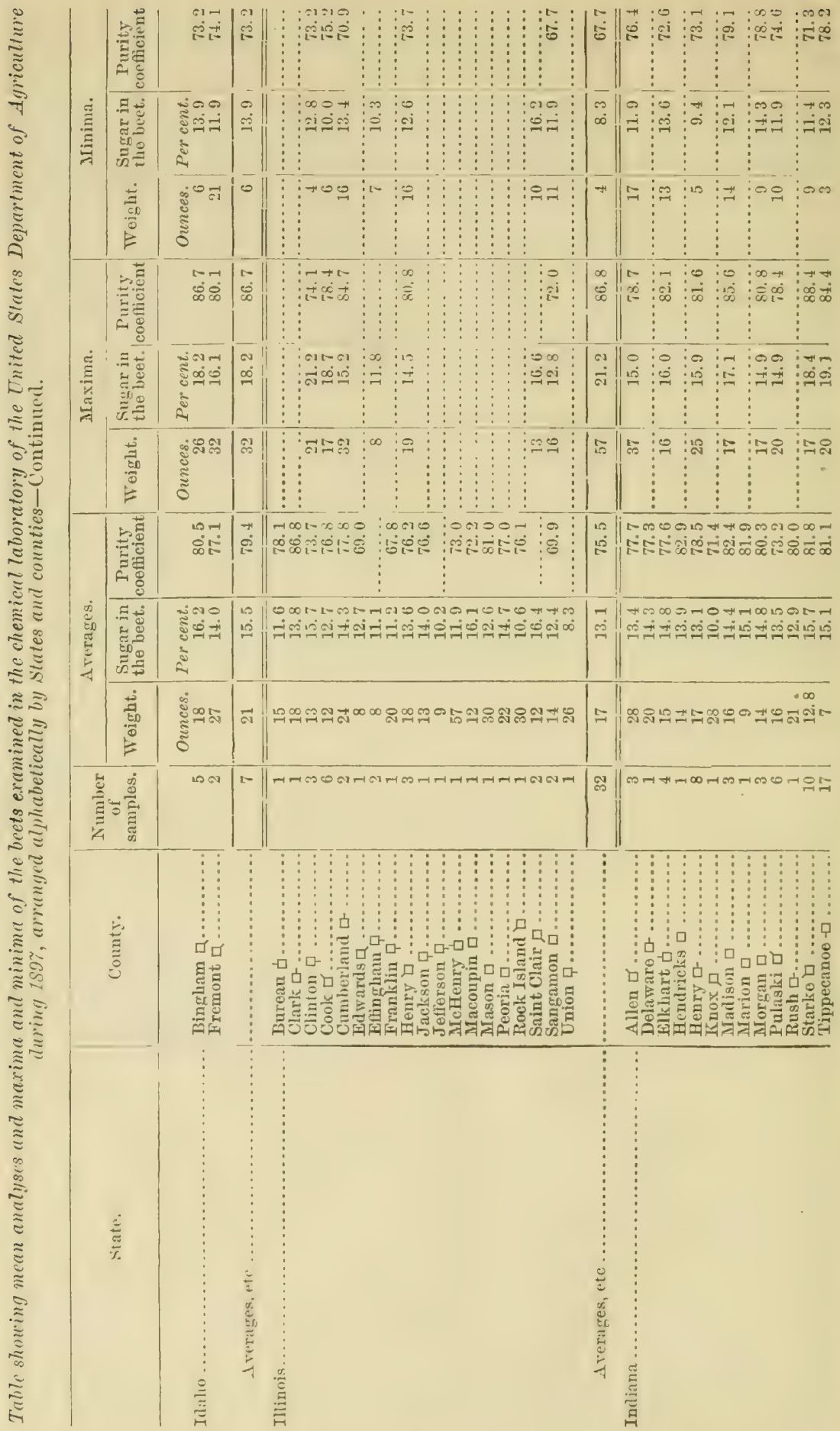




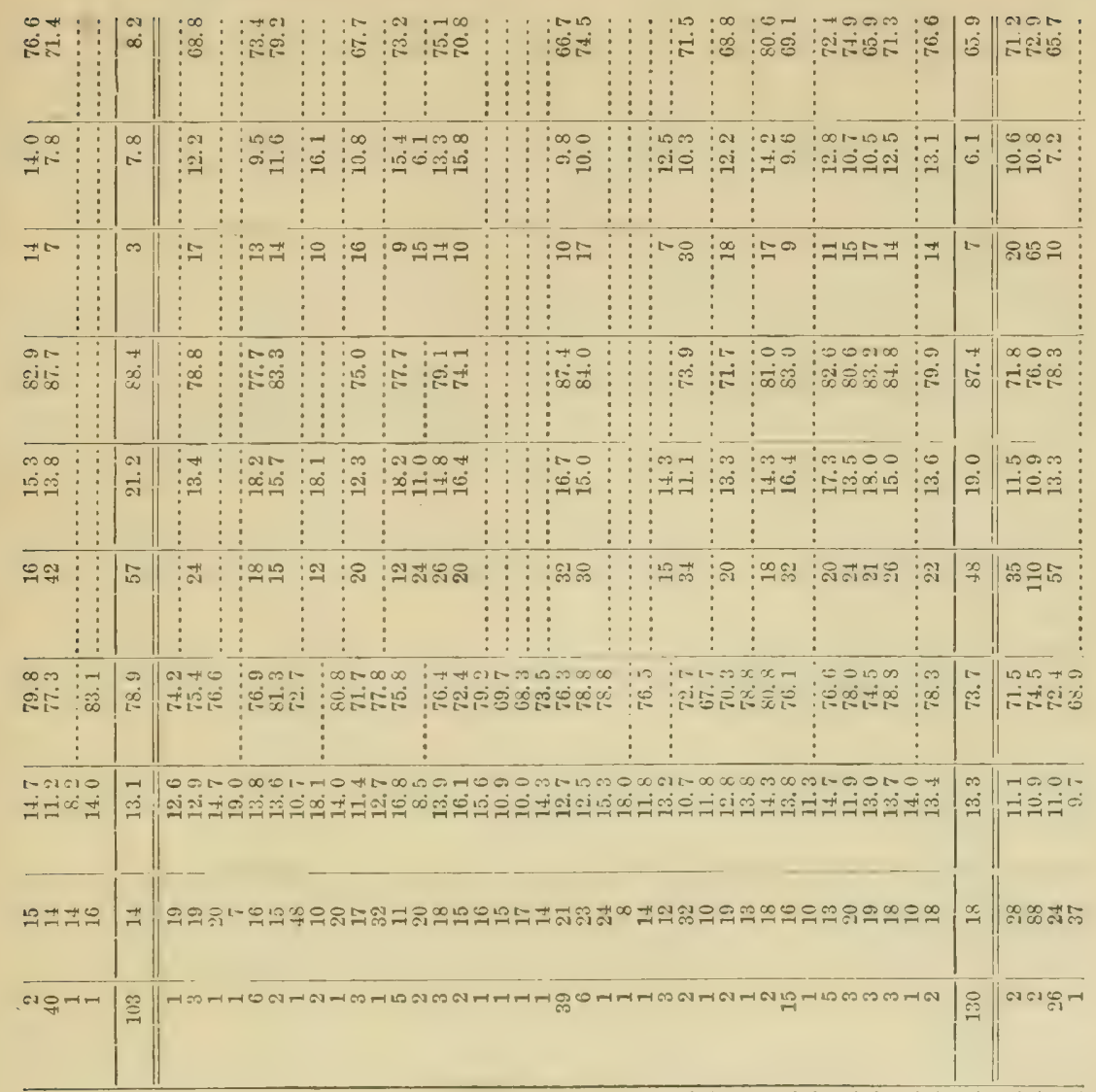

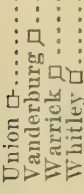
1
0
0

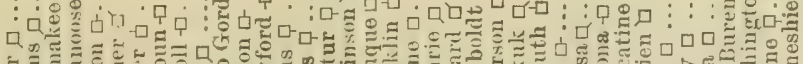

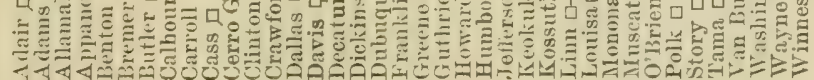




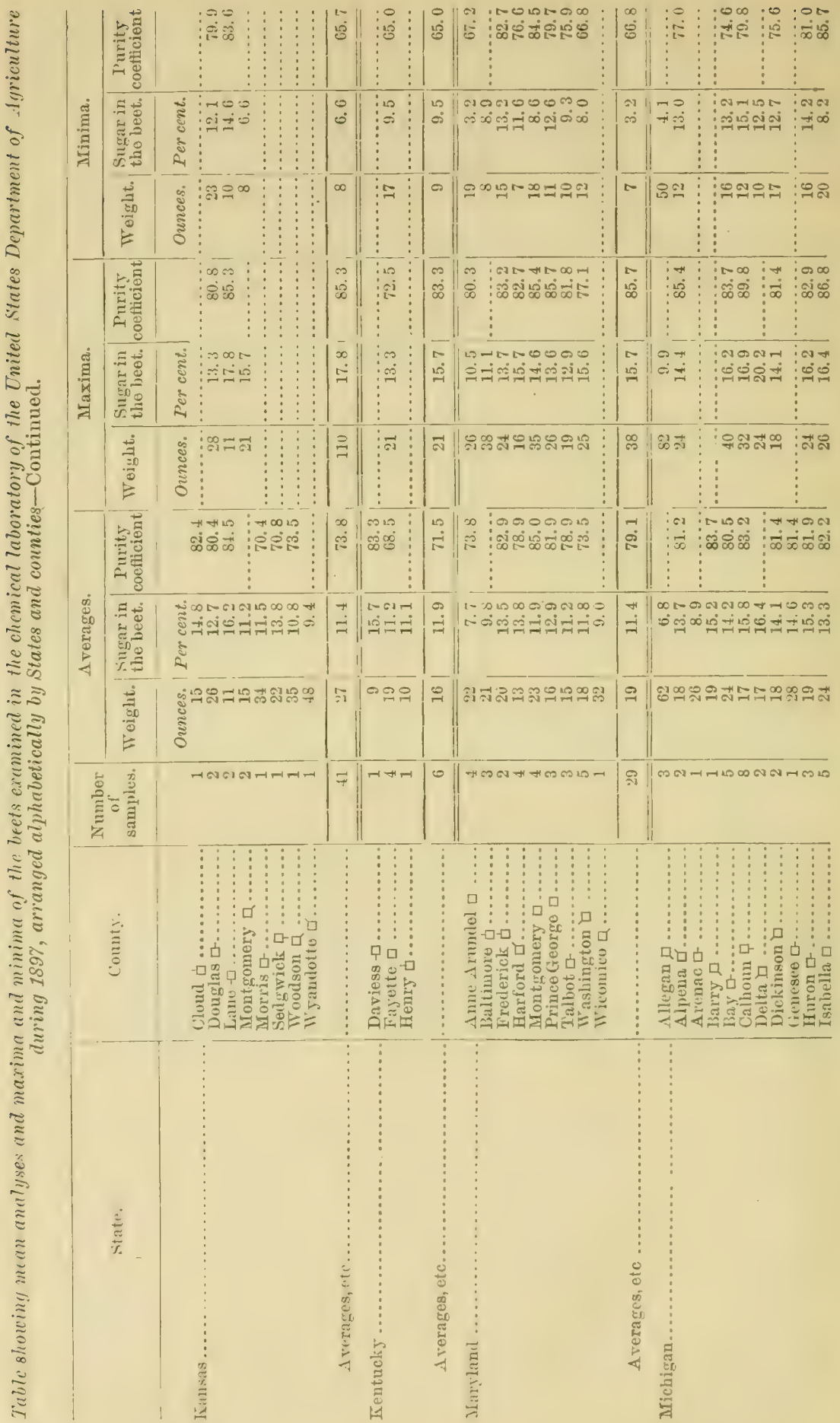




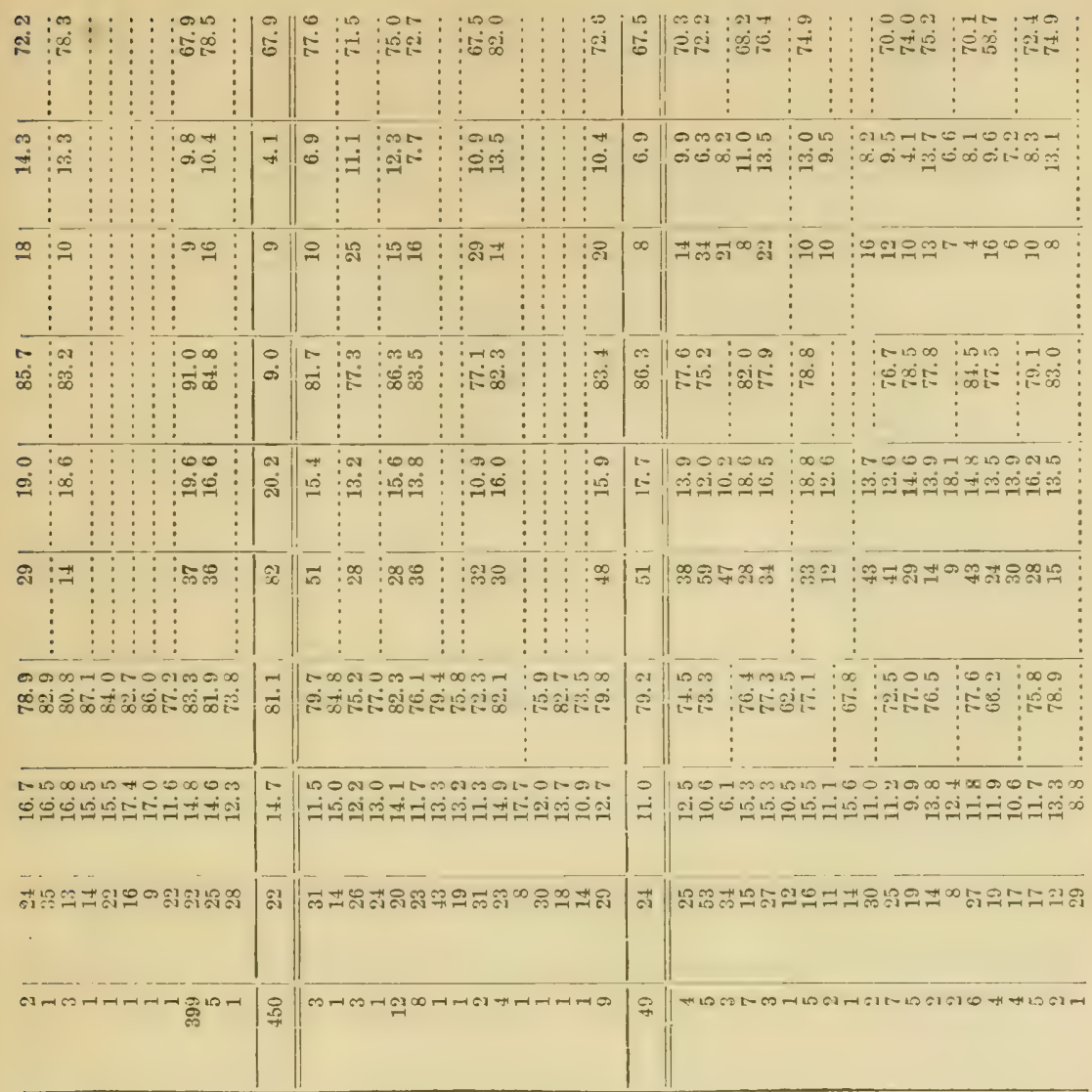

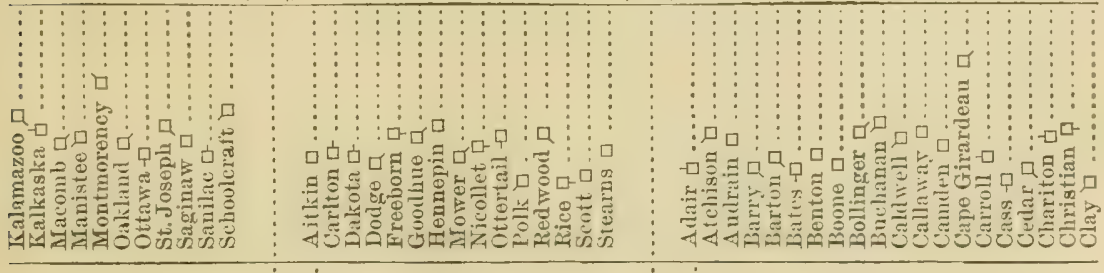




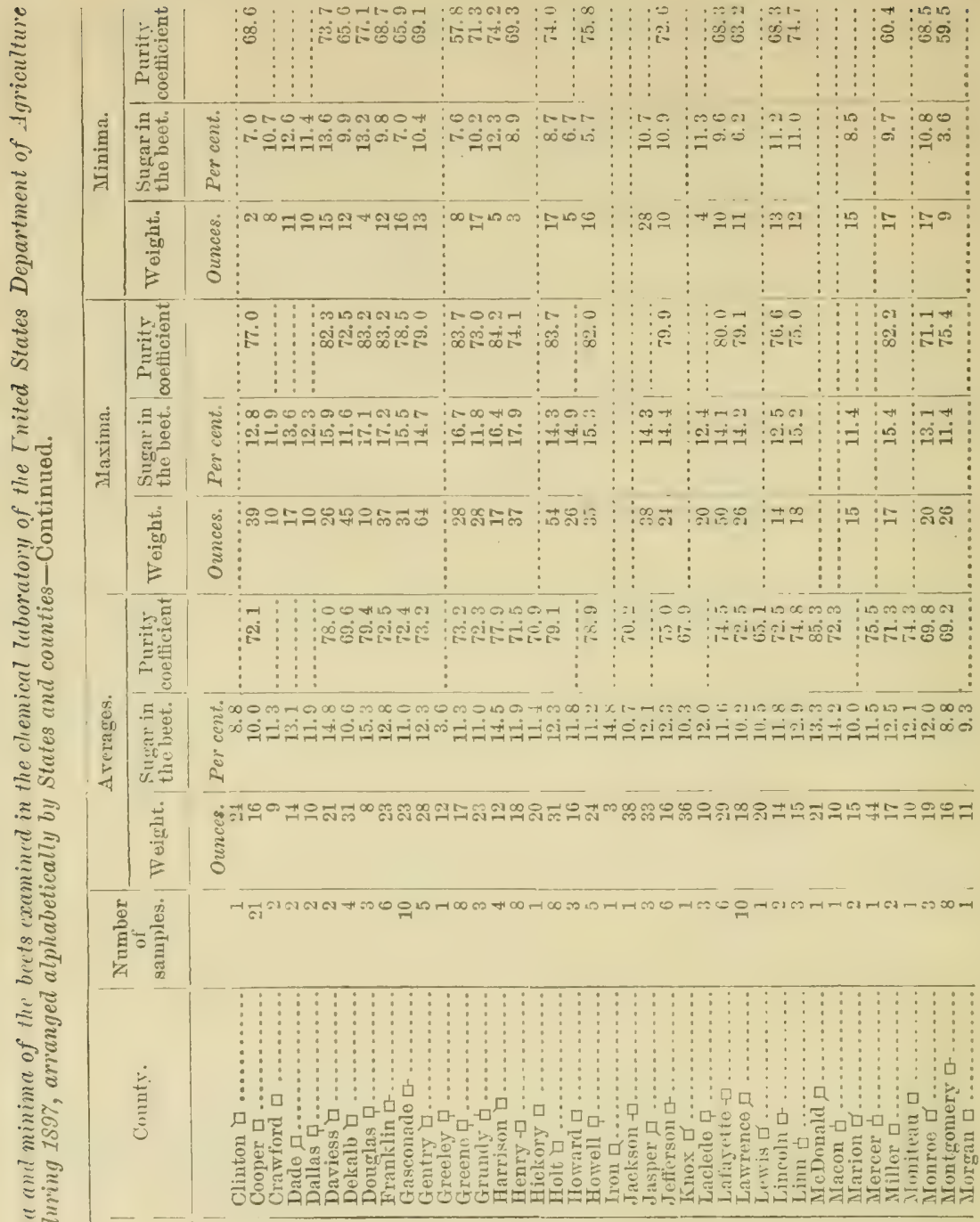




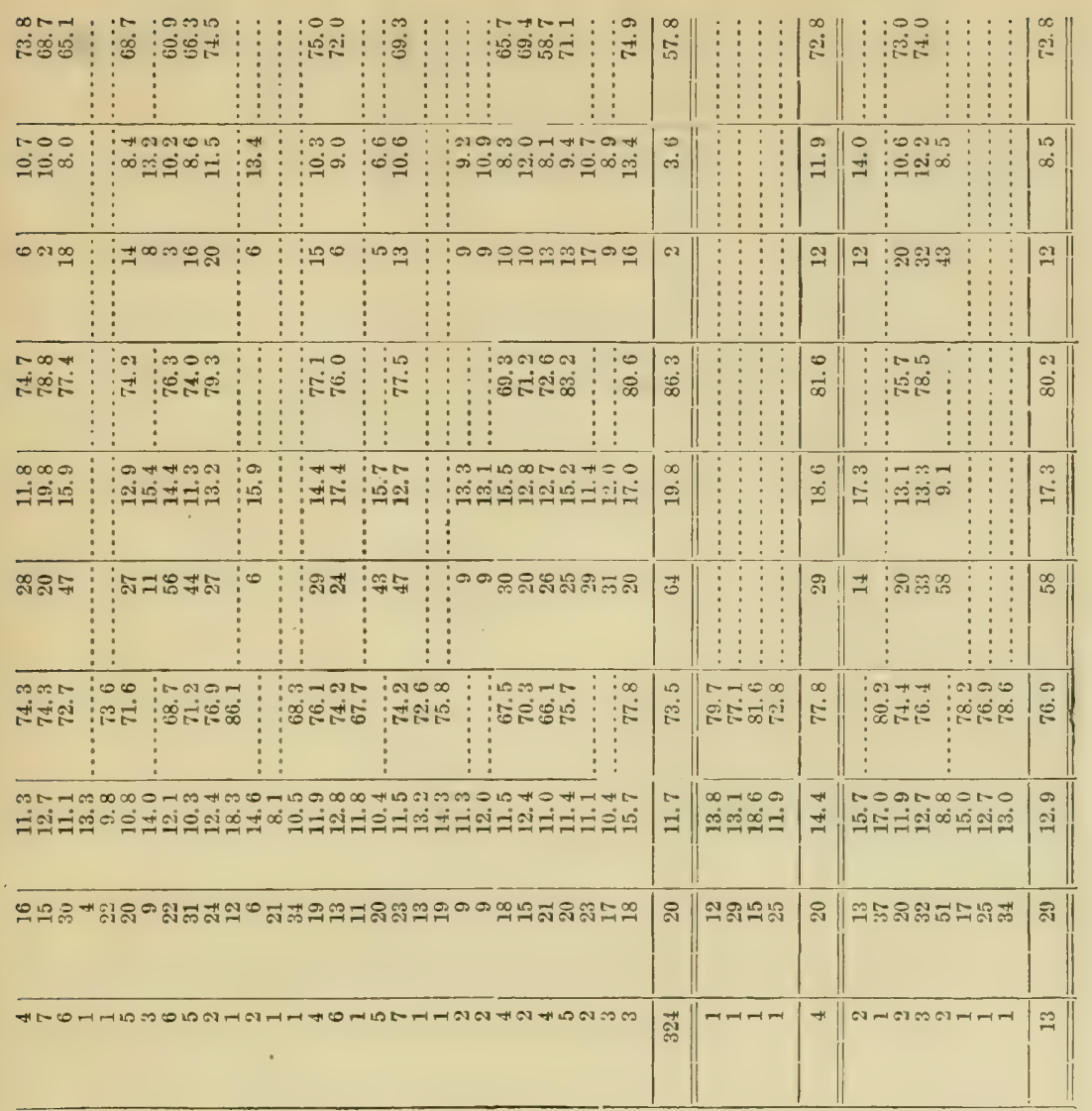

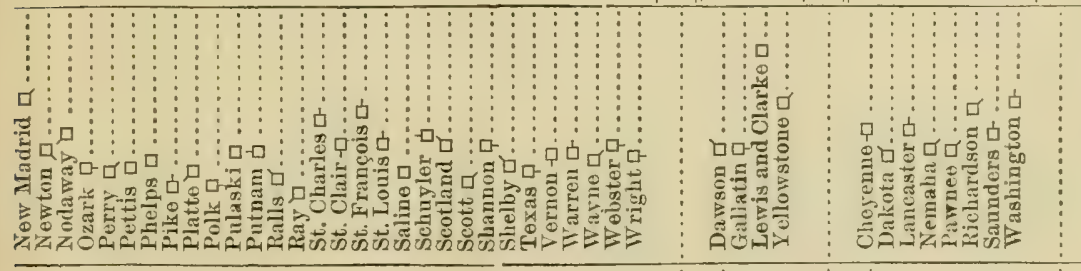




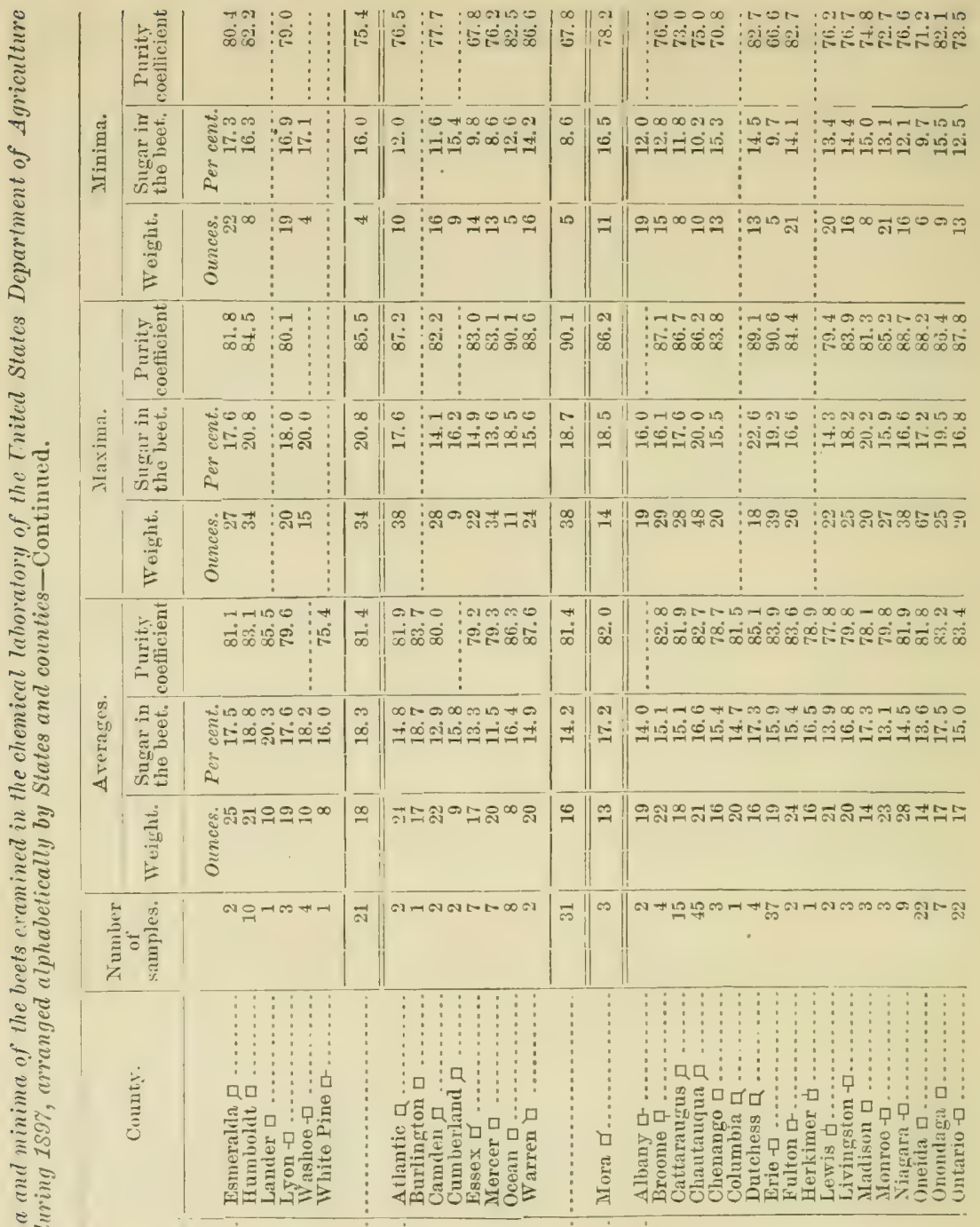




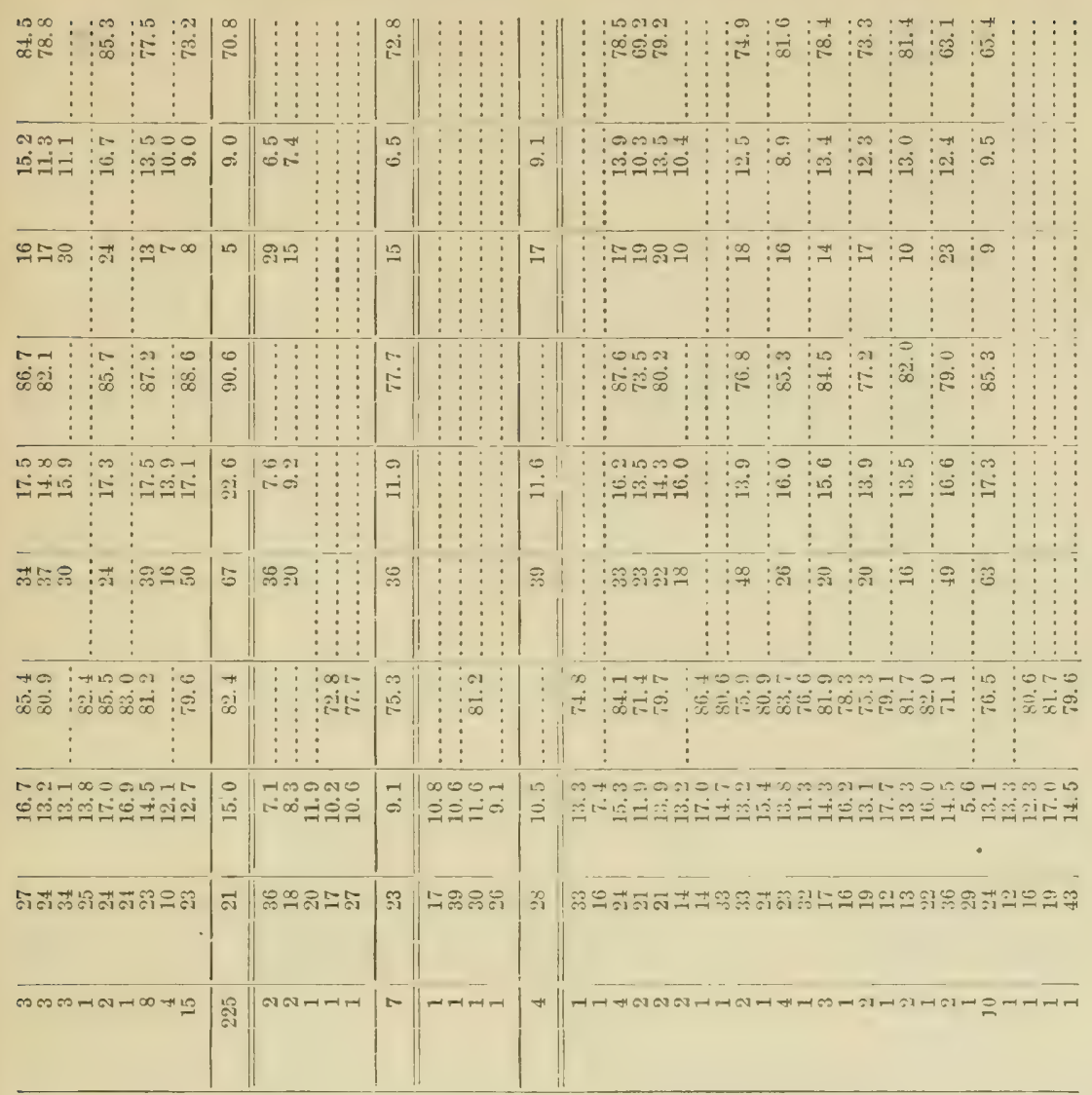

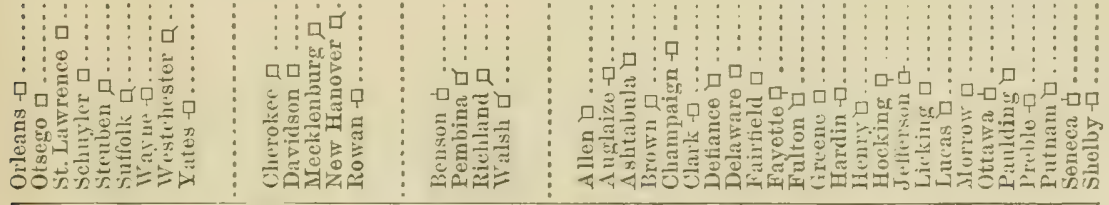




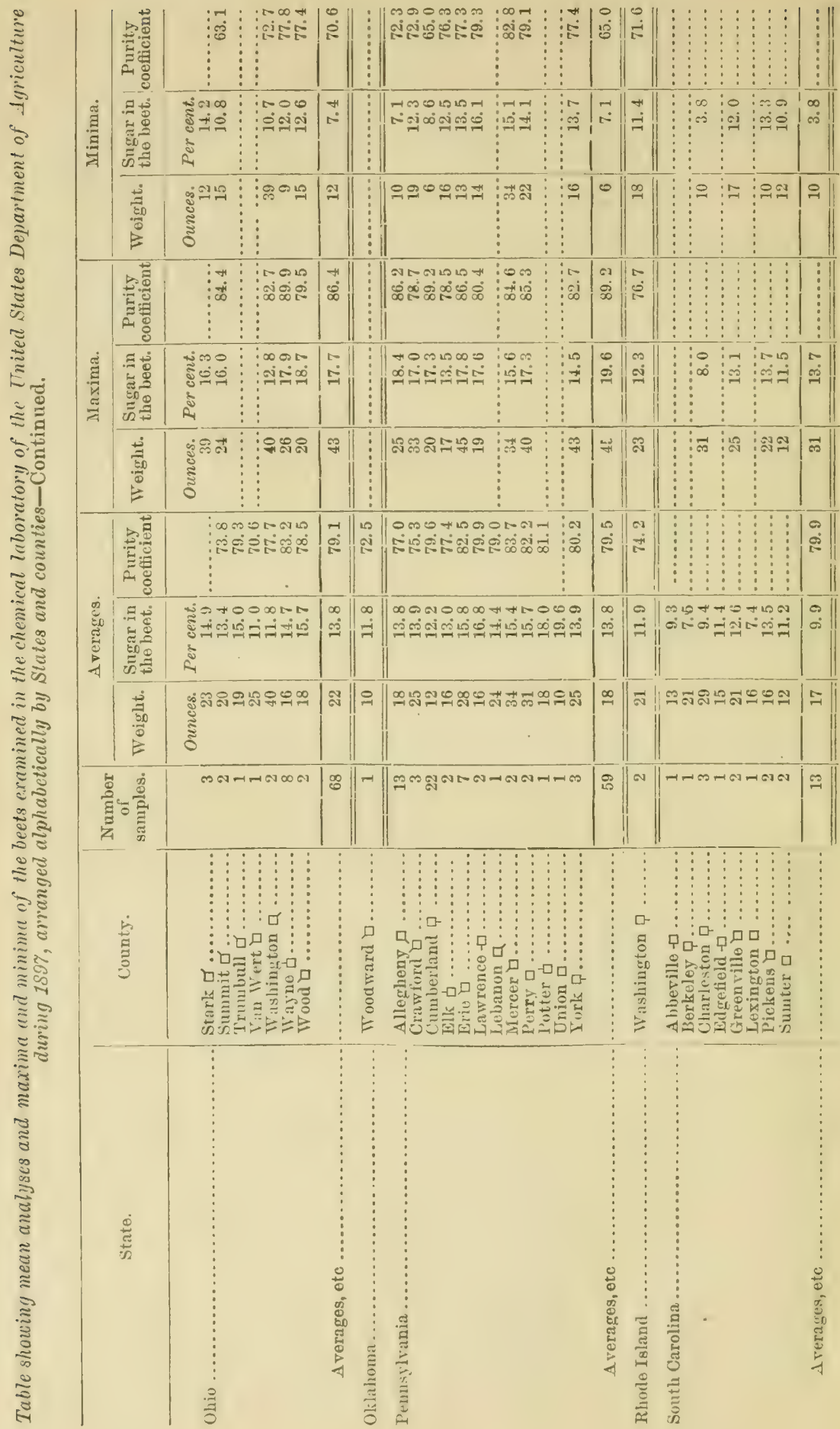




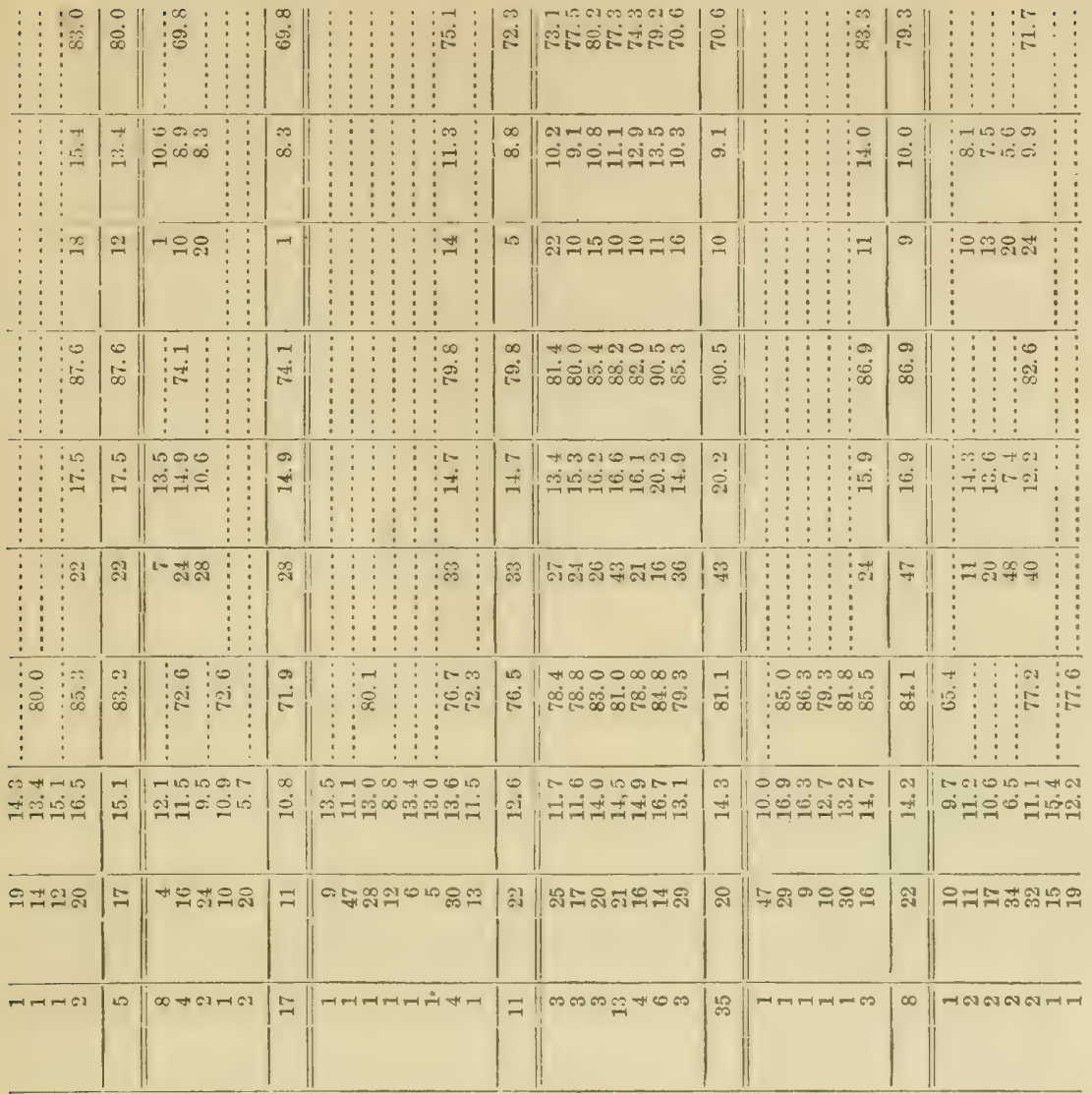

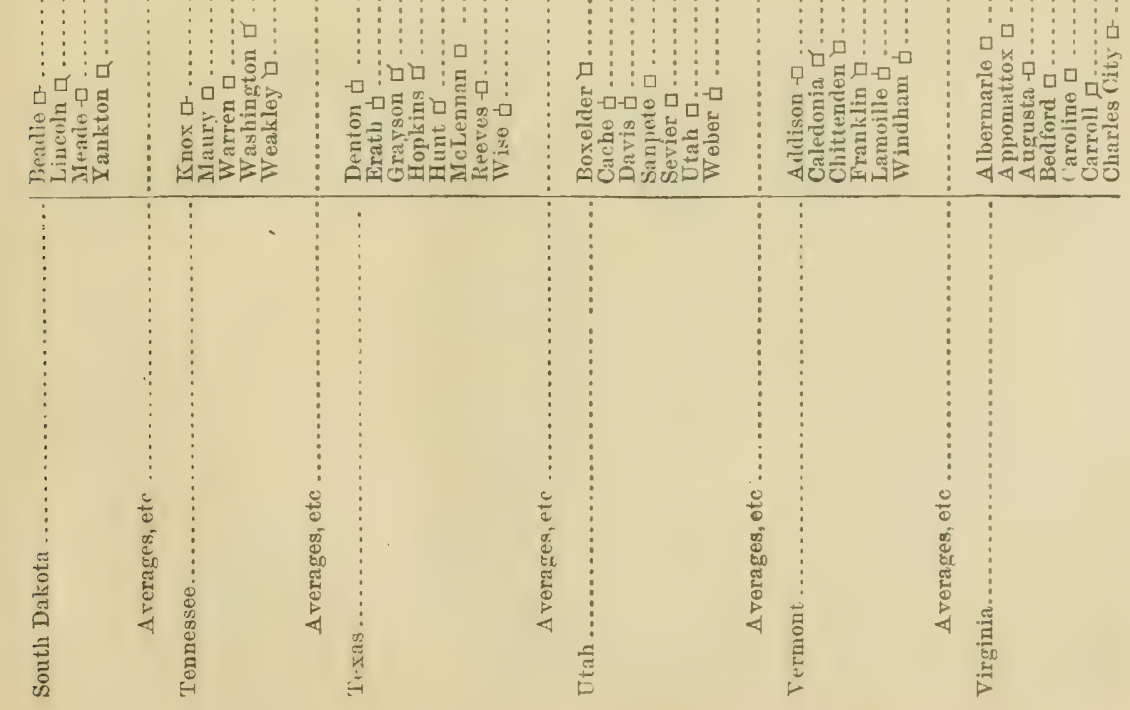




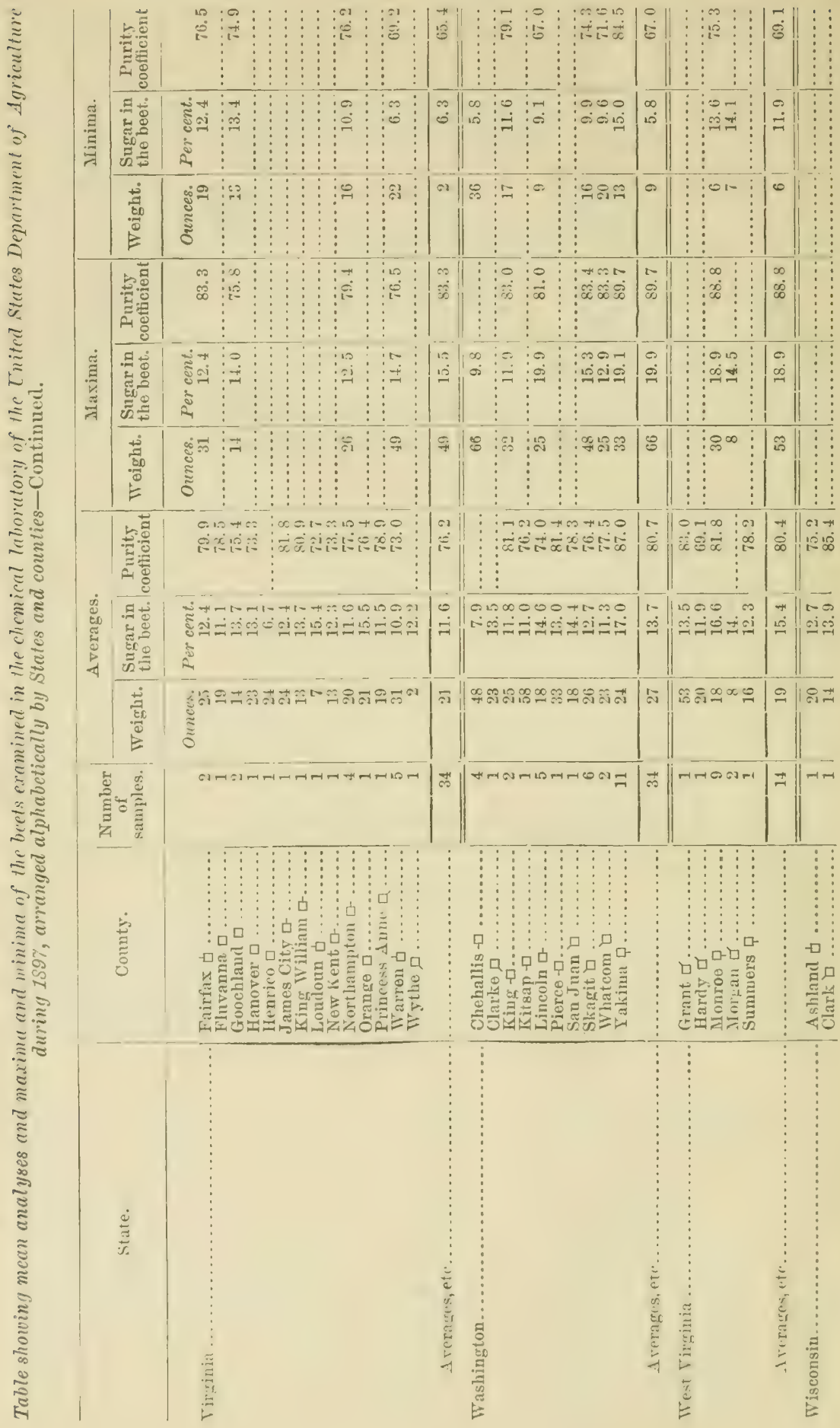




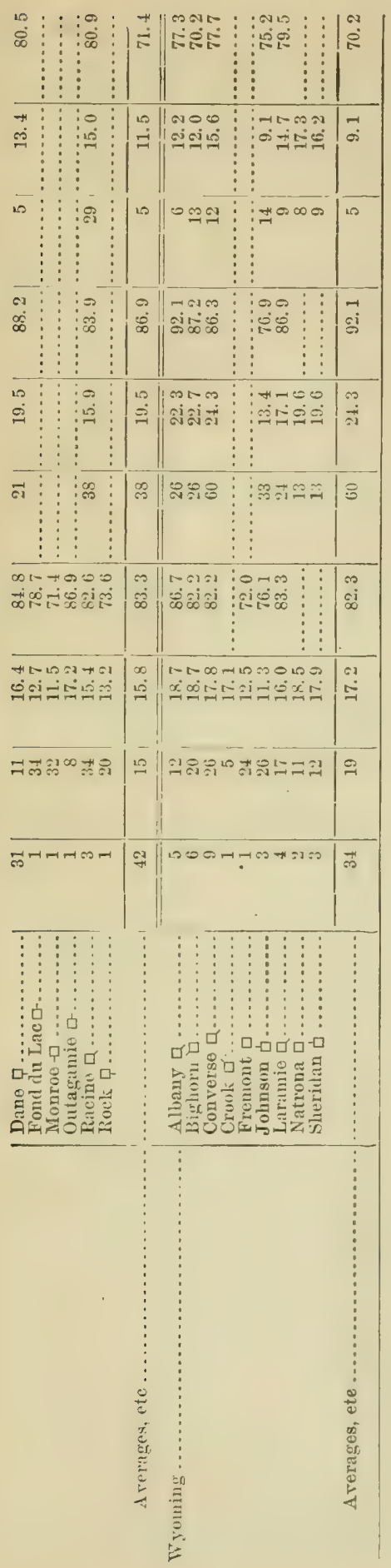


S'IUDY OF THE ANALYTICAI, DATA.

In further elucidation of the data contained in the preceding tables a brief discussion of them for each State is appended, supplemented by a summary of those secured by the experiment stations in the several States.

Arizona.

The samples from Arizona consist of one from Apache County, and six from the agricultural experiment station in Pima County. In the foregoing tables the averages of weight are given to the nearest ounce to avoid the fractions of an ounce, which would necessarily increase the space required for printing. Inasmuch as the weight of the cut beet is so easily varied by a slight difference of the position of the knife in cutting. it is evident that this method of estimation is practically sufficient.

In the analytical data obtained from Arizona, as will be seen by referring to the preceding data, the mean weight of the beets examined was 23 ounces and the mean percentage of sugar in the samples 9.3. On account of the poor quality of the beets, the purity of the juices was not determined. The highest observed percentage of sugar in the beet was 12 and the lowest 7.6.

The following report of his investigations and observations in regard to the sugar beets grown in Arizona, during the season of 1897, was made by Robert H. Forbes, chemist of the Agricultural Experiment Station of Arizona.

RESULTS OF EXPERIMENTS WITH SUGAR BEETS IN ARIZONA FOR 1897.

\section{By R. H. Forbes, Chemist.}

Briefly stated, the average for 157 analyses of beets from all over the Territory is 8.56 per cent of sugar in the juice, with a purity of 61.8 . At first glance these are discouraging figures indeed, but taken as they stand they are misleading, and their true significance can only bo gotten at by examining the whole series of analyses for difterences due to the eftect of such important factors as care and skill in growing, different kinds of soil, differences of climate found in various localities and at different times of the year, and the variety of beets planted.

In order to show the results of careful cultivation upon the quality of the beets, I have divided the samples received from Salt River Valley into three lots.

The first lot cousists of 13 samples grown by Dr. Claflin on the experimental substation grounds near Phœuix. These beets were given the most excellent care. The secoul lot consists of $2 t$ samples obtained from 12 growers near Phonix, Glendale, and Mesa. 'These beets received a fair amount of care during growth, but on the average wero probably not as carefully atteurled to as Dr. Claflin's 13 samples. The third lot consists of 60 samples from the same localities, but which were cared for scarcely at all excepting for an oecasional irrigation. The results speak for themselves. Dr. Claflin's 13 samples averaged 11.23 per cent of sugar in the juice with a purity of 68.3 . The 21 cultivated samples from other growers averaged 9.42 per "ent of sugar in the juice, with a purity of 66.3 . The 60 neglected samples gave 8.35 per cont of sugar in the juice, with a purity of 53.4 .

These figures confirm the well-known fact that intelligent and skillful eare is essential in beet "ulture; more so, I dare say, than in the production of any other great staple, and careless or ignorant treatment of our vogetable thoroughbred will 
inevitably end in disaster." The sugar beet is no exception to the well-known rule that plants, which have been developed through cultivation, if neglected or allowed to run wild, quickly return to their former primitive condition.

Because of the unusual facility with which the sugar beet returns to its former unprofitable condition, it is erident that beet culture is a high art, and in this country the more intelligence is requirer in its treatment because the conditions are in many ways unusual, and the rules which are successfully applied in other countries must be changed or modified here.

In a general way, however, we may insist that deep and thorough preparation of the soil, careful irrigation, and repeated cultivations and hoeings as long as the crop will permit are no less essential here than elsewhere.

The effect of climate is also perceptible in our analyzes. Samples have been received from St. Johus, St. Joseph, Hollhrook, Dunean, Buckeye, Thateher, Skull Talles, Tombstone, Taylor, Fort Thomas, and other more elevated or more northerly poiuts. Almost without exception, the beets from these places were much above the average in richness aud purity. The richest samples we have as set receired came from St. Joseph and contrined 16.3 per cent of sugar in the jnice, with a purity of $81 ; 17$ samples received from the above places averaged 12.37 per cent of sugar in the juice, with a purity of 75.5 .

In order to make the comparison more rigid, we select the Fileinwanzlebeuer variety only from among them, and fud that 7 samples arerage 12.4 per cent sugar, with a purity of 76.3 , as against 10.22 per cent sugar and a purity of 67.82 for this same variety in Salt River Vallej.

Knowing the great influence of temperature upon the composition of the beet, it is difficult to lay these differences to any other cause than the cooler temperature of these higher and more northerly localities.

It is a matter of regret that arable land is so scarce in theso parts of the Territory. Our observations, bowever, may guide us 11 obtaining better results in warmer localities, and in this was: Most of the salt River Valley plantings were made in March and April, so that almost from the start the plants were sulject to the hot su : mer weather, the temperature throughout the inonths of June, July, August, aud September being much ahore the point generally regarded as most favorable to sugar beets. Now, it is possible that by planting earlier in the year a cooler temperature may be secured for the first three or fon months of the life of the plints. Of course the risk from frost will be increased, but that there is some possibility of success in the plan is suggested by the fuct that on June 14 we analyzed a sample of beets from Fowler Brother, near Phunix, which gave 15.2 per cent of sugar in the juice, with a purity of 76 . The seed for this lot was planted February 12 and the beets wero probably not mature.

We can not safely draw couclusions from a single instance, but the high percentage and purity in this extremely early sample are suggestive of the possiblo advantage in early planting.

Selecting the Klein ranzlebener beets received from the northern places and comparing them with those obtained from Phonix, Glendale, Tempe, and Miesa, in the Salt River Valley, we obtain the following results:

\begin{tabular}{|c|c|c|c|c|}
\hline Showing effect of climate. & $\begin{array}{l}\text { Averago } \\
\text { Weight } \\
\text { of beots. }\end{array}$ & $\begin{array}{l}\text { Sugar in } \\
\text { juice. }\end{array}$ & $\begin{array}{l}\text { Sugar in } \\
\text { beets. }\end{array}$ & $\begin{array}{l}\text { Purity co- } \\
\text { efficient. }\end{array}$ \\
\hline 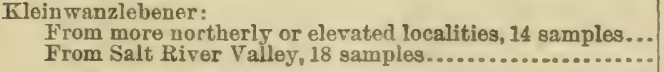 & $\begin{array}{c}\text { Ounces. } \\
18 \\
18.2\end{array}$ & $\begin{array}{r}\text { Per cent. } \\
13.35 \\
10.48\end{array}$ & $\begin{array}{r}\text { Per cent. } \\
12.35 \\
9.69\end{array}$ & $\begin{array}{l}78.8 \\
69.5\end{array}$ \\
\hline
\end{tabular}

The arerage mean monthly temperatures for $\mathrm{Ph}$ nnix, Prescott, and Fort Thomas during several years past are shown in the following table. Phœuix is in the Salt River Valley, Prescott represents the cooler northern parts of the Territory from 


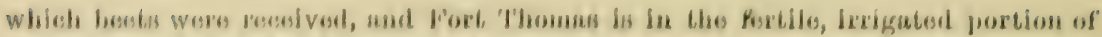

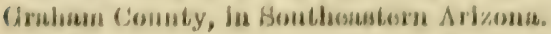

\begin{tabular}{|c|c|c|c|c|c|c|c|c|c|c|c|c|}
\hline & \multicolumn{12}{|c|}{ 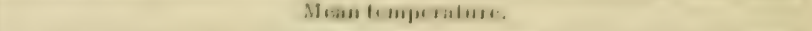 } \\
\hline & IIn. & Iinl. & Mrur. & A jur. & Mny。 & JIIII: & .Iily. & Allg. & Buspl. & Oot. & Niv. & I) \\
\hline folwosulx & $\begin{array}{l}\text { "II", } \\
\text { (i) }\end{array}$ & (1) $f_{i}$ & of & $\begin{array}{l}\text { "15', } \\
137\end{array}$ & "1', & "sis. & (iv) & "Wis & sis & $\begin{array}{l}80^{\circ}, \\
70\end{array}$ & oje, & uf', \\
\hline I'ventuali. ................. & is & 138 & 41 & (6) & (b) & (iii) & 74 & $7: 4$ & 65) & 64 & 13 & sis \\
\hline 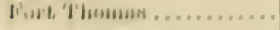 & 47 & $d n$ & bit & 131 & 70 & 56 & 81) & His & 76 & 6is & 4i) & 11 \\
\hline
\end{tabular}

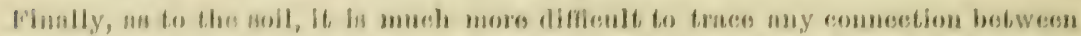

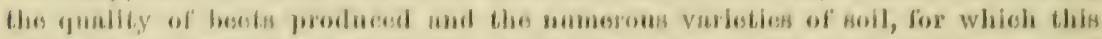

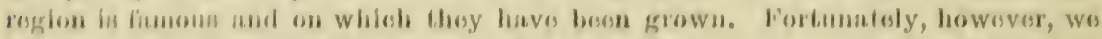

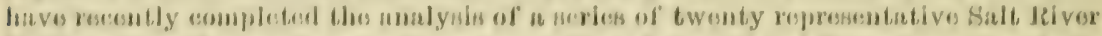

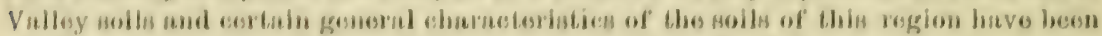
Inturminad.

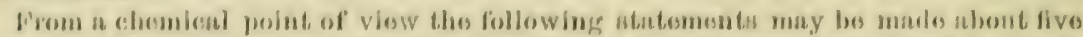

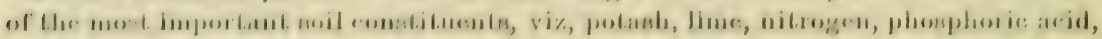

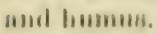

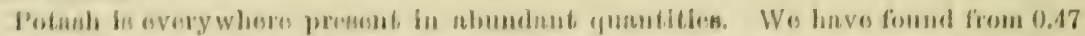

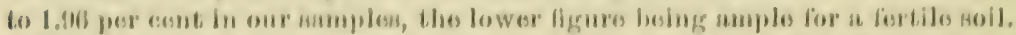

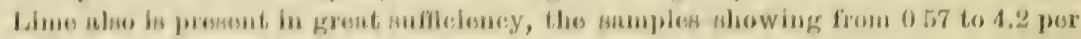
a:114.

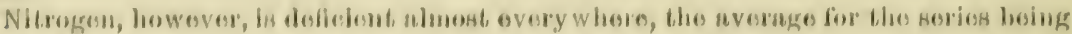

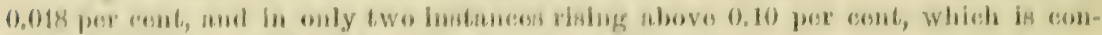

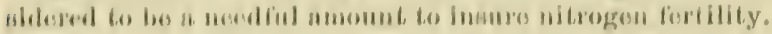

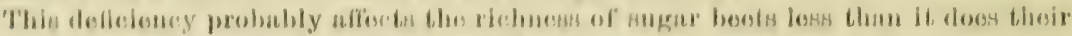

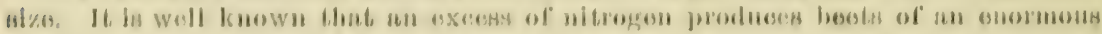

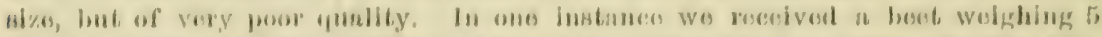

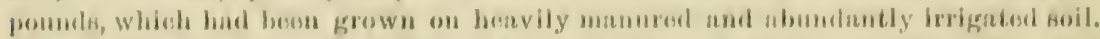

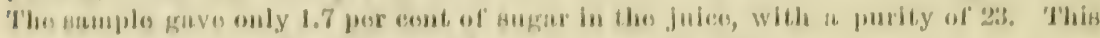

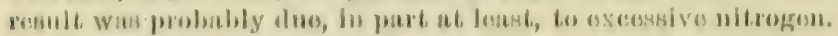

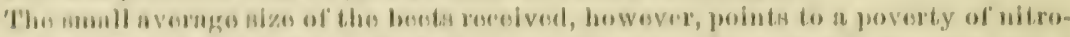

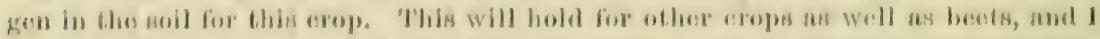

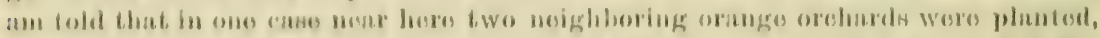

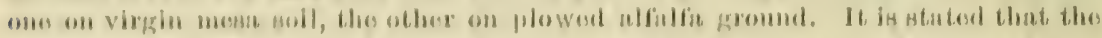

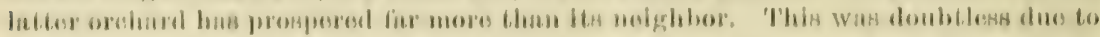

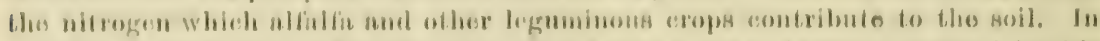

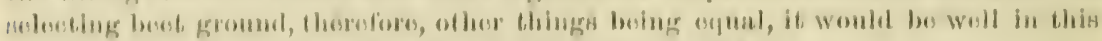

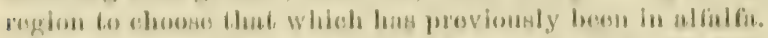

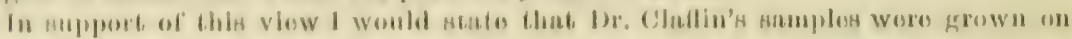

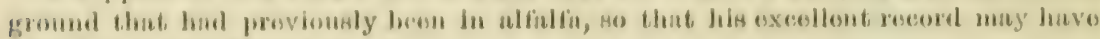

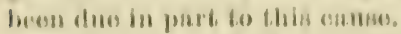

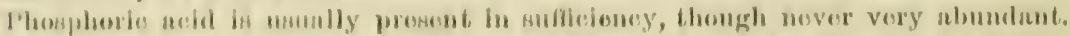

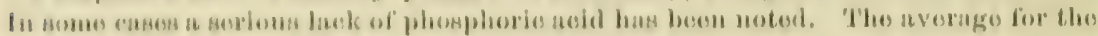

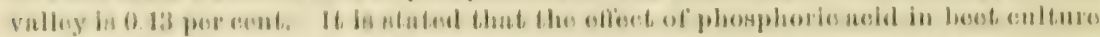

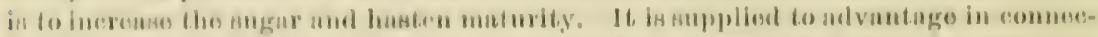

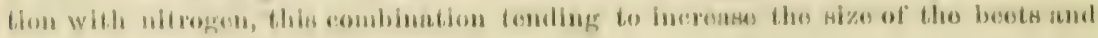

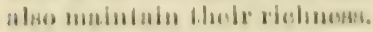

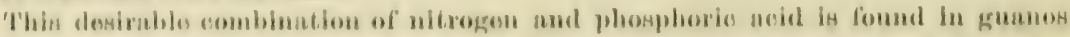

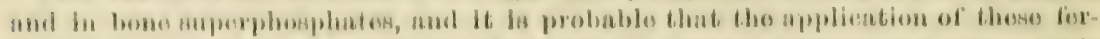

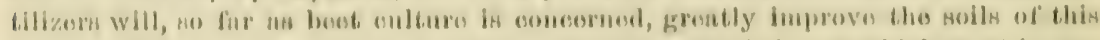

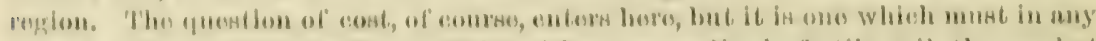

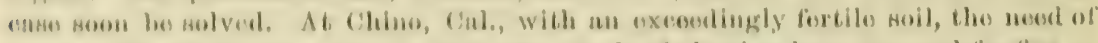

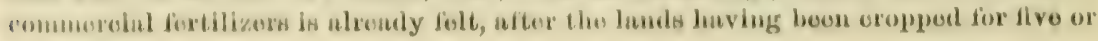
wix yestits. 


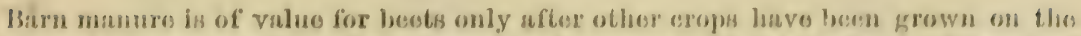

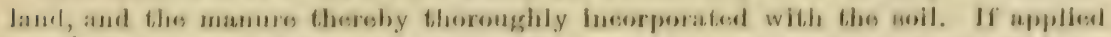

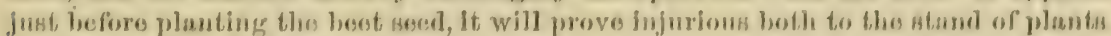
and the quality of the product.

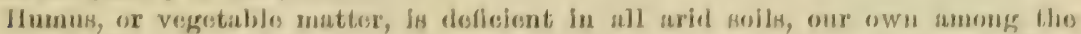

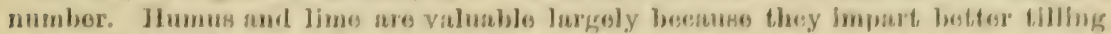

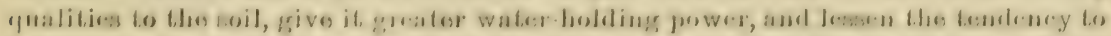

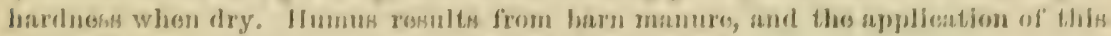

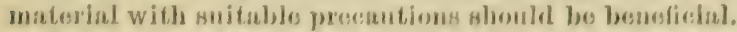

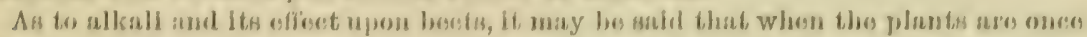

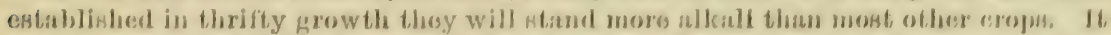

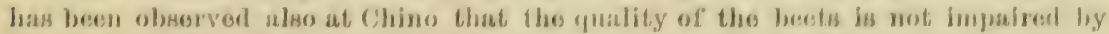
alkalino ground. It in probablos, lowover, aн st mates of opoinon, thut, young plantis

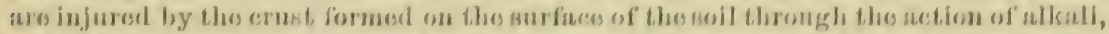

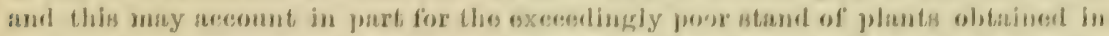

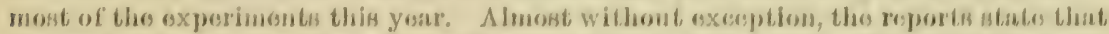

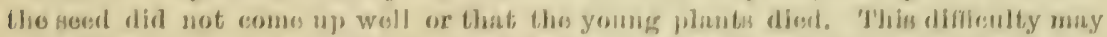

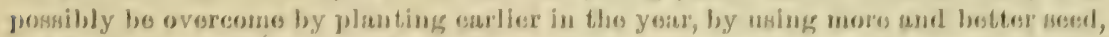

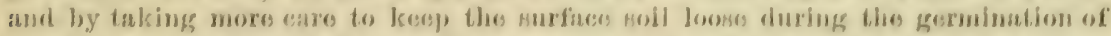

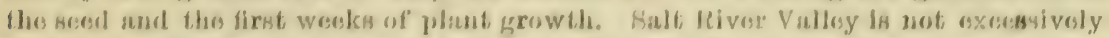

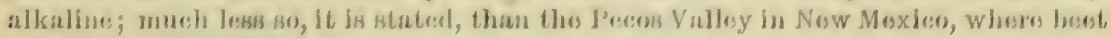
calturo in now aliosmptod.

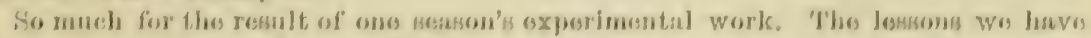

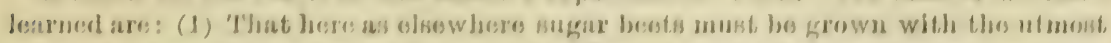

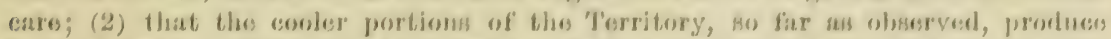

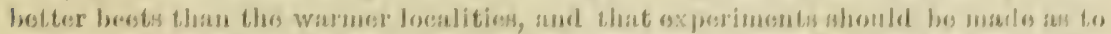

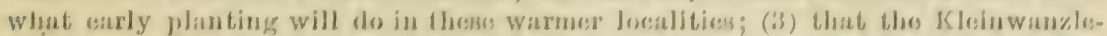

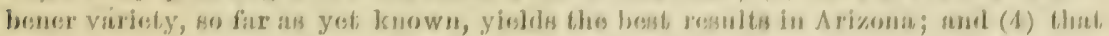

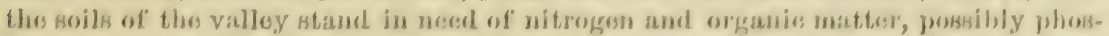

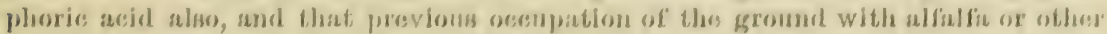
means of fortilizstion whould bes nereuzrorl.

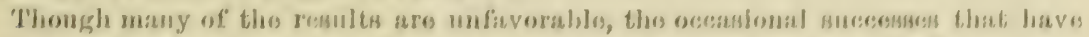

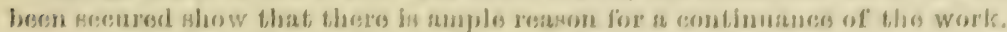

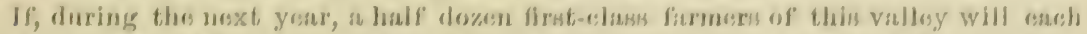

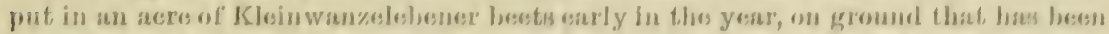

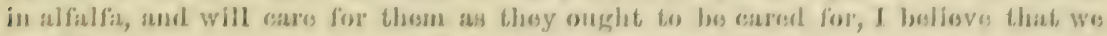

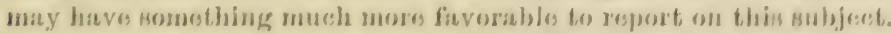

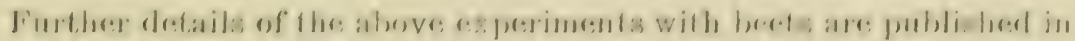

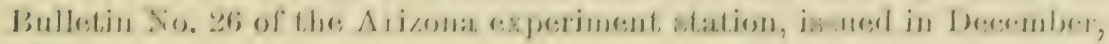
$18 \div 7$.

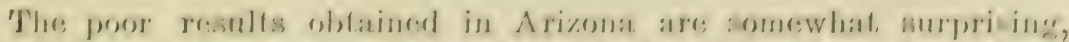

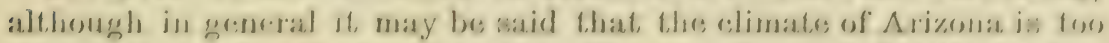

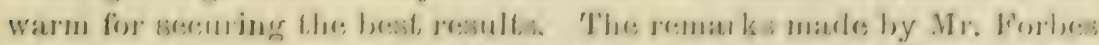

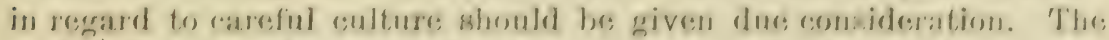

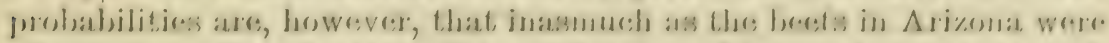

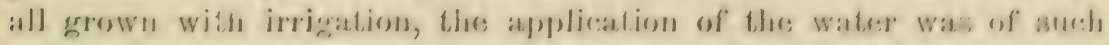

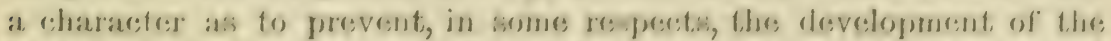

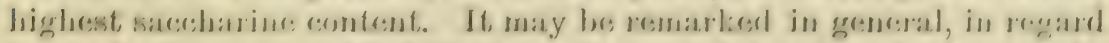

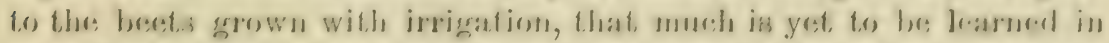

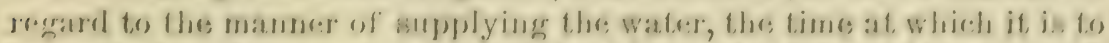

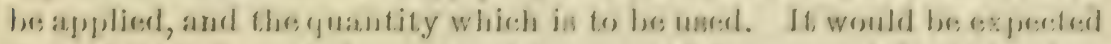

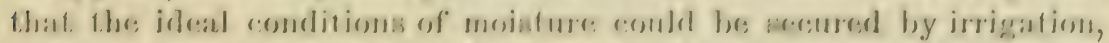

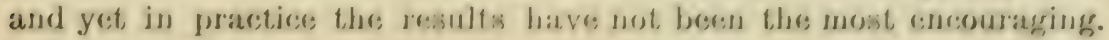


This has leeen true in regarr to the crowth of berets in l. tail and Tr:T Mexico under irrigation. There is no factor connected with the sagarbeet industry which is of more practical interest than a careful study of the conditions under which irrigated beets should be grom. The fertile soils of the arid regions are undoubterlly able to prorluce large

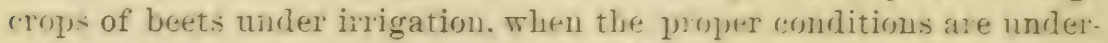
stord. Complaints have also been marle in re-jert of the eflerts of alkali upon beet - in these soils, and also of incert prests. It is imprortant that a sturiy be wade of the bacteria, mold $\therefore$ aurl inseret pessts of sucar liects, trogether with the effects of the allali. After allowing for all thes: conditions, hrowever, it must be ronfessod that the Arizond data are somewhat risalnointing. and muless gleat improvenuent can 1.. marke there is little prospert of the industry being extabli-hed on a secure foundation in that region.

ARKANSAS.

Arlankin lies a far sonth of the best belt as to make a discrusion of the poilbilitios of beet growing in that ricinity unueces-ary. Only two simples were receiverl fiom the state and as night lue experted. the e do unt show any ver 5 farorable qualities. A few censal renarks nay le marle abont growing beets in waruer climates than these best suited to oltaining the highest grade of beets, namely:

Iirst, that it is quit: possible to get fine harrests of beets with favorable tomnage per acre,

S.munt, that it is prssible to grow beets rontaining quantities of stuar which would liave made them valuable for mannfaturing purjo-es sereial years ago, before the beet reached it: present high - tate of derelopment, and

Third. that sucil bewts erould probably le arown with oreat profit for stoclifeeding purpuses in all then locilities. The full value of the

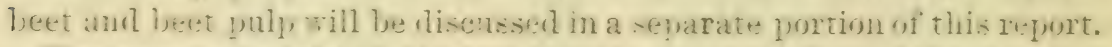

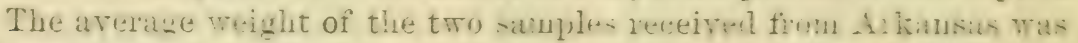
1s onuces, anl the avelage content of sugar in the beet $11 . .5$ per rest.

\section{Caltforista.}

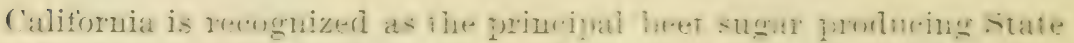
in the Union. Only one sample of beets was received from this

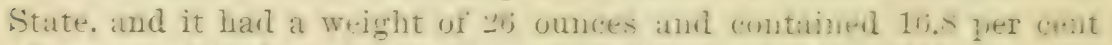
of -ugar. All of the wast valleys of Californial are lavorally situatel, in respers of temperature, for the production of sugar bests, and the same nay be sairl of certain lands. the linits of which afe not yet woll definel, in other parts of the state. Eren in the Saleanento Valley, as fan inland as the puint of junction with the San Joaquin liber. where the trmpratiur: is higher than that cousinered best for beet it has

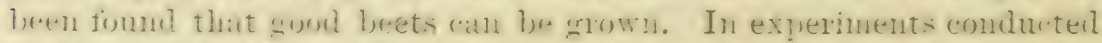

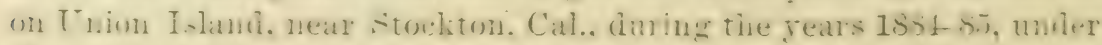
dincetion of the chief chemist of the Departuent of Agriemlture. very 


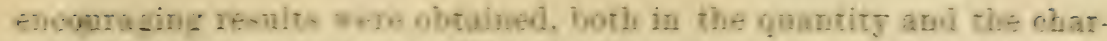

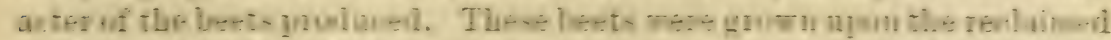

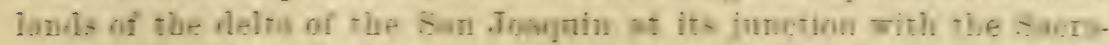

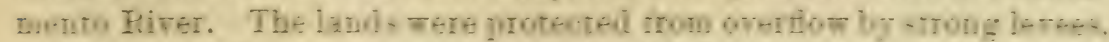

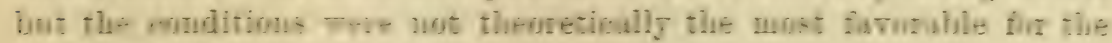
production of high-grade beets.

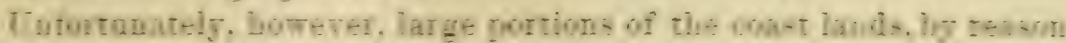

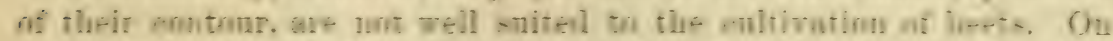

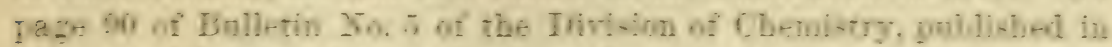

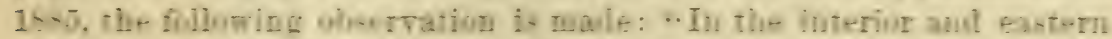

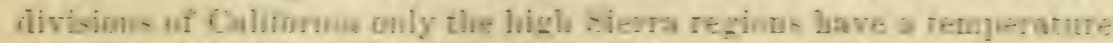

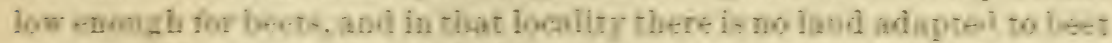

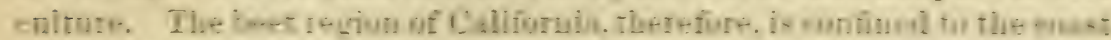

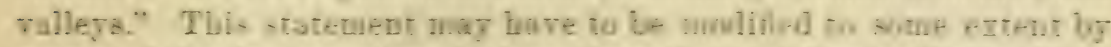
Iescon of the dath mentioned abowe from Druion I-land. Than olyes-

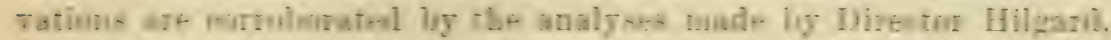

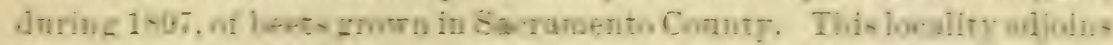

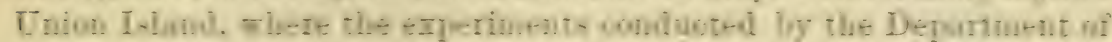

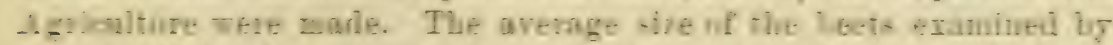

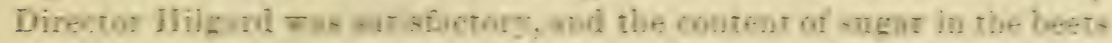

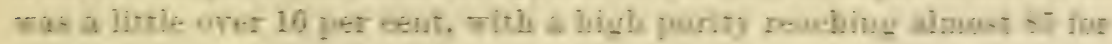
a wilole series of analsse:. These data show that in the Sacraments Talley. at least where tue temperature is sornewliat ligher than that

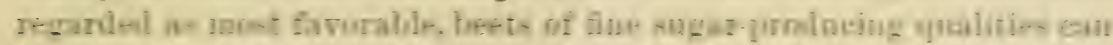

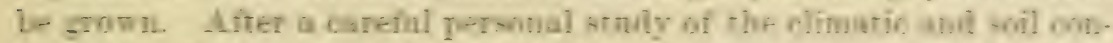

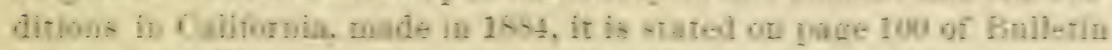

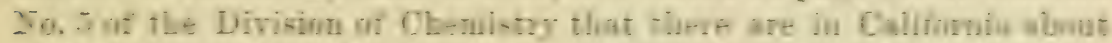

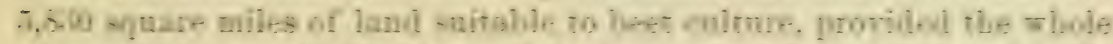

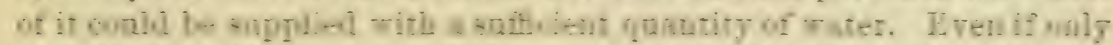

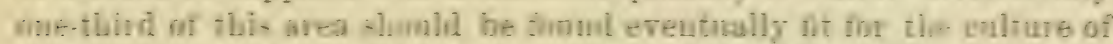

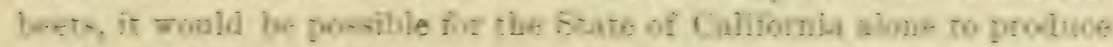

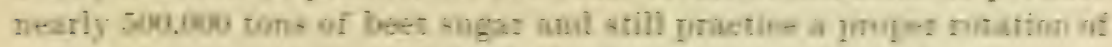
crons. In ries of the fact that the beet-sugar industry has been 50

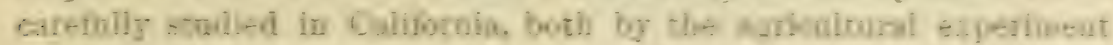

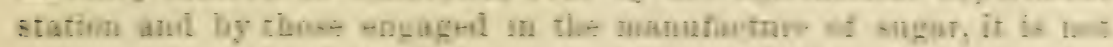

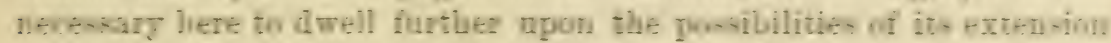
in that State.

\section{Corpparo.}

The Lumher of amples recived foum the State af Coloralo an the

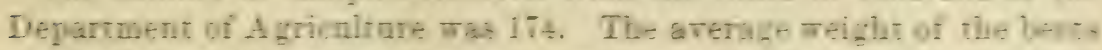

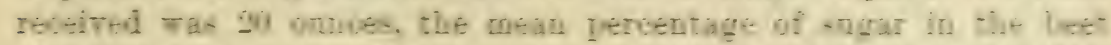

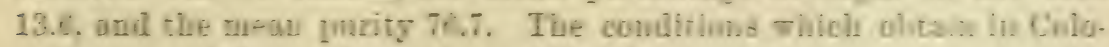

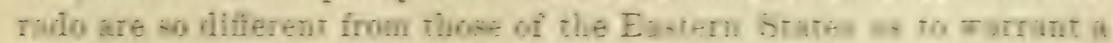

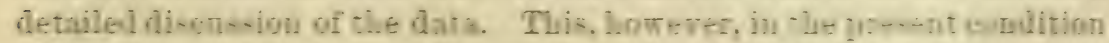

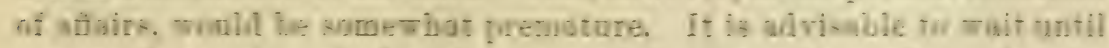

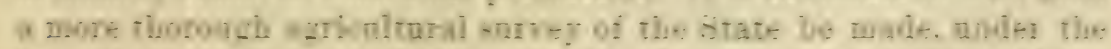

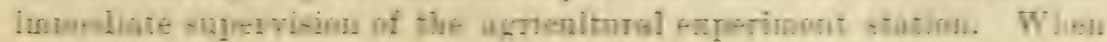


the analytical table of the data received from Colorado is consulted, it is seen that most remarkable differences exist in the returns from the different counties. Since in most cases only a very ferw samples have been receired from any given county, it is not fair to make any judgment of the possibilities of any one connty from data of so limited a nature. The great variations in altitude in the State, cansing sharp differences of temperature, must also be taken into cousideration. In addition to this, it is fair to presume that the samples have all been grown under irrigation, and it is impossible, in such data as are collected from the farmer's, to determine with any certainty what the proper conduct of the irrigation should be. In general, the data are entirely satisfactory, especially in respect of 'ontent of sugar. As regards the mean purity of the juices, the data are somerrhat unsatisfactory, since it falls more than three points below the minimum of good beets. This may be dne to the great amount of mineral salts which the soils of Colorado contain, and to the well-known property of the sugar beet of absorbing these salts from the soil. For this reason, it may be suggesterl that in many cases cultiration of the sugar beet could be advantageously practiced, not aloue on account of the profit in the beet itself, but because of the improvement in the soil which would result from the extraction of the alkaline materials. Among the counties where the samples have been somewhat numerons and the results most encouraging may be mentioned Boulder, lying to the northwest of Deuver and mostly within the favorable thermal area, where the average content of sugar in the beet was over 15, and the purity nearly 81 . This most favorable result was obtained with exceptionally large beets, the average weight of which was 31 ounces. This fact makes the data even more valuable and suggestive.

Another county where the data were extremely favorable, although the number of samples was only two, is Delta, a county lying within the theoretical thermal area, and where the average size of the samples was 20 ounces, the average content of sugar orer 17 , and the purity 80.5 .

Another favorable result may be reported from Garfield County, although the average size of the beets is a littlo low. The mean percentage of sugar in the beets was 16.6, and the purity 83.2. This county also lies mostly in the thermal belt.

In contrast with the above should be cited the returns from Logan County, showing not only small beets, but exceptionally low contents of sugar and purities. Logan County, nevertheless, is contained almost wholly within the thermal belt, which is most farorable to the growth of beets. The poor results obtained must therefore be due to causes which are not made known.

Tpon the whole, the data from Colorarlo are exceedingly encouraging and lead to the belief that there are many palts of that State where, with proper conditions of tillage and irrigation, the sugar leet ind:stry may be established with profit.

In connestion with the work done hy the l)enartment of $A$ grienlture, 
it is interesting to consider the report of the director and chemist of the agrienltural experiment station of Colorarlo at Fort Collins:

BIREF REPOITS REGARDING SUGAR BEET IXXPRIMENTS FOR THE YEAR 1897, AT THE COLORADO STATL AGRICULTURA, COLLEGE.

\section{Chemical section.}

The work of the chemical department on sugar beets can be summarized briefly as follows:

We began taking weekly samples on September 2. The varieties represented were Vilmorin, two plots; Kleinwanzlebener, two plots; Leon Brand, ${ }^{1}$ ono plot; and Imperial, one plot. The amount of sugar in the beets was determined from week to week. We did not find a very rapid inerease as the seison advanced until the beets approached maturity, when wo observed a sudden increase of about 3.5 per cent. Onr samples varied greatly in their sugar content, but agreed in inclicating that the crop in this comntry was not sufficiently matured to yield marketable beets before the middle of October. The average of the beets analyzed subsequent to this date, debarring one lot, the most of which were grown under unfarorable conditions, and a fow sumples which were clearly unmarketable beets, is 14 per cent, the range being from 10 per cent to 18.25 per cent of sugar. The coefficient of purity has rauged from 70 to 89 , and has averaged 80.7 . We believo the average percentage of sugar given to be high enongh, but the coefficient of purity-80.7-is lower than the actual coeficient rather than higher. ${ }^{2}$

Respectfully submitted.

William P. Headder, Station Chemist.

Agricultural section.

(From Report of the Director.)

In a general way it can be said that the results of this season's work are very farorable to the establishment of the beet-sugar iudustry in Colorto. The following figures are to be judgerl in the light of the statements that come. from all the beetsngar manufacturing States of the Union, that the season of 1897 was especially unfavorable to the iudustry. If in this poor year Colorado can make such a good showing, what may we expect of her in ordinary or favorable years?

The above report of the chemist of our Experiment Station gives the figures for the beets raised on the College Farm. But few analyses were made here of beets raised elsewhere, since the failure to get into our new chemical building last fall left the Chemical Department in poor shape for doing much outside work.

Practically all the analyses of Colorado beets not grown at Fort Collins were made in the Chemistry Division of the Department of Agriculture at Washington. It has seemed best to give here merely a summary with reference to our local conditions.

For the purpose of sugar-beet raising Colorado may be divided into five sections:

(1) The valley of the South Platte and its tributaries.

(2) The divide south of Denver, and the plains region where beets are grown without irrigation.

(3) The valley of the Arkansas River.

(4) The valley of the Grand River.

(5) The San Luis Valley.

All these, except the second, use irrigation. There are two features of the raising of sugar beets that require special study-namely, the quality of the beets when they are ripe and the time of the year when they reach that degree of ripeness. The

${ }^{1}$ This variety is unknown to me.-H. W. W.

${ }^{2}$ It is not clear what is meant by this expression.-H. W. W. 
earlier in the season they reach a profitahle degree of sugar and purity the longer seatson the factory will have to manuficture the crop, and the larger the amount of crop that can be handled by a factory of a given size.

Many tests were made of sugar beets dug in September, but only a fow showed beets suiterl for use in sugar making. Nerertheless, the fact that a fow samples, oren by September 18, exceedod 12 per cent sugar and a purity of 80 , shows that when our farmers are more used to growing sugar beets they can bring them to maturity sereral dings, and probahly two weeks, earier than the average crop of 1897. With the first days of October the crops ripened rapidly.

The following table presents a summary of the season of 1897 , with reference to the cunality of the beots, anil the time of ripening in different parts of Colorado:

\begin{tabular}{|c|c|c|c|c|c|c|}
\hline \multirow{2}{*}{ Section of State. } & \multicolumn{2}{|c|}{$\begin{array}{l}\text { Samples dug be- } \\
\text { tween Oct. } 1 \text { and } 10 .\end{array}$} & \multicolumn{2}{|c|}{\begin{tabular}{|} 
Samples dug be- \\
tween Uct. 10 and 15.
\end{tabular}} & \multicolumn{2}{|c|}{$\begin{array}{l}\text { Samples dng after } \\
\text { Oct. 15. }\end{array}$} \\
\hline & Sugar. & $\begin{array}{l}\text { Purity co- } \\
\text { efficient. }\end{array}$ & Sugar. & $\begin{array}{l}\text { Purity co- } \\
\text { etlicient. }\end{array}$ & Sugar. & $\begin{array}{l}\text { Purity co- } \\
\text { eflieient. }\end{array}$ \\
\hline $\begin{array}{l}\text { The valley of the South Platte.......... } \\
\text { The divide and the plains .............. } \\
\text { The valley of the Arkansas ............ }\end{array}$ & $\begin{array}{r}\text { Per cent. } \\
14.1 \\
12.5\end{array}$ & $\begin{array}{r}80.7 \\
73.7 \\
-1.7\end{array}$ & $\begin{array}{r}\text { Per cent } \\
14.6 \\
15.1 \\
13.1\end{array}$ & $\begin{array}{l}81.1 \\
80.6 \\
77.9\end{array}$ & $\left\{\begin{array}{r}\text { Per cent. } \\
15.4 \\
14.8 \\
15.3\end{array}\right.$ & $\begin{array}{l}81.1 \\
78.3 \\
81.9\end{array}$ \\
\hline $\begin{array}{l}\text { The valley of the Grand.................. } \\
\text { The San Luis Valley .......................... }\end{array}$ & $\begin{array}{l}16.3 \\
13.7\end{array}$ & $\begin{array}{l}83.6 \\
79.2\end{array}$ & 12.4 & 78.5 & $\dddot{114.8}$ & $\ddot{80.3}$ \\
\hline
\end{tabular}

IDAIIO.

The number of samples receiverl at this laboratory from the State of Irlaho was only seven, representing two counties. The arerage weight of the beets received was 21 ounces, the averige content of sugar therein 15.5 per cent, and the average purity 79.4. Botin in respect of size of the beets and content of sugar the results are very encouraging. The average coefficient of purity is almost up to the minimum standard, and doubtless could be improved later on. The alkalinity of the soil, which has been mentioned in connection with the loweriug of the average in Colorado, is doubtless active in Idaho. There are large areas in Idaho where the thermal conditions aire firorable, but they are detached from the main thermal belt crossing the continent. There are tro centers of thermal conditions in Idalio which serve as nuclei for determining the conditions most favorable. One of these lies almost wholly in the State, and Boise City may be regarded as the center of it, and the other extends into the western and northern part of the State from the State of Washington. In general, it may he said that the thermal conditions in Idaho, if they alone are to be considered, are sufficiently favorable for the culture of the beet, in so far as the growing season is concerned. The data obtained, while meager, are sufficiently encouraging to warrant a more thorough survey of the State, and also the belief that the ronditions for the sneessful establishment of the sugar industry may be found wherever the character of the soil, in respect of conton and fertility, and the facilities for irrigation and other factors favorable to the growth of the sugar bret and the manufacture of sugar can be secured. The report of the chemist of the station contains much valuable information in respect of the sugar-beet industry in the State of Idaho, and is herewith appended: 


\section{RESULTS OF EXPEIMIENTS IN IDAHO.}

In the first place, the results of the past season are cuite disappointing and unsatisfactory, due to several causes which will be eliminated largely in the experiments of next year.

The climatic conditions of Idaho are quite varied, the growing season opening several weeks earlier in Sonth Idaho, along the snake River and in the Boise Basin, than along the Clearwater or in North Idaho. The seed furnished gratis to this station by the Department of Agriculture arrived late, and before it could be distributed-May 4 to June 2-the season was well advanced, hence the seed that was planter either failed of germination, or the joung plants were killed by severe clinatic changes of heat and drought, or of cold and wet soil, which latter condition prevailed in the Palouse region. Much of the seed sown in our station plats failed to grow. The staud was irregular, weak, and of poor yuality, so that the tonnage per acre could not be estimated with any degree of reliability. It is therefore omitted from the tables.

Seed was mailed to 114 farmers, representing 41 different sections of the State, Jet samples of bects for analysis were received at this Department from only 20 farmers, representing 13 localities. This apparent apathy on the part of our farmer friends is explaiuable in part. In many cas's the seed did not reach its destination, or when plinted it failed to germiuate, or the young plants were destroyed by insects or jack rabbits. In a few cases there was not snfficient interest manifested in the experiment to induce proper cultivation of the young plants, therefore no samples worthy of shipment were grown.

Sugar-beet growing is a new industry to the American farmer, and he has yet to learn that the ordinary farm methods are not always applicable and sufficient to grow and mature a typical sugar beet. The Idaho rancher is not an exception. He has yet to learn the value of intensive methods, from the preparation of the seed bed to the marketing of his crop. The neglect to plow cleeply, to pulverize finely, to place the seer with care, to thin the plants judiciously, to cut out the weeds, withal to cultivate and hoe the growing plants regnlarly, resulted in partial or entire failure of the experiment. The sugar beet is a thoroughbred, and must be given care in keepiug with its regal characteristics if high sugar content and purity are to be attained. The successful sugar-beet grower has learned that the sucrose is practically hoed into the root. This knowledge and its application our farmers eviclently were not in possession of, or the number of samples forwarled would have been greatly augmented. It is a matter of edncation, however, which will be overcome in time by the dissemination of information through the press, the station bulletin, and closer computition induced by immigration from older States, where better methors of farming provail.

The 41 samples analyzed averaged in sugar content 15.17 per cent; in purity, 87.55. The 20 samples grown by the Station gave in sugar 1528 per cent; in purity, 92.55. The 21 samples grown els'where averiged 15.07 per cent of sugar, and 82.78 in 141 rity. The highest and lowest results gave 19 and 10.2 per cont in sugar; and 95.10 and 81.81 purity, respectively.

OTHER SUGAR BEFT DATA NOT HITIERTO GIVEN TO THE GENERAL PUBLIC.

During the fall of 1894,192 analyses of sugar beets were made by the Station, which gave an average of 13.7 per cent of sugar and a purity of 76.08 degrees. Some of the samples were large, others had heen frozen, still others were immature, while a few varieties were not at all adapted to our soil and climate. This reduced an otherwise much higher average. Excluding about 20 samples, the remainder, 55 samples of Vilmorin's Improved gave an average of 11.77 per cent of sugar and a purity of 75.55 degrees.

Forty-four samples of Kleinwanzlebener beets averaged 14.16 per cent of sugar with a purity of 82.80 .

Thirty samples of Imperial averaged in sugar 14.1 per cent, in purity, 85.42.

$$
\text { H. Doc. } 396-\tilde{z}
$$


Ten samples of French Red Top gave an average of 13.65 per cent of sugar with a purity of 82.70 .

The average of 10 samples of Lane's was 13.44 per cent of sugar with a purity of 81.69 .

Eight samples of New Danish gave an average of 13.83 per cent of sugar and a purity of 81.81 .

The highest and lowest percentages of sugar in each variety were as follows:

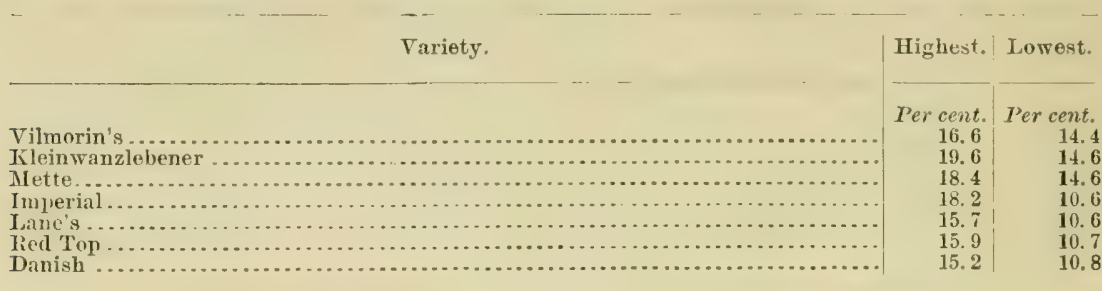

The places represented in the experiment were the University of Idaho, Ceur d'Aleue, Sand Point, Moscow, Kendrick, Lenville, Princeton, Cornwall, Genesee, substation at Grangeville, substation at Idaho Falls, substation at Nampa.

The average yield thronghout the State was estimated at 20 tons per acre.

\section{ANAI,YSES OF BEETS GROWN IN 1895.}

The experiments in sugar beets for 1895 were covered by 342 analyses of beets grown by the University of Idaho and by farmers residing near Grangeville, Nampa, Moscow, Weippe, Vollmer, Palonse, Spokane Bridge, Westlake, Starner, Newport, Salmonn, and Paris.

The average sugar conteut of the crop was $\mathbf{1 5 . 1 9}$ per cent; coeficient of purity, 79.91. In the analyses were included 15 samples of red or table beets. These 15 contained an average of 13.75 per cent of sugar in the juice and a coeficient of purity of 75.57 .

Several aualyses were made for the purpose of determining what bearing, if any, the size of the sample beet had upon the sugar content and purity. Among others I select four varieties, and submit the results without comment:

VILMORINS IMPROVED.

\begin{tabular}{|c|c|c|c|}
\hline Size. & Weight. & $\begin{array}{c}\text { Sugar in } \\
\text { beet. }\end{array}$ & $\begin{array}{l}\text { Purityco- } \\
\text { eflicient. }\end{array}$ \\
\hline $\begin{array}{l}\text { Large } \\
\text { 3edium ........ } \\
\text { 3. Small }\end{array}$ & $\begin{array}{r}\text { Ounces. } \\
21.4 \\
15.2 \\
7.8\end{array}$ & $\begin{array}{r}\text { Per cent. } \\
14.02 \\
14.31 \\
14.07\end{array}$ & $\begin{array}{l}79.96 \\
81.26 \\
78.58\end{array}$ \\
\hline
\end{tabular}

FLORIMOND DESPIEEZ.

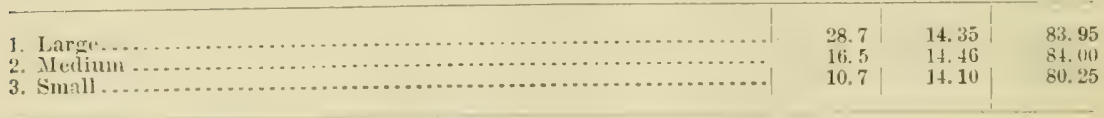

I.ANE'S IMLPERIAL.

\begin{tabular}{|c|c|c|c|}
\hline 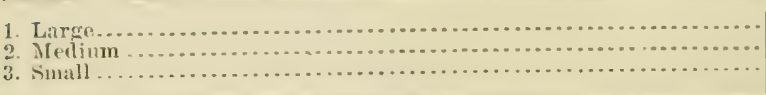 & $\begin{array}{r}24.1 \\
13.3 \\
8.0\end{array}$ & $\begin{array}{l}13.62 \\
13.69 \\
13,38\end{array}$ & $\begin{array}{l}80.92 \\
82.17 \\
82.07\end{array}$ \\
\hline KLEINWANZLEBENIR. & & & \\
\hline 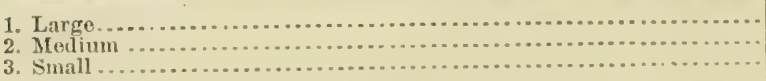 & $\begin{array}{l}26.0 \\
17.0 \\
13.0\end{array}$ & $\begin{array}{l}14.00 \\
14.06 \\
13.74\end{array}$ & $\begin{array}{l}81.13 \\
84.72 \\
83.93\end{array}$ \\
\hline
\end{tabular}

${ }^{1}$ This estimate, as is usual in such eases, is toubtless too high.- H. W. W. 


\section{ANALXSES OF BEETS GROWN IN 1896.}

The work of the year was confined very largely to the station, and consisted of a special effort in the way of growing typical sugar beets. The effect of deep and shallow plowing, regular cultivation, fertilization, and irrigation, as compared with the average treatment given the root under natural conditions as to soil, moisture, and eultivation, was noted. The seed bed was preparel and the seed sown from the 21 st to the 30 th of May. Very heavy rains prevailed on June 5 and again on June 9. All of the seed had germinated by June 11. The average per cent of stand June 5 was 10.7 ; June 24 it was 29 ; one month later it had reached 61.8 per cent. The crop was harvested and analyzed during October. The number of analyses made was 60 ; the per cent of sucrose in juice was 14.18 ; coefficient of purity, 77.30 ; yield per acre, $48,5.10$ pounds.

The sugar-beet experiments conuected with this station during 1894, 1895, 1896, and the inauguration of the work of 1897 were under the direction and control of the Agricultural Department, the ehemist heing responsible only for the analytical data. In July, 1897, under the redistribution of the powers of the station staff, the rather unsatisfactory data thus collected were assigned to the chemical department for compilation and publication, together with the power of supervision of such experiments in the future.

\section{METEOROLOGICAI, RECORD.}

The better to understand the possibilities of the sugar-beet ind ustry in the Palouse country of Idaho, as well as other experiments that may hereafter he undertaken by thestation upon the "university farm," the following meteorological data are included in this report. Wo are under ol)ligations to Prof. J. E. Bonebright, meteorologist of the station, for the results tabulated:

TABLE 11.-Meteorological record for Moscow.

\begin{tabular}{|c|c|c|c|c|c|c|c|c|}
\hline Month. & $\begin{array}{l}\text { Maxi- } \\
\text { mum tem- } \\
\text { perature. }\end{array}$ & \begin{tabular}{|c|} 
Mini- \\
mun tem \\
perature.
\end{tabular} & $\begin{array}{c}\text { Average } \\
\text { tempera- } \\
\text { ture. }\end{array}$ & $\begin{array}{c}\text { Humid- } \\
\text { ity. }\end{array}$ & Rainfall. & $\begin{array}{l}\text { Dass } \\
\text { fair. }\end{array}$ & $\begin{array}{l}\text { Dase } \\
\text { clear. }\end{array}$ & $\begin{array}{l}\text { Days } \\
\text { clouidy. }\end{array}$ \\
\hline 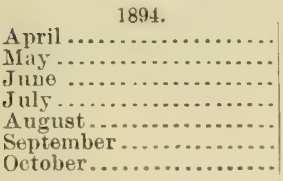 & $\begin{array}{l}\circ \\
76.0 \\
86.0 \\
84.0 \\
93.0 \\
96.0 \\
85.0 \\
74.0\end{array}$ & $\begin{array}{l}\circ \\
25.0 \\
30.0 \\
32.0 \\
40.0 \\
34.0 \\
32.0 \\
28.0\end{array}$ & $\begin{array}{l}\text { ० } \\
47.40 \\
57.40 \\
62.00 \\
78.00 \\
70.50 \\
58.80 \\
40.40\end{array}$ & $\begin{array}{r}\text { Per cent. } \\
76.0 \\
63.0 \\
74.0 \\
65.0 \\
46.0 \\
72.0 \\
85.0\end{array}$ & $\begin{array}{r}\text { Inches. } \\
1.38 \\
1.53 \\
1.23 \\
.12 \\
.25 \\
.89 \\
3.70\end{array}$ & $\begin{array}{l}8 \\
7 \\
3 \\
2 \\
3 \\
2 \\
9\end{array}$ & $\begin{array}{r}7 \\
15 \\
19 \\
29 \\
26 \\
25 \\
9\end{array}$ & $\begin{array}{r}15 \\
9 \\
8 \\
0 \\
2 \\
3 \\
13\end{array}$ \\
\hline 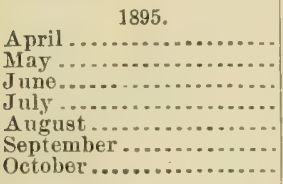 & $\begin{array}{l}76.0 \\
81.0 \\
96.0 \\
92.0 \\
94.0 \\
84.0 \\
74.0\end{array}$ & $\begin{array}{l}26.0 \\
30.0 \\
33.0 \\
41.0 \\
33.0 \\
28.0 \\
21.0\end{array}$ & $\begin{array}{l}48.10 \\
51.90 \\
59.40 \\
72.70 \\
74.50 \\
49.80 \\
46.10\end{array}$ & $\begin{array}{l}70.0 \\
68.0 \\
52.0 \\
38.0 \\
47.0 \\
70.0 \\
72.0\end{array}$ & $\begin{array}{r}1.30 \\
2.17 \\
.41 \\
.90 \\
.32 \\
3.33 \\
\text { Trace. }\end{array}$ & $\begin{array}{c}5 \\
2 \\
\cdots \\
1 \\
3 \\
2 \\
2\end{array}$ & $\begin{array}{l}12 \\
22 \\
29 \\
29 \\
26 \\
20 \\
27\end{array}$ & $\begin{array}{r}13 \\
7 \\
-3 \\
1 \\
2 \\
8 \\
2\end{array}$ \\
\hline 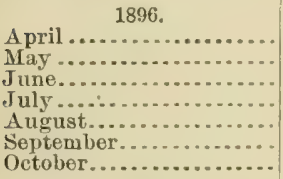 & $\begin{array}{l}68.0 \\
84.0 \\
92.0 \\
97.0 \\
93.0 \\
85.0 \\
76.0\end{array}$ & $\begin{array}{l}26.0 \\
31.0 \\
34.0 \\
14.0 \\
38.0 \\
30.0 \\
28.0\end{array}$ & $\begin{array}{l}42.53 \\
46.50 \\
61.10 \\
70.41 \\
67.17 \\
54.65 \\
46.33\end{array}$ & $\begin{array}{r}85.5 \\
61.7 \\
55.6 \\
55.4 \\
72.2 \\
\ldots . . .\end{array}$ & $\begin{array}{r}.57 \\
3.60 \\
2.21 \\
.17 \\
1.33 \\
.81 \\
1.07\end{array}$ & $\begin{array}{r}12 \\
4 \\
0 \\
0 \\
0 \\
0 \\
2\end{array}$ & $\begin{array}{l}10 \\
13 \\
30 \\
30 \\
26 \\
22 \\
17\end{array}$ & $\begin{array}{r}8 \\
14 \\
0 \\
1 \\
5 \\
8 \\
12\end{array}$ \\
\hline 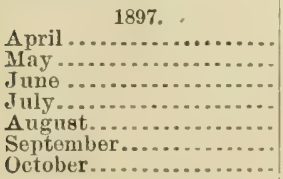 & $\begin{array}{l}63.1 \\
78.9 \\
65.6 \\
82.0 \\
81.6 \\
69.9 \\
66.4\end{array}$ & $\begin{array}{l}36.5 \\
38.8 \\
46.0 \\
48.5 \\
46.4 \\
38.4 \\
36.4\end{array}$ & $\begin{array}{r}49.70 \\
53.80 \\
70.00 \\
71.50 \\
59.20 \\
\ldots \ldots\end{array}$ & $\begin{array}{r}72.2 \\
77.4 \\
45.4 \\
40.3 \\
77.6 \\
\ldots \ldots . . .\end{array}$ & $\begin{array}{r}.40 \\
1.20 \\
2.72 \\
.85 \\
.35 \\
1.67 \\
1.10\end{array}$ & $\begin{array}{l}0 \\
0 \\
0 \\
0 \\
0 \\
0 \\
3\end{array}$ & $\begin{array}{l}19 \\
21 \\
25 \\
26 \\
30 \\
22 \\
22\end{array}$ & $\begin{array}{r}11 \\
10 \\
5 \\
5 \\
1 \\
8 \\
6\end{array}$ \\
\hline
\end{tabular}




\section{ILLINOIS.}

The samples received from the State of Illinois by the Department of Agriculture were $3:$ in number. The average weight of the samples was 17 ounces, percentage of sugar 13.1, and the purity 75.5. Twelve of these samples were from the northern, 8 from the central, and 12 from the southern belt.

When judged by the few samples analyzed by the Department of Agriculture, it is seen that Illinois presents an exception to the established rule, inasmuch as the beets grown in the northern belt are inferior to those grown in the central belt. 'The data, however, are not numerous enough to base any certain conclusions upon them, and the usual rule is established from the more numerous analyses conducted by the agricultural experiment station, as will be seen farther along. Summarized, the results obtained at the Department of Agriculture from the northern, central, aud southern belts in Illinois are as follows:

$$
\text { Summary of analyses of sugar beets from Illinois. }
$$

[Compiled from analyses of the United States Department of Agriculture.]

\begin{tabular}{|c|c|c|c|c|}
\hline - & $\begin{array}{l}\text { Number } \\
\text { of sant- } \\
\text { ples. }\end{array}$ & $\begin{array}{l}\text { Arerage } \\
\text { weight. }\end{array}$ & $\begin{array}{l}\text { Sugar in } \\
\text { beots. }\end{array}$ & $\begin{array}{l}\text { Purity co- } \\
\text { efticient. }\end{array}$ \\
\hline 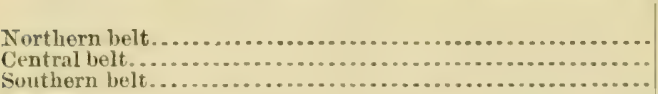 & $\begin{array}{r}12 \\
8 \\
12\end{array}$ & $\begin{array}{r}\text { Ounces. } \\
19 \\
20 \\
13\end{array}$ & $\begin{array}{r}\text { Per cent. } \\
12.6 \\
13.8 \\
13.2\end{array}$ & $\begin{array}{l}76.2 \\
76.5 \\
73.3\end{array}$ \\
\hline
\end{tabular}

At the agricultural experiment station of Illinois, at Urbana, 312 simples of beets were received and analyzed. The following summary shows the analytical data and the distribution of the samples by counties:

Summary of analyses of sugar beets from Illinois, by counties.

\begin{tabular}{|c|c|c|c|c|c|c|c|c|c|}
\hline County. & 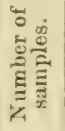 & 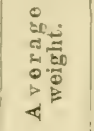 & 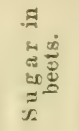 & 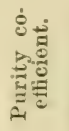 & County. & 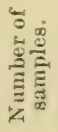 & 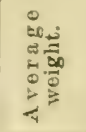 & 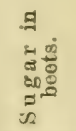 & 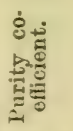 \\
\hline NORTHERN MELT. & & Ounces. & Peret. & & CENTRAL BELT. & & Ounces. & Per ct. & \\
\hline $\begin{array}{l}\text { Stophenson........ } \\
\text { Winnebago .... }\end{array}$ & $\begin{array}{l}1 \\
2\end{array}$ & $\begin{array}{l}20 \\
18\end{array}$ & & $\begin{array}{r}70.0 \\
75.8\end{array}$ & Kankakeo......... & $\begin{array}{l}8 \\
1\end{array}$ & $\begin{array}{l}24 \\
22\end{array}$ & & $\begin{array}{l}79.3 \\
70.8\end{array}$ \\
\hline McHenry ......... & 1 & 19 & 15. & 84.3 & 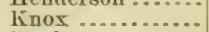 & 4 & 20 & 11.0 & 75.1 \\
\hline Carroll............. & 4 & 2 & & 8 & Stark ............. & 1 & 10 & & 78.3 \\
\hline IV hiteside....... & 6 & 22 & & 79 & Peoria. & 4 & 24 & & 80. 1 \\
\hline 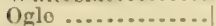 & 3 & 23 & & 74 & Mlarshall......... & 1 & 18 & 14 & 83.9 \\
\hline Lee. & 8 & 16 & & 80 & Woolford ......... & 1 & 2: & & $8: 1$ \\
\hline Dekalb............... & 7 & 20 & & & gston ........ & 3 & 17 & & 82.9 \\
\hline$g \theta \ldots . . . . .$. & 1 & 21 & & 82 & $10 \mathrm{is} . . . . . . .$. & 50 & 20 & 11 & 75.3 \\
\hline Cook....... & 3 & 24 & & 82 & Hancock........ & 1 & 17 & & 64.0 \\
\hline liock Island... & 1 & 16 & & 82.5 & Fulton ...... & 1 & 17 & 11. 2 & 77.1 \\
\hline IIe & 6 & 18 & 12.7 & 78.3 & Tazowell.... & 2 & 20 & 12.3 & 78.8 \\
\hline u... & 3 & 33 & 10.5 & 76.5 & Mrclean..... & 5 & 24 & 12.0 & $7 \% .6$ \\
\hline I_asalle ........... & 31 & 22 & 13 & 76.4 & Ford .......... & 1 & 24 & 10.8 & 77.0 \\
\hline Tíentall ........... & 2 & 14 & 13.8 & 82.8 & Adams... & 4 & 17 & 12.4 & 75.5 \\
\hline Cirumely ... & 1 & 18 & 13.9 & & MInson . & 25 & 19 & 11.1 & 73. 7 \\
\hline Will...... & 23 & 28 & 12.9 & 74.6 & Logan.... & $t$ & 29 & 9.8 & 69.6 \\
\hline Mercer.............. & 1 & 17 & 12.6 & 79.7 & Dowitt... & 1 & 27 & 13,8 & 81.7 \\
\hline
\end{tabular}


Summary of analyses of sugar beets from Illinois, by counties-Continued.

\begin{tabular}{|c|c|c|c|c|c|c|c|c|c|}
\hline County. & 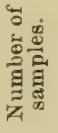 & 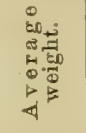 & 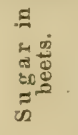 & 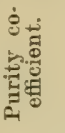 & County. & 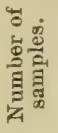 & 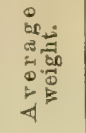 & 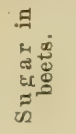 & 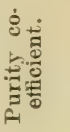 \\
\hline $\begin{array}{l}\text { CENTRAL BELT- } \\
\text { continued. }\end{array}$ & & & & & $\begin{array}{l}\text { CENTRAL HELT- } \\
\text { continued. }\end{array}$ & & & & \\
\hline Mricon ............ & 1 & $\begin{array}{c}\text { Ounces. } \\
18\end{array}$ & $\begin{array}{r}\text { Per ct. } \\
8.0\end{array}$ & 64.9 & Clark ... & 4 & $\begin{array}{c}\text { Ounces. } \\
11\end{array}$ & $\begin{array}{r}\text { Per ct. } \\
13.6\end{array}$ & 73.9 \\
\hline Piatt ................ & 2 & 20 & 12.7 & 81.0 & (6) & & & & \\
\hline Champaign ........ & 10 & 21 & 11.7 & 79.6 & SOUTHERN BELT. & & & & \\
\hline Vermilion.......... & 2 & 19 & 11. 3 & 75.2 & & & & & \\
\hline Piko ............... & 1 & 10 & 9.6 & 69.4 & Ethingham....... & 1 & 10 & 12.6 & 74.6 \\
\hline Scott ............... & 1 & 10 & 9.7 & 64.3 & Madison ......... & 15 & 21 & 10.3 & 74.0 \\
\hline Mrorgan ........... & 4 & 22 & 10.3 & 74.3 & 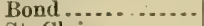 & 1 & 18 & 10. 3 & 80.8 \\
\hline Sangamon......... & 2 & 17 & 11.2 & 76.8 & St. Clair ............... & 11 & 21 & 12.3 & 77.7 \\
\hline Christian......... & 2 & 19 & 11.8 & 76.5 & Washington...... & 1 & 16 & 11.9 & 75.2 \\
\hline Shelby ............ & 3 & 21 & 10.9 & 71.9 & Jetferson ......... & 1 & 14 & 12.1 & 85. 0 \\
\hline Donglas .......... . . & 3 & 24 & 11.2 & 77.5 & Wayne........... & 1 & 16 & 14.3 & 77. 0 \\
\hline Edgar ............. & 2 & 16 & 12.1 & 74.9 & 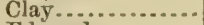 & 1 & 15 & 11.8 & 68.3 \\
\hline Calhoun.......... & 2 & 14 & 9.4 & 72.1 & Edwards......... & 1 & 15 & 8. 7 & 58.7 \\
\hline Greene... . . . . . . . . & 3 & 14 & 8.5 & 68.3 & Jackson........... & 2 & 17 & 10.8 & 73. 8 \\
\hline Macoupin ........ & 6 & 17 & 11.6 & 72.2 & Salino ............. & 3 & 10 & 9.3 & 68.9 \\
\hline Moutgomery ....... & 5 & 11 & 13.0 & 76.9 & & & & & \\
\hline
\end{tabular}

The average weight of the beets received was 20 ounces, the mean percentage of sugar therein 11.9, and the mean purity 76.4. Distributed geographically into northern, central, and southern sections, we find each of the sections represented by the number of samples of the mean average composition indicated in the following summary:

Summary of analyses of sugar beets from Illinois.

[Compiled from the experiment station report.]

\begin{tabular}{|c|c|c|c|c|}
\hline & $\begin{array}{l}\text { Number } \\
\text { of } \\
\text { samples. }\end{array}$ & $\begin{array}{l}\text { Average } \\
\text { weight. }\end{array}$ & $\begin{array}{c}\text { Sugar in } \\
\text { beets. }\end{array}$ & $\begin{array}{l}\text { Purity co- } \\
\text { efficient. }\end{array}$ \\
\hline $\begin{array}{l}\text { Northern belt } \\
\text { Central belt } \\
\text { Southern belt } \ldots \ldots \ldots \ldots \ldots\end{array}$ & $\begin{array}{r}104 \\
165 \\
43\end{array}$ & $\begin{array}{r}\text { Ounces. } \\
22 \\
20 \\
19\end{array}$ & $\left|\begin{array}{r}\text { Per cent. } \\
13.2 \\
11.5 \\
11.1\end{array}\right|$ & $\begin{array}{l}79.3 \\
75.4 \\
71.7\end{array}$ \\
\hline A rerage, otc ......... & 312 & 20 & 11.9 & $\overline{76.4}$ \\
\hline
\end{tabular}

Here we see the regular rule illustrated, and the beets derived from the northern are superior in every respect to those from the central and southern belts. It is evident, however, judged by the data obtained during the present year, that Illinois is not so well adapted to the growing of high-grade beets as some of the States to the east of it. Nevertheless, it is quite certain that, with proper drainage, scientific cultivation and fertilization, and good culture, high-grade beets can be grown in many of the northern counties of Illinois, and it would probably be safe to say that for a distance of 100 miles from the boundary between Wisconsin and Illinois the sugar-beet industry could be successfully established where the conditions of soil and factors favorable to manufacture are suitable.

INDIANA.

One hundred and three samples were received at the Department of Agriculture from the State of Indiana, representing several different 
parts of the State, but mostly from the northern portions. The largest number of samples, however, from any one county was from Vanderburg, in the extreme southwestern part of the State. The average size of the beets from Indiana was small, the percentage of sugar in the beet fair, and the purity a little below the minimum for good beets. In general, the best beets were grown in the northern portion of the State, near or in the thermal beet belt, although a few samples received from the central and eastern parts of the state were very satisfactory. Among the counties furnishing the largest number of samples may be mentioned Henry, in the central easteru part of the State, from which 8 samples were received, having an average weight of 17 ounces, containing 13.1 per cent of sugar, with a purity of 78.5 . The averages for Henry County in sugar and purity were almost exactly those for the whole State. Three samples from Marion County, in the central portion of the State, show excellent results, both in percentage of sugar and in purity, and having an average size of a pound. The best results are reported from Stark County, in the northwestern portion of the State, where the percentage of sugar was 15.7 and purity 81.8. The beets, however, from this region were small, the average size being only 12.8 ounces. The beets received from the agricultural experiment station were very much undergrown, the average weight being less than 7 ounces. The percentage of sugar in the beets was good-15.1-and the purity also above the minimum. The causes of the poor yield of beets are discussed farther on in the report of the chemist of the station. The largest number of beets from any one county was received from Vanderburg, namely, 40 samples. The people of this county have been particularly interested in the industry, and especially to Mr. H. Cordes are we indebted for the large number of samples received. In spite of the very fertile soil and other favorable conditions of eulture, the beets had an average size of only 14 ounces, and both the percentage of sugar in the beet and the purity were below the minima. In general, it may be said of Indiana that the northern portions of the State, where the character of the soil is favorable, are best suited to the culture of the sugar beet, namely, those portions either lying in the area of farorable thermal conditions, or extending to a varying distance to the sonth thereof and covering the greater portion of the northern part of the State. The central counties of the State, judged by the few samples received, may also be expected to grow beets of fair quality. A more careful agricultural survey of the state is neederl, and the data above are supplemented by the more valuable data collected by the agricultural experiment station under the supervision of the chemist, Mr. H. A. Huston.

\section{NOTES ON SUGAR BEETS RAISED IN INDTANA IN 1897.}

(From Report of H. A. Huston.)

The early part of the season was fairly favorable to the growth of the crop. In many cases, howerer, the beets were planted quite late and were much below normal size when the drought came on in Angust. From the middle of August until tho 
end of the usual growing season very little rain fell. This tenled to produce beets of high sugar content and small size. The popular interest in the subject has been much greater than in previous years and a much better return than usual was secured from the seed sent ont.

At three points in the State parties are now engaged in placing contracts for sufficient acreage to insure a three years' supply of beets for a 300 -ton factory. Reports from these localities indicate that the required acreage will be secured.

Nearly all farmers who have raised experimental crops of beets for the past few years report that they believe the crop would be a profitalle one at $\$ 4$ per ton. This estimate is based solely on their own experience with the crop.

The total number of samples analyzed at the agrieultural experiment station of Indiana $\pi$ as 205 . A rranged by connties, the following table gives the most important data connected with the analyses:

Tests of sugar beets grown in Indiana in 1897 under the direction of the Indiana agricultural experiment station. H. A. Huston and J. M. Barrett.

\begin{tabular}{|c|c|c|c|c|c|c|c|c|c|}
\hline County. & 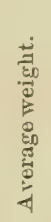 & 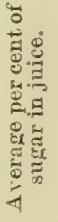 & 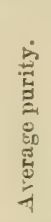 & 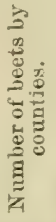 & County. & 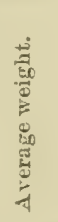 & 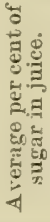 & 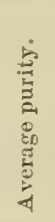 & 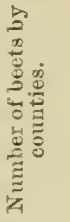 \\
\hline cake $r$ & $\begin{array}{l}\text { Ozs. } \\
51\end{array}$ & 8. & 68. & 1 & Grant & $z 8$. & 130 & & \\
\hline Porter $\square \ldots . . . . . . . .$. & 12 & 13. 7 & 84.0 & 2 & Jay ㅁ...... & 26 & 13.3 & 79.5 & $\begin{array}{l}2 \\
2\end{array}$ \\
\hline Laporte $\square \quad . . . . . . .$. & 22 & 9. & 6 & 1 & Fountain $\square . . . . . .$. & 31 & 10.1 & 8.6 & 1 \\
\hline St.Joseph म .......... & 24 & 13. & 85 & 6 & Clinton $\square$................ & 18 & 13 & 83. 2 & 4 \\
\hline Elkbart $\phi \ldots . . . . . . .$. & 12 & 1 & 83. & 7 & Boone $\square=. . . . . . .$. & 1 is & 13.6 & 82.0 & 5 \\
\hline Lagrange $\square \ldots . . . . .$. & 12 & 1 & 87 & 1 & I'ipton …........... & 20 & 13.5 & 2.3 & 11 \\
\hline 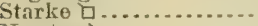 & 14 & 1 & 8 & 28 & Madisou $\square . . . . . . .$. & 33 & 9 & 0.2 & 1 \\
\hline Newton $\square \ldots . . . . . . . .$. & 11 & 1 & 96 & 1 & Randolph ㅁ........... & 24 & 12.9 & 9.0 & 3 \\
\hline Jasper ロ ............... & 2 & 17. & 81 & 1 & Parke $-\square \ldots . . . . . . .$. & 8 & 10.2 & 56.7 & \\
\hline Allen $\square \ldots . . . . . .$. & 23 & 13 & 8 & 21 & Marion ㅁ........... & 1 & 12 & 3.5 & 1 \\
\hline Bentou $\square$............... & 31 & 11. & 7 & 3 & Hancock …....... & 2 & 14 & 4 & 4 \\
\hline TV lite $\mathrm{b}$................ & 20 & 10. & ti & 1 & Henry ㅁ............. & 1 & 12 & 78.0 & 12 \\
\hline 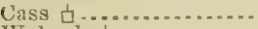 & 17 & 12. & 7 & 4 & MCorgan $0 . . . . . . .$. & 1 & 13.9 & 82.8 & 9 \\
\hline Wabash 古..... & 14 & 13. & 7 & 4 & Greene & 12 & 12.8 & 4 & 3 \\
\hline Huntingtou $\square$... & 25 & 1 & 7 & 19 & Jackson ㅁ…. & 8 & & & 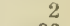 \\
\hline WV arren $\neg-\ldots . . . . . . .$. & 18 & 12.2 & 83. & 1 & Vaaderburg $\not \ldots . . .$. & 15 & 10.6 & 77.7 & 36 \\
\hline Carroll $\square . . . .$. & 11 & 12.4 & 82.0 & 5 & Averages, etc ... & 17.8 & 12.6 & 80.7 & 205 \\
\hline
\end{tabular}

Is will be seen above, nearly all the connties represented are in the northern part of the State. Only a few counties are represented in the central and southern portions of the State. Making an average of the results from the different comuties by sections of the State, it is seen that they vary considerably, as is shown in the following summary:

Summary of results.

Northern belt.

Central belt

\section{Suminting of resilts.}

\begin{tabular}{|c|c|c|c|c|}
\hline & $\begin{array}{l}\text { Average } \\
\text { weight. }\end{array}$ & $\begin{array}{l}\text { Average } \\
\text { per cent of } \\
\text { sugar in } \\
\text { juice. }\end{array}$ & $\begin{array}{l}\text { Averago } \\
\text { purity } \\
\text { coefficient. }\end{array}$ & $\begin{array}{l}\text { Namber } \\
\text { beets. }\end{array}$ \\
\hline 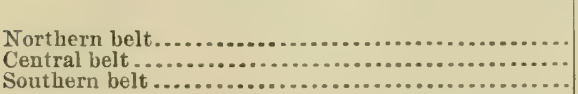 & $\begin{array}{r}\text { Ounces. } \\
18.9 \\
18.5 \\
14.2\end{array}$ & $\begin{array}{l}13.3 \\
12.9 \\
10.7\end{array}$ & $\begin{array}{l}81.9 \\
80.7 \\
78.0\end{array}$ & $\begin{array}{l}97 \\
67 \\
41\end{array}$ \\
\hline
\end{tabular}


It is seen that there are considerable areas in the northern part of the State where both soil and climatic conditions are extremely favorable to the culture of the sugar beet. The proximity of these counties to Chieago insures a marliet for all the products of the factory. In many cases these counties are situated in or near the gas area of the State, so that fuel is comparatively cheap. All of them are within easy distance of the great coal tields of Indiana, and the supply of water and limestone is abundant. It is evichent. therefore, that all the conditions favorable to the growth and mamnacture of the leets exist in the northern part of the State of Indiana, and there is no reason to doubt the speedy foundation and lie:lthy gromth of the industry in that locality.

IowA.

The thermal conditions for the growth of beets in Iowa are farorable orer almost the whole of the State from north to south. The southeru comnties are probably a little too warm for the best results, and the northern counties too much exposed to severe cold weather during harrest time.

One hundred and thirty samples of beets rere sent directly from Iowa to the Department of Agriculture for analysis.

In the results as tabulated by comnties it will be observed that a great many of the comnties are represented by a single sample, and therefore it is not possible to base any conchsions on the rork done in respect of the possibilities of gromth of beets in such counties. Benton County sent 6 samples. with an arerage weight of 16 ounces: 13.s per cent of sugar in the beet. with a jurity of 76.9 . Clinton County furnished 5 samples. The beets were very small, averaging only 11 ounces. The content of sugar was high. namely. 16.s per cent, and the purity low. 75.8. Greene County sent 39 samples of gool size, namely, 21 ounces: rather low content of sugar, namely, 12.7 per cent, and a low purity, namely, 76.3 . Guthrie County sent 6 simples of good size. namely. 23 ounces; rather low content of sugar. 12.j per cent, with a purity of $\mathbf{7 s . 3 . ~ T h e ~ a r e r a g e s ~ f o r ~ t h e ~} 130$ samples from the State are as follows: Weight. 18 ounces: sugar in beets, 13.3 per cent; purity, 73.7.

Under the direction of the agricultural experiment station of the State. in cooperation with this Department, al larce number of samples of seed was distributed. and $6 t_{-2}^{2}$ samples of beets sent to the station for analysis. Following is an abstract of the report of Prot. C. F. Curtiss, director of the Iowa station:

Total number of samples analyzed, 6.?.

One and seven-tenths per cent of the samples contained 17 per cent or more of sugar: i: per cent of these hat a purity coethicient of So or abore, and bo per cent of these samples reighed 14 ounces or abore.

Four and three-tenths per cent of the samples contuinel 16 per cent and over of sugar and less than 17 per cent; of these samples 56 per 
cent had a purity coeflicient of $S 0$ degrees or above, and 2.9 per cent weighed 14 onnces or above.

Twenty-two and three-tenths per cent of the samples contained 14 per cent or over of sugar and less than 16 per cent; of these samples i) per cent had a purity coefficient of 80 or abore, and $6:$ per cent weighed 16 ounces or above.

Forty-one and four-tenths per cent of the samples contained 12 per cent and over of sugar anc less than 14 per cent; of these samples 14.7 per cent lial a purity coefficient of 80 or above, and 69 per cent weighed 16 ounces or above.

Sixty-nine and three-tenths per cent of the total number of samples contained 12 per cent or mole of sugar.

The above percentages are based on the weight of the juice.

'The mean weight of the simples received at the Iowa station was 19 ounces, the mean perentige of sugar in the beet 12.4 , and the mean purity 76.6. The results by counties are given in the following table:

Analysęs of sugar beets grown in Iowa and analyzed by the fowa agricultural experiment station.

\begin{tabular}{|c|c|c|c|c|c|c|c|}
\hline County. & $\begin{array}{l}\text { Averago } \\
\text { weight } \\
\text { per root. }\end{array}$ & Sugar. & $\begin{array}{l}\text { P'nrity } \\
\text { coet- } \\
\text { ficient. }\end{array}$ & County. & $\begin{array}{c}\text { Averago } \\
\text { weight } \\
\text { per root. }\end{array}$ & Sugar. & $\begin{array}{l}\text { Purity } \\
\text { coef- } \\
\text { ficient. }\end{array}$ \\
\hline Aelair. & Ounces. & Per cent. & 77,45 & Johnson & Ounces. & Per cent. & \\
\hline (........... & $\begin{array}{l}19 \\
21\end{array}$ & $\begin{array}{l}\text { 1.3. } 40 \\
13.26\end{array}$ & 75.30 & $\begin{array}{l}\text { Jobnson ............ } \\
\text { Jones............... }\end{array}$ & $\begin{array}{l}20 \\
17\end{array}$ & $\begin{array}{l}12.04 \\
14.05\end{array}$ & $\begin{array}{l}76.98 \\
77.52\end{array}$ \\
\hline Allamakeo......... & 20 & 14.26 & 78.87 & Keokuk ........ & 23 & 14.06 & 76.46 \\
\hline A ppanoose ......... & 8 & 16. 11 & 82.80 & Kossuth............. & 25 & 12.58 & 77.26 \\
\hline Audubon............ & 16 & 13.09 & 78.36 & 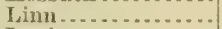 & 17 & 12.08 & 74.02 \\
\hline 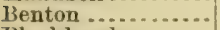 & 21 & 13.30 & 76.68 & Louisa............... & 10 & 12.65 & 74.54 \\
\hline Blackhawk ........ & 17 & 13.98 & 79.64 & 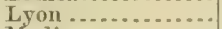 & 19 & 14.07 & 79.33 \\
\hline Boone ................ & 17 & 13. 33 & 76.81 & Marlison.......... & 18 & 12.55 & 74.34 \\
\hline Bremer.............. & 14 & 11. 21 & 78.71 & Marion ............... & 21 & 12.86 & 74. 66 \\
\hline Buchanan ......... & 15 & 14.21 & 76.25 & Marshall .......... & 22 & 12.51 & 74.85 \\
\hline Buena Vista...... & 19 & 13.62 & 77. 70 & IIills ............... & 19 & 12.94 & 76.94 \\
\hline Butler............. & 13 & 10.77 & 74.45 & MIitchell........... & 20 & 12.37 & 76.21 \\
\hline Callomu.......... & 12 & 15.80 & 81.46 & MIonona .......... & 27 & $13.86^{\circ}$ & 80.87 \\
\hline Carroll ........... & 22 & 12.31 & 75.51 & Montgomery ...... & 25 & 12. 33 & 76.52 \\
\hline 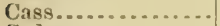 & 22 & 12.03 & 75.34 & Mruscatino .......... & 20 & 14.44 & 80.92 \\
\hline Cedar ................ & 21 & 12.56 & 74.48 & U'Brien . . . . . & 16 & 14.38 & 92.77 \\
\hline Cherokee.......... & 19 & 13.31 & 77.01 & Osceola............... & 14 & 14.16 & 81.48 \\
\hline Chickasaw ....... & 15 & 13. 34 & 75.54 & 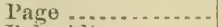 & 2 & 12.56 & 74.22 \\
\hline 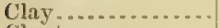 & 17 & 12. 08 & 74.06 & Palo Alto......... & 92 & 12.88 & 106.85 \\
\hline Clayton .......... & 23 & 13.48 & 78.47 & Plymouth ........ & 20 & 12.49 & 79.39 \\
\hline Clinton ............ & 17 & 15. 81 & 78.97 & Pocahontas....... & 20 & 11.76 & 78.46 \\
\hline Craw ford .......... & 23 & 10.55 & 68.24 & Polk................ & 22 & 12.96 & 76.09 \\
\hline Dallas ............. & 23 & 13.46 & 79.33 & Pottawattamio.... & 19 & 13.04 & 78. 13 \\
\hline Davis.................. & 14 & 15.78 & 73.94 & I'owesliek ........ & 26 & 12.87 & 77.52 \\
\hline Decatur ........... & 12 & 14.14 & 79.27 & Ringgoll......... & 17 & $12.5 t$ & 75.58 \\
\hline Delaware........... & 18 & 13.23 & 75.76 & 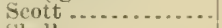 & 16 & 13.73 & 76.59 \\
\hline Dickinson ........ & 21 & 12.81 & 75.16 & Shelby -............. & 24 & 13. 43 & 78.58 \\
\hline Dubuque .......... & 17 & 14.14 & 69.76 & Sioux............... & 28 & 12.44 & 73.79 \\
\hline Fayette.......... & 17 & 14.62 & 80.33 & Story ............... & 22 & 12.30 & 76.51 \\
\hline 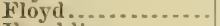 & 24 & 12.77 & 75.01 & 'Tama......... & 17 & 12.55 & 77.04 \\
\hline Franklin .......... & 17 & 12.62 & 73.23 & Taylor........ & 11 & 11.82 & 70.39 \\
\hline Fremont........... & 19 & 12.15 & 71.37 & 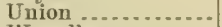 & 15 & โ3.98 & 76.51 \\
\hline Greeno .............. & 19 & 13.04 & 77.42 & Wapello ........... & 19 & 13.70 & 76.74 \\
\hline Grundy ........... & 23 & 12.00 & 73.91 & Warren............. & 20 & 13.62 & 75.79 \\
\hline Guthrio ............ & 22 & 12. 60 & 74.98 & WVashingtou ....... & 21 & 13.84 & 77.84 \\
\hline Hamilton ......... & 21 & 12.58 & 75.24 & Wayne............. & 13 & 15.15 & 70.92 \\
\hline Hancock.......... & 18 & 11.92 & 75.84 & Webster.... & 18 & 12.57 & 76.14 \\
\hline Hardin................. & 19 & 12.88 & 77. 01 & Winnebago. & 22 & 12.21 & 76.87 \\
\hline Harrison .......... & 17 & 12.65 & 76.57 & Winnesbiek ........ & 19 & 13.57 & 76.42 \\
\hline Henry ................ & 26 & 14. 24 & 78.64 & IVoodbury......... & 20 & 12.72 & 74.34 \\
\hline Howard ............ & 18 & 13.33 & 77. 48 & Worth ...... & 18 & 13.34 & 78.77 \\
\hline 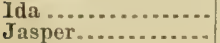 & $\begin{array}{l}21 \\
23\end{array}$ & $\begin{array}{l}12.79 \\
13.06\end{array}$ & $\begin{array}{l}77.49 \\
76.86\end{array}$ & Wright............. & 15 & 12.22 & 75.48 \\
\hline Jetierson ........... & 12 & 12.36 & 76.27 & Areri & 19 & 12.98 & 76.56 \\
\hline
\end{tabular}


The results contaned in the above table are not as satislactory as would be expeced from the location of Iowa in respect of thermal and other climatic influences. The poor resultis obtained are due either to the seasonal influences, which might have been particularly bad for the season in question, or to some unsuitalility of the soil or climate to the production of hish-grade beets. In general, it has been observed that soils particularly rich in humus and of a black color do not produce as high-grarle beets as sandy and somewhat lightercolored soils. The character of the subsoil and of the stratum underlying it must also be taken into consirleration before wo can lave an idea of the condition of aeration of the soil and the possibilities of the roots of the beets extending to the proper depth. It is fortumate that the agricultural experiment station of Iowa will continue these experiments in a more careful manner and under more efticient control of the station or some of its representatives. It is evident that with the possible exception of the southern tier of connties a large portion of the State of Iowa with favorable soil conditions should produce beets of high saccharine strength. The causes which have depressed both the content of sugar and the coeflicient of purity should be carefully investigated.

\section{KANSAS.}

Several years ago extensive experiments in growing beets in Kansas were made at Medicine Lodge, and accounts of the work are given in former bulletius on this subject. It that time it was stated, in cliscussing the results, thit the climate of Kansas was particularly unfavorable to beet culture. The extremely dry weather to which murh of the State is frequently subjected, in conjunction with the hot winds which sweep over the vast plains almost every year from the southwest, renders the growth of the beet extremely precarious. At times excellent beets can be grown; in fact, beets of fine character were produced at the time mentioned at Medicine Lodge. It is not to be expected, however, that from year to year beets of high grade can be grown in sufficient quantities to warrant the building of factories in the State. Nevertheless, considerable interest is taken in the work by the farmers in various parts of the State, and also by the agricultural college and experiment station. Forty-one samples were receiver by the Department of Agrieulture. The average size of these samples was rather large, namely, 27 ounces. The sugar content was low, $11 . t$ per cent, and the purity quite low, 73.8. While it is evident that large quantities of sugar can be made from beets of this character, it is also plain, without argument, that such a quality of beets would not be able to compete with those grown in more favorable localities.

The agricultural experiment station of Kansas, in cooperation with the Department of Agriculture, also conducted a series of experiments and received for analysis 157 samples. A detailed report of this work 
will be found in the bulletins of the agricultural experiment station of Kansas, and the following summary sufticiently indicates the character of the results obtained. The number of samples analyzed was 157 . The average net weight of the beets received was 17 ounces; the average content of sugar in the beets, 11.9 per cent, and the average coeficient of purity of the juice, 77. The percentage of the whole number of beets containing 13 per cent of sucrose or over was 15.2. The percentage of beets containing 13 per cent of sugar or over, having a coeficient of purity of the juice of 80 per cent or over, was 67 . The percentage of beets containing 13 per cent and over of sugar and weighing 16 ounces or more, net, was 42.

The analyses made at the agricultural experiment station of Fansas have beeu consolidated and tabulated by connties. The table of analyses follows:

Summary of analyses of beets from Kansas.

[Compiled from report of experiment station.]

\begin{tabular}{|c|c|c|c|c|c|c|c|c|c|c|c|}
\hline County. & 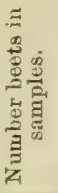 & 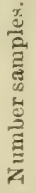 & 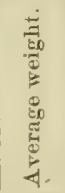 & 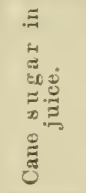 & 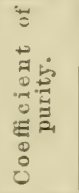 & County. & 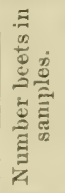 & 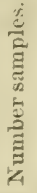 & 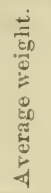 & 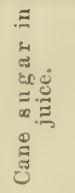 & $\begin{array}{l}3 \\
5 \\
0 \\
0 \\
0 \\
0 \\
0 \\
0 \\
0 \\
0\end{array}$ \\
\hline Ile & 10 & 1 & Ozs. & Per ct. & 720 & & & & Ozs. & Peret. & \\
\hline Atchison ............ & 17 & $\frac{1}{3}$ & $\begin{array}{l}14 \\
17\end{array}$ & $\begin{array}{l}10.64 \\
12.61\end{array}$ & $\begin{array}{l}72.0 \\
79.5\end{array}$ & $\begin{array}{l}\text { Lyon .......... } \\
\text { Marion }\end{array}$ & $\begin{array}{l}14 \\
53\end{array}$ & $\frac{2}{6}$ & $\begin{array}{l}16 \\
16\end{array}$ & $\begin{array}{l}13.29 \\
11.23\end{array}$ & $\begin{array}{l}79.5 \\
71.8\end{array}$ \\
\hline Barber........... & 14 & 2 & 12 & 14.91 & 72.5 & Marshall....... & 49 & 5 & 25 & 12.20 & 79.4 \\
\hline Barton .......... & 4 & 1 & 34 & 10.35 & 74.0 & MiPherson.... & 7 & 1 & 7 & 13. 08 & 76.0 \\
\hline Bourbon....... & 8 & 1 & 5 & 13.88 & 75.0 & Montgomery... & 21 & 3 & 15 & 11.39 & 74.6 \\
\hline Brown......... & 10 & 1 & 21 & 11.29 & 81.0 & Morrí........ & $1 \pm$ & 3 & 15 & 14.01 & 74.5 \\
\hline Butler ........... & 22 & 4 & 18 & 10.86 & 70.8 & Nemalia ...... & 48 & 4 & $2: 3$ & 10.30 & 74.2 \\
\hline Chase ............ & 6 & 1 & 14 & 11. 61 & 77.0 & 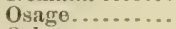 & 20 & 4 & 16 & 12.17 & 77.2 \\
\hline Cheyenne....... & 10 & 1 & 17 & 12.14 & 79.9 & Osborue ....... & 10 & 1 & 16 & 12.39 & 70.0 \\
\hline 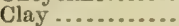 & 37 & 3 & 28 & 11. 21 & 78,0 & Ottawa ......... & 27 & 4 & 22 & 12.90 & 78.2 \\
\hline 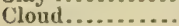 & 93 & 9 & 20 & 11.65 & 79.2 & Pawnee....... & 8 & 1 & 4 & 8. 52 & $70 . \overline{0}$ \\
\hline Coftes . . . . & 4 & 1 & 20 & 15.13 & 78.0 & Phillips ..... & 21 & 2 & 19 & 12.16 & 79.5 \\
\hline Crawford....... & 12 & 1 & 14) & 13,87 & 82.0 & Pottawatomio. & 30 & 3 & 16 & 32.20 & 83.6 \\
\hline Do & 3 & $\hat{1}$ & $28\}^{21}$ & & $\ldots$ & Pratt ........... & 14 & 2 & 8 & 12.19 & 75. 0 \\
\hline Dickinson ..... & 20 & 4 & 17 & 12.29 & 77.0 & Rawlins...... & 8 & 1 & 16 & 9.57 & 73.0 \\
\hline Doniphan...... & 15 & 1 & 24 & 13.67 & 84.0 & Keno ........... & 18 & 2 & 12 & 13.78 & 79.5 \\
\hline Douglas ........ & 11 & 2 & 20 & 12.48 & 77.5 & Ropublic ..... & 49 & 4 & 18 & 10.69 & 74.5 \\
\hline Edwards......... & 6 & I & 12 & 11. 12 & 71.0 & Rice........... & 6 & 2 & 14 & 11.71 & 74.5 \\
\hline 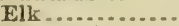 & 14 & 2 & 21 & 14.04 & 83.0 & Riley ............ & & 3 & 21 & 8.98 & 70.3 \\
\hline Ellsworth...... & 5 & 1 & 17 & $\ldots$ & ....... & Rooks : ........ & 21 & 2 & 16 & 13.39 & 80.5 \\
\hline Finney ........ & 6 & 1 & 19 & 14. 14 & 74.0 & Rush .......... & 10 & 1 & 20 & 11.88 & 77.0 \\
\hline Franklin ....... & 6 & 1 & 16 & 11.86 & 77.0 & Russell ......... & 12 & 3 & 10 & 11. 49 & 71.0 \\
\hline Geary............. & 6 & 1 & 13 & 9.51 & 70.0 & Saline ........ & 16 & 2 & 9 & 15.78 & $8 \pm .0$ \\
\hline Grabam ....... & 31 & 3 & 18 & 12.83 & 76.0 & Sodgwick...... & 12 & 2 & 12 & 11.23 & 74.0 \\
\hline Grant........... & 6 & 1 & 16 & 15.47 & 78.0 & Shawnee....... & 29 & 3 & 15 & 12. 19 & 77.3 \\
\hline Harvey ......... & 6 & 1 & 5 & $\ldots \ldots$. & $\ldots . . .$. & Sheridan....... & 20 & 2 & 22 & 11.59 & 78.5 \\
\hline 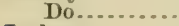 & 6 & 1 & 14 & 12.83 & 78.0 & Smith ......... & 10 & 1 & 28 & 11.12 & 78.0 \\
\hline Jackson ......... & 14 & 1 & 20 & 11.17 & 73.0 & Sumner....... & 7 & 1 & 18 & 13. 38 & 76.0 \\
\hline Jefferson ........ & 6 & 1 & 15 & 11.82 & 76.0 & TVaubaunsee... & 23 & 2 & 15 & 12.14 & 77.5 \\
\hline Jewell .......... & 40 & 4 & 19) & 11.12 & 77.3 & Wallace....... & 6 & 1 & 19 & 11.58 & 760 \\
\hline Johnson ......... & 14 & 2 & 18 & 14.23 & 83.0 & Washington ... & 99 & 10 & 27 & 10.79 & 75,2 \\
\hline Labette........ & 3 & 1 & 20 & 8.76 & 67.0 & Wichita....... & 6 & 1 & 14 & 11.24 & 79.0 \\
\hline $\operatorname{Lan} \theta \ldots . . . . . . .$. & 26 & 2 & 4 & 10.17 & 68.5 & Wilson ........ & 36 & 5 & 14 & 13. 12 & 81.0 \\
\hline Leavenworth... & 22 & 4 & 12 & 12.75 & 79.0 & Woodson ....... & 10 & 1 & 7 & 14. 32 & 73.0 \\
\hline Lincoln .......... & 16 & 3 & 28 & 11. 38 & 79.6 & Wyandotte.... & 4 & 1 & 14 & 14.11 & 75.0 \\
\hline Logan ........... & 10 & 1 & 19 & 11.40 & 76.0 & & & & & & \\
\hline
\end{tabular}

The data obtained at the Kansas station corroborate in every respect those secured at the Department of Agriculture. It is evident that 
fairly good beets can be grown in Kansas, and there are doubtless seasons when exceptionally rich beets might be secured. In general, however, it may be said that there is no immediate prospect of the successful establishment of the sugar-beet industry in that State, unless it might be in some of the extreme western or northwestern counties, where irrigation might be practiced, and where the altitude is sufficiently high to secure a lowering of the temperature. One of the great causes of danger, however, is found in the hot southwest winds, which fiequently blow over the State with disastrous couseryences at the period when the crops are growing most rapidly. It will be seen that in many instances individual analyses obtained in Kansas are extremely satisfactory, as for instance, in Elk County, where two samples, including $1 \pm$ different bects, showed an average weight of 21 ounces, an average content of sugar in the juice of $1 \pm$ per cent, and an average purity of 83. Another sample is found in Saline County, where 16 beets, forming two samples, showed a sugar content of 15.8 per cent in the juice, with an average purity of 8. . In this case, however, the beets were very much under size, the average weight being only 9 ounces. When, however, the dita received from the counties are compared with sinilar data from the State of New York, the discrepancy observer is so great as to indicate, without further elucidation, the proper locality where the first development of the sugar-beet industry should be looked for.

In the light of our previous experiments, it must be evident that high-grade sorghum, developed from carefully selected seeds, has a better prospect in Kansas of being a profitable sugar-producing plant than the sugar beet.

\section{KENTUCKY.}

Only a few samples, with the exception of those sent by the experiment station, have heen received from Kentucky. This State being situated far south of the theoretical sugar-beet belt, it is not to be expected that the results of the analyses would be particularly encouraging. The mean weight of the six samples received was 16 ounces, the mean percentage of sugar 11.9, and the purity 71.5. The six samples included four from the experiment station. The beets received were small, and the percentage of sugar only a tritle under the minimum which is advisable for profitable sugar making. The purity, however, is axcessively low, and this seems to be characteristic of beets grown too fir south, the purity coefficient usually falling in a more rapid proportion than the content of sugar.

Large numbers of samples were received from the experiment station in addition to those analyzed above, which were grown upon the special plot, which will be mentioned later on, and under the most favorable conditions of culture. The beets which were sent to the Department were of good size and mostly of a favorable shape, but the analytical dati were very disappointing, falling a great deal lower than 
was expected. Nine samples of White Improved Imperial wite, planted May 8 and harvested Jecember 9 , had an average weight of 33 ounces, with 4.9 per cent of sugar. Three samples of original Klein wanzlebener had an average weight of 23 ounces, with 10.8 per cent of sugar. Sixteen samples of Vilmorin's Improved had an average weight of 25 ounces, with 6.4 per cent of sugar. Thirty-nine samples of the Demesmay variety harl an average weight of 29 ounces, with 5.3 per cent of sugar. All of these beets were somewhat overgrown, but not sufficiently so to account for the extremely low percentage of sugar. A large additional number of samples had been selected for analysis, but the results of the preceding analyses were so discouraging as to render the further prosecution of the analytical work unnecessary. This subject will be mentioned again when the experiments in the specially cultivated plots with high grade seeds are discussed.

\section{MARYLaNi).}

All the analyses of the samples of beets grown in Maryland were made in the laboratory of this division, the agricultural station at College Park not having undertaken any work of this kind. The whole number of samples received from the State was 29 . The mean size of the beets was 19 ounces, the mean percentage of sugar in the beets 11.4, and the mean purity of the juices 79.1 . In respect of size, the samples from Maryland are about the mean. The purity of the juice is almost $\mathrm{u}_{\mathrm{p}}$ to the minimum standard, but the percentage of sugar in the beet is about 0.6 less than is advisable for manufacture.

In regard to climatic conditions, as has been before intimated, the State of Maryland occupies a somewhat peculiar position. There is a considerable area along the easteru shore, next to the ocean, where the average summer temperature is $71^{\circ}$. In the western part of the State, after a long deflection to the north, the isotherm of 70 may again be found. Lying immediately south of the isotherm of $71^{\circ}$, in the northern portion of Maryland, are found some very fine valley lands where the conditions of culture may be considered favorable. These lands are underlaid by limestone, which in many cases comes to the surface. Theoretically they are a little too warm for the most successful culture, but lying so near the favorable thermal belt there may be reasonable hopes of successful culture in many localities. In the western portion of the State, where the thermal conditions are favorable, we find the mountain ranges, and the low temperature of the summer is due to the high elevation. The quantity of table lands upon the tops of the mountains, however, is not sufficiently great to warrant the expectation of the founding of a great industry. There is no doubt, however, of the possibility of growing very rich beets ou these table lands. In general it may be said that the State of Maryland is not very favorably situated for the culture of sugar beets, but there are eircunseribed localities 
within the State where it is desirable to conduct further experiments. It is therefore earnestly hoped that the agricultural experiment station of the State will make a more careful agricultural survey of the possibilities of the culture of sugar beets therein.

\section{MICHIGAN.}

The southern peninsula of Michigan is favorably situated for the culture of sugar beets, both in respect of thermal conditions and rainfall. The soil is also for the most part well suited to sugar-beet culture. In going northwarl, however, it becomes more sandy until finally the pine regions are reached, where a soil without fertilization would not be sufficiently rich to produce large crops. The well-known tendency of a sandy soil, with proper meteorological conditions, to produce beets of a high purity is well illustrated in the samples which have been received from Michigan. In all, 450 samples from the State were sent to this laboratory for aualysis, 400 of them being from Saginaw County and grown under the supervision of Messrs. Higgins \& Lenders.

In regard to the results from particular counties, attention should be called to the fact that the samples from Allegan were all enormonsly overgrown, the average weight of the beets being 62 ounces and the corresponding content of sugar and the coefficient of purity low. The results from Calhoun County, in the southern part of the State, are particularly favorable, the average weight of the samples being 17 ounces, average content of sugar in the beet 15.8, and the average purity 83.2. The greater part of the samples having come from Saginaw County, the average data for this county are almost the same as those of the State, with the exception that the purity is considerably higher. The average composition of the 400 samples from Saginaw County was as follows: Average weight, 22 ounces; sugar content in the beet, 14.8 per cent, and purity, 83.3. For the whole State-450 samples-the average weight was 22 ounces, average sugar content 14.7 per cent, and average purity 81.1 .

The agricultural experiment station of Michigan, in cooperation with the Department of Agriculture, also made an extensive series of investigations, a résumé of which is given below:

RESULTS BY COUNTIES OF THE CULTIVATION OF SUGAR BEETS IN MICHIGAN IN 1897.

The following talble is given containing the mumber of samples sent to the station from each county, the average per cent of sugar in the juice, and coefficient of purity of all samples sent. Seed was distributed in sixty-right counties, and from the tablo below it will be seen that samples have been receiver from sixty-four of them. The average per cent of sugar in the juice of beets of the whole State, when grown on the proper kind of soil and from the rimht kind of seed, is 16.40 , and the coeficient of puxity is 84 . An average of 16.40 per cent of sugar for the whole State, fur exceeding the lrest districts in F'ance $\theta$ and (iermany, is both surprising and gratifying. ${ }^{1}$

These data are obtained by omitting from the table the analyses of samples which were known to have been grown under unfavorable conditions.-H. W. W. 
Analyses of sugar beets grown in Michigan and analyzed by the Michigan agricultural experiment station.

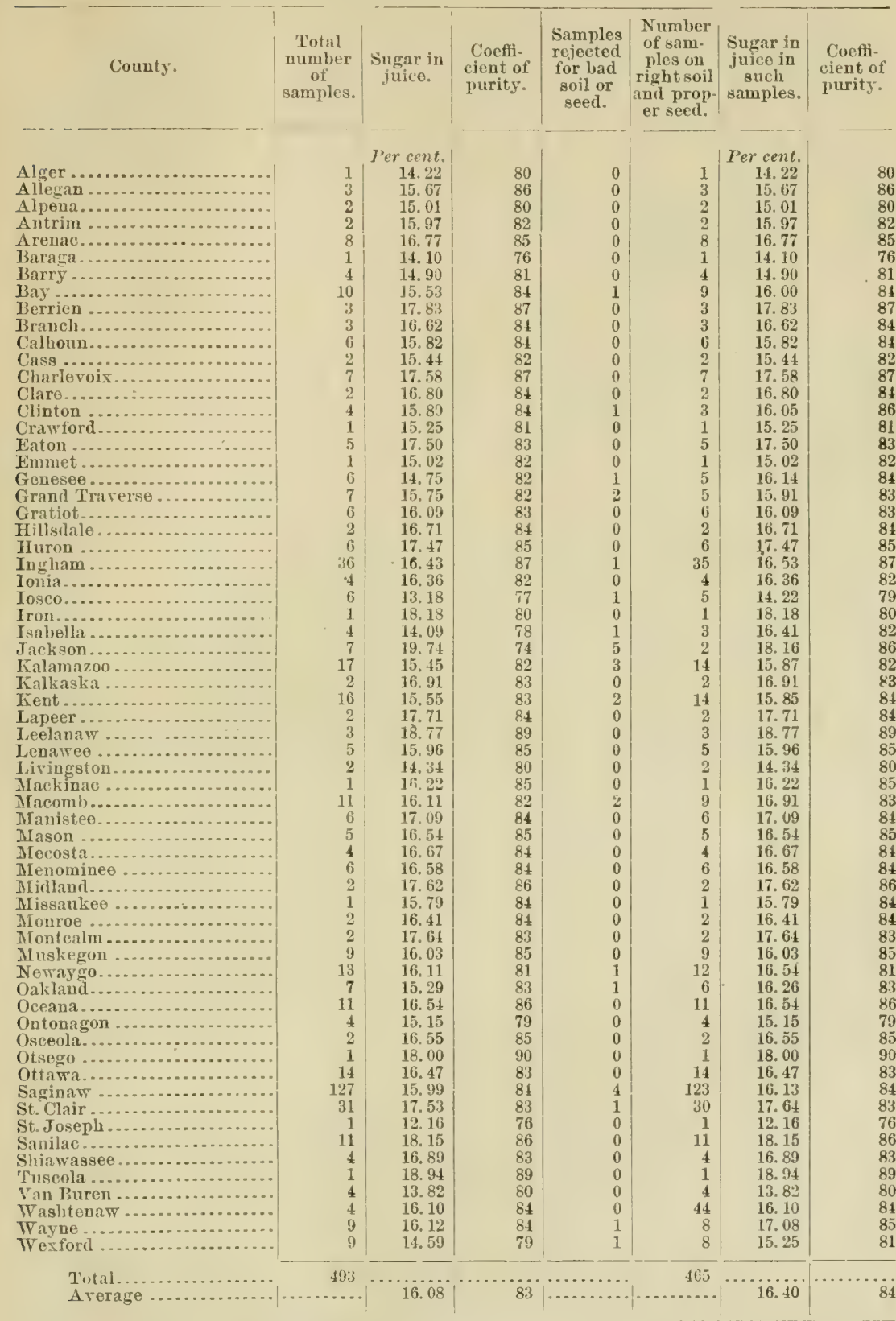

Fire samples from Oceana County are not included in results of analyses, because they were dried and damaged by keeping. 
Interesting data in regard to cost of culture were obtained at the Michigan station. The plats were planted on the Sth of May, and harvested on the 6th of October. After throwing the dirt away from the beets by a plow they were pulled by hand and the leaves and stems removed. Owing to the deep subsoiling and thorough preparation of the ground, the beets were found wholly embedded in the soil, none of them having been pushed above the surfice. The average weight of the beets before the removal of the necks was about "21 pounds. The following table gives the total labor, calculated to 1 acre, recpuired for growing and harvesting the beets:

\begin{tabular}{|c|c|c|}
\hline & $\mid \begin{array}{c}\text { Man and } \\
\text { team. }\end{array}$ & Man. \\
\hline Plowing and subsoiling & $\begin{array}{l}\text { Hours. } \\
12.00\end{array}$ & Hours. \\
\hline Harrowing ............. & 3. 75 & ...... \\
\hline $\begin{array}{l}\text { Marking .......... } \\
\text { Planting......... }\end{array}$ & .80 & 3.25 \\
\hline 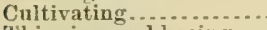 & 15.00 & \\
\hline $\begin{array}{l}\text { Thinning and hoeing... } \\
\text { Harresting... . . . . . . }\end{array}$ & 4.60 & $\begin{array}{r}75.90 \\
130.75\end{array}$ \\
\hline Total & 36.15 & 209.90 \\
\hline
\end{tabular}

The hand labor in harvesting was performed by boys at $S$ cents an hour. The work of hoeing and thinning was performed by men at $12 \frac{1}{2}$ cents an hour. The cost of team work is computed at 2: cents an hour for man and team. On the above basis, the total cost of planting, cultivating, and harvesting an are of heets at the Michigan Experiment Station was \$29.40. The yield per acre, the percentage of sugar in the juice, and the purity for each variety grown are shown in the following table:

\begin{tabular}{|c|c|c|c|}
\hline Variety. & $\begin{array}{l}\text { Yield per } \\
\text { acre. }\end{array}$ & Sugar. & Purity. \\
\hline Wohanka ............. & $\begin{array}{l}\text { Pounds. } \\
23,615\end{array}$ & $\begin{array}{r}\text { Per cent. } \\
15.22\end{array}$ & 80 \\
\hline Improved Kleinwanzlebener & 25,678 & 16.40 & 91 \\
\hline Original Klein wanzlebener . . . . . . & 27,368 & 18.27 & 94 \\
\hline Government Klein wanzlebener . . . . . . . . . . . . . . . . . . . . . . & 25,648 & 17. 78 & 94 \\
\hline 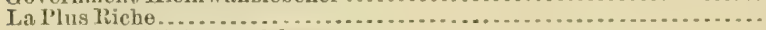 & 29,205 & 18.78 & 92 \\
\hline Government Kileinwanzlebener . . . . & 32,327 & 17.78 & 94 \\
\hline 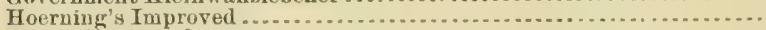 & 24,500 & 15. 20 & 89 \\
\hline Floto's Improved ................ & 20,200 & 13.21 & 88 \\
\hline 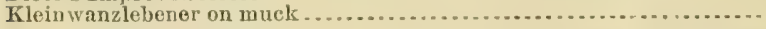 & .......... & 12.96 & 75 \\
\hline
\end{tabular}

Full details of all the experiments conducted in Michigan by the agricultural experiment station are found in Bulletin No. 150 of that station, issued in December, 1597, by Director C. D. Smith aud Chemist R. C. Kedzie.

The study of the two sets of data secured at the Department of Agriculture and by the agricultural experiment station of Michigan is suffieient to demonstrate the faret that the southern peninsula of Michigan has great possibilities for the develspment of the sugar-beet industry. When it is remembered that the most of those who grew the samples lat had no previous experience in the matter, that no systematic fertilization was attempted, and that in many instumes the soil was 
improperly prepared, the remarkably favorable results obtained are the more conviucing. It is evident that all the sonthern portion of the Southern Michigan Peninsula, in conjunction with the northern part of Indiana, forms an area in which the future will see a remarkable development of the sugar-beet industry.

Minnesota.

Forty-nine samples from the State of Minnesota were received for analysis at the laboratory of the Department of Agriculture. The mean weight of the samples received was 24 ounces, the mean percentage of sugar in the beet 11, and the mean purity coefficient 79.2.

Great variations are shown in the samples received from different parts of the State. One of the best series of results was obtained from Freeborn Cumnty, in the sonthern part of the State, from which twelve samples were received, laving an average weight of 20 ounces, an average content of sugar in the beet of 14.1 per cent, and an average coefficient of purity of 82.3 .

Another good series of samples, though less in number, was from Ottertail County, in the western part of the State, from which four samples were received, having an average weight of 23 ounces, a mean content of sugar in the beets of 14.9 per cent, and a mean coefficient of purity of $8: .1$. The general average from the State was lowered by a large number of very poor samples, which evidently had been grown under extremely unfavorable conditions.

The period of growth in Minnesota, while a little short, is nevertheless favorable from other considerations, especially in the southern and eastern portions of the state. Toward the northwestern portion of the State the rainfall is somewhat uncertain, and the autumn is perhaps a little too cold. As has been intimated before, the chief difficulty in Minnesota in the establishment of the beet-sugar industry is not in securing a proper growing seasou, but in having a sufficient time to properly harvest and protect the beets. The sudden, and often early, advent of winter in the northern and western portions of the State will be the cause of difficulties of a serious nature in the harvesting and siloing of the beets. These are factors which iutending investors will do well to carefully cousider. In general, the conditions of growth are so favorable as to warrant the careful study of the soils of the State by the agricultural experiment station with a view to selecting those localities where the conditions of culture are most favorable. In a State of such vast area it is far better to determine those restricted sections where the conditions are most favorable rather than try to establish the industry indiscriminately in every portion of the State.

In cooperation with the Department of Agriculture, the agricultural experiment station of Minnesota conducted an extensive series of culture experiments in various parts of the State. The general results of the experiments are indicated in the report of the chemist of the station, which follows.

H. Doc. $396-6$ 


\section{EXPFIIMENS CONDUCTED BY THE AGRICULTURAI, EXPERIMENT STATION OF MINNESOTA.}

The secd from which the beets wero grown was obtained from a variety of sources. Some procured seed from the stock which the Iegislaturo directed the state treasurer to purchase. About 100 pounds of seed were obtained fiom the United States Department of $\Lambda$ grieulture and distributed by the experiment station. Some serd was ohtained direct from Germany, while a few obtained seed from seed dealers and other sources. As a rule, the seed was of good quality. Only a few instances of poor seed wero reported. 'There was but little difference as to the quility of the beets produced by the seed furnished by the State and by the Department of Agriculture. $\Lambda t$ the experiment station the average of four plots of Kloinwanzlebener beets grown from State seed showed 17.5 per ent sugar, with a purity coelicient of 86.7 , while the average of four plots of Kleinwanzlebener beets grown from United States Department of Agriculture seed gave $\mathbf{1 7 . 4}$ per cent sugar aud a purity coefficient of 87.8 .

The past season has not been one partienlarly favorable to the production of the highest quality of beets. It has been the most unfavorable season in nine years. As a whole, however, tho results have been satisfactory, and I consider them of unusual value, hecause they indicate the quality of the beets which are produced in an mnfavorable rather than a favorable season.

At the experiment station the average of those plots which were grown under normal conditions gave a sugar content of 17.4 per cent and a purity coeficient of 87.3

There is one factor in onr favor which I think has been overlooked in considering desirable locations for sugar-beet factories, and that is, we have never lost a sugarbeet erop from hot, dry winds, which occasionally occur in some of the prairie States.

About thyee hundred samples of beets have been tested during the season. In many cases the results were lower than they would have been if the beets had been properly cultivated. In one of the tables the results are given of some of the beets which have been grown uuder abnormal conditions. In one case twenty-five minutes' time was spent on a quarter acro of heets, while in another case the seeds were plantech five inches. These results, while they possess no value as indicating the quality of sugar heets which may be produced in a locality, are nevortheless valuable, because they emphasize the importance of the right kind of cultivation for sugar-beet production.

Sugar beets grown at the Minnesota Experiment Station.

\begin{tabular}{|c|c|c|c|c|c|}
\hline & $\begin{array}{l}\text { No. } \\
\text { plot. }\end{array}$ & $\begin{array}{l}\text { No. } \\
\text { tests. }\end{array}$ & Sugar. & $\begin{array}{l}\text { Purity } \\
\text { coefticient. }\end{array}$ & $\begin{array}{l}\text { Average } \\
\text { weight. }\end{array}$ \\
\hline $\begin{array}{l}\text { Highest results: } \text { Rows } 18 \text { inches apart and beets } 4 \\
\text { inches in row } \ldots \ldots \ldots \ldots\end{array}$ & & & $\begin{array}{r}\text { Per cent. } \\
18.5\end{array}$ & $\begin{array}{r}\text { Per cent. } \\
92.5\end{array}$ & $\begin{array}{l}\text { Ounces. } \\
12.8\end{array}$ \\
\hline 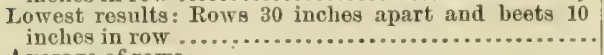 & & & 14 & 78.0 & 18. 4 \\
\hline $\begin{array}{l}\text { A verago of rows: } \\
24 \text { and } 30 \text { inches apart and beets } 4 \text { to } 6 \text { inches in row. } \\
24 \text { and } 30 \text { inches apart and beets } 6 \text { to } 10 \text { inches in }\end{array}$ & 8 & 16 & 16.0 & 86.1 & 15. 1 \\
\hline row & 8 & 16 & 15.8 & 85.5 & 14.9 \\
\hline 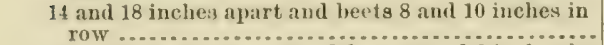 & 8 & 16 & 15.9 & 85.4 & 14.1 \\
\hline 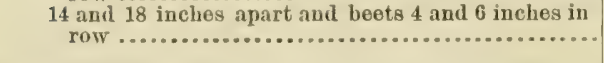 & 8 & 16 & 17.4 & 87.3 & 11. 6 \\
\hline
\end{tabular}

'The cultivation of the beets was under the supervision of the Agricultural Division. The analyses were all made by the chemist of the station.

The analytical data obtained are summarized from the details of the chemist's report in the following table:

Total number of analyses reported ................................. 143

Average weight of the beets (ounces) ............................. 17

Average per cent of sugar in the juice................................ 13.8

Average coeficieient of purity .................................. 81.8 
The classification of results is made in several portions, namely, analyses of miscellaneous samples from the State at large and analyses of special samples from definite localities. In the analyses of miscellaneous beets collected from different parts of the State, with the exception of those specially mentioned below, thirty-four samples were examined. The mean weight of the beet is not given in this table of analyses. The mean percentage of sugar in the juice is 14.25 and the mean purity coefficient 82 .

Sixteen samples grown at Mankato, Minn., showed an average weight of 21.9 ounces, a mean percentage of sugar in the juice of 12.8 , and a purity coefficient of 80.2 .

Ten samples grown at Winton and Stockton had an average weight of 17.1 ounces, contained 13.7 per cent of sugar in the juice, and had a purity coefficient of 81.9 .

Eighty-three samples grown at Albert Lea had an average weight of 16.6 ounces, contained 13.8 per cent of sugar in the juice, and had a purity coefficient of 82.1 .

In general, it will be observed that the results obtained on the samples sent directly to the station were better than those secured at the lab. oratory in Washington. Upon the whole, the results of the work done at the experiment station are eminently satisfactory, especially as they were accompanied with the statement of the director that the conditions were the most unfavorable, for the development of a crop of sugar beets, which had been kuown in the State since the commencement of the experiments in this direction, in 1888.

The results of the analyses of the beets grown at the station are extremely satisfactory. The average weight of the beet, to be sure, is somewhat low, but this doubtless was due to an unfavorable growing season. The mean percentage of sugar in the beets grown in different plots is exceptionally fine, and the coefficient of purity in one instance is higher than could reasonably be expected with the best kind of culture. Only in one of the plots cultivated on the station are the results unsatisfactory, and in this case it is the coefficient of purity especially which has fallen below the standard.

\section{Missouri.}

Very extensive experiments were made in Missouri, about 4,000 samples of seed having been distributed, and over 600 returns marte. There were sent directly to the Department of Agriculture 324 samples, detailed aualyses of which are found in the precerling tables. The average weight of the samples received was 20 ounces. The mean percentage of sugar in the beet was 11.7 and the mean purity 73.5 . Many individual samples from the State show excellent qualities, but reliable judgment, as intimated before, can only be based upon large numbers of analyses. Among the counties furnishing beets of high quality may be mentioned Barton, in the southwestern part of the State. Three samples were received from this county, all of them of 
rather large size and fine content of sugar, the mean size beng 27 ounces, the mean content of sugar in the beet 15.3 per cent; only the purity in all cases was a little low, the mean being 77.3. Benton County, in the center of the State, also showed good results, five samples having an average weight of 16 ounces, an average sugar content of 15.5 per cent, and an average purity of 77.1. The best single sample received was from Pulaski County, in the center of the State, the percentage of sugar being 18.3 , the purity 86.1 ; but the weight was low, namely, only 12 ounces.

Two hundred and ninety-nine samples of beets were sent directly to the agrieultural experiment station of Missouri and analyzed in the laboratory of that station. The mean results, by counties, obtained on analysis are given in the following table:

Summary of analyses of beets grown in Missouri.

[From Report of Missouri Experiment Station.]

\begin{tabular}{|c|c|c|c|c|c|c|c|c|c|}
\hline County. & 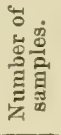 & 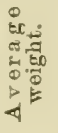 & 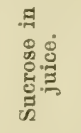 & 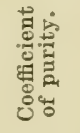 & County. & 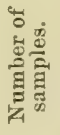 & 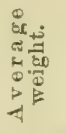 & 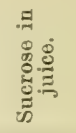 & 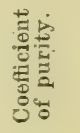 \\
\hline aIr & & Ozs. & $\begin{array}{l}\text { Per ct. } \\
14,31\end{array}$ & 82,89 & Livingston. & & Oz8. & Per et. & \\
\hline Andrew ............... & 1 & $\begin{array}{l}23 \\
22\end{array}$ & $\begin{array}{l}14.51 \\
12.16\end{array}$ & 76.76 & 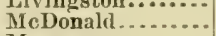 & $\begin{array}{l}1 \\
5\end{array}$ & $\begin{array}{l}12 \\
19\end{array}$ & $\begin{array}{r}9.75 \\
13.83\end{array}$ & $\begin{array}{l}70.31 \\
80.05\end{array}$ \\
\hline Audrain .......... & 1 & 32 & 7. 10 & 56.66 & Macrn ................ & 1 & 14 & 14.11 & 70.89 \\
\hline Barry .............. & 4 & 24 & 12.85 & 73.96 & Madison .......... & 2 & 20 & 13.07 & 71.85 \\
\hline Barton ................... & 1 & 41 & 16.97 & 81.62 & Maries .............. & 1 & 28 & 12.95 & 78.92 \\
\hline Bates .................. & 1 & 22 & 11.56 & 76.82 & Marion ............. & 4 & 32 & 9.76 & 69.32 \\
\hline Benton................. & 2 & 16 & 18. 19 & 86.36 & Mercer .............. & 1 & 44 & 13.51 & 80.22 \\
\hline Boone ............... & 2 & 29 & 8.19 & 63.78 & Mississippi „...... & 3 & 24 & 10.57 & 75. 00 \\
\hline Buchanan ......... & 4 & 34 & 12.20 & 81.88 & Monroe ............. & 2 & 11 & 7.71 & 57.57 \\
\hline Butler .................. & 1 & 8 & 6.47 & 58. 23 & Montgomery ....... & 5 & 21 & 12. 62 & 78.11 \\
\hline Caldwell .............. & 6 & 35 & 12.99 & 80.16 & Iv Madrid ....... & 2 & 20 & 12.30 & 79.03 \\
\hline Callaway........ & 3 & 33 & 12.45 & 76.45 & Nodaway .......... & 4 & 42 & 11. 66 & 72,61 \\
\hline 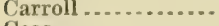 & 2 & 28 & 11. 08 & 75.03 & Oregon $\ldots \ldots$ & 1 & 20 & 8. 37 & 67.12 \\
\hline 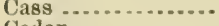 & 3 & 22 & 16. 36 & 84.75 & rk ............. & 1 & 6 & 13. 81 & 77.15 \\
\hline Cerlar ............... & 1 & 7 & 11.08 & 78.86 & $y \ldots \ldots \ldots \ldots$ & 1 & 16 & 14.06 & 74.86 \\
\hline 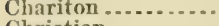 & 4 & 16 & 12.35 & 24 & is $\ldots . . . . . . . . . .$. & 8 & 24 & 10 & 65.67 \\
\hline Christian ........... & 3 & 32 & 11.14 & 67.86 & elps $\ldots . . . . . . . . .$. & 4 & 13 & 11. & 75.56 \\
\hline Clark ................ & 1 & 54 & 12.80 & 77. 76 & 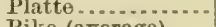 & 4 & 27 & 12. & 74.74 \\
\hline 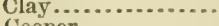 & 1 & 36 & 8.87 & 67. 16 & Pike ( & 63 & 21 & 10. 14 & 75.55 \\
\hline er & 4 & 19 & 8. 43 & 61.69 & vest.- & 38 & 21 & 10.94 & 81 \\
\hline Crawlord................. & 3 & 20 & 11.95 & 81. 27 & harvest & 25 & 21 & 9.34 & 30 \\
\hline Dade $\ldots . . . . . . . .$. & 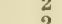 & 30 & 10.56 & 67.95 & $a=\ldots \ldots$ & 2 & 16 & 14.30 & 17 \\
\hline Dallas $\ldots \ldots \ldots$ & 2 & 16 & 14.06 & 74.95 & $\cdots \cdots \cdots$ & 0 & 44 & 10.95 & 40 \\
\hline Dokalb ................. & 2 & 46 & 10.11 & 70.40 & $\therefore \ldots$ & $\boldsymbol{j}$ & 21 & 13. 74 & 39 \\
\hline Dent & 1 & 10 & 14. 51 & 72.66 & $\cdots$ & 3 & 25 & 15. 74 & 30 \\
\hline las ................... & 2 & 4 & 15. 19 & 68 & $\cdots$ & 2 & 20 & 15.51 & 16 \\
\hline$k \operatorname{lin} \ldots . . . . . .$. & 3 & 30 & 9.31 & & $\cdots$ & 3 & 26 & 9.70 & \\
\hline onate ......... & 2 & $\begin{array}{l}19 \\
31\end{array}$ & 10.88 & 68 & $\cdots$ & 3 & $\begin{array}{r}12 \\
8\end{array}$ & 11.94 & \\
\hline$r y+\ldots \ldots \ldots \ldots$ & 1 & $\begin{array}{l}31 \\
20\end{array}$ & 12.68 & 75.42 & $\cdots$ & $\frac{1}{5}$ & $\begin{array}{r}8 \\
58\end{array}$ & $\begin{array}{r}7.87 \\
11.91\end{array}$ & 76.26 \\
\hline 9. & 1 & 20 & 12.27 & 77.17 & $\cdots \cdot$ & 1 & $\begin{array}{r}58 \\
6\end{array}$ & 11.21 & $\begin{array}{l}78.36 \\
92.19\end{array}$ \\
\hline on & 1 & $\begin{array}{r}18 \\
6\end{array}$ & 12.16 & 71.11 & …… & $\frac{1}{2}$ & $\begin{array}{r}6 \\
22 \\
2\end{array}$ & $\begin{array}{r}21.02 \\
0.68\end{array}$ & $\begin{array}{l}19 \\
99\end{array}$ \\
\hline $30 n \ldots . . . . .$. & 1 & $\begin{array}{r}6 \\
25\end{array}$ & 18.45 & 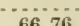 & (n....... & 6 & 27 & $\begin{array}{r}9.68 \\
13.53\end{array}$ & $\begin{array}{l}89 \\
80\end{array}$ \\
\hline rven & 3 & $\begin{array}{l}25 \\
24\end{array}$ & 11.05 & 66.76 & $\cdots$ & 1 & $\begin{array}{l}27 \\
16\end{array}$ & $\begin{array}{l}13 . \\
14 .\end{array}$ & $7 \$ .19$ \\
\hline ory.............. & 1 & $\begin{array}{l}24 \\
29\end{array}$ & 11.88 & $\begin{array}{l}76.66 \\
73.20\end{array}$ & Stodliv & 2 & $\begin{array}{l}10 \\
26\end{array}$ & $\begin{array}{l}14.79 \\
16.08\end{array}$ & 92 \\
\hline 11. & 2 & $\begin{array}{l}29 \\
28\end{array}$ & 10.26 & $\begin{array}{l}73.29 \\
78.18\end{array}$ & Sill & 3 & 15 & 13.08 & 74.95 \\
\hline $11 \ldots \ldots \ldots$ & 2 & $\begin{array}{l}28 \\
13\end{array}$ & $\begin{array}{l}13.10 \\
13.11\end{array}$ & 78 &. & 2 & 13 & 14. & 78.47 \\
\hline n & 4 & 36 & 12.14 & 79.28 & . & 7 & 36 & 13. 17 & 80.30 \\
\hline er ................ & 6 & 27 & 11.04 & 72.57 & W arren ............ & 2 & 36 & 8.07 & 60.48 \\
\hline Jeflerson ............ & 3 & 17 & 10.71 & 66.73 & Washington ....... & 1 & 28 & 10.71 & 73.71 \\
\hline Johnson .............. & 5 & 22 & 11.90 & 72.54 & 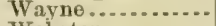 & 1 & 22 & 13.08 & \\
\hline 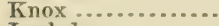 & 1 & 46 & 12.81 & 74. 87 & Webster .......... & 1 & 14 & 13. 12 & 80.58 \\
\hline Laaclede .............. & 5 & 19 & 12.36 & 68.62 & 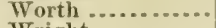 & 1 & 34 & 11. 35 & 73. 13 \\
\hline Lafayetto ............. & 4 & 25 & 11.45 & 74. 08 & Wright ........... & 4 & 13 & 14.01 & 83.24 \\
\hline Lawrence .......... & 1 & 24 & 12.12 & 78.06 & & & & & \\
\hline 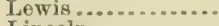 & 2 & 25 & 15. 60 & 82.27 & Total and & & & & \\
\hline Tincoln $\ldots \ldots \ldots$ & $\frac{1}{5}$ & 42 & 7. 94 & 57.18 & mean ....... & 301 & 28 & 11.1 & 74.9 \\
\hline $\operatorname{Linn} \ldots \ldots \ldots$ & 5 & 28 & 12.28 & 72.21 & & & & & \\
\hline
\end{tabular}


Of the whole number of samples, the percentage of those containing 13 per cent or more of sugar in the beet was 24 ; the percentage of these beets with a sugar content of 13 per cent or over having a purity coefficient of 80 or over was 83 ; the percentage of the number of beets containing 13 per cent of sugar which had a purity coefficient of 80 or over and weighing 16 ounces or over was 68 .

The average percentage of sugar in the beet for the whole number of samples examined at the station was 11.1. The average coefficient of purity 7.9.9, and the average weight in onnces 2:). A tabular comparison of the mean results obtained by the Missouri station and in the laboratory of the Department will he interesting:

\begin{tabular}{|c|c|c|c|c|}
\hline & $\begin{array}{l}\text { Total } \\
\text { number } \\
\text { of sam- } \\
\text { pLes. }\end{array}$ & $\begin{array}{l}\text { Average } \\
\text { weight. }\end{array}$ & $\begin{array}{l}\text { Sugar in } \\
\text { juice. }\end{array}$ & $\begin{array}{l}\text { Purity co- } \\
\text { efficient. }\end{array}$ \\
\hline $\begin{array}{l}\text { United States Department of Agriculture .................. } \\
\text { Agricultural experiment station of Missouri............... }\end{array}$ & $\begin{array}{l}321 \\
301\end{array}$ & $\begin{array}{r}\text { Ounces. } \\
20 \\
28\end{array}$ & $\mid \begin{array}{r}\text { Per cent. } \\
11.7 \\
11.1\end{array}$ & $\begin{array}{l}73.5 \\
71.9\end{array}$ \\
\hline
\end{tabular}

As will be seen above, there is a remarkable agreement between the mean results obtained in the two laboratories. The average size of the samples received at Washington was smaller than that of the beets analyzed at the agricultural experiment station of Missouri, and this is doubtless the cause of the slightly increased mean percentage of sugar obtained in the laboratory of the Department of Agriculture. A general study of the results obtained leads to the inevitable conclusion that Missouri is not very favorably situated for producing beets of the highest quality. It is possible to secure, in some instances, results which are exceptionally favorable, but that such results could be secured continnously, and from season to season, is not probable. The diata show that the whole State of Missouri belongs in the same category, in respect of growing rich sugar beets, as the southern parts of the States of Ohio, Indiana, and Illinois. Even the northern counties of Missouri are too far south to give the best results. It is evident, however, in so far as yield is concerued, that Missouri is probably the equal of any State in the Union for growing beets of fine size and large tomnge per acre. Unless exceptional conditions favorable to manufacture are found in the State, it is not probable that the sugar-beet industry will gain a foothold for some time in competition with the more favorable localities farther north and east.

\section{Montana.}

Only four samples were received from the State of Montana at the laboratory of the Department of Agriculture. The average weight of the samples was 20 ounces, the mean percentage of sugar in the beet 14.4, and the mean purity coefficient of 77.8.

Analyses were also made by the agricultural experiment station of Montana. Fifteen analyses were made of samples growu on the 
grounds of the station. The average weight of the samples was $\mathbf{1 4 . 8}$ ounces, the mean percentage of sugar in the beet 16.2, and the mean coefficient of purity of the juice 81.9. Thirty samples grown in the Gallatin Valley had a mean weight of 22 ounces, a mean content of sugar in the beet of 13.7 per cent, and a mean coefficient of purity of 76.4. Eight samples grown at Livingston had an average weight of 24.7 ounces, with a mean sugar content of 13.8 per cent in the beet, and a coefficient of purity of 74.3 . Nine samples from Kalispell had a mean weight of 32 ounces, a mean content of 13.5 per cent of sugar in the beet, and a mean coefticient of purity of 76.2. Four samples of beets from Missoula had an average weight of 32 ounces, a mean percentage of sugar in the beet of 12 , and a mean coefficient of purity of 73.6. Four samples of miscellaneous origin had an average weight of 23 ounces, an average sugar content in the beet of 12.7 per cent, and a coefficient of purity of $7 !$. The whole number of samples analyzed by the agricultural experiment station of Montana was 70 , with a mean weight of 23 ounces, a mean content of sugar in the beet of 14.7 per cent, and a mean coefficient of purity of 77 .

The results obtained at the experiment station show what can be done by careful culture, and indicate that Montana, under proper conditions, is capable of producing a fairly good sugar beet. The data in general are sufficiently encouraging to warrant the agricultural experiment station of the State in making a more thorough and careful agricultural survey of the possibilities of beet production.

\section{Nebraska.}

Thirteen samples grown in Nebraska were received at the Department of Agriculture for analysis. The mean weight of the samples received was 29 ounces, the mean percentage of sugar in the beet 12.9, and the mean purity coefficient 76.9. The studies which have been made in Nebraska have been so thorough in previous years that it would not be advisable to make any deductions from so small a number of samples as was analyzed. In connection with the work done at the I)epartment, the following report of the chemist of the agricultural experiment station of Nebraska may be considered:

\section{RESULTS OF WXPERIMENTS IN NEBRASKA.}

We distributed seed to 433 persons. Of these 158 responded, either by sending beets or written communication, or both. Of the 158, 106 returned samples of beets for analysis; 52 reported failure to secure crop. Of the 52 reporting failures, 14 said that the seed failed to germinate; 14 ascribed failure to dry weather; 21 gave various reasons for failure, 13 stating that the ('rop was destroyed by grasshoppers; 4 lost their crop by reason of stock incursions, and 7 through general neglect.

Putting these figures in the form of percentages: 36.4 per cent of those receiving seed responded in some way; 67 per cent of those who reporten to us sent beets for analysis; 26.9 per cont of failures were attributed to dry weather; 26.9 per cont of failures were attributed to poor seod; 25 per cent of failures were caused by grassholpers; 7.7 per cent of failures were caused by cattle; 13.4 per cent of failures were caused by general neglect.

The results of analyses showed an avorago of 12.34 per cont of sugar in the juice 
with a purity coefficient of 75. The highest per cent of sugar in juice was 16.8 with a purity of 78.5 . The lowest was 4.6 per cent with a purity coefficient of 45 .

Beet seed was sent into sixty-seven comnties and beets were received from thirtysix counties.

The average results obtained agree very elosely with those secured in the laboratory of the Department of Agriculture.

So long a time has elapsed since sugar-beet growing was commenced in Nebraska on a large scale that it is possible to form some idea of the adaptability of that State for beet growing. The soils of Nebraska are mostly very fertile, with a fairly level surface, and are well suited in this respect to beet eniture. The climatic conditions, as will be seen by consulting the map, are somerhat variable, and the rainfall in parts of the State is scant and in all parts of it very uncertain in respect of distribution. Periods of extremely wet weather are apt to alternate with long dronghts. Hot winds may be expected over many parts of the State during the period of most rapid growth, and these winds are extremely injurious to all kinds of vegetation. The winters are apt to come on early and with severity, rendering the harvesting season somewhat precarions. There is no doubt of the fact that good beets can be growu under favorable conditions in Nebraska, but the uncertainties of the season are such as to indicate that there will not be a very rapid expansion of the industry in that state until more favorable areas have been thoroughly exploited. For details in regard to Nebraska the reports of the agricultural experiment station of Nebraska, at Lincolu, may be consulted. For about eight years this station has been engaged in the study of this question, and has published numerous and valuable bulletins, many of which can still be obtained by applying to the director of the station.

\section{NeVADA.}

A large portion of the State of Nevada, in fact the whole of the northem and western parts, lies within the thermal area suitable to beet culture. Twenty-one samples of beets were received at the Department of Agriculture from Nevada, the average weight of which was 25 ounces, the average content of sugar in the beet $\mathbf{1 6 . 6}$ per cent, and the average coefficient of purity 81.1. These samples all came from the parts of the State lying within the favorable thermal area. The agricultural experiment station of Nevada, at Reno, also made an investigation of the possibilities of growing beets in that State, and has submitted a report on the subject. In all, twenty-two samples were received at Reno for analysis, the average weight of which was 25 ounces, and the average content of sugar 16.9 per cent, the purity not being given. These data show a remarkable agreement with those obtained by the Department of Agriculture. The beets were grown entirely under irrigation. Some of them, however, received only one irrigation and other's as high as five.

The results obtained at the station itself were in the highest degree satisfactory. The total number of s:mples grown and analyzed at the 
station was ten, the mean weight of the beets was 19 ounces, and the mean percentage of sugar 1S.9, purity coeflicient not given.

Mr. Stubbs, the director of the station, in submitting his report, states that he distributed 90 pounds of the seed received from the Department to thirty farmers residing in tifteen comties. Only five of the thirty farmers sent samples for analysis. One reported failure from stock breakiug into the field and (lestroying the crop); one, failure from lack of water, and one stated that the samples of seerls sent him did not arrive. Mr. John Harrison reports that there are 20,000 acres of land in a single body such as he used for growing his beets.

All the samples sent to the Department of A gricluture by Mr. Harrisoll, ten in number, were f:om Humboldt County; the average weight of the samples was 21 ounces, the mean content of sugar in the beets 18.S per cent, and the mean coefficient of purity $\$ 3.1$. It is evident that, if such beets as these can be grown in that locality, the 20,000 acres of land suituble to beet culture would suffice to maintain a largo factory, which must of necessity prove eminently successful if fuel, limestone, and water can be had in sufficient abundance and sufficiently cheap to operate it. The cultural results in Nevala are of the highest significance. This State, which is devoted chiefly to mining, has very small agricultural interests, but if a few areas capable of irrigation, like that at Lovelocks, in Humboldt Conuty, can he found, Nevada should become a beet prolueing State. The establishment of this agricultural industry could not fail to be of immense benefit to the Commonwealth. There is no other State in which the reports are more favorable, although it may be said that the number of samples is not sufficiently large to carry absolute conviction. Nevertheless, the uniform excellence of the samples can not be the result of accident, but must have been due to the favorable influences of soil and climate. The agricultural experiment station of this state will do well to make a more careful survey, and especially to map out the localities where the contour of the State is suitable $t$, beet eulture and where water can be obtained.

\section{NEW JERSEY.}

As has been before stated, New Jersey is traversed from the south toward the north by the mean isotherm of $71^{\circ}$ for the three summer months. A portion of it is therefore within the theoretical thermal belt for beet growing. In general, it may be said, however, that the temperature will be found a little too warm to secure the best results. On the other hand, the soil of New Jersey is of a sindy nature, suited to the growth of a beet with a high purity.

The data which have been collected during tho season from Now Jersey are encouraging. The whole number of samples received from the State was 31, the average weight 16 ounces, the meau content of sugar in the beot 14.2 per cent, and the coefficient of purity 81.4. Essex and Mercer counties each furnished seven samples; the results in Essex Oounty wers fairly good, but in Mereer County were poor. Ocean 
Cotunty furnished eight samples, with a high average percentage of sugar and purity coefficient, but with a weight only half the normal.

No investigations were made by the experiment station of New Jer. sey, but Mr. James B. Tredenburgh, of J ersey City, cond ucted some very careful experinents at Freehold, in Monmouth County. The following report of Mr. Vredenburgh is interesting and contains valuable data.

\section{RESULTS OF EXPERIMENTS IN NEW JERSEY.}

May 20,1897 . - I had one-quarter acre clover sod plowed and prepared for planting.

May $2 \mathcal{\sim}$ - I lial plauted four kinds of beet seed, viz, a strip of 111 by 2 feet 9 inches or sevon one-thousandths of an acre in imported Vilmorin.

A similar strip in imported Kleinwanzlebener; a similar strip in Government seed, and the balance of the quarter acre in cattle beets.

I fertilized the whole plot equally with 300 ponnds of phosphate. I weeder the beets twice, cultivated them five times, and gathered them November 1.

I had one of each kind analyzel each week, commencing August 3 , by an expert chemist, the result of which I herewith inclose:

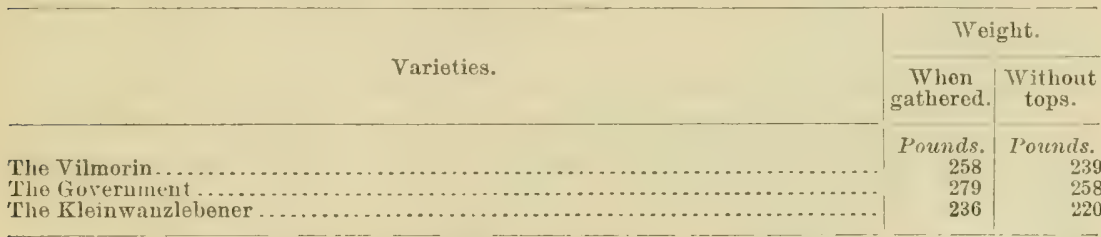

The Vilmorin, therefore, produced at the rate of $17 \frac{1}{2}$ tons to the acre, without tops; the Government, 18 tons to the acre without tops; Kleinwanzlebener, 15 tons to the acre without tops.

It will be seen that by far the best result came from the Vilmorin, the purity of the juice in the analysis of November 1 being 88.20 .

'This latter result was from an average of three beets, one small, one middle size, aud one large.

The cost of the labor, fertilizer, etc., on the one-quarter acre was about $\$ 15$.

Resuits on farm at Frechold, Monmouth County.

\begin{tabular}{|c|c|c|c|c|c|c|}
\hline \multirow{2}{*}{ Date. } & \multirow{2}{*}{ Marked. } & \multicolumn{2}{|c|}{ Weight of the beet. } & \multicolumn{2}{|c|}{$\begin{array}{l}\text { Percentage of } \\
\text { sugar. }\end{array}$} & \multirow{2}{*}{$\begin{array}{l}\text { Purity co- } \\
\text { efficient. }\end{array}$} \\
\hline & & $\begin{array}{l}\text { With } \\
\text { top on. }\end{array}$ & $\begin{array}{l}\text { With top } \\
\text { eut off. }\end{array}$ & $\begin{array}{l}\text { In the } \\
\text { beet. }\end{array}$ & $\begin{array}{l}\text { In the } \\
\text { juice. }\end{array}$ & \\
\hline 1897. & & l'onends. & Pounds. & & & \\
\hline A 12.30 & No mark.... & 1.171 & 1. 088 & 10.45 & 11. 30 & 80.14 \\
\hline 30 & (n) & 1.384 & 1. 161 & 11. 15 & 12.50 & 83.30 \\
\hline Sept. 8 & $\ldots \ldots \ldots \ldots \ldots \ldots \ldots$ & 1. 481 & 1. 168 & 11.75 & 12.55 & 79.40 \\
\hline & ...... do & 1. 251 & 1. 000 & 11.85 & A. & \\
\hline 15 & Government.... & 2. 093 & 545 & 9.80 & 10.60 & 80.60 \\
\hline 15 & 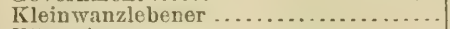 & 1. 704 & 1. 329 & 11. 40 & 12.00 & 83.90 \\
\hline 15 & 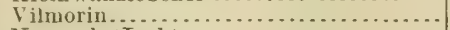 & i. 724 & 1. 311 & 12.40 & 13. 10 & 84.50 \\
\hline 20) & 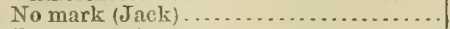 & 0.587 & 0.505 & 14.30 & 15.60 & 83.40 \\
\hline 27 & 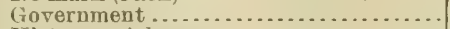 & 4. 391 & 2.923 & 10.40 & 11.25 & 81.50 \\
\hline 27 & 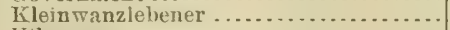 & 4. 491 & 3.000 & 10.10 & 10.35 & 77.24 \\
\hline 27 & 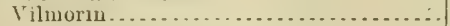 & 4. 292 & 3.058 & 9.90 & 10.55 & 78.47 \\
\hline Oct. & 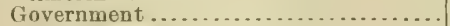 & 2.097 & 1.700 & 12.40 & 13.25 & 84.30 \\
\hline$\dot{1}$ & Kleinwanzlebener ................... & 1. 633 & 25 & 12.00 & 13. 10 & 82.40 \\
\hline 4 & 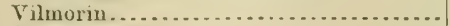 & 1. 876 & 79 & 13. 80 & 14. 10 & 86.10 \\
\hline 14 & Government . . . . . . & 1. 662 & 1,474 & 11. 50 & 12.75 & 80.20 \\
\hline 14 & 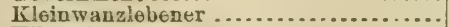 & 2. 234 & 1. 770 & 12.30 & 12. 75 & 81.70 \\
\hline 14 & $\ldots \ldots \ldots \ldots$ & 1. 706 & 1.474 & 14. 20 & 15.65 & 84. 10 \\
\hline 20 & Governmeni & 1. 583 & 1.373 & 13.50 & 14.50 & 82.00 \\
\hline 20 & 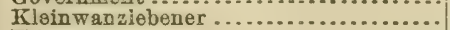 & 15 & 2.037 & 11. 90 & 12.70 & 81.90 \\
\hline 20 & 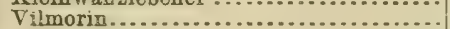 & 2.150 & 1.715 & 14. 30 & 14. 95 & 83.50 \\
\hline Nov. 1 & Government.... & 2.313 & 1. 757 & 12.40 & 13.50 & 78.00 \\
\hline 1 & 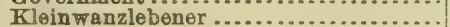 & 1.380 & 1. 000 & 13.10 & 13. 80 & 83. 10 \\
\hline 1 & Vilmorin & 1.270 & 0.958 & 14. 30 & 15.35 & 88.20 \\
\hline
\end{tabular}


Excluding the analyses made before the 20th of September, which would be anterior to the manufacturing season, and including all of those made after that date, we find that the sixteen samples analyzed had an average weight of 27 ounces, a mean content of sugar of 12.5 per cent, and a mean purity of 82.3. These data, obtained by Mr. Vredenburgh, in conjunction with those secured from the analyses of the samples forwarded to Washington, indicate the possibilities of successfully establishing the industry in the State on the lands which are particularly suited thereto. As before stated, however, the danger from a slightly too high temperature must be expected, and while good beets, capable of yielding high percentages of sugar, and with high purities, may be grown in New Jersey, it is scarcely probable that they will reach as high a grade as those grown farther north.

\section{New Mexico.}

Only three samples grown in New Mexico were received at this laboratory for analysis. These were all grown in Mora County by the La Cueva Ranch Company. The average size of these samples was small, but the content of sugar and the coefficient of purity of the juice were high. In comnection with this work the report of the director of the agricultural experiment station will be found of interest.

RESULTS OF EXPERIMENTS IN NEW MFXICO.

TABLE 1.-Analyses in the chemical laboratory of the New Mexico Experiment Station prior to October $25,189 \%$.

\begin{tabular}{|c|c|c|c|}
\hline Locality. & $\begin{array}{l}\text { Number } \\
\text { of sam- } \\
\text { ples ana- } \\
\text { lyzed. }\end{array}$ & $\begin{array}{l}\text { Average } \\
\text { weight of } \\
\text { bcets. }\end{array}$ & $\begin{array}{l}\text { A rerage } \\
\text { per cent } \\
\text { sugar in } \\
\text { the juice. }\end{array}$ \\
\hline $\begin{array}{l}\text { New Mexico A gricultural Experiment Station, Mesilla Park: } \\
\text { Harvested Sept. } 5 \text {. }\end{array}$ & & Pounds. & \\
\hline 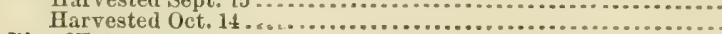 & $\begin{array}{l}31 \\
31\end{array}$ & 1.21 & 11.02 \\
\hline Blue Water: & & & 12.47 \\
\hline Harvested Sept. $8 \ldots . .$. & 4 & 1. 38 & 10.50 \\
\hline Harvested Sept. $30 \ldots .$. . & 1 & 1. 63 & 12. 70 \\
\hline Albuquerque.................. & 3 & 1.73 & 13.16 \\
\hline 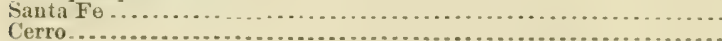 & 7 & 1.06 & 14.10 \\
\hline Cerro ${ }_{\text {Dorsey }}$ & 3 & 1.04 & 17. 03 \\
\hline 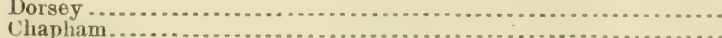 & 1 & 1. 60 & 12.60 \\
\hline 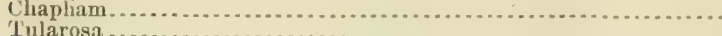 & 1 & 1.60 & 15. 10 \\
\hline & 2 & 1.98 & 11.20 \\
\hline Anthony Mraxwell City & 1 & 1.18 & 11.50 \\
\hline 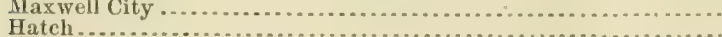 & 3 & 2. 77 & 14. 15 \\
\hline Hatch & 1 & 2. 35 & 11.50 \\
\hline $\begin{array}{l}\text { Socorro } \\
\text { Lordsburg }\end{array}$ & 1 & .48 & 15.50 \\
\hline 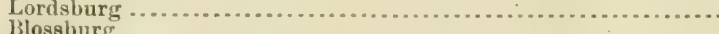 & 1 & .55 & 16. 20 \\
\hline & 1 & 3.55 & 10.80 \\
\hline Aztec Subexperiment Station..... & 1 & 1.85 & 14. 60 \\
\hline Averages, etc .. & 96 & 1.61 & 13. 18 \\
\hline
\end{tabular}


TABLE 2.-Analyses in the chemical laboratory of the New Mfexico Experiment Station between October 25 and November 15, $189 \%$.

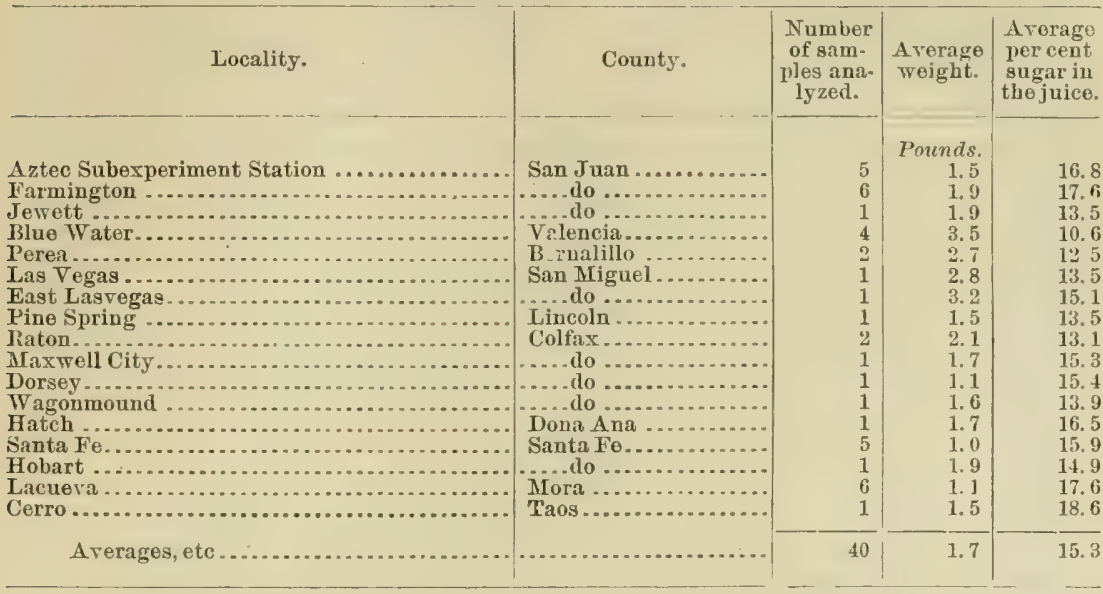

TABLE 3.-Analyses in the chemical laboratory of the New Mexico Lixperiment Station between November 15 and December $20,189 \%$.

\begin{tabular}{|c|c|c|c|c|}
\hline Locality. & County. & $\begin{array}{l}\text { Number } \\
\text { of sam- } \\
\text { ples ana- } \\
\text { lyzed. }\end{array}$ & $\begin{array}{l}\text { Average } \\
\text { weight. }\end{array}$ & $\begin{array}{l}\text { A rerago } \\
\text { per cent } \\
\text { sugar in } \\
\text { tho juice. }\end{array}$ \\
\hline $\begin{array}{l}\text { New Moxico Agricultural Experiment Station, } \\
\text { Mesilla Park. }\end{array}$ & & & Pounds. & \\
\hline Harvested Nov. 16 . & Dona Ana ............ & 31 & 1.7 & .13 .9 \\
\hline Harvested Dec. $15 \ldots . .$. & (., & 27 & 1.6 & 13.9 \\
\hline Sample came in not marked. & 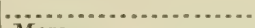 & 1 & 1.5 & 17.4 \\
\hline 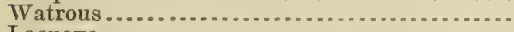 & Mora... & 1 & .8 & 12.0 \\
\hline Iacueva .... & . & 2 & 1.1 & 15. 6 \\
\hline Los Lunas... & Valencia............... & 1 & 2.5 & 14.5 \\
\hline Blue Water........... & ....do do................ & 4 & 1.2 & 13.8 \\
\hline Roswell.......... & Chavez ....... & 3 & 1. 7 & 13.8 \\
\hline Hagerman ................ & Eddy $\ldots . . . . . . . . . . . .$. & 3 & 1.2 & 13.5 \\
\hline Santa Fe................... & Santa Fo................. & 3 & .8 & 18. 0 \\
\hline Espanola ..................... & .....do & 5 & 1.6 & 14.1 \\
\hline 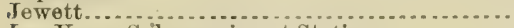 & San Juan ............... & 1 & 2.2 & 13.0 \\
\hline Las Vegas Subexperiment Station. & San Miguel ..... & 1 & 1.6 & 17. 6 \\
\hline Averages, et & & 83 & 1.6 & 14. 1 \\
\hline
\end{tabular}

Our work is still in an incomplete condition, as we have not bad time to estimate the coefficient of purity and consider some other points in connection with these analyses. I beg to call your attention to the fact that nearly all of tho bects analyzed here were grown by farmer's who had had no previous experience in growing leets, and whose habits of farming are extremely loose. We can say definitely that if these beets had been grown under such conditions as would be expected to obtain upon a wellregulated farm, the results would have been very much more satisfactory. We know that the conditions uncler which the most of the samples grew on the station farm here were not of the most satisfactory kind, as we are trying experiments on time of planting, time of harvesting, variety testing, deep and sballow plowing, different modes of irrigation, ete. It is now established beyond a doubt that Now Mexico can grow large crops of sugar beets, containing a very high percentage of sugar.

Located at Eddy, in the southeastern part of the Territory, there is already established a sugar-beet factory, doing a successful and profitable business.

In the northern portions of the Territory coal is comparatively cheap, and the 
completion of a railload now in process of building will very materially cheapen coal in the sonthern part of the 'Territory.

Limestono scems to be scattered pretty well throughout the Territory, and whilo We have not had time to go fully into this subject, the few analyses that we have made indicate that the Territory affords linestone of a very good grade. We have just taken a survey of the limestone and waters of the sugar-beet districts. The question of water is engaging our attention, too; and we believe that water of fairly good quality can be secured.

There is a lively interest taken in sugar-beet work in all parts of the Territory, and from the tables herewith inclosed the most favorable locations can casily be selected. P'articular attention should he called to the Iio Grande Valles, especially the northern portion, and tho Animas Valley. This latter las an extensive and abundant supply of very good water, but at present no railroad. 'This valley seems to be a very promising section for the production of sugar beets. See Aztec and Farmington in the tables.

The soils of the 'Territory contain, I think, about the average amount of nitrogen and phosphoric acid and about the usual amount of potash. They have a decided advantage over the soils in the rainfall distriets, because the fertility is largely kept 11) hy the plant foud contained in the irrigating water, and nearly all that once gots on the soil remains, as very little, indeed, is lost by leaching and drainage.

We expect to publish a bulletin about the 1st of February, giving our results in detail.

The analyses which were made by the chemist of the agricultural experiment station of the samples received by him are classified in accordance with the time at which they were made. Ninety-six analyses made prior to October 25 showed an average weight of the samples of 26 ounces, with an average content of sugar in the beet of 12.5 per cent. The puxity coefficient of the juice is not given.

Forty samples andyzed between the 25th of October and the 15 th oî November harl an average weight of 27 oumces, with an average content of sugar in tho beet of 14.5 per cent, the purity coefficient not being stated.

Eighty-three samples analyzed betreen November 15 and December 20 had an average weight of " 6 ounces, and an average content of sugar in the beet of $\mathbf{1 3 . 4}$ per cent. The purity was not given:

It is evident that there are many localities in New Mexico where the conditions of temperature are most favorable to the growth of beets. 'There are also large areas of fairly level land which are capable of irrigation. Wherever the temperature of these regions is sufficiently low to permit the proper development of the beet, and where sufficient water for irrigation can lhe secured, there is reason to believe that the industry may he establisher and prove to be fairly profitable. While the summer lays in New Mexico are not so long by an hour or more as in the regions farther north, the amount of sunshine which the growing beet will receive is practically as great as in more northern localities, because of the companative absence of cloudy and rainy days. The remarks which liave alrealy been made in regard to the growth of beets on irrigated areas apply to New Mexico. This is a subject which demands the most careful scientific study, and the work which is now doing by the agricultural experiment station of the Territory is certain 
to bear excellent fruits in the near future. New Mexico is provicled with a beet-sugar factory in the extreme southwestern porition of the Territory, and thus a practical demonstration of the possibilities of beet growing can be made. It is diffeult to secure definite data from this factory, but from the meager reports received it is believed that the season's work has not been so successful as had bcen expected from the results obtained during the preceding year. Accomnts have been received of a mold or fungus attacking the beets, and it is also evident that the true principles of irrigation have not yet been thoroughly worked out. There shonld not, however, be anything disconraging in accirlents of this kind, as tile conditions, upon the whole, are such as to warrant the expectation of final suecess.

\section{NEW YoIK}

On January 16, 1894, in addressing the New York Farmers Club on the subject of beet sugar, I used the following words:

The plateaus of the great West subject to irrigation aro especially suited to the production of sugar beets. The same is true of the lands of certain portions of Nebraska and Dakota, of Iowa, Minnesota, and WVisconsin, of northern Illmois, Indiana, Ohio, and Now York. Recently, in passing over the valley of tho frencseo River, I was particularly struck with the quality of the soil and its suitability to beet culture. The valley of the Genesee is only a type of hundreds of thousands of acres in New York which could be profitably devoted to beet culture.

At that time practically no experiments harl been made to determine the suitability of the soil and climate of New York for producing highgrade beets. In fact, not until the last year has any systematic attempt been made to ascertain the capabilities mentioned above. In the spring of 1896, in conversation with a committee of the board of trustees of the agricultural experiment station at Geneva, I urged upon them the desirability of stulying the capabilities of New York for beet production. In 1897 the Department of Agriculture, in cooperation with tho experiment stations at Geneva and Ithaca, conducter a series of investigations throughout the State of New Iork, which has given data of extraordinary interest and importance.

The climatic conditions, as respects temperature and rainfall, affectiug the State of New York have already been discussed. It has been seen that there are two areas in which the thermal conditions are particularly favorable, separated by a large area where the mein summer temperature is less than $69 \circ$. It has already been pointed out, however, that a lower temperature than 690 is still highly favorable to the production of beets of superior excellence if coupled with conditions which permit their maturity and harvest in time to aroid the severe frosts of winter. These conditions exist in a marked degree throughout the whole of the region in New York lying between the Hudson River on the east and the Great Lakes on the west, excluding the extreme northern portion, where the altitude and mountainous character of the country preclude the possibilities of beet culture. The 
whole of the area named, therefore, where the contour is favorable and the character of the soil suitable may be regarded as a prospective area of sugar-beet culture.

SAMPLES RECEIVED AT THE DEPARTMENT OF AGRICULTURE.

From the seed distribnted to farmers in different parts of the State, 225 samples of beets were receiver at the Department of Agriculture for analysis. The mean weight of these samples was 21 ounces, the mean percentage of sugar in the beet 15 , and the mean coefficient of purity 82.4. Every county in the State reporting results showed favorable data. The counties having the largest number of samples of course gave data which are the most instruetive.

Cattaraugus County supplied 15 samples, with a mean weight of 18 ounces, a mean percentage of sugar in the beet of 15.1, and a mean coefficient of purity of 81.9 .

Chautauqua County furnished 45 samples, with a mean weight of 21 ounces, a mean sugar content in the beet of 16.6 per cent, and a mean coefficient of purity of 82.7 .

Erie County sent 37 samples, having a mean weight of 19 ounces, a mean content of sugar of 15.9 per cent in the beet, and a mean coefficient of purity of 83.9 .

Oneida County was the source of 22 samples, with a meau weight of 14 ounces, a mean sugar content of 13.6 per cent, and a mean coefficient of purity of 81.8 .

Ontario County furnished 22 samples, having a mean weight of 17 ounces, a mean content of sugar in the beets of 15 per cent, and a mean coefficient of purity of 83.4 .

Yates County supplied 15 samples, having a mean weight of 23 ounces, a mean sugar content of 12.7 , and a mean coefficient of purity of 79.6 .

The uniformly good properties of so large a percentage of samples collected in the promiscuous way made necessary by the method of the experiments show beyond question the favorable auspices under which they must have been grown.

In addition to the special plot work on high-grade beets which was conducted under the supervision of the Geneva station, cooperative work by the Department of Agriculture, in conjunction with the farmers of the State, was also carried on. From the whole number of packages of seed distributed by the station, 135 samples of beets were received for analysis, and the results obtained, without distinction of locality, are shown in the following report of Director Jordan:

RESULTS OF EXPERIMENTS IN NEW YORK.

The number of samples reported is 135, which came from a sufficient number of points in the state to make them fitirly representative of the conditions prevailing.

I make no report to jou of the production, because in most instances, whenever the tonnage was reporter, the figures appeared to us to bo unreliablo because of the methods used in reaching thom. 
Kleinwanzlebener.

\begin{tabular}{|c|c|c|c|c|}
$\begin{array}{c}\text { Beets con- } \\
\text { taining } \\
\text { sugar. }\end{array}$ & $\begin{array}{c}\text { Number } \\
\text { of sam. } \\
\text { ples. }\end{array}$ & $\begin{array}{c}\text { Average } \\
\text { per cent } \\
\text { sugar in } \\
\text { beet. }\end{array}$ & $\begin{array}{c}\text { Coeffi- } \\
\text { cient of } \\
\text { purity. }\end{array}$ & $\begin{array}{c}\text { Average } \\
\text { weight of } \\
\text { one beot. }\end{array}$ \\
Per cent. & & & & \\
$11-12$ & 4 & 12 & 76.5 & Ounces. \\
$12-13$ & 11 & 13 & 75.4 & 18 \\
$13-14$ & 10 & 13.8 & 80 & 14 \\
$14-15$ & 11 & 14.7 & 80.3 & 17 \\
$15-16$ & 15 & 15.8 & 84.3 & 14 \\
$16-17$ & 11 & 16.5 & 85.3 & 16 \\
$17-18$ & 13 & 17.6 & 85.2 & 14 \\
$18-19$ & 3 & 18.5 & 85.9 & 13 \\
& & & & \\
\hline
\end{tabular}

Vilmorin Improved.

\begin{tabular}{|c|c|c|c|}
\hline $\begin{array}{c}\text { Number } \\
\text { of } \\
\text { saniples. }\end{array}$ & $\begin{array}{c}\text { Average } \\
\text { per cent } \\
\text { sugar in } \\
\text { beet. }\end{array}$ & $\begin{array}{l}\text { Coeffici- } \\
\text { ent of } \\
\text { purity. }\end{array}$ & $\begin{array}{l}\text { Average } \\
\text { weight of } \\
\text { one beet. }\end{array}$ \\
\hline $\begin{array}{r}3 \\
5 \\
9 \\
8 \\
17 \\
9 \\
6 \\
2\end{array}$ & $\begin{array}{l}11.7 \\
12.8 \\
13.8 \\
14.8 \\
15.6 \\
16.6 \\
17.8 \\
18.6\end{array}$ & $\begin{array}{l}75 \\
76.7 \\
82.4 \\
83 \\
82 \\
87.5 \\
85.4 \\
83.8\end{array}$ & $\begin{array}{c}\text { Ounces. } \\
16 \\
24 \\
19 \\
16 \\
16 \\
15 \\
18 \\
24\end{array}$ \\
\hline
\end{tabular}

My chief anxiety with regard to the development of the sugar-beet industry in New York is that farmers shall not reach unwarranted conclusions concerning the protits of their side of the work. I have no reason to helieve that the industry will prove more protitable to our farmers than the production of several crops which we are now growing. I recognize, of course, the benefits of adding to our list of crops another one which will have a ready cash market.

There apjears to be a move all over the state for the establishment of factories at desirable centers, and promoters are already in the field who are, as a rule, urging the farmer to invest in heet sugar-factory stock. I am very much afraid that there will be serious misdirection of capital, which will not only cause the farmer to lose money, but seriously disappoint him in regard to the benefits from growing sugar beets. Mr judgment is that the matter should be discussed by those who take the leat in the matter in the most conservative way, and both farmers and business men should be severely cautioned to proceol slowly and only after extended and careful investigation.

A carefully grown erop of sugar heet: yielded on the exporiment statiou farm this season at the rate of $16 \frac{1}{4}$ tons per acre, carrying 15.2 per cent sugar in the hect and 16 per cent in the juice. No depenrlence should, in my judgment, be placed upon the reports of yields of 25 and 30 tons per acre of high-grade beets in this State.

In studying the report of Director Jordan we see that of the Kleiuwanzlebener variety only four samples out of the whole number fell below the minimum of 12 per cent of sugar in the beets, and of the Vilmorin variety only three. This is without doubt a remarkable showing of excellence, in so far as the content of sugar is concerned. The caution of Director Jordan to proceed carefully in this matter, and with a due study of the factors, is perfectly in harmony with the tenor of the reports which have been issued by the Department of Agricul- 
ture, on the subject of beet sugar, from time to time during the past fifteen years, and is deserving of careful consileration, hoth by intending investors and farmers. Our reports have constantly dwelt upon the danger of misdirected enthusiasm and failure to study properly all the factors entering into any enterprise connected with the mannfacture of sugar.

The agrienltural experiment station of Cornell University, at Ithaca, also cooperated with the Department in the experimental work in New York. Four hundred and twenty-five samples were received for analysis at the experimentstation at Ithaca. The data obtained on analysis, arranged by comnties, are given in the report of Director Roberts. In this report the percentage of sugar in the juice of the beet only is given, the mean being 16.9. Converting this number into terms of the sugar in the beet, the percentage becomes 16.1, which is one point higher than the mean percentage of sugar in the samples from New York analyzed by the Department of Agriculture. The coefficient of purity, 83.5 , obtained at the Ithaca station is only a little over oue point higher than that secured from the analyses by the Department of Agriculture.

Director Rober's, in his report, estimates that the mean yield per acre obtained in the State of New York was 17 tous, but as his estimate is male npon the returns made by the farmers, many of which are evidently too high, it is not final as a source of deductions in regard to the average yield which may be obtained. It is not at all likely that an average yield of 16 tons per acre conld be obtained, even by the best culture.

The counties furnishing the data with the most weight are Broome, Chautauqua, Erie, Genesee, Monroe, Stenbeu, and Tryue. Chautanqua County, especially, is to be regurded on arcount of the mean data being based upon 122 separate samples, in which the mean percentage of sugar in the juice was 16.5, and the mean coefficient of purity, 83.5. The next highest number is furuished by renesee Comty, where the mean percentage of sugar in the juice from 62 samples is 16.6 , and the coefficient of purity, S:.9. Monroe, with 59 samples, shored a mean sugar content in the juice of 17.2 per cent, and a mean coefficient of purity of 83.9. Erie Connty, with 38 samples, gave a mean content of sugar in the juice of 17.9 per cent, and a mean coeficient of purity of 86.3. Wayne County furnished 27 samples, having a mean content of sugar in the juice of 16.7 per cent, and a mean coefticient of purity of 82.9. Broome County sent 25 samples, containing 16.2 per cent of sugar in the juice, with a coefficient of purity of 81.8 ; and Steuben County furnished $2 t$ samples, containing 16.2 per cent of sugar in the juice, with a coefficient of purity of 82.6. Following is the report of Prof. Roberts :

The 500 pounds of sugar-beet seed sent us by the Department of Agriculture were distributed to over 300 firmers of the state, with directions as to preparation of the soil, planting, and cultivating. During the growing season, the larger pairt of 
the plats was inspected by an officer of this station and observations made as to the general conditions found.

The season was a fitrorable one, and in nearly all cases the boots made good growth, and that the per cent of sugar was satisfactory will be shown by the tablo of analyses given later.

It is safe to say that the citizens of New York State, both capitalists and farmers, are thoronghly awakened to the importance of the subject of the manufacture of sugar from bects. During the season one factory has been in successful operation at Rome, N.Y. Other factories are contenylated, and at the present time agents are in France negotiating for machinery to be used in a large factory to be erected the coming season.

Officers of this station attended eight meetings of farmers and capitalists to give information and advice as to the advisability of locating fictories in certain sections of the State. Abundance of capital is ready to be invested once the sucess of the industry is assured. Farmers feel that in the raising of sugar beets a new avenue is open for them, and in most parts of the State fivorable for the growth of beets they are heartily faroring the new enterprise.

When the various experimental plats were harrested, agents from this station personally superintended the taking of the samples and the calculations of yield on 178 of the plats. To those farmers whose places we were unable to visit directions were sent as to how the samples should bo taken and the yield estimaterl; so it is believed that this report of results is a fair statement of what can bo dono in Now York State in tho way of raising sugar beets.

The necessity now secms to be the education of the farmers in the system of intensive culture necessary for the successful raising of the beots. The farmers appreciate the importance of this instruction, and are eager to learn. It is safe to predict that the manufacture of sugar from beets is to be one of Now York's prominent inclustries in the near future.

The following report is furnished by our chemists, summarizing the results by counties:

Report of sugar-beet experiments in New York, $189 \%$.

\begin{tabular}{|c|c|c|c|c|c|c|c|}
\hline Connty. & $\begin{array}{l}\text { Sugar in } \\
\text { juice. }\end{array}$ & $\begin{array}{l}\text { P'uxity } \\
\text { coefticient } \\
\text { of juice. }\end{array}$ & $\begin{array}{l}\text { Total } \\
\text { number } \\
\text { of sim- } \\
\text { ples ana- } \\
\text { lyzed. }\end{array}$ & County. & $\begin{array}{l}\text { Sugar in } \\
\text { juice. }\end{array}$ & $\begin{array}{l}\text { Purity } \\
\text { coolicieut } \\
\text { of juice. }\end{array}$ & $\begin{array}{l}\text { 'Iotal } \\
\text { number } \\
\text { of' sim- } \\
\text { ples ana- } \\
\text { lyzed. }\end{array}$ \\
\hline Albany. & $\begin{array}{r}\text { Per cent. } \\
17.25\end{array}$ & 86.6 & 1 & Oneida............. & $\begin{array}{r}\text { Per cent. } \\
16,16\end{array}$ & 82.1 & \\
\hline 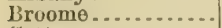 & 16,23 & 81.8 & $2 \overline{5}$ & Onondaga....... & 17. 40 & 86.6 & 1 \\
\hline Cattaraugus...... & 16.94 & 81.5 & 15 & Orleans .......... & 17.20 & 86.1 & 3 \\
\hline Cayuga ................. & 17.34 & 81.3 & 10 & Oswego........... & 14.45 & 76.1 & 1 \\
\hline Chautauqua...... & 16.83 & 83,5 & 122 & Saratoga......... & 20.25 & 86.6 & 1 \\
\hline 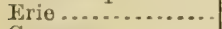 & 17. 93 & 86.3 & 38 & Schuyler.......... & 16.26 & 79.7 & 2 \\
\hline Geneser ........... & 16.62 & 82.9 & 62 & Seneca.......... & 16.58 & 83.2 & 5 \\
\hline Herkimer.......... & 13.85 & 79.2 & 1 & Steuben .......... & 16.21 & 82.6 & 24 \\
\hline Jefferson .......... & 16.16 & 81.0 & 3 & 'Tioga............... & 18. 73 & 82.7 & 2 \\
\hline Liringston ........ & 19.25 & 85.6 & 1 & Tompkins ........ & 17.49 & 83.1 & 8 \\
\hline Monroe............. & 17.22 & 83.9 & 59 & Wayne.......... & 16.74 & 82.9 & 27 \\
\hline Niagara............ & 17.31 & 83.4 & 7 & Average.... & 16.89 & 83.5 & 425 \\
\hline
\end{tabular}

From the foregoing data, the conclusion is inevitable that the State of New York stands among the first in the Union in its capabilities of producing beets with a high content of sugar and a high purity. The meager data at hand also show that a fair tomage per acre call be secured. It is evident that with proper fertilization and rotation of crops the fertility of the soil can not only be maintained, but even increased, so that it is not unreasonable to expect, under the best con-

H. Doc. $396-7$ 
ditions of culture, that the mean tonnage per acre produced in the State of New York will be quite equal to that of the best sugar regions of Germany. Judging by the data obtained from a single season alone, there is no sugar-beet producing conntry of Europe that can compete with the State of New York in the richness of its beets. If a factory, constructed on the best approved modern principles, and with every facility for converting the whole of the sugar into marketable form, could be supplied with such beets as were grown in the State of New York during the season of 1897, it would be eapable of placing upon the market 240 pounds of pure granulated sugar for every ton of 2,000 pounds of beets entering into manufacture. When, in addition to these facts, are considered the cheapness of fuel, the almudance of labor, the proximity of markets, and the importance of the dairy indus. try in its relations to the refuse of the factory as a feed, it is seen that there is no place in the United States which offers more favorable inducements for the development of the industry.

ELEVATION OF REGIONS OF NEW YORK SUITED TO BEET CULTURE.

A contour map of the State of New York, showing the elevations above tide water, is found in the fifth annual report of the meteorological bureau and weather service of the State for 1893. The elevation in the region of the Catskills in some places reaches an altitude of 3,000 feet. Immediately west of this mountainous region, and extending to Binghamton on the sonth and almost across the State through the south central portion, there is a large area in which the average elevation is 1,000 feet. In the southwestern portion of the State there is a considerable area the elevation of which is 1,500 feet. The region of the Adirondacks and the northeastern portion of the State has various elevations, but as these regions are probably too far north for successful beet culture they do not interest us here. Starting from Albany with an average elevation of 100 feet and following the course of the New York Central Railway, we pass through an area a large portion of which is below 500 feet in elevation. From Rome throngh Syracuse and as far west as Lyons the average elevation is less than 500 feet, with the exception of small areas. From Lyons to Buffalo the average elevation is above 500 and less than 1,000 feet. Immerliately along the shores of Lake Ontario the average elevation is less than zoo feet. Passing to the south near liochester, along the Genesce Valley, is a considerable area below 500 feet in elevation.

An interesting description of the physical contour of the State is given in the report mentioned above as taken from the work of I'rof. Arnold Guyot. This description is as follows:

The following ontline of the orography of New York is substantially as given by Prof. Arnold Guyot. Further details are exhibited by the accompanying relief map. 
The mass of the State is a triangular table-land elevated 1,500 or 2,000 feet above the ocean, and may be considered the northeastern extremity of the plicteau which, in this latitude, forms the western half of the Appalachian system. The natural limit of this lielt toward the west and north is the largo drpression of Lakes Lrie and Ontario, and which continues down the course of the St. Lawrence River to the ocean. In the east the table-land is terminated by the deep ralley occupied by Lale Champlain and the Hudson River, while sonthward the highlauls extend without interruption into Pennsylvania. The eastern edge along the Hudson and Champlain valleys is formed by a series of mountain chaius moro or less isolated from each other, and bearing the highest summits in the State. They are: The Highlands, which eross the Hudson at the limit of the coast region; the Shawangunk and Catskill mountains, on the western bank of the river, and the system of the Adirondacks, covering the territory between the St. Lawrence and Champlain valleys. Within this eastern wall the true mountain chains cerse, but the remainder of the platean is indented by numerous valleys, the bottoms of which are generally several humlred feet below the common level, aud which are separated by high ridges. A remarkable feature is the deep trausversal cut which forms the valley of the $\lambda$ lohawk and Lake Oneidat, opening a channel from the low country of the Lake region to the Hudson valley, and thus dividing the main plateau into the distinct masses of the Appalachian and Adirondack systems.

A subdivision of the eentral or Appalachian highlands is due to the deep channel of Seneca Lake, extending from the plains bordering Lako Ontario sunthward to the valley of the Susquelianna. The two sections of the highlands thus separated are here designated as the eastern and western plateaus, the former extending from the central lakes to the Hudson Valley, and the latter westward from the central lakes to the depression of Lake Erie.

\section{NORTIL DAKOTA.}

Ouly four samples were receivel from Nortl Dakota, the average weight of which was 25 ounces, and the mean percentage of sugar in the beet 10.5. On account of the low content of sugar, purity coeficients were not computed.

No report has been received from the director of the North Daliota station in regard to any work which has been carried on by that station. The data of the four samples received are likely to be misleading, as it is evident that North Dakota is capable of producing yery much better beets than are indicated by the data in the analytical tables.

\section{Norti Carolina.}

By consulting the map it may be seen that there are many localities in North Caroliua where the thermal cinditions awe farorable for the growth of high grate beets. It is doubtful, however, whether upon the summits of the Allegheny Nountains, where these conditions exist, a sufficient area of suitable soil could be secured to warrant the expectation of establishing successfully a beet-sugar industry in that State.

Only seven samples wero received from North Carolina by the Department of A griculture. The mean weight of these sumples was 23 ounces, and the meau percentage of sugar in the beet 9.1. On account of the 
low polarization of the samples, it was not deemed necessary to make a computation of the coefficient of purity.

No analyses were made at the laboratory of the experiment station of North Carolina during the year, althongh the director of the station has been much interested in the work, and proposes to continue it another season.

Онго.

Sixty.eight samples of beets grown in Ohio were received at the Department laboratory for analysis. The mean weight of these beets was 22 ounces, the mean content of sugar 13.8 per cent, and the mean coefficient of purity, 79.1. Grouped by belts into northern, central, and sonthern, the character of the beets grown in Ohio aud analyzed at the Department of Agriculture is shown in the following table:

Summary of analyses of beets from Ohio, by belts.

\begin{tabular}{|c|c|c|c|c|}
\hline Belts. & $\begin{array}{l}\text { Number } \\
\text { of } \\
\text { samples. }\end{array}$ & $\begin{array}{l}\text { Average } \\
\text { weight. }\end{array}$ & $\begin{array}{c}\text { Sugar in } \\
\text { beets. }\end{array}$ & $\begin{array}{l}\text { Purity } \\
\text { coeffi- } \\
\text { cient. }\end{array}$ \\
\hline $\begin{array}{l}\text { Northern belt } \\
\text { Central belt } \\
\text { Southern belt. }\end{array}$ & $\begin{array}{r}42 \\
19 \\
7\end{array}$ & $\begin{array}{r}\text { Ounces. } \\
21 \\
23 \\
26\end{array}$ & $\begin{array}{r}\text { Per cent } \text {. } \\
14.1 \\
13.6 \\
12.7\end{array}$ & $\begin{array}{l}79.9 \\
78.5 \\
75.7\end{array}$ \\
\hline
\end{tabular}

It will be seen from the above that the northern belt of the State produced the best beets, both in content of sugar and purity, and in this respect the data obtained by the Department corroborate in every particular those secured by the Ohio Experiment Station mentioned below. It is evident, from a consideration of the two sets of datib, that the northern portion of Ohio offers favorable inducements, both for the culture of the beet from an agricultural point of view aud by reason of cheapness of fuel and the facilities of transportation from the manufacturing point of view. It is evident, however, that the central and southern parts of the State, as is the ease with Indiaua and Illinois, should not be exploited with the purpose of investing money in the beet-sugar industry until the available localities in the northeru regions are entirely occupied.

With the cooperation of the Department of Agriculture, the agricultural experiment station of Ohio distributed a large quantity of seed to farmers in that State, and from the seed so distributed 607 samples of beets were forwarled to the station and analyzed. The results of the analyses by counties are given in the following table: 
EXPERIMENTS CONDUCTED BY TIE OIIO AGRICULTURAL EXPERIMENT STATION.

Summary of results of sugar-beet investigation for Ohio, $189 \%$.

\begin{tabular}{|c|c|c|c|c|c|c|c|c|c|}
\hline County. & 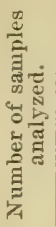 & 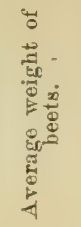 & 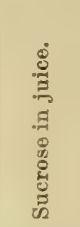 & 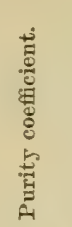 & County. & 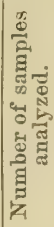 & 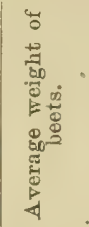 & 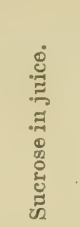 & 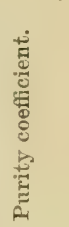 \\
\hline Ashland & 4 & $\begin{array}{r}\text { Grams. } \\
831\end{array}$ & Per et. & 76.0 & Marion. & 7 & $\underset{555}{\text { Grams. }}$ & Per ct. & 77.5 \\
\hline Ashtabul & 2 & 679 & 14.9 & 82.8 & Medin & 6 & 947 & 13.9 & 76.2 \\
\hline Auglaize.. & 9 & 1,128 & 14. 4 & 77. 0 & Mercer & 11 & 1,119 & 13.2 & 77. \\
\hline Belmont & 1 & 660 & 16. 6 & 86.9 & Miami.. & 12 & 773 & 12.6 & 75. \\
\hline Cluampaig & 1 & 825 & 13. & 77.6 & Montgon & 3 & 755 & 11.8 & 73. \\
\hline Clark. & 11 & 610 & 14.1 & 78.7 & Muskin & 5 & 566 & 14.4 & 78 \\
\hline Columbian & 1 & 610 & 18. & 83 & Ott & 13 & 694 & 15. & 78 \\
\hline Coshocton .. & 4 & 860 & 12.9 & 72.9 & Paulding & 9 & 802 & 15.6 & 80 \\
\hline Crawfo & 7 & 1,095 & 13.8 & 77.1 & Perry. & 1 & 127 & 19.1 & 80. \\
\hline Cuyalog: & 4 & 894 & 12. & 75.5 & Pickawa & 1 & 710 & 16 & 81. \\
\hline Dai & 44 & 864 & 13. & 76 & Pike & 1 & 595 & 14 & 77 \\
\hline Defianc & 23 & 851 & 13. & 77.9 & Por & 2 & 1,554 & 9. & $a 69$. \\
\hline Delaware & 4 & 559 & 14. & 79. & Put & 19 & 958 & 13. & 76. \\
\hline & 1 & 1,406 & 15. & 80. & Richland... & 9 & 496 & & \\
\hline Fairfield & 5 & 599 & 12. & 74. & Ross ... & 31 & 697 & 13 & 76. \\
\hline $\mathrm{Fa}$ & 2 & 620 & 14. & 7 & & 3 & 812 & & 79 \\
\hline Franklin & 5 & 524 & 15. & 80. & 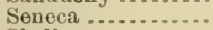 & 10 & 762 & 14 & 77. \\
\hline Fulton. & 24 & 1,065 & 14. & 79 & $\cdots$ & 8 & 607 & & 80. \\
\hline$x_{-1}+2$ & 6 & 694 & 16. & 84. & $\mathrm{~S}$ & 8 & 712 & & \\
\hline & 11 & 1,285 & 9. & 66. & nit & 28 & 684 & 14 & 80 \\
\hline $\mathrm{Ha}$ & 4 & 796 & 12. & 74. & I & 4 & & & 79 \\
\hline Hen & 33 & 810 & 15.3 & 80.9 & Unis & 2 & $\mathbf{1}, 077$ & 15. & 80 \\
\hline liand ... & 1 & 810 & 13.2 & 68 & Van Wert.......... & 21 & 1,064 & & 73. \\
\hline ing .... & 1 & 1,521 & 7.2 & a59.0 & 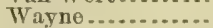 & 97 & 787 & & 80 \\
\hline Ho & 6 & 680 & 13. & 81.0 & ams. & 3 & 979 & 16 & 80 \\
\hline Hnron ...... & 1 & 303 & 16 & & & 26 & 777 & & 78 \\
\hline Knox. & 4 & 642 & 15. 9 & 81.9 & Wyandot......... & 1 & 605 & 15.1 & 79.8 \\
\hline e................ & 5 & 789 & 14.9 & 82.7 & & & & & \\
\hline Licking ........ & 11 & 562 & 11.9 & 74.9 & Souther & 69 & 892 & 12 & 75. \\
\hline $1 \ldots . .$. & 2 & 779 & 12.8 & 80.0 & M & 146 & 92 & & 78 \\
\hline Lorain .......... & 1 & 520 & 16.0 & 81.2 & Northern section.. & 392 & 834 & 14.3 & 79.4 \\
\hline $\begin{array}{l}\text { Lucas .............. } \\
\text { Madison........ }\end{array}$ & $\begin{array}{r}32 \\
5\end{array}$ & $\begin{array}{l}889 \\
711\end{array}$ & $\begin{array}{l}14.3 \\
14.3\end{array}$ & $\begin{array}{l}78.5 \\
76.8\end{array}$ & Entire State. & $b 607$ & 867 & 14.0 & 78.7 \\
\hline & & & & & & & & & \\
\hline
\end{tabular}

$a$ Not included in average of State.

$b$ Some samples were received without name and adiress of grower.

It will be observer from the above table that the number of samples analyzed was 607. Only 554, however, of these samples figure in the averages for the State, the others having been rejected for computing purposes by reason of certain abnormalties which they presented. The Ohio results are exceedingly encouraging from every point of view, with the exception of purity alone. The average weight of the beets was 867 grams, equivalent to 30.6 ounces. The average per cent of sugar in the expresser juices was 14 per cent, equivalent to 13.3 per cent in the beet, and the average coefficient of purity of the juices was 78.7. The most iuteresting grouping of the samples is shown at the end of the table, particularly so because in the State of Ohio the most favorable theoretical thermal conditious prevail only in the northeru counties. The grouping of the total number of samples into three portious, representing the northern, central, and southern sections of the State, shows in a convincing manner the effect of thermal conditions on the sugar content of the beet. The northern counties furnished 392 samples, with an average weight of 834 grams, equivalent to 29.4 ounces, with 
an average percentage of 14.3 per cent of sugar in the juice, equivalent to 13.6 per cent in the beet, with an average coefficient of purity of $79 . t$. The midlle section furnished 146 samples, with an average weight of 924 grams, equivalent to 32.6 ounces, with a mean content of sugar of 13.9 per cent in the juice, or 13.2 per cent in the beet, and a mean coeficient of purity of 78 . The southeru section furuished 69 samples, with an average weight of 892 grams, equivalent to 35 ounces, a mean percentage of 12.8 per cent of sugar in the juice, or 12.2 per cent in the beet, and a mean coefficient of purity of 75.3 .

It is seen by the above that there is marked improvement, both in the percentage of sugar and the purity of the juice, in the beets in Ohio as we advance from its southern to its northeru border.

The results of the work of the experiment station of Ohio have alrearly been published as Bulletin No. 90 of that station, and interesting details comnected with the above data can be found therein. The bulletin also contains interesting mans, showing isothermal lines and conditious of precipitation in the State. The remarks of the authors of the bulletin, namely, Mr. A. D. Selby and Mr. L. H. Bloninfield, on the general character of the results are interesting and are found below:

Taken as a whole, these analyses seem to indicate that beets of good quality may be grown in most counties of the middle and northern sections of Ohio, and, further, that many portions of the sonthern section may be adapted to sugar-beet growing, althongh on the whole less promising than more northerly districts. The analyses from Fasette, Pickaway, Ross, Pike, and Perry comties appenr encouraging. The sugar content in Ross County is deciciedly reassuring, though the purity is slightly below the standard. Judying by the samples, this might have heen greatly improved by more careful culturo and better selection of typical specimens. The unfavorable results in Greene and Montgomery counties are not taken to indicate what may really be done in these counties. For the southern section, and particularly the valley districts, further trials should be made. Close planting should be practiced on rich lands.

For the middle section, as a whole, good sugar beets may apparently be grown when growers have learned what to avoid in planting and culture. The low averages in samples from Mercer, Hardin, and Coshocton counties mily uot certainly be taken as conclusive evilence of conditions unfarorable to sugar-bect culture. Those reported from sandy soils in Mercer County show a fair purity. The results from Juluont, Muskingum, and Tusearawas comties point to better things in the eastern counties than previously anticipated. More brials in this region another sear aro certainly warranted by theso analyses.

As anticipated from previous trials, it is the northorn section which makes the most favorable showing as a whole. Samples were received from every county of the northern section except Trumbull, Mahoning, Hancock, and Allen. A sample was received from Columbiana County after the tables had bern completed. While the lake shore district shows to good advantage here, the counties sitnated along the summer isothermal of $70^{\circ} \mathrm{F}$. are lout slightly, if at all, inferior, though represented by a much larger number of samples. Ottawa County gives a low purity with a high sugar content, 15.7 per eent. It will be noterl that a large number of samples is not conducive to extremely high averages in the tables.

In fact, practically all the counties of the state show a rather high sugar content, 14 per cent in juice when all are averaged, and it is to the coeflicient of apparent purity that wo must direct on attention to discover differences. Under all the circumstances an average purity of 78 and above may bo taken as fairly satisfactory for the present year's analyses. 
It is to be borne in mind, when these results are considered, that the percentages were obtained for the most part in comparatively fresh samples, from which only the leaves had been removed. Topping the beets, as for factory use, was not encouraged, owing to the risk of water loss by evaporation. This has led, possibly, to lower percentages than where beets were topped and sent considerable distances by mail. While the actual sugar content would be but slightly, if at all, reducerl by loss of water, the apparent sucrose per cent would be changed.

\section{OKLAHOMA.}

Only one sample of beets was received at the laboratory of the Department of Agriculture from Oklahoma. The average weight of the beets composing the sample was 10 ounces, the mean percentage of sugar in the beets 11.8, and the coefficient of purity, 72.5. The director of the agricultural experiment station has submitted the fol. lowing report of the amalyses of 21 samples, showing a mean percent. age of sugar in the juice of 12 , and in the beet of 11.4 , and a mean coefficient of purity of 65.3. The mean coefficient of purity as obtained at the experiment station of Oklahoma is phenomenally low. These data, taken in connection with the climatic conditions which prevail in that Territory, are sufficient to indicate that there is no prospect of establishing a beet-sugar industry in Oklahoma.

\section{RESULTS OF EXPERIMENTS IN OKLAHOMA.}

Seed and culture directions were sent to farmers in each county, and the urmber of requests for seed quickly exhausted the available supply. But twenty-four reports were received fud twenty-one authentic samples examined. Of the three total failures reported, one is stated as due to flood, another to drought, and the third to hail. The yield, judging from the vague and indefinite reports which I have been able to secure, varied greatly. It seems that in many cases the seed was sown too far apart in the drills and that but little regard was paid the culturedirections sent out. In general, a poor stand was secured, and the majority of those reporting are not ertlusiastic as to the prospects of the sugar-beet industry in Oklahoma.

I inclose a tabular statement of the results of analyses of beets. The low coefficient of purity of the juice is especially noticeable.

Analyses of sugar beets grown in Oklahoma Territory, $189 \%$.

\begin{tabular}{|c|c|c|c|c|c|}
\hline County. & $\begin{array}{c}\text { Sugar in } \\
\text { juice. }\end{array}$ & $\begin{array}{l}\text { Coeffi- } \\
\text { cient of } \\
\text { purity. }\end{array}$ & County. & $\begin{array}{l}\text { Sugar in } \\
\text { juice. }\end{array}$ & $\begin{array}{l}\text { Coeffi- } \\
\text { cient of } \\
\text { purity. }\end{array}$ \\
\hline Canadian ................... & \multicolumn{2}{|l|}{ Per cent. } & Logan ............... & \multicolumn{2}{|l|}{ I'er cent. } \\
\hline Do $=\ldots$ & 13.0 & 66.3 & 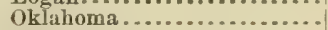 & 14.0 & 78.6 \\
\hline Do & 10.1 & 62.7 & Pawnee...................... & 12.2 & 68.5 \\
\hline 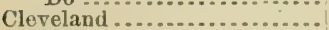 & 13.0 & 74.3 & 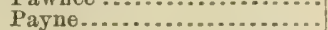 & 17.7 & 72.5 \\
\hline Custer.................... & 13.9 & 68. 1 & Do & 11.9 & 54.3 \\
\hline Gartield & 12.6 & 67.3 & Do $\ldots . . . . . . . . . . . .$. & 11.8 & 64.3 \\
\hline 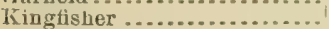 & 14.9 & 66. 2 & Do $\ldots . . . . . . . . . . . . .$. & 11.8 & 63.1 \\
\hline 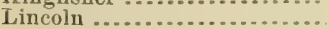 & 10.8 & 73. 0 & Do & 8.4 & 52.1 \\
\hline 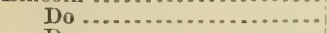 & 10.8 & 57.7 & 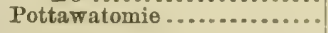 & 12.8 & 61.2 \\
\hline Do $\ldots \ldots \ldots \ldots \ldots \ldots \ldots \ldots \ldots$ & $\begin{array}{l}13.9 \\
10.1\end{array}$ & 81.8 & Averag & 12.0 & C5.3 \\
\hline 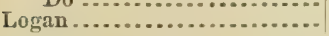 & 9.6 & 68.6 & & & \\
\hline
\end{tabular}

OREGON.

No samples of beets were recoived at the Department from the State of Oregon during the season. Previous analyses of beets received from that State have shown uniformly a high content of sugar and a 
high coefficient of purity. The agricultural experiment station of Oregon for several years has devoted a great deal of time and attention to the study of the sugar-beet industry in that State and published valuable reports on the subject. Mr. G. W. Shaw has prepared a résumé of the work of the station and of the Department, which contains the summaries of the work done, with various comments on the data obtained. This report is given below.

\section{RESULTS OF FXPERIMENTS IN OREGON.}

In his notes on the analyses of heets for the season of $1891, \mathrm{Dr} . \mathrm{H}$. W. Wiley, chemist of the United States Department of Agriculture, said: "The samples from Oregon are uniformly rich in quality, and if they truly represent the capabilities of the State there is certainly a bright future for the sugar-beet industry on that portion of the Pacific coast." This was said relative to a series of 33 analyses made at the United States Department of Agriculture, which gave the following average results: woight, 614 grams; sugar in the juice, $\mathbf{1 4 . 5}$ per cent; purity, 82.2.

It was to obtain a decided answer to the question, "Does Oregon possess the requisite conditions for the manufacture of sugar from beets?" that the writer, as chemist of the Oregon Experiment Station, began a series of experiments with beets in 1891, which were contiuued in 1892 and again in 1897 . The results of these investigations are here l,riefly set forth, more detailed account of which may he had by applying to the station for Bulletin No. 44.

The sugar beet does not differ from other plants in requiring certain conditions of climate and soil to give farorable results. In foreign countries both of these questions have been pretty satisfactorily settled, but in some parts of the United States the plant seems to thrive under very different conditions than obtain in foreign countries. Notably is this true concerning the rainfall, as is illnstrated in the case of California and Utah, as well as in the experimental culture in Oregon, as will appear later; hence foreign countries can not be taken as representing the only conditions under which the root will thrive. However, it does there thrive and these conditions can by no meaus be ignored. It also thrives, and that splendidly, in our own California, heuce her conditions can not be disregarded in a consideration of this question. Let us oxamine Oregon's condition of elimate and soil that, if possible, we may obtain some a priori ideas on these lines.

The season for the growth of beets may be divided into three periods-that of germinating, that of plant formation, and that of sugar storing. The following is a comparative table showing the temperature averages for Germany and certain parts of Oregon during these periods:

Average temperature for periods of growth.

\begin{tabular}{|c|c|c|c|c|}
\hline \multirow[b]{2}{*}{ Periol of growth. } & \multicolumn{4}{|c|}{$\Delta$ verago temperature. } \\
\hline & Foreign. & $\begin{array}{l}\text { Eastern } \\
\text { Oregon. }\end{array}$ & $\begin{array}{l}\text { Willam } \\
\text { ette } \\
\text { valley. }\end{array}$ & $\begin{array}{l}\text { Southern } \\
\text { Oregon. }\end{array}$ \\
\hline $\begin{array}{l}\text { First } \\
\text { Second } \\
\text { Third }{ }_{1}{ }_{n}\end{array}$ & $\begin{array}{l}49.1 \\
63.3 \\
56.3\end{array}$ & $\begin{array}{l}56.0 \\
65.0 \\
64.5\end{array}$ & $\begin{array}{l}52.5 \\
64.4 \\
63.3\end{array}$ & $\begin{array}{l}53.3 \\
64.5 \\
54.8\end{array}$ \\
\hline
\end{tabular}

Taking as a basis Dr. Mc Jurtrie's mean isotherm for sugar-beet culture at $70^{\circ}$ for June, July, and August, Dr. Wiley, in his report upon boet culture, gives a map of the United States, showing 100 miles on each side of this isothern, within which area favorable results may be looked for. 
It is in the rainfall of the State that we find the greatest seeming deviation from those portions of the world which are taken as typical beet-producing regions. This seeming difference should not be considered as a too serious drawback, nor would it appear so to those acquainted with all the conditions. The average amount of rainfall does not differ much from that of the beet-growing regions of other countries, yet it is not so evenly distributed. It must be borne in mind, however, that the soils of Oregon are much different with respert to their retentiveness of moisture, and that for all our crops the necessary moisture nearly all falls during the "wet season," and for this reason we do not usually consider the monthly rainfall as bearing so elose relation to the crops as it does in most other States, but rather are wont to consider the seasonal precipitation as the moro important factor. In this respect ours is similar to the condition which obtains in our sister State, Califoruia, in which the beet industry has reached a high state of development.

Champion and Pellet consider phosphoric acid as an indispensable base for the formation of sugar in the beet. They classify the order in which the plant food is indispensable as follows: (1) Phosphoric acid, (2) lime, (3) nitrogen, (4) potash.

It is foreign to our purpose to discuss, at this time, the soils of Oregon to any length, but in connection with the last statement I desiro to direct attention to the fact that the soils of Oregon are well-yes, aluudantly-supplied with phosphoric acid; that they surpass those of France in lime and equal them in potash. Below are contrasted aualy'ses of some of the Freuch sugar-bect soils with those of the uatural dirisions of this State and those of California. These results, I think, speak for themselves, and need no further comment.

Average comparative composition of soils.

\begin{tabular}{|c|c|c|c|c|c|c|}
\hline \multirow{2}{*}{ Analysis of fine earth. } & \multicolumn{2}{|c|}{ France. } & \multicolumn{3}{|c|}{ Oregon. } & \multirow{2}{*}{$\begin{array}{l}\text { Califor. } \\
\text { nia. }\end{array}$} \\
\hline & Sornme. & Nord. & Eastern. & $\begin{array}{l}\text { Willamette } \\
\text { Valley. }\end{array}$ & Southern. & \\
\hline 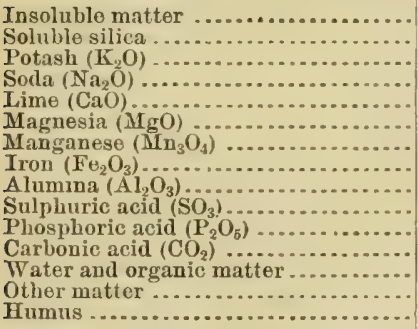 & $\begin{array}{r}81.80 \\
.06 \\
.09 \\
.51 \\
\ldots \ldots . . . \\
2.88 \\
7.24 \\
.09 \\
.40 \\
5.60 \\
1.85 \\
\ldots \ldots \ldots\end{array}$ & 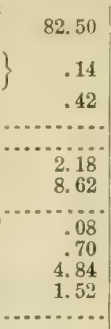 & $\left\{\begin{array}{r}66.59 \\
13.12 \\
.43 \\
.22 \\
1.22 \\
.75 \\
.10 \\
10.69 \\
.04 \\
.14 \\
6.21 \\
\ldots \ldots\end{array}\right.$ & $\begin{array}{r}65.18 \\
5.02 \\
.23 \\
.18 \\
.83 \\
.79 \\
.08 \\
16.45 \\
.03 \\
.21 \\
10.77 \\
1.63\end{array}$ & $\begin{array}{r}62.45 \\
8.74 \\
.34 \\
.21 \\
2.22 \\
.80 \\
.25 \\
15.35 \\
.01 \\
.13 \\
\ldots .52 \\
\ldots \ldots \\
2.25\end{array}$ & $\begin{array}{r}67.88 \\
8.96 \\
.61 \\
.28 \\
1.08 \\
1.49 \\
.06 \\
15.02 \\
.05 \\
.08 \\
\ldots . .0 \\
4.40 \\
\ldots .75\end{array}$ \\
\hline
\end{tabular}

Measured, then, by the foreign conditions as to temperature and the California conditions as to rainfall, and with a soil amply supplied with all the elements necessary to produce abundant crops, Oregon would certainly seem fuvored with all the requisites for success in beet culture.

The analyses made at the station during the season of 1891-92 may be summarized as follows:

County averages for 1891.

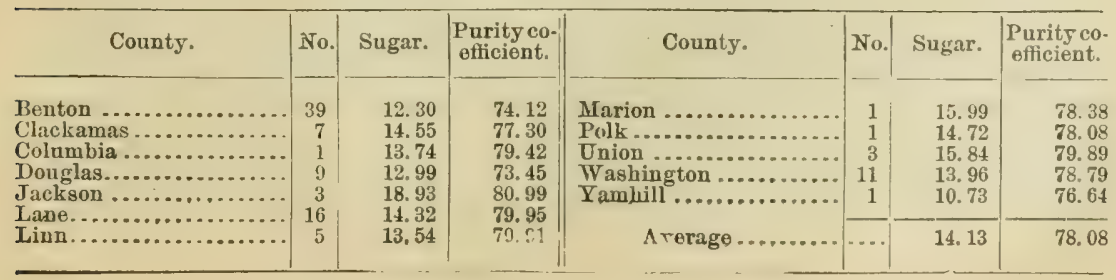


An examination of the results reveals that the analyses had a wide range, viz: From 6.77 yer cent to 22.44 per cent sugar in the juice. Of the 95 analyses made, 8 fell below 10 per cent; 76 showed over 12 per cent, and 37 over 14 per cent sugar. An arerage of 81 analyses for the Willamette Valley shows $\mathbf{1 3 . 7 6}$ per cent sugar and a purity coeflicient of 77.89 ; the average beet weighing a little over $1 \frac{1}{4}$ pounds, while an average of 10 analyses of beets from sonthern Oregon showed 13.38 per cent sugar with a little larger beet. But this does not really show the capabilities of this section of the State, as will appear later, for there were quite a number of immature beets included in this average.

lixperiments of 1892.-For the investigations of 1892 the following varieties were used, Inesprez's Early Rose, Vilmoriu's Improved, Kleinwanzlebener, and White Imprerial, all of which are favorito kinds, the first being much userl in California. Unfortunately the seed was delayed in reaching us, so it could not be distributed to the farmers as early as it should have been to secure the best results. Had the seed reached us in due time, it could have been put into the ground in April, for at that timo there was farorable weather for seeding, but by the time the seed had been distribnted cold weather set in and continued till May, after which the weather becane very dry, rendering the conditions for a fair trial very unfavorable.

The rainfall for the season was below the normal and reports all read "very dry," "extraordinarily $d x y$," "weather very unfavorable." In fact, nearly all the beets in the eastorn portion of the State failed to mature, and in many instances the seed failed to germinate. So far as the season's climate is concerned, then, the experiments were greatly landicapped and we were "in pursuit of knowledge under difficnlties."

The cultivation for this season was the same as for the previous year, except that the rows were placed 20 inches apart.

Owing to the disturbed condition of the experiment, the results are doubtless poorer than would have been the case had the season been one of more nearly normal conditions. Still, the results confirm the conclusions of the previous year, that Oregon possesses the conditions necessary for the production of excellent beets for the purpose of beet-sugar manufacture.

Expressed by counties the averages are as follows:

Averages for 1892 by counties.

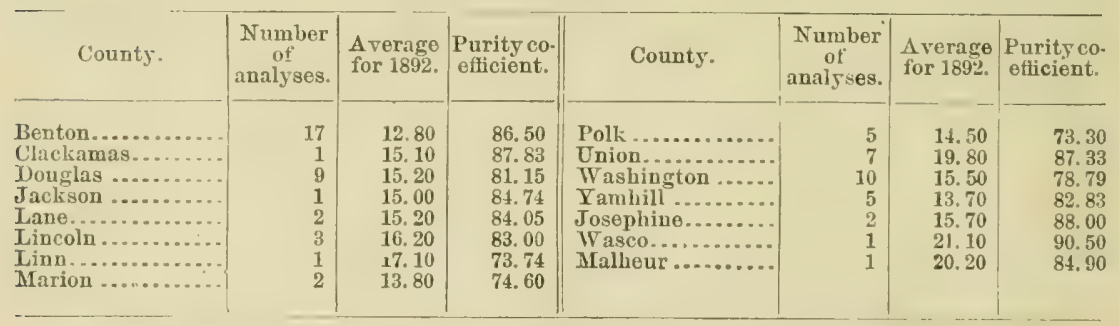

The arerage of all analyses for the State was 15.7 per cent sugar in the juice, with a purits coefticient of 78.08 , against 13.75 per cent and a purity of 77.57 for the previous season. Out of the 65 analyses made, only 11 indicated less than 12 per cent sugar in the juice, and 41 samples indicated over 14 per cent, the oxtremes being 9.4 per cent and 23.8 per cent. The average for the different natural divisions of the State were as follows:

Willamette Valley, 44 samples.................................. 14.7 Eastern Oregon, 11 samples .......................................... 19.2 Southern Oregon, 10 samples......................................... 15.1 
While from 189 ; to 1897 no definitely ontlined experiments have been conducterl, get the station has furnished more or less seed to various parties who have sint the beets to be analyzed. In other eases beet seed has been furnished by other parties, and analyses have been made in all cases when beets were forwarderl to the station. The average of the results of 23 analjses made since 1892 shows 15.05 per cent sugar in the juice and a purity coefficient of 89.8 .

Average of all results. - Let us now collect the results to 1897 which have been thus separately set forth. In the same table $\mathrm{I}$ beg to include the averages from analyses made at Washington, D. C., by the United States Department of $\Lambda$ griculture. These last-mentioned results really indicate a little too high, probably ahout 10 per cent, on account of the time that necessarily elapsed between harvesting and analyzing, which would result in a loss of water.

Expressed by counties the averages are as follows:

Average of all analyses for each county.

\begin{tabular}{|c|c|c|c|c|c|c|}
\hline Counts. & $\begin{array}{l}\text { Number } \\
\text { ot mal- } \\
\text { yses. }\end{array}$ & \begin{tabular}{|} 
Average \\
of analyses \\
made at \\
station.
\end{tabular} & $\begin{array}{c}\text { Purity } \\
\text { coefliciont. }\end{array}$ & $\begin{array}{l}\text { Number } \\
\text { of anal- } \\
\text { Jses. }\end{array}$ & \begin{tabular}{|} 
A Trerage \\
for United \\
States De- \\
partment \\
of A gricul. \\
ture.
\end{tabular} & $\begin{array}{l}\text { Purity co. } \\
\text { ofticient. }\end{array}$ \\
\hline 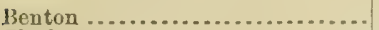 & 42 & 12.57 & 79.63 & 5 & 14.34 & 82.8 \\
\hline Clackamas.................... & 8 & 15.62 & 78. 76 & 3 & 15.36 & 84.2 \\
\hline Columbia ......................... & 1 & 13. 74 & 79.42 & 3 & 15.30 & 81. 7 \\
\hline 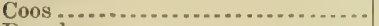 & 0 & $\ldots \ldots$. & |............. & 5 & 14.56 & 82.6 \\
\hline 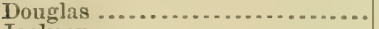 & 18 & 14.10 & 77.98 & 1 & 17. 74 & 84.3 \\
\hline Jackson ......................... . . & 4 & 17.93 & 81.00 & 1 & 18. 94 & 83.9 \\
\hline Lane & 18 & 14.42 & 80.19 & 6 & 14.24 & 85.4 \\
\hline Lincoln ${ }^{1} \ldots \ldots \ldots \ldots \ldots \ldots \ldots . . . . . . . . .$. & & $\because \because 3$. & 73 & & & \\
\hline 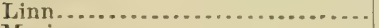 & 6 & 14.13 & 73.43 & 1 & 14.15 & 79.4 \\
\hline 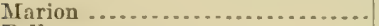 & 4 & 15.17 & 74.60 & 2 & 14.15 & 81.1 \\
\hline 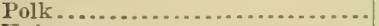 & 16 & 14.54 & 74.10 & 1 & 12.10 & 79.8 \\
\hline 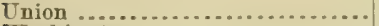 & 30 & 18.61 & 85.10 & 2 & 14. 35 & 81.8 \\
\hline Trashington ...................... & 2 & 15.29 & 80.98 & 3 & 12.49 & 80.7 \\
\hline 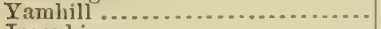 & 7 & 12.87 & 82.76 & 0 & ............... & ........... \\
\hline 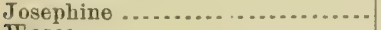 & 2 & 15. 70 & 81.21 & 0 & $\mid$ & (............ \\
\hline 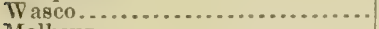 & 1 & 21.10 & 90.50 & 0 & ............. & ............ \\
\hline 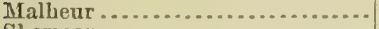 & 1 & 20.20 & 83.44 & 0 & $m-\ldots-1$ & 1............. \\
\hline 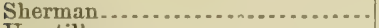 & 0 & ....... & ....... & 1 & 13.55 & 72.2 \\
\hline 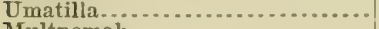 & 0 & & $\because 30$. & 1 & 15.12 & 80.9 \\
\hline 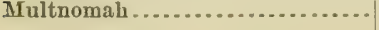 & 1 & 16.90 & 76.80 & - - & $\ldots$. & $\cdots$ \\
\hline
\end{tabular}

1 Areraged with Benton County.

If we omit from the average those beets which were inmature or overgrown, the averages for the State will be:

\begin{tabular}{|c|c|c|}
\hline & Sugar. & $\begin{array}{l}\text { Purityeo- } \\
\text { eflieient. }\end{array}$ \\
\hline $\begin{array}{l}\text { Season of } 1891 \\
\text { Season of } 1892 \ldots \ldots \ldots \\
\text { Since } 1892 \ldots \ldots \ldots\end{array}$ & $\begin{array}{l}14.3 \\
15.9 \\
15.0\end{array}$ & $\begin{array}{l}\text { 78. } 2 \\
81.4 \\
84.8\end{array}$ \\
\hline 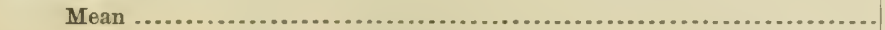 & 15.0 & 81.5 \\
\hline
\end{tabular}

During the season just ended, 1897-98, the experiments were continued, but were limited for the most part to those portions of the State which seemerl to offer not only the best couditions for growing beets, but also presented other favorable economic couditions, for unless the requisites for the manufacture of sugar can be had as well as the beets, it is useless to expend labor in an attempt to show that we can grow good beets. In these experiments the conditions were not particularly favorable-indeed, were adverse, inasmuch as the ground was entirely prepared in 
the spring and the seed was late. The results obtained in the localities selected are given below:

\begin{tabular}{|c|c|c|c|}
\hline County. & Weight. & Sugar. & $\begin{array}{l}\text { Purity co- } \\
\text { efficient. }\end{array}$ \\
\hline 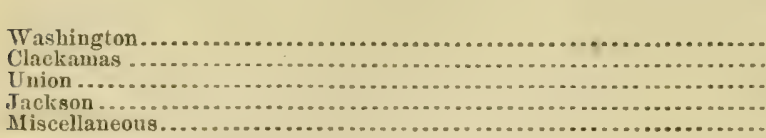 & \begin{tabular}{|r|} 
Grams. \\
395 \\
508 \\
477 \\
437 \\
512
\end{tabular} & $\begin{array}{r}\text { Per cent. } \\
15.2 \\
13.8 \\
17.5 \\
15.6 \\
14.1\end{array}$ & \begin{tabular}{|r} 
Per cent. \\
$8 \overline{5.9}$ \\
83.4 \\
88.4 \\
81.0 \\
85.8
\end{tabular} \\
\hline
\end{tabular}

Pennsylvania.

Fifty-nine samples of beets grown in Pennsylvania were received at the Department of Agrienlture laboratory for analysis. The mean weight of the beets in the samples was 18 ounces, the mean content of sugar in the beet 13.8 per cent, and the mean coefficient of purity, 79.5. The size and sugar content of the samples received from the whole State were satisfactory, but the coefficient of purity falls a little below the minimum standard.

The samples received may be divided, for the purposes of study, into two sets, namely, those from counties lying in and north and west of the favorable thermal belt, and second, the counties lying south and east of that belt. Collected by counties, the samples divided according to the above classification show the following data:

Counties of Pennsylvania above and below isothermal line $70^{\circ}$.

\begin{tabular}{|c|c|c|c|c|}
\hline County. & $\begin{array}{c}\text { Number } \\
\text { of } \\
\text { samples. }\end{array}$ & $\begin{array}{l}\text { Average } \\
\text { weight. }\end{array}$ & $\begin{array}{c}\text { Sugar in } \\
\text { the } \\
\text { beets. }\end{array}$ & $\begin{array}{l}\text { Coeffi. } \\
\text { cient of } \\
\text { purity. }\end{array}$ \\
\hline Above $70^{\circ}$. & & Ounces. & Percent. & \\
\hline Allegheny................... & 13 & & 13.8 & 77.0 \\
\hline Craw ford & 3 & 25 & 13.9 & 75.3 \\
\hline 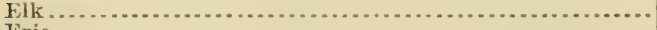 & 2 & 16 & 13.0 & 77.4 \\
\hline ( & 7 & 28 & 15.8 & 82.5 \\
\hline 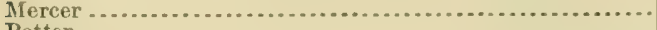 & 2 & 34 & 15.4 & 83.7 \\
\hline 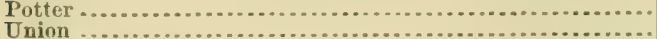 & 1 & $\begin{array}{l}18 \\
10\end{array}$ & $\begin{array}{l}18.0 \\
19.6\end{array}$ & 81.1 \\
\hline Lawrence.................. & 2 & 16 & 16.8 & 79.9 \\
\hline Averages, ete.... & 31 & 21 & 14.8 & 78.9 \\
\hline Belowo $70^{\circ}$. & & & & \\
\hline Cumberland .... & 22 & 12 & 12. 2 & 79.6 \\
\hline Lebanon ............. & 1 & 24 & 14.4 & 79.0 \\
\hline (n) & $\begin{array}{l}2 \\
3\end{array}$ & $\begin{array}{l}31 \\
25\end{array}$ & $\begin{array}{l}15.7 \\
13.9\end{array}$ & $\begin{array}{l}82.2 \\
80.2\end{array}$ \\
\hline A verages, etc... & 28 & 15 & 12.7 & 79.8 \\
\hline
\end{tabular}

It will be seen that the 31 samples coming from the counties lying in and to the north and west of the favorable thermal belt have an average weight of 21 ounces, a mean content of sugar in the beet of 14.8 per cent, and a mean coefticient of purity of 78.9. The 28 samples coming from counties lying south and east of the favorable thermal belt have a mean weight of 15 ounces, a sugar content in the beet of 12.7 
per cent, and a mean purity of 79.8. With the exception of the coefficient of purity, the influence of the more favorable thermal conditions is easily distinguished.

Of the counties in Pennsylvania furnishing the most data may be mentioned Allegheny, with 13 samples, having an average weight of 18 ounces, a mean content of sugar in the beet of 13.8 per cent, and a mean purity of 77. Cumberland County, in the southern part of the State, sent 22 simples, having a mean weight of 12 ounces, a mean content of sugar in the beet of 12 per cent, and a mean purity of 79.6 . Erie County sent 7 samples, having a mean weight of 28 ounces, a mean content of sugar in the beet of 15.8 per cent, and a mean purity of 82.5. The samples from Erie County are decidedly the most favorable, and this is to be expected, since Erie County has conditions of soil and climate which are entirely analogous to those pervading the New York area from Albany to Buffalo.

Attention has been called before to the mountainous character of a large part of the State of Pennsylvania, even where favorable thermal conditions prevail. It is evident, however, that in the northern and western portions of the State, where suitable soil can be found, the culture of the sugar beet may be introduced under the most favorable conditions, and with every prospect of success.

HXPERIMENTS CONDUCTED BY THE AGRICULTURAL EXPEIRMENT STATION.

The agricultural experiment station of Pennsylvania cooperated with the Department of Agriculture in the investigation of the beet-sugar work, and has published the results of its work in Bulletin No. 40 of that station. For details of the analytical werk and of the observations made by the director of the station the reader is referred to the bulletin mentioned. In discussing the aualyses Director Armsby says:

Of the 69 samples reported upon in the above table, 55 (or 80 per cent) showed over 12 per cent of sugar in the beet. Thirty-four samples (or 49 per cent) showed a coefficient of purity of over 80. Thirty-two out of the total number (or 46 per cent) showed over 12 per cent of sugar and also a purity coefficient of over 80 . In view of the fact that practically all of the beets were raised ly fitrmers who had harl no experience in the eulture of this plant for sugar, the results must be regarded as decidedly favorable so far as the quality of the beets is concerned.

In 40 cases out of the whole number we have data regarding the average weight of the beets. Of these 40 samplos, 14 (or 35 per cent) weighed between 0.80 and 1.35 pounds, 18 (or 45 per cent) were below 0.80 pound in weight, and 8 (or 20 per cent) were above 1.35 pounds. It thus appears that, as a rule, the size of the beets was rather small.

Thirty-four of the experimenters reported the yield of beets. In most cases the yield wascalculated from that of a comparatively small area, and in many eases there is evidence that the results may be considerably in error. Taking them as they stand, however, 10 (or 29 per cent) reported a yield of over 15 tons per acre, 2 (or 6 per cent) a yield of between 10 and 12 tons per acre, and 17 (or 50 per cont) a yield below 10 tons per acre. It thus appears that while, as stated abore, the general quality of the beets was good, the yield was rather small. 
As statel above, 32 of the samples showed moro than 12 per cent of sugar with $\approx$ purity coefficient of more than 80 . Of these 32 experimeuts, 7 (or 22 per cent) reported a yield of over 10 tons per acre, 4 (or 13 per cent) a yield of between 8 and 10 tous per acre, 7 (or 22 per cent) a yield of less than 8 tons per acre, while 1 t (or 14 per cent) did not report the yield. These figures confirm those given above in showing that the yield was, as a whole, rather small.

\section{RHODE ISLAND.}

Only 2 samples were received from Rhode Island, and no deductions of any value can be made from such limited data. The average weight of the beets composing the samples was 21 ounces, the mean percentage of sugar therein 11.9, and the mean purity 74.2 . These data of course are far from encouraging, but there are reasons for supposing that the climate of Rhode Island is favorable to the production of a much richer beet. The available area for cultivation in beets in Rhode Island is small, and it may not be worth while to prosecute the experimental work. Nevertheless, it is suggested that it might be profitable for the agricultural experiment station of Rhode Island to study the subject to a greater extent.

\section{Soutir Carolina.}

Thirteen samples were received at the Department of Agriculture from South Carolina. The mean weight of the samples was 17 onnces, the percentage of sugar in the beet 9.9, and the mean pruity 79.9 . These data, taken into consideration with the latitude and thermal conditions, indicate that there is no prospect of South Carolina becoming a sugar-producing State.

\section{S)Uth Dakota.}

Only 5 samples of heets grown in South Jakota were receivel at the I) partment for analysis. The mean weight of the beets composing these samples was 17 ounces, the mean content of sugar in the beet 15.1, and the mean purity coeficient 83.2. These data are favorable, but too meager for the basis of any definite conclusions.

EXPERIMENTS BY THE AGRICULTURAI, EXPERIMENT STATION OF SOUTI DAKOTA.

Extensire investigations in cooperation with the Department of A griculture were carried on by the South Dakota station during the past season. The whole number of samples analyzed at the South 1)aliota station was 337. For convenience of elassification they are wrouped according to the different regions in the State, aud by comuties in the regions as is shown in the following table: 
Averages by counties and regions.

[From report of Jas. H. Shepard, Chemist of Experiment Station.]

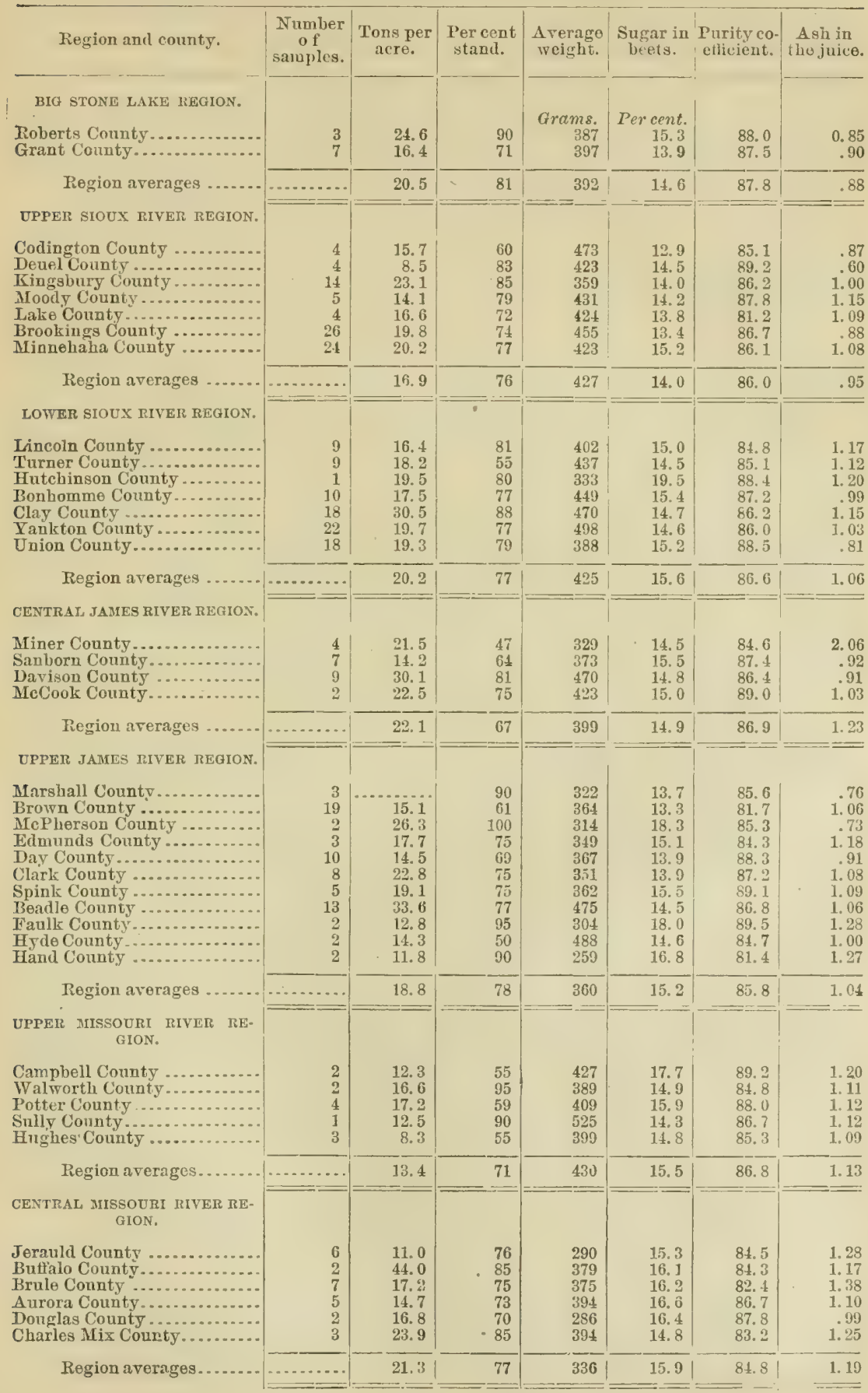


Averagcs by counties and regions-Continued.

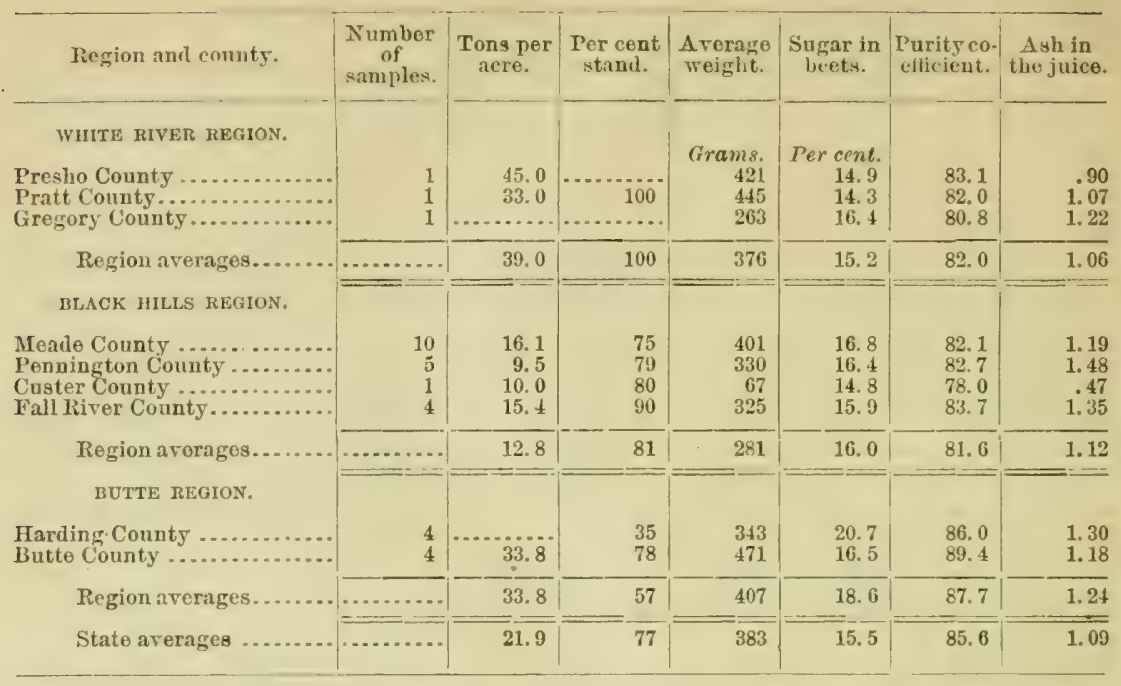

From an inspection of the above data it is seen that the results of the experiments conducted by the station are quite encouraging. The mean average weight of the beets analyzed was a little below the normal, 383 grams, equivalent to 13.5 ounces. The mean content of sugar in the beets was 15.5 per cent, and the mean purity coefficient 85.6 . The datit for yield per acre are probably unreliable, as many reports of tonnage are given which are evidently erroneous, as, for instance, in Presho County, where a yiels of 45 tons per acre is reported, and in Pratt County, 33 tons per acre, a quantity of beets which is not to be expected under the most favorable circumstances of growth. In so far as producing a crop of beets rich in sugar is eoncerned, the conditions in South Dakota seem to be extremely favorable. Attention, however, should be celled to former statements that the furmers of this State will have to contend with the great diffeulty of an early and sudden coming of winter. If, therefore, the industry should secure a hold, this will be the most important point in the agricultural part of the work to be considered, namely, the harvesting and preserving of the crop for manuficturing purposes. The high purity eoefficients which obtain in South Dakota are especially encouraging. There is no other State which has equaled South Dakota in the purity of the juices of the beets. There is abuudant reason found in the data published above to eneourage the agricultural experiment station of the State to continne its work of investigation, and to attract the favorable attention of intending investors.

TEXAS.

The northwestern portion of Texas reaches an altitude where the thermal conditions become more favorable to beet production. It is not to be expected that the southern and western portions of the State will ever bo seriously considered for this purpose. 
Eleven samples were received from Texas at the Jepartment of A griculture laboratory, having an average weight of 22 ounces, a mean content of sugar in the beets of 12.6 per cent, and a mean purity of 76.5 . All the comities represented were in the northern and western portions of the State except McLennan, which is in the center. There is reason to believe that on the high plateaus in the northwestern portion of the State, where irrigation is possible, the culture of the sugar bect miglit be introduced with considerable prospects of success.

A fer analyses were made by the agricultural experiment station of Texas, and these are given below:

REVIEW OF THE WOIK DONE BY THE AGRICULTURAL EXPEIIMIENT STATION OF TEXAS.

All of the seeds that wo received for distribution in this Stato during the past season came to band too late for proper planting in a State so far south as Texas. For this reason the dry season prevented a fair growth of tho beets at an important perion in their development, aud the crops waited for the fiall rains to develop sizo. These fall rains wer: accompanied hy a swall per rent of sunshine, resulting in a low sugar content. These conclusions are based upon the fact that where beets wore planted late and irrigated, the sugar content was higher than when samples were grown ly late fall rains and then sent us for analysis. Of course the extreme westeru portion of the State produced beets of high sugar content.

Results of experimcnts in Texas.

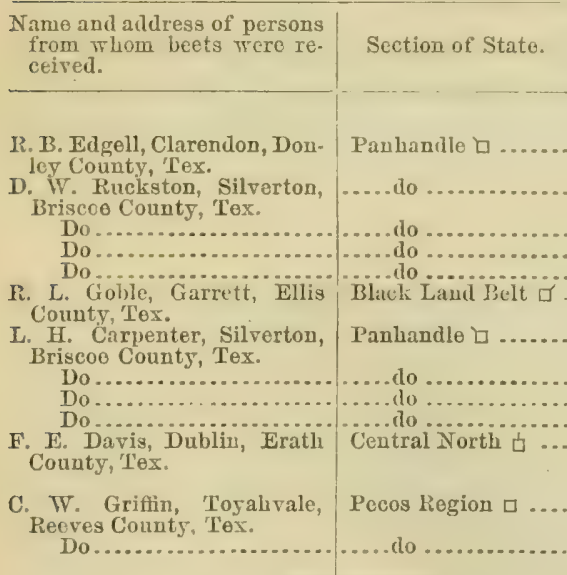

* 4 beets, 1 sample.

\begin{tabular}{|c|c|c|c|c|c|}
\hline $\begin{array}{c}\text { Labora. } \\
\text { tory } \\
\text { number. }\end{array}$ & Erix: & Sucrose. & $\begin{array}{l}\text { Purityco. } \\
\text { etlicieut. }\end{array}$ & \multicolumn{2}{|c|}{ Weinut. } \\
\hline 1 & 16.8 & 11.88 & 70.68 & $\begin{array}{c}L b s . \\
1\end{array}$ & $\begin{array}{c}\text { ozs. } \\
10\end{array}$ \\
\hline 1 & 15.5 & 9.69 & 62.5 & 2 & 4 \\
\hline $\begin{array}{r}2 \\
3 \\
4 \\
4\end{array}$ & $\begin{array}{l}17.0 \\
14.0 \\
13.2 \\
13.5\end{array}$ & $\begin{array}{r}11.02 \\
6.89 \\
7.98 \\
7.79\end{array}$ & $\begin{array}{l}64.82 \\
49.19 \\
60.91 \\
57.7\end{array}$ & $\begin{array}{l}2 \\
2 \\
3 \\
1\end{array}$ & $\begin{array}{r}6 \\
10 \\
11 \\
11\end{array}$ \\
\hline 1 & 15.2 & 6.27 & 41.8 & 1 & 5 \\
\hline $\begin{array}{r}2 \\
3 \\
4 \\
+1\end{array}$ & $\begin{array}{l}13.5 \\
11.0 \\
11.3 \\
12.55\end{array}$ & $\begin{array}{l}4.89 \\
5.04 \\
5.46 \\
7.07\end{array}$ & $\begin{array}{l}36.9 \\
45.7 \\
48.34 \\
56.01\end{array}$ & $\begin{array}{l}1 \\
2 \\
3 \\
2\end{array}$ & $\begin{array}{r}11 \\
6 \\
2 \\
11\end{array}$ \\
\hline$+\frac{1}{1}$ & $\begin{array}{l}16.5 \\
15.0\end{array}$ & $\begin{array}{l}9.69 \\
9.5\end{array}$ & $\begin{array}{l}58.7 \\
63.3\end{array}$ & $\begin{array}{l}1 \\
1\end{array}$ & $\begin{array}{l}7 \\
6\end{array}$ \\
\hline 2 & 21.1 & 15.68 & 71.5 & 1 & $8 \frac{1}{2}$ \\
\hline
\end{tabular}

r Red.

TenNesseE.

Seventeen samples of beets were received at the laboratory of the Department of Agriculture from Tennessee, of which eight were from the agricultural experiment station at Knoxville. The mean weight of the beets received was 11 ounces, the mean percentage of sugar 10.8, and the mean purity 71.9. The mountainous regions of Tennessee are probably favorably situated in regard to thermal couditions for the H. Doc. $396-8$ 
growing of beets, but the contour of the country will prevent any extensive planting of this erop. Hiddle and western Tennessee ane evi. dently too warm for successful beet culture.

\section{VIRGINIA.}

Thirty-four samples grown in the State of Virginia were received at the Department of $\Lambda$ grieulture for examination. The mean weight of the beets composing these samples was 21 ounces, the mean content of sugar in the beets 11.6 per cent, and the mean purity 76.2 .

Virginia lies almost entirely south of the region where thermal conditions are most favorable to beet culture. It is only in the seacoast counties, where the temperature is moderated by the sea breezes, and in the mountainous counties, where the altitude is great enough to lower the temperature, that good results can be expecter. A great deal of interest has been manifested in the State in regard to the building of factories, but it is evident that intending investor's as well as farmers should stop to consider the matter very seriously before investing their money and their labor in this enterprise.

A fer analyses received from Virginia show favorable results, as for instance, the sample from Carroll County, weighing 15 ounces, and containing 15.1 per cent of sugar in the beet. There is little in the data, however, to encourage the belief that Virginia is a favorable region for beet growing.

Investigations were also made by the agricultural experiment station of Virginia, but only to a very limited extent. The datia obtained on analysis, together with the observations of the official in charge of the investigations, are found in the following report:

\section{INVESTIGATIONS BY THE AGRICULTURAL EXPERIMENT STATION OF VIRGINIA.}

Before stating the results of the analyses made at this station I think it best to make some comments won the work attempterl this season. In the first place, it was quite late before we concluded to undertake the distribution of seeds and then by the time they reached us from the Department of Agri'nlture the seison was sa far arlvanced that a considerable number of persons to whon the seeds were distribnted failed to plant them. This, of course, disturbed the experiment to a considerable oxtent. Another disturling factor was the extreme drought which prevailed during tho latter part of the season over this stato in general, which resulted in many cases in practically destroying the crop. As a consequence, our results are not what we conld wish. After much correspondence with those to whom seerl was distrihutell, we concluded to analyze only samples representing fairly well the tide-water and limestone sections of the State. The results of these analyses follow:

Sample No. 1. From IV.J. Phillips, Accomac County, Va. Weight of whole beet, 372 grams. Per cent of sugar, 16.11.

Sample No. 2. From Henry Jones, Suffolk, Nansemond County, Va. Weight of whole beet, 1,325 grams. Per cent of sugar, 4.17 .

Sample No. 3. From L. T. Barnes, Boulevard, Now Kent County, Va. Weight of whole bect, 581 grams. Per cent of sugar, 14.64.

Sample No. 4. From T. A. Eller, Atkins, Smyth County, Va. Weight of whole beet, 760 grams, Per cent of sugar, 9.61. 
Sample No. 5. From experiment station. Weight of whole beet, 584 grams. Per cent of sugar, 13.63.

The first three samples represent the eastern section of the State aud tho last two the limestone section. We endeavored to secure sixteen samples covering more perfectly the geologic areas of the Stato, but from the causes abovo mentioned we failed to procure proper samples.

Dr. M[cBryte desires mo to say that if the Department wishes us to atid in the conduct of this work the coming year wo will be pleased to do so, and that the work will be talien in haud in proper season aud the growing experiments arranged on a much botter plan, so as to securo reliable samples from tho diflerent sections of the State.

Mxperiments in the growth of beets in Virginia during 1897 were also made by the State board of agriculture, and are described on page 206 of the annual report of the board for the year 1897. One hundred and eight samples were aualyzed during September and October. It is stated in this report that these samples varied in saccharine strength from 8.5 to 17.1 per cent; thirty-five of them were below 12 per cent, and seventy-three showed a sacharine value of from 12 to 17.1 per cent, with a coeffieient of purity of from 79 to 58.5 , or a saccharine average of 14.7 per cent, and an average purity coeficient of 85 , which is erpuivalent to 250 pounds of raw sugar per ton of beets.

The data obtained by the State board of agrieulture are more favorable than those secured by the Department of Agrieulture or by the experiment station at Blacksburg. It is hardly probable, however, that the map which accompanies the report of the State board of agriculture will be regarded as a final jndgment in regard to the localities in Virginia suitable to the growth of beets of the different qualities noted. A much larger series of oxperiment;, extending over a greater number of years, will be necessary to definitely determine that point.

\section{WASIINGTON.}

Thirty-four simples of beet. grown in the State of Washington were received at the Lepartment of Agriculture for analysis. The mean weight of the beets received was 27 ounces, the mean percentage of sugar 13.7, and the mean purity coefficient 80.7.

The agricultural experiment station of the State of Washington for many years has conducted careful studies in regard to the possibilities of producing sugar in that State. During the past year 60 samples of beets grown in Washington were analyzed at the laboratory of the agricultural experiment station. The mean weight of the beets analyzed was 23 ounces, the mean percentage of sugar in the beets 13.6, and the mean coefficient of purity 75.7. Of the whole number 6s per cent contained over 12 per cent of sugar, and 78 per cent weighed more than 16 ounces. The reports of the director and chemist of the station are given below. 
Summary of analyses of beets from Tashington.

[Compiled from report of experiment station.]

\begin{tabular}{|c|c|c|c|c|c|c|c|c|c|}
\hline County. & $\begin{array}{l}\text { Num- } \\
\text { ber of } \\
\text { sam- } \\
\text { ples. }\end{array}$ & $\left\{\begin{array}{l}\text { Net } \\
\text { weight } \\
\text { beets. }\end{array}\right.$ & $\begin{array}{l}\text { Sugar } \\
\text { in } \\
\text { beets. }\end{array}$ & $\begin{array}{l}\text { Coeffi- } \\
\text { eient } \\
\text { of } \\
\text { purity. }\end{array}$ & County. & $\begin{array}{l}\text { Num- } \\
\text { ber of } \\
\text { sam- } \\
\text { ples. }\end{array}$ & $\begin{array}{l}\text { Not } \\
\text { weight } \\
\text { beets. }\end{array}$ & $\begin{array}{l}\text { Sugar } \\
\text { in } \\
\text { beets. }\end{array}$ & $\begin{array}{l}\text { Coelfi- } \\
\text { cient } \\
\text { of } \\
\text { purity. }\end{array}$ \\
\hline 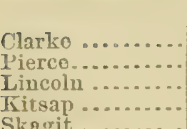 & $\begin{array}{r}1 \\
7 \\
20 \\
2 \\
8\end{array}$ & $\begin{array}{c}\text { Ounces. } \\
29 \\
25 \\
17 \\
22 \\
33\end{array}$ & $\begin{array}{r}\text { Per ct. } \\
14.3 \\
12.0 \\
15.8 \\
12.3 \\
12.5\end{array}$ & $\begin{array}{l}77.7 \\
73.7 \\
79.2 \\
70.9 \\
72.9\end{array}$ & $\begin{array}{l}\text { King ............ } \\
\text { Clallam ......... } \\
\text { Whitman ...... } \\
\text { Klickitat....... }\end{array}$ & $\begin{array}{r}10 \\
1 \\
2 \\
2\end{array}$ & \begin{tabular}{|r|} 
Ounces. \\
15 \\
$5 \pm$ \\
46 \\
26
\end{tabular} & $\begin{array}{r}\text { Perct. } \\
12.1 \\
14.3 \\
14.2 \\
12.4\end{array}$ & $\begin{array}{l}71.4 \\
77.4 \\
76.3 \\
7 \pm .5\end{array}$ \\
\hline $\begin{array}{l}\text { San Juan....... } \\
\text { WVhatcom ....... }\end{array}$ & $\begin{array}{l}4 \\
3\end{array}$ & $\begin{array}{l}27 \\
25\end{array}$ & $\begin{array}{l}13.5 \\
11.8\end{array}$ & $\begin{array}{l}75.6 \\
80.4\end{array}$ & Averages, otc. & 60 & 23 & 13.6 & 75.7 \\
\hline
\end{tabular}

RESULTS OF EXPERIMENTS IN WASHINGTON.

I have the honor to report as follows:

The appointment was made so late in the summer that it served only the purpose of providing for the freo transportation of beets to this point for analysis, consefueutly tho report must necessarily deal with facts of an earicr tate chiofly, if it is to be of any valne as au indication of the adaptalility of the soil and climate of the State of Washington to the culture of sugar beets. Permit me to say that we regarded our experimentation as practically complete before the hegimning of this jear. In consequence of this fact it had been announcerl early in tho scason that no distribution of seed would be made. At a later period some seed was obtained from the Department of Agriculture. The planting soason in Washington begins very early considering the latitude, and tho seed was received too late for general use. Seerl was, however, supplied to those requesting it, and in the main theso requests wero from localities not so well adapted to the culture of sugar beets, so that the results of this year's planting can in no way bo taken as representative.

The Tashington State Experiment Station began the investigation of this problem throngh its chemical department in the spring of 1894 , and conducteri it with the greatest thuroughuess through that and the two succeding seasons, making more than 3,000 analyses. Beets were raised in both small and large plats. The results wero so uniform as to demonstrate the peculiar alaptability of this region to the culture of sugar beets. These results are given in Bulletins 15 and 26 of the State experiment station. I submit herewith the report of Professor Fulmer, of the department of chemistry, relative to the results of this year. I might mention the fact that Professor Fulmer was for some time chemist of a beet-sugar factory in Nebraska, and is particularly well fitted for dealing with this subject. T'ho results thus far obtained in the State show a percentage of sugar of about 15, and a purity of nearly 81 .

Pullaman, Wasir., Jamuary 6, 1898.

Dran SIR: In compliance with your request I hand you herewith a tabulated statement of the aualyses marlo in the station laboratory of beets grown from soed inruisher by the United states lepartment of Agriculture. The data presented are far from boing complote. The rery important item of "variety of seel" is entirely omitted, hecanse in almost all cases the rariety indieated by the grower of the beets was not at all in harmony with tho characteristics oxhibited by the samples. For eximple, beets with pink skins were often marked "Kloinwanzlebener," which is a pure white variety. It is quite "lear to my mind that the lack of harmong between the character of the beets and the names they bore was due to the seed sont out lyg the Government being a mixed seed. 
Parties sending in beets for analysis failed in most cases to sund any data coneerning the time of planting, thinning, and harvesting; character of soil; amount of cultivation, ete. On account of this great lack of reliablo data, the meager results obtained are of little value.

I wish to direct your attention to the fact that this kind of experimental work with sugar beets in our State is at this time a useless expenditure of time and energy. During the past fonr years this station has male over 3,000 analyses of sugar bects grown in all parts of the State, and under all couditions of temperature and rainfall. The detuils of these analyses, and of the field experiments, have been published in full in Bulletins 15 and 26. The raising of high-grade beots in this State has been fully demonstrated to be a practical snecess, and we believe any further experimentation with small plats is wholly unnecessary.

The uniformly excellent results that wo have obtained in the past are in striking contrast to the very poor outcome of this year's test. We believe the low sugar content and purity exhibited by the beets this year is due to sereral causes:

(1) The seed from Washington was received altogether too late in the spring for distribution in time for early planting. In most sections of the State the seed shonld be planted not later than the middle of April.

(2) Nearly all of the samples were grown in sections of the State that have not heretoforo shown any special adaptability to sugar-beet culture.

(3) We believe tho seed was of poor quality. In support of this assertion I wish to call your attention to the samples that were raised at Croscent; in Lincoln County. Iferefofore this section has always produed high-grade beets. The samples sent in by William Adam, P. Carstens, and the first two of W. B. Warron wero grown from Government seed, and gave a very low sugar content and purity. The samples of Wollweber, and the last three of Warren, wore grown from seed raised at Crescent last year, and gave most excellent resuits. These facts and the vary general poor quality of samples leads mo to regard the seed furnished as an inferior quality.

The inclosed results do not do justice to our State, and I wish to protest against their publication as an index of the character of beets that can be raised here.

Yours, very respectfully,

Elton Fulmer,

Chemist Experiment Station.

Director F. A. BRYAN, Pullman, Tash.

In regard to the report of the chemist, attention should he called to the fact that he is evidently inistaken in regard to blue quality of the seed sent by the Department of Agriculture. This seed was, of course, not of the direct prouluction from high-grade mother beets, but was the ordinary commercial seed which was imported by the Oxuard Com. pany for distribution among their beet growers. It was the same seed which was sent to Michigan and to New York, which produced in those States the excellent results which have been recorted in previous portious of this report. In over 2,200 analyses of beets which were made in this laboratory during the past season, only about 25 samples were received which had a pink skin, and in most cases these were marked with different names. It is possible, however, that a few seeds of this kind may have been mixed in with the large lot of commercial seeds which were imported into this country. The Department of Agriculture neither purchased nor packed the seeds which were dis- 
tributed, so that the possible admixture of other varieties can not be positively denied.

With the exception of the excessive rainfall on some of the coast areas, it has been demonstrated that the State of Washington is well suited to the growth of beets of a high grade. An extended report on the possibilities of Oregon and Washington for beet production was made in Bulletin No. 5 of this Division, the investigations, which were published in 185, having been made in the antumn of 188t. A description of the topographical features and climate of western Washington is given on pages 103-104 of that bulletin. The conclusions which I derived from a study of the conditions at the time are given on page 105 in the following words:

"In view of the preceling description I am inclined to helieve that in Washington Territory and Oregon, soil and climate are very favorable to the growth of a sugar beet of high saccharine strength.

"The mildness of the winter is, though to a less elegreo than in California, favorahle to the season of manufacture. With a wise and careful encouragement of the industry I have no hesitation in saying that the prospects for the development of an indigenous sugar industry in the extremo northwestern part of our country are decidedly bright. It is a field worthy the attention both of experimenters aud capitalists."

Investigations which have been made subsequent to this period have abundantly verified the predictions given above. The chemist of the station, in the results of his work for 1897 , says that the data are not so fivorable as were obtained in preceding investigations, but, as he says, the beets analyzed eame from parts of the State less favorable to beet culture than did those samples which had previously been examined. The data obtained by analyses of beets received at the Department from Oregon are decidedly filvorable. The average size of the beets, 27 ounces, shows the possibilities of a large yield, while both the content of sugar and the purity coeficient are favorable to the production of large quantities of sugar from the beets produced. The thermal conditions which prevail in Washington are noticed in another place. The coast region is cooler than the mean temperature of $69^{\circ}$ for the summer months, but, as has been remarked before in more than one place, this is not minfavorable to the production of high-grade beets; on the contrary, rather promotive of it. The mild autumns, especially in the western part of the State, afiord ample opportunity for the complete harvest and care of the beets. In considering the data which have been obtained through a long series of years, therefore, it is safe to say that there are extensive areas in the State of Washington which invite the carefiul consideration of intending investors in the beetsugar industry. 
WISCONSIN.

Forty-two samples of beets were received at the laboratory of the Department from Wisconsin, of which number 31 were grown in Dane County, representiug the beets grown by the agricultural experiment station. It is evident, that the mean results of the samples from $W$ is. (n)sin are influenced in a marker degree by those obtained from the agricultural experiment station. These nean results therefore represent a highel quality of beets than would have been grown in the promiscuous manner already referred to. The mean weight of the beets grown in Wisconsin was 15 ounces, the mean content of sugar therein was 15.8 per cent, aud the mean purity 83.3. The small mean size of the beets is due chiefly to the 31 samples received from the agricultural experiment station, of which the average weight was only 11 ounces. With the exception of 1 sample from Outagamie County, which weighed only 8 ounces, the other samples were of good size. Especially is this true of the 3 samples received from Racine County, the mean weight of which was 34 ounces, the mean content of sugar 15.4 per cent, and the mean purity 82.6.

The data obtained by our analyses are encouraging, but, on account of the small number of samples, not convineing. Therefore the following report of the results of the analyses made at the agrieultural experiment station will show more conclusively the intluence of the character of the soil and climate of Wisconsin on the quality of sugar beets.

EXPERIMENTS CONDUCTED BY THE AGRICULTURAL EXPERINENT STATION OF WISCONSIN.

Three classes of experiments were conducted by the agricultural experiment station of Wisconsin during the year 1897. An elaborate report of these experiments has already been printed as Bulletin No. $6 \pm$ of that station. The following interesting summaries represent the principal data obtained:

The three methods were the following:

First meihod.-A general distribution of seed was made promiscuously to farmers in the State who desired to experiment. In all, 13,766 packages were distributed. Each package contained directions for planting and cultivating the beet. One thousand six hundred and sixty-three samples of beets grown under these auspices were received at the station for analysis. The quality of the beets, together with the malyses of beets grown in $1890,1891,1892$, and 1897, with a summary for the four years, is shown in the table on page 120. 
Resulls of analyses of sugar bects grou'n on Tisconsin farms during 1590-189,2 and 1897.-. Averages by counties.

\begin{tabular}{|c|c|c|c|c|c|c|c|c|c|c|c|c|}
\hline \multirow[b]{2}{*}{ County. } & \multicolumn{4}{|c|}{$1890-1892}$. & \multicolumn{4}{|c|}{1897.} & \multicolumn{4}{|c|}{ Summary for four years. } \\
\hline & 总 & 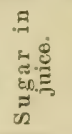 & 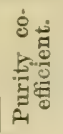 & 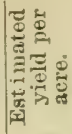 & 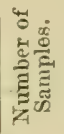 & 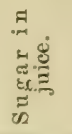 & 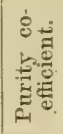 & 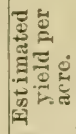 & 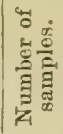 & 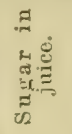 & 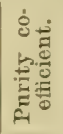 & 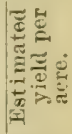 \\
\hline & & & P. ct. & 107ro. & & & $P^{\prime}$. ct. & Tons. & & & & ons. \\
\hline Allams & 3 & 11.99 & 76.1 & 9.3 & 6 & 13. 67 & 75.5 & 10.2 & 9 & 13.11 & 75.9 & 9.8 \\
\hline$A s l$ & & & & & & 11.42 & 74.2 & 3.0 & 5 & 11.42 & 74.2 & 3. 0 \\
\hline $\begin{array}{l}\text { Barron... } \\
\text { Barfield }\end{array}$ & 3 & & 77.0 & 77 & $\begin{array}{r}15 \\
1\end{array}$ & $\begin{array}{l}12.94 \\
10.96\end{array}$ & $\begin{array}{l}74.3 \\
73.5\end{array}$ & $\begin{array}{l}12.0 \\
16.5\end{array}$ & $\begin{array}{r}18 \\
1\end{array}$ & $\begin{array}{l}12.90 \\
10.96\end{array}$ & $\begin{array}{l}74.7 \\
73.5\end{array}$ & $\begin{array}{l}14.1 \\
16.5\end{array}$ \\
\hline Brown . & 4 & 10.75 & 74.9 & 17.9 & 101 & 13.12 & 75.5 & 14.0 & 105 & 13. 03 & 75.5 & 14.3 \\
\hline Buffalo & 9 & 13.48 & 77.4 & 15.9 & 8 & 12. 96 & 75.3 & 11,2 & 17 & 13.24 & 76.4 & 13. 0 \\
\hline Burnett. & & & & & 2 & 12.92 & 75.0 & 18.0 & 2 & 12.92 & 75.0 & 18.0 \\
\hline Calumet & 8 & 1 & 82.6 & 14.7 & 48 & 12.61 & 72.4 & 11.8 & 56 & 13.19 & 73.8 & 12.1 \\
\hline Chippewa & 13 & 12.72 & 77.5 & 23.6 & 34 & 12.18 & 71.2 & 11.7 & 47 & 12,25 & 75.2 & 15.1 \\
\hline Clar & 7 & 14.15 & 81.4 & 10.9 & 61 & 11.97 & 74.9 & 11.7 & 68 & 12.19 & 75.6 & 11.6 \\
\hline Colv & 19 & 12. & 74.7 & 55 & 30 & 12.68 & 71.8 & 13.4 & 49 & 12.53 & 72.9 & 14.2 \\
\hline Crawford & 4 & 10.09 & 72.0 & 15.3 & 2 & 12.09 & 72.3 & 9.7 & 6 & 10.76 & 72.1 & 13.1 \\
\hline Dar & 14 & 12. & 76.7 & 10 & 44 & 13.51 & 71.3 & 12.7 & 58 & 13. & 72.6 & 13.2 \\
\hline Dodge & 13 & 11.77 & 76.2 & 2 & 47 & 12.86 & 71.9 & 12.5 & 60 & 12. 62 & 3.0 & 13.8 \\
\hline Doo & 3 & 14.59 & 80.0 & 21.4 & 15 & 15.11 & 77.4 & 10.0 & 18 & 15.02 & 77.7 & 13. 0 \\
\hline Douglas & & & & & 8 & 13.92 & 78.8 & 16.7 & 8 & 13.92 & 78.8 & 16.7 \\
\hline Dur & 13 & 12. & 79.8 & 11.5 & 26 & 12.97 & 73.7 & 12.6 & 39 & 12. & 75.6 & 12.2 \\
\hline N. & 10 & & 76.0 & & 63 & 10.70 & 73.8 & 11. & 73 & & 74.1 & 11 \\
\hline For & 10 & 12. & 74.1 & & 38 & 12.04 & 71.2 & 16 & 48 & 12. & 71.7 & 15.1 \\
\hline For & 1 & 4 & 72.5 & & 1 & 11.31 & 70.2 & 15 & 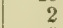 & 10 & 71.3 & 10.5 \\
\hline $\mathrm{Gr}$ & 9 & 10.24 & 69.3 & 13.2 & 26 & 12. 21 & 71.2 & 13 & 35 & 11. & 70.5 & 13. 0 \\
\hline Gree & 6 & 12. & 77.5 & 15. & 4 & 10.16 & 65.5 & 14 & 10 & i. & 72.7 & 15.0 \\
\hline $\mathrm{G}$ & 1 & 11.31 & 78.1 & & 13 & 12. & 72.9 & 11 & 14 & 12 & 73.2 & 11.5 \\
\hline Iowa & 7 & 11.32 & 74.9 & 2 & 1 & 10.40 & 70.2 & 12 & 8 & 11. 20 & 7 & 23.5 \\
\hline Iro & & & (1) & & 1 & 9.96 & 64.7 & 15 & 1 & 9. & 61.7 & 15 \\
\hline so & 1 & 7.79 & 65.6 & & 61 & 11.57 & 77.4 & 10. & 65 & 11.51 & 77.2 & 10 \\
\hline Jet & 23 & 13. 96 & 9.0 & & 13 & 13.55 & 72.8 & 15 & 36 & 1 & 76.8 & 16 \\
\hline & 6 & 13.04 & 76.0 & & 0 & 12 & 72.9 & & 1 . & & 74.1 & 13 \\
\hline$K e$ & 1 & 12.71 & 78.1 & 21.8 & 13 & 14.31 & 74.2 & 15 & 14 & 14. & 74.5 & 15 \\
\hline & 30 & 13. & 77. & & 74 & $1:$ & 75.4 & & 104 & & & 16 \\
\hline & 10 & 1 & 76. & & 60 & 1 & 6 & 12 & 7 & & & 13 \\
\hline $\mathrm{La}$ & 4 & 12 & 77.0 & & 6 & 10. & 66.3 & 9 & i & 11. & 70.6 & 16 \\
\hline & 1 & 1 & 4 & & 15 & & 0.8 & 11 & 1 & & & 12 \\
\hline & 3 & 17.43 & 5.9 & & 7 & 13. & 75.9 & 4. & 1 & 14. & 9 & 10 \\
\hline $\mathrm{Mt}$ & 16 & 1 & 8 & & 49 & & 74.9 & 11 & 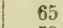 & 13 & 3 & 14.8 \\
\hline & 9 & 12. & 6. & & 44 & & & & 5 & & & 15 \\
\hline Ala & 2 & 8.77 & & & 2 & 13 & 76.6 & 9 & 2 & 12 & 75.7 & 10 \\
\hline & & & & & & & 77.7 & & 1 & & & 8 \\
\hline Mil & 6 & 15 & 83. & 19.8 & 14 & & & 15 & 20 & & & 18 \\
\hline & 16 & 1 & 2 & & 24 & 12 & 73.1 & 11. & 40 & 12. & 74.3 & 11 \\
\hline & 12 & 13 & 80.7 & 1 & 11 & & 79.6 & 17.4 & 23 & 14.56 & 80.2 & 15.1 \\
\hline & & & & & 4 & & 75.5 & & 4 & 13. 78 & 75.5 & \\
\hline O & 14 & 1 & 75.2 & & 63 & & 75.4 & 15 & 77 & 12.77 & 75.3 & 16. 6 \\
\hline & 5 & & 79.0 & & 17 & & & & 22 & & & 13 \\
\hline & 5 & 1 & 79.1 & 1 & 4 & & 73.7 & 23. & 9 & 13. & 76.6 & 17 \\
\hline & & & & & 12 & & 73.2 & 15. & 12 & & & 15 \\
\hline & 1 & 11.09 & 75. & & 5 & & 72.6 & 17. & 0 & & 73. 0 & 17.3 \\
\hline 0. & 8 & 12. & 75.1 & 12.5 & 33 & & 73.2 & 8. & 41 & 12. 91 & 73. 6 & 9.3 \\
\hline & & & & & & & 67.2 & 11. & 7 & & 67.2 & 11.0 \\
\hline & 4 & 14.27 & 80.6 & 10.5 & 17 & 13 & 75.3 & 14. & 21 & & & 13. 9 \\
\hline d) & 9 & 11. 34 & 79.6 & 12.9 & 15 & 10.61 & 68.7 & 15. & 24 & 10.88 & 72.8 & 14.4 \\
\hline & 17 & 12. 96 & 76.7 & & 36 & 13. & 73.5 & 15. & 53 & & 74.5 & 14 \\
\hline oix & 8 & 12. 55 & 74.7 & 19. & 18 & 12.11 & 72.2 & 13.3 & 26 & 12. & 73.0 & 15 \\
\hline & 8 & 9.87 & 71.5 & 23. & 23 & 12.78 & 72.4 & 13.0 & 31 & 11.98 & 72.2 & 14.8 \\
\hline & 1 & 10.69 & 73. & 20 & & & & & & 10.69 & 73.8 & 26.1 \\
\hline 10. & 7 & 12.53 & 76.3 & 16 & 28 & 13.35 & 75.0 & 8.2 & 35 & 13.19 & 75.3 & 10.4 \\
\hline . & 27 & 11. 71 & 74.3 & & 55 & 12.96 & 78.0 & 15.1 & 82 & 12.55 & 76.8 & 15.6 \\
\hline Taslor. & 15 & 13,61 & 78.9 & 8.8 & 10 & 10.87 & 70.6 & 13.6 & 25 & 12.52 & 75.5 & 11.0 \\
\hline
\end{tabular}

It will be noticerl that the table includes the analyses of 527 samples collected suring the years 1890-91-92, together with the 1,663 collected in 1897 , or a total of 2,190 samples. In the discussion of the analytical data Mr. F. IT. Woll, who has compiled the report, makes the follow. ing interesting observations:

Sixty-oight of the eomution of the state aro represented in the sugh-beet analyes made during the past season. Brown county leads with 101 samples of beets, 
Kewaunee being second with 74 samples. Ten counties furnished 50 or more samples each. The highest average for the sugar in the juice, 11 samples analyzed, was obtained for Oconto County, namely, 15.48 per cent with a purity coofficient of 79.6, followed hy Door County, which gare 15.11 per cent sugar in the juice, purity 77.4 , as the average of 15 samples. The averago sugar content of the juice of the beets was abore 12 per cent in case of 49 comities, above 13 per cent in case of 26 connties, and above 14 per cent in case of 8 counties.

Adaptability of different parts of the State to sugar-beet culture.-A close study of the results given in tho precening tables will ho of interest, and is necessary in order to properly unterstand the situation of the question of sugar-beet culture in our State. The tal)le indientes what an investigation continner through four growing seasons has revealed as to the adantability of the soil in difierent parts of tho State to the culture of this crop. In case of a few counties, especially the extreme northern ones, the number of aualyses made is not suffieiently large to warrant our drawing definite conchusions as to the quality of heets there gromn, but in the large majority of counties the number of analyses is ample to be considered a true representation of what beets grown in the respective counties will show when raised by farmers who have no special knowledge of the requirements of the sugar beet as to culture, soil, etc.

If the averages of the sugar contents for the various counties, as given in the last table, be marked on a Wisconsin map, and the counties whose averages come, say, alove 13 and above 14 per cent of sugar in the juice be shaded, it will at once bo noticed that the counties producing the richest heets are thoso lying east and southeast of the Wisconsin River, and those in the northwestern coner of tho State along the Mississippi and. St. Croix rivers, from Buffalo County and north. The Lake Shore region is shown to be peculiarly well allapted to the culture of sugar beets; all counties producing beets with an average content of sugar in the juico above 14 per cent in the past season's analyses border on Lake Michigan or are adjacent to counties bordering on this lake.

Mr. Woll is also of the opinion that those soils of the State which have been derived from limestome are best suited to the girow th of sugar beets. He malies the following comment in regard to the sugar cuntent of the beets:

Sugar content of beets. - The table shows that the average per cents of sugar in the juice for the jears given were as follows: 1890-1892, 12.76 per cent; 1897, 12.67 per cent, or an average of 12.70 per cent for the years 1890-1897, the last figure being the mean of nearly 2,200 malyses. The nsual minimum standarl for heets adapted to factory purposes is 12 per cent sugar in the beet. Sinco beets contain about 95 per cent of juice, this will correspond to $\frac{12}{95}=12.63$ per cent of sugar in tho juice. Our averace therefore exceeds this minimum fignre by a small fraction of 1 per cent.

The influence of the character of the soil upon the weight, sugar content, aud purity of the beets is summarized by Mr. Moll in the following statements:

In the sections of our State where exclusive grain raising has given way to diversified furming, dairying, stock raising, or market gardeniug, the liun is usually in a good state of fertility, and a sufficient amount of barnyard manure is produced crery jear so that no artilicial fertilizers need be purchased. But whero grain raising is still continued as the sole reliance of the farmers, there is wo hope for sugarbeet culture until the system of farming is changed, and the manure produced by the stock kept is carefully saved and applied, or commercial fertilizers are purchased for tho beet fields. 
Sceond methor.-The second line of investigations conducted by the experiment station consisted in the establishment of substations in different parts of the State. As was mentioned in a previous part of this report, this is loy fur the most hopeful manner of conducting an agricultural survey of the State for the purpose of determining its suitability for the growth of sugar beets. In all, 3:3 farmers who took charge of this substation work made complete reports to the central station. The arerage expense pur acre reported by 32 of these was $\$ 28.7: 3$. One report, showing an expense of $\$ 94.34$ per acre, was excluded from the average. The average yield per acre, as reported from the 33 stations, was 29,850 pounds, or 14.9 tons of 2,000 pounds each per acre. This piek includes only 27 returus, since 6 of the substations failed to return the yield per acre. The lowest yield per acre reported was 6 tons, and the highest $2 \frac{1}{2} .8$ tons. The average result of the analyses of the samples from the different substations is shown in the following table:

\begin{tabular}{|c|c|c|c|c|c|c|}
\hline & $\begin{array}{l}\text { Weight } \\
\text { of beets. }\end{array}$ & $\begin{array}{l}\text { Sugar in } \\
\text { juice. }\end{array}$ & $\begin{array}{l}\text { Purity co- } \\
\text { efficient. }\end{array}$ & $\begin{array}{l}\text { W eight } \\
\text { of beets. }\end{array}$ & $\begin{array}{l}\text { Sugar in } \\
\text { juice. }\end{array}$ & $\begin{array}{l}\text { Purity co- } \\
\text { eflicient. }\end{array}$ \\
\hline & Pounds. & Per cent. & I'er cent. & Pounds. & Per cent. & P'er cent. \\
\hline 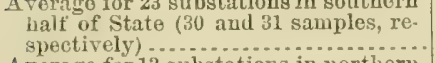 & 1.17 & 13.58 & 80.0 & 1.79 & 15.35 & 79.0 \\
\hline $\begin{array}{l}\text { A verage for } 13 \text { substations in northern } \\
\text { half of State }(17 \text { and } 15 \text { samples, re- } \\
\text { spectively) ......................................... }\end{array}$ & 1.42 & 13.35 & 81.7 & 1.59 & 14.97 & 82.5 \\
\hline $\begin{array}{l}\text { A verage for } 56 \text { substations ( } 47 \text { and } 46 \\
\text { samples, respectively) } . . . . . . . . . . . .\end{array}$ & 1.26 & 13.49 & 80.6 & 1. 72 & 15.22 & 80.2 \\
\hline
\end{tabular}

For the first attempt at collecting data by a complete agricultural survey, the above results may be regarded as exceedingly encouraging. With larger experience on the part of the farmers in charge of the experimests, however, much more valuable and convincing data might be obtained.

Third meihor.-The third class of experiments conducted by the Wisconsin station consisted in investigations at the station farm itself. For the details of these experiments Bulietin 64 may be cousulted. The following is a summary :

The field selected for the experiments was divided into two portions. The eastern half had been a meadow continuously since it came into cultivation up to 1895 , when rape was grown thereon, followed by a crop of peas in 1896 . The westem half of the field had been plowed only once during the past twenty years, when it was cultivated in Indian corn. It had been pastured during the past ten years until 1896, when it was planted to rape and the rape eaten of by sheep. The beet crop) dia not do well on this field, the whole northwestern portion of it, affer the 1st of Angust, showing no increase in the growth of the beets, the foliage turning yellow and the plants dying away to a large extrut. The field was plowed 6 inches deep on May 7 , and powerl again 1:2 inches deep on May 20. About four-fifths of it 
was subsoiled to a depth of 6 inches. The agricultural analytical data obtained from this field are given in the following table:

Field of beets and of sugar per acre, main field.

\begin{tabular}{|c|c|c|c|c|c|c|c|c|c|}
\hline \multirow{2}{*}{ 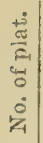 } & \multirow{2}{*}{ Name of seed. } & \multicolumn{4}{|c|}{ Eastern half: } & \multicolumn{4}{|c|}{ Western half. } \\
\hline & & $\begin{array}{c}\text { Fiold } \\
\text { of beets } \\
\text { from } \\
\text { plat. }\end{array}$ & $\begin{array}{c}\text { Yield } \\
\text { of beets } \\
\text { per } \\
\text { aero. }\end{array}$ & $\begin{array}{l}\text { Sugar } \\
\text { in tho } \\
\text { beot. }\end{array}$ & $\begin{array}{l}\text { Sugar } \\
\text { per } \\
\text { acre. }\end{array}$ & $\begin{array}{c}\text { Field } \\
\text { of beets } \\
\text { from } \\
\text { plat. }\end{array}$ & $\begin{array}{c}\text { Yieli } \\
\text { of beets } \\
\text { per } \\
\text { acre. }\end{array}$ & $\begin{array}{l}\text { Sugar } \\
\text { in tho } \\
\text { beet. }\end{array}$ & $\begin{array}{l}\text { Sugar } \\
\text { per } \\
\text { acre. }\end{array}$ \\
\hline & & Pounds. & Pounds. & Perct. & Pounds. & Pounds. & Pounds. & Per ct, & ounds. \\
\hline 1 & Klein wanzlebener, Neb........ & 3,422 & 24,010 & 12.72 & 3,059 & 2,874 & 25,030 & 15.80 & \\
\hline 3 & & 2,826 & 22,060 & 11.71 & & & 30 , & 13 & 44 \\
\hline 4 & Klei & 3,6 & 21 & 10. & & 2, & 32, & & \\
\hline 5 & Viln & $\begin{array}{l}2,0 \\
2,2\end{array}$ & 15, & 14. & & & & & \\
\hline 6) & nzlebener... & 2,47 & 17,3 & 10. & 1 , & 2 , & 23 & & \\
\hline & Vilmorin Fre & 2,485 & 17,4 & 11. & 1 , & 2,701 & 23.5 & 13.58 & 3 , \\
\hline 8 & Klein & 2,25 & & 14. & & & 12, & & \\
\hline 0 & Desp & 2,08 & 14, & 10. & & 1,4 & & 14 & $\mathbf{1}$, \\
\hline 10 & Despr & 2,108 & 14,8 & 15. & 2, & 1, & 12 & & \\
\hline 11 & Wernich's Kleinw, Floto*... & 2,111 & 14 & 15. & & 1,23 & 10 & & \\
\hline 10 & Demesmay * ........ & 1,321 & 15 & 14. & 2, & 799 & 11, & & \\
\hline \multirow[t]{2}{*}{13} & Kleinwanzlebener, $\mathrm{N}$ & & & & & & & & \\
\hline & Averages, & 30,121 & 18,043 & 13.22 & 2,385 & 23,032 & 18,472 & 14.18 & 2,620 \\
\hline
\end{tabular}

* Not included in average for western half.

\section{The cost of cultivating this field is given as follows:}

Cost of growing an acre of sugar beets. - $\mathrm{A}$ careful account was kept thronghont the season of the labox done on the 3 -acre beet field; valuing labor as previously given, we have the following summary:

Plowing and preparing the land $\$ 12.42$

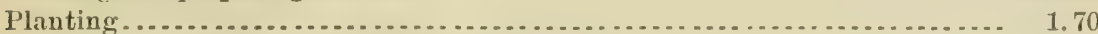

Cultivating, hooiug, thinning and transplanting................... 51.6. 63

Harvesting and placing in cellar ................................. 31.60

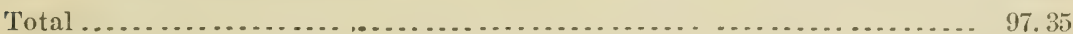

This sum, $\$ 97.35$, or $\$ 32.45$ per acre, does not include the cost of seed or rent of land. It is nearly $\$ 4$ higher than the corresponding figure obtained as the arerage for 28 substations; the greater cost with us is easily accounted for by the weedy condition of the western half of the field, as well as by the fact that the liarvesting of our heots was a comparatively slow and difticult job, since tho different lots and varieties had to be harvested and kept separately.

In addition to the work summarized above the station took part in the growth of high-grade beets on special plats under the supervision of the Department. The results of these experiments are given in another place.

\section{WYOMING.}

Thirty-four samples of beets grown in Wyoming were receiver at the Department of Agriculture for aualysis. The mean weight of the beets receiver was 19 ounces, the mean content of sugar in the beet 17.2 per cent, and the mean purity 82.3. These data are exceptionally fine, and slrow that, in so far as the production of a crop is concenerl, Wyoming will be able to compete with any State in the Union. The thermal conditions which prevail in the State are extremely irregular, the low valleys having warm and the high plateans cool summers. It 
is evident that only on the plateans, where the land is reasonably level, and where irrigation can be practiced, will it be possible to grow, with absolute certainty, a crop of beets of high saccharine strength.

Among the counties of Wyoming the two which furnish the most data are Converse and $\mathrm{Big}$ Horn. Converse Connty lies in the southeastern part of the State and Big Horn in the northwestern. In the beets from Converse Connty the average weight was 26 ounces, the mean content of sugar 17.8 per cent, and the mean coeficient of purity, 82.2 . Big Iforn County furnished six samples, of which the arerage weight was 20 ounces, the mean content of sugar 18.7 per cent, and the mean coefficient of purity 82.2 .

When these analyses were made, showing such fine results, we wrote at once to the parties to see if we could not get a quantity of the beets for mothers in producing beet seed. The reply was made that they had all been frozen, and therefore no samples conld be furmished. This reply to on inquiry indicates the chief difficulty to be encountered in Wyoming in introducing the beet industry, namely, the sudden advent of cold reather and the severity of the early winters in that locality. In Big Horn Comuty some of the altitndes are 10,000 feet, and the whole connty lias a rery great elevation. In the southeastern portion of the State the altitude generally reaches 7,000 feet. It is evident, therefore, that these high elevations give cool summers and favor the early advent of winter.

Another point to be considered is the mountainous character of the State, which, of course, precludes the possibility of culture over extensice areas. In low valleys protected by mountain ranges, if from 15,000 to 25,000 acres of land in a body conld be secured, it seems probable that the industry of beet growing might be introduced with every probability of success. The temperature conditions, however, of October and November should be most carefully considered, as it would doubtless be necessary, even in the most favored valleys of Wyoming, to have the beets securely protected by the middle or end of November. This short harvesting season can not help but add a great deal to the cost of production, and hence must be taken into consideration.

In that part of the country also the question of the supply of water is a very important factor, and must not be lost sight of, as not ouly will water be required for the growing of crops, but also in immense quantities for manufacture.

The data at hand only permit us to study the composition of the beet itself, and surely Wyoming is to be.congratulated on having jrodnced, judged from the limited number of samples supplied, an excellent quality of beets.

VERMONT.

Only $\&$ samples of beets from Termont wero received at the lyepartment of Agriculture, aud these were of very high quality. The mean weight of the samples received was 22 ounces, the mean content of sugar in the beet 14.2 per cent, and the mean coeflicient of purity, st.1. 
At the agricultural experiment station of Vermont 32 samples were received. The average weight of the beets received at the experiment station was 17 ounces, the mean percentage of sugar in the beet 16.3, and the mean purity 84.2 . In reporting the results of the experiments the director of the station makes the following observations:

RESULTS OF EXPERIMENTS IN VERMONT.

One hundred persons guaranteed at the outset of the season to grow the crop and ship us samples. We hal returns from twenty-sovou. The remaining sorenty-throe, howevel, were not so much at fault as was the Weather Bureau. The weather throughout the State during the months of May, June, and July aurl the first part of August was execrable, there being several times the normal rainfall. In almost every case of not sending samples the report was that tho crop was drowned out. It strikes me as somewhat doubtful whether the results obtained in the tweutyseven cases reported are truly representative of what might be expected under normal conditions of weather. The percentages of sugar certainly run quite high. I find that several of the growers sent their samples to Washiugton. I should be gratified, if it wero possible, to receive the statement of the analyses, as we may wish to make some use of the sugar-beet data ourselves, which, as I understand, wo are at liberty to do.

The majority of those who made a failure of the work this year expressed their desire to try again next year.

Of 32 beets analyzed at the agricultural experiment station of Vermont the number containing from 12 to 14 per cent of sugar was 2 ; the number coutainiug from 12 to 14 jer cent of sugar and weighing 16 ounces or over was 1 ; the number containing more than 14 per cent of sugar was "28; the number containing more than 14 per cent of sugar and weighing 16 ounces or more was 12 .

It is seen from the above data that the only limitations upon the growing of beets in Vermont are the extent of the area suitable to the culture of the beets and the length of the growing season. It is evident, in so far as growth is concerned, that such a season as that of 1897 is capable of producing beets of the highest grade, but the growing season includes properly the season of harvest and preservation of the beets. The high northern latitude of Vermont and the early and severe winters must be taken into consideration in this particular. Vermont is also a mountainous country, and the areas of level land are not proportionately so great as in most of the States which have been considered for beet growing. Where bodies of from 15,000 to 25,000 acres of level and fertile land can be found with the antumnal conditions favorable for the harvest and preservation of the beets, there is no reason to doubt the possibility of successfully establishing the beetsugar industry.

INFLUENCE OF TEMPERATURE ON THE QUALITY OF SUGAR BEETS.

The influence of temperature and other climatic conditions upon the growth of beets is discussed under the head of special experiments in growing beets from high-grade seeds. It will be interesting, however, to compare the deductions from that discussion with those from data 
obtained from certain parts of the conntry where favorable conditions exist for making this comparison. The States of Ohio, Indiana, and Illinois are situated in a peculiarly favorable manner for a study of this kincl. Each of these States has a portion of its area in the theoretical thermal belt and a large portion of its area ontside of that belt. In each of these States, therefore, the data received from the various comnties were classified into three portions, vamely, the northern, the central, and the southern belts.

The following is a tabulation of the data from each one of these sections in the three States:

Relation of latitude to development of sugar content.

\begin{tabular}{|c|c|c|c|c|c|c|c|c|c|}
\hline & \multicolumn{3}{|c|}{ Northern belt. } & \multicolumn{3}{|c|}{ Central belt. } & \multicolumn{3}{|c|}{ Southern belt. } \\
\hline & $\begin{array}{c}\text { Average } \\
\text { weight of } \\
\text { beots. }\end{array}$ & $\begin{array}{l}\text { Sugar } \\
\text { in } \\
\text { beets. }\end{array}$ & $\begin{array}{l}\text { Purity } \\
\text { coefli- } \\
\text { cient. }\end{array}$ & $\begin{array}{c}\text { Average } \\
\text { weight of } \\
\text { beets. }\end{array}$ & $\begin{array}{l}\text { Sugar } \\
\text { in } \\
\text { beots. }\end{array}$ & $\begin{array}{l}\text { Purity } \\
\text { coeffi: } \\
\text { cient. }\end{array}$ & $\begin{array}{c}\text { A verage } \\
\text { weight of } \\
\text { beets. }\end{array}$ & $\begin{array}{l}\text { Sugar } \\
\text { in } \\
\text { boets. }\end{array}$ & $\begin{array}{l}\text { Purity } \\
\text { coeffi- } \\
\text { cient. }\end{array}$ \\
\hline 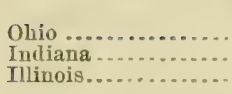 & $\begin{array}{r}\text { Ounces. } \\
29.4 \\
18.9 \\
22.0\end{array}$ & $\begin{array}{r}\text { P'er ct. } \\
13.6 \\
13.3 \\
13.2\end{array}$ & $\begin{array}{l}79.4 \\
81.9 \\
79.3\end{array}$ & $\begin{array}{r}\text { Ounces. } \\
32.6 \\
18.5 \\
20.0\end{array}$ & $\begin{array}{r}\text { Per ct. } \\
13.2 \\
12.9 \\
11.5\end{array}$ & $\begin{array}{l}78.0 \\
80.7 \\
75.4\end{array}$ & $\begin{array}{r}\text { Ounces. } \\
35.0 \\
14.2 \\
19.0\end{array}$ & $\begin{array}{r}\text { Pcr ct. } \\
12.2 \\
10.7 \\
11.1\end{array}$ & $\begin{array}{l}75.3 \\
78.0 \\
74.7\end{array}$ \\
\hline
\end{tabular}

The data in the above table have a peculiar value in establishing, by experimental results, the validity of the scheme employed in the construction of the theoretical thermal belt suitable to the growing of beets. In every one of the States mentioned ther is a gradual deterioration in the quality of the beet, hoth as respects its sugar content and its purity, in passing from the northern to the southern belt of the State. It may be said that the difference between the two extreme areals is not very great, and that for this reason it would be arvisable to establish factories indiscriminately in one or the other of the belts, according to more or less favorable local conditions, aside from the sugar content of the beet. 'The fallacy of this statement, however, will be evident to anyone who studies carefully the conditions of manuficture. An increase of 1 per cent in the sugar content of the beet means an increase of 20 pounds per ton in the amount of sugar manufactured, without any corresponding increase in the expense of manufacture. In other words, the cost of extractiug the sugar from a tom of beets which would yield 180 pounds would be just as great as that atteuding i ton of beets which would yield 200 pounds of sugar. But the additional value of the 20 pounds of sugar manufactured might in many instances determine whether the business would be conducted at a profit or a loss. The above assumption is true on the supposition that the coefficient of purity remains the same in each case. When we consider in addition to the loss of the sugar, the lepreciation in the purity of the juice, the discrepancy between the sections becomes all the greater. Not only is the loss attending the lower sugar content of the beot to be cousidered, but also the additional loss 
which is coupled with the lower purity. In other words, a ton of beets with a coefficient of purity of 80 , which would yield 200 pounds of sugar by the ordinary processes of manufacture, would yield very much less than this if the purity coefficient should fall to 76 , and would yield very much more if it should rise to 85. The data obtained in the above table aftord convincing proof of the fact that it is not safe to push the manufacture of beet sugar too far south of the theoretical thermal belt, unless the depreciation in the sugar content and purity of the beet is compensated for by some remarliable local factors, in the way of cheapness of manufacture, which will make good the loss due to the low content of sugar and the low purity of the juice. These figures, obtained in this miscellaneous way, are fully corroborated by the cureful experimental data obtained in the culture of high-grarle beets at the six statious which are mentioner in another place. From exactly the samo seeds, planted in oxactly the same way and eultivated in the same manner, exceptionally high-grade beets of fine sugar content and high purity were obtained from the New York station, good beets were grown at the Wisconsin station, fairly good beets at the Iowa station, beets with a fairly good content of sugar but dininutive in size on account of the drought at the Indiana statiou, beets of good size and very low content of sugar at the Kentucky station, beets of only minimum content of sugar and very small size at the Tennessee station. These results are such as allould be studied carefully by intending investors who desire to place their money where the certainty of return is the greatest. With such maguificent areas open to eultivation as are found in the States of New York, uorthwestern Peuusylvania, northern Ohio, northern Indiana, and sonthern Michigan, it would not be wiso for men of enpital to select localities which the figures at hand indicate are less favorable to the production of high-grade beets. The data which have been obtained from New York and from Michigan indicate that with the best principles of eulture, with good fertilization and slilled oversight, beets can be grown over wide areas fully equal in sugar-producing power to those which are grown by the skilled farmers of Germany. On the other hand, it is fluite certain that if the area of culture be pusherl to the south, so as to fall eutirely without the linits of the thermal belt, the same fertility of soil, the same fertilization, and the same care in culture will produce beets less rich in sugar, with a lower purity, and yielding less sugar per ton than those grown in the localities first mentioned.

As to how far the successful growth of the sugar-beet industry cau be pushed north of the limit of $69^{\circ}$, it may be said that the ouly condition to be considered in this matter is the possibility of producing and ripening a crop aud larvesting it before the rigon's of winter set in. The culture of the sugar beet may be very successfully practiced in localities where the mean summer temperature falls even as low as 610 , 
provided the latitude is far enough north to get sufficient sunshine to mature the beets before the frosts of autumn. If the antumn be mild and merge gradually iuto winter, the limit of successful culture will be found where the freezing weather of winter cuts short the time reçuired for the harvesting and siloing of the cropl of bects. In the light of the data at present available, therefore, the southern limit of the sugar-beet belt may be regarded as the isotherm of $71^{\circ}$ for the three summer months, occasionally pushing 50,75 , or even more miles south of this line, where exceptional conditions of soil and mannfucturing facilities are presented. The facts of the case, however, warrant the statement that the safer plan will be not to push south of the isotherm of $71^{\circ}$ so long as equally favorable conditions of soil and manufacture are obtainable north of this line of demarcation. It is deemed wise to dwell particularly upon this subject, because of the fact that so many people living sonth of the isotherm of $71^{\circ}$ are vitally interesterl in this matter and so eager to have the industry established in the neighborhookls in which they live. The conclnsions which have been drawn are not meant to discourage experimental work in areas widely remote from those mentioned. It is only just, however, to call attention to the fact that investments of large amounts of capital which result disastronsly do more to deter the successful establishment of an industry than a much larger number of snccessful investments faror it. For instance, in the State of Wisconsin we have an illustration of the financial failure of an attempt to manufacture beet sugar, and as a result of this failure it will be difficult to induce capital to look for investment in Wisconsin in the sugar-bet industry, although the conditions in that State are exceedingly favorable to success. Had it not been for the failure of the factory projected at Menominee Falls, it is quite certain that other capital would be invested in the State at the present time, and instearl of the industry being in an stagnant condition it would be advancing on the road toward success. It is extremely important that no mistakes be made from a financial point of view, and that every precuution to avoid these mistakes be observed. When subsequent experimentation shall have demonstrated that there are areas outside, and especially south of the theoretical belt, erually as well suited to the growth of beets sufficiently rich in sugar as those which have been mentioned, it will be time enough to ask capital to seek investment in those localities.

SUGAR BEETS AS CAT'ILE FOOD.

Thousands of farmers in varions parts of the country are growing bects in an experimental way and have no opportunity to dispose of their product to sugar factories. These furmors may, nevertheless, find the growing of small ruantities of sugar beots profitable by using the product for cattle food. Following is an andysis lately made in 
this laboratory of a sample of sugar beets received from a locality such as is mentioned above:

Composition of fresh bcet pulp.

\begin{tabular}{|c|c|c|}
\hline & $\begin{array}{c}\text { Fresh } \\
\text { pulp. }\end{array}$ & $\begin{array}{c}\text { Dry } \\
\text { matter. }\end{array}$ \\
\hline 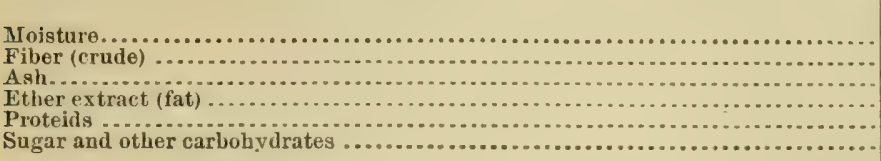 & $\begin{array}{r}\text { Per cent. } \\
73.87 \\
1.53 \\
1.35 \\
.11 \\
2.21 \\
20.93\end{array}$ & $\begin{array}{r}\text { Per cent. } \\
5.89 \\
5.18 \\
.42 \\
8.47 \\
80.01\end{array}$ \\
\hline & 100.00 & 100.00 \\
\hline
\end{tabular}

The sample in ruestion contained 73.87 per cent of water and 26.13 per cent of dry matter. The analyses of hundreds of samples of beets in this laboratory show that the average content of fiber, usually called "mare," is about 5 per cent. In the process of analysis all this mare is dissolved except that which is entered above as crude fiber, namely, 1.53 per cent. The difference between this and the 5 per cent average content of mare, namely, 3.47 per cent, shows the quantity of carbohydrate matter not sugar contained in the 20.93 per cent of total sugars and carbohydrates. The quantity of sugar in the sample analyzed was, therefore, 17.46 per cent. Practically all, however, of the carbohydrates, except those represented by the crude fiber, are digestible, so that the soluble mare has practically the same food value as the sugar itself. The ratio of the proteid matter to the digestible carbohydrates plus fat multiplied by $2 \frac{1}{2}$, is 9.59 . This ratio shows that the food is particularly a fattening one, and conld be used to great advantage in preparing fat stock for market. The analysis also indicates that the food, to secure the best results for all round sustenance, should be fed with some highly nitrogenous ration in order to secure a smaller ratio between the two groups of nutrients. It may be said with perfect confidence that it will be far more profitable for the farmer to grow sugar beets at 12 tons per acre for cattle food than other root crops, such as turnips and ruta-bagas, which will yield double that quantity per acre. The food value of these crops does not denend upon the gross tonnage, but upon the actual nutrients which they contain. Sugar beets contain, as is seen, over 20 per cent of their weight of actual nutrients, while turnips and radishes may contain ouly from 6 to 12 , per cent.

\section{USE OF BEET PULPS FOR CATTLE FOOD.}

The residue from beet factories, in the form of the beet pulp, is also a valuable cattle food. In this country no carefully. controlled feeding experiments have been conducted with this material, but the question has been studied most thoroughly in Europe, and the data obtained can be used for our guidance. There is practically no difference in ehemical composition between the beet pulps obtained in H. Doc. $396 \longrightarrow$ ? 
Europe and in this country, so that the deductions to be drawn from the feeding experiments in that country can be applied with perfect safety to similar work here. At many of the factories in this country practical feeding test have been made, and with favorable results. IIaving leard that successful experiments in feeding cattle and sheep had been conlucted at the factory of the Pecos Talley Beet Sugar Com. pany, I addressed a letter to the manager of that factory, and received the following reply:

DEAR SIr: I have your letter of the 14th. Shortly before the close of our campaign, Mr. A. J. Crawford, a large sheep owner of this section, looked into the question of feeding beet pulp to sheep, and finally decided to try a bunch of 500 Iimulos as an experiment. These lambs were the culls of his tlock, and when brought to the feeding pens at the factory wore in very poor condition. In a few days they took to the pulp very readily, and are now eating 7 to 10 pounds of pulp per day each, with sufticient hay (alfalfi) as roughening. They have picked up wouderfully during the time they have been here, and Mr. Craw ford tells me that they are now the best looking of any he has. He is so well satisfied with the result of his oxperiment that about a week ago he brought in 2,000 ewes with the intention of feeding them on the pulp during the lambing season. You, of course, are aware that tho pulp is a great milk producer, and by feeding it Mr. Crawford will be able to carry both ewes and lambs through in good shape mutil the grass comes, and, of course, thereby prevent the loss which he wonld otherwise have to stand of the many ewes and lambs which would die on the rauge.

When the lambing season is over and we see how the sheep come through I shall be glad to write you fully. Mr. Crawford is anxious to make a contract for all onr next year's pulp, and I have no doubt that the feeding of sheep on pulp in this valley will become quite an industry.

Yours, truly,

A. S. Goetz,

General Manager.

Mr. II. W. WILEY,

Division of Chemistry, Washington, D. C.

It is evident from the above that these practical experiments in feeding, although not controlled by actual chemical analyses, have been eminently successful, and it is not at all mulikely that within a few years our beet factories will be able to contract in advance for all the pulp which they can possibly produce. To illustrate more clearly the value of the prily and its value for feeding purposes, the following extracts, taken from standard European athorities, are published:

DIFFUSION PULPS OR EXIIAUSTLD COSSETTES.

The following table contains an average of analyses made by Messrs. Vivien, Lncas, Duvin, Durot, and Dupont as a commission of experts in France:

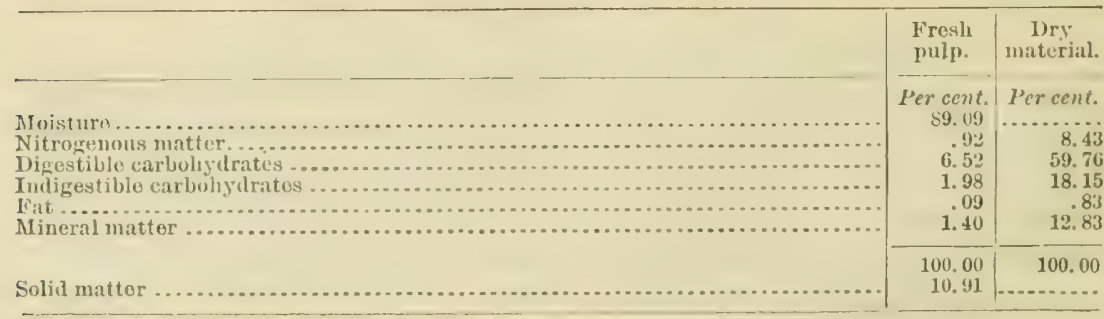


FEEDING EXPLIRIENTS WITH BEET PULP.

Extensive tests in feeding pulps have been marle at the Francières sugar house of M. Gallois. The following animals were used: (1) Beef cattle, (2) oxen, (3) milch cows, (4) sheep, (5) ewes. Before begrinning the tests, these animals were all gradually aceustomed to the change from their customary ration to that of diffusion pulp.

(a) Beef cattle.-Twelve beeves each received every day, in three meals, 52.26 kilograms (115 lbs.) of diffusion pulps, mixed with 3 kilograms of linseed oil calie and 3 kilograms $(6.6$ lbs.) of chopped alfalfal. Their weight increased an average of 1.004 kilos ( 2.214 lbs.) per day. If we consider the value of the meat as 0.95 franc $(\$ 0.19)$, that of the oil cake 0.25 franc $(\$ 0.05)$, and that of the alfalfa 0.08 franc $(\$ 0.016)$ per kilogram (2.2 lbs.), we find that the feeding value of the diffusion pulp was 6.55 francs (\$1.316) per 1,000 kilograms (2,205 lbs.).

(b) Oxen.-Fom oxen each received the following ration per day: 57.5 kilograms (126.5 lbs.) of diffusion 1 ul $)$ mixed with 5 kilogrums (12 1bs.) of alfalfa and 1 kilogram (2.2 lbs.) of linseed-oil cilie. These cattle decreased somewhat in weight in the first fifteen days, and did less than the usual amount of work, but in the second fifteen days they had entirely recovered. The trial continued two and a half months. In making a calculation analagous to that above, the value of the diffusion pulp was 4.78 franes (\$0.956) per 1,000 kilograms (2,205 los.).

(c) Milch covos. - The test with milch cows lasted thirty days. Two cows were employed-one Flemish and the other Dutch. Before the tests the cattle were fed on dry alfalfa with a small quantity of beet pulps produced by the hydraulic-press method. The cows were each given, per day, 45 kilograms (99.2 lbs.) of diffusion pulp with "2 kilograms (1.4 lbs.) of alfalfat. The tests demonstrated that the diffusion pulp is more advantageous as regards lactation than in the production of tlesh.

Cows fed on ditfusion pulps.

\begin{tabular}{|c|c|c|}
\hline \multirow{2}{*}{ Dato. } & \multicolumn{2}{|c|}{$\begin{array}{c}\text { Cream per } 100 \text { ec. of } \\
\text { milk. }\end{array}$} \\
\hline & Cow No.1. & Cow No. 2. \\
\hline 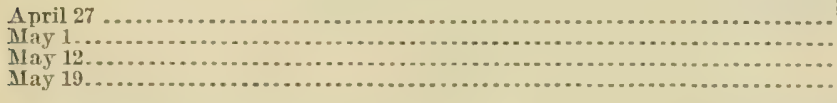 & $\begin{array}{l}8.00 \\
7.50 \\
7.50 \\
7.50\end{array}$ & $\begin{array}{l}\text { 7. } 00 \\
\text { 8. } 00 \\
\text { 8. } 00 \\
\text { 8. } 00\end{array}$ \\
\hline
\end{tabular}

From these tests it was shown that the milk of the cows fed from diffusion julp contained an average of 7.65 jex cent of cream. The butter produced from this milk did not have the peculiar disagreeable odor which is present in that from cows fed on press pulps. 
(d) Sheep.-In this test twenty merino sheep were fed on diffusion pulp. The following table shows the result of this test and the rations fed per animal:

\begin{tabular}{|c|c|c|c|}
\hline $\begin{array}{l}\text { Weight: } \\
\qquad \begin{array}{l}\text { April } 4 \\
\text { April } 26 \ldots \ldots \ldots\end{array}\end{array}$ & $\begin{array}{l}\text { Kilos. } \\
948 \\
1,008\end{array}$ & $\begin{array}{l}=2,085.6 \\
=2,217.6\end{array}$ & $\begin{array}{l}\text { pounds. } \\
\text { pounds. }\end{array}$ \\
\hline Total & 60 & $=132.0$ & ids. \\
\hline Increase per sheep per day ... & 0.137 & $7=$ & pounds. \\
\hline erage rations per head: & & & \\
\hline Pulp ................ & 5.4 & 11.88 & 3 pounds. \\
\hline Linseerl-oil cake ..... & .2 & $=$ & t pounds. \\
\hline Chopped alfalfa............................. & .5 & 1.10 & pounds. \\
\hline
\end{tabular}

It was not necessary to make other additions to the diffusion pulp, since the sheep ate it with avidity. With the aid of these figures we may calculate the value of the pulp as follows:

The sheep) gained per day 0.137 kilogram (.3 lb.) in meat, which at 1 franc $(\$ 0.20)$ per kilo (2.2 los.) equals 0.137 franc $(\$ 0.027)$. They consumed a ration, exclusive of the pulp, costing 0.09 franc, therefore the value of the 5.4 kilos (11.9 lbs.) of diffusion pulp was $0.047(\$ 0.01)$, or 8.70 franes (\$1.74) per 1,000 kilograms (2,205 lbs.).

Experiments made with exes. - The ewes were obtained from a flock from which the lambs had just been separated. In feeding the ewes, to which a somewhat larger ration was given, the value of the pulp wats found to be 6.03 francs $(\$ 1.206)$ per 1,000 kilograms $(2,205$ lbs.). Taking all of these elements into account, the experts estimated definitely the value of 1,000 kilograms (2,20; lbs.) of diffusion pulp to be 5.55 francs (\$1.11). They also demonstrated that diffusion pulps keep perfectly.

Not taking into account (questions of transportation, ete., the value of diffusion pulp) was estimated at 6.10 franes (\$1.22) per 1,000 kilograms (2,205 lbs.). Basing a conclusion upon the chemical analysis of the pulp, a value of 6.44 francs $(\$ 1.285)$ was obtained, as compared with the 6.10 francs $(\$ 1.22)$ per 1,000 kilograms $(2,205$ lbs.) given by experiments.

EXPERIMENTS BY ANDOUARD AND DÉZAUNAI.

(Sucrerie Belge, Vol, 12, No. 7.)

In tests in feeding diffusion pulp to milch cows this pulp was given in a ration, first of "27 kilograms (599.5 lbs.) and later 55 kilograms (121.3 lbs.) per day, and produced immediately an increase of approximately 32 per cent in the yield of milk. It appeared, however, to be without influence on tine richness of the milk in casein and mineral matter, but produced an increase in the yield of butter of 13.4 per cent, and in that of the sugar of 24.63 per cent over the previous proportions of these constituents, It, however, gave the milk a less agreeable taste and a 
certain predisposition to an acid fermentation. The butter, therefore, would probably not be of excellent quality.

Analyses of diffusion pulps before ensilage.*

\begin{tabular}{|c|c|c|}
\hline Constituents. & Maercker. & Kühn. \\
\hline 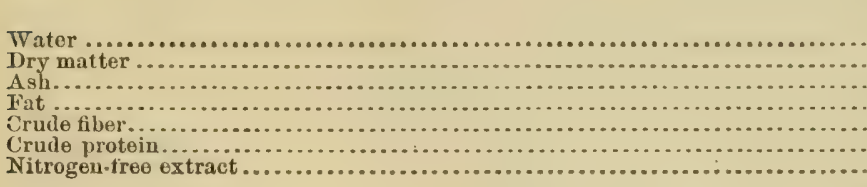 & $\begin{array}{r}\text { Per cent. } \\
89.77 \\
10.23 \\
.58 \\
.05 \\
2.39 \\
.89 \\
6.32\end{array}$ & $\begin{array}{r}\text { Percent. } \\
88.9 \\
11.1 \\
.9 \\
.1 \\
2.5 \\
6.9\end{array}$ \\
\hline
\end{tabular}

Diffusion pulps afier having been stored in the silos.*

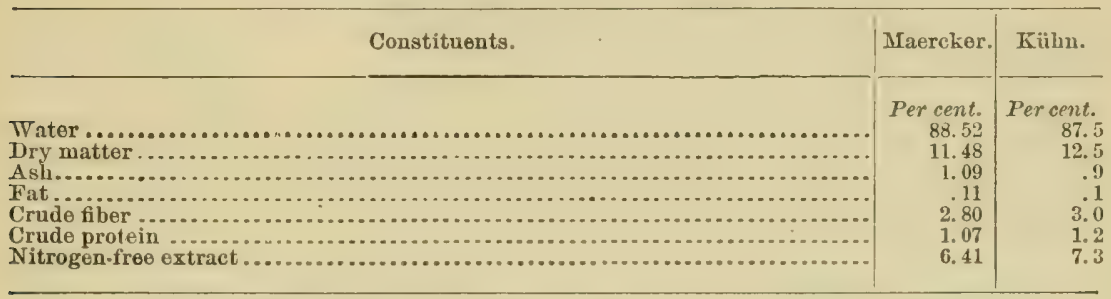

* Sachs' Revue Universelle des Progrès de la Fabrication du Sucre, 1, 428.

Analysis of diffusion pulps, by Pellet.

\begin{tabular}{|c|c|c|}
\hline Constituents. & $\begin{array}{l}\text { Pressed } \\
\text { pulp. }\end{array}$ & $\begin{array}{c}\text { Dry ma- } \\
\text { terial. }\end{array}$ \\
\hline Water............ & $\begin{array}{l}\text { Per cent. } \\
88.06\end{array}$ & Percent. \\
\hline Nitrogenous matter. & .84 & 7.04 \\
\hline Digestible carbohydrates ......... & 7.30 & 61.14 \\
\hline 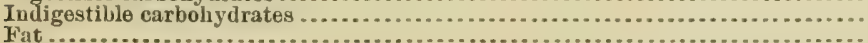 & 2.46 & 20.60 \\
\hline $\begin{array}{l}\text { Fat } \\
\text { Soluble mineral matter }{ }_{1}\end{array}$ & $\begin{array}{l}.06 \\
.43\end{array}$ & $\begin{array}{r}.50 \\
3.60\end{array}$ \\
\hline Insoluble mineral matter.............. & .85 & 7. 12 \\
\hline Dry matter ............... & $\begin{array}{r}100.00 \\
11.91\end{array}$ & $\begin{aligned} 100.00 \\
\ldots . . .\end{aligned}$ \\
\hline
\end{tabular}

Maercker (Sucrerie Belge, vol. 11, page 464) determined that siloer pulps, in addition to losing water, also lost a considerable portion of their dry matter. This is shown in the following statement of the analysis of pulps which were siloed for five months, in which time they lost the following percentages:

Thirty-seven and eight-tenths of nitrogen free extract, 25.5 of nitrogenous matter and 29.6 of the fiber which they contained: The pulps gained, on the contrary, in fat, owing to the lactic and bntyric fermentations. The losses were due to decomposition, and not to entrainment in the moisture lost. 
Analyses of diffusion pulp, by Vivien.*

\begin{tabular}{|c|c|c|c|}
\hline Constituents. & $\bullet$ & $\begin{array}{l}\text { Pressed } \\
\text { pulp. }\end{array}$ & $\begin{array}{l}\text { Dry ma- } \\
\text { terial }\end{array}$ \\
\hline Direstible proteirls (nitromen $\bar{T} 6.25$ ) & & Percent. & Per cent \\
\hline 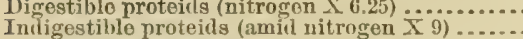 & .............. & 0.64 & 7. 73 \\
\hline $\begin{array}{l}\text { Indigestible proteids (amid nitrogen } \bar{X} 9 \text { ) } \ldots \ldots \\
\text { Nitrate of potassium } . . . . . . . . .\end{array}$ & . & $.0 \pm$ & .48 \\
\hline 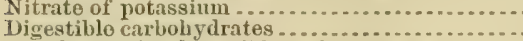 & 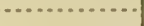 & .05 & .60 \\
\hline 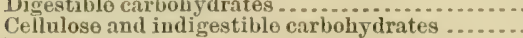 & C.2. & 4. 07 & 49.15 \\
\hline 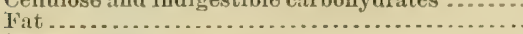 & $\ldots . . .6$ & $\begin{array}{r}1.92 \\
.05\end{array}$ & .60 \\
\hline Sugar & . . . . . . & .54 & 6. 52 \\
\hline 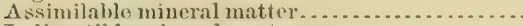 & $\ldots \ldots \ldots . . . . .$. & .35 & 4. 23 \\
\hline Indigestible mineral matter.................... & ............... & .61 & 7. 37 \\
\hline \multirow[t]{2}{*}{ Water } & ............ & 91.72 & ........ \\
\hline & & 100.00 & 100.00 \\
\hline
\end{tabular}

Analyses of diffusion pulp, by Pellet.*

\begin{tabular}{|c|c|c|}
\hline Constituents. & $\begin{array}{c}\text { Pressed } \\
\text { pulp. }\end{array}$ & $\begin{array}{l}\text { Dry ma- } \\
\text { terial. }\end{array}$ \\
\hline 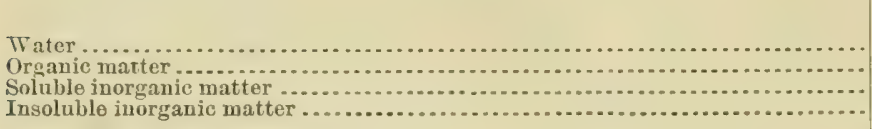 & $\begin{array}{r}\text { Per cent. } \\
88.88 \\
9.95 \\
.57 \\
.60\end{array}$ & $\begin{array}{r}\text { Per cent. } \\
\cdots . .50 \\
89.50 \\
5.13 \\
5.40\end{array}$ \\
\hline 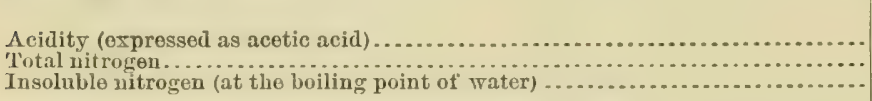 & $\begin{array}{r}100.00 \\
1.01 \\
.147 \\
.111\end{array}$ & $\begin{array}{r}100.00 \\
9.08 \\
1.32 \\
-. .2\end{array}$ \\
\hline
\end{tabular}

* Sachs' Rerue Universello des Progrìs de la Fabrication du sucre, 1, 429.

The prlps diminished in weight in the silos, the diffusion pulps losing 6 per cent per month. At the same time there was a diminution in the weight of the dry matter, approximately 1 per cent of the diffusion pulp.

It is evident from the above data that the value of the pulp from beetsugar factories, especially in thickly settled comtries and in those regions where the dairy interests are prominent, will prove of no inconsiderable advantage in the successful introduction of the beet sugar industry and its rapid advancement. Beet pulps form a wholesome and mutritious, though a somevhat poorly balanced ration. Their chicf nutriment is found in the carbohydrates, composing the mare of the beet and including the unextracted sugar, and in the proteid nitrogenous matters, and a large percentage of these is easily digested. While beet pulp is not suitable for the entire food of the animal, it can he male a principal part thereof, varying its proportions with the nature of the effect desired to be prorluced. Experience has shown that it is esporially relished by dairy cattle, produces an abundant supply of milk, and where properly preserved and fed, it can be used in great abundance without imparting to the milk, butter, or cheese any umpleasant flavor.

\section{SUMMARY OF DATA COLLECTED IN PREVIOUS YEARS.}

In order to present data covering as wide a field as possible, and including the experiments of several seasons, the following table has 
been compiled fiom the reports of the Division of Chemistry and fiom the bulletins of the various State experiment stations:

\section{Analyses of sugar beets grown in various States.}

[ $\Lambda$ compilation of the analytical data obtained at the various State experiment stations for the years 1888 to 1897, inclusive, and at the United States Department of Agriculture for the years 1884 to 1897, inclusive.]

\begin{tabular}{|c|c|c|c|c|c|c|c|c|c|}
\hline \multirow[b]{2}{*}{ State. } & \multicolumn{5}{|c|}{$\begin{array}{l}\text { Analyses by the United States De- } \\
\text { partment of Agriculture. }\end{array}$} & \multicolumn{4}{|c|}{$\begin{array}{l}\text { Analyses by the State experi- } \\
\text { ment stations. }\end{array}$} \\
\hline & Year. & $\begin{array}{l}\text { Num- } \\
\text { ber of } \\
\text { sam- } \\
\text { ples. }\end{array}$ & $\begin{array}{l}\text { Aver. } \\
\text { rye } \\
\text { weight. }\end{array}$ & $\begin{array}{l}\text { Sugar } \\
\text { in } \\
\text { beet. }\end{array}$ & $\begin{array}{l}\text { Purity } \\
\text { coetti- } \\
\text { ciont. }\end{array}$ & $\begin{array}{l}\text { Num- } \\
\text { ber of } \\
\text { sam- } \\
\text { ples. }\end{array}$ & $\begin{array}{c}\text { A ver- } \\
\text { age } \\
\text { weight. }\end{array}$ & $\begin{array}{c}\text { Sugar } \\
\text { in } \\
\text { beet. }\end{array}$ & $\begin{array}{l}\text { Purity } \\
\text { coeffi- } \\
\text { cient. }\end{array}$ \\
\hline Alahama .. & I893 & $\underline{\cdots}: \underline{=}$ & $\begin{array}{l}\text { Ounces. } \\
\cdots\end{array}$ & $\begin{array}{r}\text { Per ct. } \\
5.9 \\
\end{array}$ & 66.7 & & $\begin{array}{l}\text { Ounces. } \\
\ldots\end{array}$ & $\begin{array}{l}\text { Peret. } \\
\cdots\end{array}$ & \\
\hline Arizona...... & 1891 & $\frac{2}{7}$ & $\begin{array}{l}51 \\
23\end{array}$ & $\begin{array}{l}7.7 \\
9.3\end{array}$ & $\begin{array}{l}56.9 \\
70.4\end{array}$ & 157 & & $a 8.1$ & 61.8 \\
\hline Average & |...... & 9 & 29 & 9.0 & 67.4 & 157 & & 8.1 & 61.8 \\
\hline Arkansas .. & $\begin{array}{l}1891 \\
1892 \\
1897\end{array}$ & \begin{tabular}{l|l}
2 \\
3 \\
2
\end{tabular} & $\begin{array}{l}40 \\
12 \\
18\end{array}$ & $\begin{array}{r}6.4 \\
9.4 \\
11.3\end{array}$ & $\begin{array}{l}58.8 \\
64.7 \\
71.5\end{array}$ & & & & $\begin{array}{l}\cdots . \\
\cdots . . \\
\cdots\end{array}$ \\
\hline Average. & ....... & 7 & 22 & 9.1 & 65.0 & ..... & & & 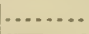 \\
\hline California.... & $\begin{array}{l}1881 \\
1888 \\
1889 \\
1890 \\
1891 \\
1892 \\
1892 \\
1894 \\
1895 \\
1896 \\
\mathbf{1} 897\end{array}$ & 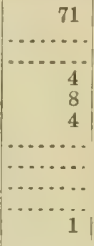 & $\begin{array}{c}19 \\
\ldots \ldots \\
13 \\
48 \\
14\end{array}$ & $\begin{array}{r}13.7 \\
\cdots \ldots . . \\
\cdots 14.7 \\
11.1 \\
14.7\end{array}$ & \begin{tabular}{c}
85.3 \\
$\ldots \ldots$. \\
\hdashline$\ldots .$. \\
84.6 \\
75.8 \\
77.6
\end{tabular} & $\begin{array}{r}5 \\
14 \\
18 \\
\ldots . . . \\
\ldots . .\end{array}$ & $\begin{array}{c}19 \\
17 \\
\cdots \ldots\end{array}$ & $\begin{array}{r}10.7 \\
12.1 \\
10.7 \\
b 13.0 \\
b 14.0 \\
b 14.0 \\
b 15.0 \\
b 15.0 \\
b 14.0\end{array}$ & $\begin{array}{l}77.7 \\
73.0\end{array}$ \\
\hline$\Delta$ verago & ........ & 88 & $21 !$ & 13.6 & 85.3 & 37 & 18 & 11.2 & $=$ \\
\hline Colorato & $\begin{array}{l}1848 \\
1889 \\
1890 \\
1891 \\
1892 \\
1893 \\
1897\end{array}$ & $\begin{array}{r}29 \\
51 \\
170 \\
18 \\
174\end{array}$ & $\begin{array}{l}20 \\
26 \\
18 \\
17 \\
20\end{array}$ & $\begin{array}{l}12.5 \\
13.1 \\
14.8 \\
13.2 \\
13.6\end{array}$ & $\begin{array}{l}76.1 \\
76.1 \\
81.7 \\
74.9 \\
76.7\end{array}$ & $\begin{array}{r}37 \\
73 \\
4 \\
16 \\
12\end{array}$ & $\begin{array}{r}25 \\
\ldots \ldots \\
\hdashline \\
\hdashline\end{array}$ & \begin{tabular}{r}
9.9 \\
10.2 \\
11.0 \\
$* 13.5$ \\
$* 13.8$ \\
\hdashline 17.3 \\
14.3
\end{tabular} & $\begin{array}{l}83.0 \\
79.3 \\
80.6 \\
79.7\end{array}$ \\
\hline A rerage .. & ....... & 442 & 20 & 13.9 & 78.4 & 142 & 25 & 11.5 & 82.1 \\
\hline Connecticut.... & $\begin{array}{l}1890 \\
1891\end{array}$ & $\stackrel{2}{5}$ & $\begin{array}{l}14 \\
27\end{array}$ & $\begin{array}{r}9.7 \\
10.8\end{array}$ & $\begin{array}{l}76.1 \\
77.3\end{array}$ & & & & \\
\hline Average ... & $\ldots$ & 7 & 23 & 10.5 & 77.0 & ......... & $\ldots \ldots$ & $\ldots \ldots$ & $\ldots$ \\
\hline Georgia.......... & 1891 & 2 & 12 & 11.1 & 64.9 & n...... & $\cdots$ & & .. \\
\hline Idaho.... & $\begin{array}{l}1890 \\
1891 \\
1892 \\
1893 \\
1894 \\
1895 \\
1896 \\
1897\end{array}$ & $\begin{array}{r}1 \\
1 \\
2 \\
2 \\
\cdots \ldots . . \\
\cdots \\
7\end{array}$ & $\begin{array}{r}4 \\
15 \\
34 \\
78 \\
\ldots . \\
\cdots \\
21\end{array}$ & \begin{tabular}{r}
8.0 \\
12.7 \\
14.7 \\
10.2 \\
\hdashline$\ldots . .$. \\
$\ldots . .$. \\
15.5
\end{tabular} & \begin{tabular}{r}
68.3 \\
74.9 \\
79.1 \\
76.2 \\
\hdashline$\ldots .$. \\
\hdashline 79.4 \\
\hdashline $7 . .$. \\
79.4
\end{tabular} & $\begin{array}{r}192 \\
342 \\
60 \\
41\end{array}$ & $\begin{array}{c}\cdots \\
\cdots \ldots \\
\cdots \\
\cdots\end{array}$ & $\begin{array}{l}13.7 \\
15.2 \\
14.2 \\
15.2\end{array}$ & $\begin{array}{l}76.1 \\
79.9 \\
77.3 \\
87.6\end{array}$ \\
\hline Average .. & ... & 13 & 30 & 13.8 & 77.6 & 635 & ..... & 14.6 & 80.2 \\
\hline
\end{tabular}

* The sign * indicates that the number given is $0.95 \times$ per cent of sugar reported since it wras doubt. ful whether the per cent of sugar was expressed in terms of the weight of the juice or that of the beet. thongh probalily the former.

a Analyses of Kleinwanzlebener only show : 32 samples, sugar 11.8, purity 73.6.

$b$ From report made on the total crop by the Chino Valley Beet Sugar Company. 
Analyses of sugar beets grown in various States-Continued.

\begin{tabular}{|c|c|c|c|c|c|c|c|c|c|}
\hline \multirow[b]{2}{*}{ Statc. } & \multicolumn{5}{|c|}{$\begin{array}{l}\text { Analyses by the United States De. } \\
\text { partment of Agriculture. }\end{array}$} & \multicolumn{4}{|c|}{$\begin{array}{c}\text { Analyses by the State experi- } \\
\text { ment stations. }\end{array}$} \\
\hline & Year. & $\begin{array}{l}\text { Num- } \\
\text { ber of } \\
\text { sam- } \\
\text { ples. }\end{array}$ & $\begin{array}{c}\text { Aver. } \\
\text { age } \\
\text { weight. }\end{array}$ & $\begin{array}{c}\text { Sugar } \\
\text { in } \\
\text { beet. }\end{array}$ & $\begin{array}{l}\text { Purity } \\
\text { coefti- } \\
\text { cient. }\end{array}$ & $\begin{array}{l}\text { Nim- } \\
\text { ber of } \\
\text { sam- } \\
\text { ples. }\end{array}$ & $\begin{array}{c}\text { Aver. } \\
\text { age } \\
\text { weight. }\end{array}$ & $\begin{array}{c}\text { Sugar } \\
\text { in } \\
\text { beet. }\end{array}$ & $\begin{array}{l}\text { Purity } \\
\text { coefti- } \\
\text { cient. }\end{array}$ \\
\hline Illinois..... & $\begin{array}{l}1890 \\
1891 \\
1892 \\
1897\end{array}$ & $\begin{array}{r}8 \\
36 \\
59 \\
32\end{array}$ & $\begin{array}{r}\text { Ounces. } \\
31 \\
32 \\
15 \\
17\end{array}$ & $\begin{array}{r}\text { Perct } \\
10.3 \\
11.7 \\
10.9 \\
13.1\end{array}$ & $\begin{array}{l}72.1 \\
76.4 \\
75.2 \\
75.5\end{array}$ & $\begin{array}{r}\ldots \\
\cdots \\
\cdots \\
312\end{array}$ & $\begin{array}{c}\text { Ounces. } \\
\ldots \ldots \\
\ldots \ldots \\
20\end{array}$ & $\begin{array}{c}\text { Perct. } \\
\cdots \\
\cdots \\
11.9\end{array}$ & $\begin{array}{r}\cdots \\
76.4\end{array}$ \\
\hline A verage ................. & $\ldots \ldots$ & 135 & 21 & 11.6 & 75.4 & 312 & 20 & 11.9 & 76.4 \\
\hline Indiana.... & $\begin{array}{l}1898 \\
1889 \\
1890 \\
1891 \\
1892 \\
1893 \\
1894 \\
1897\end{array}$ & $\begin{array}{r}56 \\
77 \\
57 \\
4 \\
103\end{array}$ & $\mid \begin{array}{r}\ldots \\
23 \\
27 \\
14 \\
10 \\
14\end{array}$ & $\begin{array}{r}10.7 \\
11.6 \\
11.2 \\
10.7 \\
13.1\end{array}$ & $\begin{array}{r}72.7 \\
76.9 \\
72.5 \\
73.1 \\
78.9\end{array}$ & $\begin{array}{r}5 \\
10 \\
26 \\
131 \\
95 \\
49 \\
81 \\
205\end{array}$ & $\begin{array}{r}7 \\
a 20 \\
12 \\
12 \\
25 \\
18\end{array}$ & $\begin{array}{r}12.2 \\
11.9 \\
9.1 \\
12.0 \\
11.1 \\
11.8 \\
11.8 \\
12.0\end{array}$ & $\begin{array}{r}78.8 \\
76.8 \\
79.3 \\
78.8 \\
\mathbf{8 0 . 7}\end{array}$ \\
\hline Average ............... & $\cdots$ & 297 & 19 & 11.9 & 75.9 & 605 & 17 & 11.7 & 79.2 \\
\hline Indian Territory............ & 1891 & $=$ & 27 & $\underline{=11.6}$ & 76.9 & …...... & …........ & 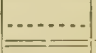 & 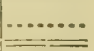 \\
\hline Iowa....................... & $\begin{array}{l}1888 \\
1889 \\
1890 \\
1891 \\
1892 \\
1893 \\
1894 \\
1897\end{array}$ & $\begin{array}{r}30 \\
321 \\
30 \\
7 \\
130 \\
1\end{array}$ & $\mid \begin{array}{r}\ldots \\
22 \\
30 \\
24 \\
17 \\
18 \\
18\end{array}$ & $\begin{array}{r}11.8 \\
11.8 \\
10.9 \\
12.8 \\
13.3\end{array}$ & $\begin{array}{r}74.5 \\
75.7 \\
76.2 \\
75.8 \\
73.7\end{array}$ & $\begin{array}{r}4 \\
12 \\
34 \\
503 \\
404 \\
563 \\
150 \\
642 \\
\end{array}$ & $\begin{array}{l}17 \\
34 \\
33 \\
16 \\
21 \\
19 \\
19 \\
19 \\
\end{array}$ & $\begin{array}{r}11.9 \\
9.9 \\
10.7 \\
12.1 \\
11.6 \\
11.9 \\
11.5 \\
12.4\end{array}$ & $\begin{array}{l}76.5 \\
64.9 \\
71.4 \\
74.0 \\
72.9 \\
76.1 \\
74.9 \\
76.6\end{array}$ \\
\hline Average ............... & $\cdots \cdots$ & 518 & 26 & 12.1 & 75.2 & 2,312 & 19 & 12.0 & 75.0 \\
\hline 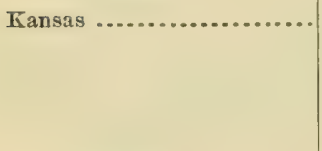 & $\begin{array}{l}1889 \\
1890 \\
1891 \\
1892 \\
1893 \\
1897\end{array}$ & $\begin{array}{r}22 \\
36 \\
22 \\
1 \\
41\end{array}$ & $\begin{array}{r}32 \\
33 \\
25 \\
27 \\
\end{array}$ & $\begin{array}{r}8.3 \\
10.7 \\
11.1 \\
14.3 \\
11.4\end{array}$ & $\begin{array}{l}69.3 \\
68.2 \\
74.2 \\
72.8 \\
73.8 \\
\end{array}$ & $\begin{array}{r}7 \\
16 \\
183 \\
115 \\
22 \\
158\end{array}$ & $\begin{array}{r}31 \\
19 \\
21 \\
21 \\
17 \\
\end{array}$ & $\begin{array}{r}8.9 \\
7.9 \\
9.6 \\
10.2 \\
10.1 \\
11.9\end{array}$ & $\begin{array}{r}69.7 \\
70.6 \\
73.4 \\
71.8 \\
77.0\end{array}$ \\
\hline Average $\ldots \ldots . . . . . .$. & $\cdots \cdots$ & 122 & 29 & 10.6 & 71.4 & 501 & 19 & 10.4 & 73.4 \\
\hline Kentucky......... & $\begin{array}{l}1891 \\
1892 \\
1897\end{array}$ & $\begin{array}{l}3 \\
4 \\
6\end{array}$ & $\begin{array}{l}34 \\
13 \\
16\end{array}$ & $\begin{array}{r}9.1 \\
8.9 \\
11.9\end{array}$ & $\begin{array}{l}63.7 \\
77.2 \\
71.5\end{array}$ & \begin{tabular}{|r|}
$\ldots \ldots \ldots$ \\
$\cdots \ldots \ldots$ \\
$\cdots \ldots \ldots$
\end{tabular} & \begin{tabular}{|l|}
$\ldots \ldots \ldots$ \\
$\cdots \ldots \ldots$ \\
$\cdots \ldots \ldots$ \\
\end{tabular} & $\mid \begin{array}{c}\ldots \ldots \ldots \\
\ldots \ldots \ldots \\
\cdots \ldots \ldots\end{array}$ & $\begin{array}{l}\ldots \\
\ldots \\
\ldots \ldots\end{array}$ \\
\hline A verage .............. & ....... & 13 & 19 & 10.3 & 72.2 & $\ldots \ldots \ldots$ & $\underline{\ldots \ldots}$ & $\cdots$ & $=$ \\
\hline Louisiana................ & 1893 & $\underline{3}$ & 12 & 8.9 & 68.3 & $\ldots$ & $\cdots$ & $\underline{\underline{W}}$ & $\ldots$ \\
\hline MIarylaud .................... & $\begin{array}{l}1890 \\
1891 \\
1897\end{array}$ & $\begin{array}{r}83 \\
2 \\
29\end{array}$ & $\begin{array}{l}15 \\
16 \\
19\end{array}$ & $\begin{array}{r}12.2 \\
7.4 \\
11.4\end{array}$ & $\begin{array}{l}79.3 \\
68.5 \\
79.1\end{array}$ & $\begin{array}{r}\quad 5 \\
\ldots \ldots \ldots \\
\ldots \ldots \ldots \\
\end{array}$ & $\begin{array}{r}10 \\
\ldots \ldots \ldots \\
\ldots \ldots \ldots \\
\end{array}$ & $\begin{array}{r}12.2 \\
\ldots \ldots \ldots \\
\ldots \ldots \\
\end{array}$ & $\begin{array}{r}79.7 \\
\ldots \ldots . \\
\ldots \ldots . \\
\end{array}$ \\
\hline A veragis .... & (n...... & 114 & 16 & 11.9 & 79.1 & $\underline{5}$ & 10 & 12.2 & 79.7 \\
\hline MIassachusetts ............ & $\begin{array}{l}1889 \\
1890 \\
1891\end{array}$ & 6 & $\begin{array}{c}\cdots 6 \\
\ldots \\
\end{array}$ & $\begin{array}{r}12.0 \\
\ldots \ldots\end{array}$ & $\begin{array}{r}82.8 \\
\ldots \ldots \\
\end{array}$ & $\begin{array}{r}10 \\
6 \\
6\end{array}$ & $\begin{array}{l}17 \\
17\end{array}$ & $\begin{array}{l}12.2 \\
13.4 \\
13.4\end{array}$ & $\begin{array}{r}677.1 \\
78.1\end{array}$ \\
\hline Average ............. & $\ldots . .$. & 6 & 16 & 12.0 & $=$ & 22 & 17 & 12.8 & $\begin{array}{r}77.6 \\
=\end{array}$ \\
\hline Michigan .... & $\begin{array}{l}1889 \\
1890 \\
1891 \\
1892 \\
1893 \\
1897\end{array}$ & $\begin{array}{r}30 \\
50 \\
71 \\
88 \\
450 \\
\end{array}$ & $\begin{array}{l}31 \\
32 \\
19 \\
15 \\
22 \\
-\end{array}$ & $\begin{array}{l}12.0 \\
12.6 \\
14.1 \\
13.3 \\
14.7\end{array}$ & $\begin{array}{r}7 . . . \\
78.4 \\
83.4 \\
82.1 \\
81.1\end{array}$ & $\begin{array}{r}6 \\
\ldots \ldots \\
229 \\
\ldots \ldots \ldots \\
\ldots \ldots \\
465\end{array}$ & $\begin{array}{r}c 19 \\
\ldots \ldots \ldots \\
\cdots \ldots \ldots \ldots \\
\ldots \ldots \ldots \\
\ldots \ldots \ldots \\
27\end{array}$ & $\begin{array}{r}12.6 \\
13.3 \\
\ldots \ldots . . \\
\cdots \\
16.4\end{array}$ & $\begin{array}{r}\ldots . \\
86.2 \\
\cdots \\
84.0\end{array}$ \\
\hline Average .... & $\cdots$ & 689 & 22 & 14.2 & 81.1 & 700 & 27 & 15.5 & 84.7 \\
\hline
\end{tabular}

a Average weight of 71 samples.

6 Purity of but 1 sample.

c Avorage weight of 2 samples. 
Analyses of sugar beets grown in various States-Continued.

\begin{tabular}{|c|c|c|c|c|c|c|c|c|c|}
\hline \multirow[b]{2}{*}{ State. } & \multicolumn{5}{|c|}{$\begin{array}{c}\text { Aualyses by the United States De. } \\
\text { partment of Agriculture. }\end{array}$} & \multicolumn{4}{|c|}{$\begin{array}{c}\text { Analyses by the State experi- } \\
\text { ment stations. }\end{array}$} \\
\hline & Year. & $\begin{array}{l}\text { Num. } \\
\text { ber of } \\
\text { sam- } \\
\text { ples. }\end{array}$ & $\begin{array}{c}\text { Aver- } \\
\text { age } \\
\text { weight. }\end{array}$ & $\begin{array}{c}\text { Sugar } \\
\text { in } \\
\text { beet. }\end{array}$ & $\begin{array}{l}\text { Purity } \\
\text { coeffi- } \\
\text { cient. }\end{array}$ & $\begin{array}{l}\text { Num. } \\
\text { ber of } \\
\text { sam. } \\
\text { ples. }\end{array}$ & $\begin{array}{c}\text { Aver- } \\
\text { age } \\
\text { weight. }\end{array}$ & $\begin{array}{l}\text { Sugar } \\
\text { in } \\
\text { beet. }\end{array}$ & $\begin{array}{l}\text { Purity } \\
\text { coeffi- } \\
\text { cient. }\end{array}$ \\
\hline Minnesota .... & $\begin{array}{l}1890 \\
1891 \\
1892 \\
1893 \\
1897\end{array}$ & $\begin{array}{r}107 \\
41 \\
22 \\
7 \\
49\end{array}$ & $\begin{array}{r}\text { Ounces. } \\
30 \\
29 \\
29 \\
60 \\
24\end{array}$ & $\begin{array}{r}\text { Per ct. } \\
11.8 \\
12.4 \\
12.2 \\
10.8 \\
11.0\end{array}$ & $\begin{array}{l}75.2 \\
75.7 \\
78.1 \\
70.8 \\
79.2\end{array}$ & $\begin{array}{r}55 \\
467 \\
180 \\
\ldots 143\end{array}$ & $\mid \begin{array}{r}\text { Ounces. } \\
\ldots \ldots \ldots \\
a 23 \\
17 \\
\ldots \ldots \\
17\end{array}$ & $\mid \begin{array}{r}\text { Per ct. } \\
* 12.3 \\
* 13.0 \\
14.3 \\
\ldots 13.1\end{array}$ & $\begin{array}{r}76.5 \\
79.7 \\
85.5 \\
81.8\end{array}$ \\
\hline Average ............ & $\ldots \ldots$ & 226 & 29 & 11.7 & 76.3 & 845 & 19 & 13.2 & 81.1 \\
\hline Missouri ..................... & $\begin{array}{l}1890 \\
1891 \\
189 . \\
1897\end{array}$ & $\begin{array}{r}2 \\
67 \\
13 \\
324\end{array}$ & $\begin{array}{l}21 \\
20 \\
33 \\
20\end{array}$ & $\begin{array}{r}8.4 \\
10.4 \\
8.1 \\
11.7\end{array}$ & $\begin{array}{l}66.7 \\
62.4 \\
63.4 \\
73.5\end{array}$ & $\begin{array}{r}5 \\
59 \\
30 \sharp\end{array}$ & $\begin{array}{r}17 \\
28 \\
2 \ldots \\
26\end{array}$ & $\begin{array}{r}13.4 \\
9.3 \\
\ldots \ldots .6 \\
10.6\end{array}$ & $\begin{array}{r}67.3 \\
71.0\end{array}$ \\
\hline A rerage ............. & - $\cdots$ & 406 & 20 & 11.4 & 71.6 & 368 & 26 & 10.4 & .70 .4 \\
\hline Montana ...................... & $\begin{array}{l}1891 \\
1892 \\
1893 \\
1897\end{array}$ & $\begin{array}{r}35 \\
6 \\
2 \\
4\end{array}$ & $\begin{array}{l}25 \\
22 \\
15 \\
20\end{array}$ & $\begin{array}{l}13.2 \\
10.9 \\
14.3 \\
14.4\end{array}$ & $\begin{array}{l}76.8 \\
72.8 \\
75.0 \\
77.8\end{array}$ & $\begin{array}{r}\cdots \\
\cdots \\
\cdots\end{array}$ & $\begin{array}{r}\cdots \\
\cdots \\
\cdots\end{array}$ & $\begin{array}{r}\cdots \\
\cdots \\
\cdots\end{array}$ & $\begin{array}{r}\cdots \\
77.0\end{array}$ \\
\hline Average .............. & - . . . & 47 & 24 & 13.1 & 76.3 & 70 & 23 & 14.7 & 77.0 \\
\hline Nebraska ................. & $\begin{array}{l}1888 \\
1889 \\
1890 \\
1891 \\
1892 \\
1893 \\
1895 \\
1297\end{array}$ & $\begin{array}{r}269 \\
62 \\
27 \\
8 \\
13\end{array}$ & $\begin{array}{r}\ldots \\
20 \\
35 \\
21 \\
17 \\
\ldots \ldots \\
29\end{array}$ & $\begin{array}{r}11.8 \\
11.7 \\
14.2 \\
10.1 \\
12.9\end{array}$ & $\begin{array}{r}71.9 \\
75.3 \\
79.3 \\
69.7 \\
\ldots \ldots . . \\
76.9\end{array}$ & $\begin{array}{r}9 \\
159 \\
462 \\
218 \\
98 \\
(c) \\
6: 37 \\
106 \\
\end{array}$ & $\begin{array}{r}46 \\
17 \\
623 \\
17 \\
\ldots \ldots \ldots \\
\cdots \ldots \ldots \\
\cdots \ldots \ldots\end{array}$ & $\begin{array}{r}12.7 \\
10.3 \\
* 12.3 \\
12.8 \\
9.8 \\
11.3 \\
12.1 \\
11.7\end{array}$ & $\begin{array}{r}54.5 \\
73.9 \\
77.9 \\
72.4 \\
77.0 \\
76.9 \\
75.0\end{array}$ \\
\hline Average ............. & (...... & 379 & 23 & 12.0 & 73.1 & 1,689 & 22 & 11.9 & 73.7 \\
\hline Nevala ................... & $\begin{array}{l}1891 \\
1892 \\
1893 \\
1894 \\
1895 \\
1896 \\
1897\end{array}$ & $\begin{array}{r}18 \\
81 \\
\ldots \ldots \ldots \\
\ldots \ldots \ldots \\
\ldots \ldots \ldots \\
21 \\
\end{array}$ & 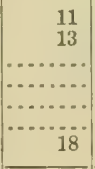 & 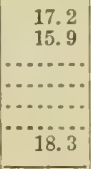 & $\begin{array}{r}88.0 \\
83.4 \\
\ldots \ldots . . \\
\ldots \ldots . . . \\
\ldots . . . \\
81.4 \\
\end{array}$ & $\begin{array}{r}222 \\
221 \\
51 \\
\cdots \\
176 \\
10\end{array}$ & $\begin{array}{r}25 \\
18 \\
20 \\
\ldots \ldots . . \\
\ldots .2 \\
19\end{array}$ & $\begin{array}{r}12.5 \\
14.8 \\
13.6 \\
\ldots \ldots . . \\
13.1 \\
18.9\end{array}$ & $\begin{array}{r}76.9 \\
80.8 \\
80.8 \\
\ldots . .8 \\
d 77.8 \\
\ldots \ldots . . .\end{array}$ \\
\hline Averago ............ & $\cdots \cdots$ & 120 & 14 & 16.5 & 83.7 & 680 & 21 & 13.6 & $\begin{array}{r}78.7 \\
\end{array}$ \\
\hline New Hampshire ............ & 1891 & 1 & 19 & 11.6 & 80.0 & $\ldots$ & $\underline{\underline{ }}$ & $\cdots$ & 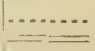 \\
\hline New Jersey .......... & $\begin{array}{l}1891 \\
18 ! 13 \\
1897\end{array}$ & $\begin{array}{r}1 \\
31 \\
\end{array}$ & $\begin{array}{r}17 \\
16 \\
\end{array}$ & $\begin{array}{r}7.3 \\
1.2 .2 \\
\end{array}$ & $\begin{array}{c}70.8 \\
81.4 \\
\end{array}$ & & & ii. 7 & $\begin{array}{r}76.2 \\
\end{array}$ \\
\hline Average .............. & $\ldots \ldots$ & 32 & 16 & 14.0 & 81.1 & 8 & |........ & 11.7 & | 76.2 \\
\hline New Mexico ................ & $\begin{array}{l}1891 \\
1892 \\
1897\end{array}$ & $\begin{array}{r}17 \\
29 \\
3 \\
\end{array}$ & $\begin{array}{l}28 \\
19 \\
13\end{array}$ & $\begin{array}{l}13.8 \\
15.3 \\
17.2\end{array}$ & $\begin{array}{l}74.8 \\
83.2 \\
82.0\end{array}$ & 219 & $\mid \begin{array}{l}\cdots \\
26\end{array}$ & $\begin{array}{r}{ }^{*} 17.0 \\
13.2\end{array}$ & 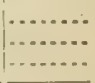 \\
\hline Average ...... & ....... & 49 & 22 & 14.9 & 80.2 & 222 & 26 & 13.3 & $\mid \ldots \ldots . .$. \\
\hline
\end{tabular}

* The sign * indicates that the number given is $0.95 \times$ per cent of surar reported since it was loubt ful whether the per cent of sugar was expressed in terms of the weight of the juice or that of the beet, though probably the former.

a Average weight of 229 samples.

$b$ Average weight of 88 samples.

c Analyses reported by the Standard Cattle Company.

d Averages for 1893 to 1896 , inclusive. 
Analgses of sugar beets grown in various States-Continued.

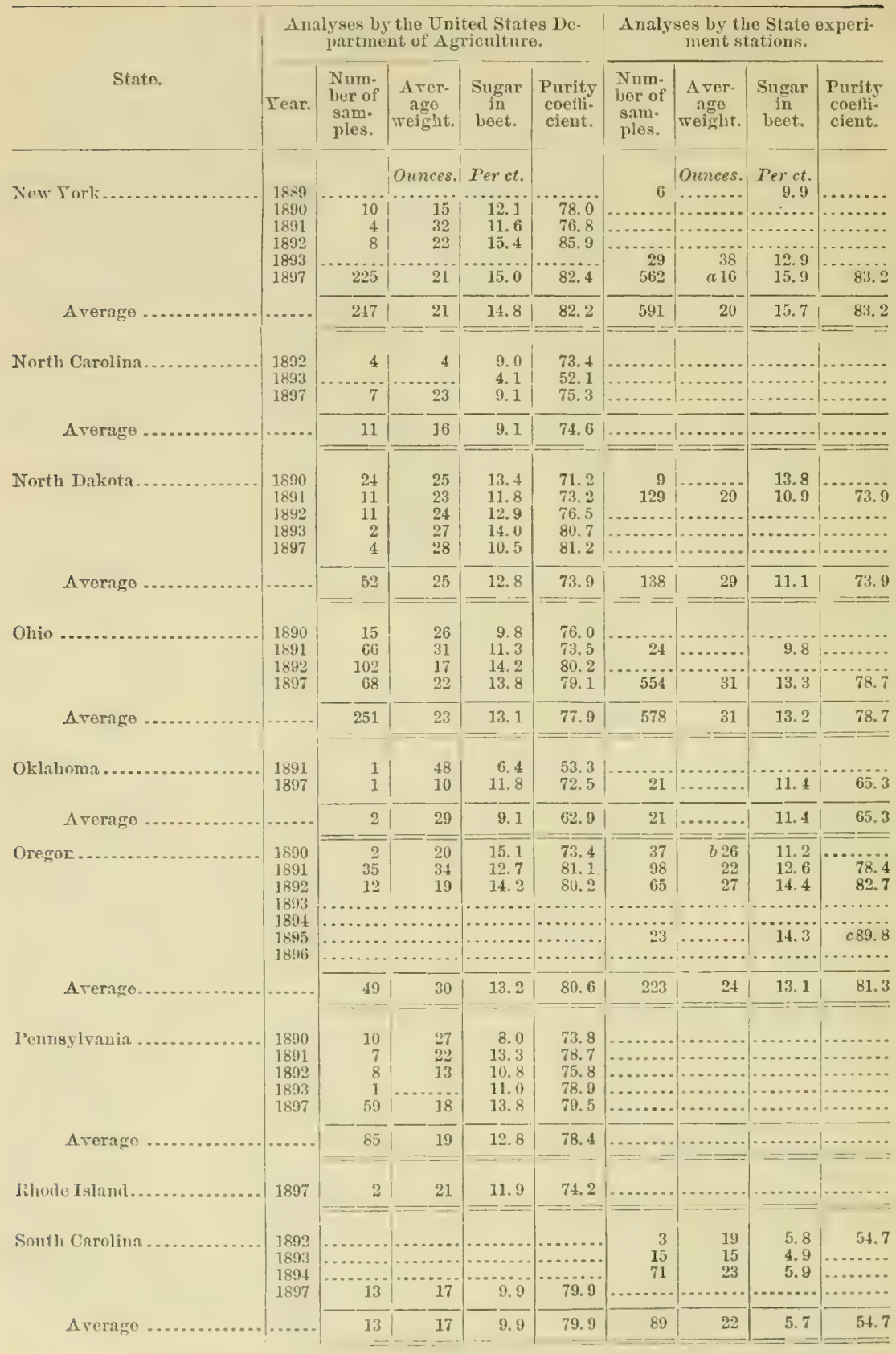

a Average weight of 137 samples. 6 A rerage weight of 2 samples.

o $\Delta$ verages for 1893 to 1896 , inclusive. 
Analyses of sugar beets grown in varions Siates-Continued.

\begin{tabular}{|c|c|c|c|c|c|c|c|c|c|}
\hline \multirow[b]{2}{*}{ State. } & \multicolumn{5}{|c|}{$\begin{array}{l}\text { Analysos by the United States De- } \\
\text { partment of Agriculture. }\end{array}$} & \multicolumn{4}{|c|}{$\begin{array}{l}\text { Analyses by the State experi- } \\
\text { ment stations. }\end{array}$} \\
\hline & Yoar. & $\begin{array}{l}\text { Num- } \\
\text { ber of } \\
\text { sam- } \\
\text { ples. }\end{array}$ & $\begin{array}{c}\text { Aver. } \\
\text { age } \\
\text { weight. }\end{array}$ & $\begin{array}{l}\text { Sugar } \\
\text { in } \\
\text { beet. }\end{array}$ & $\begin{array}{l}\text { Purity } \\
\text { coethi- } \\
\text { cient. }\end{array}$ & $\begin{array}{l}\text { Nume } \\
\text { ber of } \\
\text { sarn. } \\
\text { ples. }\end{array}$ & $\begin{array}{c}\text { Aver- } \\
\text { age } \\
\text { weight. }\end{array}$ & $\begin{array}{c}\text { Sugar } \\
\text { in } \\
\text { beet. }\end{array}$ & $\begin{array}{l}\text { Purity } \\
\text { coetli- } \\
\text { cient. }\end{array}$ \\
\hline 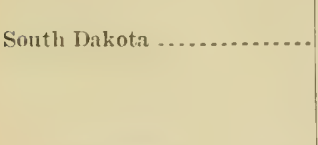 & $\begin{array}{l}1889 \\
1890 \\
1891 \\
1892 \\
1897\end{array}$ & $\begin{array}{r}21 \\
202 \\
67 \\
5\end{array}$ & \begin{tabular}{|r|} 
Onences. \\
-20 \\
22 \\
20 \\
17
\end{tabular} & $\begin{array}{c}\text { Per ct. } \\
13.1 \\
12.5 \\
13.1 \\
15.1\end{array}$ & $\begin{array}{l}78.6 \\
75.3 \\
75.5 \\
83.2\end{array}$ & $\begin{array}{r}17 \\
58 \\
1,264 \\
680 \\
337\end{array}$ & \begin{tabular}{|r|} 
Ounces. \\
$\cdots . . . .$. \\
\hdashline... \\
25 \\
14 \\
14
\end{tabular} & $\begin{array}{r}\text { Per et. } \\
9.1 \\
14.2 \\
11.9 \\
14.2 \\
15.5\end{array}$ & $\begin{array}{r}71.7 \\
73.3 \\
80.7 \\
85.6\end{array}$ \\
\hline Arorage.............. & ........ & 295 & 21 & 12. 7 & 75.7 & 2,356 & 22 & 13.1 & $7 \pi .3$ \\
\hline T'ennessee................... & $\begin{array}{l}1891 \\
1892 \\
1894 \\
1897\end{array}$ & $\begin{array}{r}5 \\
1 \\
17\end{array}$ & $\begin{array}{r}20 \\
10 \\
11\end{array}$ & $\begin{array}{r}8.8 \\
9.4 \\
\ldots . .3 \\
10.8 \\
\end{array}$ & $\begin{array}{r}65.8 \\
72.4 \\
71.9\end{array}$ & $\begin{array}{r}22 \\
8\end{array}$ & $\begin{array}{r}22 \\
4\end{array}$ & $\begin{array}{r}9.5 \\
12.0 \\
\end{array}$ & $\begin{array}{r}75.1 \\
7.2 .\end{array}$ \\
\hline Averago .................. & (...... & 23 & 13 & 10.3 & $\begin{array}{r}70.6 \\
-\quad \\
\end{array}$ & $=$ & $\begin{array}{r}17 \\
\end{array}$ & 10.2 & $\begin{array}{r}75.1 \\
- \\
\end{array}$ \\
\hline Texas ............................ & $\begin{array}{l}1890 \\
1891 \\
1897\end{array}$ & $\begin{array}{r}2 \\
10 \\
11\end{array}$ & $\begin{array}{l}38 \\
23 \\
22\end{array}$ & $\begin{array}{l}10.0 \\
10.3 \\
12.6\end{array}$ & $\begin{array}{l}69.3 \\
69.1 \\
76.5\end{array}$ & 14 & $\begin{array}{r}\ldots \ldots \\
\cdots 4\end{array}$ & 8.0 & 56.3 \\
\hline 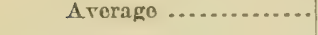 & $\ldots \ldots$ & 23 & 24 & 11.4 & 72.7 & 14 & 34 & 8.0 & 56.3 \\
\hline Utah......... & $\begin{array}{l}1890 \\
1891 \\
1892 \\
1893 \\
1894 \\
1895 \\
1896 \\
1897\end{array}$ & $\begin{array}{l}\ldots \\
\ldots \ldots \\
\ldots \\
\ldots\end{array}$ & 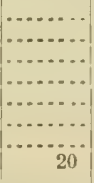 & $\left.\mid \begin{array}{r} \\
\ldots \\
\cdots\end{array}\right]$ & 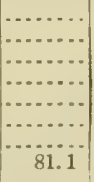 & $\begin{array}{l}21 \\
43\end{array}$ & $\left|\begin{array}{r} \\
\ldots \ldots \\
27 \\
\ldots \ldots \\
\cdots \ldots\end{array}\right|$ & $\begin{array}{r}15.3 \\
a 1.1 .0 \\
\times 12.5 \\
a 11.6 \\
a 12.7 \\
a 13.5 \\
a 13.9 \\
\ldots \ldots . . .\end{array}$ & $\begin{array}{r}86.1 \\
80.0 \\
82.2 \\
79.5 \\
80.2 \\
81.5 \\
81.8 \\
\end{array}$ \\
\hline . Average .................... & $\mid \ldots \ldots$ & 35 & 20 & 14.3 & 81.1 & 64 & 27 & 13.4 & 83.5 \\
\hline Vermont .................... = & 1897 & 8 & 22 & 14.2 & 84.1 & 32 & 17 & 16.3 & 81.2 \\
\hline 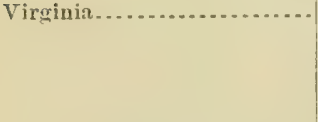 & $\begin{array}{l}1890 \\
1891 \\
1892 \\
1893 \\
1897\end{array}$ & $\begin{array}{l}20 \\
72 \\
13 \\
14 \\
34\end{array}$ & $\begin{array}{l}15 \\
21 \\
12 \\
16 \\
21\end{array}$ & $\begin{array}{l}10.8 \\
11.1 \\
12.0 \\
13.3 \\
11.6\end{array}$ & $\begin{array}{l}74.0 \\
76.0 \\
79.6 \\
83.9 \\
76.2\end{array}$ & $\begin{array}{l}\cdots \\
\cdots\end{array}$ & $\mid \begin{array}{r}\ldots \\
\cdots \\
\cdots \\
\cdots\end{array}$ & 11.6 & 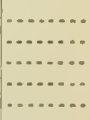 \\
\hline Average .............. & $\cdots \cdots$ & 153 & 19 & 11.4 & 76.8 & 5 & 21 & 11.6 & $\ldots \ldots$ \\
\hline Washington......... & $\begin{array}{l}1890 \\
1891 \\
1892 \\
1893 \\
1894 \\
1895 \\
1896 \\
1897\end{array}$ & $\begin{array}{r}1 \\
11 \\
31 \\
183 \\
\ldots \ldots \ldots \\
\ldots \ldots \ldots \\
\ldots . \ldots\end{array}$ & \begin{tabular}{r}
16 \\
18 \\
18 \\
28 \\
$\ldots \ldots \ldots$ \\
\hdashline$\ldots \ldots \ldots$ \\
27
\end{tabular} & $\begin{array}{r}15.2 \\
14.5 \\
14.5 \\
12.3 \\
\ldots \ldots . . \\
\ldots \ldots \ldots \\
13.7\end{array}$ & $\begin{array}{r}84.2 \\
83.9 \\
76.8 \\
74.0 \\
\ldots \ldots . . \\
\ldots \ldots . . \\
\ldots .7\end{array}$ & $\begin{array}{r}\ldots \ldots \ldots \\
\ldots \ldots \ldots \\
1,666 \\
5 \div 1 \\
211 \\
60\end{array}$ & 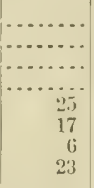 & $\begin{array}{r}13.5 \\
16.2 \\
13.4 \\
13.6\end{array}$ & $\begin{array}{r}83.6 \\
87.9 \\
80.9 \\
75.7\end{array}$ \\
\hline Average ........ & $\mid \cdots \ldots$ & 260 & 26 & 12.8 & 75.7 & 2,458 & 22 & 14.1 & 83.4 \\
\hline West'Virginia. & $\begin{array}{l}1892 \\
1897\end{array}$ & $\begin{array}{l}12 \\
14\end{array}$ & $\begin{array}{l}14 \\
19\end{array}$ & $\begin{array}{l}11.3 \\
15.4\end{array}$ & $\begin{array}{l}68.5 \\
80.4\end{array}$ & & $\ldots$ & & \\
\hline Average & 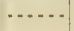 & 26 & 17 & 13.5 & 74.9 & -. & ......... & ......... & ......... \\
\hline
\end{tabular}

* The sign * indicates that the number given is $0.95 \times$ per cent of sugar reported since it was doubt. ful whether the per cent of sugar was expressed in terms of the weight of the juice or that of the beet, thougli probably the former.

a Report made on total erop by Utah Sugar Company, 1891-1896.

b Average weight (net) estimated from average gross weight. 
Analyses of sugar beels grown in various States-Continued.

\begin{tabular}{|c|c|c|c|c|c|c|c|c|c|}
\hline \multirow[b]{2}{*}{ State. } & \multicolumn{5}{|c|}{$\begin{array}{c}\text { Analyses by the United States De. } \\
\text { partment of Agriculture. }\end{array}$} & \multicolumn{4}{|c|}{$\begin{array}{l}\text { Analyses by the State experi- } \\
\text { ment stations. }\end{array}$} \\
\hline & Year & $\begin{array}{l}\text { Num. } \\
\text { ber of } \\
\text { sam- } \\
\text { ples. }\end{array}$ & $\begin{array}{c}\text { Aver- } \\
\text { age } \\
\text { weight. }\end{array}$ & $\begin{array}{c}\text { Sugar } \\
\text { in } \\
\text { beet. }\end{array}$ & $\begin{array}{l}\text { Purity } \\
\text { cueftl. } \\
\text { cient. }\end{array}$ & $\begin{array}{l}\text { Num- } \\
\text { ber of } \\
\text { sam- } \\
\text { ples. }\end{array}$ & $\begin{array}{c}\text { Aver- } \\
\text { age } \\
\text { weight. }\end{array}$ & $\begin{array}{c}\text { Sugar } \\
\text { iil } \\
\text { beet. }\end{array}$ & $\begin{array}{l}\text { Purity } \\
\text { coeffl- } \\
\text { cient. }\end{array}$ \\
\hline Wisconsin & $\begin{array}{l}1890 \\
1891 \\
1892 \\
1897\end{array}$ & $\begin{array}{r}10 \\
432 \\
21 \\
42 \\
\end{array}$ & $\begin{array}{c}\text { Ounces. } \\
21 \\
26 \\
22 \\
15\end{array}$ & $\begin{array}{r}\text { Per ct. } \\
12.8 \\
11.1 \\
12.7 \\
15.8\end{array}$ & $\begin{array}{l}81.3 \\
75.8 \\
77.8 \\
83.3\end{array}$ & $\begin{array}{r}94 \\
373 \\
61 \\
1,663\end{array}$ & $\begin{array}{r}\text { Ounces. } \\
35 \\
32 \\
26 \\
\ldots . . .\end{array}$ & $\begin{array}{r}\text { Per ct. } \\
11.7 \\
11.9 \\
15.2 \\
12.1\end{array}$ & $\begin{array}{l}76.3 \\
76.2 \\
81.6 \\
74.1\end{array}$ \\
\hline Average & ...... & 505 & 25 & 11.4 & 76.6 & 2,191 & 32 & 12.1 & 74.7 \\
\hline Wyoming - & $\begin{array}{l}\mathbf{1 8 9 0} \\
\mathbf{1 8 9 1} \\
\mathbf{1 8 9 2} \\
\mathbf{1 8 9 3} \\
\mathbf{1 8 9 7}\end{array}$ & $\begin{array}{r}5 \\
18 \\
6 \\
48 \\
34\end{array}$ & $\begin{array}{r}26 \\
12 \\
8 \\
19 \\
19\end{array}$ & $\begin{array}{l}15.1 \\
13.5 \\
15.2 \\
15.9 \\
17.2\end{array}$ & $\begin{array}{l}78.8 \\
78.1 \\
85.2 \\
80.5 \\
82.3\end{array}$ & $\begin{array}{r}55 \\
71 \\
33 \\
\ldots \ldots \\
\end{array}$ & $\begin{array}{r}11 \\
14 \\
\ldots \ldots\end{array}$ & $\begin{array}{r}15.4 \\
15.9 \\
16.2 \\
\cdots\end{array}$ & $\begin{array}{r}77.8 \\
78.7 \\
80.9 \\
\end{array}$ \\
\hline A rerage & $\ldots$ & 111 & 18 & 15.8 & 80.8 & 159 & 13 & 15.8 & 78.8 \\
\hline
\end{tabular}

NOTES ON PRECEDING TABLE.

In a few instances analyses reported to the stations by sugar companies or organizations designed for the promotion of the sugar industry have been included. It is noticeable that in many States but few analyses have been made. In view of this fact, it is well to be cautious in accepting the results of these few analyses as being representative of the beets grown in the State.

The reports from the State of California are especially incomplete. Most of the analyses reported are from data obtained in the laboratory of the Chino Valley Beet Sugar Company. In view of the fact that California has several very large and very successful factories, we do not regard the data included here of great value in judging of the State as a producer of high-grade sugar beets. We have data of factory averages obtained in California representing in some cases more than 100,000 tons of beets, showing that the State produces beets of very high sugar content. Factory averages have been reported this year higher than 15 per cent of sugar in the beets. It will be noticed that in most instances the results obtained by the Department of Agriculture corroborate those obtained in the stations.

A notable exception to this is in the tabulation of the results obtained with beets grown in the State of Washington. The Department of Agriculture, however, has only made about one-tenth as many analyses of Waslington beets as the station. The average of the results of the large number of IVashington beets analyzed shows that this State is destined to be a large producer of sugar.

In many cases the averages are based on very incomplete data, and therefore must not be considered strictly representative of all the results included. In figuring the general averages each anmul average is weighted in proportion to the number of samples it represents. 


\section{INVESTIGATIONS IN SEED PRODUCTION.}

The second line of experiments carried on by the Department of Agriculture during the season of 1897 was devoted especially to the culture of high-grade beets in cooperation with a few of the agricultural experiment stations. The localities selected for the experiments were such as would represent as wide a range as possible of climatic conditions, and be compatible with the time at the disposal of the Chemist of the Department for doing the work, and with the quantity of high-grade seeds on hand. It was not deemed arlvisable to go into the arid regions with these experiments, because it was not possible, in the short time at our disposal, to make proper preparations for the conduct of our work. Under authority of the Secretary of A grienlture the Chemist of the Department made arrangements with the following experiment stations to conduct the work under as nearly as possible identical conditions, except those pertaining to climate:

The agricultural experiment station of New York, at Geneva.

The agricultural experiment station of Indiana, at Lafayette.

The agricultural experiment station of Wisconsin, at Madison.

The agricultural experiment station of Iowa, at Ames.

The agricultural experiment station of Kentucky, at Lexington.

The agricultural experiment station of Tennessee, at Knoxville.

In order that the experiments might be conducted on plots of equal area, each director of the stations mentioned above was furnished with

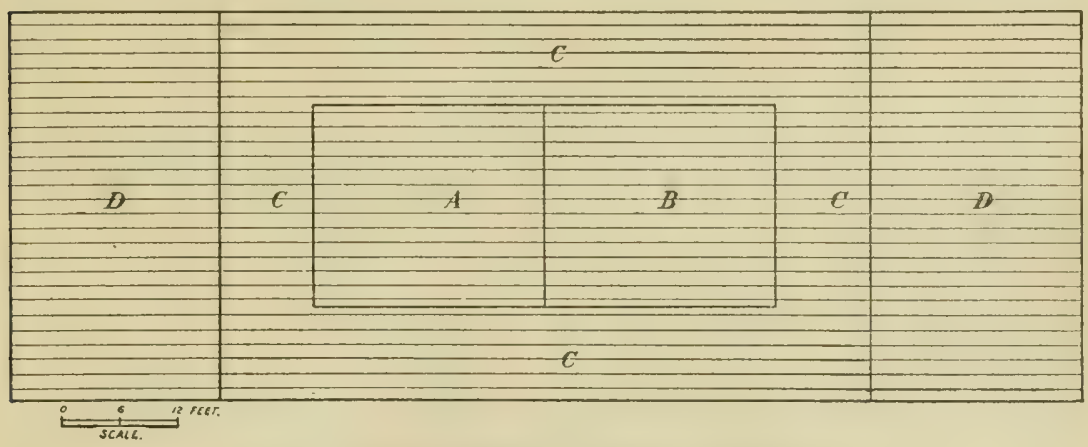

FiG. 2-Plot for guidance in planting sugar beets.

a diagram showing the manner in which it was thonght most advisable to plant the different varieties of seeds. The diagram shown in figure 2 was accompanied by the following descriptive letter:

United States Department of Agriculture, DIVISION OF CHEMISTRX, Washington, D. C., April \$3, $189 \%$.

Dear Srr: For the sake of having complete uniformity in the comparative tests of high-grade beet seeds, I seud herewith a diagram for the purpose of gniding you in the preparation of the plots and in the planting of the seed. 'The object of this diagram is to secure the planting of the high-grade seed in the interior smaller plets AB. each one of which has almost exactly the area of 500 square feet. If preferred the 
size of the interior plots may bo varied so as to make each of them exactly one onolinndredth of an acre, namely, 435.6 square feot. I thlnk it would bo better, however, to lieep the interior plots $\mathrm{AB}$ earh 500 square feet, as they fit the rows as indicated by the horizontal line, allowing exactly 14 rows in the plots, of a total length, including both interior plots, of about 47.6 feet. The interior plots $A B$ are surrounded by a horder CCCC, which is to he planted with the high-yrale commercial seeds which $I$ shall send you. The end plets DD aro to be planted with the same kind of high-grade commercial seeds as CCCC, but these end plots are not necessary to the success of the experiments. The object of the border CCCC is to surround the high-grade seeds AA with beets grown under the same conditions, so that the exterior rows of the plots AA may be subjected to the normal contitions of beet growth, which would not be the case if such small plots were left nuprotected. The scale of these plots is 1 inch=12 feet. I think it is important that the soil of the plots be prepared in accordance with the directions contained in Bulletin No. 52, a copy of which I transmit herewith. The plowing and subsoiling should loosen the ground to a depth of not less than 16, and, better, to a depth of 18 inches, and the surface of the soil, after plowing aud subsoiling, should be reduced to perfect tilth.

I am now awaiting the remainder of the high-grade seeds, which $I$ expect in a few days. There will be two varieties of the high-grade seeds, one to be planted in Plot A and the other in Plot B. All the seeds sent you will be plainly marked, so that no mistake can be made. The quantity of seed required for plots $\mathrm{A}$ and $\mathrm{B}$ will be about 5 oumces. I think it best that the interior plots A and B at least should be planted by hand. The number of secls in the 5 ounces being known, they should be planted in groups at intervals of 9 inches; that is, in such a way as to secure one good, vigorous plant at about every 9 inches in the row after thinning. Five ounces of seed will contain approximately 5,000 seods, aud in the two plots $A$ and $B$ there will he 885 hills, which gives approximately nearly 6 seeds to a hill. In this case the planting would be accomplished as follows: Six seeds placed in the row at distances of 1 inch apart followed by an interval of 3 inches, then again 6 seeds at intervals of 1 inch, and so on. This grouping is shown in the following line:

9 in.

9 in.

Of course the spacing will vary according to the number of seeds to be planted.

If there be anything in connection with the diagram that you do not understand please let me know.

Respectfully,

H. W. Wiley, Chief of Division.

The high-grade seeds furnished for planting the above plots were as follows:

(1) The Vilmorin Improved, grown at the experiment station of the United States Department of Agriculture at Schmyler, Nebr., in 1s93. This station was abolished in the autmm of that year by Secretary Morton, and the principal part of all the high-grade seeds on hand was sold to the Oxnard Beet Sugar Company, of Grand Island, Nebr. A small portion of each variety was retained, however, in the hope that at some day the experiments might be reestablished. When sub. jected to a germination test, however, of all the varieties which had been preserved, only the Tilmorin Improved showed mimpaired vitality. All the other varieties grown at Sehuyler showed a vitality too low to warrant planting.

(2) Original Kleinwanzlebener, grown by Kiilın \& Co., Naarden, near Amsterdam, Holland. These seeds were from specially analyzed mothers, showing the very highest yualities for seed production. 
(3) High-grade commercial seed, grown by F. Demesmay, Cysoing, France. These seeds were not grown from specially analyzed mothers, but represented the high grade commercial seeds produced at that place.

These three varieties were furnished for plunting in Section B. There were also sent at the same time some of the high-grade commercial Kleinwanzlebener and Vilmorin's La Plus Riche for plinting seetions CCCC and DD, as indicated in the diagram. These seeds were sent to the various stations specified above on the 24th of April, 1897. The high-grade seeds which were to be used in planting Section $A$ had not yet been received, and were not forwarded at that time.

The seeds ordered from Europe did not arrive until May 15, aud were sent at once to the several stations on that day. In addition, seeds were received from $\Lambda$ ugust Rülker \& Sons, representing Dippe Brothers, at New York, and from Martin Grashoft, of Quedlinburg. These sceds were also sent for planting the margins of the plot indicated above.

In the general instructions given to the directors of the stations it will be noticed that all the details of the work were left to be decided by them at the proper time, as any directions for time of planting, ete., would be but fintile. Each one of the directors undertook to do the work strictly in accordance with the instructions provided in so far as the preparation of the land, planting, cultivation, and harvesting of the samples were concerned. The Chemist of the Department visited three of the stations duriug the season and couferred personally with the directors in regard to the progress of their work. The other directors were communicated with only by letter.

In the analytical work samples were selected according to instructions and sent to the Department of A griculture, and other's were analyzed in the laboratories of the collaborating experiment stations.

On May 6, the high-grade seeds not yet having arrived from Europe, I sent to each of the stations for planting Section A some high-grade seeds grown by Iartin Grashoff, of Quedlinburg, obtained from Mr. Jellinek, an agent of the grower in this country. I suggested that Section A be planted with this seed, and then if the other seed expected from Germany came in time the plants could be dug out and the section replanted. The name of the seeds sent for planting Section A was White Improved Imperial Elite, which were produced by a cross of another variety with the Kleinwanzlebener. Directions for planting the seeds according to the plot were furnished each dixector.

The additional quantity of high-grade sugar-beet seed ordered from Dippe Brothers, Quedlinburg, Germany, was received and distributed to the stations on the 17th of May. In most cases the beets in Section A which were previonsly planted were not dug out, but the new seeds were planted in other localities.

The conditions of growth varied greatly in the different localities during the season. At the New York station the spring was backward and cold, and the planting and first development of the beets were 
delayed. The subsequent conditions were favorable to good growth. The beets received no backset, and reached a fair maturity by the 1st of October. The autumn was mild and cool, and dry enough to prevent second growth, so that the beets could be left in the ground with perfect security until late in November.

At the Indiana station less favorable conditions obtained. A poor stand of the beets was secured in many instances where a perfect stand was secured at the New York station. The early leaves were barlly eaten by an insect, and this prevented the early rapid development of the plant. Subseruently a period of extreme drought set in, lasting for nearly two months-during July aud August. The result of all these unfavorable conditions was practically a complete failure of the crop, so that even in the case of the beets which were secured there were evidences of arrested develojment. The general result of the experiment was exceedingly discouraging.

At the Wisconsin station the field which was selected for the growth of the beets was not particularly well suited to the purpose. It had not been under previous cultivation for many years, and a portion of it, as is seen in the report of the director, suffered severely from various causes. The special plots which were eultivated in the high-grade seeds gave fairly good results, as will be seen farther on, and the beets produced were of good size, fair shape, and tine quality.

At the Iowa station fairly good seasonal conditions prevailed, and the character of the beets produced on the specially prepared plots was satisfactory.

At the Kentucky station the beets obtained a good start, and grew well for the greater part of the season. They were slightly retarded by dry weather at one period of their growth, but on the whole reached a fair stage of maturity without untoward accidents. The beets which were harvested in September and October showel a higher content of sugar thau those that were left later in the ground, and this is probably due to the second growth, which was produced by the warm climate of that locality. The sugar content was exceedingly low, and the data secured from the station show conclusively that Kentucky is not in the list of possibilities as a sugar-producing State in so far as beets are concerned.

The data from Tennessee are extremely meager, and no definite conclusions can be drawn from those at hand.

In the study of the data received, it will be convenient to begin with the most southern station, namely, Tennessee, and then continue with the Kentucky, Indiana, Iowa, Wisconsin, aud New York stations in the order named.

Tennessee.

The results obtained at the Tennessee station were extremely unsatisfactory. On account of the poor quality of the beets, only one sample was sent for analysis, which was harvested on the 25th of September. These beets were so small as to hardly deserve the name, and no attempt 
was made to determine the purity of the juice. It is evident, from an inspection of the table which follows, that there was nothing in the result of the experiment to justify a further examination of the beets produced.

The cause of failure in Tennessee has been reported by the secretary of the station in the letter given below, and therefore no further explanation need be made here of the failure to attain even farly satisfactory results.

\section{The Agricultural Experiment Station}

OF THE UNIVERSITY OH' 'TENNASSEE, Knoxville, February 15, $189 \%$.

DEAR SIr: A reference to plat sent you May 26, 1897, will explain the following: Sugrar beets grown from seod sown May 19, 20, 1897, were lifted when properly ripe, tops removed and put into separate piles on the ground close by, and covered with earth. In this condition the varions lots remained until taken up to be weighed on 13th of this month. Roots found in good order, and are now being fud to our cows. The weights of the several lots were as fullows:

\begin{tabular}{|c|c|c|c|}
\hline Plat. & Variety and from whence received. & Area. & Weight. \\
\hline Subdivision N........ & $\begin{array}{l}\text { Vilmorin's Improred White, from P. Henderson \& Co., } \\
\text { New York. }\end{array}$ & $S_{q \cdot f t}$ & $\begin{array}{l}\text { Pounds. } \\
175\end{array}$ \\
\hline Subdivision J ... & $\begin{array}{l}\text { Kleinwanzlebener Elite, Dippe Brothers, from Depart- } \\
\text { ment. }\end{array}$ & 589 & 54 \\
\hline Subdivision $\mathrm{D}$. & Vilmorin's, la plus rich, from Department ............ & 1,568 & 280 \\
\hline Subdirision $\mathrm{C}$ - & High grade Kleinwanzlebener, from Department....... & $1,6+2$ & 369 \\
\hline Subdivision $\mathbf{A}$. & $\begin{array}{l}\text { Memte Ober W urst, Quedlinburg, Dippe Brothers, from } \\
\text { Department. }\end{array}$ & 448 & 64.5 \\
\hline Subdirision 8 (2rows). & Original Klein wanzelebener (Holland), from Departmeut. & 64 & 16.5 \\
\hline Subrivision B (3 rows). & Vilmorin's Improved (Sehuyler, Nebr.), from Department. & 96 & 12 \\
\hline Subrtivision B (9 rows): & 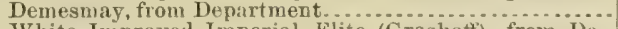 & 288 & 56 \\
\hline \multirow{2}{*}{$\begin{array}{l}\text { Subdivision E (trian. } \\
\text { gle). }\end{array}$} & \multirow[t]{2}{*}{$\begin{array}{l}\text { White Improved Imperial Elite (Grashott), from Do- } \\
\text { partment. }\end{array}$} & 224 & 124.5 \\
\hline & & 5,796 & $1,115.5$ \\
\hline
\end{tabular}

\section{8,715 pounds per acre.}

A miserably poor yield.-Soil prepared in best manner; germination good; when first leaves were formerl an excellent stand. A few days after an incursion of flea beetles destroyed almost every plant in an irregular strip across the whole plat; this was doue between tho hours of $11 \mathrm{a} . \mathrm{m}$. and $3 \mathrm{p} . \mathrm{m}$., in one day. Cultivation was well and thoroughly fone, but the planting was much too late. A plat of Vilmorin's Improved White grown near the farm building, the seed for which was planted April 1, gave us a very heary yield. These were planted for table use and for stock feeding, and were purposely grown to make feed stuff, not for sugar.

Very respectfully, yours,

CiIAS. F. VANDERFORD, Secretary.

Dr. II. IV. WILEY, Chief Dirision of Chemistry, U.S. Department of Agriculture, Washinijton, D.C.

The details of the analytical data are found in the accompanying table of data.

\section{KENTUCKY.}

Special care was taken by the director of the station at Lexington to secure satisfactory results. During the early part of the season the beets grew exceptionally well and presented a fine appearance. The H. Doc. $396-10$ 
guantity produced was fairly good, althongh the beets were somewhat irregular in size, some of them being quite large and ofhers yuite small. The sugar content of the beets and the purity of the juice were both axtremely low. The lirst series of samples was analyzed on the $2 S t h$ of September, and a secomd set of samples from two of the varieties was analyzer at a later date. The original Kleinwanzlebener (Hollaul) seed was represented by thirty-seven beets in this second sample, the average size of which was small and the sugar content medium. The White Improved Imperial Iilite was represented in the second sample by forty-eight beets, also extremely small, and with a low content of sugar. The final harvest of the heets resulted in securing three barrels of beets of fine size and shape, but when these beets were preforated for analysis it was found that the content of sugar was low, falling, in some cases, as low as 2 per cent. The sugar content in general was so small that it was not deemed worth while to report it, as the beets were utterly worthless for seer production. The depressing influence of climate on the character of the beets is illustrated in a most striking manner by a comparison of the results obtained from beets grown in Kenturky and in Geneva, N. Y., from the same seeds, and under as nearly as possible identical conditions of culture.

\section{INDIANA.}

The unfortunate seasonal conditions which obtained at the experiment station at Lafayette have alyearly been mentioned. The result of the prolonged drought during the growing season was a diminution of the weight of the beets to such an extent that for practical purposes they were useless. For this reason the data obtained are of little value. On account of the inferior character of the beets, no attempt was mate to select any of them for mothers for the subseruent production of seed. 'The analytieal data connected with the special plot work in Indiana are found in the tables following.

Iown.

Only one set of samples was receired from the plots grown in Iowa, the sample of the Demesmay having been harrested on the 25th of September and all the other samples on the 13th of November. The average size of the beets received was small, the percentage of sugar only fair, and the purity not up to the minimum standard. The seasonal influences at $\lambda$ mes were therefore evidently inferior in sugarprolucing qualities to those which olstaned in New York. The final harvest of beets was not forwarled to tho Department for the purpose of selecting mothers by leason of a misunderstanding whereby the riflerent variefies were mixel in such a way that the separation of them was impracticable. A general statement in regard to the special 
plot work done at Ames is contined in the following letter from Director Curtiss:

AMEs, IowA, Junuary 25, 1898 .

1)EA SIr: Roplying to your inguiry concerning the test of hiegh-grade sugar-hoet seed furnishod by your l)opartment, will say that wo liave forwarded you two samples of the Vilmorin's Elite from the plats grown aceording to your instructions, and lave lately had your report of tho last sample. The beets from theso plats wero analgzeal by Dr. Weoms, of om chemistry section, with the following results:

\begin{tabular}{|c|c|c|}
\hline Variety. & Sugar. & $\begin{array}{l}\text { Y'urity } \\
\text { eoefficiont }\end{array}$ \\
\hline 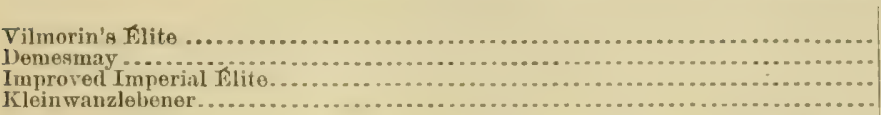 & $\begin{array}{r}\text { Per cent. } \\
16.07 \\
14.30 \\
13.31 \\
16.91\end{array}$ & $\begin{array}{l}84.30 \\
78.38 \\
76.14 \\
90.76\end{array}$ \\
\hline
\end{tabular}

These samples and the one forwarled to you gave substantially the same results aud wero harvested November 11. The first samplo sent you was taken earlier and was probibly immature. The past season was quite baekwart here, and tho beet crop correspondingly lato in maturing. Oving to a chango in onr field-experimont departuent during tho past year, tho beets from these plats were, throngh a misunderstanding, thrown together instead of beiug kopt soparato after tho analysos were made, and we will not be able to distingnish between varieties in testing these beets and carrying on future work along this line. Wo vory much regret that this mistake has occurrod, as wo would like to continuo tho work of developingr high-grade beets for seek production. Wo will bo grlad to cooperate with you arain during the coming season if you can furnish us moro seed.

Very truly, yours,

Dr. H. W. WILEY,

C. F. Cur'tiss.

Washington, D.C.

The analytical data deriver from the analyses of beets sent from the lowa station to this labonatory are of little value. ()uly one set of samples was received, mamely, of the Demesmay variety, harvested on tho 25th of September, and of the three varieties harvested an the listh of November. With the exception of the Vilmorin Elite, which was received on the 220 of $>$ orember, the analytical data are not satisfacetory. In the case of the variety just mentioned the sugar content and the purity were satisfactory, but the beets were very much under size. It is evident that the data obtained in the past soason do not firirly represent the capabilities of Iowa, either for the production of anod commercial bects or for the growth of beets for seerl-proslucing yurposes. 'The analytical data obtained on amalysis of tho samples recerved at the Department are found in the table given farther on.

\section{Wisconsin.}

Complete details of experiments with high-eralle beet seerls, grown under the auspices of the Department of Agriculture, are found in the 
Wisconsin report, contained in Bulletin No. 64 of that station. These details are so valuable as to warrant their reproduction in full:

\section{FXPERLIENTS WITH HIGH-GRADE SUGAR-BEET SEED.}

These experiments were, as already stated, conducted under the anspices of the United States Department of Arriculture. In a letter received in the early part of April last, the chief chemist of the Department, Dr. H. W. Wiley, requested this station to cooperate with the Department in growing a number of varieties of beets from high-gradr seed fumished by them, giring the beets the leest of conditions in respect to subsoiling, preparation of the seed bed, and cultivation. Some of the kinds of seed sent were produced by the highest possible scientific culture from specially analyzed beets, which were stated to arerage 19 per cent of sugar. According to the directions received, the Government plat was surrounded on all sides by our regular beet field and was located in the southeastern quarter of our main field. The different kinds of seed receivet and planted by hand on Miay 22 were as follows:

Plat A.-Dippe Brothers, Vilmorin Ẽlite R I, from Dippe Brothers, Quedlinburg, Germany.

Plat B.-1. Original Kileinwanzlebener, growu by Kiihu, Naarden, Holland. 2. Vilmorin Improved, grown at United States Sugar Beet Station at Schuyler, Nebr. 3. Demesmay sugar-beet seed, grown by F. Demesmay, Cysoing (Nord), France.

Plat C.-High-grale Commercial Kleinwanzlebener.

Plat D.-High-grade Commercial Vilmorin's Improved "La Plus Riche."

White Improved Imperial Elite, grown by Martin Grashoff, Quedlinburg, Germany.

Dippe Brothers, Kleinwanzlebener Elite W I, from Dippe Bros., Quedlinburg, Germany.

The plats were arranged, as suggesterl by Dr. Wiley, in the following manner: Plats A and B, each 21 by 24 feet, were placed in the middle and were surrounded by a borter, CC, 67 feet long and $9 \frac{1}{2}$ feet wide; the plats $\mathrm{D}^{1}$ and $\mathrm{D}^{2}$ were placed at the east and west ends of the C plat, being 21 by 40 feet. South and north of the whole plat three rows were run 110 feet long, in which were planted the varieties given in the precoling statement, White Imperial being planted in the south three rows, and Kleinwanzlebeuer Elite in the north three rows. The rows were 18 inches apart. The effort was to have one good vigorous beet plant at about every 9 inches in the row after thinning.

The germinations of the seed planted in this experiment, as well as of that planter in our other trials, were determined by Professor Goff, and are given on parges $300-$ 301 of our Fourteenth Annual Report. It will be seen that the germinative power of the different kinds of seed was very good, with the possible exception of the Schuyler, Nebr., seed, which was old, and the Dippe Brothers' Vilmorin Elite seed. The average germination of the seed was 167 per cent, ranging from 115 to 231 per cent, the latter result being obtained with the White Improved Imperial Elite.

The first samples of the beets raised on the Government plat were taken September 20; another sample was taken September 27, and after that time every fourteen days nutil the beets were harrested, on November 5. In sampling the beets four beets were ding of each kind. Two of these were forwarded to Washington, D. C., to the Department of Agriculture, and the other two retained for analysis in our own laboratory.

The results of the analyses made by the writer are given in the following table. The $\mathrm{C}^{1}$ samples were taken sonth of the $\mathrm{A}$ and $\mathrm{B}$ plats and the $\mathrm{C}:$ samples north of these plats. In the same manner the $\mathrm{D}^{1}$ and $\mathrm{D}^{2}$ samples were taken from the plats east and west, respectively, of the central plats. 
Main field, Government plat.

\begin{tabular}{|c|c|c|c|c|c|c|}
\hline \multirow[b]{2}{*}{ Variety. } & \multirow{2}{*}{$\begin{array}{l}\text { Date of } \\
\text { sam. } \\
\text { pliug. }\end{array}$} & \multirow{2}{*}{$\begin{array}{c}\text { Per cent } \\
\text { root of } \\
\text { whole } \\
\text { plant. }\end{array}$} & \multirow[b]{2}{*}{$\begin{array}{l}\text { TV eight } \\
\text { of beets. }\end{array}$} & \multicolumn{3}{|c|}{ Analysis of juice. } \\
\hline & & & & $\begin{array}{l}\text { Specific } \\
\text { gravity. }\end{array}$ & Sugar. & \begin{tabular}{|c} 
Purity \\
coeticient
\end{tabular} \\
\hline Iunerial Elite..... & $\begin{array}{l}\text { Sept. } 20 \\
\text { Sept. } 27 \\
\text { (let. } 11 \\
\text { Oet. } 25 \\
\text { Nov. } 5\end{array}$ & $\begin{array}{r}70 \\
70 \\
78 \\
80 \\
\end{array}$ & $\begin{array}{r}\text { Pounds. } \\
0.21 \\
.40 \\
.40 \\
.58 \\
.83\end{array}$ & $\begin{array}{l}\text { 1. } 0755 \\
\text { 1. } 0934 \\
\text { 1. } 0834 \\
\text { 1. } 0858 \\
\text { 1. } 0740\end{array}$ & $\begin{array}{r}\text { Per cent. } \\
14.44 \\
17.92 \\
17.04 \\
16.35 \\
14.35\end{array}$ & $\begin{array}{l}79.1 \\
80.5 \\
85.0 \\
79.4 \\
80.1\end{array}$ \\
\hline Average..... & $\ldots \ldots$ & $\ldots \ldots \ldots$ & .48 & $\ldots$ & 16.02 & 80.8 \\
\hline Vilmoriu La Plus Riche, $\mathrm{D}_{1} \ldots . . .$. & $\begin{array}{l}\text { Supt. } 20 \\
\text { Sept. } 27 \\
\text { Oet. } 11 \\
\text { (let. } 25 \\
\text { Nov. } 5\end{array}$ & $\begin{array}{r}75 \\
73 \\
72 \\
82 \\
\ldots\end{array}$ & $\begin{array}{r}.34 \\
.80 \\
.98 \\
.95 \\
1.20\end{array}$ & $\begin{array}{l}1.0882 \\
1.0423 \\
1.0895 \\
1.0860 \\
1.0882\end{array}$ & $\begin{array}{l}16.96 \\
17.58 \\
17.93 \\
16.40 \\
16.53\end{array}$ & $\begin{array}{l}80.4 \\
79.9 \\
83.8 \\
79.5 \\
78.3\end{array}$ \\
\hline Average... & $\ldots \ldots \ldots$ & ......... & .85 & $\ldots$. & 17.08 & $\overline{80.4}$ \\
\hline High-grade Kleinwanzlebener, $C_{1} \ldots$. & $\begin{array}{l}\text { Sept. } 20 \\
\text { Sept. } 27 \\
\text { Oet. } 11 \\
\text { Oet. } 25 \\
\text { Nov. } 5\end{array}$ & 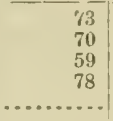 & $\begin{array}{r}.37 \\
.55 \\
.50 \\
.50 \\
1.13\end{array}$ & $\begin{array}{l}1.0825 \\
1.0898 \\
1.0870 \\
1.0810 \\
1.0845\end{array}$ & $\begin{array}{l}16.45 \\
17.21 \\
16.15 \\
14.35 \\
16.90\end{array}$ & $\begin{array}{l}83.0 . \\
80.0 \\
77.5 \\
73.6 \\
83.5\end{array}$ \\
\hline Average......... & $\ldots . .$. & $\ldots \ldots \ldots$ & .61 & $\cdots$ & 16.21 & 79.5 \\
\hline Vilmorin Improved, Nebr., B.......... & $\begin{array}{l}\text { Sept. } 20 \\
\text { Sient. } 27 \\
\text { Oet. } 11 \\
\text { Oet. } 25 \\
\text { Nov. } 5\end{array}$ & $\begin{array}{r}70 \\
76 \\
80 \\
91 \\
\ldots . . .\end{array}$ & $\begin{array}{r}.75 \\
.45 \\
1.13 \\
.75 \\
.71\end{array}$ & $\begin{array}{l}1.0725 \\
1.0810 \\
1.0848 \\
1.0857 \\
1.0800\end{array}$ & $\begin{array}{l}15.06 \\
16.70 \\
17.01 \\
15.86 \\
15.71\end{array}$ & $\begin{array}{l}85.7 \\
85.7 \\
83.6 \\
77.2 \\
81.5\end{array}$ \\
\hline Average ............. & $\ldots \ldots \ldots$ & $\ldots \ldots \ldots$ & .76 & $\cdots$ & 16.07 & 82.7 \\
\hline Original Kleinwanzlebever, Holland, B . & $\begin{array}{l}\text { Sejt. } 20 \\
\text { wejt. } 27 \\
\text { or:t. } 11 \\
\text { Ort. } 25 \\
\text { Nor. } 5\end{array}$ & $\begin{array}{r}68 \\
67 \\
73 \\
73 \\
73\end{array}$ & $\begin{array}{l}.45 \\
.20 \\
.40 \\
.30 \\
.35\end{array}$ & $\begin{array}{l}1.0860 \\
1.0946 \\
1.0935 \\
1.0980 \\
1.0920\end{array}$ & $\begin{array}{l}16.63 \\
18.57 \\
17.95 \\
17.34 \\
18.65\end{array}$ & $\begin{array}{l}80.7 \\
82.4 \\
80.6 \\
74.5 \\
81.8\end{array}$ \\
\hline Average.... & & $\ldots . .$. & .37 & $\ldots \ldots \ldots$ & 17.83 & 80.0 \\
\hline Dippe's Kleinwanzlebener............ & $\begin{array}{l}\text { Sewt. } 20 \\
\text { Sejit. } 27 \\
\text { Oct. } 11 \\
\text { Oct. } 25 \\
\text { Sov. } 5\end{array}$ & \begin{tabular}{c|}
64 \\
68 \\
71 \\
71 \\
\hdashline$\ldots$
\end{tabular} & $\begin{array}{l}.70 \\
.00 \\
.93 \\
.50 \\
.95\end{array}$ & $\begin{array}{l}1.0695 \\
1.08: 36 \\
1.0917 \\
1.1070 \\
1.0812\end{array}$ & $\begin{array}{l}14.57 \\
17.11 \\
18.17 \\
21.45 \\
16.42\end{array}$ & $\begin{array}{l}86.3 \\
85.2 \\
83.0 \\
85.2 \\
84.0\end{array}$ \\
\hline A verage ............... & ......... & $\ldots \ldots \ldots$ & .80 & $\cdots$ & 17.54 & 84.7 \\
\hline Tilmorin's La Plus Riche, $\mathrm{J}_{2} \ldots \ldots \ldots$. . & $\begin{array}{l}\text { Sept. } 20 \\
\text { sept. } 27 \\
\text { Oet. } 11 \\
\text { Oet. } 25 \\
\text { Nov. } 5\end{array}$ & $\begin{array}{l}67 \\
72 \\
73 \\
78 \\
\ldots \ldots\end{array}$ & $\begin{array}{l}1.03 \\
1.15 \\
1.23 \\
1.35 \\
\cdots \ldots\end{array}$ & $\begin{array}{r}1.0735 \\
1.0800 \\
1.0868 \\
1.0917 \\
\ldots . . . . . .\end{array}$ & $\begin{array}{c}16.13 \\
16.90 \\
17.56 \\
18.88 \\
\ldots \ldots \ldots\end{array}$ & $\begin{array}{l}90.6 \\
83.0 \\
84.4 \\
86.3 \\
\ldots . . .\end{array}$ \\
\hline Average..... & ....... & $\ldots$ & 1.19 & $\ldots$ & $\overrightarrow{17.37}$ & 86.1 \\
\hline High-grate Ǩleinwanzlebener, $C_{2} \ldots \ldots . .$. & $\begin{array}{l}\text { Sept. } 20 \\
\text { Sept. } 27 \\
\text { Uct. } 11 \\
\text { Oet. } 25 \\
\text { Nov. } 5\end{array}$ & 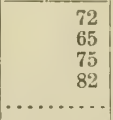 & $\begin{array}{r}1.05 \\
.70 \\
.70 \\
1.30 \\
\cdots \ldots\end{array}$ & $\begin{array}{r}1.0850 \\
1.0842 \\
1.0885 \\
1.0940 \\
\ldots \ldots . . .\end{array}$ & $\begin{array}{l}17.94 \\
16.70 \\
17.57 \\
19.18 \\
\ldots \ldots . .\end{array}$ & $\begin{array}{l}87.9 \\
82.6 \\
83.0 \\
85.7 \\
\ldots \ldots\end{array}$ \\
\hline Averige..... & $\ldots \ldots \ldots$ & $\ldots \ldots \ldots$ & .94 & 1......... & 17.85 & 84.8 \\
\hline Demesmay Imploved, $13 \ldots$ & $\begin{array}{l}\text { Sept. } 20 \\
\text { Sept. } 27 \\
\text { Oct. } 11 \\
\text { Oet. } 25 \\
\text { Nox. } 5\end{array}$ & $\begin{array}{l}76 \\
81 \\
78 \\
89 \\
\cdots\end{array}$ & $\begin{array}{r}.80 \\
.93 \\
1.10 \\
.85 \\
.93\end{array}$ & $\begin{array}{l}1.0655 \\
1.0695 \\
1.0678 \\
1.0798 \\
1.0690\end{array}$ & $\begin{array}{l}13.23 \\
13.49 \\
12.85 \\
15.95 \\
13.66\end{array}$ & $\begin{array}{l}82.8 \\
79.8 \\
77.9 \\
83.0 \\
81.4\end{array}$ \\
\hline Arerage........ & $\ldots \ldots \ldots$ & $\ldots \ldots \ldots$ & .92 & $|\ldots \ldots \ldots|$ & 13.84 & 81.0 \\
\hline Dippe Vilmoris, A. & 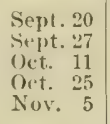 & $\begin{array}{r}63 \\
73 \\
73 \\
82 \\
\quad . \\
\end{array}$ & $\begin{array}{r}.62 \\
1.00 \\
1.10 \\
1.03 \\
.75\end{array}$ & $\begin{array}{l}1.0790 \\
1.0852 \\
1.0895 \\
1.0920 \\
1.0827\end{array}$ & $\begin{array}{l}16.05 \\
16.86 \\
17.49 \\
18.34 \\
16.91\end{array}$ & $\begin{array}{l}84.3 \\
82.5 \\
81.7 \\
83.6 \\
85.1\end{array}$ \\
\hline Average. & & & .90 & & 17.13 & $\overline{83.4}$ \\
\hline
\end{tabular}


We notice that the per cent of sngar in the juice but rarely (amo orer 18 in case of the diflerent varieties, the averiage fignres ringing from 13.84 per cent 'Demesmay) to 17.85 per eent (High-grade Commercial Kleinwanzlebener, $\mathrm{C}_{2}$ ); the purity of the beet juice was good, viz, lowest 79.5 (High-grade Commercial Kkleinwanzlebener, $\mathrm{C}_{1}$ ), highest 86.1 (Vilmorin La Plus Riche, $\mathrm{D}_{2}$ ).

The average results of the analyses of these beets obtained by the Department of Agrieulture and in this laboratory aro given below:

\begin{tabular}{|c|c|c|c|c|}
\hline Determinations made by - & $\begin{array}{l}\text { Number of } \\
\text { analyses. }\end{array}$ & $\begin{array}{l}\text { Polariscope } \\
\text { method. }\end{array}$ & $\begin{array}{l}\text { Alc. ex- } \\
\text { traction } \\
\text { method. }\end{array}$ & $\begin{array}{l}\text { Purity co- } \\
\text { efticient. }\end{array}$ \\
\hline 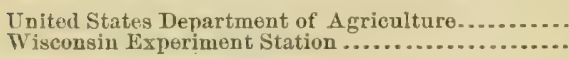 & $\begin{array}{l}38\left(31^{*}\right) \\
38\left(31^{*}\right)\end{array}$ & $\begin{array}{l}16.27 \\
16.09\end{array}$ & 15.13 & $\begin{array}{l}84.7 \\
82.0\end{array}$ \\
\hline
\end{tabular}

* Number of determinations of purity of juice.

While the agreement is as grood a s could be expected between the results obtained by the polariscope method, the purity coefficient liffers rather more than allowable in duplicate samples. The two sets of analyses differ in this way, that the Department of Agriculture samples wero always analyzed at least several days after our analyses were made, since the latter were always finished within twenty-four hours from the time of sampling. In single instances, variations oceurred between the Department of Agriculture and our analyses of 3 per cent of sugar in the juice and of over 7 per cont purity, owing to diflerences in the stage of maturity of the beets analyzed; it is evident that no absolutely correct idea of the sugar content of the beets in a certain plat or field ean he obtained by pulling and analyzng two single beot roots, even if these do appear to be at about average stage of maturity.

The yield of beets from the plat, obtained at larvesting, November 5, and the caleulated yiold of hoots and of sugar per acre, are shown in the following table:

Yield of beels and of sugar, Government plat.

\begin{tabular}{|c|c|c|c|c|c|}
\hline \multirow[b]{2}{*}{ Name of variety. } & \multicolumn{2}{|c|}{ Yield of beets. } & \multirow{2}{*}{$\begin{array}{l}\text { Average } \\
\text { weight } \\
\text { of beets. }\end{array}$} & \multirow{2}{*}{$\begin{array}{l}\text { Sugar in } \\
\text { the beet. }\end{array}$} & \multirow{2}{*}{$\begin{array}{c}\text { Sugar } \\
\text { per acre. }\end{array}$} \\
\hline & $\begin{array}{l}\text { From } \\
\text { plat. }\end{array}$ & Per acre. & & & \\
\hline 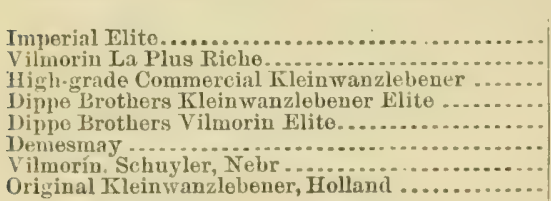 & $\begin{array}{r}\text { Pounds. } \\
272.3 \\
1,167.3 \\
1,170.0 \\
311.7 \\
336.6 \\
234.4 \\
76.7 \\
26.0\end{array}$ & $\begin{array}{r}\text { Pounds. } \\
24,210 \\
28,290 \\
30,660 \\
34,380 \\
29,090 \\
31,520 \\
30,940 \\
15,730\end{array}$ & $\begin{array}{r}\text { Pound.s. } \\
0.45 \\
.64 \\
.56 \\
.66 \\
.58 \\
.61 \\
.59 \\
.27\end{array}$ & $\begin{array}{r}\text { Per cent. } \\
13.63 \\
15.70 \\
16.05 \\
15.60 \\
16.06 \\
12.98 \\
14.92 \\
17.72\end{array}$ & $\begin{array}{r}\text { Pounds. } \\
3,300 \\
4,441 \\
4,920 \\
4,995 \\
4,672 \\
4,092 \\
4,616 \\
2,788\end{array}$ \\
\hline Averages, etc.. & $3,595.0$ & 28,103 & .... & 15.04 & 4,228 \\
\hline
\end{tabular}

The average yield of beets per acre obtained was over 14 tons, or about 5 tons more than the yich obtained from either half of the main fiold. 'The average calenlated yield of sugar per acre was 4,228 pounds, the lowest yield being obtained in case of Original kloinwanzlehener, Holland (2,788 jounds), which varioty planly sulteret most from the droight, and the highest in case of Jippe's likeinwanzlebener Elite ( 1,995 pounds).

ANALYNIS MADE AT THE LABORATORY OF THE DEPARTMFNT OF AGRICUL'T'URE.

Samples of beets from the high-grade plots were sent from time to time to the laboratory of the Department of A grienlture for analysis, and tinally all the remaining beets of proper size were forwarded for 
examination. The following table contains the analyses of the samples received from the various stations of the three separate harvests of beets, ranging from the last of September to the last of October, together with the analyses of all the samples of the high-grade beets harvested in the middle of November:

Table showing analyses of beets of high grade from experiment stations of Tennessee, Kentucky, Indiana, Iowa, Wisconsin, and New York.

KNOX COUNTY, THNN.

[Experiment Station, Knoxville.]

\begin{tabular}{|c|c|c|c|c|c|c|c|c|}
\hline $\begin{array}{l}\text { Serial } \\
\text { Yio. }\end{array}$ & Variety. & $\begin{array}{l}\text { Time of } \\
\text { planting. }\end{array}$ & $\begin{array}{l}\text { Tims of } \\
\text { harrest- } \\
\text { ing. }\end{array}$ & \begin{tabular}{|} 
Date \\
received.
\end{tabular} & $\begin{array}{l}\text { Num- } \\
\text { bex of } \\
\text { beets. }\end{array}$ & $\begin{array}{l}\text { A verage } \\
\text { weight. }\end{array}$ & $\begin{array}{l}\text { Sugar } \\
\text { in the } \\
\text { beets. }\end{array}$ & $\begin{array}{l}\text { Purity } \\
\text { coutti- } \\
\text { cient. }\end{array}$ \\
\hline 200 & White Improved Imperial & 1897. & 1897. & 1897. & & Ounces. & Perct. & \\
\hline 201 & Kleinwanziebener Elite.. & may 24 & $\begin{array}{ll}\text { sept. } 20 \\
\ldots . d 0 \ldots\end{array}$ & sop. & $\begin{array}{l}2 \\
2\end{array}$ & $\begin{array}{l}4 \\
7\end{array}$ & $\begin{array}{l}11.5 \\
10.7\end{array}$ & \\
\hline 203 & $\begin{array}{l}\text { Original Kleinwanzleben- } \\
\text { or (Dippe Brothers) }\end{array}$ & May 18 & ....d & 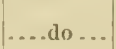 & 2 & 3 & 12.5 & \\
\hline 204 & $\begin{array}{l}\text { Original Klein wanzloben- } \\
\text { er (Holland) }\end{array}$ & & & & 4 & 1 & 12.5 & \\
\hline 206 & $\begin{array}{l}\text { High grade Kleinwanz- } \\
\text { lebener ....................... }\end{array}$ & ..do & ... do & $\ldots 1$ & 21 & 6 & 12.0 & \\
\hline 202 & $\begin{array}{l}\text { Vilmorin's "La PIu } \\
\text { Riebe" }\end{array}$ & . .... & ....(10) & ....n & $=$ & 7 & 10.6 & \\
\hline 205 & Vilmorin's Improved ..... & ....do. & -...do & $\ldots d$ & 5 & 1 & 13.2 & \\
\hline 207 & Demesmay.................. & ... do & .... do & ... do & 3 & 1 & 13.5 & \\
\hline
\end{tabular}

FAYET'IE COUNTY, KY.

[Experiment Station, Lexington.]

\begin{tabular}{|c|c|c|c|c|c|c|c|c|}
\hline & & 1897. & 1897. & 1897. & & & & \\
\hline 285 & $\begin{array}{l}\text { Original Klein wanzleben- } \\
\text { er (Hollaud) }\end{array}$ & & Sept. 27 & Sept. 29 & & 21 & 13.3 & 72.5 \\
\hline $834-870$ & .... do .................... & 1 & Oct. 14 & Oct. 18 & 37 & 7 & 15.8 & \\
\hline 286 & $\begin{array}{l}\text { Vilmorin's Improved } \\
\text { (Schuyler, Nebr.)....... }\end{array}$ & & Sept. 27 & Sept. 29 & & 19 & 10.9 & 68.5 \\
\hline 287 & 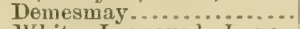 & $\ldots$ & ....do... & ....do .... & $\ldots \ldots$. & 18 & 9.5 & 65.0 \\
\hline 293 & $\begin{array}{l}\text { White Improved Inpe- } \\
\text { rial Elite ...................... }\end{array}$ & $\therefore$ & $\ldots$.... & .... do ... & $\ldots$ & 17 & 10.9 & 68.1 \\
\hline $785-832$ & ..... dlo ..................... & ........ & Oct. 14 & |........... & 48 & 7 & 11.1 & $\ldots \ldots$ \\
\hline
\end{tabular}

TIPPECAYOE COUNTY, IND.

[Experiment Station, Lafayette.]

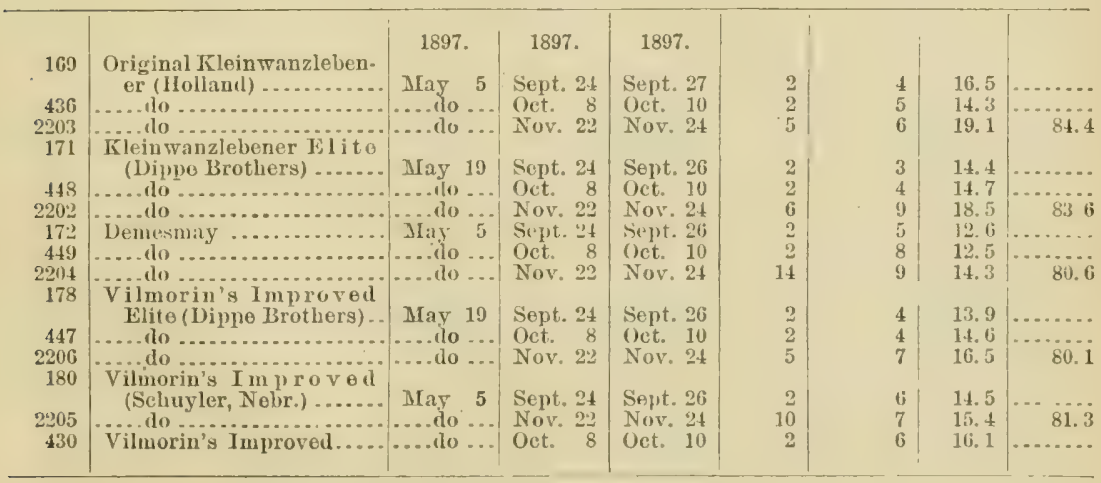


Table showing analyses of beets of high yrade from experimenl stations of Tennessee, fientucky, Indiana, Iowa, Wisconsin, and New York-Contiunerl.

STORY COUNTY, IOWA.

[Experiment Station, Ames.]

\begin{tabular}{|c|c|c|c|c|c|c|c|c|}
\hline $\begin{array}{l}\text { Serial } \\
\text { No. }\end{array}$ & Tariety. & $\begin{array}{l}\text { Tine of } \\
\text { planting. }\end{array}$ & $\begin{array}{l}\text { Time of } \\
\text { Jiarvest. } \\
\text { ing. }\end{array}$ & $\begin{array}{c}\text { Date } \\
\text { receiven. }\end{array}$ & $\begin{array}{l}\text { Num. } \\
\text { ber of } \\
\text { boets. }\end{array}$ & $\begin{array}{l}\text { Average } \\
\text { weiglit. }\end{array}$ & $\begin{array}{l}\text { Sugit } \\
\text { in tho } \\
\text { beets. }\end{array}$ & $\begin{array}{l}\text { Purjty } \\
\text { emefti- } \\
\text { cient. }\end{array}$ \\
\hline 249 & Demesniay & $\begin{array}{l}1897 \\
\operatorname{May} 29\end{array}$ & $\begin{array}{l}1897 . \\
\text { Sept. } 25\end{array}$ & $\begin{array}{l}1897 . \\
\text { Sejt. } 28\end{array}$ & 3 & Ounces. & $\begin{array}{r}\text { Per ct. } \\
13.9\end{array}$ & \\
\hline 2078 & $\begin{array}{l}\text { Whitu Improved Imperial } \\
\text { Elite. }\end{array}$ & & por & & & & & \\
\hline 2088 & Vilmoriu's Impre & ....do ... & ....do ... & ....do. & 2 & 1 & & 72.5 \\
\hline 2099 & Vilmorin's Elito .......... & ..... dlo... & ....do... & .... do ... & 2 & 12 & 17.3 & 82. 6 \\
\hline 9100 & $\begin{array}{l}\text { Original Kleinwanzlebe } \\
\text { ner ........................... }\end{array}$ & .... do & ....do & $\ldots . . . d$ & 2 & 20 & 12.8 & 72.4 \\
\hline
\end{tabular}

DANE COUNTY, WIS.

[Experiment Station, Madison.]

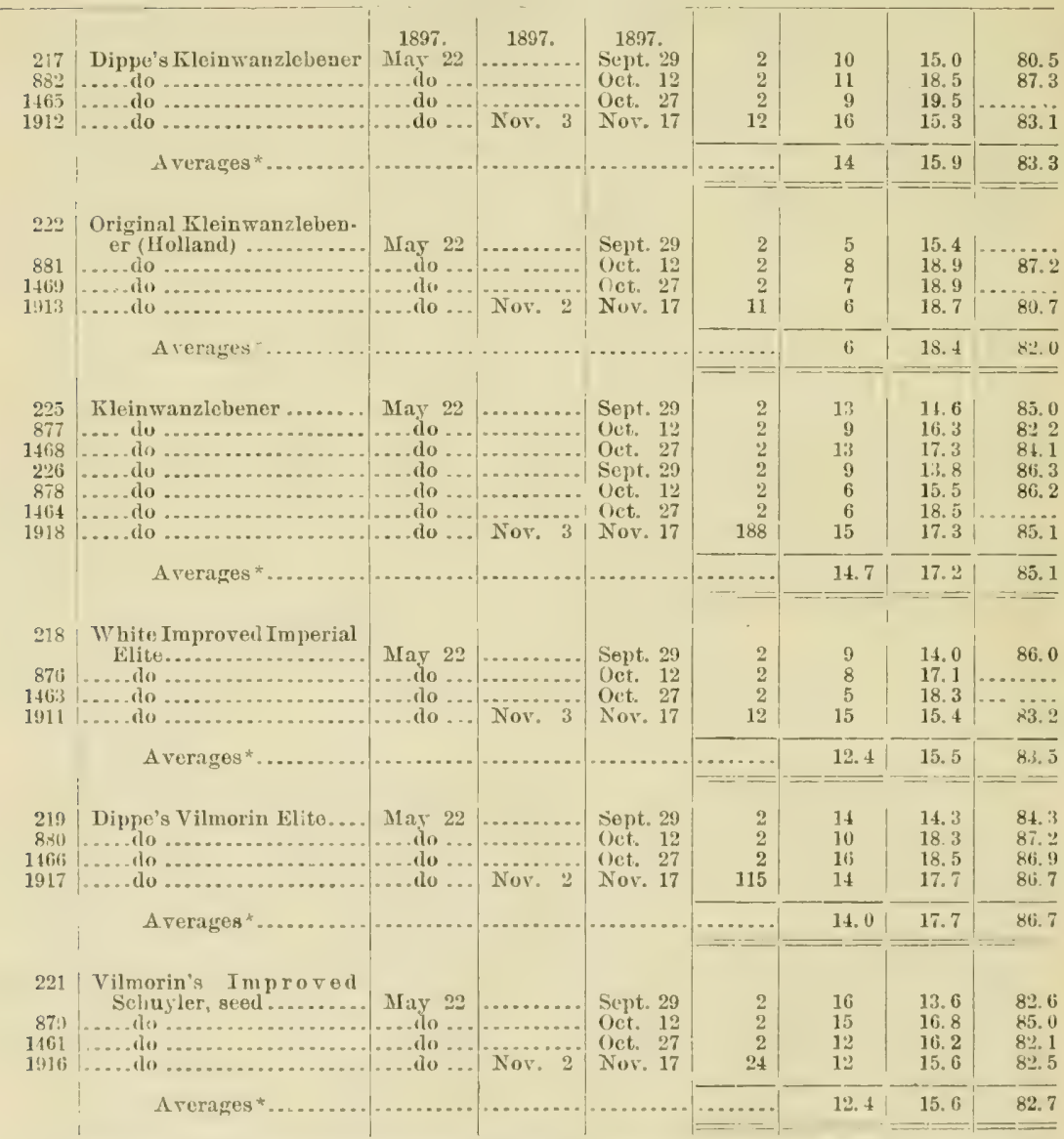

* In figuring the averages, each analysis is valnod in proportion to the weight of the sample. 
Table stowing analyses of be's of high grade fiom experiment stations of Iennesset, fintucky, Indiana, Jowa, Visconsin, and New York-Coutiuned.

DANE COUNTY, WIS.-Contiuled.

\begin{tabular}{|c|c|c|c|c|c|c|c|c|}
\hline $\begin{array}{c}\text { Sierial } \\
\text { Nio. }\end{array}$ & Varicty. & $\begin{array}{l}\text { Time of } \\
\text { planting. }\end{array}$ & $\begin{array}{l}\text { rime of } \\
\text { harvest. } \\
\text { ing. }\end{array}$ & $\begin{array}{c}\text { Date } \\
\text { received. }\end{array}$ & $\begin{array}{l}\text { Num- } \\
\text { bet of } \\
\text { lects. }\end{array}$ & $\begin{array}{l}\text { A verage } \\
\text { weight. }\end{array}$ & $\begin{array}{l}\text { Sugar } \\
\text { inthu } \\
\text { beets. }\end{array}$ & $\begin{array}{l}\text { Yurits } \\
\text { coefli- } \\
\text { cient. }\end{array}$ \\
\hline $\begin{array}{r}223 \\
871 \\
1462 \\
221 \\
875 \\
1167 \\
1915\end{array}$ & 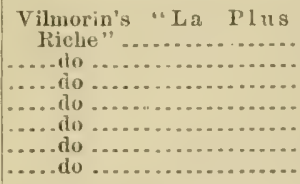 & 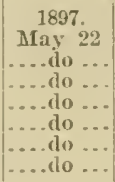 & 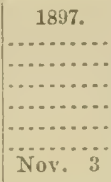 & $\begin{array}{l}1897 . \\
\text { Sept. } 29 \\
\text { Oct. } 12 \\
\text { Oct. } 27 \\
\text { Sept. } 29 \\
\text { Oct. } 12 \\
\text { Oct. } 27 \\
\text { Nor. } 17\end{array}$ & $\begin{array}{r}2 \\
2 \\
2 \\
2 \\
2 \\
2 \\
2 \\
236\end{array}$ & $\begin{array}{c}\text { Ounces. } \\
18 \\
16 \\
12 \\
13 \\
8 \\
10 \\
15\end{array}$ & $\begin{array}{r}\text { Perct. } \\
14.9 \\
17.9 \\
17.6 \\
14.3 \\
19.2 \\
19.0 \\
17.7\end{array}$ & $\begin{array}{r}83.4 \\
88.2 \\
85.2 \\
86.2 \\
85.4 \\
86.7\end{array}$ \\
\hline $\begin{array}{r}220 \\
1470 \\
1914\end{array}$ & 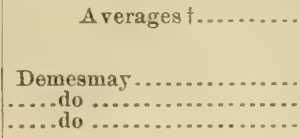 & $\mid \begin{array}{c}\text { May } 22 \\
\ldots \text { do }\end{array}$ & Not. & $\begin{array}{l}\text { Sept. } 29 \\
\text { Oct. } 12 \\
\text { Nov. } 17\end{array}$ & $\begin{array}{r}2 \\
2 \\
91\end{array}$ & $\begin{array}{l}12 \\
12 \\
13\end{array}$ & $\begin{array}{l}13.4 \\
15.0 \\
13.6\end{array}$ & $\begin{array}{l}84.8 \\
83.5 \\
81.0\end{array}$ \\
\hline & Averagest.... & & & & . & 13 & 13.0 & 81.1 \\
\hline
\end{tabular}

ONTARIO COUNTT, N. Y.

[Experiment station, Genera.]

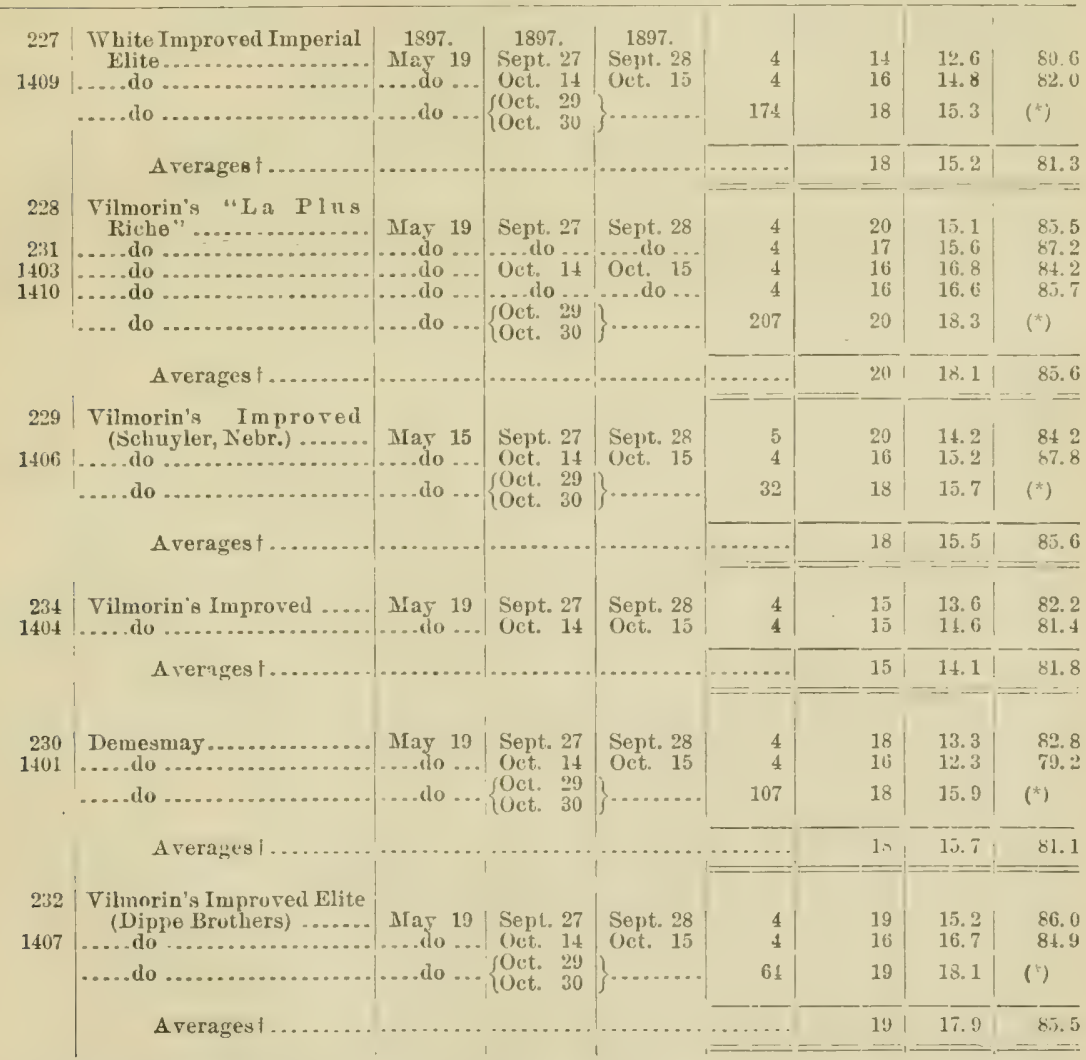

* Not included in areraging the purity coefiicients.

in figuring the averages, each analysis is valuerl in proportion to the woight of the sample it represents. 
Table showing analyses of beets of high grade from experiment stations of Tennessee, Kientucky, Indiana, Iowa, IVisconsin, and New York-Coutiuued.

ON'IARIO COUNTY, N. Y.-Continued.

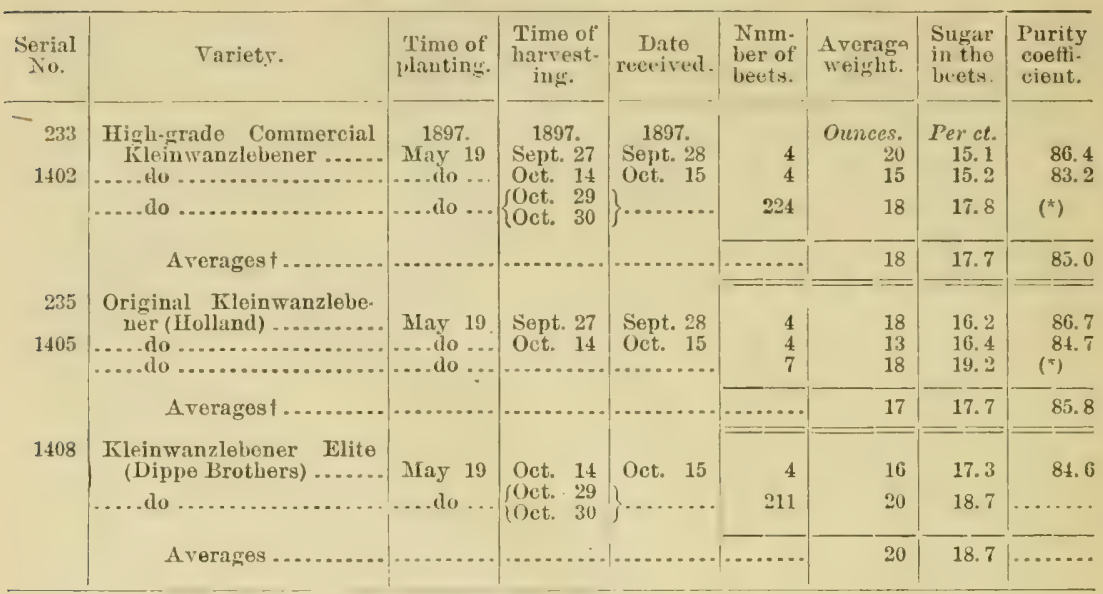

* Not ineluded in averaging the purity coeflicients.

† In figuring the averages, each analysis is valued in proportion to the weight of the sample it represents.

Discussion of abore datu.-No further discussion of the analytical data contained in the above table is necessary, except in the case of the samples received from Wisconsin and New York. These samples were exceptionally fine. By an unfortunate misunderstanding all the beets received frcm Wisconsin were reduced to pulp for the purpose of getting an average sample for analysis. The selection for mother beets was, therefore, confined to the samples from New York.

\section{WISCONSIN.}

AImost uniformly good results were obtained in these experiments. The (riginal Kkleinwanzlebener (Holland) seed prodnced beets, however, too small for all practical purposes, although the stigar content and purity were high. Tho largest beets and those of the inghest purity were produced by the Vilmorin La Plus Riche seed. The I)emesmay seed which were used were only the commereial articie, and were not grown from sipecially analyzed mothers. It is not surprising, therefore, to see that they produced a crop which was the poorest of all in sugar content.

The particular analyses of the most importance are those which were made on the beets received November 17, and harvested on the id of November. These practically represent the beets at their full maturity, as it is not probable that they would improve in ruality in the climate of Natison after the 1 st of November. The analyses also represent the greatest number of beets, and therefore are the most reliable. 'The largest number of beets of proper size and shipre were produced by the Vilmorin Lat Plus liche seed, and the 
smallest by the Original Kleinwanzlebener. The beets grown from the Schuyler seed are of particular interest becanse they represent the link of union between the experiments which were discontinued by the Department in 1893 and reinangurated in 1897. 'The average size of the beets produced by the Schuyler seed is somewhat small, but the content of sugar and the purity are satisfactory. Upon the whole, the effect of high-grade seed and high culture are most distinctly marked. It is only necessary to compare the results obtained in the experiments with these high-grade seeds with those secured in the State at large to show the possibilities of beet production in Wisconsin. With such data before the investigator, it is evident that he must be convinced of the fact that it is possible, with proper conditions of seed and culture, to produce a grale of beets of the highest quality in Wiscousin.

NeW YoRK.

Most satisfactory results were obtained from the experimental work in the State of New York at Geneva. Two sets of samples were received from the station, representing intervals of about two weeks in harvesting, the first set of samples having been harvested on the 27 th of September and the second on the 14th of October. It will be noticed that a marked improvement was secured by postponing the harvest for two weeks, showing that as a rule it is not to be expected that the season for manufacturing in New York should begin before the middle of October. The above table includes also the final harvest, which was made much later in the season, viz, October : $9-30$, aud shows even a greater improvement. The beets from the final harvest were all sent to Washington, and were carefully selected for seed production. The data obtained in this selection are given as the third in the series of analyses. The samples which were grown at the New York station were from seeds of two different qualities: First, commercial seeds, as represented by the Demesmay White Imperial and highgrade commereial Kleinwanzlebener; and, second, seeds grown directly from high-grade mothers, represented by the Vilmorin La P'lus Riche, the Vilmorin Improved (Schnyler), and the Original Kleinwanzlebener. The average size of the beets selected for analysis was not quite 20 ounces; the sugar content in most cases was high, and the purity extremely satisfactory. After leaving the beets unharvested until the end of October they were found to have increased their content of sugar very markedly, as will be shown in the table of analyses for the selection of mothers. The encouraging data obtained at the New York station suggests that if the Department should reestablish its experiment stations for the production of high-grade seeds one of them should be placed in this locality.

In the analysis of the beets to be selected as mothers for producing seeds no attempt was made to determine the coeficient of purity, as the amount of pulp removed was only suficient to determine the 
pereentage of ansar directiy therein. It is evident, however, that the purity coefircients of all the different varieties wonld not lave been diminished ly pridert matarity, so that they may be regarled as fully eyual to the average in each case. In liact, it would be fair to assume that the arerages of the final havest of the most mature beets were slightly above those taken for the average of the three analytical periods of the season. In the discussion of the data obtained by the analysis it must be rememberel that the averages in all cases an o made upou the total weight of the material entering into the aualysis. Not only is this true of each individual sample, but also of the average analyses of the samples. It is evident that this is the owe exact method of obtaining arerago result: and it. is only the averages obtained by such a method that have a convincing value.

\section{DA'A OF EACII VARIETY.}

The White Improved Imperial Élite, grown from commercial seeds gave beets of fair commereial quality. An average weight of 15 ounces, with a content of 15.2 per cent of sugar in the beets and a coefficient of purity of 81.3 , would insure a large yield in a well-built and welloperated factory. From the complete harvest, $17 \pm$ beets were found of the required size, shape, and sugar content to warrant saving for the production of seed. It is evident, however, that this seed would be only of a medium srade commercial quality, and not suited to the improvement of the beet.

Tilmorin La I'lus liche.-This plot gave excellent results throughout. The arerage size of the beets was the largest of auy of the plots growu. The purity coefficients were exceptionally high, and the sugar contents most satisfactory. Two hundred aud seven beets grown on this plot, llaving an average weight of 20 ounces and a mean content of sugar of 1S.3 per cent, were selected for seed production. It is evident that the coefficient of purity of this selection must have been at least 86 . These mothers will therefore prochuce seerls of the highest quality, which can subsequently be planted, growing beets for the production of seeds of exceptional properties.

Tilmorin Tmpnonct, Schuyler Seed.-This variety is chiefly of interest now becanse it represents the continuation of the work in seed production which was discontinued four years ago. The seeds evidently have lost in vitality by their long liecping, and the product, therefore, is not as satisfictory as could have been desired. The average sugar content is not exceptionally ligh, but the purity is excellent. The beets produeed from these seeds in another year will doubtless derelop some exceptionally high-grade mother's, and thus the strain will be continned. This plot represents the sole surviving result of the three years' experiments at Schuyler, commenced in 1890. 'Thirty-two beets, with an average weight of 18 onnces and an arerage content of sugar of 15.7 per cent were put aside for seed production. It is seen, from an 
inspection of the table, that the coefficient of purity of this lot was $S 7$ or more. It therefore represents the highest grade of purity of any of the lots.

rilmorin Improved.-This is a commercial seed, used for planting around the central plots, and has produced a crop of only fitir commercial value.

Demesmay. - This is also a commercial seed, obtained directly from the growers in the north of France, and, as will be secu from an inspection of the table, produced a crop of excellent commercial valne.

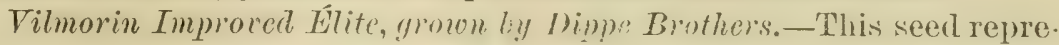
sents the improvement in the strain of the Filmorin beet when cultivated according to the highest scientific principles in Germany. Sixty-fon beets grown on this plot, having an average weight of 19 onnces, were selected for mothers. The mean content of sugar in theso beets was 1S.1. It is evident, also, that the purity was at least sti per cent. This harvest, therefore, represents a very high grade quality of mothers for continuing the improvement.

High-grade Commercial Kleinwanzlebener.-This variety of seen rep). resents the highest grade of commercial seerls offered to tho marlict. The results of culture show that tho temelency of this seer to pronluce rich beets is extremely well marlied. Two hundred and twenty-four beets grown on this plot, with an average weight of 1is onuces, welc selected as mothers. The mean content nf sugar in these beets was 17.s per cent, and the purity, as seen by the table, is evidently high. These high-grade commercial seeds, therefore, produce as stain of beets almost as valuable for sugar moduction as the specially high grade seeds from analyzed mothers.

Original Fleinuanzlebener (Hollant.)-This variety of seed ropresents tho Kleinwanzlebener type as cultivater to the highest degreo in IInlland. The tendency in that country seems to be to the prodnction of a beet of small size and exceptionally high sugur content. Only a fer of these high-grade seeds were planted, and this, together with their small size, accounts for the fact that only seven were selected. Who mean weight of the seren was 18 ounces, the mean content of sugar therein 19.2, and the coeflicient of purity evidently $S \%$ or over. This variety jorluced the highest content of sugar of any cultivated, but on account of the small size is less to be recommended for seneral culti. vation in this country than some of the other varieties.

Kieinwan lebener Thite.-This varity represents the sperially-selected seeds grown by Dippe Brothers. at Quedlinbnig. The bests; grow to a fine size, are of good shape, aud have excellent qualities to recommend them to the manufacturer. Two hundred and eleven of these beets, having an average weight of 20 onnces, wereselected as mothers. The mean content of sugar in these beets was 18.7 per' cent, and the coefit. cient of purity, as will be seen by the table, good. 
CLASSIFICATION OF THE BEETS OF EACH VARIETY.

It will be inferesting to study the distribution of the beets of each variety accorling to sugar content. 'This can be done by means of the following table:

\begin{tabular}{|c|c|c|c|c|c|c|}
\hline \multirow{2}{*}{ Tariety. } & \multicolumn{4}{|c|}{$\begin{array}{l}\text { Number of beets having contents of } \\
\text { sugar from- }\end{array}$} & \multirow{2}{*}{$\begin{array}{c}\text { Maximum } \\
\text { polariza- } \\
\text { tions of } \\
\text { individual } \\
\text { beets. }\end{array}$} & \multirow{2}{*}{$\begin{array}{l}\text { Minimum } \\
\text { polarizat. } \\
\text { tions of } \\
\text { individnal } \\
\text { beets. }\end{array}$} \\
\hline & $\begin{array}{l}15 \text { to } 16 \\
\text { per cent. }\end{array}$ & $\begin{array}{c}16 \text { to } 17 \\
\text { per cont. }\end{array}$ & $\begin{array}{l}17 \text { to } 18 \\
\text { per cent. }\end{array}$ & $\begin{array}{l}18 \text { per } \\
\text { cent and } \\
\text { above. }\end{array}$ & & \\
\hline White Improved Imporial Elito & 65 & 20 & 23 & 4 & $\begin{array}{r}\text { Per cent. } \\
19.6\end{array}$ & Per cent. \\
\hline Vilmorin La Plus Riche ............... & 7 & 16 & 32 & 94 & 23.4 & 13. 4 \\
\hline Vilmorin Improred, Schuyler Seed.. & 4 & 8 & 5 & 3 & 18.8 & 12.4 \\
\hline 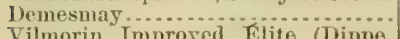 & 11 & 14 & 5 & 40 & 22.0 & 9.6 \\
\hline 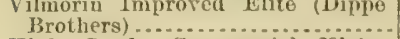 & 1 & 4 & 5 & 47 & 21.6 & 10.6 \\
\hline $\begin{array}{l}\text { High Grade Commercial Klein- } \\
\text { wanzleberter }\end{array}$ & 19 & & & 107 & & \\
\hline $\begin{array}{l}\text { Wanzlenerter .... } \\
\text { Kleiuwanzlebener (Holland).......... }\end{array}$ & 0 & 1 & $\begin{array}{r}0+1 \\
9\end{array}$ & 50 & $\begin{aligned} 22.0 \\
22.2\end{aligned}$ & $\begin{array}{l}1.0 \\
18.4\end{array}$ \\
\hline Kleinwanzlebener Elite........ & 6 & 15 & 24 & 165 & 23.0 & 14.6 \\
\hline
\end{tabular}

PRESERTATION OF THE MOTIER BELTS.

The spaces in the beets cansed by the removal of the diagonal core for analysis were filled with cotton saturater with formaldehyr. The beets thus prepared were placed in silos, where they will remain until March.

GROWTH OF SEED FROII THE MOTIERS ABOVE DESCRIBED.

Since the pollei of the beet is easily transported, it is necessary that each variety of seed be srown in plots entirely removed from any danger of f'ertilization from other localities. In orrler to secure this, one of the varieties preserved will be planted, through the cointesy of $\mathrm{Mr}$. William Samnders, superinterdent of the garden and gromuls, in the Jepirtment garden at Washington and arrangenents have been made with the following experiment stations to giow one variety each of the romaining beets, viz: Maryland; Ithaca and Geneva, N. I.; Miehigan, Wiscousin, and Ioma. As soon as practicable in the spring the silos will be openel and the beets formarded to the stations above named for transplanting.

The beets of each variety of different degrees of strength should be planted as far removed as possible from the other classes. For instance, the beets in the grade of 20 per cent of sugar should be planted fir enough from other grales of the sane variety to prevent intermixing of the pollen. In this way the strain of excellence can be best preserved. The brets which havo been saved for mothers are to be divided into classes representing difterent degrees of saccharine strength, and each of these classes planted separately to produce high-grade seed for future use.

\section{NECESSITY OF SEED DEVELOPMENT.}

It is himly important for the rapid and sife progress of the beetsugar industry in this comntry that attention should be paid to the production of high-grade seeds. We have in the tuited states such great differences in soils and climatic conditions as to render it evident that 
a single station for the production of seeds would not be sufficient. Beets of different qualities should be developed in diflerent localities. The character of beets best suited to the fields of New York and Wisconsin, for instance, would not be the ideal plant for the semiarid regions of Nebraska. On the other hand, it is evident that beets grown in an arid region, as, for instance, Chino and other valleys of California, without irrigation and with searcely any rainfall, should have a longer tap root than those grown in localities where rainfall is abnudant on irrigation is practiced. It seems plain, therefore, that thee, if not four, stations shonld be established, and in orler that this work maty be conducted under uniform methods these stations should be established and maintained by the Department of Agrieulture.

One of these stations should be located in an area of average rainfall and ordinary meteorological conditions as presented, for instance, by the States of New York and Michigan.

The second station should be established in a locality where a deficient ranfall is to be expected, and where the vicissitudes attending meteorological changes are the greatest, as, for instance, in South Dakota or Nebraska.

The third station should be established in a region where irrigation is practiced, as, for instance, in Colorarlo, New Mexico, or Utah.

A fourth station should be devoted to the development of a beet hest suited to arid regions where irrigation is not practiced, as, for instance, in the coast valleys of Califoruia.

It is only by a careful, systematic, and scientific development of beets suited to these rifferent localities that we ean expect to promote in the most favorable manmer the development of the beet-sugal industry in the United States. It is evident that the continuation of the experiments which have been conducted by the Department of Agriculture for so many years in the analysis of beets and in the delimitation of areas suited to beet culture shomld now be supplemented by a more rigid scientific attempt to develop beets of characteristics best suiter to the four typical localities which have been specified above. The maintenance of a small experiment station entirely competent to aceomplish this work in each of the localities mentioned would not require a very great outlay of money and rould result in the greatest possiblo good to the industry.

\section{S'TATISTICS OF AMERICAN BEET-SUGAR PRODUCTION.}

The information contained in the following table has been obtainer through the courtesy of the beet-sugar factories:

Statistics of the production of beet sugar in the United Siates for the year $159 \%$

Number of factories in operation...

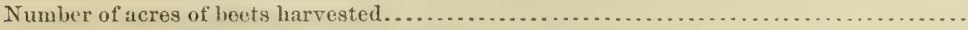

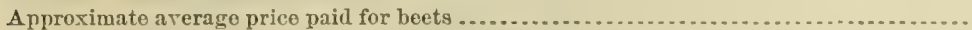

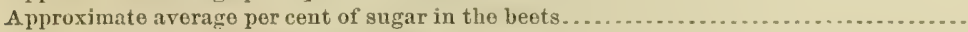

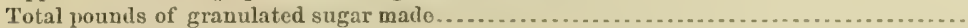

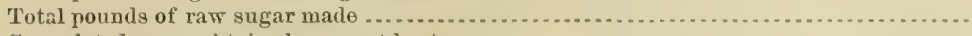

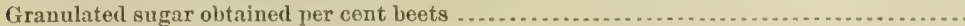

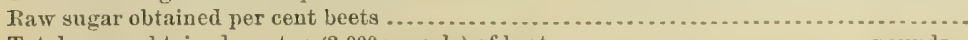

Total sugar obtained per ton (2,000 pounds) of beets. 
Statistics of indivilual factories for the year $189 \%$.

\begin{tabular}{|c|c|c|c|c|c|c|}
\hline Namo of factory and location. & 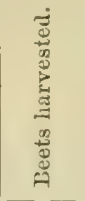 & 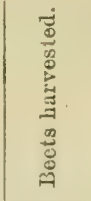 & 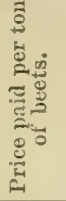 & 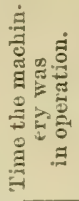 & 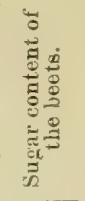 & 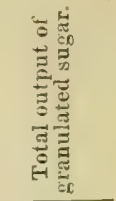 \\
\hline lamoedas & $\begin{array}{l}\text { Acres. } \\
4.808\end{array}$ & Tons. & $\$ 4.00$ & $\begin{array}{r}\text { Days. } \\
90\end{array}$ & Per ct. & Pounds. \\
\hline Chino Valloy Beet Sugar Co., Chino, Cal. & $\begin{array}{l}4,800 \\
9,678\end{array}$ & 97,197 & $\begin{array}{l}\$ 1.00 \\
(a)\end{array}$ & 151 & 15. 10 & $24,303,122$ \\
\hline Wirst New York Beet Sugar Co., Rome, N. Y... & 700 & 4,325 & 5.00 & 45 & (b) & $c 765,700$ \\
\hline Oxuard Beet Sugar Co., Grand Islaud, Nebr .... & 4,282 & 38,607 & $(d)$ & (d) & 12. 80 & $6,798,300$ \\
\hline Los Alamitos Sugar Co., Los Alamitos, Cal.... & 2,800 & 29,512 & 4. 16 & 105 & 15. 73 & $6,017,900$ \\
\hline Norfolk Beet Sugar Co., Norfolk, Nebr.......... & 4,029 & 36,113 & $(d)$ & $(d)$ & 13. 60 & $7,9+1,400$ \\
\hline l'eeos Valley Beet Sugar Co., Eduy, N. Aex .... & 1,600 & 5,700 & 4.00 & 38 & 14. 00 & $1,020,000$ \\
\hline Utah Beet Sugar Co., Lehi, Utah....... & 3,000 & 18,500 & 4. 25 & 56 & 13.20 & $3,670,600$ \\
\hline Western Beet Suyar Co., WVatsonvillo, Cal..... & 10,375 & 110,878 & 4. 00 & 104 & $1 \overline{5} .00$ & $29,776,000$ \\
\hline Total & 41,272 & 1389625 & & & & $90,491,670$ \\
\hline
\end{tabular}

$a \$ 3.50$ per ton for 12 prer cent beets, and 25 cents per ton for each per cent above 12 . The Chino fac. tory employed a saccharate process.

6 Rerl lieets, $5 \frac{1}{2}$ to 12 per cent sugar; white beets, 13 to 17 per cent sugar. Arerago analysis not reporterl.

c 131,200 pounds raw sugar aro includerl.

$d$ Not reported.

\section{REMARKS ON THE BEET-SUGAR STATISTICS FOR 1897.}

The past season was not very favorable to the production of beets in several localities in California and in Now Mexico and Utah. Insufï. cient rain in Culifornia at the time of planting resulted in a smaller acreage being planted to loeets and in a small yield of roots per acre. The great shortage in the erop relneerl the quantity of sugar prorlucerl in California below that of the previons year, notwithstanding the fact that the new factory at Los Alamitos was overated and that at Chino increased its ontput.

The iirst New York bect-sugar factory was somewhat unfortunate in tho varieties of bests selecterl. The red beets eontained very little sngar, and mudoubtedly decreased the onthut below what it should have been moler favorable conditions. The white beets were of satisfactory sugar content. Ls may be noted by an examiuation of this report of the experiments made in tho state of New York during the past season, that State is capable of problueing beets of very great richness.

The shortage in the ontput of sugar is to some extent due to a lecreased acreage at Leli, Utah, and at Wationville, Cal., these two

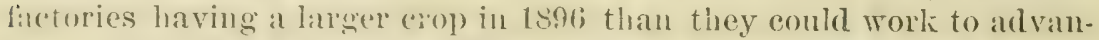
tage. In 1896 the fiactory at IVatsonville produced nearly 20,000 short fons of sugar firm alluroximately 150,000 tons of beets, and the past year 14, sis short toms fom 110,878 tons of beets. The total profluction ion the comatry shows an increase of approximately 5,000 tons in 1897 over that of 1896 . The increase in the output of sugar next season, should more favorable conditions prevail in California, will be very large, since wight new fartories, having a daily capacity of approximately 6,700 tons of beets, will be in operation.

The ontput is reported in the tables in pounds of granulated sugar,

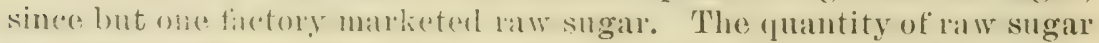
produced does not materially morlify tho statisties of the production. 


\title{
REPOR'T OF SPECIAL AGENT
}

\author{
CHARLES F. SAYLOR. \\ LETTER OF TRANSMITTAL. \\ U. S. Department of Agriculture, \\ OfFice of the Siecial Agent, \\ Washington, D. C., February 15, 1898.
}

SIr: I have the honor to present herewith, for your inspection and approval, my report for 1897 as special agent aud iuvestigator of the sugar-boet industry, which is submitted in compliance with your instructions of April 10, 1897.

Respectfully,

Cifarles F. SaYlor.

The honorable the Secretary of Agriculture.

'The Experinents in Growing Sugar BeEts in the United STATES IN 1897.

The history of the experiments in growing sugar beets is probably not unlike that of auy other agricultural product, exeept in this, it is more general. The sugar beet has so wou its way with the farmer and business man in all parts of the country that it may now be said to enjoy national approval.

Most other industries having an agricultural or horticultural foundation have seemed to renuire conditions that localized the interest in them. This, however, is not so with the sugar beet. The writer of this report spent the spring, summer, and fall in the field, thoroughly covering all the States and Territories west of Missouri River, and, in addition, the States of Missouri, Iowa, Minnesota, Wisconsin, Michigan, and Illinois, and he has yet to find a State or Territory that is not thoroughly alive to the benefits of the beet-sugar industry and making efforts to discover its resources in this direction. And why should this not be the case? We will offer below some of the causes which, in our opinion, have led up to what appears a national sentiment tonching this industry.

\section{THE EXTENSIVE CONSUMPTION OF SUGAR.}

The Department of Agriculture, realizing the diversitied soil and climatic resources of this country and the benefits to accrue from the sucessful domestication of the sugar-beet industry, has undertaken as

H. Doc. $396-11$ 
a part of its active policy to secure to the people of the United States the business of producing $\$ 100,000,000$ worth of sugar now brought into it for our consumption from the other countries of the world. It is a proposition that the people are ripe to consider. The trausfer of this vast amount of business to our people from the countries of Europe, carrying with it, as it does, the employment of so much capital and labor, not only in the raising of the beets and in the processes of making the sugar, but in the consumption of raw materials, such as fuel, limestone, etc., makes the proposition at once a national, financial, and labor issue.

Our consumption of sugar has been rapidly increasing in this country. This is due not only to our rapidly increasing population, but to the fact that as our country grows older our people become more and more liberal in provirling themselves with the necessaries and luxuries of life. There is also to be considered the increase in use from the constantly growing demands of the arts and sciences.

\section{PRESENT STATUS OF THE INDUSTRY.}

The beet-sugar investigation of the United States, so far as the Department of Agriculture is concerned, is confined to a study of the adaptability of the various parts of this country for growing the beets and of our facilities for entering into the successful manufacture of beet sugar in competition with Germany, France, Russia, and other countries which have achieved success along the line of this enterprise. At present the mamufacture of beet sugar in this country is confined to Grand Island and Norfolk, Nebr. (under the control of the Oxnards), to Iehi, Utah (the Utah Sugar Company), and ranging down the Pacific coast, in the State of Ualifornia, to four very extensive beet-sugar factories. The first factory is that of the Alameda Sugar Company at Alvarado, which was the first continuous beet-sugar factory in operation in this country, and has been. in operation under varying experience of profit and loss for many years, having, however, had a successful record for the past seven or eight years. The second is that of the Spreckles Beet Sugar Company, at Watsonville, Cal., about 100 miles south of San Francisco, which is under the management and ownership of Mr. Claus Spreckles, who contributed so extensively to the development of Hawaiian sugar interests. The third factory is that of the Chino Valley Beet Sugar Company, at Chino, near Pomona, Cal., about 30 miles southeast of Los Angeles, under the control of the Oxnards. The fourth factory is that of the Alamitos Sugar Company, at Los Alamitos, about 30 miles southwest of Los Angeles, Cal., controlled by W. A. Clark and J. Ross Clark, of Butte, Mont. At Eddy, in the Pecos Valley of New Mexico, is situated another factory. At Rome, N. Y., a factory started operations in the fall of 1897 . This completes the list of factories now in operation in the United States. At Omaha, Nebr., in New York State, in Michigan, and elsewhere, arrangements have been made to establish 
factories, commencing with the next sugar-beet campaign. At Salinas, Cal., Mr. Clans Spreckles has made arrangements for constructing a factory with a larger capacity than that of any other factory known in the world.

The two Nebraska factories have a ćapacity of about 300 tous per day each; the Alvarado factory about 800 tons; the Watsonville factory about 1,100 tons; the Los Alannitos factory about 350 tons, and the ('hino factory 800 tons. Factories in this country are able to extract in the neighborhood of 11 per cent to 13 per cent of sugar from the gross weight of the beets, and sugar beets range in the average of their sugar percentage in the various factories from 13 to $16 \frac{2}{3}$. In Europe farmer's are required to do a great deal of fertilizing, while in this country we have sufficient lands to produce our sugar without fertilizationlands which will excel the production of Europe, both in tonnage and perrentage of sugar and purity of beets; and now that Congress has arrangerl for a protective tariff, having in view the fostering of the beet. sugar industry, extensive experiments are being carried on in various parts of the United States in the culture and test of sugar beets. There can be but one answer to the question as to whether this country will eveutually manufacture its sugar. We not only think that it will manufacture the hundred million dollars' worth of sugar that we now purchase, but we feel sate in predicting that, in this industry history will repeat itself, and the United States will be offering its sugar to the other countries of the world at a profit. Although the sugar industry has only Inal a run of about eight years in the United States in the fer factories that have been established, yet, in that short time, those in control of these factories have revolutionized the process and materially improved the machinery; the implements of culture and the plan of agriculture in raising the beets have also been materially improved. In a few more years we will have so changed all the methods of growing, manufacturing, and refining beet sugar that the conservative foreigner will hardly recognize it as one of his original inchustries. The growing of sugar beets is the reverse of almost all other kinds of farming, in that the point to be attained is quality rather than quantity; in fact it is not farming, unless we consider it of the most intensive kind. It is the highest type of gardening, requiring much labor and attention; and the real problem that we have to meet in this country is to get our farmers to appreciate this fact, and to uuderstand that the growing of sugar beets stands out as a special agricultural problem. If beets be given judicious attention and be grown properly, where the best conditions prevail, there is nothing that will reward the farmer so greatly, provided he has a market through the medium of a factory; but if neglected, or not handled properly, there is no crop that will remind the farmer so forcibly of his failure in these particulars when the harvest comes.

There is no doubt that the United States has a wide and varied extent 
of lind that will successfully grow high-grade beets, that the enterprise of the people of this country will appreciate this fact, and that in a short time all the sugar consumed in this country will be furnished by our own people.

\section{The SÜGAR-BEeT BeLT.}

Working along the lines of the sugar-beet industry in the United States, it became a part of the duty of the writer to aid in establishing as nearly as possible a sugar-beet belt, comprising those regions in the United States which by their conditions of soil, moisture, and temperature will permit of the successful growing of sugar beets of a high grade of sugar content and purity. Of course, the sugar content, which refers to the percentage of sugar in the beet, will readily be appreciated as an important requirement by all. The purity refers to the constituent elements of the beet or to the absence of certain solids which are usually found in varying proportions among these elements. One demand of a factory devoted to the manuficture of beet sugar is a pure beet. Purity is not only intimately associated with the quality of the sugar produced, but it affects materially the process of extracting the sugar from the beet, and with an excess of impurities there is a material loss in the amount of sugar obtained. It is hardly possible in the process to eliminate all these impurities. If these impurities are present to any extent in the sugar there will be certain odors that can be easily detected by those accustomed to them when the sugar is confined in packages, barrels, etc. These impurities also have the effect of discoloring the sugar, which can be readily discovered by experts in sugar testing. Hence, the farmer will always be met at the factory door with the demand on the part of the superintendent for pure beets. In fact, all contracts made by the manufacturers with the farmers for growing sugar beets demand beets of a certain sugar content and purity. The standard in this country is usually put at 12 per cent of sugar in the beet, with a coefticient purity of 80 per cent. The three natural conditions that influence this sugar content and purity most are the physical properties of the soil; the moisture, either through irrigation or rainfall; and the temperature during the growing seasou. The sugar-beet region of the United States must, therefore, be such a region or belt as will admit of growing beets equal or superior to the above standard. In some of the bulletins and other publications issued by the Department of Agriculture on the sugar-beet industry a map has been published showing the region or territory in this country which, owing to the conditions of temperature through a series of years during the growing season, is particularly adapted to the growth of the sugar beet. This map was compiled from data in the Weather Burean covering a series of ten years, taking $70^{\circ} \mathrm{F}$. as the standard requirement for the growth of the beets during the growing season, which is considered to be June, July, and August; $70^{\circ} \mathrm{F}$. was selected because a study of the temperature conditions of the most 
successful sugar-beet regions of Europe showed that this was the prevailing average temperature for a series of years during the growing season there. This map has been considerably misunderstood by the public generally and by some of those intimately associated with the stimulation of the beet-sugar industry. It has appeared to some as though it was inteuded for an ontline of the sugar-beet belt in this conntry, althongh in the references to it in all of the publications of the Department of Agriculture it has been distinctly stated that this was only a thermal map, showing where only one of the required conditions prevailed, that of temperature, which seemed best adapted in Europe to the srowth of these beets. Of course, when an arbitrary standard like $70^{\circ} \mathrm{F}$. is selected, the compilers of maps will have to draw their thermal lines as shown by the data on record, and it ean be stated here that while this number of degrees may be the temperature condition demanded in Enrope, still the fact that our conditions are so vastly different in other respects might modify the temperature demanded here. Under these circumstances, when tre come to compile a thermal map in the future, as demauded by our experience in the growth of the sugar beets, for a number of years, it may show a somewhat different basis of temperature. This is all speculative, however, and future experience will probably give us a true temperature standard. One thing that the writer wishes to impress upon all interested is that the map referred to was based on a thermal standard entirely. It was intended simply as a suggestion, and never to show the actual sugar-beet belt of the United States.

It might be well to suggest in this discussion of the sugar-beet belt of the United States that the factories now in operation in this country, viz, at Rome, N. T.; Grand Island and Norfolk, Nebr.; Lehi, Utah; Alvarado, Watsonville, Chino, and Los Alamitos, Cal., and Eddly, Pecos Valley, N. Mex., are all in the thermal belt shown on the nap referred to.

THE WORK OF THE DEPARTMENT.

It will probably be interesting to the public to understand something of the policy of the Department of Agriculture with reference to the work it has inaugurated along the line of discovery of the actual sugarbeet belt of the United States-that is, to locate it by actual experiment and experience in growing the beets. These beets are to be tested for sugar content and jurity, and then a study is to be made of soil, moisture, and climate. This will show the merits of each locality, after a series of experiments, where normal conditions prevail. In earrying out this policy 7 tons or more of sugar-beet seed were distril)uted over a large portion of the country, and about trenty-eight States participater in the experiment. As a rule the seeds were sent to the agrieultural experiment stations to be delivered to the farmers from lists made up by the experiment station in the State. Some miscellaneous lots were sent ont under the direction of Members of Congress and Senators, who furnished lists of names. In these cases the 
seeds were sent direct to the farmer by the Department of Agriculture. In a few instances parties applied direct to the Secretary of Agrieulture for the seed, indicating a strong interest in the enterprise, as well as a desire to test the growth of sugar beets in their respective localities. In such cases the seeds were sent. Bulletins giving directions for cultivating and harresting were distributed with the seeds. The writer of this was directed to secure lists of the names of all parties to whom seerls were sent and who were participating in the experiments, and then to visit as many such persons during the growing season as might be possible. He was to note such facts as might be of interest, and to make a general study of the conditions, both for growing the sugar beets and manufacturing them into sugar; in fact, to gather all general practical information possible touching this industry. As stated, the seeds were sent to all parts of the country, and the State experiment stations entered actively into the investigation, North, South, East, and West; so that the results of the expriments will not only show to some localities that they are well adapted to sugar-beet raising, but it will demonstrate to others, probably, that they are not.

\section{MODIFYING CONDITIONS.}

We will refer to some conditions other than temperature that modify the sugar-beet belt. The sugar beet, like other farm products, requires moisture, aithough we believe that it is generally accepted that the sugar beet will succeed with considerably less moisture than the ordinary farm products, such as corn, wheat, oats, barley, potatoes, etc. The beets grow in the Mississippi Valley; in Nebraska they are grown commercially and under rain conditions. We have been informed by practical sugar-beet growersin Nebraska that the beets will suceeed with considerably less moisture than is necessary for the other crops namer, some persons putting it at less than one-half. The writer's observation has been that this is true, provided the physical conditions of the soil are favorable. It is believed that the sugar beet does not require so much less moistme, but that it has a propensity and better facilities for getting moisture after it loas gone deeper into the soil. The sugar beet will send its tayoot down as far as 12 or 13 feet. It is not mulike alfalfa. in this respect. If we have, therefore, the conditions of soil that they have in a large part of Nebraska along the Platte Valley, the sugar beet will readily get its moisture. The underlying soil in a large part of the sugar-beet district of Nebraska has a moisture-bearing stratum firom 4 to 6 feet in depth, and it is not uncommon to hear farmers say "we get our first water from 4 to 6 leet from the surface." The soil being loose and sandy and the subsoil being sufficiently penetrable, the sugar beet readily goes down to this depth. In its earlier stages it is aided in securing its moisture by (ap)illary attraction, which, inducel by proper cultivation, hrings the water up from below. It might be said that one of the ideal conditions for growing sugar beets is a soil having a sandy or porous moisture-bearing stratum such as we have mentioned. 
Sugar beets are grown where there are both rain conditions and irrigation. Such is the case with the beets grown for the Lehi factory in Utah. The growth of the beet is started with rains, and moisture is continued with irrigation. Of course these are conditions which might modify considerably the sugar-beet belt. Sugar beets are also glown entirely under irrigation, as, for example, the beets grown for the factory in the Pecos Valley, New Mexico. As this country is to demonstrate to the world what can be accomplished in the growing of sugar beets by irrigation, which has not been attempted to any considerable extent in Europe, it will probably show that irrigation will greatly modify our sugar-beet belt. Experience has shown that sugar beets can be successfully grown by irrigation, and our experiments are now showing that in the vast areas in the arid regions of Colorado, Utah, Montana, and other States which have natural facilities for irrigation, a high-grade beet can be grown successfully. When this is known, there is no doubt that the enterprise of these localities will take advantage of this fact to extend their resources. Sugar beets are also growu successfully without either rain or irrigatiou. This is the case with nearly all of the sugar beets grown in California. The sugar-beet grower of California takes advantage of the fact that his soil is thoroughly saturated with heavy winter rains and puts it in coudition for planting the seed while the soil is sufticiently moist for its germination. The beets secure their moisture for the remainder of their growth from the moisture-bearing propensity of the soil, which is not yet fully uuderstood. This moisture-bearing propensity seems to come from the drainage of the mountains which are saturated during the heavy rains of the winter, as the sugar-beet region might be saicl to be on the coast side of the mountain ranges in California. These lands are called by the Californians "damp lands," and the drainage seems to keep up during the growing season. The grower appears to understand fully the effect of capillary attraction in raising this moisture during the earlier growth of the beets, and aims to keep a dust mulch by cultiva. tion to prevent excessive evaporation. There is a large region in California yet unimproved, and also some improved areas, which have conditions similar to those described and which can be utilized for growing sugar beets; in fact, we believe that Califoruia has demonstrated facilities so extensive and conditions so favorable to the beet-sugar industry that this State will only be limited in production by the extent of its market, modified by freight rates and shipping facilities.

\section{PHYSICAL CONDITION OF THE SOIL.}

The physical coudition and properties of the soil are features that might be considered as modifying the sugar-beet belt. There has been mentioned above, under "Moisture," the physical condition inducer by subirrigation. Now, while a great deal has been said aud written about the kinds of soil desirable for growing sugar beets, it does not seem 
that enough stress has been put upon the necessity of a desirable subsoil. It has been seen that the plant strikes deep down in to the soil; this is its habit, and conditions are favorable only when it can do this without obstruction or interference from a hard or tough subsoil. The subsoil should be of a porous and penetrable nature. Hardpans aud other stiff subsoils are fatal to the sitccess of the beet. In regard to the surface soils, it has been found that there are quite a number of such soils in which the beets do well. It is generally admitted that a sandy loam is best; clay loam is consiclered good; and dark loams are also considered good if they are fiee from elements that stimulate impnrities. New timber and binsh lands that are considered very desirable for corn, potatoes, and some other crops are undesirable. These lands have a tendency to make a large beet and to give it too much opportmity for taking up impurities. Still, soils made from the disintegrated rock which has been washer down from the mountains into the valleys seem quite favorable for the growth of the sugar beet. The physical property of porosity is an important feature. The sugar beet generally succeers well in any soil that does not become packed and hard, provided the soil does not contain undesirable plant-food elements. The best and only safe test of the soil as to its desirable or obnoxions elements is that made by experimenting with the actual growth of the beets in such soil.

\section{ALIITUDE。}

There is another class of influences that modify the sugar-beet belt. Take, for instance, altitude. There may be an extent of territory sufficient to support a beet-sugar factory where, on account of its altitude, the conditions are quite different from those prevailing in the surrounding country, and we have no doubt that there are a great many localities of this kind. It shonld be the aim of the people of these high localities, if they are interested in this industry, to test their conditions separately and apart from the experiments in other portions of the State. The trend of mountains and location of valleys modify materially the season in localities. Take, for illustration, the sugar beets furnished to the factory at IVatsonville, Cal. Some of them are planted as early as February and others as late as $\Lambda$ pril. Some are harvested as early as the latter part of July and others not until the latter part of the fall; thus showing that in a very small seope of country there is a material difference in the dates of the beginning and ending of the seasons, as affected by mountains, prevailing winds, ete. It might be interesting to note here that there is an important economical point in this difference of season in connection with the beets grown for a particular factory. It permits the factory to begin the harvesting of beets in the district where they ripen first and to continue the harvesting in districts according as they range in order of season. Of course, this 
would not be true in any of the Mississippi Valley States, but it shows one of the advantages of the conditions prevailing in California.

Mr. Cutter, manager of the Lehi (Utah) factory, says of Utah: "All localities in our State where the elevation is not more than 5,000 feet and where they have about the same kind of temperature the beets show good results in sugar and purity." Thrcughout different sections in Colorado sugar beets are grown at an altitude of 6,000 feet. While talking with a gentleman at Glenwood Springs, Colo., who is very much interested in growing sugar beets in that locality, which is a very mountainous and broken district, we asked where he had grown those under the experiment he had referred to, he replied: "On top of the mountains you see around here."

\section{The Inportanch of THE INDUstry to This Country.}

The anuual import of sugar into this country is something like $1,800,000$ tons. The valuation of this importation is over $\$ 100,000,000$. We think that it will be generally accepted now as a fact that this sugar could be produced in this country at a profit. We believe that if the factories were built and in operation in those localities having the best eonditions for the growth of the sugar beet, with the farmers thoroughly educated in its culture, the United States, with the superior natural advantages mentioned, could enter into free competition with the other sugar-producing countries of the world.

There will now be considered the home production of this amount of sugar under the present status of Government enconragement, which the writer believes is highly necessary to establish the industry. Leaving to the future the policy of the Government as to exereising a fostering care, we will suggest some of the great benefits that will accrue from this vast business of producing $\$ 100,000,000$ worth of sugar.

\section{RENTS AND VALU்ES.}

The writer observed during his inspection of sugar-beet farms this summer that the owners of the land received in many instances as high as $\$ 5$, in some cases $\$ 6$, and in a few cases $\$ 7$ per acre cash rent for land devoted to the raising of sugar beets, and this in localities where $\$ 3$ per acre would have been the highest possible amount which could have been obtained as rent for similar land used for other farming purposes. Inquiry was made particularly into the value of land on which sugar beets were being raised around Watsonville and Alvarado, Cal., and it was rarely placed lower than $\$ 200$ per acre. Rents were rated at from $\$ 10$ to $\$ 15$ jer acre, yet these farmers claimed to be making a good profit raising beets. The sugar-beet lands of Utah were very much enhanced in value, so that the experience of this comtry up to the present time seems to be that the location of a beet-sugar factory in a district causes a healthy rise in rents and values of lands. 


\section{HIGII STATE OF LAND OULTURE.}

Another important feature that must not be lost sight of is the high state of cultivation to which the lands are brought in raising sugar beets. The culture of the sugar beet must be considered really as the best type of garden culture. It requires deep plowing, careful pulverizing, and more careful tillage. It is intensive farming in every sense of the word. The value of a year's work in raising sugar beets must not be estimated entirely by the money received for the beets after they have been marketer, but the wonderful effect it has on the succeerling crops, both as to quality and quantity, must be taken into consideration.

The attention of the writer was drawn during the summer to the splendid condition of the soil where corn was being cultivated. The soil, which was absolutely clean from weeds, was soft and mellow, and the effect on the growing corn was marked. 'The attention of the farmer' being called to this fact, he remarked, "Why should it not be? I grew sugar beets there two years ago." So we must realize that the extensive raising of sugar beets will bring the farms up to this high state of cultivation. It will also cause the farmer to observe the effect of this kind of cultivation, and will thus gradually lead to the same cultivation and better crops in localities where the sugar beet is not cultivated, resulting in better farmers in the future under the influence of the beetsugar industry. To repeat, it will lead to better methods in the farming industry generally by offering wider opportunities for more systematic and economic rotation of crops and the better balancing of nitrogen furnishers and nitrogen consumers.

\section{EMPLOYMENT OF I,ABOR AND DEMAND FOR CRTDE MATERIAL.}

The introduction of this industry into this country means the employment of a large amount of labor, both directly aud indirectly. The raising of sugar beets reyuires cousiderably more labor than any other firm product, and it is labor of such a kind and extent that no farmer doing considerable business could hope to perform more than a swall jortion of it. The larmer would receive enough for his beets to pay the expense in this direction, and of course would feel free to hire the labor, so that the raising of the quantity of beets sufficient to furnish the sugar demanded for our own cousumption would call for the employment of large numbers of the laborers whose efforts are now employed in other directions, thus greatly increasing the avenues of employment. The sugar factories themselves would require many eiuployees. In these two directions alone many people would receive employment directly in the beet-sugar enterprise. In aldition to this the factories will have demands which will call for an extensive cmployment of labor in other branches of industry. For instance, they will be extensive users of fuel, and this would mean the employmont of miners on a large scale and the remuneration of mine operators in mining and marketing the coal. 'The factories will also require considerable coke for 
burning their limestone, which is demanded in large quantities for furnishing the carbonic-acid gas and lime necessary in the purification of the beet juices. This would require the employment by the coke producers of quarrymen and laborers. To build the factories and to place the necessary machinery in them to neet this great demand for sugar wonld mean the employment of many laborers-mechanies in building and mechanies in machine shops-both skilled and otherwise. Then We unst consider that all these crude materials mentioned must be transported from their various sources of supply to the factories, and that after the beets have been worked and the sugar produced the finished product must be put upon the market and hauled to its destination. This means greatly increased freight transportation, calling for the further employment of labor. Then the extensive use of eapital required in the building up and the carrying on of the industry is one of the most important factors to be considered.

\section{BY-PRODUCTS.}

There would be advantages to this country accruing from the beetsugar industry in the stimulation it wonld give to corollary industries. After the juice is extracted from the beets we have remaining the beet cossetts, or pulp). This is known to be very useful and desirable feed for animals. In Europe it is extensively used in feeding. In this country it is gradually growing in favor as a desirable element in a well-balanced ration for animal feed. In another place in this report we shall give the views of a gentleman who is an extensive feeder of eattle and who has made many experiments with feeding beet pulp to animals in different rations aguinst other animals that were not so fed, and he is very enthusiastic in his praise of beet puly as a feed for animals. Some factories in this country are enabled to dispose of their pulp to a greater extent than others. It depends largely upon the edncation or information those engaged in the feeding industry have acquired in this direction and ujon whether they have had an opportunity of availing themselves of it. Farmers as a rule seem to be slow in taling hold, but where they do give the pulp a trial it becomes a popular feature on their farms afterwards. Around some of the factories companies have been organized and arrangements made for feeding on a large scale. They are dependent upon the demands of the farmers, and it can be said that the demand for the pulp is constantly increasiug. It is probable that in a short time the demand will exceed the supply. It is found to be very desirable for cattle feediug as well as for sheep, and for dairy feeding it is ideal. Dairies and creameries follow naturally in the wake of factories, and we think the introduction of beet-sugar factories in this country will afford the creamerie. and dairies an opportunity for providing a ration for their cows which will secure the best results. Three dairies have started in connection with beet-sugar factories in the United States, aud since we have from 35 to 50 per cent of pulp from the original beet, depending upon the amount of pressure that is applied in extracting 
the water before the pulp goes into silos or is hauled away, any factory will furnish a large amount of feed for the adjacent country, and it can be shipped by railroad or hauled profitably long distances by wagon. The pulp is usually preserved by placing it in silos at the factory, but it .has wonderful keeping qualities, which are advantageous. At Grand Island pulp three years old was used for feeding purposes which had simply been hanled ont on the prairie in large quantities and left there. After a few inches of the top were scraped off the pulp seemed to be pure and fresh and palatable. In fact, we are informed that this pulp was preferred by the feeder. At present pulp is sold from 10 to 50 cents per ton, depending largely upon the demand for it. There are places where the factories are giving the pulp away to the farmers in order to get them to use it and thus gain a knowledge of its utility for feeding purposes, as well as to get it out of the way. The disposal of this pulp, should it not find an avenue in the direction of feeding purposes, would be a serious question to the factories. The farmer will find in the future that it is a cheap feed; that he can conveniently store it and keep it; that he can easily prepare it for feerling and handling, and that feeding it will give good returns for a small outlay of labor and expense.

During the summer the writer talked with a gentleman who had been examining the fiber of the pulp with a view to experimenting with it for manufacturing paper. What this will lead to we do not know, but it is probalble that experience will discover other uses for it, possibly as desirable as for feed for animals. The more a farmer has to do with this pulp the more he will see that he can make it a thing of value. In this way the demand for the pulp will increase, and when this demand becomes greater than the supply it will bring higher prices. While this will mean greater expense to the farmer, it will mean a better remuneration to the factory owner in his business, and the equilibrium between the farmer and the factory will be the better adjusted.

MOLASSES.

There is a very important residuum which occurs in the manufacture of beet sugar known as "molasses." This is an item of considerable importance, and it is receiving consideration at present, as it has since the industry was inangurated. It has been and is desirable to keep this molasses at the lowest possible minimum. The amount of this residum left after the sugar has been extracted depends largely upon the purity of the beets and the effectiveness of the processes of the different factories. Of sugar, it still contains fiom 16 to 25 per cent of "boiled stuff," depending largely on the purity of the beet and. as has been stater, the effectiveness of the process. It has a very bitter and disagreeable taste, because it contains all the impurities which were not eliminated originally from the juice, and also the impurities introduced during the manufacture of the sugar, and which could not be 
wholly extracted. These impurities exist in a condensed form in this residuum molasses, and it is not to be considered in any sense as proper for human diet. The manufacturer looks upon it as an item of considerable importance, and he has been working with a view of turning it in some way to the profit side of his account. Experiments are being made in this direction. One set of experiments is to reduce the molasses to the lowest possible minimum. There have been different processes used for this purpose. We believe the "Stefien process" stands first. Considerable progress is being made in this direction, notably at Chino, Cal., where this process, improved by the factory, is being used with, it is understood, highly satisfactory results to the factory experts and superintendents.

In the Steffen process the sugar in the molasses is converted into a compound by adding a proper proportion of finely pulverized lime to a proportion of the solution of molasses, and the whole is cooled down to a low temperature by means of ice. A tricalcium saccharate is formed, and this is extracted from the solution by passing the whole through a filter. The juice is then heaterl to a certain temperature, about $190^{\circ} \mathrm{F}$., when a further precipitation of this calcium sugar compound occurs, which is known as hot saccharate. This is separated again from the juice by means of a filter; the juice then is allowed to pass away in the sewer. The process deals further with this calcium sugar compound, which is sent back into the factory and suspended in solution of water, and carbonic-acid gas again introduced, which forms a union with the lime and precipitates the same as calcium carbonate. The juice is then further operated on in a manner similar to that employed for the regular juice found in the beet. This description is given more for the general public than for the benefit of experts, but it is pertinent to state here that throngh this Steffen process the factories are able to secure a large part of the sugar in this molasses that has formerly been a loss to them. There does not seem to be any doubt about the effectiveness of the process. It is simply a question of the expense, and it is hoped that further experience and improvements in this process will enable the factories to practically and profitably recover the sugar contained in this residumm. This matter has been mentioned here as an illustration of one of the sources from which the factories are hoping to reduce the cost of production.

There are other processes being used to recover the sugar in this molasses, and the feeling is quite hopeful that one or more of them will finally be improved and cheapened to such an extent as to be available for the work, and that the final loss of sugar in the molasses will be very considerably lessened. The writer was informed by a technical superintendent of one of the factories that there is a process linown as the "alcohol process" of working the molasses to recover the sugar, and that through it, if the laws in this country were favorable to its use, this loss might be largely eliminated. In this process it would be 
necessary to recover the alcohol by distillation after each operation, in order to save expense by using the same alcohol over and over again in working the molasses. This, however, would be a violation of the internal-revenue laws unless the factories met the demands of the Goverument as distillers, and this they could not afford to do.

ALCOHOL.

The factories are also working along other lines to reduce the loss in this direction. They are trying to discover useful and valuable by-products that might be manufactured from this molasses. One of the things that has been made from the molasses is alcohol. We believe that in some places in Europe they are making alcohol profitably from this residuum. Some of the factory people in this country claim that if the internal-revenue laws were more favorable and would offer more encouragement processes could be worked that would practically eliminate this loss in the molasses.

FOOD FOR STOCK.

A great deal has been done with the molasses in various mixtures to utilize it as a feed for stock by placing it in ground feeds and other rations. There are also places where it is mixed with leaves of the beet, and, after being allowed to stand in silos, is ferl out in this way. It has been mixed with the pulp in certain localities. All these problems have received nore or less attention fiom scientific and agricultural journals, aud are said to be attended with quite favorable results. These matters, however, will undoubtedly be thoroughly tested when the beet-sugar industry shall have been fully inaugurated in this country, and we simply suggest them here under the hearling of "By-products," so that the public may see in a general way that a beet-sugar factory may be useful in other directious than the direct production of sugar.

FERTILIZERS.

Molasses has been used more or less in restoring to certain soils those mineral elements which the molasses is known to contain, and it is understood that this has been attended in some cases with good results, especially in places where the soil is defective in these elements. It has been stated that lime is nsed in large quantities in the production of beet sugar, from 6 to 10 per cent being used to the ton of beets.

As the factories in this country have a capacity of from 350 to 1,000 tons of beets per day, it is easy to figure the large amount of limestone that is reguired. Most of this lime does service in a mechanieal way, and results finally as a residuum. It will thus be seen that the factories have large quantitiss of this waste product in a pulverized or soft state. In all of the factories except one this material is simply a waste as far as the factory is concerned. It is used to fill depressions and holes should any exist near the lactory. If not used in this way it 
accumulates and forms large bulky ricks or piles, which are in the way of the factory. This waste lime would be very useful on some lands as a fertilizer. It can be easily hauled away by the farmer who has brought in a load of beets to the factory, and he can thus return to his home with a load of lime fertilizer for his farm. We understand that in Europe the value of this lime is appreciated and the output is largely used for fertilizing.

Around most of the factories large feeding centers are being established. As a result there are large collections of manure, which are scraped ont of the way and formed into piles. This manure is readily given to the farmer for removal, and a thoughtful, frugal, and scientifie farmer can utilize his time, after delivering a load of beets, to no better advantage than by returning with a load of feed in the form of pulp, a load of manure, or a load of lime fertilizer. In this way his time is economized and his land profited and enriched.

The beet leaves and that portion of the beet cut off in "topping" the beets are considered very valuable for feeding. It has been discovered that this course, however, has a tendency to exhaust the soil, and it is better to allow the tops and leaves to remain on the field to act as a fertilizer and thus preserve the soil. Much of the more valuable portion of the elements contained in the sugar beet which the soil needs for recuperation is in the top and leaves. This fact has become so thoroughly well kuown to the fictories in this country that some of them even stipulate in their contracts with the farmer that the leaves and tops shall remain on the ground, which seems to be a wise provision.

\section{The Uníled States as a Competitor of Europe in the Beet- SUGAR INDUSTRY.}

If we consider only those localities in this country that have the best conditions and facilities for taking up the beet-sugar industry and limit the territory simply to that portion eapable of producing our own consumption of sugar, it might be said that the United States possesses some material advantages over Europe.

\section{NATURAL FER'TLITY OF THE SOIL.}

One of the advantages in this country is the natural fertility of the soil. One of the strong items of expense in producing sugar beets in Europe is the costly fertilization which must be resorted to in order to grow them. We have looked over many of the European estimates of cost of raising an acre of sugar beets and find that $\$ 10$ to $\$ 20$ is not an unfair estimate for this purpose. The bests grown in this country are produced from the natural fertility of the soil, and our agriculturists generally believe that this will be true for some time to come. 


\section{AMELIOAN INGENUITY AND ENTWRPIRISE.}

From onr history in other directions in the past, and from the interesting leatures that can now be noted in the beet-susar industry, it is lair to count the ingemuity and enterprise of our people as among this eountry's alvantages over lurope. Among the interesting things the writer observed in his visits to the beot-sugar factories in this country during the past year was the rapidity with which our peoplo are changing the machinery of the factories, shortening the processes and perfecting them loy improving the machinery, and lowering the cost of production by simplitication. In this connection wo might instance the lactories of lachi and las Alamitos, all the machinery in which was made and designed in the United States, and it was with pleasure we noted that the latetory people generally looked upon these two factories as models, especially the one at. Los Alamitos, which was established later than the one at Ledri. It maty be said that the factories of the United States ane liept up to date with all improvements in fitetory work, and at large portion of their resting period after eateh campaign is utnlized in orerhanling and replacing some of their manhinery with the newest and best of its kind. It is interesting to noto in this respect, that a large part of this replatement is with Amerean machinery. One finetory, after two years use, took out in one division matehinery that cost 8:3,000, madoolsolete by 1 merican improved processes. This improve. ment has also gone on in the implements used in the eultivation of the beet. I firm in Illmois which, in the boginning of sugar-beet growing in this eomitry, begall a catreful stmely of the needs and demands of the firmer in this respect, has put ont a tull line of implements to meet erery demand of the sugar-beet, grower, from seeding, through cultivation, to hatresting. 'These implements have heen improved and liept up to date and form a wonderful and interesting eomparison with the most moleru implements imported from burope. It was the writer's privilege during last summer to examine a enltivator imported from firmany by a gentleman who had eome here from that country, whero he had heen a beet grower on a larege seale, to embark extensively in the growing of stegar beets. He was growing at the time about zon aleres, and asked the writer to inspect this eultivator, which he sadel was the most moleren coltivator in fiemany. It repuired two horses to haml it, one man to guide or lead the lorses, another to operate the geniele wheel and lieep the cultivator straight in the rows, and a third man to manipulate the cultivator hamdles. Thus we see that to operate this entivator required a heary team and three men. Fomr rows of beets were cultivated at once, amd the work was suceessfully done. The sitme afternoon, while looking over the beet firm, we diseovered an up-to-date Anerican-male enltivator of the Illinois firm above relered to. 'This enltivator was doing the work apparently as suecessfully as the ferman implement and was not nearly so emubersome. It was drawn by one mule and was handled by one man. It was 
cultivating four rows, the same as the other cultivator, and it was the opinion of several beet grower's present that tlis American cultivator with one mule and one man was doing as much work and as successsfully as the other implement with three men and two large horses.

The same instincts that lead the American to better his implenents and improve his mathinery will probably lear the American farmer into a closer investigation of the sugar beet to understand its nature, relation to the soil, and habits of srowth, to the curd that he may adopt more effective methods of cultivation.

\section{HAVORED MARKJ'LS.}

Another item of material advantage to our people is the fict that we live in a market that lats to be suppliesl, and the linopean has to transport his products a long distance to reach the same market. A great deal of the territory that is showing firtelass anditions for growing sngar beets and for mannfacturing them into sugar is located around our Great lakes, and the great centers of trarle are easily acressible at low freight rates throngh eompetition of railroads and water navigation, and with the choies of transportation by either. The above are natural advantages.

The Filty-fifth Congress at its first session placed a duty of 95 cents per hunded pounds on raw sugar not above 16 Dutch standarel in color, and not above fis degreess polarization, and then on a rising scalles of 3.is cents per humdreal pounds for each anditional degree for higher grades of sugar until it reaches 18:5 cents per humbled pounds on refined sugar of 100 degrees polarization. Where the sugar imported is higher in color than 16 Dutch standard, 12.5 cents per hundred pounds anditional atuty is charged. This is called differential. Where comotries like diermany pay a bounty to the manulactures of sugar there must be an alditional amount paid on sureh sugar before it can be reseived into this conntry ergual. to the bonnty pain on its production. In cermany this is 31 to 39 cents per hundred pounds, and in France it is more. This act puts all countries on an ecrual footing when they present their sugar at our doors. It also gives the American producer the benefit of the fact that the foreign manufacturer must forfeit his bounty to the Uniter States (iovernment before he can besome a competitor with our manufacturers here.

\section{COMPARATIVELY SMALL AREA NEEDED.}

When we consirler the number of acres neederl to raise the heets for the production of our own sugar, in commarison with the vast leruitory of the United States, the amount seems small, and, indeerl, the amount of such land is small in comparison with the extent of on territory that possesses conditions suitable for the purpose. The fiut that we are in the infancy of this industry is to be considered an arlvantage at this time, in that it gives us an opportunity to select the best and most H. Doc. $396-12$ 
resourceful section of territory for this industry. It should be our aim in building up an industry of this kind, where competition is close, where we are really feeling our way, and where large capital is reryured to inaugurate it, to utilize our best resources in the pioneer work. As the industry works its way up, asserting its possibilities and demonstrating its trade relations, we can bring into action our reserve resources when it is found that we can enter the other marliets of the world. It must be kept in mind by our people that they not only have to meet the competition of other countries, but that they are entering into competition with each other in our own markets. There is, therefore, the strongest necessity for intelligent study of resources before embarking in the enterprise. It requires large capital to inaugurate and start a factory. As time goes on we will know more about our resources in this direction, and those localities having the very best conditions should be allowed to demoustrate the fact.

\section{General Observations on Experiments of Last Year.}

We found, as a rule, that the farmers were going more upon their own experience and knowledge of growing field crops than they were upon the directions given them by the Department and experiment stations. They seemed to think that these directions were superfluous, calling for work that was difficult and requiring the planting and the cultivation of the beets in a manner that was totally foreign to their experience, and therefore wrong. They failed to appreciate the fact that they were dealing with a new feature in farming, or one which they had hitherto neglected, and in modifying the directions they were violating some of the fundamental principles on which the success of the sugar beet for factory purposes depenils. They seemed to look upon the experiment of growing the sugar beet as a thing in which there was no remuneration, and, therefore, a thing on which they conld not afford to waste much time. In considering the experiment of growing sugar beets during the past year the general public may get an indication of the first great difficulty the industry in this country is to meet and master, and that is the education of the farmer to the necessities of the cultivation required. With a view of offering a suggestion that may help in the future, some of the facts that came under our observation in this work will be recorded, noting only experiments of growing sugar beets on small plats on farms miscellaneously.

\section{EXPERIIENTAL BEET PLANTS.}

It is the aim of the experiment to demonstrate the facts and conditions that might obtain in a general way by showing the result through efforts directed in a small way. The farmer, when he receives beet seeds, with the understanding that he will grow them on his farm, does so with the implied obligation that he will conduct the experiment according to the directions, whether they suit his notions or not. Te 
should know that the results of the experiment must stand on its own merits, whether good or bad, since it was undertaken simply to gain the facts. Any other course than this is not only worthless as an experiment, but is mislearling. When a place is to be selected for growing the beets the farmer should have in mind, first, such a plat of ground as will be typical of the region in which he lives. The plat should also be typical of his own farm land, so that the results obtained will indicate what might be expected from his particular region or from his own firm. It was found that in selecting these plats it was too often the tendency of the farmer to take a piece of ground, either in his garden or field, which was not used, for one reason or another, in growing other crops. This plat of land would stand out as a sort of nondescript, and would attract his attention, the only basis of his decision for selecting it as a place to make the sugar-beet experiment. The objection to such in selection would be that it is not necessarily typical of any soils whose qualities he wishes to demonstrate. The following are some of the reasons, selected from hundreds of the same kind, given by farmers visited for their choice of plats npon which to grow sugar beets: "It was three-cornered." "Too low for a garden." "It was recently heavily manured, and thought it would grow good beets." "It was a new clearing, and I thought I could grow good beets" (and yet there might not be a hundred acres of new clearing in the country). "I could not grow anything else on it, and I thought I would try beets." "I had that ground left when I sowed my oats, and this will square the piece." "I had that small piece left, and I did not know what else to plant there."

The above reasons are entirely foreign to any which should have actuated a man in selecting a plat of land on which he was to make an experiment for growing sugar beets. As already stated, he should have chosen a piece of land, not the best or the poorest, but one that was typically representative of his farm and of the general farming region in his locality.

\section{PREPARATION OF THE SOIL FOR EXPERIMENTS.}

The preparation of the soil largely affects the success of the crop, and should be attended to with care. It should be the aim in growing sugar beets to grow them underground as much as possible. Any portion of the beet that appears above the ground is simply a loss. This is governed by (leen) plowing and close pulverization of the soil. The first plowing is generally done in the fall, followed by shallow spring plowing and harrowing. The soil is then ready for planting. It is sometimes rolled after planting, but this depends on the nature of the soil. The beet is now in a position to go down in the soil, in its earliest stages, with the least resistance. It was found that the farmers were loth to give the attention to the preparation of the soil which the proper cultivation of the sugar beet demands. Very few instances were found 


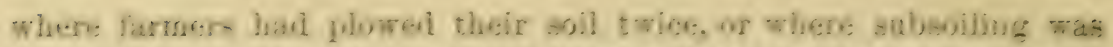

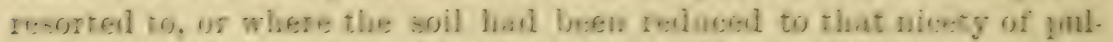
verikation which is demanded. The furner thonglet this was unreges-

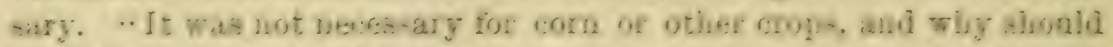

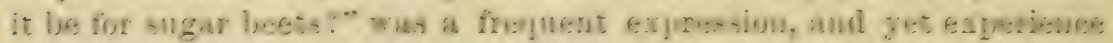

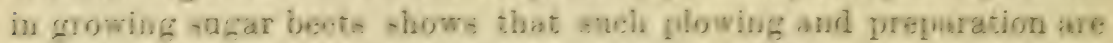

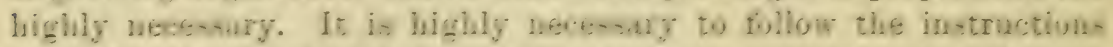

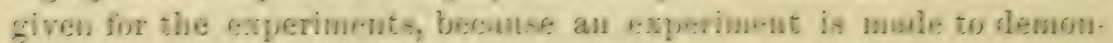
strate the po-ibilities of growing angar beete on a yarticular hrm or

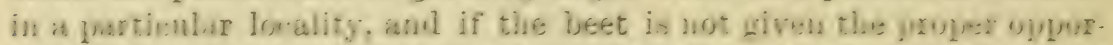
tunity to rlo se, the foxperiment demonstrates anthine. In the foul, if

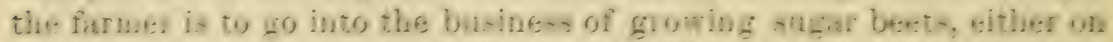

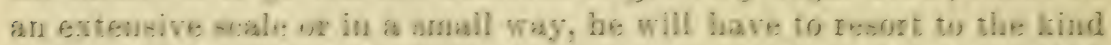
of plowing describeri above, atui if he deres not rane to take the tmeble:

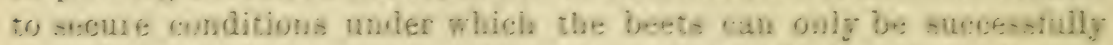

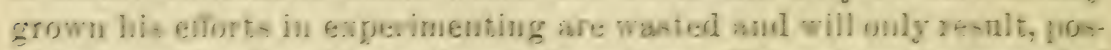

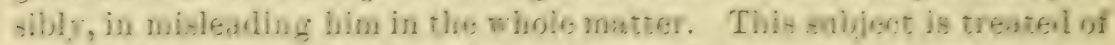

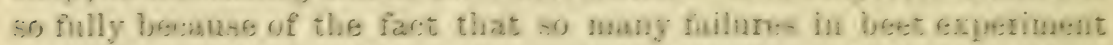

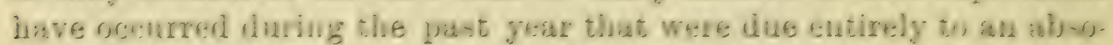
lute want of careful preparation of the anil and aseal beal. While the ability of the American farmer as an agrioulturist has beten denou-

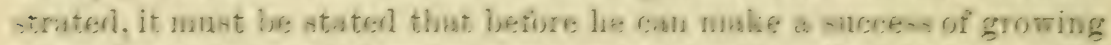
megar biete lie must abandon some private notions that he bas on the subjert and sturly the methrals of ondtivatiug the beeta on the lines labil down by the bng experienc: of thros who have grown thera exteubively and successfully for factory purposes.

\section{PLAYTIY; IY EXPEPIYENTAL BEDS.}

The beet plant mnst be linited in its growing opace. If not it is liable

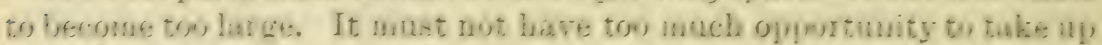

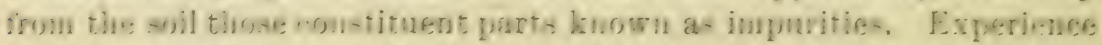
in Fermany, Frunce, and other conntries has thowen that the bests

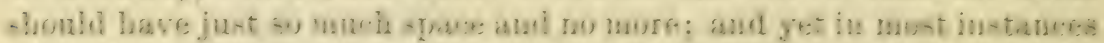
where hes.s were grown fir experimental purposes by the furmes the

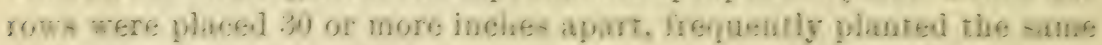

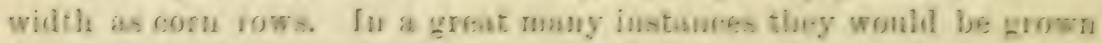
iu one or twe bong wws, and in sone places the bests were spaced out in clie rowe we that thi, would show un in sows two ways aud crula

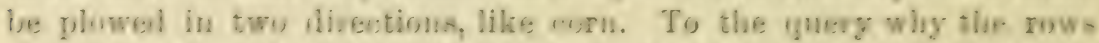
were wot placesl rlower together and tles lowets nearer to each other in the row the acewers were: "We have plenty of groumi, and it is not

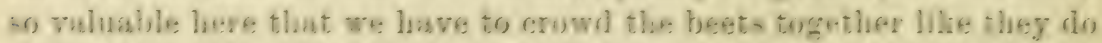
when they grow algar bests in Wa-hington." ". We glant them that way $\rightarrow$ we can plow and cultivate thene." " Nolordy could cultivate

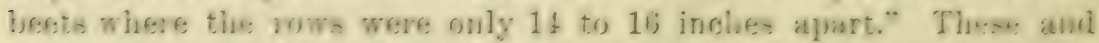
aimilar aneweres showed that the irlsa was timuly one as to ralue aud 
amount of land necessary for the experiment or having the beets arranged handily for cultivation, losing track of the fundanental principle involved-that to raise pure beets and get successful results generally they must be grown close together and limited to the space which experiment has directed.

\section{CULTIVATION OF EXPERIMENTAL PLATS.}

To grow sugar beets successfully, supposing the conditions to be favorable, the soil must be kept free from the grasses and weeds and the ground stirred so as to allow the air to do its work in conjunction with the sunshine and moisture in order to secure from the beet the results that are desirable after it has matured. This is where some of the laborious efforts necessary in growing the sugar beet successfully are expended. The soil is not to be kept simply passively clean, as would perhaps be only necessary for corn, potatoes, and some other crops. It must be kept clean in every sense of the word, as clean as a well-regulated garden. It was found to be too often the case with the jlants where beets were being grown from seed sent out by the Department of Agriculture and the experiment stations that weeds were allowed to grow and stand. The plats were neglecterl for almost every other part of the farm. In talking with the farmer in these cases it was found that it was his "intention as som as he got something else done that he had in hand to clean ont the beds," and in some instances this was done. The effects, however, of allowing the beets to stand in that condition even for a short time could not be eradicated and would show bad results at the end of the experiments.

\section{SAMPLING.}

The directions regarding samples provided a method for securing average samples as to size, form, and quality of the beets, but the growers often disregarded the instructions, and sclected what in their judgment were the best samples from those grown in experiment. The information derived from the analyses of such samples is entirely misleading. In the first place, if the beet specimens are secured, we get results that are not in keeping with the majority of the beets grown in that ease. Hence, the information that the farmer and the public receive on this point is not accurate, and the tendency is to inspire hopes on the part of both that probably will not be realized. It might happen that the grower, in his attempt to get the best samples, is actuated hy ideas of choice that will lead to securing the worst samples, and the result will he as misleading in this as in the first case. For instance, he is liable to select a large beet, which might be a test of good specimens in other crops, but which in the case of the sugar beet is the reverse. The sugar beet shouid range from 1 to 2 pounds in weight, but beets between these figures are the best samples. The factories in their contracts with the farmers in raising sugar beets 
always limit the size of the beet-usually to 2 pounds-and if many beets are larger the crop is condemned or the farmer is docked. These large beets are coarse, and the sugar percentage and purity are low.

The sugar beets will grow to an enormous size, sometimes as large as 18 pounds; so that the farmer can readily observe that it is one of the nice questions in connection with growing sugar beets to hold his crop down to the proper size.

\section{YIELD, OR "TONNAGE," PER ACRE.}

It has been impossible to secure throngh these general experiments any accurate knowledge of the tonnage per acre that has been grown in the different parts of the country. It might seem a simple matter to take one of these small plats and get accurately the number of pounds of sugar beets grown and easily estimate the number of tons per acre from this fraction of an acre. It is, however, the opinion gencrally of the directors of the experiment stations, as well as the conclusion that the writer has formed from observation, that it is not possible to give any definite idea of the tonnage. This is an important feature of the information to be acquired in growing sugar beets in an experimental way, becanse it is the foundation upon which the success of growing these beets will depend as far as it affects the farmer, provilled he can grow beets of sufficient quality, ami it is to be hoped that from future experiments in this liue more caref will be secured.

One of the points to be observed on the part of the farmer, of course, is to get as large tomnage per acre as possible. This is a legitimate ambition, and this is the point at which he should aim, keeping in mind that he must grow a beet not larger than 2 pounds; a beet that will be acceptable to the fictory and not be subject to dockage or rejection. The average tonnage where beets are grown for factory.purposes varies in different loealities. It might be placed between 10 and 14 tons per acre, yet farmers ean raise a good quality of beet with a tonnage ranging as high as 25 tons per acre.

SMALL BEE'TS.

A great deal has been said about growing beets ton large, and some. thing shonld now be said about growing beets too small. A beet may be properly cultivated through a season, and yet, through lack of moisture or some such eanse, attain only a small size. The tendency of such a beet is to be high in sugar and purity per cent. This is very desir. able. But the objection to this kind of a beet is that it is neither profitable for the farmer nor desirable for the factory, because of the tedious work required in its handling. We noticed in looking over the analyses of many beets grown this year that in cases where a high percentage in sugar and purity is shown the beets are very small. This is misleading to the farmer, and apt to lead him to suppose that he can grow beets of this high grade profitably for the market, but such is not the case; he 
can not afford to grow the small sizes. The experiment has only demonstrated what the sugar percentage is in these small beets, and does not give the percentage it would likely be in a large beet, such as the farmer could afford to raise.

[NOTE.-It might be thought by some after reading certain remarks under some of the headings in this portion of the report that the writer is inclined to be a little hypereritical, but we wish to assure any such person that such is not our intention. It was our instrnctions when starting ont in this work to make careful note of anything affecting the beet-sugar industry, and we have simply offered a few suggestions along this line in the hope that they might lead to a more careful consideration of the subject on the part of those participating in sugar-beet experiments in the future. If we shall have accomplished this ohject or shall have been instrumental in furthering it we shall feel highly rewarded for making these suggestions.]

\section{THE FACTOR OF INTELLIGENCE IN FARMING.}

It has been our olservation that some localities take up the problem of sugar-beet growing more readily than others. It is well understood that the community is like the individual, and has its peculiarities, formed, of course, from the characteristics of the people. For instance, there are in the United States communities which are German, Russian, French, etc. In these instances it often happens that these communities have grown from some colonization scheme which brought the majority of the people from the same part of the mother country, and in the case of colonies from Germany, France, and Russia it is very likely that the settlers came from the sugar-beet regions of those countries. Some of them may have had considerable experience in growing these beets, while others not having this experience have gained a knowledge of the nature of the sugar beet, the manner of its cultivation, and the amount of labor involved in its growth from the first-named class. A community of this kind is better equipped to begin the growing of sugar beets than a community without these advantages. In other parts of this country there are localities in which the intelligent American farmer predominates. In such localities the farmer who has his farmers' organizations is an intelligent reader of agricultural literature, takes an interest in farmers' institutes, and studies all opinions pertaining to his line of work; he seeks and appreciates any knowledge relating to anything that he wishes to accomplish; he meets his fellow farmer at farmers' meetings, and discusses new features in farming, or the introduction of new plants in his section. In a locality where these conditions prevail a factory can well be established, the promoters being sure of the best results from mutual and reciprocal relations, which ought always to exist between the factory and the beet grower. The factory may also hope to secure in such a district the best beets that can be grown, and, indeed, we think that it is to this class that the beet-sugar enterprise must look for the highest development of the sugar beet and the final victory of this industry in the United States over foreign competitors. 


\section{LOCAL PROSPERITX AT'TENDING TIIE BEET-SUGAR INDUSTRY.}

The prosperous condition of a town or a locality where a beet-sugar factory was in operation was one of the interesting features of this investigation. The two factory towns in Nebraska and the one (Lehi) in Utah may be citerl as examples, becanse the factory interest of these places stands out more clearly as the one cause of this local prosperity. It may be said that there is no one in these towns desiring employment during the growing season of the sugar beet that can not secure it readily, and it was a wonderfully interesting sight, in traveling over the firms, to see persons of all ages, sometimes in long rows stretehing entirely across the fields, employed in this industry. The statement of business men in these towns was that "anybody wanting work here can get it," and the result is that there is not a family of those depending upon daily labor bnt what has several members receiving weekly wages. There are probably more people here with savings bank accounts than in any other place of the same size. On Saturlay afternoons and evenings the people appear on the streets well dressed, looking halply and contented, showing in every way the effects of prosperous conditions.

\section{THE WORK OF .THE EXPERIMENT STATIONS.}

Justice would hardly be done to a full statement of our observations if attention was not called especially to the great work being performed by the agrienltural experiment stations of the United States along this and many other lines in which the agriculturist and business man are interested. To test a State's condition thoroughly with reference to its capacity for growing sugar beets requires a great deal of labor at these stations, and in most of the States the station stafl's are thoroughly alive to the importance of demonstrating the possibilities of the beet-sugar industry. They are sifting the matter to the bottom, not only in arranging for growing the beets all over their respective States, but in making a study of the soils, both by chemical and mechanical analyses, as well as the climatic and moisture eonditions. They are also gathering data with reference to the facilities and opportunities of the States for operating factories. There is no doubt that these stations are doing a wonderful work in the United States. The results of this work, however, are coming on so gradually that most of us do not appreciate them until we are bronght to realize them by comparing the past with the changes in many rirections that have taken place in recent years. In analyzing the cause which has brought these changes about, the experiment stations will be found to be the strong factors at work. We are attracting the attention of those nations which have been supposed to stand first in the application of seience to their industries, and foreigners are coming to us to make a study of our experiment-station work. The relation between the farmer and these 
stations is becoming more pronounced, and they are gradually getting nearer to each other. The stations are becoming more practical and the farmer becoming more scientific.

\section{ORGANIZED EFFORT.}

In connection with what has been stated witin reference to some defects of experimenting in a general way, such as have characterized the earlier stages of the experiments in raising sugar beets, mention will be made of some of the conditions under which the best experiments were being conducted. A great many sections have formed county and local associations for handling this work in an organized way. Some of them have gone so far as to raise the money preparatory to starting a factory in case the conditions of the locality are such as to justify it. Many of these organizations have exereised more or less supervision over the growing of the sugar beets in their localities, have held meetings where subjects pertaining to the industry, as well as methods of cultivation and other matters of interest, have been discussed. Other localities were not satistied with a general supervision, or felt that the responsibilities and the inducements were such as to warrant them in going to more or less expense in getting before their own citizens and the public generally as complete and reliable data as possible. In these localities a fund has been raised and an experienced man secured from the factory districts, one thoronghly posted on the sugar beet and its methords of eultivation. Such a man has been placed in charge of the various plats, so that from his supervision he is able to give accurate data relative to the beets grown, the methods of enltivation, time of planting and harvesting, the tonnage per acre, quality of beets, moisture precipitation, amount of heat, etc. Such a report, as this will not only demonstrate aceurately the results obtained, but will give an idea whether the results secured were obtained under normal conditions, and whether or not they are liable to be permanent results. With snch knowledge as this, those interested in a locality are prepared to meet the capitalist, and, with an intelligent showing of facts, conclusions are soon arrived at as to whether it is ardvisable to furnish the money necessary to operate a factory in that locality. If the conditions will not justify the establishment of a factory, the people are prepared to drop the further consideration of the question and give their attention to something else. Our view of the case is that this is the true method, and that it shonld be the aim of the experiment stations, and those interested in demonstrating the conditions for the beetsugar industry, to cooperate strongly in encouraging in every way possible such organization. It will lead to accurate information and will be educational in the dissemination of knowledge regarding methods and requirements demanded by this industry. 


\section{General Suggestions for Raising Sugar Beets.}

Iong experience in the enltivation of the sugar beets has furnished certain rules which are general in their application and which govern the preparation of the soil, seeding, thinning, and cultivating the beet plants. There are other rules which are applicable according to the conditions that obtain in certain cases. We will give below some general requirements and suggest some others that have local application. Reasons for the requirements or rules are also given in some instances.

\section{SOIL AND PREPARATION OF THE SEED BED.}

There are many kinds of soil in which the sugar beet will thrive. It must, however, be a soil that is inclined to be loose and friable, and without a tendency to become packed and hard. The sugar beet has a tendency to send down its taproot a good distance when compared with some other plants. In order to produce a beet of right form and pure throughout, the soil must be such as will permit the beet to do this, and also permit it to ember itself wholly therein. If this is not the case, the tendency of the beet is to "sprangle" out, which it should not do. It should liave a single taproot, which tapers off in a long threadlike appendage, striking down deep into the soil. It should grow under the soil as much as possible and the top portion should not stick out above the surface, because this will not only be deleterious to the whole beet, but will make it necessary to cut off that portion which projects above the ground before the beet is sent to the factory, causing that much loss to the grower. This suggests a reason for the deep plowing, followed by subsoiling, demanded in the case. The soil should be usually plowed about 8 inches deep, followed with a subsoiler that loosens to the extent of 7 inches more. Then it shonld be harrowed back and forth until it becomes thoroughly pulverized and softened. Here we have a condition that is necessary to germinate the seed and assure ourselves of a stand of beets. If seeds are sown in ground where the surface is inclined to be lumpy and cloddy, even if the lumps are quite small, the effect will be as follows: The seed are sown from a half inch to an inch in depth, and it will be remembered that the beet seed have a rongh, dry husk with convolutions on the exterior, making it quite rough on the outside, with small depressions, so that they must be planted in a soil that is soft, for the purpose of haviug it press against the sirles of the seed, filling up these little depressions in order that the eapillary attraction may bring the moisture from the soil to be absorbed by the seed, and thus induce germination. On the other hand, if the soil is clotdy in the least these small clods are inclined so keep little air channels around the seed, through which the dry air circulates and dries ont the seed, which finally dies, and thus our opportunity for securing a good stand is diminished, as well as the chance of securing a strong and healthy plant at the outset, so that 
one condition requisite is a highly pulverized soil. It is usually the practice, in stirring up the ground preparatory to planting sugar-beet seed, to do the first plowing in the fall. The subsoiling is also done at this time. In the colder regions we thus have the benefit of the effects of freezing and tharring, which crumbles and pulverizes the soil, of which most farmers are amare. In the spring the ground is plowed again with a shallow stirring plow or a good cultivator, and this is followed by harrowing, etc., to prepare the surface. In the sugar-beet districts of California it is the rule for the farmers to do the larger part of their cultivating in the early spring. In fact, they aim to kill all the reeds they would have to contend against before the seeds are planted. The conditions there at this season are more alvantageous for this purpose thin in most other sections, because the winter rains and early germination bring the grass and weed seed out, and then the ground is cultivated and the weeds killed. Another crop of weeds is then allowed to germinate, when the ground is cross cultivated for the further lilling of weeds. This destroys weeds and helps to get the soil in condition for planting. After planting there are no further rains, and of course there are no such opportunities for weeds to grow as there are in States where there are rain conditions. We have, how. ever, found sugar-beet growers following this method of killing weeds to some extent and to good effect even in the Mississippi Valley, where weeds grow luxuriautly during the growing season of the beets.

\section{PLANTING.}

Under this and other heads we will consider implements that are used for the purpose in growing sugar beets, the depth of sowing the seed, the distance of the rows apart, the distance apart of the plauts in the rows, and the amount and kind of seeds, etc.

Special implements or drills are used for the purpose of soming sugar-beet seed. Some of these implements have special arrangements for sowing the seeds in ridges and others for planting them on level ground, the latter being more usually the case in this country. There are places in the United States where the conditions will peruit planting beet seed in ridges, and these ridges are maintained throughout the cultivation with apparent advantage to the beet, in that it allows more readily the action of the air and sun; but we believe this planting is not considered good practice in most of the present sugar-beet regions. Where seed are to be sown on a large scale it is preferable, and at least more economical of time, to use the four.row seeder, which can be regulated almost to precision for sowing a definite number of pounds of seed to the acre. We find that the best practice in this country is to sow from 15 to 20 pounds per acre, with a leaning toward the latter amount. It is better to be a little out of pocket on account of seed wasted than a good deal out on the amount of beets grown, as well in the quality of the same, owing to a poor stand. 


\section{PLANTING AND CULTIVATING IMPLEMENTS.}

The companies that make a specialty of implements for the cultivation of sugar beets have what they call a "full set of tools." In a case where the four-row seeder is used, a four-row cultivator is a part of the set. This is desirable, from the fact that the cultivator follows the same four rows and in the same order that the seeder planted them, so that if there is any variation in the rows planted from a straight line the same variation will occur in each of the four rows being cultivated. The person who is holding the cultivator handles and following it has only to watch one row, and if it becomes necessary to shift the implement to one side or the other, on account of a variation in that row, the same will be true of the other three rows. The implement companies have also a set of two-row implements that operate in the same way. The cultivators used in this country are usually drawn by one horse or mule, and we found that most of those who have had experience with both animals prefer the mule for this purpose. This preference has often been expressed to us. It is claimed that the mule is more compact for the same amount of power, and having smaller feet, when the width between the rows is narrow, say 14 inches, he is not so liable to injure the beet plants. It is claimed that the mule is more susceptible to training in this particular line of work, especially in following the rows faithfully. He needs less attention from the person holding the handles of the cultivator, who thus has more time to devote to cultivation. This one mule or horse is all that is needed to pull the cultivator, taking four rows at a time. The first cultivation is accomplished with small plows or knives attached to the eultivator, called "goose feet," "hecause they resemble very much the form, shape, and size of a goose's foot. The edge of the knife rums within $1 \frac{1}{2}$ inches to 2 inches of the beet, a knife rumning on each side of the beet plants in each of the four lows, the side next to the heet presenting a square surface. The cutting part, or rim, of the feet run from one-half to an inch below the surface, and parallel with it. It is thus seen that it is not the intention to stir the soil to any depth, but simply to run the knives muder the surface for the purpose of cutting ofl the roots of the weeds and grasses and breaking up the crust of the soil. This is the usual practice in the earlier stages of eultivation. Later it is usual to replace the "goose-feet" knives with "bull-tongne" cultivator blarles, so named from their similarity in form to a tongue. These cultivate down 3 to 6 inches. After the seeds are planted it is usual to roll the ground, and by this means compress the soft dirt thoroughly around the shell of the beet seed, as has been suggested. This practice serves well to accomplish this purpose except in localities where it is found to be undesirable to retain this smoothly rolled surface, when it is sometimes "ronghened up," to prevent evaporation, by the aid of a harrow. This is done because the soil is quite sandy and the prevailing winds are very strong in the spring, so that where the ground is 
very level the wind earries along with it, sliding over this smoothly rolled surface, small particles of sharp sand, which strike the sugarbeet plants, entting them off even with the surface. This is very damaging to the crop.

\section{WIDTH OF ROWS.}

The rows are generally made from 14 to 18 inches apart, sometimes as many as 21 inches, and the plants should stand in rows, from 6 to 10 inches apart. These distances in both cases are governed largely by the character and responsiveness of the soil, it being evident that some soils require closer planting than others. We wish to call especial attention right here to the distances governing the separation of rows and plants, because it is a governing principle, and no furmer can afford to violate the directions in this case. We have shown elsewhere in this report that there is a tendency on the part of the minitiated to do this differently for varions reasons. They look upon it as a hard task to cultivate the beets so close together, ete., but no one who understands the nature of the sugar beet and feels a responsibility in the snceess of his crop will allow himself to violate the principle goveruing the proper spacing of rows and plants. Long experience with growing sugar beets for factory purposes has demonstrated that the space occupied by the beet in the field from which it draws its sustenance must be limited. If allowed too much space it becomes coarse in texture and quality. The sugar beet not only sends down a long taproot but it has numerous lateral roots which will, if allowed, reach out several feet in cifferent directions, and if this latter effort is not arrested it is liable to assimilate too much of those elements which are recognized in the laboratory and in the factory as impurities. This is prevented by spacing the beets as closely together as is practicable, and, as suggested above, in limiting the distance between the rows and the plants in the rows. The writer once called a prominent horticulturalist's attention to the practice of some farmers of driving nails into the limbs of their apple trees, or wrapping them with wire, or in some other way injuring them to a certain extent, in order to make the tree bear. In reply (while he did not commend it) he gave as a reason for this practice that "it makes them bear fruit the next year," which, of course, we observerl to be the case. On asking him what he thought was the governing principle that brought this abont, he stated: "You arrest the growth of the tree, aud it has to exert its energies in another direction, which it does by storing up materials for a fruit supply and startiug fruit buds." Now, if we apply this principle to a sugar beet which has been wastiug its energies in the direction of growth, etc., we may be able to discover the philosophy of this governing principle of spacing. It gives us a beet of the proper size and texture, which we must keep in mind is from 1 to 2 pouuds, the ideal we are striving for. 


\section{THINNING AND BUNCHING.}

It is customary, as soon as the beet plants get through the ground so that the rows can be readily discerned, to go over the field once with the cultivator" with the "goose-feet" knives attached. This catches the first weeds in their early stages, breaks up the hard surface, and permits bunching and thinning to better advantage. Bunching is resorted to to save time and labor. A person goes aloug the rows, and with a sharp hoe cuts out the surplus plants in the row, leaving the plants in bunches from 6 to 10 inches apart, according as may be desired. 'This is followed by the person who does the thinning, who crawls along the rows on his hands and knees, and, selecting the most thrifty plant in a bunch, takes it between the first two fingers, with the back of the hand toward the grombl then with a quick movement of the fingers of the other hand he grasps the surplus plants and removes them from the soil. This is ono of the most laborions features of sugar-beet raising. It can be done by girls and boys from 12 to 16 years old, who are very active in the work. Iu fact, this linel of labor can be used to a great extent all through the various stages of the cultivation of the beet. We have known farmers in their earlier experience with raising sugar beets who looked upon this thimning out as a great waste of seed, and would try the experiment of planting less seed the next year. This experiment usually ended in disaster, especially if the conditions for germinating the seed happened to be not very favorable, and it is not customary for the firmer to repeat this experiment very often.

\section{THE IIME FOR THINNING.}

It is a very serious mistake to allow the plants to become too large betore they are thimmed, and we noticed that the agriculturists at the different factories were particular on this point when scanning the work of the farmers who were growing beets for the factories. There is a tendency of the plants, where they are grown close together, to twine around each other, and the principle to be observed in thinning beets is to remove the surplus plants, leaving the plant that is to mature intact in the soil, disturbing its roots as little as possible. If other plants are twined about the one that is to remain in the soil, the larger these entwining plants become the more the entwined plant is disturbed in thinning. The beet plants send out theix laterals very rapidly, and in thinning out the surplus plants these roots are liable to be more or less disturbed. The larger the beet that is to remain in the soil the more likelihood there is of its being disturbed, so that this thinning process must not be neglecter. The beet plants that are to remain can be set back three weeks in this way, and in a dry season a number of the plants are likely to be killed, thus affecting the "stand." 


\section{CUL'IIVA'TION.}

We have said considerable abont cultivation in discussing the "Soil and preparation of the seed bed," as well as in describing the implements used in cultivation, and we wish to state now that harrowing is to be very strougly recommended in the cultivation of sugar beets. Three things must be kept in view in this cultivation: First, the beets must be kept absolutely free from weeds and grasses, so that the beneficial effects of the sun and air may be fully realized; second, the ground must be kept loose for the same purpose; third, in case of dry weather the soil must be kept stirred, in order that a dust mulch may be sustained to prevent evaporation of moisture. Frequent hoeing by hand is highly beneficial to the crop.

\section{HARVESTING.}

The time of harvesting is goverued by the time of the ripening of the beets. This ripening is made apparent by the outside leaves of the plant taking on a yellowish tinge and drooping to the ground. An experienced eye soon learns to detect a field of ripe beets that is ready for harvesting, the whole field being colored to this yellow tint and the leaves showing this drooping tendency peculiar to the matured plant. The beets have now finished their work, and the next step of the grower must be governed by his locality. If he is in a locality where there is a probability of rain, the beets must be harvested and placed in silos. This would be the ease in most of the sections where rain conditions prevail, such places usually having strong rains in September and October, followed by more or less warm days. The effect of the rain will be to cause the beets to begin growing again and new leaves will soon be noticed starting ont, as well as new lateral roots from the beet in the soil, all the beets showing a general tendency to a second growth. Serious damage to the crop will soon be done in this way. The sugar content of the beet goes down materially and its impurities increase, so that if the rains are marked and followed by warm days, it is possible for a whole erop to be lost, so far as their fitness for factory purposes is concerned.

SILOS.

It is the custom in localities of this kind to haul the beets to the factory if possible, and if it is not possible to do this they are gathered and placed in long ricks or piles on the surface of the ground. The base of these ricks or piles is from 3 to $3 \frac{1}{3}$ feet, with a height of 3 to 4 feet, tapering toward the top. Along each side of these ricks several furrows are run with a stirring ylow in order to loosen the dirt. The ricks are then completely covered with this dirt by the aid of shovels. This covering is put on to the depth of about 6 inches, occasionally air spaces or ventilator's being left on the tops of the ricks, which are usually made by the use of tiling or small elongated wooden boxes or 
simply straw, the purpose being to prevent fernentation. Storing the beets in this way is called siloing, and the ricks or piles are called silos. These silos are closely watched, in order that no heating may oceur and cause fermentation, which lesseus the sugar content of the beet, and they are opened occasionally for this purpose. It is the aim of the grower, as already staterl, to get his beets to the factory as soon as possible, but this will depend on "his turn." In case he is delayed in this way until cold weather comes on, these silos are covered with straw manure, straw, or something of that sort, and then an arditional amount of dirt is thrown on the straw covering. In this way it has been found that the beets will keep in very good condition until the last of January, if necessary.

It might be stated in this connection that it does not necessarily follow that the beets are lost even if they should be frozen solid, as the factories can readily work them frozen; and, in fact, some factory superintendents have told us that they prefer to work frozen beets. The one thing to be guarded against in the case of frozen beets is that they must not be allowed to freeze and then thaw. In California, where rains or freezing are not liable to occur, after the beets have ripened and have gone into this state of rest they are allowed to remain in the field until the grower is notified by the factory that his beets must be delivered, when they are harvested and taken to the factory. Thus the expense of siloing is avoided.

\section{HARVESTING IMPLEMEN'IS.}

IIarvesting is aceomplished by means of an implement especially prepared for the purpose. We have seen several kinds of these implements, all of which seemed to do the work admirably. In some places it is done by means of a long slender plow, which works on the principle of the stirring plow. It goes deep down into the ground with a sharp plowshare. This plow is run close to the beet in such a way that the share cuts the taproot just below the enlargement of the beet, at the same time loosening, lifting, and laying it on its side. Another harvester, instead of having a share, has two prongs, one of which passes on either side of the lower portion of the beet root; the space in front between the two prongs being larger than that in the rear, causes the beet root to be forced into the smaller space between these prongs as they pass by, and the beet is lifted bodily 3 or 4 inches and the tap. root broken. As the plow passes on the beet drops back into its place loosened and ready to be lifted from the ground by the hand. Following the plow are persons who pick up these beets and by one stroke with a large knife male for the purpose separate the crown of the beet together with the leaves. This is called "topping;" and it is the aim of the person doing this "topping" to make the cut where the line of the beet shows that portion has projected above the ground. Where the beet has been grown entirely under the ground only enough is cut 
off to carry with it the crown and the leaves. If the beets are to be sent to the factory at once, the "topper" simply throws them in piles, from which they are taken and placed in steks and put in wagons for delivery to the factory. They are s metimes thrown loosly into the wagons from the piles. Most of the factories, however, have arrangements for quickly handling the beets. Some of them have wagons provided with nets for receiving the beets, and upon reaching the factory these nets are taken from the wagons by the aid of machinery, and their contents dumper into the beet sheds. At other factories the wagons are hauled upon an elevated driveway, which is arranged in such manner that the portion on which the wagon rests can be tipped, and the wagon tipping at the same time, the loal of bets is precipitated into the beet sheds. By either of the above methods the beets in the wagons are very quickly handled at the factory, and the advantages of these arrangements can be appreciated when it is known that long lines of wagons, loaded with sugar beets, stand ready at the factory to be handled. Either of these arraugements quickly dispose of many wagon loads, and teams are not required to wait long, as would be the case if unloaded in the ordinary way of shoveling ont of the wagons into the shed.

\section{IRRIGATION.}

It has been stated that beets can be grown successfully under irriga. tion conditions, and in fact two factories in the United States, one located at Lehi, Utah, and the other at Eddy, in the Pecos Valley, New Mexico, secure their beets entirely through irrigation. There is a large amount of land in this country available for this purpose in Western Nebraska, Colorado, Utah, Montaua, Wyoming and other States having like conditions; and this industry is one that should appeal to these sections on account of their aheady well-known grazing resources and the fact that stock feeding and dairying are so intimately related to the beet-sugar industry. The first beets that were ever suecessfully raised by irrigation for factory purposes were grown at Lehi, Utah. We believe that it is maintained in Europe that beets can not be successfully grown by irrigation-at least it is seriously questionedbut the experience at Lehi, Utah, and Eddy, N. Mex., has forever exploded this theory. There are a few things that must yet be learned about the application of irrigation to growing sugar beets, but these obstacles are fast being overcome, aud the two factories inentioner are teaching the world lessons along this line, and in doing this are demonstrating the possibilities of the vast resources of the territory in the West having like conditions. Irrigation is especially adapted to raising sugar beets where the particular region is favored with rainfall in the earlier stages of planting time. The ground is moistened through rains, and in this way the seeds gre germinated and sturted on their first growth. Experience has demonstrated that irrigation should bo H. Doc, $396-13$ 
held off as long as possible and applied as little as possible. Water should not be applied by irrigation until the natural supply has failed, and even then the grower must be careful not to apply too much. Too much is as disistrous as not enongh. We have learned by talking with those experienced in the application of water by irrigation of the tendency of the land to dry out quickly after being irrigated and of the ground to become packed, so that cultivation must follow as soon as practicable after irrigation. It has been noticed that the beet has a tendency to send down its taproot deep into the soil, and especially is this true in the arlier stages, if the necessities of the case demand it in order to procure moisture; and this is to be desired. If water is applien too lavishly in the beginning this tendency of the beet is arrested, and it shows a disposition to rely on artificial supply of water rather than to seek its own, and we have thus interfered with a natural tendency that is desirable in the growth and maturity of the heet. The effect will be, under these cireumstances, that the taproot will divide and the beets will become bunchy and sprangle out, assuming a form entirely undesirable. The beet may show a tendency to slightly droop) its leaves and to become lighter in color, but this does not indicate that irrigation is needer. If the beet recover's its vigor in the evening it is a sufficient indication that it is getting along all right. When it comes to suffer from dronght the tendency will be to droop and get darker in color, and it will not apparently recover vigor with the approach of the cool of evening. This is the time to consicler the question of applying irrigation.

We have noticed two methods of irrigating beets, either of which seems to accomplish the work successfully. One of them is to plant the beet in rows, say, from 18 to 20 inches apart, and then when it is desirable to tum on the water, a small furow is rum between every other row by the use of an implement marle for this purpose. The water is then tuned on and allowed to trickle down these furrows. This causes the water to pass down on one side of every row in the field, and leaves the space between every other row that is not so furrowel. When it becomes necessary to apply water again a furrow is marle between the rows not furrowed before, the former furrow having been leveled mp by cultivation. The second plan is to plant the first two rows the usual width apart, say, from 14 to 20 inches, and tilen the next space between the other two rows will be considerably wider, say up to 20 inches apat. This wider space is entirely.tor the purpose of having an irrigating furrow, which is made in similat manner to the one rlescribed above, the wider space occmring between every couplet of rows. In either "ase water can be held in these furrows by throwing a shovelful or two of dirt into the furrow in front of the water until the ground becomes thoromglily satmated around the beets, and then the obstruction is removed and coutinued down the furrow. Of course the supply furrows alo condueterl along the higher places and the cross furrows alluged in such a way that all parts of the field are reached. 
This simply suggests that the grower in the application of water by irrigation must thoroughly understand the science of economically distributing the water in the field, which is a question too broad to be entered into here, but by experience the farmer becomes more or less adept.

In regions where the beets are started in the spring with moisture from rainfall it is the aim of the grower to produce his crop with four or five irrigations of the beets. After they begin to ripen all irrigation must cease, for the same reason that it is not desirable to have a rainfall after the beets are ripe.

\section{SUBIRRIGATION.}

Simply as an interesting observation of one of the wonderful provisions of nature, we will call attention to the moisture conditions under which beets are grown on the Pacific Coast. As has been stated, beets are grown there without the aid of either rainfall or irrigation. There seems to be some sort of mechanical provision of the soil for holding the. moisture precipitated during the winter, and gradually letting it out during the growing season of summer. This same condition prevails in the eastern part of Washington and in many sections of what might be called the arid regions, so far as the amount of rainfall is considered. In a trip made between Spokaue and Pullman, two towns in eastern Washington, we saw some splendid fields of wheat, oats, and erops of like nature, but we wish to refer especially to the wheat, which both in quantity and quality was superior to anything we observed anywhere else in the United States. These fields of wheat were located on hills, which in some cases reached the magnitude of small mountains. All over the sides of these elevations and on top of them were growing these fields of wheat, that were yielding from 40 to 60 bushels to the acre of fine quality, and, indeed, it was believed that on the top of the hills the crops were doing better than on the other portions, if possible. Now, the rainfall during the growing of these crops was hardly worth mentioning, and yet this wheat had grown, matured, and was harvested as describel. We conld not imagine for a moment that such crops conld grow on such hills anywhere in the Mississippi Valley under any conditions with which we are acquainter. We think that these crops are due to the inherent tendency of the soil to retain and emit moisture. We believe that experts and scientists are unable satisfactorily to explain this phenomenon. We have called on some experts for an explanation, and they state that they are working on the problem, but so far are unable to solve it. One of these experts informed the writer that he had noticed a place where a second growth of tobacco and other succulent plants had occurred, and right in this spot an 80 -foot well had been dug withont the slightest show of water. Scarcely any rain had fallen in this locality since the early spring. We cau ouly say that the moisture is there in the ground and 
is given out to the plants, as has been described in the case of the fine wheat crop. These peculiar conditions prevail over extensive sections in the western mountain regions, as well as in the part of Washington referred to, and aloug the coast of California. It is under such conditions as these that they grow sugar beets in California for the factory.

\section{BLIGH'T IN BEE'S'S.}

We noticed during the inspection last summer that in some sections, especially in the arid regions, where beets were raised by irrigation, that the beets were liable to be affected by disease or blight. This disease seemed to attack the taproot at a considerable distance under the surface and then gradually work up through the body of the beet, the lateral roots feeding the beet and keeping the leaves green during the progress of the disease. The diseased part would rot completely, and finally the whole beet would be consumed in this way, the disease generally completing its work when the beet was about two-thirds grown. After this the leaves would die, the disease having consumed the beet, and thus killed the lateral roots which had fed them. . A very sour odor could be detected during the prevalence of this disease. We are not prepared to say whether this blight is peculiar to irrigated beets or not, but we found this disease throughont the regions where the beets were grown by irrigation. We found irrigated fields, however, where the crop was not affected in this way, and some fields where the beets were only slightly affected. If the disease is due to irrigation, the people who irrigate will have to tell us by experimenting with the disease how to overcome it. It seems that the tronble was cansed by intensely hot weather and irrigation together, and it occured to the writer that if the colder days and nights were selected for the time of irrigation as far as possible, it wonld be better for the beets. On this point MIr. Cutter, of Lehi, says: "Irrigation has nothing at all to do with the blight of root on the part of beets. There has been blight of beets in several localities this year, whether irrigated or not. It is simply a secondary consideration; the primary cuse being the lack of moisture."

CONDITIONS IN 'THE SPRING OF 1897.

In the Mississippi Valley the ground was too wet for the early planting of the sugar.beet seed, hence the planting was delayed and the spring season of 1897 was nufavorable. In northern Iowa, South J)akota, Minnesota, and Wisconsin musually late frosts occurred, which aflected the beets. We believe the spring was quite favorable in Nebraska tor the growth of the beets. Thronghout Colorado, Utah, and the coast region there was an unusual drouglit at the time when the seeds should have been planted, and the conditions were quite unfarorable for the raising of a crop. Cutworms very naterially affered the young plants in Suntiı Dakota, and in the northern section 
of New Mexicn insects attacked to an alarming extent the sugar beets being grown for the factory at Lddy, in that Territory. It might be stated, therefore, in a general way, that the year of 1897 was not a very favorable one for the sugar-beet crop.

\section{VALUE OF CROP.}

We have considered the question of raising sugar beets, the different methods applied in cultivation, and the agricultural problems to be worked out in counection therewith. We will now consider the value of the crop.

The worth of a crop of beets to the farmer will be different in different localities. In order to eneourage the growing of sugar beets some of the States have offered a bounty, say $\$ 1$ per ton, or so much for every ton of sugar produced. In some cases the bounty is to go to the farmer, and in other cases it goes to the factory, with the condition that the factory will pay the farmer a certain price for the beets. The usual price of beets ontside of this government encouragement is $\$ t$ per tonthat is, where the beets are purchased straight without reference to their purity or sugar content, except that they be stanclard. It is usual for the factory to establish a standard to which all beets that are deliv. ered must come, and before they are received the beets are tested for this purpose. This standard usmally requires that the beet shall contain 12 per cent of sugar and show a purity coefticient of 80 per cent. Beets lower than this standard are rejected or docked. Some other factories purchase beets from the farmer and pay for them according to the amount of sugar contained. Such factories usually fix 12 per cent of sugar as the basis npon which they will pay, say $\$ 3.25$ to $\$ 3.50$ per ton, increasing the price 25 cents for each additional 1 per cent of sugar shown in the beet. For instance, if $\$ 3.50$ was the price for standard 12 per cent beets per ton, and beets should be delivered that showed 14 per cent sugar, the farmer would be pair $\$ 4$ per ton, and for beets showing 15 per cent he wonld receive $\$ 4.25$.

The amount of beets that can be grown per acre will depend largely, like other crops, on the stani aud responsiveuess of the soil, as well as the enltivation the crop has received and the favorableness of the season during the growing time. It is difticult to state accurately what the average tonnage per acre should be. As stated, this varies for different localities and different seasons. It would be safe, however, to put the average crop at from 10 to 14 tons of beets per acre, and the maximum and minimum at 30 and 6 tous. A great many estimates have been made as to the ecst and profit of growing sngar beets. These, again, will vary in different localities and seasons, as well as for differeut people. Some persons will not accomplish the same results with the same amount of effort that others will. In this connection, two estimates, one for beets grown for the factory at Lehi, Utah, made by the factory superintendent, Mr. Granger, and the other for 
beets grown for the factory at Yorfolk. Yelur.. ane presented. The Allowiug is Mr. Granger's statemeut. and the writer, sylaking from personal acouaintance, presents the agures as entirely tristworthy:

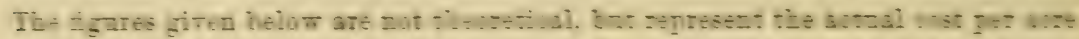
or the wort with wages at \$2.50 to \$s per dar for man and team; $\$ 1.35$ to $\$ 1.50$ per dar io man, and 50 ceats to $\$ 1$ per das ior boys-

Fall plowing. 1. inches deep ............

Pulrerizing in spring ................................................. 10

Rollivg ................................................................... 25

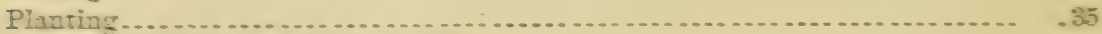

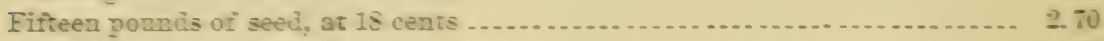

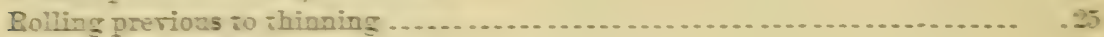

Cultivating prerions to thinaing -.................................... . .

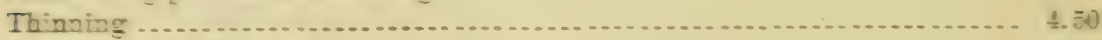

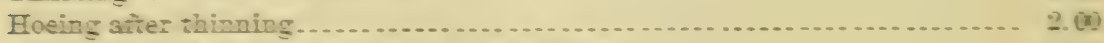

Furroming out for imigation twice, at 25 cents . . . . . . .

Irigating twice, at t0 cents. . . . .

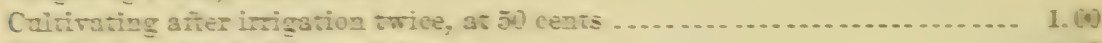

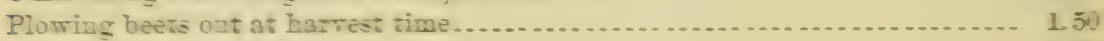

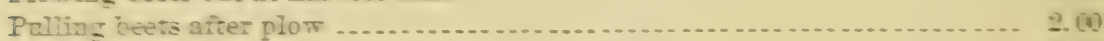

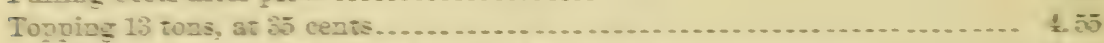

Sacking and badliag 13 tons (3 miles), st $\mathrm{a} 5$ cents..................... 8. 45

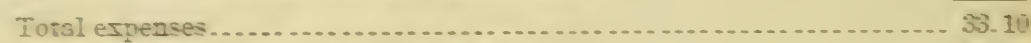

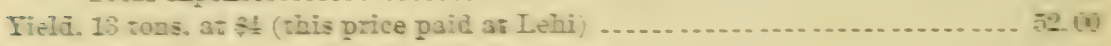

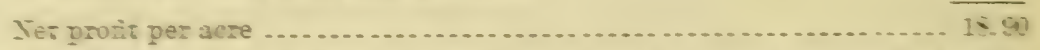

The sbore ifgares may. in some instances, be subject to slight ebanges, but in the azplegute they are comeck.

The rerg conserratire estimate of only 13 tons per aese is csed bete merelt to siom whar size crop can be made to par well.

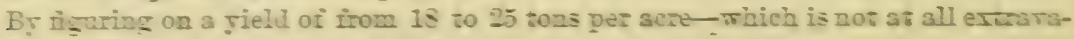
sant-ihe possibilities of the crop msy easild be reeognized.

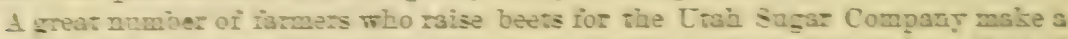
net proit of fiom 350 to $\$ 50$ per aere, atter allowing themselves and fumill full wages ror all work coue on the crop.

The fllowing is a statement of expense and ut retarns from 41 t Mre- of sugar beets groma at Coumdi Blufts. Inwa. by H. C. Amaves $\$$

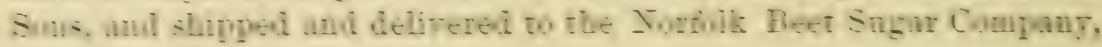
at Fortolk, Febr.:

Statement of exrense.

\begin{tabular}{|c|c|c|}
\hline 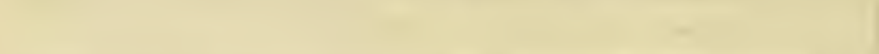 & $\begin{array}{l}\text { Iutsin? } \\
\text { evest. }\end{array}$ & $\begin{array}{l}\text { Cos: per } \\
\text { sure- }\end{array}$ \\
\hline 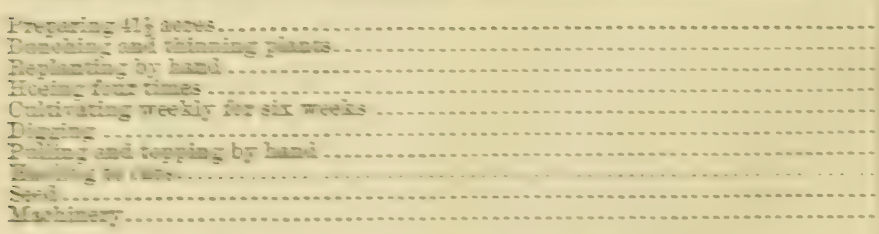 & 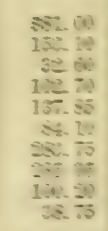 & 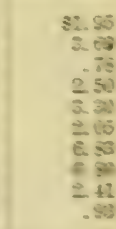 \\
\hline 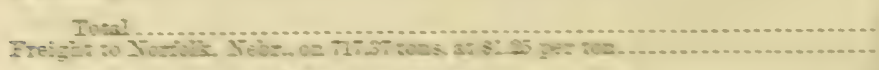 & 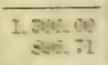 & $32 \approx$ \\
\hline 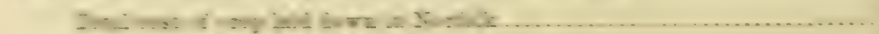 & 1.:- - & {$[\ldots \ldots \ldots$} \\
\hline
\end{tabular}


Statement of returns from beets.

$\$ 5$ per ton for 654.1 tons.

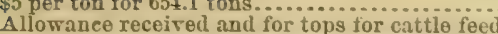
$\$ 3,270.50$

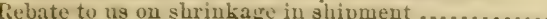

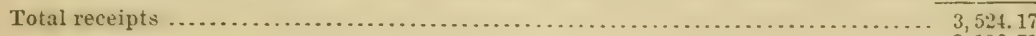
Cost . $2,196.71$

Net profit for use of land $1,327.46$

This gives $\$ 31.98$ per acre for use of ground. Total acreage, $41 \frac{1}{2}$; total tonnage, 654.10 ; average tonnage to acre, 15 ; average tare, 8.83 per cent; avorage sugar content, 14.39 per cent; highest purity, 84.2 per cent; lowest sugar contout, 11.8 per cent; highest sugar content, 17.1 per cent.

The following figures show net result if wo could have delivered to a factory at Council Bluft's and saved shipment to Norfolk:

Gross weight of beets at this end before shipment................... 1, 513, 330

Gross weight of beets at Norfolk after shipment ................... 1, 435, 200

Shrinkage in weight iu shipment, 5.2 per cent, or .................. 78,130

Leaving a net loss to us in shriukage in weight .............. $\$ 171.82$

ITe paid in freight .............................................. 896.71

Net loss to us because of having to ship beets.................. 1,068.53

Net profit as shown abore after shipment........................ 1,327.46

$2,395.99$

Showing that we could have male \$2.39.99 if we condel have deliverect to a Conneil Blufi's beet-sugar factory. 'This would have been a profit of $\$ 57.73$ per acro.

A sugar manufretory at Council Bluft's having a capacity of 300 tons of beets per day will produce almost $6,000,000$ pounds of sugar in a season. It will pay to the farmers for beets, at $\$ 4$ per ton, $\$ 112,000$. It will give employment to 150 men in the factory, in addition te 500 or 600 men, women, and children in the beet tields.

Beets grown here this season tested as high as 17.1 per cent, and averaged almost 15 per cent, which is fully 5 per cent above requirements of German beet-sugar manufactories. There aro many thousands of acres of land adjacent to Council Bluffs fully as well adapted to sugar-beet raising.

[NoTE.-The amount received for the beets is too large, accorling to present prices, which are about $\$ 4$ per ton. The above parties received $\$ 5$ per ton on account of the State bounty of $\$ 1$ per ton paid at that time, so $\$ 1$ per ton should be deducted. Attention is also called to the heary freight charges in the above statement, which are dne to the fact that the beets were hauled to the cars and shipped nearly 100 miles. The item of "hauling to cars" is equivalent to the delivery to the factory.C. F. S.]

\section{BEET SEED.}

The question of buying heret seal is one of considerable importance. There is a disposition on the part of the people to he dissatistied with the custom of importing the larger portion of our sexts. The feeling seems to prevail generally that these beet seeds can easily be, and should be. gromu in this country. This is a spirit to be commended, but when it is understood that the growing of sugar-bert seed is one of the most intricate features of the whole enterprise. reyuiring a large investment of capital and the application of consiclerable scientific knowledge, it will be readily seen that it will be some years before the Cnited States will have fully established a safe and reputable sugarbeet seed production. These sards are not produced in the same 
manner as ordinary garlen seeds, such as cabbage, turnip, lettuce, etc., simply by planting ont the beets and harvesting the seeds at the end of the year. They are produced in a series of plantings, and, according to the best information, it takes five years to realize a crop of sugar.beet seed after the series has begmu. The series is required in order to pro. duce seed of a high grade and sure quality, and is the result of testing and selection. The sugar content and quality of the beet is held up by this constant testing and selecting, and it is a matter of vital importance. The sugar beet, as such, is of too recent origin to have its habits of sugar producing so thoroughly fixed that we ean depend upon it. These are facts that we must be absolntely sure of, as they lie at the foundation of success in the sugar-beet enterprise. Under these circumstances we must depend upon the old established and thoroughly equipper firms of Europe to produce our sugar-beet seed until such time as twe can gradually and safely raise our own seed. There are undoubtedly firms in Europe which will, whenever they can, impose a poor quality of seed upon the American or any other purchaser. It becomes a matter of the greatest importance to the people in this country to be sure of the character of the firm from which they intend to purchase sugar-beet seed. Buyers should surround themselves with all possible safeguards in these transactions. In the first place they should understand thoroughly the responsibility of the firm, and in the next place they should buy seeds in original packages when they purchase abroad, and shonld demand an oflicial cortificate showing a test of their quality, germinating power, etc.

When these seeds are intended to be used in ruantities, they should be thoroughly tested as to their germination upon arrival. Seeds can be inporter wholesile into this country for about 9 cents per pound. We muderstand they have been bounht recently for next year's use for something less than this. When we shall be able to safely produce our own seed, it will undonbtedly be to onr advantage, as the tendency will be to build up, estalblish, and perpetuate the sugar-producing habits of the plant under our own elimatic conditions.

\section{FACTORY CONDIITONS.}

Conditions that would largely aply to the agriculturist or farmer in answeriug questions as to whether he was in position to profitably grow sugar beets have been considered; but in considering the beetsugar industry there is another sicle to the question, which might be called the factory side. It might be possible to grow successfully sugar beets, and yet the local conditious might not be favorable to operating a factory, and without a factory the Parmer las no market for his beets. He could only use them as a food for stock. So we will consider some of the necessary factory conditions. 
QUALITY OF BEETS.

One of the first things that every factory will consider is the quality of beets grown in the locality that must supply the factory. As has been observed, the effectiveness of the process, the quality of the finished product, and the expense of operating the factory depend largely upon this point. The more impurities, or such elements as are recognized as impurities, contained in the beet, the more difficulties there are in extracting the sugar. It should therefore be the aim of everyone investing in a factory for the production of bect sugar in this country to require the best conditions in the matter of purity of beets as well as a tomnage that is remunerative and profitable both to the manufacturer and the furmer. It is along this line that the Department of Agriculture and the agrienltural experiment stations in the several States are working industriously and earnestly in order to be able to offer reliable information to all concerned.

PURE WATER.

A factory requires sarge water facilities. For a fictory having a capacity of $3 \check{5} 0$ tons of sugar per day (which is considered about the minimum in this country for a factory working under fivorable conditions) there should be a permanent supply of ahout "2,000,000 gallons of pure water a day. In the first place, water is used as a medium of conveyance for bringing the beets from the beet sheds, which in many cases are several humber feet away from the fictory. These sheds are connected with the factory by canals abont 1.1 feet wide and 2 feet reep. The bottoms of the sheds are arranged on an inclined plane, so as to allow the beets to slide into the canal as they are needer. In some instances the beets are shover into the canal by workmen. Sufficient water must be allowerl to flow throngh these canals to flood beets and to carry them to the receptacles in the factory arranged for receiving and washing them. The watei performing the service of transporting the beets is permitted to pass through a grating into the sewer. Water is also extensively used all through the factory for steam power and other operatious of the machinery and in the process of manufacture, and, since the rork of the factory is largely for the purpose of eliminating impurities in the beets, the water used in these processes must be of such quality as will not increase these impurities, and thus add to the difficulties of the manufacturer. (See muder "Lime and water for beet-sugar factory purposes," pl. 205-207.)

\section{FUEL.}

Fuel is another item that should be carefully considered as one of the conditions necessary in establishing a beet-sugar factory. In manufacturing a ton of beets into sugar about 2 or 3 pel cent of colie is required and 13 to 15 per cent of conl. The coke is required for burning the limestone, and it may be used for producing carbonic-acio gas, 
which is obtained by the combustion of coke aud charcoal in ovens specially prepared for the purpose. It will readily be seen that fuel is a factor that is closely related to tlie matter of economy in a factory, since it is one of the heavy items of expense. In California crude petroleum is used to a large extent for fuel. This oil is found in the southern part of the State, and its use compares favorably, so far as economy is concerned, with coal in the districts where the latter is mined. As fuel, it is well adapted to the factory work. It is eleaner and requires less labor to handle it. In these respects it makes up largely for what it lacks in cheapness. It has been claimed by some sectious that in heavily wooder districts cheap wood can be used to advantage. We are not prepared to state as to the desirability of wood for fuel in this comnection, but it would be well for those entertaining this view of the subject to investigate it thoronghly. The price of coke in the districts already manufacturing beet sugar, or begimning the work preliminary to doing so, ranges between $\$ 4$ and $\$ 13$. Some of the districts can supply coal to the factory of sufficient quality for the jurpose at 75 cents to $\$ 1.25$ per ton, and it costs in other districts already manufacturing, or intending to do so, from $\$ 3$ to $\$ 4$ per ton. These difierences in prices of fuel, when considered in connection with other items of expense that enterinto factory work, will be strong factors in the mannfacture of beet sugar further along in the history of the industry in deciding the contest when competition becomes active. It should be the aim of every local. ity to study fully these points.

\section{IHITES'TONE.}

It has been noticel before that the factory is a large comsumer of limestone. This stone is burned in the factory in a specially arranger kilu. It is well ublerstood that in the process of huming limestone carbonic-acid gas is driven off', and the objoct of burning the lime in the factory, instearl of buying the prepared lime, is for the jurpose of securing this carbonic-acid gas, which is usent in the processi of mannfacturing the beet sugar as well as the burnerl Jime. The burned lime is put into the juice, either in a powdered state or as milk of lime, as the first process after the juice has been sufticiently warmed. The. object of this is to have the lime mite with the impurities in the juice both chemically and mechanically, and then by injecting the carbonicacid gas, hy bubbling it through the limed juice, a union of ealcium and the earbonicacid gas is effected. 'This forms calcium-carbonate, the substance originally started with in the limestone before burning. This carbonic acid gas, it will be remembered, was secured by burning limestone and then collected, after having been driven off, for the purpose stated. In this process is scen the nice arlaphation and application of the prineiples of science, by which the cructe stone is separited into its elements, one part placed in the juice of the beet to jerform a certain function and another part injected again, and after uniting the two in the process forming the original substance, which holds in its grasp 
the impurities that were contained in the beets. The whole is then removed from the juice by forcing the juice, under high pressure, through a very finely woven cloth called a filter. Now that we know the use for which this lime is required, the suggestion naturally follows that this limestone should be pure. It should not contain any of the elements which the sugar maker believes to be deleterious to the quality of his product. It should be a pure limestone, and since it is extensively used, it should be a cheap stone, and one that could be obtained near at hand. It is therefore necessary, in studying the conditions of a locality with a view to establishing therein a factory, that we should consider very carefully the quality and cheapness of its limestone as well as its supply. (See under "Lime and water for beet-sugar factory purposes," pp. 205-207.)

\section{MARKETS.}

It naturally follows in any factory enterprise that a market is one of the conditions necessary to its success. In investigating the conditions necessary for establishing a factory it is requisite to have fully in mind its accessibility to trade centers; also whether the transportation facilities are sufficient to permit it to compete with other localities more especially favored in these respects. We might mention as sections having ideal conditions of this kind the lower peniusula of Michigan, which has shown good conditions for raising beets and a disposition of the people to embark in the enterprise. The finished product in the factories here wonld be available for some of the best trade centers in the country, such as Detroit, Milwaukee, Chicago, etc., and it would have the benefit of transportation by water throngh the Great Lakes as well as by the network of railroads which extend in every direction. These insure cheap freight and ofler facilities for shipping the product to market quickly. What is said of this locality might be equally true of Indiana, New York, and other localities having similar conditions. Localities taking upon themselves the responsibility of maintaining factories should study these facilities under the best conditions, because these are the questions that will meet them in competition on the market.

\section{ORIGINAL COS'T:}

It requires considerable money to build a factory, and as the original cost of improvements is the larger portion of the investment, we must include in our estimates of the cost of production the interest upon the money so tied up. The cost of building materials is also an item that demauds careful consideration. It is one, however, upon which it is easy to make comparisons.

\section{PERMANENT AGRICULTURAL CONDITIONS.}

One must make a thorongh investigation as to the general agricultural conditions of a locality when considering the establishment of a factory. It will be impossilin to raise sugar beets continuously on the 
same tract of land, as is the case with other crops, and a locality is best suited to raising sugar beets as a permanent enterprise that can secure a series of rotation of crops. We have in mind a locality that is now raising sugar beets extensively for the factory that can not, it is claimed, successfully raise anything else, and experience is evidently showing, what all good agriculturists would predict, that the farmer there will come to grief before long. If something is not found to rotate with the sugar beet, where the sugar beet alone is grown, the result will be a lessening of the tonnage and purity of the beet. In considering the successful groming of sugar beets, we include not only the conditions that insure the permanency of the enterprise, but such a rell-balanced series of rotation of erops as will readily restore the soil to its productiveness and make the permaneney of the sngar beet possible. In the case of the sugar beet a large part of the work of its cultivation can not be accomplished by the aid of machinery. For instance, when the plants have reached the point that is called "putting out the fourth leaf," the beets must be "bunched and thinned." It will be recalled that the farmer is asked to sow from 15 to 20 pounds of seed per acre; 3 or 4 pounds would do the work, however, if he was absolutely sure that all the seed would grow. This larger number of pounds is used. in order to be sure of a "stand," because a "stand" he must have. This places the beet seed in rows close to each other, say, tonching each other, and it can be readily observed that all of the beets must not he allowed to grow. It therefore becomes necessary to "thin out." This has been described under "Thinning and bunching," p. 190.

The success of the crop after the bunching and thinning depends largely upon the thoroughness of cultivation-careful hoeing and weeding. The field must be kept elean and free from weeds, not only with the cultivator, but with the hoe and hand. So that another condition that affects the permanency of beet farming in a community is its ability to furnish the necessary labor. Large cities and tomus are usually depended on for labor of this kind. Boys and girls, from 12 to 16 years of age, on account of their suppleness and nimbleness, are employer for this purpose in many sections, and secm to stand the wear of the labor better than arlults. It requires all the fortitude of a community in establishing a beet-sugar factory to meet the first shork when the revelation of the amount of labur to be performed in raising the beets first dawns upon them; it is so out of proportion with what is usually necessary in growing other rops. We ro not wish to be understood as trying to muduly alarm any one in this direction, but think it is but fair that sufficient emplasis should be put upon the point in question, in orrer that it may be fully understood before such responsibilities are assumer. If we were to write the history of the beet-sugar enterprise in the United States, a large part mould be devoted to a statement of the rexing and trying experiences of the manufacturer and the farmer in arriving at a solution of this labor jroblem. liut our factories now in operation have met the difliculties, 
and throngh experience our farmers have learned what is required in growing this crop. They have also learned that they can receive enough money for the crop to employ sufticient labor to do the work, pay all other expenses, and still have a handsome proitt.

\section{Line AND WATER for BeET-sugar FaCtor Y PURposes.}

We have often been asked by organizations and others interested in the beet-sugar ind ustry, desiring to investigate closely the facilities and resources for this purpose, "What constitutes a good limestone and good water for beet-sugar factory purposes?" For the purpose of auswering this question we quote the following papers from "A hanubook for chemists of beet-sugar houses and seed-culture firms," prepared by Giulford L. Spencer, D. Sc., of the United States Department of Agriculture:

\section{SALTS IN SOLUTION AND THEIR EFFECT IN WATER USED IN SUGAR IIANUFAC'IURE.}

The conclensation waters from the multiple elferts, vacuum pans, ete., form an abundant and very satisfactory supply of water for the boilers.

The water for the diffusion battery should be as pure ats possiblo and should contain a minimum amount of calcium and magnesium salts and of the salts mentioned below as melassigenic. The calcium and magnesium salts, notably the loicarbonates and the sulphate of calcium, foul the heatiug surfue of the battery and evaporat. ing apparatus. The bicarbonates decompose to some extent in the diffusers and deposit the normal carbonates upon the cossettes and probably indinence the diffusion unfavorably. The water should not contain more than 10 parts per 100,000 of calcium sulphate, otherwise incrustations may form at some stage of the concentration of the liquors.

Pure water should also be used in slaeking the lime, though for economy of sugar and in the ovaporation certain wash waters containing sngar, etc., are used for this purpose.

The most important melassigenic salts are sulphates, alkaline carbonates, aud nitrates. The chlorides are rather indifferent as regards the formation of molasses.

SUGGESTIONS ON TIL DESIRABLE AND UNDESIRABLE COMPOSITION OF LIMESTONE USED IN SUGAR MANUFACTURE.

The difficulties usually encountered in the management of the limekiln are as follows: A limestone containing too much silica will show a tendency to fuse, and if overheated will adhere firmly to the walls of kiln. Stone in too small pieces, or stone and coke not properly distributed, or stone with an excess of coke, will sometimes "scaffold," or bridge. The above conditions soon prevent the downward progress of the stone and line. These difficulties are obviated hy the use of suitable stone, properly mised with the colse and evenly distributed in the kiln, and by the withirawal of lime at regular intervals. Shonld the charge "seaffolel" in the kiln, it ean only be broken town by the withdrawal of a considerable quantity of material at the lime doors and energetic use of an iron bar at the "peep-holes." The use of too little coke or the too rapil withdrawal of lime results in an undue proportiou of underburned or raw lime. The admission of too little air to the kiln results in an imperfect combustion and an excess of carbonic oxile in the gas. This carbonic oxide not only is a loss of oarbon, but, if carelessly inhaled by the workmen, way result in serious poisoning. The addition of too much air dilutes the gas. This latter may result from leakage in the pipes, careless charging, or from driving the gas pump too fast. The following tablo contains valuable information relative to the quality of the limestone. 
Analyses of limestones and comments ${ }^{1}$ on their composition.

[Messrs. Gallois and Dupont, Paris.]

\begin{tabular}{|c|c|c|c|c|c|c|c|c|c|c|}
\hline Substance. & 1 & 2 & 3 & 4 & 5 & $i^{6}$ & 7 & 8 & 9 & 10 \\
\hline 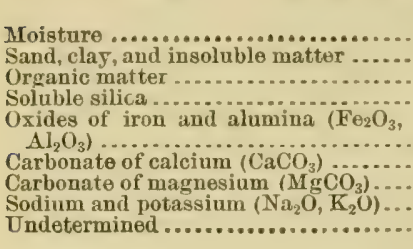 & $\begin{array}{r}P . c t . \\
4.10 \\
4.50 \\
1.20 \\
2.10 \\
\\
.37 \\
85.86 \\
.95 \\
.05 \\
.87 \\
\end{array}$ & \begin{tabular}{|r|}
$P . c t_{.}$ \\
5.10 \\
5.15 \\
1.17 \\
1.75 \\
.41 \\
85.12 \\
.47 \\
.06 \\
.77 \\
\end{tabular} & $\begin{array}{r}P . c t . \\
7.25 \\
4.90 \\
1.37 \\
3.30 \\
\\
.27 \\
81.67 \\
.59 \\
-65 \\
\end{array}$ & $\begin{array}{r}P . c t . \\
4.15 \\
2.15 \\
1.05 \\
1.05 \\
.17 \\
90.13 \\
.75 \\
.10 \\
.45\end{array}$ & $\begin{array}{r}P . c t . \\
4.17 \\
3.07 \\
.97 \\
.98 \\
.19 \\
88.65 \\
.95 \\
.01 \\
1.00 \\
\end{array}$ & $\begin{array}{r}P . c t \\
6.25 \\
3.17 \\
1.12 \\
.64 \\
.15 \\
87.93 \\
.50 \\
.21\end{array}$ & $\begin{array}{r}P . c t . \\
5.16 \\
2.25 \\
.86 \\
.56 \\
.20 \\
90.03 \\
.45 \\
.39 \\
\end{array}$ & \begin{tabular}{r}
$P . c t$. \\
0.52 \\
2.85 \\
.30 \\
.06 \\
.32 \\
93.80 \\
1.81 \\
\hdashline .34 \\
\end{tabular} & \begin{tabular}{r}
$P_{0} c t$. \\
1.21 \\
.55 \\
.41 \\
.20 \\
.23 \\
96.58 \\
.50 \\
\hdashline .32 \\
.32
\end{tabular} & \begin{tabular}{r}
$P . c t$. \\
0.11 \\
.27 \\
.15 \\
.03 \\
\hdashline 99.10 \\
\hdashline$\ldots$. \\
\hdashline .34 \\
\end{tabular} \\
\hline & 100.00 & $\overline{100.00}$ & 100.00 & 100.00 & 100.00 & 100.00 & 100.00 & 100.00 & 100.00 & 100.00 \\
\hline
\end{tabular}

Nos. 1, 2, 3, and 4 are bad, Nos. 5, 6, and 7 are passable, and Nos. 8,9 , and 10 are excellent.

Limestone No. 3 was used in a sugar house, and caused much tronble, notably, "scaffolding," difficnlty in the mechanical filtration, incrustations in the triple effect and on the vacuum-pan coils. No. 9 was substituted for this stone, and these difficulties disappeared.

In the examination of a limestone, its physical condition as well as its chemical composition must be taken into account. The stone should be compact and hard, thus reducing the quantity of fragments and the risk of "scaffolding" in the kiln.

Excessive moisture, 5 per cent or more, in the stone reduces the temperature of the kiln when charging, involving an imperfect combustion and the production of carbonic oxide (CO); further, such stones break into small pieces under the influence of the heat. A small proportion of water, approximately 1 per cent, probably facilitates the decomposition of the stone, and is advantageous.

Magnesium is not objectionable, so far as the operation of the kiln is concerned, except in the presence of silicates, but it iutroduces difficulties in the purification of the jnice and forms incrustations on the heating surfaces of the eraporating apparatus. It forms fusible silicates at high temperatures, and thus mereases the tendency to "scaffolding." The objections to the sulphate of calcium are practically the same as to magnesium.

The objections to the presence of silicates are, as indicated abore, in the formation of fusible silicates of lime and mianesium. Part of the silica passes into the juice with the lime, retards the filtration with the presses, and coats the cloth of the mechanical filters, to their detriment. Silica also forms part of the scale on the heating surface. Less harm results from this substance in hard limestones than from that in soft stone; hence, if the stone be hard and compact, a larger content of silica is admissible than in a soft stone.

When necessarily using stone of comparatively poor quality, the best obtainalle coke should be employed.

\section{MELASSIGENIC SAITS.}

The following salts are positive molasses makers, that is, salts which promote the formation of molasses: 2 (arbonate, acetate, butyrate, and citrate of potassium.

The following have no influence on the formation of molasses and are classified as indifferent: Sulphate, nitrate and chloride of potassium, carbonate and chloride of sodium, calcium hydrate, valerate, oxalate and succinato of potassium and oxilate, citrate, and aspartate of sodium.

${ }^{1} M r$. Cutler, manager of the Lehi factory, Utah, says: "We would regard as a good quality of limestme one containing from 95 to 98 per cent of carbonate of lime and not more than one-half to 1 per cent of silica."

"This is to be avoided, becauso the more molasses the less sugar. 
The negative molasses muke's, that is, salts which promote the erystallization of sucrose, aro sulphate, nitrate, acetate, butyrate, valerate, and succinate of sorlium, sulphate, chloride, and vitrate of magnesium, the chloride and witrate of calcium, and the asjuartate of potassium.

LIME ROCKS AND WA'TERS USED IN THE MANUFACTURE OF BEET SUGAR.

The following pajer on the lime rocks and water used in the manufacture of beet suger is by Mr. G. S. Dyer, superintendent of the beet. sugar factory at Los Alamitos, Cal.:

I give below the analysis of three types of rock:

\begin{tabular}{l} 
Constituents. \\
\hline
\end{tabular}

Moisture is the first important point, as it takes just that much more coke to drive it oft, and, besides, it eauses the breaking of the rock while undergoing cooking, also the resulting dust helps to cause the massing of the kiln. Hard rocks contain but little water, but soft ones may contain as high as 20 per cent. Hygroscopic rock should be sheltered from the rain. If possible, do not use rock that contains more than 2 per cent of noisture.

Silica anit alnminum present great inconviniences, inasmuch as these two substances form silitates and aluminates of calcimm and magnesium during calcination, causing an insoluble coat to form on the outsides of the lime lumps that prevent it from slacking readily. The silica that enters the juic'e is broken up by the action of the alkalies aud is precipitated on the tubes of the evaporators. Magnesium is not particularly harmful in quautities not to exceed 3 per cent; if more, it silicates in the lurning, and if abundant causes a false alkalinity of the juice besides incrustations on the tubes of the evaporators and vacuum pau. Calcium sulphate presents the same faults as magnesium, and pronortiouately lowers the saline coefficient of the product, therelyy hindering the crystallization of sugar. It is well also to aroid a rock that decrepitates badly during cilcination. A great many times the rocks can be mixed to good advantage-hard asd soft.

What has been said about the indivicual composition of the lime rocks can be applied to the water as well. It is needless to say that the purer the water the better. The water used at Alvarado has 22.5 grains per gallon; Lehi, 21; Eddy, N. Mex., 17.2, and Los Alamitos, 20. Just what the extreme limit would be I am not prepared to state, probably in the vicinity of $35 \mathrm{or} 40$. The mineral matter taken into the juice in this manner amounts to considerable when one stops to think that an ordinary factory uses about 200,000 galloss in twenty-four hours.

By using condensed water from the evaporators the troublesome scale in the boilers is very much improved, and at this particular plant this scale, which formed for the whole seatson of one hundred days, was not of the thickness of ordinary note paper. 


\section{ANSWELS OW FAC'TURY OFICLALS TO QULS'TIONS RELATIVE TO FACTORY WORK.}

During the investigations of the past year certain questious were propounded to the superintendents, managers, and experts of the beetsugar factories with the view of gaining information touching the mechauical and practical problems incident to the factory side of the beet-sugar industry. The public generally is not so much interester in the particular person as it is in the fact that the answer was made by one thoroughly experienced in the operation of a factory; hence, the official answering is given after each answer, which is therefore worthy of consicleration as coming from good anthority. The number of each auswer refers to the order in which the factory was visited.

The questions and answers are as follows:

What do you pay farmers for the sugar beets?

(1) We pay $\$ 4.25$ per ton for beets, and we pay a part of the freight, which brings the price of the beets up to something like $\$ 4.50$.-(Superintendent.)

(2) We pay $\$ 1$ per ton for beets. When we recoive a bounty we pay $\$ 5$ per tou.(Assistant superintendent.)

(3) We pay $\$ 4$ per ton for beets.-(Superintendent.)

(4) Wo pay $\$ 4.50$ per ton.-(Suporintendent.)

(5) Wo pay $\$ 3.50$ per ton for beets showing 12 per cent sugar content and 80 percent purity.-(Manager.)

(6) We pay $\$ 4.50$ per ton for beets as they run.-(Manager.)

How much does the recent improvement in machinery reduce the cost of making sugar?

(1) Saves cost and time-(Superintonilent.)

(2) We are making sugar cheaper than ever.-(Assistant superintendent.)

(3) Quite materially.-(Superintendent.)

What would be a fair estimate of the cost to the farmer for raising the beets and delivering them to the factory?

(1) I would say that the average cost to the furmer for raising and delivering a ton of beets would be ordinarily, with a good erop, from $\$ 2.50$ to $\$ 3$ per ton.-(Superintendent.)

(2) It will cost the farmer from $\$ 25$ to $\$ 30$ an acre.-(Assistant suporintendent.)

(3) It will cost from $\$ 23$ to $\$ 30$ per acre.-(Superiutendent.)

(4) It costs our farmers about $\$ 23$ an acre.-(Superintendent.)

(5) It will cost our farmers from $\$ 20$ to $\$ 25$ to produce and deliver an acre of beets.(Manager.)

(6) It will cost the farmers here from $\$ 25$ to $\$ 35$ to produce and deliver an acre of beets.-(Manager.)

What is the average rent that farmers have to pay for sugar-bect land?

(1) The rental per acre for good sugar-beet land in this vieinity is from $\$ 10$ to $\$ 15$ per acre.-(Superintendent.)

(2) The farmers usually give from one-fourth to one-fifth of the crop.-(Assistant superintendent.)

(3) The rent is usually from $\$ 15$ to $\$ 20$ per acre. In some places, however, it is as low as $\$ 4$ per acro. - (Superintendent.)

(4) The farmer usually gives one-fourth of the erop deliverod, which would mean nsuaily $\$ 9$ to $\$ 12$ ront per acre.-(Superintendent.)

(5) Our farmers give from one-fifth to one-fourth of the crop. Vory little lasel is rented on the basis of so much per acre cash rent,-(Manager.) 
(6) The land is largely owned by a company, and they sell the land to the furmer, who raises his own beets. The company either hires its own beets raised on the rest of the land, or if it rents receives one-fourth of the erop.-(Manager.)

[Notw.-In Nebraska good sugar-beet land rents at from $\$ 4$ to $\$ 6$ per acre.-C.

\section{F. S.]}

\section{What do you do with the pulp?}

(1) We have a large creamery here that uses considerable of the pulp and the farmers are beginning to use it quite extensively. The pulp is fed to eattle and sheep. The cattle readily eat alout 100 pounds of julp pur day and 15 pounds of hay, the sheep eating in proportion. They make excollent heef and fatton in a short time; the meat is much sought after at home and in Eustern markets.--(Superintendent.)

(2) Sell one-half for 10 cents per ton to cattle company and some to farmers. The latter demaud is increasing rapidly. The remainder is disposed of as waste.(Assistant superintendent.)

(3) Give it away mostly and sell some of it. Most of it is used by the farmers; they are trying it.-(Superintendent.)

(4) Some of our pulp is hauled away as it is prodnced; some we are siloing and arranging stoek yards where it will be used in feeding. Some dairies aro using the pulp aud the demand from farmers is growing strouger. Wo sell it to-day at 50 cents per ton.-(Superintendent.)

(5) Our pulp is contracted for by another company, which sells it to cattlemen; 1,500 to 3,000 head of cattle are fed here. The creameries are using some. The farmers are using very little. All of our pulp is consumed in this way. It is better foed after standing for a while.-(Manager.)

(6) We fed our pulp last year to cattle. This is a great cattle country and we will dispose of all of our pulp in this way.-(Manager.)

What do you do with the molasses?

(1) We do nothing with the low-product molasses, but we have now contracterl to sell it to a company for from 1 to $1 \frac{1}{2}$ cents per gallon to be used in the manufacture of alcohol.-(Superiutendent.)

(2) Nothing.-(Assistaut superintendent.)

(3) Nothing.-(Superintendent.)

(4) We use the "crystallization-in-motion process," and aim to extract as mach sugar from the molasses as possible. After the purity drops below 60 we throw it away.-(Superintendent.)

(5) We use the Steffens process in the manufacture of sugar. We have a special department in the factory for working up the low-product molasses, and throtigh this process we are enabled to extract most of the sugar.-(Manager.)

(6) The low-product molasses is thrown away. It contains from 50 to 53 per cent of sugar.-(Hanager.)

What is the cost of making beet sugar ready for the market?

(1) It would be very difficult to give you the data as to making a ton of sugar in this country as yet. In 1896 we worked 43,000 tous of beets, making therefrom $9,156,000$ pounds of sugar, the cust of which was $\$ 3.71$ por 100 pounds.-(Suporintendent.)

[NoTE.-This would bo about $\$ 74.20$ per ton.]

(2) About 3 cents per pound.--(Assistant superintendent.)

(3) About $\$ 70$ per ton or 3 to $3 \frac{1}{2}$ cents per pound.-(Superintendent.)

(4) Seventy dollars per ton or 3 to $3 \frac{1}{2}$ cents per pound.-(Superintendent.)

(5) Three to $3 \frac{1}{2}$ cents per pound,-(Manager.)

(6) The cost of making sugar varies from $\$ 2.25$ to $\$ 2.75$ per ton of beots, not figuring the cost of the beets.-(Manager.)

What kind of beet seed does best in your locality?

(1) We have found the seed best adapted to our locality is the Kleinwanzlebener.

We have also har good success with home-grown seed.-(Superintendent.)

H. Doe. $396-1 \pm$ 
(2) Wo found the Vilmorin and the improved Fleinwanzlebener do best.-(Assistant superintendent.)

(3) Vilmorin and its derivations seem to be better for arid climates.-(Superintendent.)

(4) We succeel better with the original Kleinwanzlebener and improved V'ilmorin.

(6) We have had good luck with Klein wanzlebener and improved Kleinwanzlebener. We find the home-grown seed grow splendidly.

That per cent of !yor machincry is American made and what per cent is American design?

(1) Nearly all our machinery is American made and American design.-(Superiutendent.)

(2) Twenty per cent is American made and design.-(Assistant superintendent.)

(3) Ninety-nine and one-half per cent of our machinery is American made and all of it modified to suit our improved conditions.-(Superintendent.)

(4) Nearly 100 per cent of our machinery is American made and design.-(Superintendent.)

(5) ()rignally all of our machinery was of Germau make, but now 50 and $66 \frac{2}{5}$ per cent is American made and design.-(Manager.)

(6) We secured our machinery originally by purchasing a factory in Canada of French design and make. Our improvements are generally of Amerien desigu and make.-(Manager.)

When do your farmers plant beet seed?

(1) The seed is planted here in April or fore part of May. The amount of rainfall that we have from time of planting until the time of harvesting is very small as a rule. We therefore irrigate the beets, and they roquire watering from tro to five times during the season.-(Superintendent.)

(2) From February to June. We draw our beets from several valleys with different climates, which causes the difierence in time of planting and harvesting.(Assistant superintendent.)

(3) Should plant in tho middle of March, but the bulk is planted in April and some as late as June.-(Superiuteudent.)

(4) We plant from March 1 to April 30; sometimes we can plant in February if it turns warm enough. We havo planted in September and had 18 per cent of sugar in the beets and good purity.-(Superintendent.)

(5) We plaut from February to June, according to the locality and the season.(Manager.)

(6) That is the problem. Wo are new. Early planting did the best; this year wo planted as late as the milllle of June. Wo feel that it is best to plant in February and March for our season, or wait for the usual rain in May and June, our second season.-(Manager.)

When do your farmers havest?

(1) We berin harvesting the last of September.-(Superintendent.)

(2) August 15 to Jinuary 1 ; sometimes we finish in December and sometimes in March.-(Assistant superintendent.)

(3) From the nindile of $A$ ugust to the last of Norember, according to season and locality.-(Superintendent.)

(4) We can harvest from July 5 to end of campaign, about November 1.-(Superintendent.)

(5) We harvest from July to November 15, according to the loeality.-(Manager.)

(6) Irarvesting is clone here from the middle of October to the midcle of Novem her.-( Manager.)

How do your farmers care for the beets until they are workel by the factory?

(2) Leavo them in the ground.-( (ssistant superintendent.)

(3) Leave them in the wronnd until we call for them and put the balance that is loft in November in the sheds. - (Superintendent.)

(4) Leavo them in the ground and harvest them as needed.-(Superintendent.)

(5) The boets aro leit in the gromud until they are ealled for by the factory when 
our fall rums begin in November. After this some of the beets may still be unworked. These beets will have to be siloed; not many have to bo treated in this way, however.-(Manager.)

(6) We aim to keep about 1,000 tous of beets in the sheds. The farmers leave the balance of the beets in the ground until called for.

How do you buy your seed?

We buy early in the fall of a good, safe firm, either in Europe or through their agent here.-(Assistant superintendent.)

(3) We buy our seeds in Austria, Germany, and Russia abont the 15th of September, and have them shipped right along in original packages, of standard firms having established reputations.-(Superintendent.)

(4) We buy of best European firms through their American agent. We buy in September.-(Superintendent.)

(5) We buy from best houses in Europe and have the seeds tested when they arrive.-(Manager.)

(6) We buy original Kileinwanzlebener of the agent who represents that firm in this country.-(Manager.)

What fuel do you use; where is it from; and what does it cost?

(1) We use coal for fuel. It cost us last year $\$ 3$ per ton delivered; and it is derived from a point in our Stato abont 70 miles from the factory. It requires about 13 per cent of coal to 1 ton of beets.-(Superintendent.)

(2) We use crude petroleum. Our supply comes from Los Angeles, Cal. It costs about $\$ 1.05$ per barrel f. o. b. there.-(Assistant superintendent)

(3) We use lignite coal from England. It cost $\$ 6.30$ per ton.-(Superintendent.)

(4) We burn crude petroleum. We get our supply from Los Angeles, Cal. Its cost is about equal to steam coal at $\$ 3$ per ton.--(Superintendent.)

(5) We use petroleum. Our source of supply is near the factory. About four barrels of oil is equal to 1 ton of coal.-(Manager.)

(6) We nse bituminous coal. Our source of supplies is about 400 miles away. It costs us $\$ 3.35$ per ton. The cost at the mine is 90 cents.

What does coke cost your factory?

(1) Our coke coste us $\$ 11$ per ton delivered. We only nse 2 per cent of it to 1 ton of beets.-(Superintendent.)

(2) We getour supply of coke from Wales. It costs us about \$12 per ton.-(Assistant superintendent.)

(3) We got our supply of coke from England. It costs from $\$ 7$ to $\$ 8 .-$ (Superintendent.)

(4) Our coke costs about $\$ 11$ per ton.-(Superintendent.)

(5) We use coke from England. It costs us $\$ 13$ per ton.-(Manager.)

(6) We use coke from Pennsylvania. It costs $\$ 10.35$ per ton.-(Manager.)

From whence do you secure your supply of limestone and what docs it cost you per ton?

(1) Limestone costs us about $\$ 2$ per ton delivered and broken up to the size that we require. This we get from a quarry about 16 miles distant, and it is hauled to the factory by teams, as there are no railroads. We require abont 6 per cent of lime to a ton of beets. Wo require a good quality of limestone, one containing 95 to 98 per cent of lime and not more than one-half to 1 per cent of silica.-(Superintendent.)

(2) Our limestone costs us from $\$ 1$ to $\$ 1.25$ per ton.-(Assistant, superintendent.)

(3) Our limestone costs us about $\$ 1.50$ per ton. We hare to ship it about 60 miles.(Superintendent.)

(4) Our source of supply of limestone is about 90 miles from the factory. We pay $\$ 2.50$ per ton.-(Superintendent.)

(5) Our source of supply is about 90 miles distant.-(Manager.)

(6) Our limestone comes about 12 miles. It costs $\$ 1.80$ per ton.-(Manager.)

How many tons of beet are required to make a ton of white granulated sngar\%

(1) It would be difficult to give you any accurate data as to the cost of making a 
ton of beet sugar in this conutry as yet. In our locality last year the average tonnage was 14 per acre. The average sugar in the beets was 13.9 per cent, with 82.5 jurity. With such beets we olstain nearly 210 pounds of sugar from a ton of beets. In 1896 we malo our sugir run abont a tou to $9 \frac{1}{2}$ tons of beets. - (Superintendent.)

(2) We secure about 13 per cent of raw sugar and 8 to 9 per cent of refined sugar from a tou of beets.-(Assistant superintendent.)

(3) We require abont 101 tous of beets to make a ton of white grauulated sugar.(Superintendent.)

(4) You can extract about 75 to 80 per cent of the sugar in the beet. Of course, if the beet shows an average of 15 per cent sugar, such as ours will, this would be 12 per cent of the actual tonmage of beets worked.-(Superinteudent.)

(5) Under our process, which is to get as much sugar ont of the molasses as possible, we lose about $3 \frac{1}{2}$ to 4 per cent of the original sugar in the beet, and in case the average be 15 per cent sugar in the beet the amount of sugar that could be extracted would be equal to 15 minus $3 \frac{1}{2}$ or $4 \frac{1}{2}$.- (Manager.)

(6) There is a loss of about 3.65 per cent of the original sugar in the beet. Subtracting this from the average amount of sugar in the beet originally you will have the amount of sugar that can be extracted.-(Manager.)

How much pulp is left after working a ton of beets?

(1) About 50 per cent of dry-pressed pulp will result from a ton of beets.(Superintendent.)

(2) We generally have about 40 per cent of pulp of the original tonnage of beets.(Assistant superintendent.)

(3) That depends on the amount of pressure applied in forcing out the water, but it will usually run about 38 per cent of the original tonuage of beets.-(Superintendent.)

(4) We have left about 46 per cent in pulp of the original weight of beets.(Superintendent.)

(5) Our pulp runs about 50 to 55 per cent of the original weight of the beets.(Minager.)

What experiments have you tricd with pulp and molasses?

(1) There has been a local company organized here to buy the low product molasses, from which they will make alcohol. They pay us fromi 1 to $1 \frac{1}{2}$ cents per gallon for the molasses.

(3) There is an aleohol process for extracting the sugar in the molasses. If wo could use this process we could get practically all of the sngar out of the molasses, but in doing so we would have to recover our alcohol after each process, so that in doing this we would come in contact with the United States revenue laws. Therefore it is not used.-(Superintendent.)

(t) We have tried no experiments with either pulp or molasses.-(superintenclent.)

OBSLRVATIONS GROWTAG OUT OF ANSWWRS TO (pUESTIONS SUBMITIED TO FACTORY OPERATORS.

\section{COS'T OF FACTORIES.}

There is a gencral inquiry in localities where the question of establishing a bect-susar faldory is heing agitated as to the cost of constructiug and conipluning a tiactory. The cost of a factory will vary in different localities, depending upon the local cost of building materials, the fieight rates for shipping these materials, and the cost of freight on machinery, ete. There is a general rule, however, that appears to be aceepted as a fair estimato by those best informed in heet-sugar factory construction, namely, that it will cost $\$ 1,000$ per ton of daily eapacity to coustruet an? equilip a lactory of 300 tous per day 
or over. Factories having capacities of less than 300 tons per clay will cost more than $\$ 1,000$ per tou, and it is to be presumed that for a factory of considerably more than 300 tons capacity per lay the cost of construction would be materially less than $\$ 1,000$ per ton. According to the rule mentioned, however, the estimate must be $\$ 300,000$ to construct and equip a factory of 300 tons capacity per day, $\$ 500,000$ for one with a capacity of 500 tons per day, etc. We have before us an estimate by a gentleman thoroughly familiar with the construction of beet-sugar factories. These estimates give considerable details in the matter of construction aud will be especially valuable in suggesting items that must be considered by people in a locality where the question of coustructing a factory is being considererl. The first estimate is for a factory of 300 tons capacity per day, and the second is for a factory with a capacity of 500 tons per day. Each estimate is based on one hundred days as the length of the "campaign," or the time the factory will be engaged in working the beets for the year.

ESTIMATE OF A BEET-SUGAR FACTORT OF 300 TONS CAPACITY PER DAY.

In presenting these estimates for your consicleration we beg to call your attention to the following points, to wit:

Our figures are hased on first-class brick buildings, constrneted as nearly firoproof as possible, also brick smokestack and A1 boilers.

Wo inclucto in our estimate large beet sheds, sugar storehouse, limekilns, office, and laboratory, including outfit.

Wo figurerl on the latest inproved, most modiern, and labor-saving machinery and apparatus, either foreign or American manufacture, to malko whito grauulated sugar direct from the beets without refining, and have also included in our estimate a process for the working up of all afterproduets during the campaign, which latter arrangement is quite an item of cost.

The whole plant to he of tho very best and latest design and morkmanship, and so constructed that its capacity can ho easily enlarged at the minimum cost and for the special purpose of saving every possible item of labor and expense.

Our estimates, although very conservatively marle, are to he taken approximately, because correct estimates of the cost of a plant, of expenses, and profits vary so widely with varying conditions in the different States (as to cost of fuel, labor. material, beets, etc.) that it is impossible to submit here a moro detailed estimate, We may add that we figured ou a campaign of one humbred days and one hundred nights and based the amount of product and profit on 12.7 per cent yield of the weight of the beets, which is the general average jield of sugar bects in America.

Estimate of cost, running cxpenses, and profits of " beet-sugar fucfory of capacity of soo tons of beets per day of twenty-four hours.

Total capital needed, not including cost of land for factory and additional

buildings, which site should be 15 to 20 acres, to be about .............. $\$ 315,000$

Running capital:

The capital required to operate the factory to be

Usually the bills for fuel, lime, and other materials and work are paid at the end of every month, and it is the same with farmers in regard to payment for their beets. Sugar, as one of the most required staple articles, is sold for eash or on short time, and every day 38.10 tons, or 76,200 pounds, of sugar will be ready for sale. The company should at the end of each month have sufficient money collected from their sales not only to meet all payments, but have a good surplus. For this purpose the sum of $\$ 30,000$ will be sufficient. 
Cost of plant:

For all factory buildings, sugar storehouse, beet sheds, office and laboratory, limekilns, foundation for engines and apparatus, including all other mechanical work.

For boilers, engines, pumps, machinery, and millwright work; also for the entire inside outfit and apparatus of either American or foreign manufacture

Cost of plant complete

Salaries and general expenses:

Technical superintendent

$\$ 5,000$

General manager...................................... $\quad 3,000$

Agricultural expert ....................................... 2,000

2 chemists during "campaign" .......................... 1,000

Head machinery engineer and assistant.................. 2,300

2 sugar boilers, at $\$ 250$ each ................................. 500

2 overseers, at $\$ 800$ each................................. 1,600

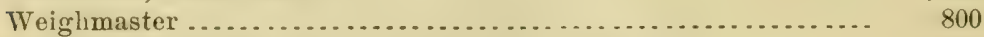

Bookkeepers, clerks, typewriter, and other office help.......... 4, 000

Stationery, advertising, and incidentals................... 1,000

Expenses of meetings of the board of directors............... 1,200

Selling expenses of sugar to jobber..................... 5,000

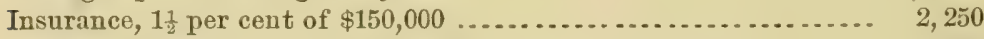

Repairs on machinery per campaign ....................... 3,000

Depreciation, 7 per cent on $\$ 200,000$ machinery ............... 14,000

6 per cent interest on $\$ 315,000$ capital invested . . . . . . . . . . . . . $\quad 18,900$

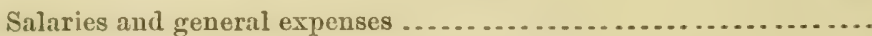

Wages for labor:

20 skilled laborers, 100 days and 100 nights, 12 hours per day, or

together 4,000 days' work, at $\$ 2.50 \ldots \ldots \ldots . . . \ldots . . . . . . . \quad 10,000$

40 common laborers, 100 days and 100 nights, or together 8,000

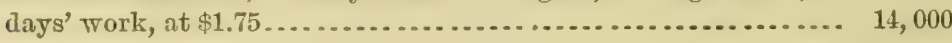

Total wages .......................................... 24, 000

Running expenses:

4,500 tons of coal (slack), equal to 15 per cent of weight of beets,

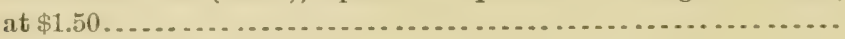

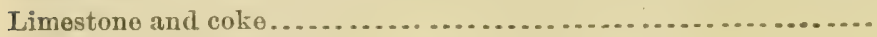

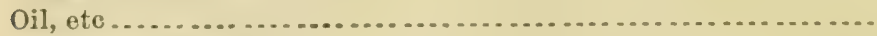

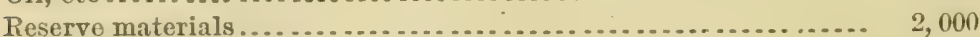

Linen for filter presses . . . . . . . . . . . . . ..................... 1,400

Electric light ......................................... 1,200

Sacks............................................... 1,400

30,000 tons of beets, at $\$ 4$ per ton ......................... 120,000

Total for running expenses............................. 140,650

Total salaries, wages, and all expenses ......................

Product and return for same:

The general average yield of sugar in America has been 11 per cent of the weight of the beets; taking this as a basis and the present price of sugar at $\$ 92$ per ton, the total production from 30,000 tons of granulated sugar,

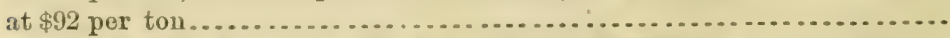

For pulp at 25 cents per ton, say for campaign, 6,000 tons............. 1,500 
Margin on seed, 3 cents per pound, on 60,000 pounds

Total returns

Total expenses

Net profits

76,700

[NoTE.-Cost of coal, lime, labor, and other materials may be cheaper in your locality than figured in above investment; and if this is the case, the expenses will be less and the cost of producing sugar cheaper.]

Estimate of cost, running expenses, and profits of a beet-sugar factory of capacity of 500 tons of beets per day of twenty-four hours.

Total capital needed, not including cost of land for factory and additioual buildings, which site should be 15 to 20 acres large, to be about....... $\$ 425,000$ Rumning capital:

The capital required to operate the factory to be.................. 50,000

Usually the bills for fuel, lime, and other material and work are paid at the end of every month, and it is the sume with farmers in regard to payment for their beets. Sugar, as one of the most required staple articles, is sold for cash or on short time. Every day 63.5 tons, or 127,000 pounds, of sugar will be ready for sale. The company should at the end of each month have sufficient money collected from their sales not only to meet all payments but have a good surplus. For this reason the sum of $\$ 50,000$ will be sufficient.

Cost of plant:

For all factory buildings, sugar storehouses, beet sheds, office and laboratory, limekilns, foundations for engines and apparatus, including all other mechanical work .........................................

For boilers, engines, pumps, machinery, and millwright work; also for the entire inside outfit and apparatus of either American or foreign manufacture

Cost of plant complete

Salaries and general expenses:

Technical superintendent . ............................. $\$ 5,000$

General manager ....................................... 3, 000

Agricultural expert ........................................ 2, 2, 000

Two chemists during campaign ........................... 1,000

Head machinery engineer and assistant.................... 2, 300

2 sugar boilers, at $\$ 250$ each.............................. 500

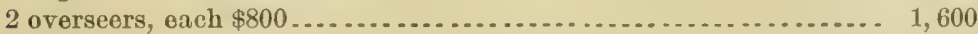

Weighmaster ............................................ 800

Bookkeepers, clerks, typewriter, and other oftice help ........... 5,000

Stationery, advertising, and incidentals .................... 1,000

Expense of meeting of board of directors ..................... 1,200

Selling expenses of sugar to jobbers ....................... 8,000

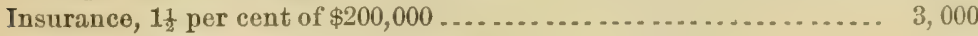

Repairs on machinery per campaign ....................... 3, 800

Depreciation of 7 per cent of $\$ 250,000$ machinery .............. 17,500

6 per cent interest on $\$ 425,000$ capital iuvested................. 25,500

Salaries and geueral expenses .......................... 81,200

Wages for labor:

20 skilled laborers, 100 days and 100 nights, 12 hours per day, or

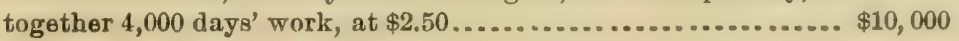


40 common laborers, 100 days and 100 nights, or together 8,000 days'

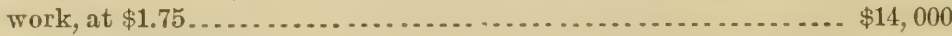

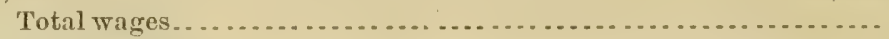
$\$ 24,000$

Running expenses:

7,500 tons of coal (slack), oqual to 15 per cent weight of beets, at

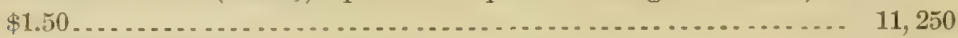

Limestone and coke..................................... 12,000

Oil, etc ................................................. 1,350

Reserve materials ....................................... 3,000

Linen for filter presses ................................. 1,800

Electric lights furnished by city station ................... 1,200

Sacks............................................ 2,000

50,000 tons of beets, at average of $\$ 4$ per ton . . . . . . . . . . . . . 200, 000

Total salaries, wages, and all expenses .................... 337,800

Product and return for same:

The general average yielil of sugar in America has been 11 per cent of the weight of beets; taking this and the present price of sugar at $\$ 92$ per ton as a base, the total production from 50,000 tons would be 5,500 tons of granu-

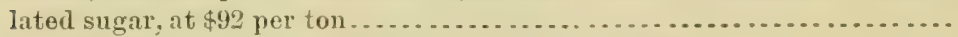
For pulp, at 25 cents per ton, say, per campaign, $7,500 \ldots \ldots \ldots \ldots \ldots \ldots$ Margin on seed, 3 cents per pound on 100,000 pounds ................. 3,000

Total returns ....................................... 510,877

Total expenses...................................... 337, 800

Net profits....................................... 173,077

[NotE.-Cost of coal, lime, labor, and other materials may be cheaper in your locality than fignred in above estimate, and if this is the case the expenses will be less and the cost of producing the sugar cheaper.]

\section{NEW FACTORIES.}

Ten or fifteen new factories are now in process of capitalization in different sections of the conntry, and will probably be realy for working the crop of beets that will be raised in 1898. We are reliably informed that there will be at least two adritional factories in New York, one or two in Iowa, one in Miehigan, one or two in Indiana, one in Utah, one in Wisconsin, one in Montana, one in Virginia, and one in Oregon. These factories, which will to more to demonstrate the possibilities of the States in which they are to be ereoted than anything else, will be established under such sme conditions, that they will he the first strong. stout round in the ladder that will carry us to funal success in the beetsugar industry in the United States.

\section{PULP FEEDING.}

The following is a report mate by Mr. John Reimers, of crand Island, Nebr., to the special agent, on pulp feeding:

As requested in your favor of the 13 th instant to $\mathrm{X}$. $R$. Alter, I wish to give you my opinion of four years' experience in feeding bect-sugar pulp to cattle.

I consider it a valuable food in connection with grain and other feed, as it is a 
great digestive food and appetizer. It has some fattening qualities, but I do not depend on it for that purpose, but mainly to digest the other foods.

When I begin feeding, I use for the first few days from 20 to 25 pounds of pulp per head daily, with hay and little grain or meal mixed with it. Then increase gradually to 40 or 50 pounds per head. I have also tried 80 to 90 pounds per head, but am positive that this is of disadvantage in fattening cattle, as they eat less grain and meal. Too much pulp is inclined to be loosening. Cattle can be put on fall feed of grain much quicker with puIp, as it helps to digest the food and lessens the danger of overfeeding or getting the cattle stalled and foundered.

After feeding from ninety to one hundred days, I would ad vise groing back gradually to 20 and 25 pounds of pulp per day and increasing the grain food, which oach feeder must judge for himself the amount his cattle can stand.

Cattle eat as much grain per day with the limited amount of pulp as they do withont it, but this food in connection produces flesh more rapidly and thereby shortens the feeding season.

I find it better to feed ground feed with pulp rather than whole grain, but the pulp is heneficial with any kind of food. Have found, when feerling pulp with the same amount of roughness and grain that generally is required in the West to fatten cattle, that I would put on an extra gain of from 50 to 75 pounds per head; or $I$ can make the same amount of gain as I obtain in the ordinary way of feeding in three-fourths of the time, and consequently save considerable grain and roughness.

The pulp-fed cattle will sell as readily as any other, as they dress and ship as well, even for export, which I myself have tried. Consider the pulp also a great food for stock eattle, if mixed with roughness, as it is a wholesome food and makes joung stock thrive and grow. Cattle will eat poor and damaged roughness, which they otherwise would not touch, if mixed with pulp.

I have fed fresh pulp direet from the factory and also so-called sour pulp after it has been in silo. The pulp will keep in silo for years, but it will shrink some.

The result is virtually the same in feeding either kind of pulp, and I consider them equally good, only that sometimes it takes three or four days before all the cattle learn to eat the sour pulp, while they will all eat fresh pulp readily the first day.

[Noтk.-In talking with others having had extensive experience in feeding pulp to eattle, wo secured facts in the main agreeing with the above report. All appear to agree that pulp ferding aids the work of digestion; that the same amount of fued adds more fat and flesh to the animal; that an animal will be prepared for the market six weeks earlier, showing a wonderful economy of time and feed. The gentleman making the report is connected with the Grand Island Live Stock and Commission Company, and has had an extensive experience with the cattle and sheep feoding industry.-C. F. S.]

\section{CRUDE MATERIALS REQUIRED PER TON OF BEETS WORKED.}

The following shows the per cent of lime, coke, and coal used in two factories in the United States, based npon the tons of beets worlied, and will afford a basis of estimating the amount of these crude materials that will be required by a factory having a stated daily capacity and definite number of days in its working campaign:

Per cent of lime, coke, and coal required to every ton of beets worked.

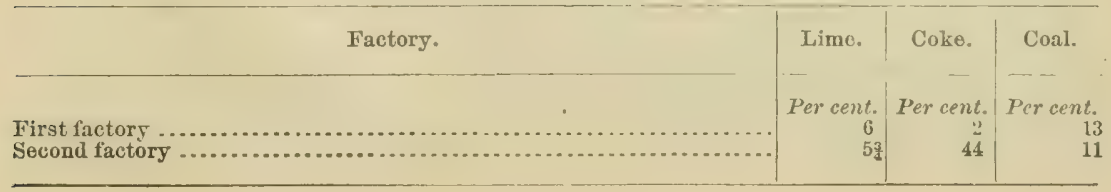


Sugar Consumption of Leading European Countries and THE UNITED STATES.

The following statement shows the consumption of sugar in the United States per eapita from 1867 to 1896, inclusive:

Sugar consumption per capita in the United States.

Pounits.

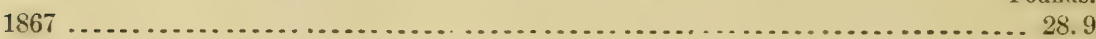

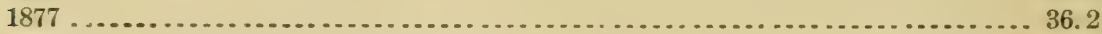

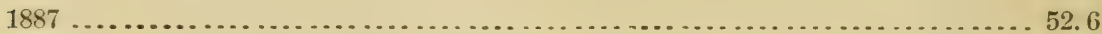

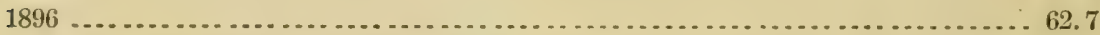

It will be seen that in less than thirty years the amount of sugar consumed in a year per eapita in the United States has more than doubled. This is to be attributed to two causes: (1) The people in becoming more prosperous have become more liberal in their daily living; (2) the people are becoming more intelligent, and by investigation better understand the uses of sugar in the arts and sciences and its application to maunfacture. We point to the wonderful development of the confectioner's art and the art of making sirups of all kinds for pharmacentic compounds, soda fountains, ete, during the past thirty years. Sugar is extensively used for curing and flavoring wines and for many other purposes, most of which have been introduced during the period of 1867-1896. Sugar was just beginning to come into use as a food in Queen Elizabeth's time, and the increase in its use has been continuous ever since. This increase in the use of sugar has been going on all over the world. The table following shows the rate of increase in the use of sugar per capita in the lealing countries for twenty-three years. The United States leads, as it does in almost all other things, in this increased consumption of sugar.

Rate of increase in consumption of sugar per capita.

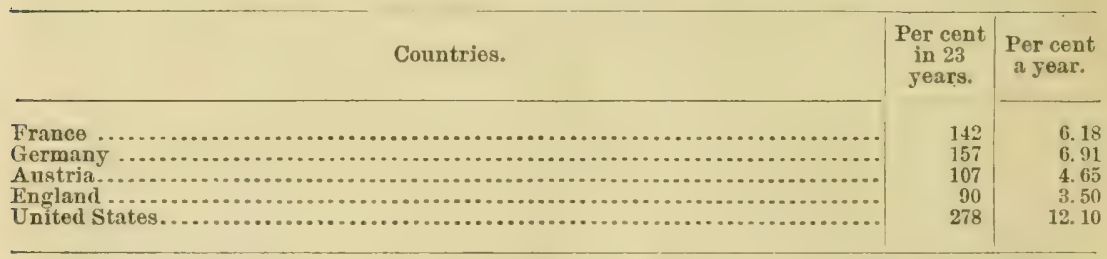

If we were to make a classification of countries based upon the intellectual staudard of their people and upon the ability of those people to appreciate the daily comforts of life, we would find that our list would represent two things: (1) The countries would stand in the order of the freedom of the people and the liberality of their government; (2) in the order of the amount of sugar consumed per eapita in those comntries. Under this classification the United States should stand first, but as our country is not old enough to have her position fixed, England takes the first rank. The United States, however, is gaining at the rate 
12.1 per cent per year while England's rate is but 3.5 per cent. The following statement shows consumption of sugar per capita in the countries named during 1894-95:

Sugar consumption per capita, 1894-95.

Pounds.

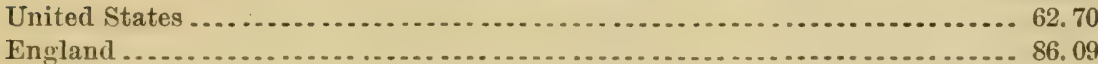

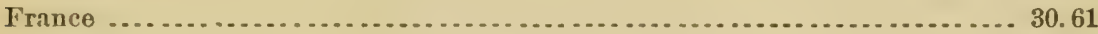

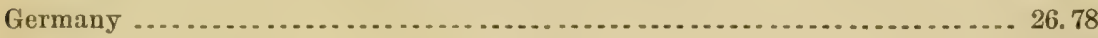

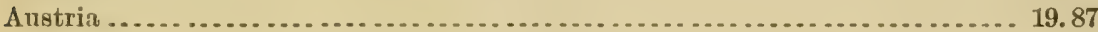

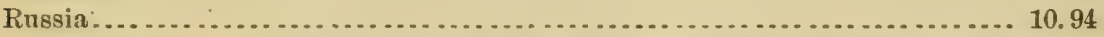

The three foregoing tables are taken from a pamphlet by E. W. Hilgard, rlirector of the California Agricultural Experiment Station. Professor Hilgard says:

Two prominent facts are shown by the above tables. The first is that in the United States and in England the consumption of sugar iucreases in a more rapid ratio than the population, and similar tables show the same to he true of all European countries at least. There is probahly a natural limit to tho posibility of sugar consumption, even hy the American boy and his elders, but it is uot likely that that limit will be reached within the next quarter century.

\section{THE BEET-SUGAR INDUSTRY IN GERMANY.}

The following table from The Sugar Beet gives in condensed form information concerning the beet industry of Germany.

Condensed data concerning the beet-sugar industry of Germany, 1892-1895.

\begin{tabular}{|c|c|c|c|}
\hline & $1894-95$ & $1893-94$. & $1892-93$ \\
\hline 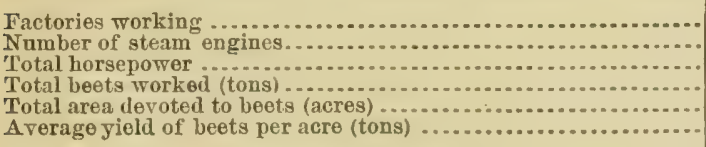 & $\begin{array}{r}405 \\
5,324 \\
91,952 \\
14,526,030 \\
1,098,465 \\
12.8\end{array}$ & $\begin{array}{r}5,405 \\
87,4256 \\
10,644,352 \\
987,723 \\
10.9\end{array}$ & $\begin{array}{r}401 \\
5,122 \\
81,596 \\
9,811,940 \\
880,000 \\
11.7\end{array}$ \\
\hline 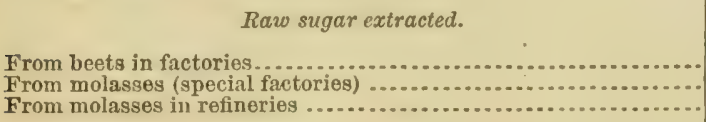 & $\begin{array}{r}\text { Tons. } \\
1,769,331 \\
61,447 \\
\mathbf{4}, 396\end{array}$ & $\begin{array}{r}\text { Tons. } \\
1,319,006 \\
55,165 \\
1,427\end{array}$ & $\begin{array}{r}\text { Tons. } \\
1,175,137 \\
48,925 \\
500\end{array}$ \\
\hline 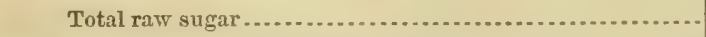 & $1,835,174$ & $1,375,598$ & $1,224,562$ \\
\hline 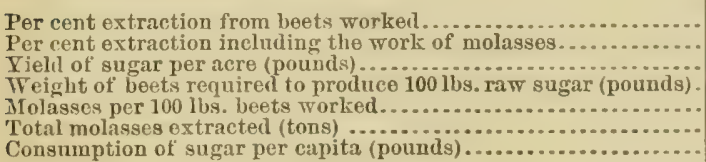 & $\begin{array}{r}12.17 \\
12.64 \\
3,514 \\
822 \\
2.4 \\
347,125 \\
23.5\end{array}$ & $\begin{array}{r}12.36 \\
12.92 \\
3,149 \\
809 \\
2.63 \\
279,757 \\
20.2\end{array}$ & $\begin{array}{r}11.98 \\
12.48 \\
3,276 \\
835 \\
2.54 \\
246,272 \\
26.78\end{array}$ \\
\hline
\end{tabular}

The above table is presented here because the $1,835,174$ tons of raw sugar prorluced in Germany represents within about 100,000 tons the quantity of all kinds of sugar imported by this country. The details of the sugar industry in (xermany are therefore of importance as showing about what would be the condition of the industry in the United States were it established to the extent of producing all the sugar required for home consumptinu. 
Aside from the information set forth in this table, other facts are easily obtained; for instance, the following estimates made from averages of cost of crude materials and labor, prorated on the cost of each for working a ton of beets, are compiled from data secured from the factories in this country:

To install this industry on a scale adequate to providing onr entire domestic consumption it would require an investment of capital to the extent of ................................... $\$ 200,000,000.00$

Farmers twonld receive annually for beets.................... 60,000,000.00

Coal operators and miners, or other sources of fuel supply, would. receive ..............................................

Lahorers in the factory, skilled and unskilled, would receire.......

Coke manufacturers would receive ..............................

There would be paid to quarrymen for limestone, etc...............

The textile manufacturers would receive for filter cloth and bags, chemicals, sugar bags, etc ................................ There would go to municipalities to relieve the burden of taxation. Insurance companies would receive..........................

$5,665,151.70$

$14,000,000.00$

$2,500,000.00$

$1,743,123.60$

$5,156,000.00$

$1,45 ?, 603.00$

$726,301.00$

The working of the $14,526,030$ tons of beets would result in the production of $5,810,412$ tons of pulp.

The following estimates are condensed from an article on "Pulp feeding," by Mr. Joln Reimers, of Grand Island, Nebr., and provide 60 pounds of pulp per day for milch cows for a year, and 40 pounds per day for cattle during the feeding season; the saving of feed is baserl upon a reduction of the feeding period by one-fourth:

When this pulp is thoroughly understood and appreciated, it will be worth to the facturies for animal food $\$ 2,905,206$. This pulp would form the principal part of the best feed ration known for milch cows, and would feed for one year 528,219 cows. This amount of pulp could be turned to feeding and fattening cattle, and would he sufficient for feeding ration to prepare for the market $2,421,005$ cattele.

It is estimated by extensive, intelligent, and experienced feeders of pulp that a steer can be fattened six weeks earlier on this ration containing grain and pulp [Mr.Reimers puts it: "In three-fourths the time"], so that it ean be estimated that the actual saving through the eronomy of feerling our entire output of pulp would be the whole nutritive ration necessary to fatten 605,251 cattle.

\section{Experience of Successful Growers of Sugar BeEts.}

The information under this head is compiled for the purpose of giving the results of the experience of successful growers of sugar beets. The numbers preceding the names of those answering the questions in the list correspond to the number preceding the answers.

\section{ANSWERS TO OUESTIONS IBY SUGAR-BBEET GROWERS IN NERRASKA.}

The following is a list of sugar-beet growers in Nebraska, the cuestions propounded to them, and the answers to the same:

(1) James Seilley, Standard Cattle Company, Ames, Dodge County.

(2) John Duggleby, Standard Cattlo Company, Ames, Dodge County.

(3) Gustave Koehler, Grand Island, Hall County.

(4) Gotlieb D. Neunernan (raised beets in (iermany), Merrick County. 
(5) Fred. Ernstmeyer, Grand Island, Hall County.

(6) John Friend, Grand Island, Hall County.

(7) William Mun and D. A. Finch, Grand Island, Hall County.

(8) Fred. Roby, Grand Island, Hall County.

(9) George C. Humphrey, Doniphan, Hall County.

(10) Edmund Starke, Grand Island, Hall County.

(11) 'Theo. Sievers, Grand Island, Hall County.

(12) Whitmore Brothers, Valley, Douglas County.

(13) Henry Joehucke, Grand Island, Hall County.

(14) F. H. Brown, Fremont, Dodgo County.

Number of acres grown?
(1) 100.
(2) 55.
(3) 36.
(4) 10 .
(5) 2 .
(6) 5 .
(7) 150 .
(8) 10 .
(9) 30 .
(10) 100 to 250 . (11) 15 . (12) 50 .

Usual time for ploughing?

(1) Fall or early spring. (2) Fall. (3) Soon as frost is out of ground. (4) Fall and spring. (5) Fall and spring. (6) Fall and spring. (7) Fall. (8) Fall and spring. (9) Fall and spring. (10) Fall. (11) April. (12) April. (13) Spring. (14) Spring.

For harvesting?

(1) October. (2) October. (3) October. (4) Last September. (5) Last September. (6) October 12 to 20. (7) October to November 1. (8) October to November 15. (9) September 15 to October 30. (10) September 15 to Oetober 15. (11) October 1. (12) October and November. (13) October 15. (14) October 15 begin.

How do you prepare the ground?

(1) Plow; then follow by harrowing, pulverizing, and go over with chain harrow or leveller; then roll and harrow with light harrow.

(2) Pulverize the soil tinely and leave surface level.

(3) Plow 12 inches in fall and 6 inches in spring; harrow, then drag to level the ground and plaut; as soon as plaut is up, use the spider eultivator; then bunch and thin to 6 and 8 inches; hoe once aud cultivate twice with Planet, jr.

(4) Plow 3 inches in fall and 9 inches iu spring; harrow, roll, and harrow again; then plant.

(5) Same as 4.

(6) Plow 7 inches in fall and 8 inches in spring from April 1 to 15 to kill weeds and loosen the soil; then harrow good; roll the ground and plant an inch.

(7) Extirpating; harrowing; rolling and harrowing.

(8) Plow two or three times in all, last time 15 to 16 inches; cultivate in the spring to stir the grouud; harrow and plant.

(9) Plow 4 to 5 inches in the fall and 10 inches as late as possible in the spring in blocks; to be planted immediately. Follow with slant-tooth harrow as I plant, then float (plank), then plant.

(10) Fall plowing; then cultivate with disk in the spring and harrow thoroughly.

(11) Plow 3 inches in fall and 8 inches in spring, and subsoil 6 inches; tarrow and roll or plank.

(12) Best to plow in fall, and either plow or disk harrow early in spring, and then thoroughly harrow the ground.

(13) Plow 3 inches in fall to kill weeds and 10 inches in spring; drag with plank, 3-lapped; then harrow and plank again.

(14) Stubble ground. Plow 9 to 11 inches when weeds started in spring, lapdisked again; then harrow, rolled, and planted.

Explain your mode of cultivation?

(1) First cultivate with knives in cultivator once or as often as may be necessary;

then bunch and cultivate; thin and weed; cultivate; cultivate and hoe.

(2) Deep hoeing and deep cultivation.

(3) Seo (3) under "How do you preparo the ground?" 
(4) Cultivate as soou as the plants are up; then bunch and thin; hoe, according to the weeds, two or three times; then cultivate three to four times.

(5) Same as (4).

(6) Bunch and thin 8 to 10 inches apart; cultivate with four-row German cultivator; with knives cultivate once more; cultivate once more with knives and once with plow blades; hoe if weedy. Loosen with beet loosener and pick.

(7) After the beets are just up cultivate with the German cultivator and with knives about 2 inches deep; after that use goose feet.

(8) Cultivate first and then bunch and thin; eultivate and hoe, after which cultivate once more if needed; then pull weeds by hand.

(9) Cultivate with Fremont with drag attachment about the time the beets are up with no cultivator attachments, and harrow again; then bunch and thin; after which eultivate with goose feet. I do not hoe; the harrow answers. I cultivate about six times.

(10) After planting use small harrow; cultivate when up; bunch and thin; hoo twice or three times.

(11) Cultivate with Moline three times; hoe once. We bunch and thin after first cultivation.

(12) Hand hoe and thin; then cultivate with small, fine one-horse cultivator made for the purpose.

(13) Cultivate early with Moline before the beets are up, if necossary, for weeds; cultivate three or four times to keep weeds down and soil open; hoe twice; also thin and bunch.

(14) As soon as plants show I go over with a wheel hoe operated by two men; then use Fremont horse cultivator; after which thin and bunch; then cultivate twice, aud afterwards cut out weeds.

Describe your soil?

(1) Sandy loam, black loam, and gumbo.

(2) Gumbo.

(3) Sandy loam with gravel and clay subsoil.

(4) Very sandy; sandy subsoil.

(5) The same as (4).

(6) Sandy loam; sandy subsoil, with some clay.

(7) Sandy loam; clay subsoil.

(8) Sandy loam; sometimes clay; sometimes sandy followed by hardpan under that.

(9) Black sandy loam; yellow clay subsoil.

(10) Sandy loam.

(11) Sandy loam and clay subsoil.

(12) Rich black sandy loam, with free sandy subsoil.

(13) Sandy loam, with sand and sometimes clay subsoil.

(14) Rich black loam. Would prefer a little sand.

What are the requirements of beets for moisture?

(1) Beets seem to be able to stind dry weather after they start to grow; they also do well with lots of rain.

(2) They will stand wet or dry weather.

(3) Require much less moisture; taproot will go down sometimes 8 to 10 feet.

(4) Can stand more rain and much less than any other crop.

(5) Same as (4).

(6) Will thrive with one-half less moisture than is required hy other crops and will stand more until time of ripening.

(7) If ground is in good condition in the spring, will need only one rain to sprout; should have a good and damp August.

(8) Need less moisture and can stand more than other crops.

(9) They do not require as much moisture as other crops. 
(10) Can stand more or less moisture than any other crop.

(11) Require much less than other crops.

(12) Damp, fine seed bed with frequent showers while growing.

(13) Require less moisture than other crops, and ean stand more.

(14) Not as mucl as corn, as they grow deoper in the ground.

What are your estimates per aore for cost of raising and marketing beets?

(1) $\$ 25$ per acre and $\$ 13$ for marketing without froight.

(2) The same as (1).

(3) \$20. Improved machinery and cheaper labor where available make these figures much less. Harvesting will be about $\$ 9$ additional.

(4) $\$ 15$ to $\$ 16$, and $\$ 9$ to $\$ 10$ for harvesting.

(5) The same as (4).

(6) $\$ 15$; which includes bunching, thinning, hoeing two times, and plowing three times. Harvesting costs me $\$ 6$ per acre; 4 miles from factory.

(7) Abont $\$ 36$ per acre. This includes barvesting.

(8) \$16 per acre; harvesting and marketing \$14 more.

(9) $\$ 25$; harvesting and marketing will be $\$ 8$ more. My beets must be delivered 5 miles by wagon and then 12 miles by railroad.

(10) $\$ 16$ to $\$ 17$ for raising the beets, and about the same for harvesting.

(11) I do not know.

(12) Generally about $\$ 30$ per acre, ane $\$ 10$ for marketing and harvesting.

(13) $\$ 20$ to $\$ 25$, and about $\$ 4$ marketing the beets.

(14) $\$ 20$ to raise the beets, and $\$ 6$ per acre when harvested without siloing.

How many tons do you average per acre?

(1) 18 tons. (2) 17 tons. (3) 12 tons. (4) 10 to 12 tons. (5) The same as (4). (6) 14 tons. (7) About 11 tons. (8) 16 to 18 tons. (9) 10 tons. (10) 10 to 15 tons. (11) 13 to 15 tons. (12) 15 tons. (13) 12 tons. (14) 10 to 15 tons.

What is the average sugar quality of your beets?

(1) 14 per cent sugar content, 81.5 per cent purity. (2) 13 per cent. (3) 16 per cent. (4) 14 per cent sugar, 80 per cent purity. (5) The same as (4). (6) 14 per cent. (7) Last year 14.2 per cont. (8) 14 per cont. (9) 14.8 per cent sugar, 82 per cent purity. (10) 15.8 per cent sugar, 85 per cent purity. (11) Gooul test. (12) 12 per cent sugar, 80 per cent purity. (13) Do not know. (14) 12 to 15 per cent.

What do you recommend in the way of equipment, horses, and implements?

(1) For small farmer would recommend stirring plow, corn cultivator to go both ways and to harrow both ways; Moline's seeder, roller, and small harrow cultivator. F. M. Wallace, of Fremont, has the best cultivator I kuow, and A1 puller can be obtained at Fremont foundry.

(2) Mules. Any implements can be used that will leave the ground level, loosened down deep, and thoronghly pulverized.

(3) Stirring plow, beet seeder, harrow, drag, two horses, Planet, jr. cultivator, and hoes. My work was largely experimental in starting the industry. I came from the beet-sugar districts of Germany.

(4) Stirring plow, roller, cultivator (Molino), harrow, and hoes.

(5) The same as (4).

(6) Stirring plow, harrow, cultivator, seeder, hoes, beet puller, roller. I find that planking pulverizes the ground but does not make it compact.

(7) Use, if possible, mules; Jewell beet drill, cultivator.

(8) Stirring plow, two to four horses, a stirring-plow cultivator (Fremont), harrow (no roller or plank), hoes.

(9) A good tean of three horses, stirring plow, float, harrow, a good cultivator like the Fremont. I think a cultivator should take ouly two rows, on account of the unevenness of the ground.

(10) Two horses, plow, cultivator, harrow, seeder, beet puller.

(11) Stirring plow and subsoiler, Moline cultivator, roller, harvester, hoes. 
(12) Use same plows, teams, men, etc., as for other farm work, adding fine harrow, cultivators, hoes, hand weeders, ete.

(13) Moline enltivator, good stirring plow, small strong horse or mule, good harrow, three loorses for stirriug-plow work, plank harrow.

(14) Ono combined seeder aud cultivator, plow and harrow.

How many acres with good equipment can one man tend?

(1) Ten acres by himself.

(2) Sereu acres, if alone.

(3) After the thinning and bunching and help to hoe once, one man cultivated 35 acres.

(4) Five acres, alone.

(5) Five acres, alone.

(6) One man and two boys can thin and buuch 10 acres in ten days, then one man can tend 10 acres alone.

(7) Five acres.

(8) Ten acres, if the man hires the bunching and thinning, which will cost $\$ 70$.

(9) Thirty acres, by paying $\$ 1.50$ per acre for bunching and thinning. This is my experience. My ground is quite free from weeds, however.

(10) Five acres, working alone.

(11) I do not know.

(12) 2 acres.

(13) 10 acres, working alone.

(14) Onecultivator will tend 10 acres, but will have to have extra help in thinning and weeding.

What are the obstacles you encounter, includiny diseases, insects, ete?

(1) Have had no disease to contend with. Have had trouble with black cutworms and white bugs usually found on cockleburs, and with another bug that flies in swarms; do not know name, but they only affect the plant in spots, which usually grow again.

(2) Trouble with nothing besides cut and grub worms.

(3) Have had no difieulties of this kind.

(4) The same as (3).

(5) The samo as (3).

(6) Sometimes small red ants are encountered when the plants first come up.

(7) Cold and wet Mays are injurious for sprouting and heavy winds are apt to burt the plants just after they come up.

(8) Nothing.

(9) High winds, which drive the sand aud cause it to cut off the plants. We have trouble with hail, but it does not injnre beets as much as other crops. The leaves of my erop were all cut off twice last year, but they grew out again, but the hail did not hurt the roots.

(10) None whatever so far.

(11) Nothing.

(12) Encounter about tho samo dificulties as in growing a garlen. Sometimes bugs eat the plants.

(13) Poor seed. Too much wet or dry weather. In 1892 small striped worm, about half the size of entworm, destroyed all leaves.

(14) Insects do but littlo daunage. The wind does more danage than anything else.

What are the staple products of your locality?

(1) Corn, oats, and wheat; principally wheat.

(2) Corn and oats.

(3) Corn, oats, barley, whent, alfalfit.

(4) Corn, oats, rye, wheat, and barley.

(5) The same as (4). 
(6) Rye, oats, corn, wheat, and vegetables.

(7) Corn, oats, and rye.

(8) Corn, oats, rye, wheat, potatoes, otc.

(9) Corn, oats, wheat, rye.

(10) Corn, wheat, rye, oats, alfalfa.

(11) Corn, oats, rye, wheat.

(12) Corn, hay, oats, potatoes, onions, beets.

(13) Corn, oats, rye, and some wheat.

(14) Corn, wheat, oats, wild and domestic grasses.

How do sugar beets compare with the above crops for profit?

(1) If properly handled the beets are much more profitable.

(2) Better.

(3) The beets pay a man 100 per cent better for the same effort and capital.

(4) One acre of sugar beets will pay better than 10 acres of corn or other crops mentioned.

(5) The same as (4).

(6) Beets give a much higher profit.

(7) No answer.

(8) Much better.

(9) Beets pay better.

(10) Five acres of beets pay in comparison better than 30 acres of other prorlucts.

(11) They afford considerably more profit.

(12) The net profit, as a rule, in raising sugar beets is no better than in raising the other crops mentioned.

(13) Pay better than any of the staple crops mentioned.

(14) When the beets come up to a good test they pay better than other crops mentioner.

How long have you been raising sugar beets?

(1) Five years. - (2) Five years. (3) Three years. (4) Four sears in Germany and six years in Nebraska. (5) Four years. (6) Two years. (7) Two jears. (8) Seven years. (9) Two years. (10) Four years. (11) Six years. (12) Four years. (13) Six years. (14) Three years.

What fertilizer do you use?

(1) Barnyard manure. (2) None. (3) Barusard manure. (4) Barnyard manure. (5) Barnyard manure. (6) Stable manure. (7) No answer. (8) Barnyard manure. (9) Barnyard manure. (10) Barnyard manure. (11) None. (12) Manure. (13) Barnyard manure. (14) None.

How do you apply fertilizer?

(1) Haul it to the field in the fall; scatter it lightly and evenly over the ground, and plow it under as soon as possible.

(2) Do not apply fertilizers.

(3) Well-rotted manuro gives good results.

(4) For fall plowing apply 10 to 12 loads per acre.

(5) For fall plowing apply 10 to 12 loads per acre.

(6) Apply thin coat, well rotted, and get good results.

(7) Scatter it broadcast immerliately after plowing and before harrowing.

(8) Apply it thickly and well rotted the year before planting.

(9) Applied well rotted increases the growth.

(10) Apply it to the field before plowing.

(11) Do not uso fertilizers.

(12) Plow in well the year before the plants are to be planted.

(13) Applied well rotted gives good results.

(14) Do not apply fertilizers.

How deep should ground be plowed?

(1) Ten to 12 inches.

H. Doc. $396-15$ 
(2) In the fall as deep as possible and 8 inches in the spring.

(3) Plow 12 inches in the fall and cultivate in the spring.

(4) In the fall 3 inches and in the spring 10 inches.

(5) In the fall 3 inches and in the spring 10 inches.

(6) Plow 7 inches in the fall and 10 inches in the spring.

(7) It should be plowed about 10 inches.

(8) Shallow plow in the fall twice and then 15 to 16 inches.

(9) Plow 4 inches in the fall and 10 inches in the spring.

(10) The ground should be plowed from 12 to 15 inches.

(12) Plow 12 inches.

(13) The ground should be plowed 10 inches.

(14) Plow 9 to 11 inches.

How deep should seed be planted?

(1) The depth of planting should be governed by condition of the land.

(2) Plant seeds 2 inches.

(3) Plant 1 inch or 8 times the diameter of the seed.

(4) Plant seed about one-half inch.

(5) Plant seed about one-half inch.

(6) Plant 1 inch.

(7) Plant from one-quarter to one-half inch.

(8) One inch, but if soil is dry plant deeper.

(9) Seed should be plauted from one-half to three-quarters inch.

(10) Should be planted one-half inch and no deeper.

(11) Plant 1 ivch deep.

(12) Plant 1 inch or less.

(13) If soil is moist plant three-quarters inch, but if dry 1 inch.

(14) Seeds should be planted from one-half to three-quarters inch.

What do you think about ridging the rows?

(1) Prefer smooth cultivation, but have had very good success with ridging.

(2) I do not like ridging the rows.

(3) I found it a good plan in Nebraska to plant level and ridge by cultivation.

(4) Never have done anything of this kind.

(5) Never have done anything of this kind.

(6) We can cultivate the beets in this way.

(7) I think it is a mistake to ridge any beet rows.

(8) I do not like ridging the rows.

(9) I keep the rows as flat as possihle; ridging has a tendency to raise the hects out of the ground and the rain washes away the dirt.

(10) I never ridge my rows and do not believe it is a proper thing to do.

(12) Do not ridge the rows, but mellow the ground deeper instead.

(13) Do not ridge the rows.

(14) Do not ridge; cultivate 9 inches deep so the beets can grow down.

How do you silo your beets?

(1) Take about thirty-five or forty rows of beets; begin in the center; leaving a place for the silos, I throw the beets in piles and top under bottom leaves. Throw in piles as you top, cover with 6 inches of earth, leaving air holes on tops of piles; later cover with hay, then cover with more earth.

(2) Put the beets in piles of 2 tons and cover with dirt 6 inches deep, leaving air holes.

(3) I never lieep my beets after harvesting; the fictory being near they are hauled there at once.

(4) Put the beets in a ditch 1 foot deep and 4 feet wide; after these piles are 3 feet high cover with 6 inches of dirt and then with horse manure when very cold. Place ventilators along the top of the ridge, made with straw.

(5) Use the same process as (4).

(6) Take off surface of the ground 5 to 12 inches and pile the beets until $2 \frac{1}{2}$ to 3 
feet high, then cover with 6 inches of dirt. Will keep in this way until Christmas. If it gets too cold cover with straw or manure.

(7) Put about 5 tons in silo and cover the same with 8 inches to $1 \frac{1}{2}$ feet of dirt.

(8) In long ridges, 4 to 5 feet wide and 3 feet high; cover with 6 inches of dirt, and later cover with hay and coarse manure.

(9) Short ricks of $1 \frac{1}{2}$ tons, 3 feet wide at bottom and 3 feet high; cover with 4 inches of dirt; about midlle of November cover with coarse straw 4 to 6 inches. In this way I had beets that kept all winter.

(10) Place the beets on top of the ground in rows 5 foet wide and $3 \frac{1}{2}$ feet high and inake length as may be convenient. Cover with dirt 6 inches.

(11) I pile the beets on the ground in ricks 10 to 30 feet long, 5 feet wide at bottom and 3 feet high. I cover the ricks with straw and 4 to 5 inches of dirt.

(12) I dig a trench with a road scraper, into which I throw the beets and cover with hay or straw and dirt.

(13) I pile the beets on the ground in rows of convenient length, 6 feet wide at the base and 3 to $3 \frac{1}{3}$ feet high, and cover with 6 inches of dirt, learing ventilator holes every 8 or 10 feet. The beets in this way will keep until Christmas. If necessary cover with coarse manure or straw in the coldest weather.

(14) Put them in silos 20 to 50 feet long.

How many times do you hoe after thinning?

(1) Twice. (2) Twice. (3) Hoe once. (4) Once. (5) Once. (6) Twice. (7) Hoe at least twice. (8) Once. (9) Do not hoe after thinning. (10) Hoe two or three times. (11) Hoe twice. (12) Three times. (13) Hoe twice. (14) Once.

Does hoeing increase the yield?
(1) Seldom.
(2) Yes.
(3) No answer.
(4) No answer.
(5) No answer. (6) No answer. (7) Yes. (8) No answer. (9) No answer. (10) Yes. (11) Yes, cultivation also increases yield. (12) Yes. (13) Yes. (14) Not if cultivation is deep.

What is your experience?

(1) If land is in good, olean condition and properly cultivated, a good deal of hoeing can be dispensed with.

(2) I have always hoed twice or three times.

(3) The greater the cultivation the better the results.

(4) I think one hoeing is enongh.

(5) I think one boeing is enough.

(6) Working the land often will produce good results.

(7) No answer.

(8) Each hoeing will make two tons to the acre.

(9) Keep the field clean and loose by cultivation. Hoe if the weeds get a start.

I was weigh-master at Grand Island for two campaigns, 1895 and 1896, under the appointment of secretary of state on account of bounty. The factory rejected seventy car loarls of beets during my first year, but afterwards accepted the beets and worked them up, paying $\$ 2.50$ per ton. During my second year no beets were rejected. I think the first rejection was due to poor seed and bad, dry year. Very few beets tested 12 and 80 per cent in 1895 .

(10) Frequent hoeing will increase the yield of beets considerably.

(11) Cultivation increases the yield.

(12) The principal reasons that growing sugar beets has not been more profitable are high-priced labor (regular men getting $\$ 1.25$ per day); high freight (\$1 per ton) to factory. We must raise at less expense and have a factory nearer home.

(13) They can not be worked too much after the 4th of July, as will become too large.

(14) No answer.

How far apart do you plant the rows?

(1) 18 inches apart. (2) 18 inches apart. (3) 18 inches apart. (4) 18 inches apart. (5) 18 inches apart. (6) 18 inches apart. (7) 14 inches apart. (8) 18 to 20 
inches apart. (9) 18 inches apart. (10) 14 inches apart. (11) 18 inches apart. (12) 17 inches apart. (13) 18 inches apart. (14) 18 inches apart.

How far apart do you thin out the beets? How much seed do you use per acre?

(1) On very rich land, 8 inches; poorer land, 9 or 10 inches.

(2) 8 to 9 inches.

(3) 6 to 8 inches. I use 20 pounds seed to the acre.

(4) 8 inches. We use 15 pounds seerl to the acre. With use of hand machine can get along with 8 pounds seed.

(5) 8 inches.

(6) 8 inches. I use 20 pounds seed to the acre; more than necessary if seed is good.

(7) 8 inches.

(8) 5 to 8 inches. Twenty pounds seod should be planted to the acre.

(9) I average 6 inches. I plant 18 pounds seed to the acre.

(10) 8 to 10 inches.

(11) 6 inches; plant 18 to 20 pounds seed to the acre.

(12) 6 to 8 inches.

(13) 8 to 10 inches. I plant 20 pounds to the acre.

(14) 8 to 10 inches.

ANSWERS TO QUESTIONS BY FACTORY OFFICIALS AND FARMERS IN CALIFORNIA AND NEW MEXICO.

Following is a list of sugar-beet growers in California and New Mexico, the questions propounded to them, and the answers to the same:

(1) Agriculturists at Alvarado factory, Alvarado, Alameda County, Cal.

(2) S. D. Galliger (one of the best farmers) Watsonville, Santa Cruz Count, Cal.

(3) S. Jenson (one of the best farmers) Watsonville, Santa Cruz County, Cal.

(4) W. C. Waters, manager Watsonville factory, Watsonville, Santa Cruz County, Cal.

(5) E. H. Dyer, builder and operator of five factories in the United States, Alvarado, Alameda County, Cal.

(6) L. Hache, agriculturist, Chino factory, Chino, Cal.

(7) J. L. Elam, farm superintendent, Alamitos factory, Los Alamitos, Cal.

(8) R. C. Nisbet, farm superintendent of factory, Eddy, Eddy County, N. Mox.

Number of acres grown?

(1) 4,900 acres, by the farmers for the factory. (20) 60 . (3) 30 . (4) No answer.

(5) No answer. (6) No answer. (7) No answer. (8) $2,100$.

What is the usual time for plowing and havesting?

(1) Grain ground in fall after first rain; other gronnd in the spring. Harvesting begins middle of August and lasts until November.

(2) Plow in winter; harvest from August to December.

(3) Plow Christmas time; harvest between middle of August and December.

(4) Plow in fall and harvest August to Jannary.

(5) Plow midtle of April and in lowlands. June 1; harvest from September 1 to last November.

(6) Plow deep as possible bofore rain and harvest from July to November 15.

(7) Plow as oarly as possible and harvest from July 1 to ond of campaign.

(8) Plow fall and winter. Harrest 150 to 160 daşs after planting in this climate. How do you prepare the ground?

(1) Plow stiff land 16 inches and sandy land 10 to 12 inches; subsoil; pulverize very thoroughly, and roll before sowing; in dry weather roll after sowing.

(2) I'low 12 inches; cultivate or plow again 8 to 10 inches; harrow fine and thin; hand hoo once. 
(3) Plow 10 to 12 inches. The harvesting of beet crop plows the ground for the next crop, which will be barley or potatoes.

(4) Plow in fall; cultivate four to five times before planting and gain a little depth each year; harrow down fine and let it rest about five days for moisture line to establish itself.

- (5) Plow 12 to 14 inches in spring; harrow to very fine and pulverized condition; roll after planting.

(6) Plow ground as deep as possible, before rain if possible, 12 to 14 inches, using 4 to 6 horse singlo plows; harrow, roll, and pulverizo; cultivate during the winter to kill the weeds; eultivato deep in the spring and roll aud plant; thin when threequarters of the plants have four leaves, then cultivate with goose-feet cultivator three or four times; hand loe once to clean ont weeds. Plant February 15 to June 1.

(7) Plow as early as possible; then plow 12 inches across the second time; harrow the ground, and in the spring, after the rains, cultivate or harrow the land well; plant, thin out, and cultivate with Moline or kinclred four-row plow several times, and hand hoe. It pays to hand hoe. The soil runs down about 6 feet and then we have a quicksand subsoil; subirrigation comes down into this sancl strata and capillary attraction brings it up in the soil. Wo must keep a dust mulch to stop evaporation. We plant from February to March 30.

(8) Plow 12 to 14 inches in fall; cultivate in spring or disk, then harrow and plant the same day; previously (say four days) to this we have irrigated; harrow on the level.

Explain your mode of cultivation and describe your soil.

(1) We cultivate with one-row cultivator, on account of unevenness of ground, about 7 iuches, simply loosening and turning up the soil twice; heo twice. The soil is sandy, with little loam, then sandy loam and disintegrated soil.

(2) Hire Japanese at 50 cents per ton to thin, hand hoe, and keep out weeds; hand hoe once; horse hoe once; black sand loam.

(3) Thin out as early as possible, or about the time 4 leaves are out; early thinning is important; then with horse hoe, single-row hoe once; cut ont weeds if any last; previous to horse hoeing hand hoe once; prepare land by cultivating once or twice in spring before planting; black loam soil.

(4) 'Thin and weed in the rows by hand; push hoeing once single row; one to three horse cultirations, according to the loosenest of sand, down 3 to 6 inches. Tho soil is (1) sandy sediment, (2) clay sediment, (3) adobe. The latter is good as any, but requires more labor.

(5) Cultivate with Planet, Jr., once; hand hoe once; thin and bunch early so as not to disturb the plants, the earlier the hetter, or as soon as you can tell beets from weeds. The soil is saudy made land from wash of mountains; saudy adobe which becomos hard.

(6) Answered as to cultivation in reply to previous question. Mostly sandy loam, 3 to 8 feet; subsoil, white clay; sometimes layers of coarse sand.

(7) Auswered in reply to previous question. Soil, sandy loam; subsoil, clay with sand strata.

(8) To insure thorough stand, follow planting with water furrowing and water; cultivate three or four times; hoe once; irrigate three to four times. The rows alternate 14 to 26 inches apart, with water furrow in wide row. The soil is a very fine dust sediment 3 to 20 feet deep, followed by a lime solid hardpan.

What are the requirements of sugar beets for moisture?

(1) Plenty at time of germination. We want no moisture after June. Light showers and heavy rains bake the soil and not much is required. Got none this year.

(2) Heavy winter and March rains; light showers for summer.

(3) My beets had no rain after planting; should have showers before planting and heavy rains in winter and spring. 
(4) Want three or four rains in November, none in December, five in January, three to four in February, aud spring showers to 24 th May, and this will do the business. Beets do best in dry years.

(5) If we plant on fresh ground, the seeds germinate, dry out, and die. Wo wait until the top dries and moisture comes up from below. We need April rains, and then the reserve the soil carries will mature the crop with slight showers.

(6) We get rain from December to March and showers in April.

(7) The moisture comes up in November to the surface without rain; in low places it stands in pools. The dajs are short, the nights are cool and winds less in fall, consequently evaporation is reduced.

(8) Four or tive irrigations, with one for cultivating the seed bed in the spring. Irrigate after seeding once about thinning time and the other two when the beets call for it.

What are your estimates per acre for cost of raising and marketing beets? What are the rent values?

(1) $\$ 22$ to $\$ 30$ per acre rent; $\$ 15$ to $\$ 20$ per acre cash, The cost of raising the beets includes the marketing.

(2) $\$ 19.50$ per acre; rent $\$ 10$. I pay Japanese 50 cents per ton and deliver the beets to the factory at $\$ 1.50$ cost to me.

(3) $\$ 36$ per acre; rent $\$ 8$ per acre. I get about $\$ 56$ per acre. The cost per acre includes marketing.

(4) $\$ 28$ per acre, delivered to the factors; rent $\$ 8$ to $\$ 20$. We have 10,000 acres that average $\$ 10.50$. Sugar beets double the price of rents.

(5) $\$ 30$ and $\$ 35$, raised and delivered.

(6) $\$ 20$ to $\$ 25$ per acre; rent one-fifth to one-quarter of crop. We average $\$ 4.25$ per ton for beets.

(7) $\$ 25$ per acre; rent one-quarter crop. Beets average 9 tons, at $\$ 4.50$ per ton, making rent about $\$ 10$. Will make more later.

(8) I had 30 acres and paid for everything, and it cost me $\$ 25$ per acre to put the beets on the cars. With farmers the amount is usually about this figure.

How many tons do you average per acre, and what is the average sugar quality of your beets?

(1) 11 to 14 tous per acre; $10 \frac{1}{2}$ per cent white sugar quality.

(2) 15 tons; do not know the sugar quality.

(3) 14 tons per acre; I do not know the sugar quality.

(4) 12 tons sure; 18 per cent sugar quality; 80 purity.

(5) 15 tons per acre; 14 to 15 per cent sugar quality; 80 to 83 purity.

(6) Average 12 to 15 tons; 15 to 16 per cent sugar quality; purity 80.

(7) This year 9 tons; 16.5 sugar quality; purity 84

(8) I had 9 tons per acre. The returns from the factory from general sonrces showed about 8 tons. Last year had $16 \frac{2}{8}$ per cent for sugar quality and purity 86 for entire campaign.

What do you recommend in the way of requirement, horses, and implements?

(1) No answer.

(2) Double gang heavy 5 -foot cut cultivator; hand hoes; 5 or 6 horses (heavy); beet seeder, beet harvester, and beet cultivator.

(3) Gang plow (this takes from 5 to 6 horses); hoe cultivator which takes 5 feet and for preparing land 12 inches deep will take 5 to 7 horses; hand hoe.

(1) Hand wheel hoe; horse 4-row cultivator; two 12-inch stockton grangs; har rows; horses.

(5) Single-man wheel hoes; horse single-row hoes; deep roller.

(6) No answer.

(7) No answer.

(8) Four good horses; stirring plow; cultivator; disk; harrow. 
How many acres, with good equipment, can one man tend?

(1) No answer.

(2) With 50 cents per ton for Japanese labor he can tend 40 acres.

(3) 40 to 50 aeres with help to do the thinning and hoeing.

(4) 10 acres.

(5) I do not know.

(6) No answer.

(7) No answer.

(8) 25 to 30 acres.

What are obstacles you encounter, including diseases, insects, eto.?

(1) Worms and extreme dry weather.

(2) Nothing.

(3) Some lings, some cutworms, and dry weather.

(4) Black beetles do some damage, but seldom cutworms; a small black fly does some damage when the beet is ripening, but not serions.

(5) Dry or wet weather occasionally; sometimes cutworms cause damage.

(6) No answer.

(7) No answer.

(8) We had a small beetle that produced a worm that attacked the beets, completely destroying some. It was similar to the Coloralo beetle. Then, beets suffer seriously here from a rot that attacks the taproot, which rots and completely destroys the root as it works up the beet, which in time dies. We have suffered seriously from this disease at this time.

How often do you rotate, and with what?

(1) Plant corn one year, potatoes one year, ànd then beets.

(2) Barley or wheat; potatoes; beets.

(3) Beets; grain; potatoes; some two years beets.

(4) Every year. Beets; barley; potatoes.

(5) Three erops. Beets; then barley; then beets.

(6) We do not grow much of anything but beets; rest ground when necessary.

(7) No answer.

(8) We have raised beets but one year; we can grow alfalfa and corn, and we will probably rotate with these.

Would you treat land for beets that had grown beets the year before, and what are the staple crops of your locality?

(1) You can grow beets for two years in succession, possibly; it dries the soil too much to continue longer. Staple produets here are fruit, potatoes, corn, onions; ordinarily beets pay about as well.

(2) Our staple crops are barley, potatoes, whent, and beets. Beets will pay as well on the average as wheat. This year I made $\$ 40$ per acre clear above all expenses but rent; I own the land.

(3) Barley, potatoes, wheat, and fruit. Beets are much the best crop; they compare favorably with wheat this year.

(4) Never follow with beets the next year; our staple products are barley, potatoes, beans.

(5) Staple products are barley, wheat, corn, fruit, potatoes, and gardening. Beets are much the best erop.

(6) Wheat, barley, and beans are grown here. We do not raise much of any thing but beets, as they pay best. We do not rotate, but rest the soil when necessary. We raise 15 to 20 sacks barley to an acre.

(7) We rotate with barley or corn. We grow besides beets, potatoes, corn, some wheat, and fruit.

(8) Our staple products are alfalfa, corn, beets.

[NOTE.-The comparisons with wheat were in September, when it was selling for $\$ 1$ per bushel. -C. F. S.] 
How long have you been raising suga. beets? That fertilizer do you use, and how do you apply it?

(1) Eight years. (No ansiver as to fertilizer.)

(2) Five years. (No answer as to fertilizer.)

(3) Five years. (No answer as to fertilizer, )

(4) No answer.

(5) Several years. Do not uso fertilizer.

(6) No answer.

(7) No answer.

(8) One year. Do not nse fertilizer.

When and how deep should ground be plowed, anil how deep should seed be planted?

(1) No answer as to ground. Seed should be planted one-half iuch to 2 inches, depending on moisture; if dry, plaut deep.

(2) Plow full and winter 12 to 14 inches. Plant seed one half to three-fourths inches if dry.

(3) Plow 12 inches at Christmas time, and cultivate once or twice in the spring. Plant seed 2 to 4 inches when ground is dry.

(4) Plow in fall and cultivate in spring; plow 8 inches to start with. Plant seed an inch, and deeper if the moisture line is deep.

(5) Plow 12 to 14 inches in the spring. We have no frost, and the ground packs with fall plowing. Plant seed one-half inch if dry.

(6) No answer.

(7) No answer.

(8) Plow 12 to 14 inches in fall and winter. Plant seed 1 to $1 \frac{1}{2}$ inches.

What do you think about ridging the rows, and do you silo your beets?

(1) Ridging will not do here. It is too dry. Do not silo.

(2) Flat farming prevails here. Do not silo.

(4) All flat. Generally plaut the other way and put the rows at right angle with the wind, which is usually from the west, so that the sand will not dry and cut the beets; thin as soon as possible or just as soon as plant has two leaves. The cost for four leaves will be $\$ 4$ uore than for two leaves for thinuing.

(3) We farm flat; in fact, would rather put in trenches.

(5) Do not ridge, but make them as level as possible. Do not silo.

(6) No answer.

(7) No answer.

(8) Do not approve ridging. I plant that and furrow in the wide rows. Do not silo, but keep them in the ground.

How do you top beets?

(1) One at a time with a knife.

(2) With single stroke of a large knife.

(3) With a single stroke of large knife and throw tops in piles.

(4) By hand with one stroke of 12 -inch knife and pile on end in rows.

(i) Top by hand with one stroke of large kuife in the field; eut all above ground.

(6) No answer.

(7) No answer.

(8) With one stroke of a large knife.

How many times do you hoe after thinning, and docs frequent hoeing increase the yield?

(1) Once before and once after thinning; frequent hoeing increases yield very much.

(2) Once by hand and once by horse hoe; cultivate mostly before planting.

(3) Once with wheol hoe and once with hand hoo.

(4) I seldoin hoe after thinning, except to kill woeds.

(5) Once; we have no trouble with weeds after first hoeing; I think twice is enough.

(6) No answer. 
(7) No answer.

(8) Orice; does not increase the yield much.

How far apart do you plant the rows, and how far do you thin out?

(1) 18 inches apart; on ordinary land I think 6 to 10 inches, on good land 6 inches.

(2) 20 inches apart; thin 6 inches.

(3) 20 inches apart; thin 8 to 10 inches.

(4) 20 inches apart; thin 3 inches to 2 feet, depending on soil; if very light and sandy thin 2 feet.

(5) 15 inches apart, and sometimes 18 inches; thin 4 to 5 inches.

(6) No answer.

(7) 18 inches apart; thin 6 to 8 inches in rows.

(8) Alternate 14 and 26 inches apart; thin 8 inches.

How much secd do you plant per acre, and what varieties do you use? Which do you prefer?

(1) 15 pounds per acre; Kleinwanzlebener and Vilmorin seed. Prefer Kleinwanzlebener for stiff land and Vilmorin for soft and loose land.

(2) 10 pounds per aere; Kleinwauzlebener.

(3) 12 pounds per acro; use Kleinwanzlebener seed.

(4) $2 \frac{1}{2}$ pounds to 10 pounds, according to width of rows; use Kleinwanzlebener, which I prefer.

(5) 15 pounds per acre. I use Kleinwanzlebener. I prefer Imperial Rose (Verbersetta Rosa). The latter while not a high sugar beet does better.

(6) No answer.

(7) No answer.

(8) Use original Klein wanzlebener and the Horning strain of the same; prefer the Horning.

Are the tops good stock feed?

(1) Yes; but better for fertilizer.

(2) Yes; but better for fertilizer.

(3) Yes; we sell it for 25 cents per load.

(4) Yes; but we do not allow the tops to be removed, as they are used as a fertilizer.

(5) Yes; butit pays better to use them as a fertilizer.

(6) No answer.

(7) No answer.

(8) I think not.

What do you think of sugar beets for feed?

(1) I think they make good feed for cattle, sheep, and hogs.

(2) Make a good feed.

(3) Do not know.

(4) Make a first-class feed.

(5) They make a first-class feed. I once fattened 1,000 hogs by steaning beets.

Make a good horse feed and are good for milk.

(6) No auswer.

(7) No answer.

(8) Do not think much of them for this purpose.

What do you think of pulp for feed?

(1) First-class for milk and feed of cattle, sheep, and hogs.

(2) Makes a fine feed for all kinds of stock.

(3) I have not tried it.

(4) The pulp is first-class for fattening.

(5) Pulp is good for foed for dairying and for ration for fattening animals.

(6) No answer.

(7) No answer.

(8) I have not experimented with it. 



\section{IN DEX.}

Page.

Agricultural surveys, importance and plans .......................... 21

Alcohol, manufacture from beet-sugar molasses . . . . . . . . . . . . . . . . . . . 173, 174

Altitude as modification of sugar-beet growing ...................... 168

Aluminum and silica, inconvenience in beet-sugar making .............. 207

American ingenuity and enterprise as factors in best-sugar industry ........ $176^{\circ}$

Analyses of sugar beets, cautions regarding . ....................... 41

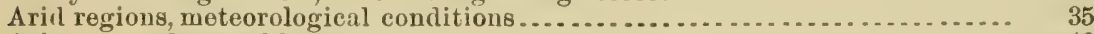

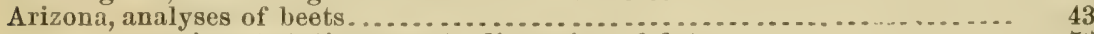

experiment station report; discussion of data..................... 56

Arkansas, analyses of beets; discussion of data . . . . . . . . . . . . . . . . . . . .. 43, 60

Armsby, H. P., report. ............................................ 15, 109

Beet pulps. (See Sugar-beet pulps.)

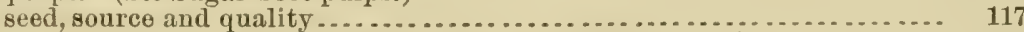

sugar, answers of factory officials regarding factory work ........... 208

factories in operation, list. ................................ 16

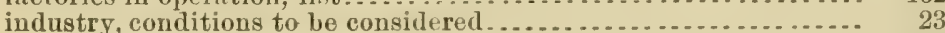

local prosperity as result . . . . . . . . . . . . . . . . . . 184

United States as competitor with Europe............ 175

problem of making ready for market...................... $\quad 209$

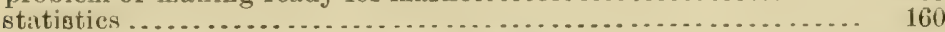

yield in factory of 300 tons capacity per day ................ 214

Beets, crude materials required per ton in sugar making ................. 217

discussion of blight and its relation to irrigation ................. 196

estimate of number of acres for cultivation by one man ............ 224

general suggestions for raising .............................. 186

number of acres for one man in California and New Mexico .......... 231

tous necessary to produce ton of white sugar ........... 211

obstacles to growing in California and New Mexico ................ 231

reports by Nebraska growers of number of years' experience........ 225

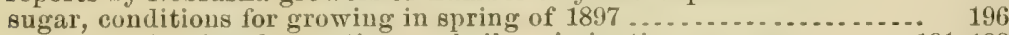

cultivation, harvesting, and silos; irrigation .............. 191-193

distance apart of planting in California and Now Mexico...... 233

equipment for raising in Nebraska ......................... 223

factors afrecting yield .................................. 197

indication of need of water by irrigation................... 194

notes on depth to which roots go seeking moisture ......... 166, 168

obstacles to growing, as reported by Nebraska growers......... 224

opinions of Nebraska growers on ridging of rows ............. 226

recommendations of growers as to equipment for growing ..... 230

relation of permanent agricultural conditions .............. 203

reports of average yield per acre........ . . . . . . . . . . . . . . 228

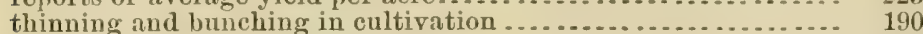

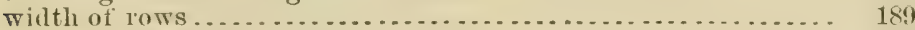

vield, or "tonnage" per acre............................ 182

treatment of land in California and New Mexico ................... 231

use of tops for feed.............................................. 233

Bibliography of Department publications relative to beet sugar . . . ........ $\quad 12$

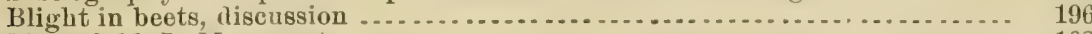

Bloomfield, L. M., report........................................ 102

By-products of beet-sugar making, nature and value ................. 171

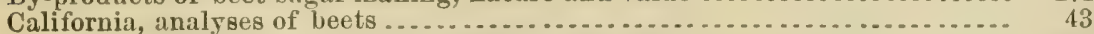

answers of farmers and factory officials as to sugar beets ....... 228

discussion of data as to sugar beets ........................ 60

growth of sugar beets without rain or irrigation . . . . . . . . . . . . 167

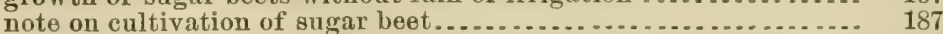

Capillary attraction, influence in bringing water to beet crop .............. 166

Capital, amount necessary for beet-sugar factories to supply United states with sugar 
Cattle food, use of sugar beto ................

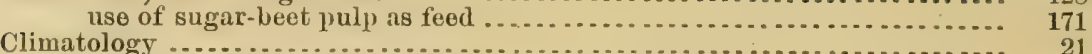

Coal, notes on use in beet-sugar factory .............................. 202

Coke and limestone, use by beet-sugar factories ............................. $\quad \mathbf{1 7 0}$

cost to beet-sugar factory; answers of factory officials................ 211

Colorado, analyses of beets.............................................. 43

discussion of data as to sugar beets........................... 61

experiment station report ............................... 63

Connecticut, meteorological conditions .................................... 29

Consumption of sugar, exteut .................................... 161

rate of increase per capita for leading countries....... 218

Corn, cleanness from weeds on land previonsly in sugar beets .............. 170

Cossettes, exhausted. (Sie Sugar-beet pulps.)

Cost of firctories for beet sugir .................................. 212

per acre of raising and marketing sugar beets ........................ 223, 230

Council Blutîs, Iowa, note on lands for sugar-beet growing .............. 199

County associations for sugar-beet investigation...................... 185

Crop, value of sugar beets ....................................... 197

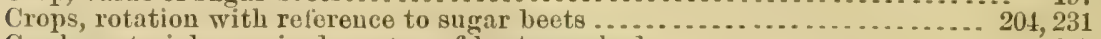

Crude materials required per ton of beets worked...................... 217

Cultivation, high state for sugar beets ..................................... 170

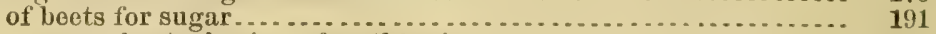

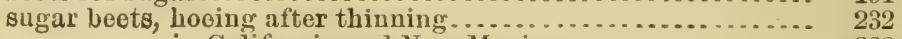

in California and New Mexico ................. 228

Nebraska ............................ 227

methods in Nobraska.................... 221

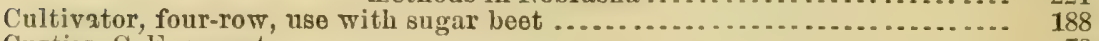

Curtiss, C. F, report .................................................... ${ }_{72}$

Cutworms, damage to boets in spring of 1897 .......................... 196

Dairies in connection with sugar-beet factories .......................... 171

Data as to beets obtained in the Department of Agriculture.................... 40

Delaware, meteorological conditions ..................................... 28

Department of Agriculture, discussion of work ou sugar-beet problem...... 165

Dust mulch, use in growing sugar beets in California ................... 167

Dyer, G. S., discussion of lime rocks and waters for beet-sugar making ...... 207

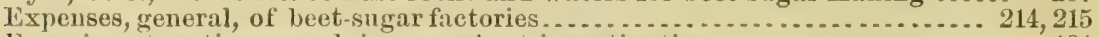

Experiment stations, work in sugar-beet investigation . . . . . . . . . . . . . . . . . 184

Experimental beds for planting sugar beets .......................... 180, 181

work, comments in early Chemical Division bulletins.......... 17

Experiments in 1897, correspondence and plan; observations........... 16, 17, 178 feeding beet pulps. . . ................................ 131

growing sugar beets in the United States................. 161

Factories, beet-sugar, estimato of capacities............................. 163

for beet sugar in Germany .................................. 219

new, note on capitalization in different sections .................. 216

Factory, heet-sugur, estimates of cost for 300 and 500 tous calpacities per day. 213, 215 conditions in beet-sugar industry ......................... 200

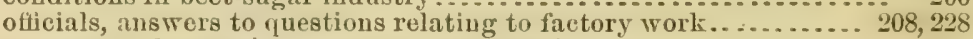

operators, observation on answers to questions ................. 212

Farmer, cost of raising sugar beets and delivering to factory ................ 208

obligation to use seed as direeted ............................. 178

Farmers in beet-sugar industry in California and New Mexico, answers....... 228

Firming, fictor of intelligence ................................. 183

Feerl, use of sugar leets; of tops; of pulp................................... 233

lertilizer for sugar beets, kind and application ............................ 225, 232

Fertilizers, use of beet-sugar molasses........................................ 174

Food for stock, use of molasses from beet sugar ......................... 174

Forbes, R. H., report.................................................. ${ }_{56}$

F uel for beet-sugar factory, discussion.................................. 201, 211

use by beet sugar factories .................................. 170

F'ulmer, Eiton, report .................................................... 116

Germany, discussion of beet-sugar industry ............................. 219

Goetz, A.S., letter relativo to beet pulp .............................. 130

Goose feet, use as implement in cultivation of sugar beets .................. 188

Growers of sugar beets in Nebraska, auswers to questions.................. 220

Irarvesting implements for sugar beets ................................ 192

of sugar beets, time ............................ 191,210,221,228

Headen, W. P., report .............................................. 63 
Page.

Hoeing of sugar beets after thinning, practice of Nebraska gromers .......... 227 frequency and effect............................. 232

Huston, H. А., report .......................................... 70

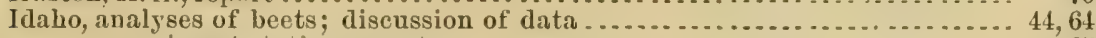

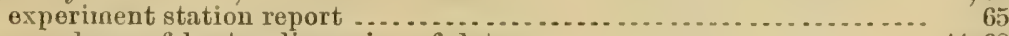

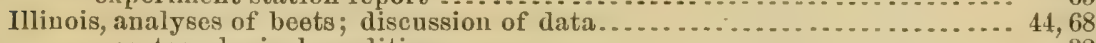

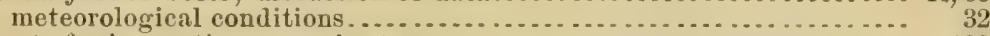

Implements for harvesting sugar beets . . . . . . . . . . . . . . . . . . . . . . . . . 192

sowing sugar beets; for cultivating.................... 187, 188

Indiana, analyses of beets; discussion of data . . . . . . . . . . . . . . . . . . . . 44,69

beets for seerl production .............................. 146

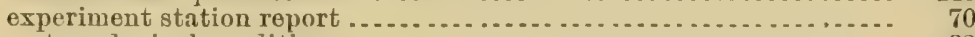

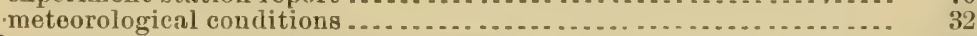

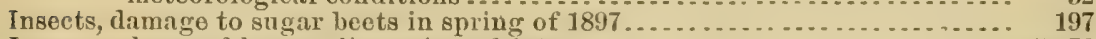

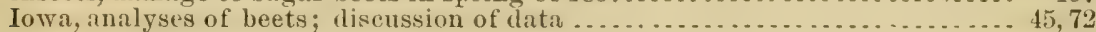

beets for seed proluetion. . . . . . . . . . . . . . . . . . . . . . . . . . . 146

meteorological conditions ....................................... 33

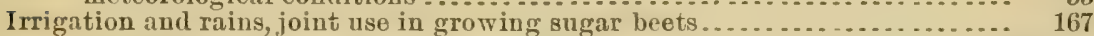

for sugar beets, discussion; signs of need...................... . . . . . . . 194

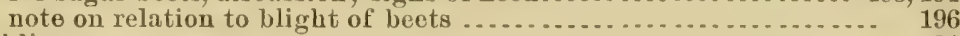

Isothermal lines . . . . . . . . . . . . . . . . . . . . . . . . . . . . .

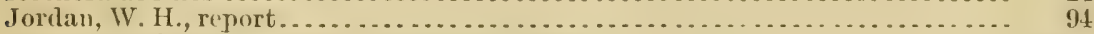

Kansas, analyses of beets; discussion of data ........... . . . . . . . . . . . . 45,74 summary of analyses by the experiment station ............... 75

Kentucky, analyses of beets; discussion of data....................... 46,76

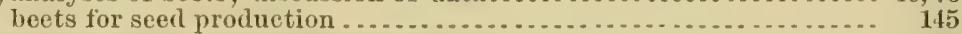

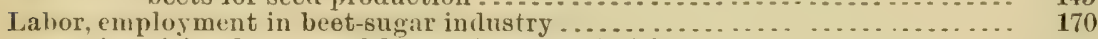

in raising beets, usefulness of boys and girls ................... . . 204

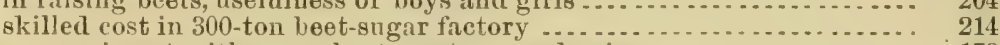

Land for experiment with sugar beets, notes ou selection . . . . . . . . . . . . . . 179

sugar beets, average rent to farmers . . . . . . . . . . . . . . . . . . . . . . 208

Lime and water for beet-sugar factory purposes...................... 205

rocks and waters iu manufacture of beet sugar ...................... 207

use of residuum from beet sugar factories as fertilizers. . . . . . . . . . . . 174

Limestone and coke, demand of beet-sugar factories. . . . . . . . . . . . . . . 171

disenssion of use in beet-sugar industry . . . . . . . . . . . . . . . . . 202

source and cost for beet-sugar making ...................... 211

suggestions on composition for beet-sugur manufacturo ........ 205

Machinery, estimate of factory ofticials on reduction in cost of sugar by recent

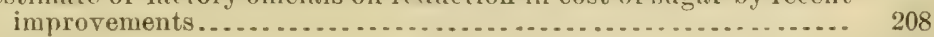

for beet-sugar making, percentage of Americau mako in use...... 210

Map of the thermal belt. . . . . . . . . . . . . . . . . . . . . . . . . . . . . . . . . . 23, 24

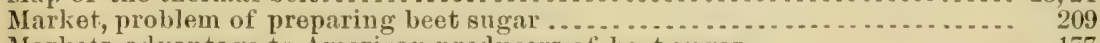

Markets, advantago to American prodncers of bect sugar . . . . . . . . . . . . 177

discussion for beet-sugar iudustry ......................... 203

Maryland, analyses of beets; discussion of data . . . . . . . . . . . . . . . . . . . 46,77

Eastern Shore, meteorological conditions .................... 27

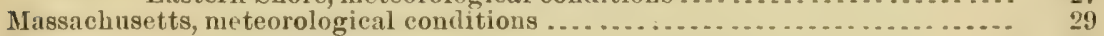

Melassigenic salts, discnssion . . . . . . . . . . . .

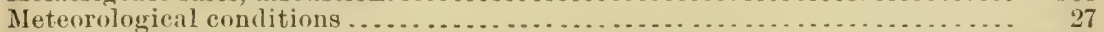

Michigan, analyses of beots; discussion of data ..................... 46,78

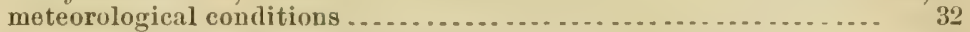

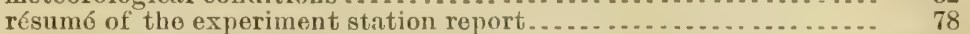

Minnesota, analyses of beets; discnssion of data . . . . . . . . . . . . . . . . . . 47, 81

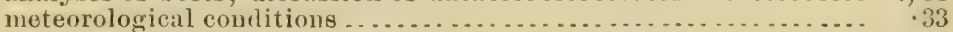

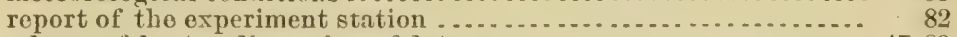

Missouri, analyses of beets; discussion of data........................ 47,83

summary of data from the experiment station . . . . . . . . . . . . . . 84

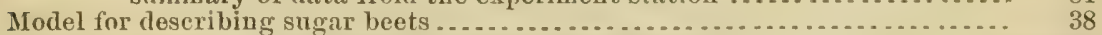

Ioisture, relation to prololem of growing sugar beets . . . . . . . . . . . . . 166,222 requirements of sugar beets in California and New Mexico . . . . . . . 229

Molasses, experiments in making beet sugax ... . . . . . . . . . . . . . . . . . . 212 from sugar bets, discussion................................ 172

in beet-sugar making, problem of disposal ................... 209

made from beets in Germany . . . . . . . . . . . . . . . . . . . . . . . . . 219

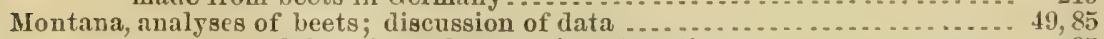

snmmary of clata from tho experiment station................ 85

Mulch, dust, uso to prevent ovaporation in growing sugar beets in California - 167

Mule, superior value in eultivation of sugar bets .................... 188 
Page.

Nebraska, analyses of beets; discussion of data.................... 49,86

answers of growers of sugar beets......................... ${ }_{2}^{2} 20$

details of expenses of sugar-beet growing at Norfolk ............. 198

moteorological conditions ................................ 35

obstacles to growing of sugar beets........................... 224

recommendations as to equipment for raising sugar beets.......... 223

report of the experiment station ............................ 86

staple products of sugar-beet sections...................... 224

Nevada, analyses of beets; discussion of data ........................... 50,87

report of the experiment station ............................... 88

New Hampshire, meteorological conditions ............................. 29

New Jersey, analyses of beets; discussion of data ....................... 50,88

experiments in Monmouth County ....................... 89

meteorological conditions................................ 28

New Mexico, answers of farmers and factory officials as to sugar beets ........ 228

experience of beet growers sending answers ................ 232

report of the experiment station; discussion ................ 90

staple crops in beet sugar section........................... 231

New York, analyses of beets; discussion of data................... 50, 93

meteorological conditions................................. 30

regions suiterl to beet culture ............................ 98

report of the Cornell University experiment station............... 96

State experiment station ...................... 94

Norfolk, Nebr., report in detail on expenses of sugar-beet growing ........... 198

North Carolina, analyses of beets; discussion of data ................... 51,99

meteorological conditions................................. ${ }_{27}$

North Dakota, analyses of beets; discussion of data.................. 51,99

meteorologieal conditions ............................ 34

Officials, factory, answers to questions regarding factory work .............. 208

Ohio, analyses of beets; discussion of data.......................... 51, 100

moteorological conditions ......................................... 31

report of the experiment station ................................. 102

Oklahoma, analyses of beets; discussion of data ..................... 52, 103

report of the experiment station .......................... 103

Oregon, report of the experiment station ................................ 104

Pacific coast, unusual conditions of soil moisture...................... 195

Paper, experiments in manufacture from sugar-beet pulp ................ 172

Penusylvania, analyses of beets; discussion of data .................. 52, 108

moteorological conditions........................... 31

summary of analyses .............................. 108

Petrolenm, note on use in beet-sugar factory ........................ 202

Planting of beets for sugar making, time............................ $\quad 210$

sugar beets, depth...................................... 232

distance apart of rows in Nebraska............. 227

points considered ........................... 187

reports of Nebraska growers .................... 226

Plowing for sugar beets, depth .................................... 225, 232

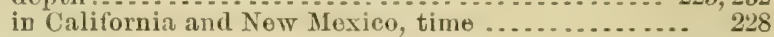

notes on thoroughness for sugar beets .......................... $\quad 180$

of sugar beets, usual time...................................... 221

Price of sugar beets, answers of factory officials.......................... 208

Product and returns of 500 -ton beet-sugar fictory ............................ 216

of beet-sugar factory of 300 tous capacity per day ................. 214

Production of sugar beets, cost aud net protit per acre.................... 198

Profits and running expenses of factory of 300 tons capacity per day ........ 213

Pulp, beet, flemand as feed for animals ............................. 171

estimato of value of product of factory of 300 tons capacity ........... 214

feeding, report by John Reimers, of Grand Islind, Nebr .............. 216

of sugar beets, problem of disposal................................ 209

quantity of residue from ton of beets; experiments................. 212

value and price for feeding purposes............................... 172

Pulps. (Sce Sugar-beet pulps.)

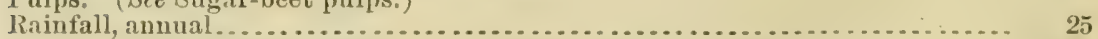

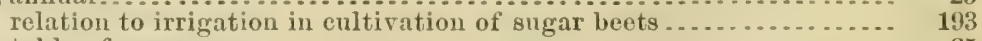

table of averages .......................................... 25

Rains and irrigation, joint use in sugar-beet growing ..................... 167

Rent of sugar-beet lands in California and Now Mexico .................. 230

Rhodo Island, analyses of beets; discussion of data................. 52, 110

Roberts, I. P., report............................................... 96 
Rows, width in cultivation of sugar beots; ridging

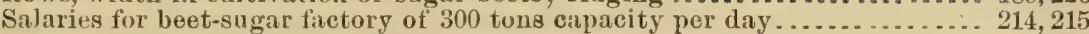

Salts in solution and effect in water used in sugar munufacturo ............ 205

Sampling of sugar beets by growers, discussion ......................... 181

Saylor, Charles F. report as special agent .......................... 161-233

Seed bed for sugar beets, soil and preparation ........................ 186

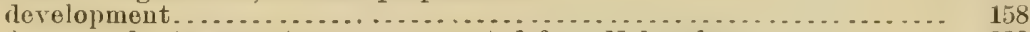

for sugar beet, amount per acre reported from Nebraska .............. 228

depth of planting ............................... 232

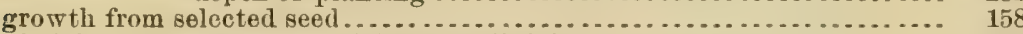

kind found best, answers of factory officials . . . . . . . . . . . . . . . . . . 209

of sugar beets, discussion ..................................... 199

margin for factory of 300 tons capacity per day ........ 215

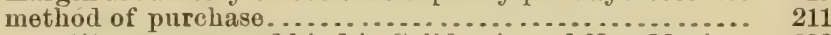

quantity per acre and kind in California and New Mexico. 233

note on necessity for large quantity in growing beets for sugar . ....... 201

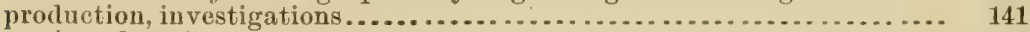

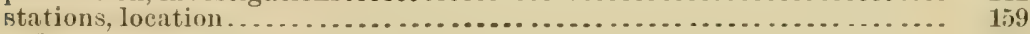

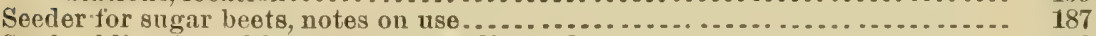

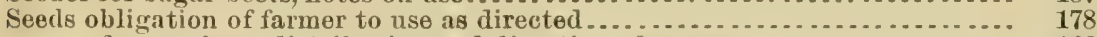

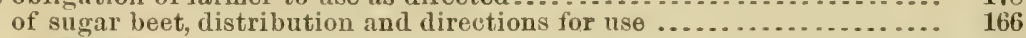

Selbr, A. D., report ............................................... 102

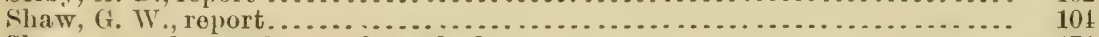

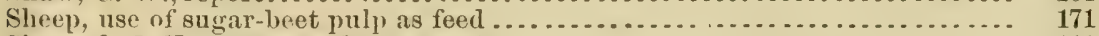

Shepard, .J. H., alostracts from report............................. 111

Silica and aluminum, inconvenience in beet-sugar making ................. 207

Silo for sugar beets, methods of making in California and New Mexico...... 232

reports of Nebraska growers ...................... 226

Silos for sugar beets, notes ........................................ 191

Soil for sugrar beets, descriptions by Nebraska growers . . . . . . . . . . . . . . . 22

in Califormia and New Mexico .................... 229

natural fertility in United States as factor in beet-sugar industry ......... 175

physical condition for sugar-beet growing ....................... 167

preparation for experiments ................................... 179

South Carolina, analyses of beets; discussion of data . . . . . . . . . . . . . 52, 110

South Dakota, analyses of beets; discussion of data . . . . . . . . . . . . . . . . . 53, 110

meteorological conditions......................... 34

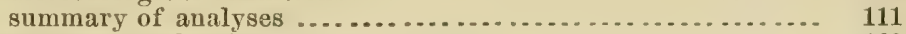

Statistics of beet-sugar proluction................................ 160

Steffen process for treatment of beet-sugar molasses.................... 173

Storage of sugar beets prior to hanling to factory ........................ 210

Subsoils favorable and unfavorable to sugar beet ...................... 168

Sugar, average quality from beets in Nebraska . . . . . . . . . . . . . . . . . . . 223

beet, comparatively small area necessary for growing ............ 177 discussion of factory conditions of industry ................ 200

importance of industry to United States .................. 169

necessity of pure water for manufacture ................... 201

note on original cost of factory ........................... 203

present status of manufacture in United States ................ 162

quantity of beets necessary to make ton of sugar .............. 211

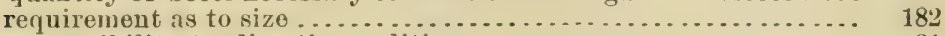

susceptibility to climatic conditions ............................ 21

Sugar-beet belt as mapped by Dr. Antisell; notes on zone ................ . 12,25

modifying conditions other than temperature .............. 166

of United States, discussion ........................... 164

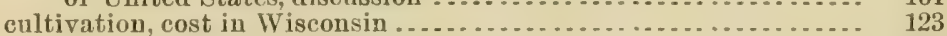

farms, rents and values, discussion........................ 169

pulp, composition ......................................... 129

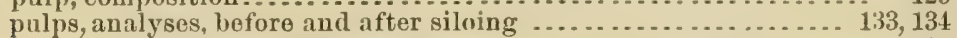

composition and feeding tests...................... 130

use for cattle food ................................... 129

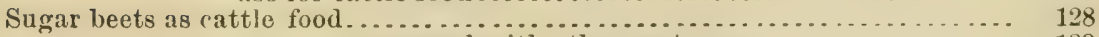

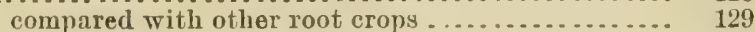

cantions in using the analy tical data................... 41

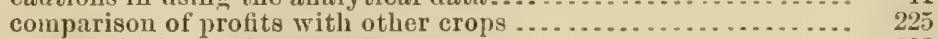

cost of raising and net profit per acre..................... 198

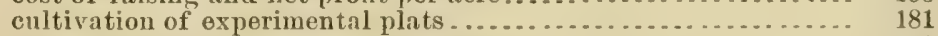

demand for crude material by factories ................... 170

directions for taking samples ........................... 37 
Sugar beets, directions for topping ................................ 38

experiments of successful growers ........................ 220

from high-grade seed, aualyses by tho Department ........... 150

discussion of data................ 154, 156

influence of temperature on the quality .................... 125

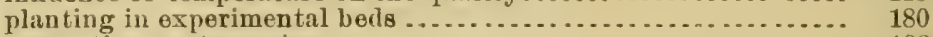

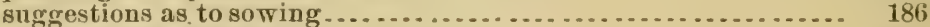

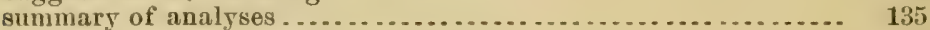

table of analyses by the Department....................... 43

value of crop.............................................. 197

work of experiment stations............................ 181

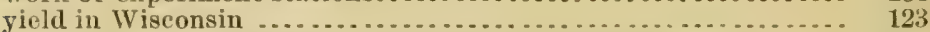

consumption of leading European countries and United States ....... 218

conteut and purity of beets, conditions which influence............ 164

duty as an aid to beet-sugar industry ...................... 177

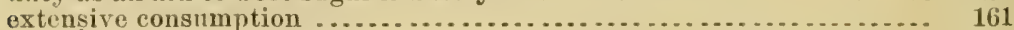

percentage extracted from beets by factories ................... 163

raw, quantity made from beets in Germany .................... 219

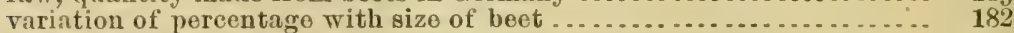

Temperature, remarks on requirement for growing sugar beet.s............ 161

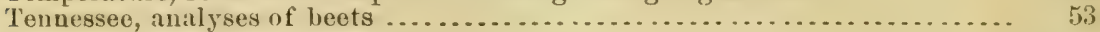

leets for seed production ..................................... 144

Texas, analyses of beets; discussion of data ........................... 53,112

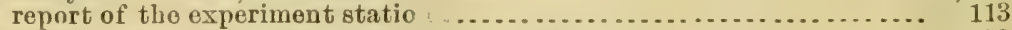

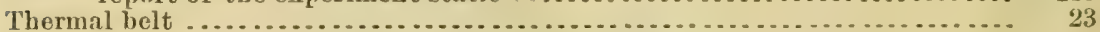

for growing of sugar beets, remarks on map ............. 165

Thinning of sugar bets in Nebraska ................................... 228

sugar beets, discussion.................................. 190

Topping of beets, methods in California and New Mexico ................. 232

Utah, advantages of elevation and temperature for growing sugar beets..... 169

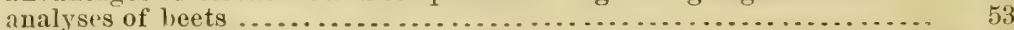

Vermont, analysis of beets; discussion of data......................... 53, 124

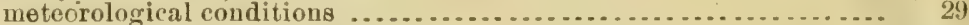

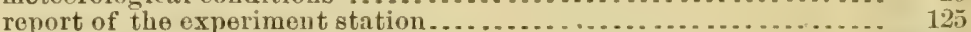

Virginia, analyses of beots; discussion of tata ...................... 53, 114

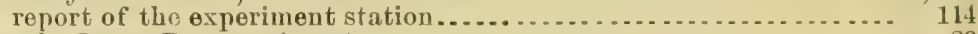

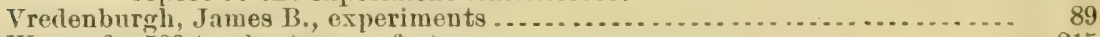

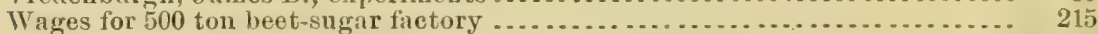

in sugar-beet work for fuctory of 300 tons capacity .............. . 214

Washington, anal $y$ ses of beets; discussion of data .................... 54,115

report of the experiment station . ....................... 116

Water and lime for beet-sngar factory purposes . . . . . . . . . . . . . . . . . . 205

condensed from evaporators, alvantage of use in beet-sugar making ... 207

for beet-sugar factory, necessity of purity ....................... 201

suggestions as to application in irrigation ..................... 194

Weeds, necessity for thorough cleanness in sugar-beet culture ............. 204

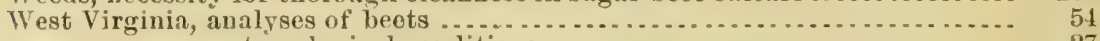

moteorological conditions ........................... 27

Wheat, production of fino crops on Pacific coast withont rain ............. 196

IViley, Harvey IV., special report as chemist ... . . . . . . . . . . . . . . . . . 11-160

IVisconsin, analyses of beets; discussion of diata . . . . . . . . . . . . . . . 5t, 119

beets for seed production .............................. 146

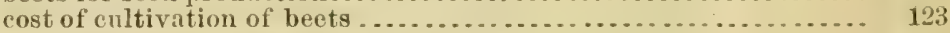

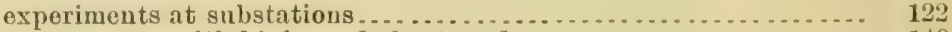

with high grade beet seed .................... 148

influence of the Menominee Falls failnre with beets. . . . . . . . . . . 128

investigations by tho experiment station.................... 119

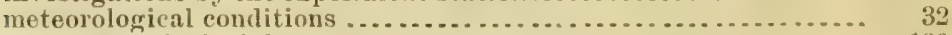

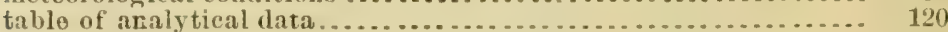

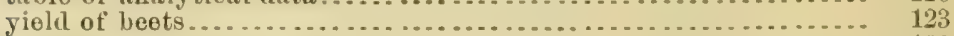

WVoll, F. W., report ............................................... 120

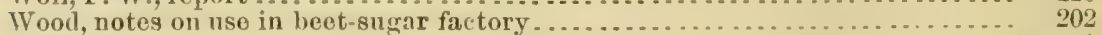

Vyoming, analyses of beets; discnssion of data..................... $55,123$. 


LIBRARY OF CONGRESS 